Universidad Nacional de La Plata

Facultad de Bellas Artes

Doctorado en Artes

\title{
Sensación táctil y audiotáctil en la música
}

El caso de las músicas electrónicas utilizadas para el baile social en locales de baile de la Ciudad Autónoma de Buenos Aires y alrededores

\author{
Doctorando: Sergio Iván Anzil \\ Director: Gustavo Basso \\ Codirector: Carlos Mastropietro \\ La Plata, diciembre de 2016
}


El movimiento corporal está apretadamente atado de varias formas a la percepción y a otras formas de cognición y emoción. [...] el cuerpo, a través de sus habilidades motoras, sus propios movimientos y su postura, informa y forma a la cognición.

Shaun Gallagher ${ }^{1}$
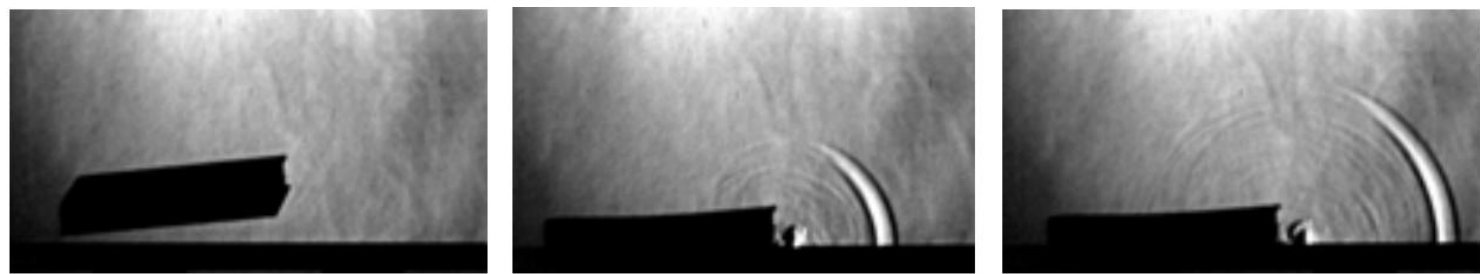

Visualización de ondas sonoras y de choque originadas en la caída de un libro. ${ }^{2}$

\footnotetext{
1 "Bodily movement is closely tied in various ways to perception and to other forms of cognition and emotion. [...] the body, through its motor abilities, its actual movements, and its posture, informs and shapes cognition." Citado en Zeiner-Henriksen, H. The PoumTchak pattern. Correspondences between Rhythm, Sound and Movement in Electronic Dance Music. pp. 26-27

${ }^{2}$ Fuente de la imagen: Settles, G. y otros. (2008). Schlieren imaging of loud sounds and weak shock waves in air near the limit of visibility. pp. 8
} 


\section{ÍNDICE GENERAL}

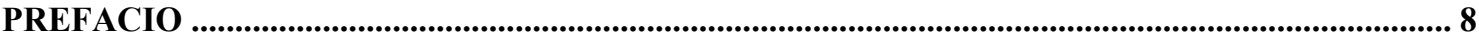

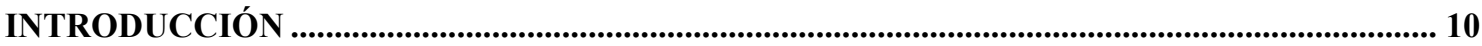

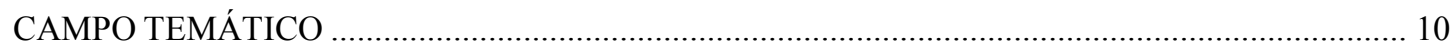

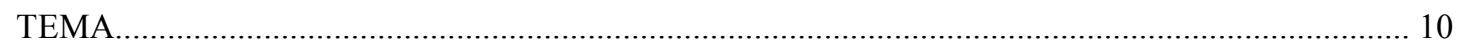

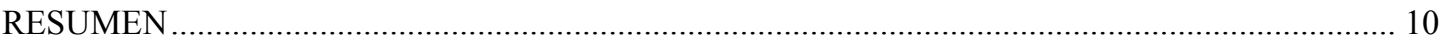

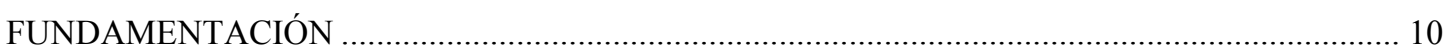

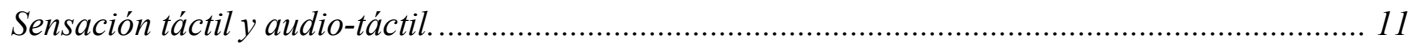

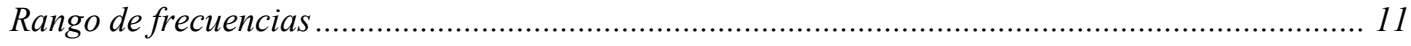

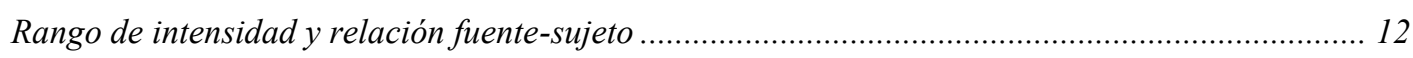

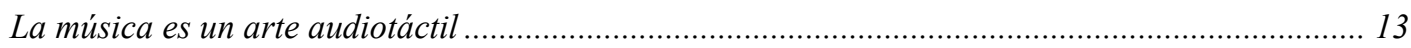

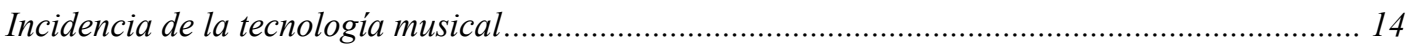

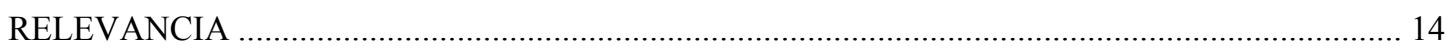

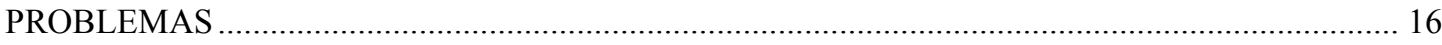

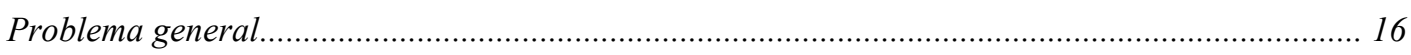

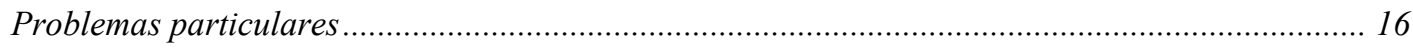

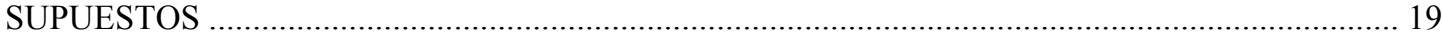

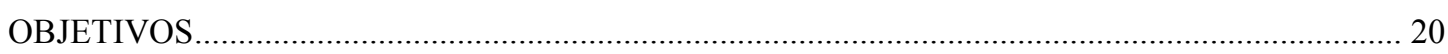

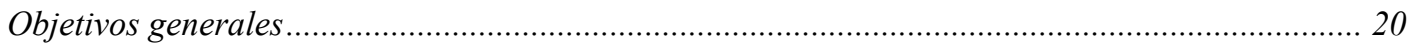

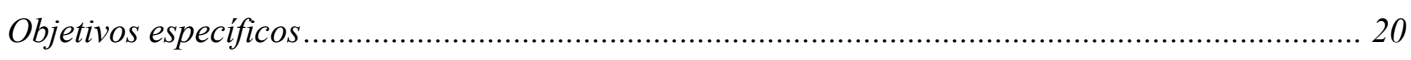

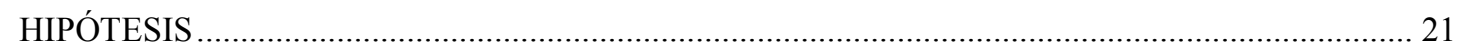

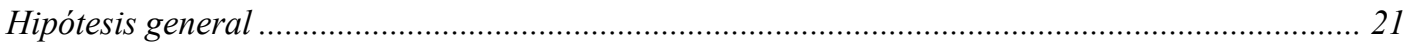

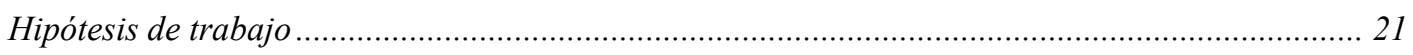

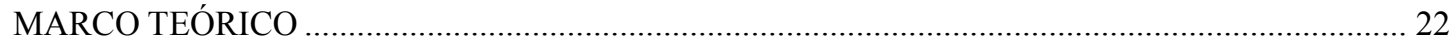

Saber común

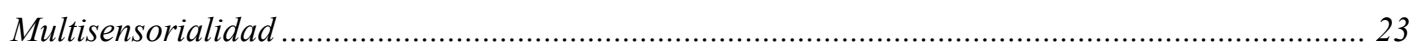

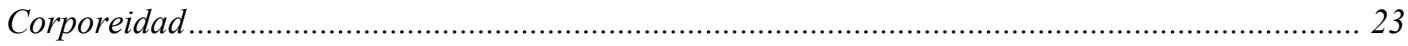

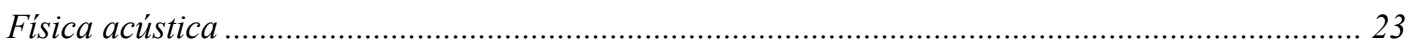

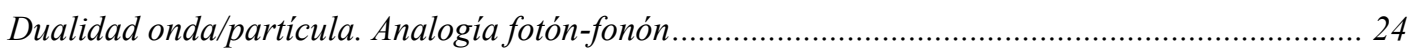

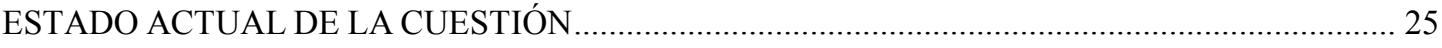

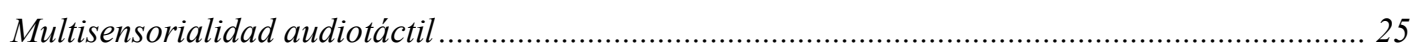

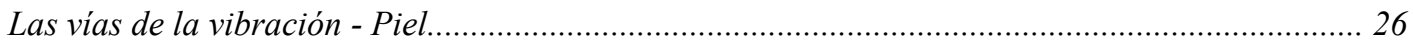

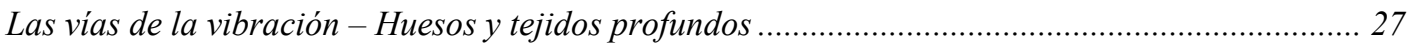

Ámbito musical, contexto social y experiencias personales............................................................... 29

Distribución y desarrollos geográficos e históricos de la música electrónica de baile ...................... 31

Corolario, aportes y aplicaciones posibles de la investigación propuesta ....................................... 32

ADVERTENCIA A MODO DE DELIMITACIÓN DEL OBJETO DE ESTUDIO …………...................................... 33

CONSIDERACIONES EN RELACIÓN A LAS FUENTES DOCUMENTALES Y METODOLOGÍA ................................. 34

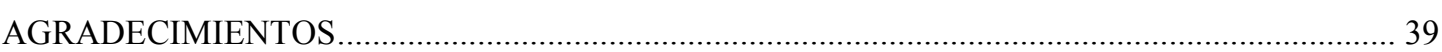




\section{CAPÍTULO I}

MÚSICA ELECTRÓNICA DE BAILE. MARCO TEÓRICO................................................................ 41

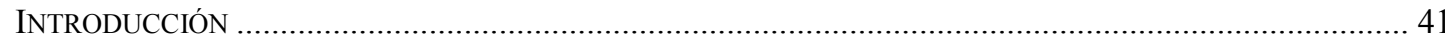

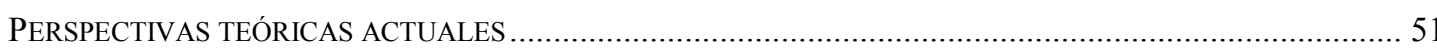

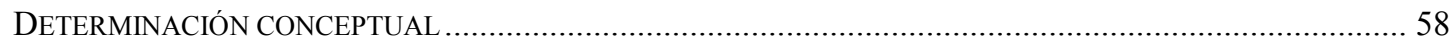

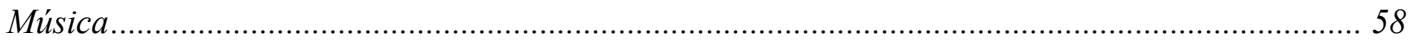

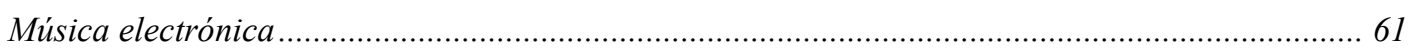

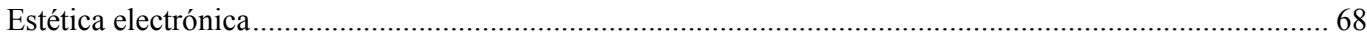

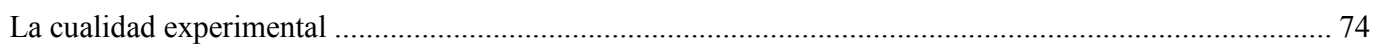

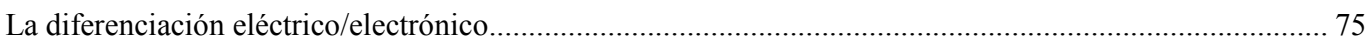

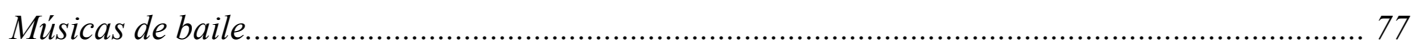

Músicas electrónicas de baile ......................................................................................................... 79

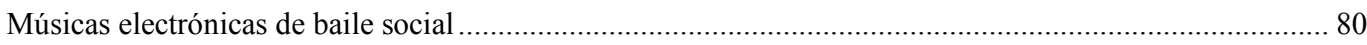

Músicas utilizadas para el baile social ........................................................................................ 82

Caracteristicas comunes del universo de músicas utilizadas para el baile social........................... 85

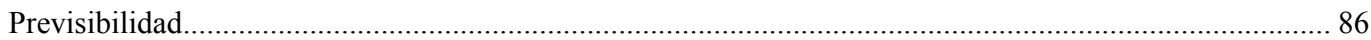

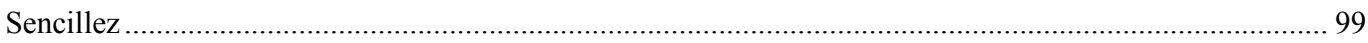

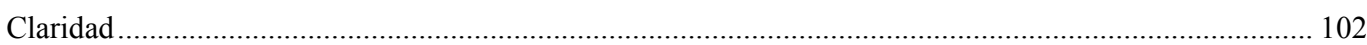

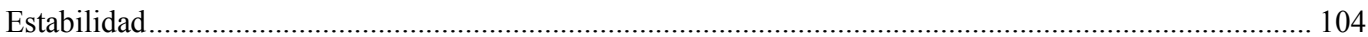

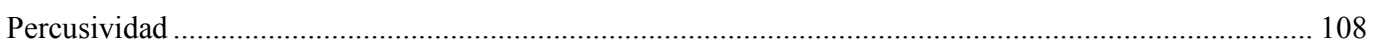

Concordancia directa entre tempo, densidad cronométrica y activación de movimiento ........................... 111

Músicas utilizadas para el baile social y movimiento ........................................................................ 114

GLOBALISMO E HIBRIDACIONES. UNA APROXIMACIÓN AL CONCEPTO DE MÚSICAS ELECTRÓNICAS

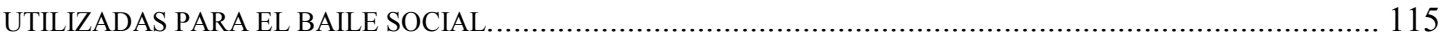

\section{CAPÍTULO II}

MÚSICAS ELECTRÓNICAS UTILIZADAS PARA EL BAILE SOCIAL. APLICACIÓN

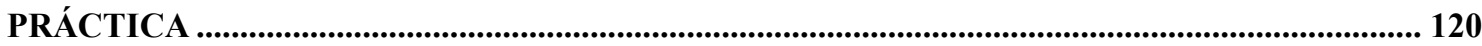

ANÁLISIS AUDIOTÁCTIL DE LAS MÚSICAS ELECTRÓNICAS UTILIZADAS PARA EL BAILE SOCIAL .............. 120

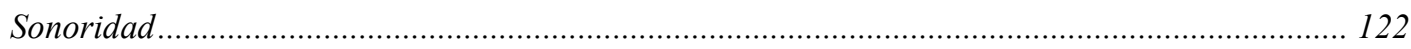

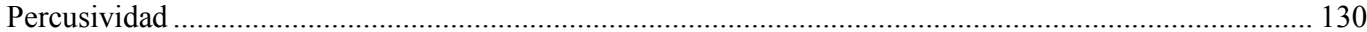

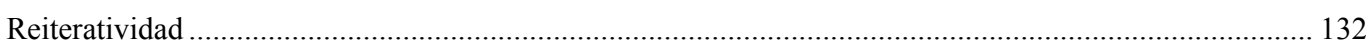

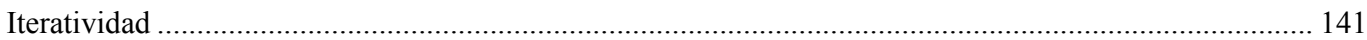

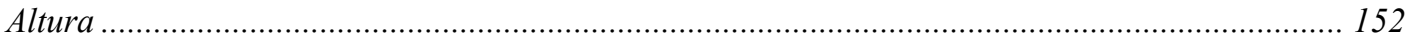

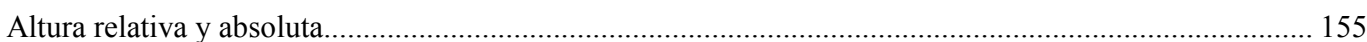

Tratamiento de la altura como cualidad relativa...................................................................................... 156

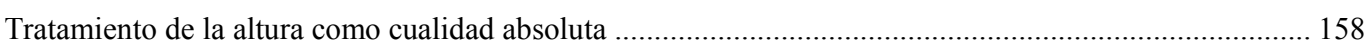

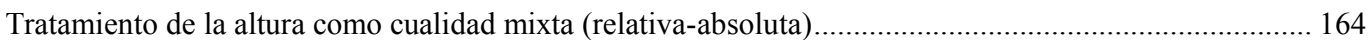

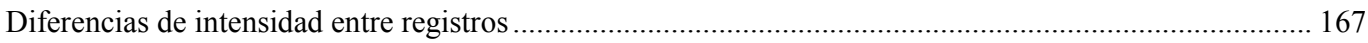

Frecuencias, intensidades y generación de sensación táctil ................................................................. 169

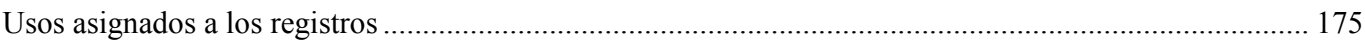




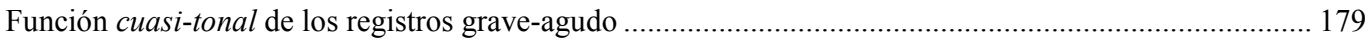

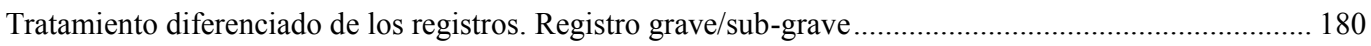

Tratamiento diferenciado de los registros. Registros medio, agudo y sobre-agudo.................................. 183

Repetición de alturas tonales definidas, de tonicidad débil y de altura tonal no definida .......................... 184

La repetición como proceso objetivador de materiales musicales ............................................................. 185

Repetición de una única altura en sonidos de bajo ................................................................................. 190

Repetición de una única altura con timbre de altura tonal no definida ................................................... 208

Repetición de una única altura con timbres de tonicidad débil............................................................... 212

Localización espectral grave/sub-grave como ánimo o carácter audiotáctil ................................................ 213

RESULTADO Y CONCLUSIONES

SENSACIÓN TÁCTIL EN LAS MÚSICAS ELECTRÓNICAS UTILIZADAS PARA EL BAILE

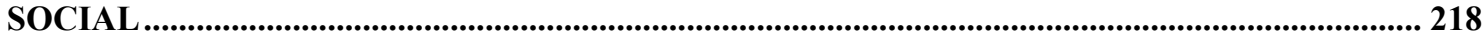

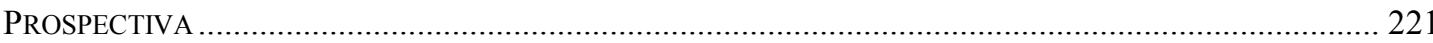

\section{ANEXO I}

EXPERIENCIAS DE CAMPO.

SENSIBILIDAD TÁCTIL A VIBRACIONES ORIGINADAS EN MÚSICAS ELECTRÓNICAS UTILIZADAS PARA EL

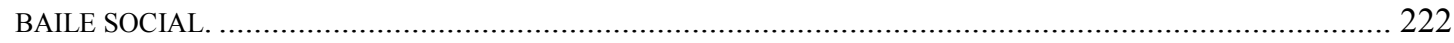

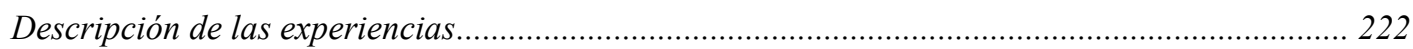

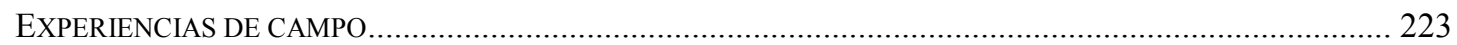

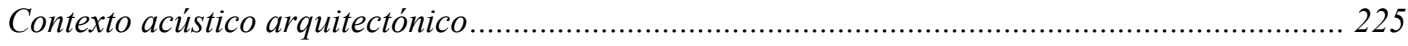

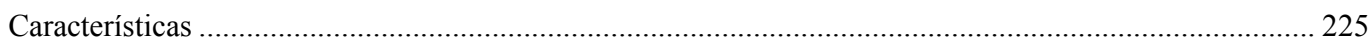

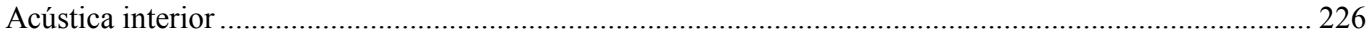

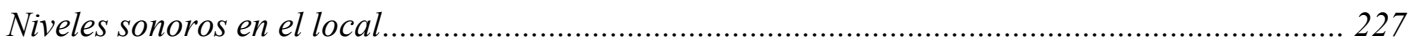

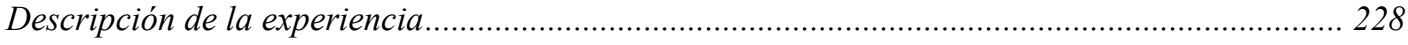

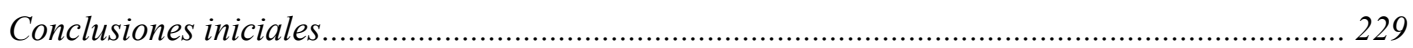

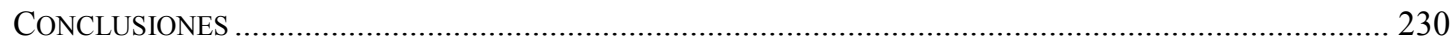

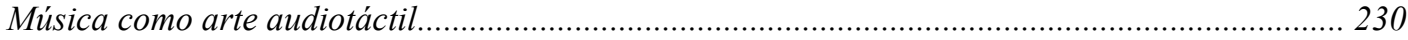

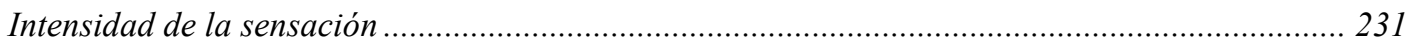

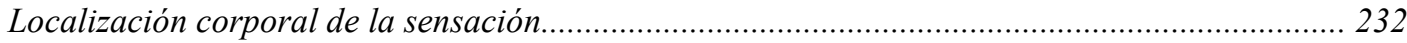

Profundidad de la sensación ............................................................................................................ 232

Calidad o cualidad de la sensación .............................................................................................. 233

Relaciones complejas entre el estímulo y la sensación ......................................................... 234

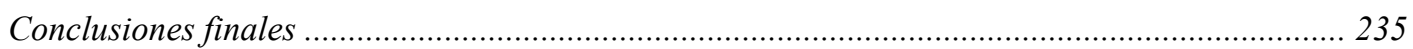

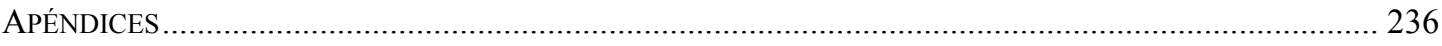

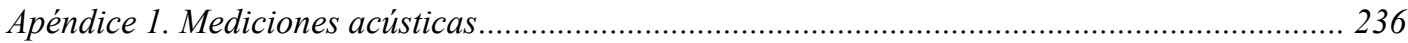

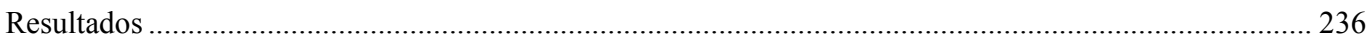

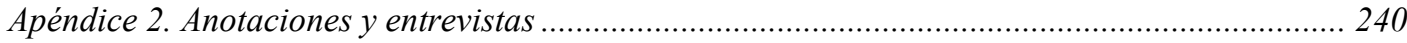

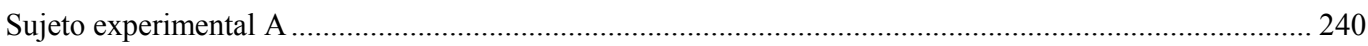


Sujeto experimental B

Sujeto experimental D 241

Sujeto experimental C 241

\section{ANEXO II}

EL PROBLEMA DE LOS GÉNEROS

ESTADO DE SITUACIÓN 244

GÉNEROS "MAYORES" Y LOS DEMÁS 259

SUBGÉNEROS, SUB-SUBGÉNEROS Y ESTILOS 277

SUBGÉNEROS, SUB-SUBGÉNEROS Y DEMÁS... EN LOS GÉNEROS "MAYORES". 291

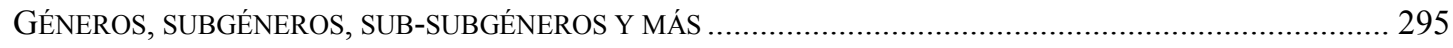

GÉNEROS, SUBGÉNEROS, SUB-SUBGÉNEROS Y ESTILOS COMO ÍNDICES ............................................... 305

FORMALIZACIÓN DE LA PERSPECTIVA A MODO DE CONCLUSIÓN AL PROBLEMA DE LOS GÉNEROS ......... 313

UN PASO MÁS ALLÁ: LA CUALIDAD EXPERIMENTAL COMO ÍNDICE TRANSVERSAL ................................ 316

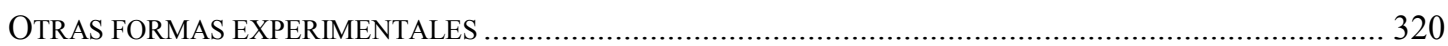

\section{ANEXO III}

\section{CARACTERÍSTICAS IDENTITARIAS GENERALES DE LA MÚSICA ELECTRÓNICA DE}

BAILE Y DE LOS ÍNDICES ASOCIADOS A SUS GÉNEROS MAYORES................................. 324

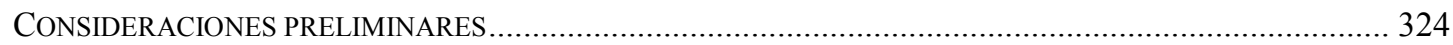

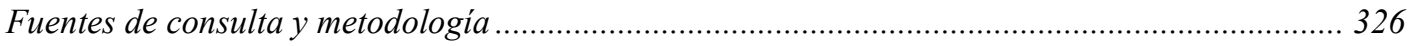

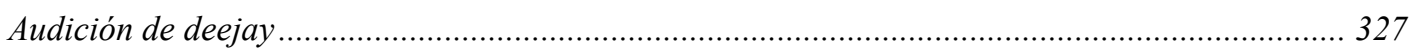

Necesarias y múltiples perspectivas de análisis.................................................................. 329

CARACTERÍSTICAS GENERALES DE LA MÚSICA ELECTRÓNICA DE BAILE. ANÁLISIS COMPLEMENTARIOS A LOS REALIZADOS DESDE LA PERSPECTIVA AUDIOTÁCTIL............................................................... 332

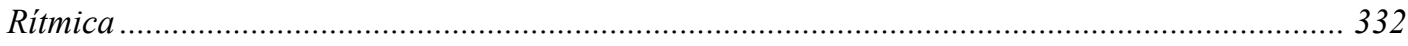

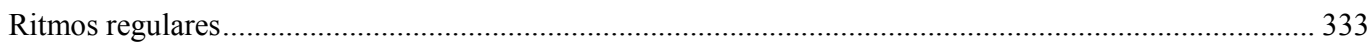

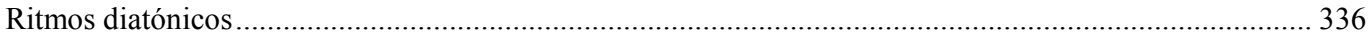

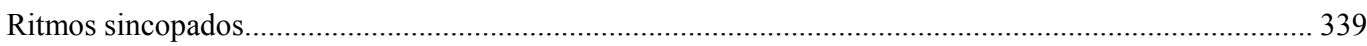

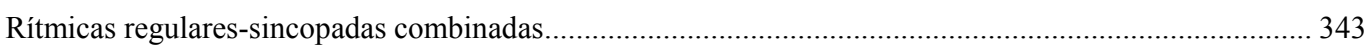

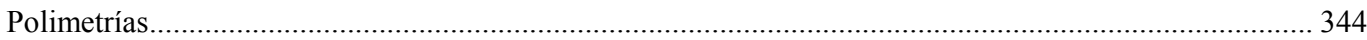

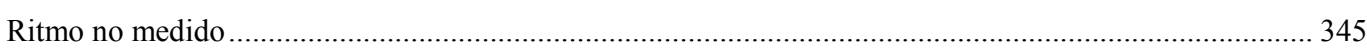

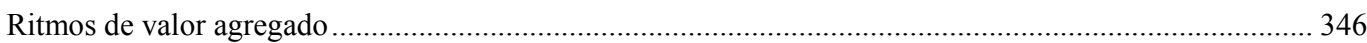

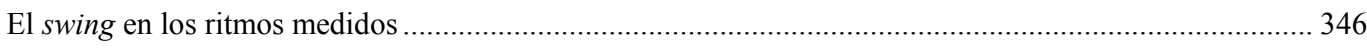

Localismos e hibridaciones. Algunas conclusiones en torno a la rítmica .................................................. 347

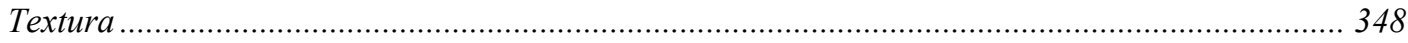

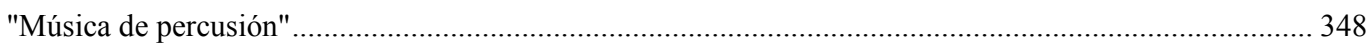

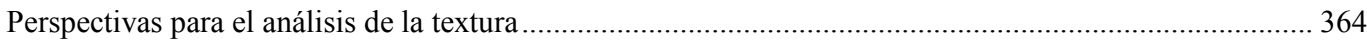

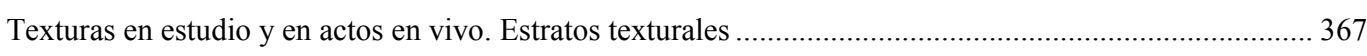

Texturas en estudio y en actos en vivo. Tipos texturales ......................................................................... 369 


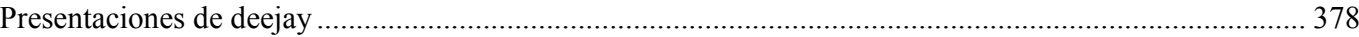

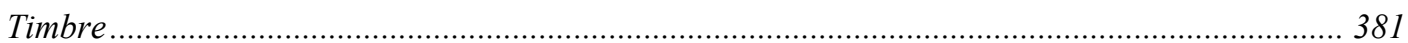

CUALIDADES DE LOS ÍNDICES MÁS NOMBRADOS DE LA MÚSICA ELECTRÓNICA DE BAILE .................... 381

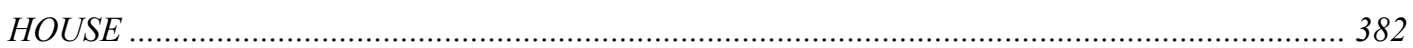

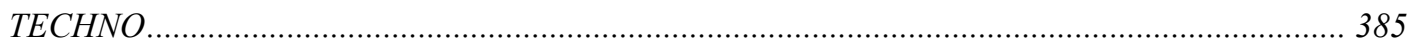

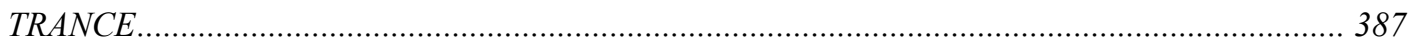

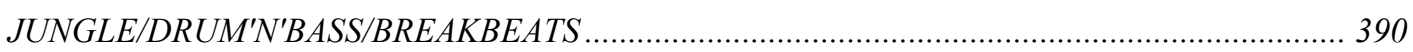

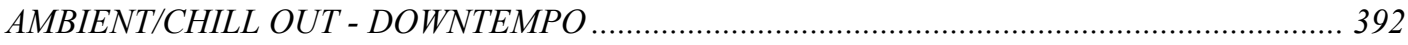

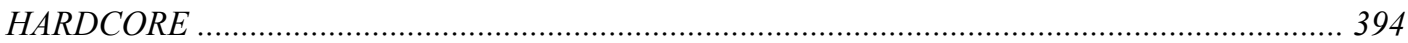

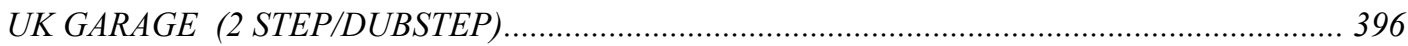

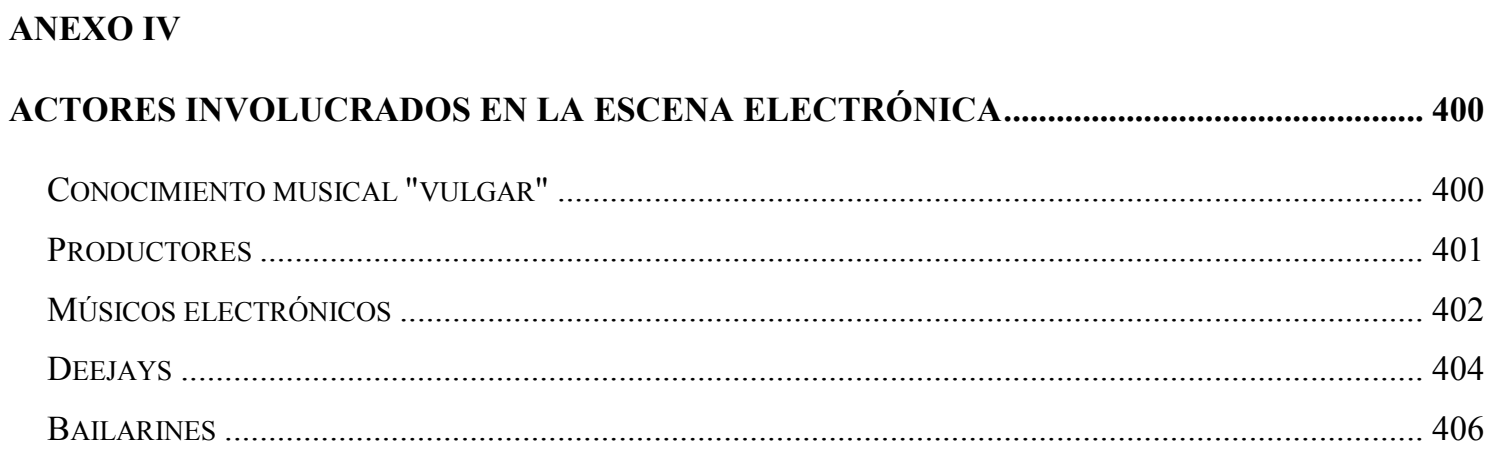

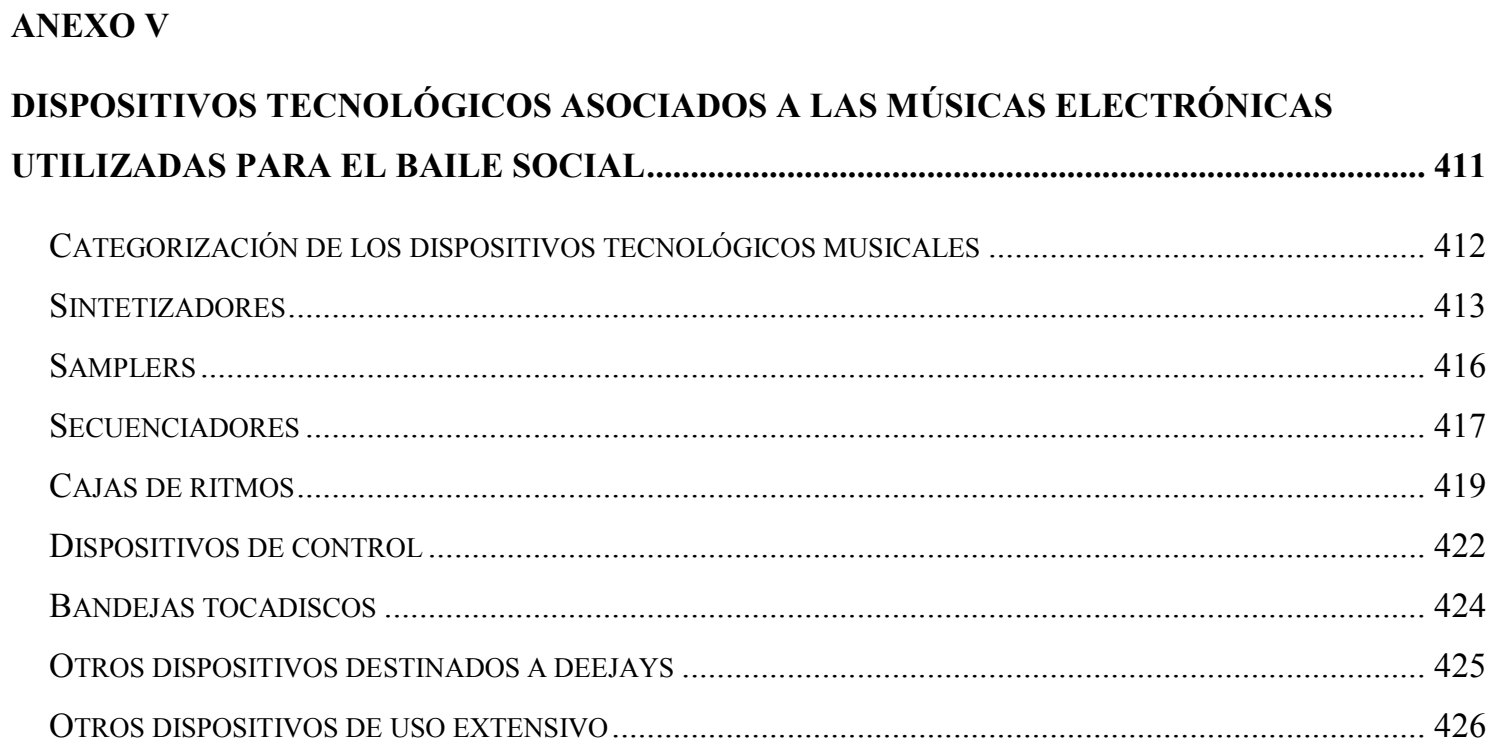

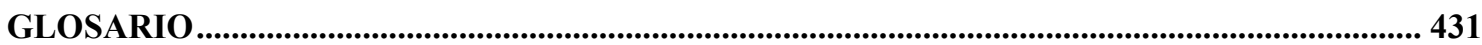

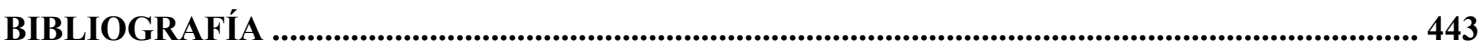

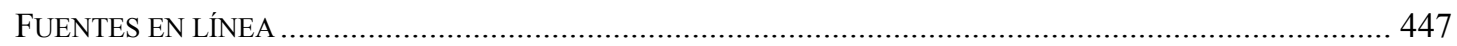

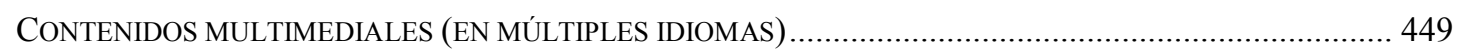

VIDEOS EN LA PLATAFORMA YOUTUBE (EN MÚLTIPLES IDIOMAS) …........................................... 450 


\section{PREFACIO}

La presente tesis doctoral aborda el estudio de las músicas electrónicas utilizadas para el baile social. Expresión artística que presenta características novedosas e innovadoras en numerosas dimensiones, se diferencia de otras músicas particularmente por el hecho de que sus realizadores hacen uso intencional de la sensación táctil y/o audiotáctil como recurso estético musical. Cualidad que determina múltiples aspectos de las creaciones e interpretaciones de sus productores, músicos electrónicos y deejays, se ha vuelto tanto una característica inseparable de las propiedades audibles como un estímulo buscado (quizá inconscientemente) por los aficionados a la especie.

Presente en el estímulo sonoro y musical desde tiempos ancestrales, las sensaciones táctiles y audiotáctiles han pasado siglos desapercibidas tanto para la musicología como, incluso, para los creadores que hacen uso de estos materiales. ${ }^{3}$ En años recientes, la presencia de este fenómeno se ha visibilizado (o "tactibilizado") parcialmente: promovido principalmente por el desarrollo de los modernos sistemas de amplificación sonora y por su capacidad de producir altos niveles de presión acústica en rangos extendidos de frecuencias, esta conciencia parcial ha tomado la forma de múltiples referencias a cualidades táctiles en los relatos que los actores de la comunidad electrónica hacen de su objeto de preferencia.

Estas referencias, confrontadas con el hecho de que las músicas electrónicas hacen uso de los mismos sistemas de amplificación que otras especies, pone en evidencia que, en las música que constituyen nuestro objeto de estudio (y a diferencia de lo que sucede en otras) ocurren configuraciones sono-musicales que resultan más eficaces para la generación de sensación táctil y audiotáctil. Estas cualidades distintivas -en combinación con condiciones no musicales que confluyen en la comunidad electrónica y su universo de influencia- vuelve a las músicas electrónicas utilizadas para el baile social a) el contexto paradigmático para la ocurrencia de sensación táctil y audiotáctil y b) la especie por excelencia para explorar un fenómeno que -en definitiva- acontece en mayor o menor medida en otras estéticas y disciplinas que hacen uso de sonido y música.

La ocurrencia de sensaciones de vibración, golpe, cosquilleos y otros, localizadas en diferentes sub-sistemas constituyentes del cuerpo o en su totalidad, es un hecho científico extensamente estudiado y documentado en numerosos trabajos. Constituyendo un área de la bioacústica conocida como vibroacústica y presentando interés para disciplinas entre las que se cuenta (como ejemplo) la medicina laboral, es un fenómeno que ha sido explorado desde diversos ángulos; algunos de los trabajos mencionados han sido incluidos como referencias en el Estado actual de la cuestión. Así también, aunque en menor número, estudios de diversos

\footnotetext{
${ }^{3}$ Si bien no es tema del presente trabajo, durante su desarrollo veremos surgir también algunas razones que podrían explicar por qué este fenómeno atravesaría invisibilizado un tiempo tan prolongado.
} 
autores (entre los que se cuenta quien suscribe) dan cuenta de situaciones donde ocurre sensación táctil y/o audiotáctil a partir de fenómenos musicales.

En otras palabras, el acontecimiento de sensación táctil y audiotáctil a partir de estímulos sonoros o musicales es un fenómeno que se encuentra fuera de toda discusión y no será puesto en cuestión aquí. Todo lo contrario, la exposición que sigue se constituye en un desarrollo teórico y aplicación práctica de ciertos principios y categorías derivados precisamente de considerar a la sensación táctil y audiotáctil parte inherente de la experiencia sono-musical. $\mathrm{Su}$ objetivo principal consiste en explorar formas para su aprovechamiento con fines estéticos, a partir de hallar modos de controlar sus cualidades y de detectar maneras posibles para su maximización.

Analizaremos entonces para ello a las músicas electrónicas utilizadas para el baile social desde una perspectiva audiotáctil. Del total de esta producción realizaremos un recorte latinoamericano, de éste, tomaremos al caso argentino y, en particular, al de la Ciudad Autónoma de Buenos Aires y alrededores. Si bien, como veremos luego, las músicas electrónicas utilizadas para el baile social podrían caracterizarse -al menos hasta cierto puntocomo la primera especie musical global, la forma concreta que asume en cada región del planeta presenta características locales. Como sostendrá Robertson, es una expresión cultural que se inscribe en las dinámicas de la glocalización (i.e.: global-local). ${ }^{4}$

Antes de dar por finalizado este prefacio creemos necesaria la mención de una última cuestión: los altos niveles de presión acústica necesarios para la generación de sensación táctil y audiotáctil -usuales en los locales de baile dedicados a la especie electrónica- son sin duda nocivos para el sistema auditivo humano. Por esta razón, desaconsejamos y desalentamos enfáticamente la participación en eventos electrónicos sin protección auditiva. ${ }^{5}$

Llevamos años de uso regular de protectores en cada uno de los eventos a los que asistimos, lo que nos permite afirmar que -luego de un período de adaptación- la experiencia puede tornarse incluso más placentera. Por otra parte, en varias oportunidades hemos compartido la pista con individuos hipoacúsicos, sin que su condición se reflejara en lo más mínimo en sus movimientos de baile. Es así que, como objetivo de máxima, esta tesis se propone como un conjunto de herramientas que permitan organizar configuraciones musicales

\footnotetext{
${ }^{4}$ En muy breves palabras, la forma de describir los modos en que las homogeneidades y heterogeneidades -culturales en nuestro caso- se implican mutuamente y "se han vuelto características de la vida en el mundo de la última parte del siglo XX" ([...] "have become features of life across much of the latetwentieth-century world."). Robertson, R. (1995). "2. Glocalization: time-space and homogeneityheterogeneity". Artículo. pp.27

${ }^{5}$ Asistir desprotegidos a un único evento expone a los concurrentes a daños auditivos permanentes; habiendo sido testigos de la masividad de algunos festivales, creemos no exagerar al decir que la sociedad como todo se encuentra frente a un problema de salud pública que requiere solución. Campañas de concientización al respecto es una acción necesaria que debe tomarse seriamente en consideración y en las cuales el Estado tiene un rol ineludible. Así como hiciéramos durante nuestra experiencia de campo con cada uno de los participantes, es muy importante que el disfrute de estas músicas y estas sensaciones sea a conciencia y munidos de protectores auditivos.
} 
que -al maximizar las sensaciones táctil y/o audiotáctil- favorezcan este tipo de inclusión y promuevan un disfrute protegido y saludable en términos auditivos. Una línea de acción futura consiste en la realización de eventos electrónicos de baile configurados para oídos especialmente resguardados.

\section{INTRODUCCIÓN \\ CAMPO TEMÁTICO}

Artes - Música

Ciencias físicas - Acústica general, musical y Bioacústica

Ciencias de la cognición / Neurociencias - Psicoacústica

Ciencias médicas - Salud pública/Medicina laboral

\section{TEMA}

Análisis cualitativo y cuantitativo de los sistemas complejos involucrados en la generación de sensación táctil y audiotáctil a partir de estímulos sono-musicales, y de las relaciones causales que entre dichos sistemas determinan su ocurrencia y percepción. Se sitúa el estudio de este fenómeno en el marco de las músicas electrónicas utilizadas para el baile social, tomado como caso testigo aquellas que se presentan en la Ciudad Autónoma de Buenos Aires y alrededores.

\section{RESUMEN}

En presencia de vibraciones originadas en fuentes remotas y -en particular- de música reforzada electroacústicamente, piel, huesos y demás sub-sistemas constituyentes del cuerpo humano resuenan de modos diversos, originando percepciones táctiles y/o audiotáctiles asociadas. Frente a la presencia en la comunidad electrónica de un número mayor de testimonios que refieren a estas sensaciones y a la casi total ausencia de investigación al respecto, a partir de estímulos vibratorios originados en músicas electrónicas utilizadas para el baile social el presente proyecto se propone determinar: a) los rangos de frecuencia e intensidad que inciden en la generación de sensación táctil y audiotáctil; b) los sistemas y sub-sistemas corporales que resuenan en presencia de dichos estímulos y los modos en que lo hacen; c) las relaciones causales que se establecen entre las cualidades principales del estímulo, de la música y de la sensación táctil y/o audiotáctil; d) las conformaciones sono-musicales paradigmáticas que maximizan la generación de sensación táctil y/o audiotáctil y e) las cualidades diversas que asume la sensación táctil.

\section{FUNDAMENTACIÓN}

Sonido y música presentan, desde el inicio de los tiempos, un componente táctil, corporal, que resultara ignorado hasta hace apenas una década. Las sensaciones táctiles y 
audiotáctiles se configuran entonces como cualidades del sonido que, invisibilizadas por muy diversas razones, requieren una nueva línea de investigación. Con múltiples y profundas implicancias filosóficas, tecno-científicas, estéticas y poéticas que alcanzan a la base misma y abarcan a la totalidad de las disciplinas que hacen uso de sonido, la sensación táctil se constituye en una poderosa perspectiva y herramienta para el análisis, creación e interpretación de todas aquellas obras que presentan una dimensión sonora y/o musical.

En el universo de las músicas electrónicas utilizadas para el baile social confluyen numerosas características multidimensionales, de muy diversa índole y origen; en su interacción, dichas características resultaron en la configuración de ciertas condiciones que pueden describirse como las paradigmáticas e ideales para la generación de sensación táctil y audiotáctil. En el contexto estético y acústico de los locales de baile donde se las presenta, las tecnologías del sonido y la amplificación sonora se interfieren con numerosas prácticas y hábitos culturales, resultando en sensaciones táctiles más evidentes que en cualquier otro contexto. Realizar aquí los primeros estudios sobre esta materia resulta no solo lógico sino también necesario.

\section{Sensación táctil y audio-táctil.}

La capacidad de las vibraciones mecánicas de baja frecuencia de producir sensación táctil y/o audiotáctil es un hecho ampliamente aceptado por la comunidad científica. También es un hecho aceptado entre músicos, musicólogos, ingenieros acústicos, bailarines, sonidistas y disc jockeys. A las preguntas directas “¿Ha sentido vibraciones o golpes en su cuerpo en recitales o locales donde hay presencia de música? ¿Asociaría esas sensaciones como originadas por la música?" la (casi) totalidad de las personas ofrecen respuestas categóricamente afirmativas. $^{6}$

Autoconciencia de parte o de la totalidad del cuerpo del sujeto perceptor, frente a la presencia de un estímulo vibratorio, la sensación táctil se manifiesta en la forma de vibración, golpe, temblor, empuje, escozor y/o presión, entre otros, en parte o en la totalidad del cuerpo. Consecuentemente, la sensación audiotáctil es sensación táctil y auditiva asociadas. Dicha asociación ocurre en el sujeto perceptor al momento en que éste vincula ambas sensaciones como originadas en una misma fuente de vibración (i.e: un único parlante, instrumento musical, dispositivo vibratorio artificial o natural).

\section{Rango de frecuencias}

El rango de frecuencias comprendido entre los $2-20 \mathrm{~Hz}$ (subsónicas e inaudibles) y los $8000 \mathrm{~Hz}$ ha sido señalado por la comunidad médica y tecno-científica como causante de

${ }^{6}$ Fueron encuestados numerosos músicos, sonidistas, bailarines, deejays, veejays, personal de gastronomía de locales bailables y público en general; no llegan a la decena los individuos que respondieron negativamente. 
sensaciones táctiles. De entre los trabajos relevados, la amplia mayoría se enfoca en estímulos de baja frecuencia ( 2 a $100 \mathrm{~Hz}$ aproximadamente) cuya fuente se encuentra en contacto directo con el cuerpo del sujeto perceptor.

A su vez, las frecuencias asociadas a la música son las mismas que tradicionalmente se vinculan a la generación de sensación auditiva: oscilaciones comprendidas aproximadamente entre los 16-20 y los $20.000 \mathrm{~Hz}$. Sin embargo, numerosos instrumentos musicales producen frecuencias que se encuentran por debajo de este rango (sub-sónicas).

En este sentido y a modo de ejemplo, las salas de proyección cinematográficas modernas cuentan con lo que se conoce como canal "LFE" ("Low Frequency Enhancer" o Refuerzo de Bajas Frecuencias), cuya finalidad es la de producir vibraciones en piso y butacas de la sala y en el cuerpo de cada espectador. Este sistema reproduce un rango de frecuencias que se encuentra entre los 3 y los $80 \mathrm{~Hz}$. Así también, la amplia mayoría de sintetizadores generan frecuencias sub-sónicas que los modernos sistemas de amplificación instalados en estudios de producción musical y locales de baile son capaces de reproducir.

Una excepción histórica (donde la sensación táctil fuera considerada) es el piso de las plateas de los auditorios de música, que desde el siglo XIX se deja vibrar entre los 50 y $100 \mathrm{~Hz}$ para que los asistentes perciban también la sensación audiotáctil, muy valorada en ese contexto.

\section{Rango de intensidad y relación fuente-sujeto}

Las sensaciones táctiles y audiotáctiles se tornan más evidentes en presencia de altos niveles de presión acústica (locales bailables, los ya citados cines, teatros, vía pública, terminales aéreas, polígonos de tiro y obras en construcción, entre otros). No se han hallado estudios dirigidos a determinar los umbrales-límite para la sensación táctil o audiotáctil; hecho lógico si se tiene en cuenta (como ya fue dicho) que la amplia mayoría de las investigaciones utiliza para el estímulo fuentes en contacto directo con el sujeto perceptor ${ }^{7}$ y cuando los datos referidos a fuentes remotas provienen de trabajos enfocados en problemáticas diferentes, donde los registros de sensaciones táctiles o audiotáctiles son considerados accesorios.

En la música la fuente de vibración es remota. Durante el trabajo de revisión bibliográfica realizado para la elaboración del Estado actual de la cuestión se detectaron solo dos antecedentes directos que consideran a la sensación táctil o audiotáctil originada en fuentes de vibración remotas:

a.- el hacer musical y difusión del mismo por parte de la percusionista hipoacúsica inglesa Evelyn Gleenie en su sitio de internet ${ }^{8}$ y;

\footnotetext{
${ }^{7}$ Estos estudios se focalizan en sensación táctil pura. Una situación experimental usual es la de situar al sujeto, de pié o sentado, sobre una plataforma vibrante.

${ }^{8}$ En línea. Accesible en http://www.evelyn.co.uk [09062015]
} 
b.- La tesis doctoral del Prof. Pablo Kogan Musso Análisis de la eficiencia de la ponderación "A" para evaluar los efectos del ruido en el ser humano."

El primer caso no evidencia trabajo científico sistemático que apoye -lo que parece- la exposición de una experiencia subjetiva y personal. El texto de Kogan Musso establece un marco general más amplio y -por los objetivos propios del trabajo- no focaliza especialmente en la sensación táctil o audiotáctil, sino que las considera una variable mas del tema que analiza. En definitiva, no se hallaron estudios extensivos respecto del tema, y apenas existen antecedentes con los cuales pueden establecerse vínculos. Dichos vínculos debieron rastrearse y deducirse en lecturas entre líneas de trabajos de investigación relacionados solo tangencialmente, y en áreas del conocimiento alejadas de la que nos ocupa.

Lo anterior no pone en duda la existencia de la sensación audiotáctil para la comunidad científica, sino que expresa la necesidad de un estudio más extenso que permita establecer sus rangos y umbrales. Similar a lo realizado para el rango audible en la década de 1930 por Fletcher-Munson, dichos rangos y umbrales requieren ser puestos en relación a la intensidad y a la frecuencia del estímulo.

\section{La música es un arte audiotáctil}

En la actualidad se sigue considerando a la música como un arte puramente "sonoro", dejando completamente de lado y obviando cualquier incidencia que pudieran tener sobre la percepción de las producciones musicales la sensación táctil y audiotáctil. El hecho de que el sonido posee una dimensión táctil, presente desde siempre en la música, ha permanecido invisibilizado durante siglos, cuanto menos parcialmente, debido probablemente a tabúes de nuestra cultura referidos al cuerpo. A pesar de la utilización prolífica de adjetivos que describen cualidades táctiles para caracterizar aspectos del timbre y de otros parámetros musicales, ${ }^{10}$ nula mención se hace de la sensación táctil o audiotáctil al momento de explicar los modos utilizados para la composición, interpretación y/o análisis de obras musicales; diseño de instrumentos reales o virtuales; diseño de salas de grabación o cualquier otra actividad vinculada al hacer musical. ${ }^{11}$ Esta dimensión del timbre se encontró ausente por completo de toda currícula musical hasta hace unos años.

\footnotetext{
${ }^{9}$ Kogan Musso, Pablo. (2004). Análisis de la eficiencia de la ponderación “A” para evaluar los efectos del ruido en el ser humano. Accesible en http:/www.fceia.unr.edu.ar/acustica/biblio/kogan.pdf [09062015]

${ }^{10}$ Por parte de músicos, ingenieros de sonido y demás integrantes de la comunidad musical.

${ }^{11}$ Salvo el caso del diseño de salas de concierto citado más arriba.
} 


\section{Incidencia de la tecnología musical}

Las tecnologías electrónicas derivaron en el desarrollo de nuevas fuentes sonoras con rangos extendidos de frecuencias e intensidades y en la invención de sistemas de refuerzo y amplificación electro-acústico para fuentes sonoras tradicionales. Estos dispositivos permiten sostener en el tiempo niveles de presión acústica difíciles o imposibles de obtener por medios puramente acústicos. Estas capacidades han puesto de relieve, han hecho más evidente para nuestra percepción, la existencia de sensaciones táctiles y audiotáctiles. Han servido para poner en evidencia estas sensaciones, ya presentes desde el inicio de los tiempos en los instrumentos acústicos: basta acercarse a un percusionista que se encuentre interpretando un tambor medianamente grave para, con cada golpe, sentir la onda expansiva alcanzando nuestro cuerpo.

La música (como todo arte sonoro) es un arte audiotáctil. Frente a la casi total ausencia de investigación al respecto, esta tesis doctoral constituye como su objeto de estudio a las relaciones complejas que se establecen entre las cualidades del estímulo vibratorio, la música y las cualidades de la sensación táctil y audiotáctil.

\section{RELEVANCIA}

La presente tesis propone una revisión del concepto mismo de "sonido" y por lo tanto de los conceptos de "música" y "arte sonoro". Estas artes amplían sus áreas de influencia, corriendo sus límites e incorporando una dimensión táctil a su territorio. Consecuentemente, todo arte que involucra sonido es -ya no solo sonoro sino que- audiotáctil. Los datos obtenidos permitirán:

a.- Profundizar la comprensión de los procesos involucrados en la percepción de los fenómenos tradicionalmente denominados "sonoros" y que hoy podemos definir como "audiotáctiles", tanto para el campo artístico como para la percepción lisa y llana en la vida diaria.

b.- Conocer algunos de los modos en que los seres humanos interpretan los datos audiotáctiles presentes en el espectro de una vibración compleja (el tradicionalmente denominado "espectro del sonido"). Como consecuencia, esto permitirá...

c.- Evaluar la incidencia de factores táctiles en la caracterización de ciertos aspectos de las sensaciones tradicionalmente identificadas como "sonoras", sobre la percepción de música y sobre la generación de su sentido.

d.- Comprender las razones que condujeron a que las sensaciones táctiles y audiotáctiles se pusieran en evidencia en el contexto específico de las músicas electrónicas utilizadas para el baile social.

e.- Identificar las vías corporales a través de las cuales los seres humanos consiguen información táctil y audiotáctil de su entorno. 
f.- Determinar las cualidades que asumen las sensaciones táctiles y audiotáctiles generadas a partir de variaciones de la presión acústica.

g.- Evaluar la utilidad de la sensación táctil como herramienta para el análisis, creación e interpretación de piezas artísticas que hagan uso de sonido y/o música.

Propone la descripción, desde una perspectiva audiotáctil, de configuraciones, lógicas organizativas y procesos musicales. Tomando a las músicas electrónicas utilizadas para el baile social como caso testigo y contexto paradigmático de ocurrencia de sensación táctil y audiotáctil, su análisis posibilita:

a.- Explorar posibles herramientas y categorías audiotáctiles, plausibles de ser aplicadas para el análisis de formas, procesos y actividades musicales.

b.- Caracterizar al estímulo musical audiotáctil.

c.- Determinar las variables musicales táctiles plausibles de ser trabajadas con fines estéticos.

d.- Comprender la incidencia de la sensación táctil y/o audiotáctil sobre los procesos cognitivos activos durante la producción, creación, interpretación y recepción musicales -en general- como también de las músicas electrónica y destinada al baile social -en particular-.

e.- Facilitar el trabajo sobre la materia audiotáctil con fines estéticos.

f.- Comprender los modos de operar sobre las variables de la materia audiotáctil (frecuencia, intensidad, etc.) que permitan una maximización de las sensaciones táctiles y/o audiotáctiles generadas/percibidas.

Accesoriamente, estos análisis permitirán también:

a.- Realizar un aporte a la caracterización de los conceptos de "música", "música electrónica" y "música de baile".

b.- Eliminar ciertos sesgos hallados en la caracterización que se hace de la música electrónica de baile.

c.- Caracterizar a las músicas electrónicas utilizadas para el baile social.

Más allá de los beneficios musicales enunciados -que podemos resumir en el término "operativos"-, este trabajo se propone también como demostración de un fenómeno que subvierte a la materia musical misma. El terreno sobre el que dicha disciplina asienta sus bases se transforma en su esencia más íntima, reconvirtiendo (a modo de ejemplo) a una entidad esencialmente abstracta destinada al tímpano y a la idea (como puede ser el conglomerado 
timbre-textura) en una forma concreta que se efectiviza en el aire y se destina al cuerpo del sujeto perceptor como todo (i.e.: la forma de onda, como forma de presión que se desplaza por el aire).

Es de esperar también que la presente investigación aporte datos que:

a.- conduzcan a mejorar o modificar el diseño de dispositivos electrónicos musicales, como también vinculados a la problemática de hipoacúsicos y no-videntes (destinados a suplir la falencia auditiva y/o a facilitar o mejorar la navegación por eco-localización) y; b.- permitan determinar la incidencia sobre la salud pública de diferentes dispositivos (i.e.: herramientas, transportes, etc.), locales y situaciones; útiles y necesarios para determinar políticas y normativas en áreas de esparcimiento, tránsito, trabajo, espacio público, urbanización, transporte público y privado, entre otras.

\section{PROBLEMAS}

\section{Problema general}

¿Qué relaciones se establecen entre las vibraciones presentes en música reforzada electroacústicamente y la sensación táctil y audiotáctil?

\section{Problemas particulares}

1.- ¿Qué características del estímulo son relevantes para la generación de sensación táctil y/o audiotáctil?

Numerosos estudios han demostrado que frecuencia, intensidad y duración de los sonidos influyen sobre la sensación táctil y audiotáctil. ${ }^{12}$ Cabe preguntarse si -en los contextos musicales explicitados con anterioridad- estos son los únicos factores o si, por el contrario, otras cualidades del estímulo favorecen o maximizan su generación, provocando variaciones o incrementos en la sensación táctil y/o audiotáctil percibida.

Por otra parte, considerarlas en su evolución temporal abre nuevos interrogantes, ya que estas cualidades establecen entre sí interacciones complejas. En otras palabras, modificar los valores de una conducirá a cambios en las demás. A modo de ejemplo, la ocurrencia de un ataque $^{13}$ breve provocará el acontecimiento de transitorios de ataque. ${ }^{14}$ Dada la amplia preeminencia de sonidos con ataque breve en las músicas utilizadas para el baile social,

\footnotetext{
12 Para un resumen de los mismos ver el Estado actual de la cuestión.

13 Ataque: el tiempo que tarda un sonido en alcanzar (desde "cero" o silencio) su máxima intensidad. En lo que se ha dado en llamar envolvente de intensidad (la evolución temporal de dicha cualidad) se reconocen tradicionalmente cuatro fases: ataque, decaimiento, sostenimiento y liberación (o extinción).

${ }^{14}$ Transitorios de ataque: componentes de ruido de rápida extinción que acontecen en diferentes regiones del espectro de frecuencias.
} 
indagaremos respecto del posible rol que los componentes de ruido pudieran tener en la generación de sensación táctil y/o audiotáctil.

En términos generales, el fenómeno previamente descripto acontece debido a que las cualidades mencionadas pueden ser subsumidas al interior -de la cualidad totalizadora- del timbre. Nuestra pregunta última consiste entonces en si el timbre posee algún grado de incidencia sobre la sensación táctil y audiotáctil. Siendo un campo muy vasto, lo formalizaremos a partir del establecimiento de las siguientes categorías:

a.- Oscilaciones de primer orden: los sonidos concretos emitidos por las fuentes sonoras. ${ }^{15}$ En este ámbito indagaremos la incidencia del ancho de banda sobre la sensación táctil y audiotáctil. Específicamente la distinción entre sonidos de altura tonal definida, tonicidad débil y altura tonal no definida.

b.- Oscilaciones de segundo orden: vibraciones que -de diferentes modos y presentando diversos orígenes- modifican la evolución temporal de las oscilaciones de primer orden. ${ }^{16}$ Exploraremos si el efecto de las cualidades de estas oscilaciones -sobre las oscilaciones de primer orden- tiene alguna incidencia sobre la sensación táctil y audiotáctil percibida. Rápidas modulaciones en la intensidad u otras cualidades de las oscilaciones de primer orden (i.e.: iteraciones) pueden agregar componentes de ruido equiparables a los transitorios de ataque. Por esta razón, frecuencia, intensidad y (especialmente) forma de onda de las oscilaciones de segundo orden podrían incidir de modo similar a aquéllos, provocando diferencias en las sensaciones táctiles y audiotáctiles (esto, tomando como referencia a oscilaciones de primer orden que no presentan este tipo de iteraciones).

2.- ¿Qué características asume la sensación táctil? ¿Qué diferencias de tipo, calidad, localización y profundidad corporales (entre otras) son perceptibles?

El cuerpo humano puede ser considerado un conjunto de sistemas y sub-sistemas resonantes. Dependiendo de los valores que asuman sus dimensiones principales (como todo otro cuerpo y espacio confinado), para su puesta en resonancia serán necesarios diferentes valores de frecuencia, intensidad y duración en el estímulo. Dadas estas relaciones y la ocurrencia de un estímulo musical de propiedades conocidas, es posible entonces preguntarse acerca de cuáles son los sistemas y sub-sistemas corporales de resonancia que se establecen y en los que se percibe sensación táctil o (lo que es lo mismo) cual es su localización corporal/qué elementos componen a cada sistema y sub-sistema corporal de resonancia.

\footnotetext{
${ }^{15}$ Las vibraciones principales y secundarias que constituyen a los eventos sonoros en sí mismos. Para más detalles ver el Glosario.

${ }^{16}$ Para más detalles ver el Glosario.
} 
Precisar estas variables corporales permitirá, en el mismo acto, determinar las relaciones que se establecen entre las cualidades del estímulo y las corporales. Dicho de otro modo, las cualidades de los diferentes sistemas y sub-sistemas corporales efectivamente resonando por presencia de un estímulo de características conocidas, permitirá deducir las cualidades (de uno y otro componente del sistema) que interactúan y determinan la ocurrencia de sensación táctil y/o audiotáctil.

De este mismo modo pueden hallarse respuestas acerca de la profundidad corporal que, si bien se encuentra en íntima relación con la cualidad previamente descripta, es posible de ser en cierta medida independizada. Así como para la localización corporal (a partir de un estímulo musical conocido), determinar las diferentes profundidades corporales en las que se percibe sensación táctil permitirá deducir las propiedades del estímulo que inciden sobre esta variable de la sensación.

Aún otra propiedad de la sensación táctil pueda establecerse por esta metodología. Entrecruzar un análisis de las relaciones complejas que se establecen entre las diferentes variables del estímulo sono-musical (i.e.: timbre, ritmo, textura, etc.), con las caracterizaciones de la sensación táctil que pudieran suministrar sujetos experimentales en las experiencias de campo proyectadas (i.e.: golpe, vibración, etc.), permitirá determinar tanto la calidad o cualidad de la sensación táctil percibida como el tipo de conformación musical que la provoca.

Por último, en presencia de sensación táctil y dependiendo principalmente de las cualidades de frecuencia que presente el estímulo, aquella podrá encontrarse asociada a sensación auditiva. La determinación de las relaciones que se establecen entre estímulos musicales diversos y las diferentes variables corporales permitirá -en cada caso- determinar el tipo de sensación percibida (i.e.: auditiva, audiotáctil o táctil).

3.- ¿Qué características corporales del sujeto experimental se tornan relevantes en el proceso de generación de sensación táctil y/o audiotáctil?

Si bien numerosos estudios han documentado la puesta en resonancia de sistemas y subsistemas corporales, estos lo han hecho a partir de estímulos vibrantes o sonoros, pero nunca musicales. Para el caso presente es posible suponer que algunas dimensiones corporales incrementarán -por resonancia- la intensidad de la sensación táctil percibida, mientras que otras podrán operar como atenuadoras de la misma. Estrechamente vinculado a las propiedades de las sensaciones táctil y audiotáctil, es necesario entonces indagar aquí qué dimensiones corporales pueden considerarse los resonadores principales. Como ejemplos, resonadores podrán ser -entre otros- la longitud y diámetro principal de los principales huesos del cuerpo, la densidad de vellosidad, la capacidad pulmonar, la longitud y diámetro de la tráquea, el diámetro del cráneo, etc. 
4.- ¿Qué cualidades poéticas, estéticas y técnicas de las músicas electrónicas utilizadas para el baile social pueden comprenderse como factores que condujeron a que la comunidad electrónica sea el contexto donde se detecta la mayor cantidad de testimonios al respecto de la sensación táctil originada en música?

Expandiendo temporalmente el concepto de iteración es posible establecer analogías y paralelismos con la reiteración, una de las cualidades particularmente propias de las músicas utilizadas para el baile social (y especialmente de las electrónicas). La ocurrencia de rápidas repeticiones se conjugan necesariamente con ataques y extinciones veloces y duraciones breves, configuración que responde (casi sin variantes) a los mismos principios enunciados para la iteración y que, consecuentemente, presenta las mismas posibles implicancias que aquella para con la sensación táctil y audiotáctil.

Ésta es entonces una de las muchas formas en que se incluyen cuestiones poéticas, estéticas y técnicas entre las consideraciones relacionadas a la sensación táctil y audiotáctil. ${ }^{17}$ Diversas cuestiones (demasiado extensas para siquiera mencionar aquí) determinan que junto al ritmo ingresen también aspectos que presentan aún mayor complejidad poético-estética: la textura. Variables de ambas propiedades musicales serán analizadas, procurando detectar las conformaciones que favorezcan/maximicen la generación de sensación táctil y/o audiotáctil.

\section{SUPUESTOS}

1.- Vibraciones derivadas de la ocurrencia de música -de características a determinarcausan sensación táctil y/o audiotáctil.

2.- La perspectiva que considera posible la cuantificación de la presión acústica en fonones (como equivalente acústico de los fotones lumínicos) para el análisis de frecuencias hipersónicas es plausible de ser aplicada a fenómenos macroscópicos originados en vibraciones de período de oscilación mayor.

3.- El cuerpo humano, como todo cuerpo y espacio confinado, posee frecuencias de resonancia naturales, dependientes de dimensiones corporales y espaciales principales.

Dichas dimensiones, dependiendo de las cualidades del estímulo vibratorio al que el cuerpo del sujeto perceptor es expuesto, resuenan provocando sensaciones táctiles y/o audiotáctiles de cualidades diferenciadas.

\footnotetext{
${ }^{17}$ En este caso concreto al ritmo, propiedad musical que se desarrolla en una escala temporal mayor y donde -por esa misma razón- la incidencia de cuestiones poético-estéticas resulta mayor que en la iteración. Esta última podría comprenderse como una propiedad puramente sonora o pre-musical y hasta cierto punto más próxima a lo "microscópico".
} 
4.- Los productores, músicos electrónicos y deejays de las músicas electrónicas utilizadas para el baile social, al momento de la creación, re-creación e interpretación de piezas musicales, toman en consideración al aspecto táctil del estímulo musical.

\section{OBJETIVOS}

\section{Objetivos generales}

1.- Explorar los vínculos y relaciones que se establecen entre las cualidades del estímulo sono-musical reforzado electroacústicamente y las cualidades de las sensaciones táctil y audiotáctil, procurando determinar las condiciones acústicas y fisiológicas necesarias para la ocurrencia efectiva de dichas sensaciones y para su detección consciente.

2.- Determinar las características del estímulo sono-musical y los valores de las dimensiones corporales que se tornan relevantes para la generación y percepción de sensación táctil y audiotáctil.

\section{Objetivos específicos}

1.- Determinar el modo en que frecuencias, intensidades y duraciones del estímulo sono-musical inciden en la generación de sensación táctil y/o audiotáctil. Este objetivo involucra también la búsqueda de corroborar o refutar la incidencia de la forma de onda y de la envolvente de intensidad sobre las cualidades percibidas de la sensación táctil y audiotáctil.

2.- Determinar las cualidades que asume la sensación táctil y/o audiotáctil. Se considerarán las siguientes variables y valores:

- Tipo de sensación: táctil o audiotáctil

- Calidad: golpe, vibración, presión, escozor y otros.

- Localización corporal: sensación de cuerpo entero o localizable en sistemas o subsistemas. En el último caso se procurará determinar en qué sistemas o sub-sistemas concretos se detecta la sensación.

- Profundidad corporal: cutánea, profunda, textil y otras. ${ }^{18}$

- Intensidad: imperceptible, apenas perceptible, media o fuerte.

Se procurará evaluar también un componente emocional. Así, la variable respuesta emotiva podrá asumir los valores: placer, displacer o neutra.

\footnotetext{
${ }^{18}$ El término "textil" refiere a una sensación detectada en algunas ocasiones, que consistiera en percibir la vibración de la ropa que se viste.
} 
3.- Determinar los sistemas y sub-sistemas corporales resonantes que se tornan relevantes en el proceso de generación y percepción de sensación táctil y/o audiotáctil.

La aproximación a este objetivo se realizará sin el establecimiento a priori de categorías. Se espera que los sistemas y sub-sistemas corporales resonantes surgirán de las mismas experiencias de campo a realizar. Sin embargo, a partir de los trabajos relevados por Kogan Musso y como fuera dicho, es posible suponer que presentarán resonancia efectiva dependiendo de las relaciones que se establezcan entre los valores de sus dimensiones principales respectivas y los de las cualidades de los estímulos musicales concretos que en dichas oportunidades se presenten.

Mas allá de esto, las propiedades de localización y profundidad de la sensación (ver objetivo 2) se encuentran en íntima relación y establecen ciertos criterios y límites aplicables a la cuestión aquí tratada.

4.- Determinar las cualidades que deben asumir las conformaciones musicales para que faciliten/maximicen la sensación táctil y/o audiotáctil generada/percibida.

Estrechamente vinculado al objetivo 1, se analizarán los desarrollos poético-estéticotécnicos concretos que, de las cualidades musicales mencionadas, realizan los creadores de las músicas electrónicas utilizadas para el baile social. Se procurará determinar así la incidencia que los mismos tienen sobre la sensación táctil y/o audiotáctil generada/percibida.

\section{HIPÓTESIS}

\section{Hipótesis general}

La generación efectiva de sensación táctil y audiotáctil depende primordialmente de la relación entre -por un lado- frecuencia, intensidad y duración del estímulo vibratorio y -por el otro- las dimensiones de las diferentes partes del cuerpo del sujeto perceptor.

\section{Hipótesis de trabajo}

1.- Ciertas cualidades de la sensación táctil y audiotáctil, como su intensidad o localización corporal, resultan determinadas por la relación entre las dimensiones de las diferentes partes del cuerpo del sujeto experimental y la frecuencia e intensidad del estímulo consideradas en su evolución temporal.

Las exploraciones se basarán en la premisa de que una relación causal -probablemente no lineal- se establece entre la forma de onda y/o la envolvente de intensidad (causas) y las cualidades de la sensación táctil y audiotáctil (efectos). Así, características impulsivas ${ }^{19}$ en el estímulo serán consideradas como facilitadoras de la puesta en resonancia de la masa corporal, rol que repercutirá amplificando la sensación táctil y/o audiotáctil percibida. De modo similar,

\footnotetext{
${ }^{19}$ En otras palabras, sonidos de ataque y extinción rápida, sin sostenimiento.
} 
se considerará que diferentes conformaciones espectrales serán causa de cambios cualitativos y/o cuantitativos en la sensación táctil y/o audiotáctil percibida.

2.- Sonidos impulsivos de altos niveles de presión acústica y, por extensión, iteraciones presentes en sonidos con cuerpo sostenido, pueden ser interpretados como fonones y facilitan la generación de sensación táctil y audiotáctil.

Otras investigaciones se apoyaran en la idea de que características impulsivas en el estímulo producen cambios cualitativos y/o cuantitativos en la sensación táctil y/o audiotáctil.

3.- Diferentes dimensiones del cuerpo humano provocan una respuesta no lineal a las frecuencias, espectro, intensidad y duración del estímulo vibratorio, resultando en resonancias deslocalizadas y de cuerpo entero, o localizadas en diferentes sub-sistemas corporales; lo que consecuentemente posibilita una detección de la sensación táctil en diferentes localizaciones corporales.

Para la organización de algunos aspectos del estudio se supondrá que diversas dimensiones corporales (como la longitud y diámetro principal de los principales huesos del cuerpo, la densidad de vellosidad, la capacidad pulmonar, longitud y diámetro de la tráquea u otras) resuenan a partir de diferentes frecuencias e intensidades, provocando sensaciones táctiles de cualidades diferenciadas en su localización corporal.

4.- Productores, músicos electrónicos y deejays de las músicas electrónicas utilizadas para el baile social, en ciertas situaciones configuran y modifican voluntariamente ciertas variables musicales con el objetivo de generar sensación táctil y/o audiotáctil.

\section{MARCO TEÓRICO}

\section{Saber común}

Es un saber común que la música produce sensaciones táctiles. La totalidad de las personas consultadas en el transcurso de los años que llevamos explorando el tema, ${ }^{20}$ al ser interrogadas respecto de si han experimentado sensación táctil cuyo origen asocian a acontecimientos musicales, dan una respuesta unánime y categóricamente afirmativa. Los individuos cuya respuesta fuera negativa constituyen un porcentaje tan pequeño que permiten catalogarlos como casos excepcionales.

\footnotetext{
${ }^{20}$ Ver nota al pie 6.
} 


\section{Multisensorialidad}

Numerosos estudios ${ }^{21}$ han demostrado multisensorialidad audiotáctil y una estrecha interrelación entre las percepciones auditiva y táctil. Sin embargo no se han encontrado estudios musicológicos que exploren este tema.

\section{Corporeidad}

La conductividad a las vibraciones de piel, ${ }^{22}$ huesos y órganos internos ${ }^{23}$ para el conjunto y segmentos del cuerpo humano ha sido probada en numerosas investigaciones; muy pocas para vibraciones originadas en fuentes remotas, sin contacto directo entre la fuente y el sujeto experimental, ${ }^{24} \mathrm{y}$ ninguna desde un punto de vista musical.

\section{Física acústica}

La física acústica ha determinado hace largo tiempo ya que todo espacio y cuerpo confinado posee frecuencias de resonancia determinadas por sus dimensiones principales dominantes (ancho, largo, profundidad, etc.) ${ }^{25}$ y el cuerpo humano no es excepción. Resta corroborar aún los valores concretos que inician y sostienen su vibración.

La dependencia de frecuencia e intensidad del estímulo es un hecho comprobado. Aún cuando vibraciones de baja frecuencia parecen ser más efectivas, se ha recopilado información que cuestiona este prejuicio y que determina al rango comprendido entre los 2 y los $8000 \mathrm{~Hz}$ como el plausible de generar sensación táctil. ${ }^{26}$

La experiencia de Merzenich y Harrington sugiere que sensaciones audiotáctiles podrían originarse también en bajas frecuencias de segundo orden (i.e: moduladores de intensidad,

21 Eimer, M. (2004). Multisensory Integration: How Visual Experience Shapes Spacial Perception. Current Biology, pp. R115-R117; Kayser, C. y otros. (2005). Integration of Touch and Sound in Auditory Cortex. Neuron, pp. 373-384. y Schürmann, M. y otros. (2006). Touch activates human auditory cortex. NeuroImage, pp. 1325-1331 por citar algunos.

${ }^{22}$ Por ejemplo Merzenich, M. y Harrington, T. (1969). The Sense of Flutter-Vibration Evoked by Stimulation of the Hairy Skin of Primates: Comparison of Human Sensory Capacity with the Responses of Mechanoreceptive Afferents Innervating the Hairy Skin of Monkeys. pp. 236-260; y Wernert, E. y Arns, L. (2004). Lecture 3.1 - Human Perception (II): Olfactory, Haptics, Motor Capabilities, \& Sensory Interaction en Introduction to Virtual Environments. En línea.

${ }^{23}$ Murfee, W. y otros. (2005). High-frequency, low-magnitude vibrations suppress the number of blood vessels per muscle fiber in mouse soleus muscle. pp. 2376-2380

${ }^{24}$ Véanse Toma, S. y Nakajima, Y. (1995). Response characteristics of cutaneous mechanoreceptors to vibratory stimuli in human glabrous skin. pp. 61-63 o Morgan, M. (1999). Sensory perception: Supernormal hearing in the blind? pp. R53-R54

${ }^{25}$ Basso, G. (2001). Análisis espectral. La Transformada de Fourier en la Música. Editorial de la UNLPREUN, La Plata.

${ }^{26}$ Entre otros: Mowbray, G. y Gebhard, J. (1957). Sensitivity of the Skin to Changes in Rate of Intermitent Mechanical Stimuli. pp. 1297 - 1298; Merzenich, M. y Harrington, T. (1969). Op. cit.; Von Gierke, H. y Nixon, C. (1959). M11. Experiments on the Bone-Conduction Threshold in a Free Sound Field. pp.128 y Urias, C. (2007). Vibración. Seguranca e Trabalho Online. En línea. 
sonidos diferenciales u otros). Este hecho podría explicar algunas de las dimensiones del timbre. $^{27}$

La comparación de resultados según las perspectivas de onda y de partículas puede suministrar datos cuantificables que favorezcan el control de la generación de sensaciones táctiles y audiotáctiles.

\section{Dualidad onda/partícula. Analogía fotón-fonón}

El sonido puede analizarse desde dos perspectivas, respectivamente coincidentes con la dualidad onda/partícula propuesta por la mecánica cuántica en $1927 .^{28}$ Desde la perspectiva de onda el fenómeno vibratorio asociado al sonido es visto como perturbaciones (crecimientos y decrecimientos de la presión del aire, tomando como referencia la presión atmosférica) continuas e indiferenciadas. ${ }^{29}$ Sonidos largos o de evolución lenta son ejemplos paradigmáticos y -por extensión y analogía- podemos decir que el movimiento de las moléculas de aire circundante "masajea suavemente" al cuerpo del sujeto receptor. El movimiento del aire es analizado en conjunto, como una entidad homogénea, elástica e indiferenciada.

La perspectiva de partícula toma en cuenta la característica no dispersiva del aire. ${ }^{30} \mathrm{Un}$ conglomerado de frecuencias originado en un mismo instante se propaga como un paquete de energía, fonón o vibrón [ver Ref.Biblio.3] y como tal alcanza al sujeto. ${ }^{31}$ Fenómenos vibratorios con rápidos cambios de intensidad hacen más evidente esta cualidad (i.e: sonidos pulsantes o impulsivos). ${ }^{32}$ El estímulo vibratorio es visto como discontinuo y diferenciado ${ }^{33}$ provocando cambios irreversibles en el medio gaseoso por el que se propaga. ${ }^{34}$ Fonones u ondas de choque han sido detectados en la fase de ataque de trombones ejecutados en intensidad forte. ${ }^{35}$ Análogamente, grupos de moléculas de aire "golpean" al sujeto de forma discontinua y diferenciada.

Comparar fenómenos acústicos que presenten una y otra característica permitirá detectar la importancia relativa de las oscilaciones/alternancias (de baja frecuencia) de segundo orden en la intensidad de la sensación táctil y/o audiotáctil generada/percibida.

27 Basso, G. (2001). Op.cit. y Štěpánek, J. (2006). Musical Sound Timbre: Verbal Description and Dimensions. pp.121-126

${ }^{28}$ Penrose, R. (2004). The Road to Reality. Traducción de Sanz, J. (2006). El Camino a la realidad.

${ }^{29}$ Ver Basso, G. (2001). Op.cit.; Lyver, D. (2000). Principios básicos del sonido para video. y Puig, S. (1997). Audio digital y MIDI, Guías Monográficas.

${ }^{30}$ Russell, D. (ca. 2001). En línea.

${ }^{31}$ Entre otros: Bertram, Martin y otros. (2005). Phonon Tracing for Auralization and Visualization of Sound. p. 20 y Deines, Eduard y otros. Sound visualization using phonon tracin and FEM. En línea.

${ }^{32}$ Long, C. (2003-04). Shock wave theory. Riffle Internal Ballistics, Longitudinal shock waves, and Shot Dispersion. En línea. y Maher, R. (2006). Summary of Gun Shot Acoustics. En línea.

${ }^{33}$ Bertram, Martin y otros. (2005). Op.cit. y sitio de la empresa Clark Synthesis. What is Tactile Sound? En línea.

34 Jagadeesh, G., (2008). Fascinating world of shock waves. pp.752-767

${ }^{35}$ Hirschberg, A. y otros. (1996) Shock Waves in trombones. 


\section{ESTADO ACTUAL DE LA CUESTIÓN}

\section{Multisensorialidad audiotáctil}

Durante las últimas décadas ha habido un renovado interés en el estudio de fenómenos de percepción multisensorial. Numerosos estudios prueban que zonas de la corteza cerebral que tradicionalmente se creían asociadas a un determinado sentido hoy se saben activadas por varios. ${ }^{36}$ Estudios en humanos ${ }^{37}$ y en macacos ${ }^{38}$ han probado la activación de la corteza cerebral en las mismas zonas, tanto para estímulos auditivos cuanto para táctiles. Resonancias magnéticas del cerebro de estos macacos dieron como resultado que:

[...] agregar un estímulo táctil simultáneo a un estímulo auditivo acentúa significativamente las activaciones dentro del cortex auditivo. [...] Así también, el cortex auditivo y las regiones insulares vecinas son enervadas por fibras del núcleo vestibular, introduciendo otra señal no auditiva a esta región, que puede integrarse con la actividad vinculada al sonido (Akbarian y/o., 1994; Guldin y Grusser, 1998). Juntos, estos resultados sugieren que el cortex auditivo está involucrado en el procesamiento multisensorial de varias formas, proveyendo entonces un interesante campo de trabajo para futuras investigaciones y generando el interrogante acerca de qué puede ser considerado como el verdadero cortex auditivo. ${ }^{39}$

El núcleo vestibular, asociado al sentido del tacto, suministra información que es procesada en la zona del cortex auditivo. La estrecha relación demostrada experimentalmente aparece, en este último párrafo, apoyada por la estructura física del sistema nervioso central.

La percepción alterada del tacto por el sonido conocida como la "ilusión de piel de pergamino" ${ }^{40}$ es otro ejemplo de interferencia audiotáctil. En referencia a este fenómeno encontramos que el:

[...] sonido producido cuando tocamos superficies texturadas provee información relacionada a aquellas superficies. Ha sido recientemente demostrado que la percepción de la textura de las manos puede ser modificada simplemente manipulando el contenido de frecuencias de esos sonidos asociados al tacto. ${ }^{41}$

Comparaciones entre la frecuencia percibida a través del tacto y de la audición muestran linealidad para estímulos de entre 10 y $320 \mathrm{~Hz}$; “esto sugiere que el mecanismo para la detección de la frecuencia es el mismo para la piel y el oído."42

Estos estudios prueban que los sentidos de la audición y del tacto se encuentran íntimamente relacionados en lo que respecta a las zonas de nuestro cerebro que procesa la

\footnotetext{
${ }^{36}$ Eimer, M. (2004). Op.cit.

${ }^{37}$ Schürmann, M. y otros. (2006). Op.cit.

${ }^{38}$ Kayser, C. y otros. (2005). Op.cit.

${ }^{39}$ Ibidem.

40 "Parchment-skin illusion" en el original. Jousmäki, V. y Hari, R. (1998). Parchment-skin illusion: sound-biased touch. pp. R190 y Schürmann, M. y otros. (2004). Hands help hearing: Facilitatory audiotactile interaction at low sound-intensity levels. pp. 830-832

${ }^{41}$ Guest, S. y otros. (2002). Audiotactile interactions in roughness perception. pp. 161-171

${ }^{42}$ Mowbray, G. y Gebhard, J. (1957). Op.cit.
} 
información tradicionalmente asociada a ellos. Los datos de interferencia mutua cuestionan la separación misma y obligan a abandonar aquella concepción que los definía como independientes y compartimentados.

\section{Las vías de la vibración - Piel}

Numerosos estudios médicos y neurológicos han explorado los mecano-receptores de la piel humana y de otros mamíferos probando su sensibilidad a distintas frecuencias e intensidades de vibración. La casi total ausencia de estudios que exploren la vía aérea de estimulación táctil hizo necesario buscar en áreas que tratan el tema de forma tangencial.

Si bien en la mayoría de las investigaciones mencionadas o por mencionar (salvo cuando se explicita lo contrario) los estímulos táctiles utilizados fueron de contacto directo, resulta posible suponer que las vibraciones generadas por la música son percibidas -por lo menos en parte- a través de alguno de los mecano-receptores de la piel humana. Esto puede inferirse a partir de que las “...unidades de adaptación rápida del Tipo II de los corpúsculos de Paccini y las de adaptación lenta de las terminales de Ruffini”...”son sensibles al estímulo remoto." 43

Una de las pocas referencias vinculadas a sensaciones audiotáctiles generadas por vía aérea la realiza Michael Morgan cuando expresa que:

[...] personas visualmente impedidas han descrito frecuentemente la experiencia de navegar por eco-localización, como siendo más cercano a sentir por tacto que por sonido: un objeto borroso ("looming object" en el original) parecerá rozar el seño más que ser oído aproximándose ${ }^{44}$

Cabe destacar que el área del rostro, junto con antebrazos y manos, es una de las zonas que mas activación de la corteza cerebral produce frente a estímulos táctiles. ${ }^{45}$

Lamentablemente, estudios sobre eco-localización han ignorado esta forma de percepción por completo. ${ }^{46}$ Los resultados potenciales del presente estudio, pueden aportar mayores datos y detalles sobre los modos de percepción de sujetos impedidos visuales que permitan mejorar el diseño de los dispositivos que dichas personas utilizan para su navegación.

El rango de frecuencias total aproximado del conjunto de los mecano-receptores de la piel según estudios centrados en los corpúsculos de Paccini, en los corpúsculos de Meissner y de los folículos pilosos para estímulos por contacto directo, se encuentra entre los 2-5 y los 400

${ }^{43}$ Toma, S. y Nakajima, Y. (1995). Op.cit.

${ }^{44}$ Morgan, M. (1999). Op.cit.

${ }^{45}$ Wernert, E. y Arns, L. (2004). Op.cit.

46 Després, O. y otros. (2005). Auditory compensation in myopic humans: Involvement of binaural, monaural, or echo cues? pp. 56-65 y Ramos, O. y Arias, C. (1997). Human Echolocation: The ECOTEST System. pp. 439-445 
Hz. ${ }^{47}$ La sensación subjetiva se divide en dos rangos de cualidad diferente: a) entre los 5 y los $60 \mathrm{~Hz}$ para la sensación de agitación/pulsación ("flutter" en el original) y b) entre los 50 y los $400 \mathrm{~Hz}$ para la sensación de vibración ("vibration" en el original) "con una rápida transición de cualidad en la zona de superposición”,48 cuando en el estímulo la frecuencia cambia de modo continuo. Aquí se reseñan también los 30 y $250 \mathrm{~Hz}$ como las frecuencias en las que se detecta máxima respuesta. Resultados similares fueron obtenidos por Toma y Nakajima para los mecano-receptores de adaptabilidad rápida del Tipo I. ${ }^{49}$ Otros estudios extienden el umbral de altas frecuencias hasta los $600 \mathrm{~Hz} .^{50}$

Los mecano-receptores operan aquí también, detectando vibraciones que son transmitidas a la piel por vía indirecta. Huesos, músculos, cavidades y tejidos del cuerpo humano, vibran por resonancia generando microdesplazamientos de la piel que son detectados por sus mecano-receptores, ${ }^{51}$ esta sensación suele ser llamada kinestésica y se encuentra asociada al modo en que "la posición del cuerpo, el peso, la tensión muscular y el movimiento son percibidos" [ver Ref.Biblio.1]. A su vez, los receptores de músculos y tejidos profundos envían su propia información al cerebro.

\title{
Las vías de la vibración - Huesos y tejidos profundos
}

Como en el punto anterior, múltiples investigaciones han explorado la sensación kinestésica por contacto directo con la fuente de vibración.

\begin{abstract}
Los humanos pueden percibir el sonido a través de dos vías diferentes: una es la transmisión del sonido a través del canal auditivo, otra es a través del cráneo. La tecnología de conductividad ósea ha sido utilizada principalmente para... [ayudar a] ...la audición en hipoacúsicos y como herramientas de comunicación en organizaciones militares. $^{52}$
\end{abstract}

La probada incidencia de las vibraciones en el incremento de la masa muscular y ósea en ratones ${ }^{53}$ ha determinado que plataformas vibrantes sean consideradas por la NASA como una posible solución parcial al problema de la pérdida de masa ósea y muscular en astronautas expuestos a la ausencia de gravedad. ${ }^{54}$ Entre otros resultados, estudios similares han detectado

\footnotetext{
${ }^{47}$ LaMotte, R. y Mountcastle, V. (1975) Capacities of humans and monkeys to discriminate vibratory stimuli of different frequency and amplitude: a correlation between neural events and psychological measurements. pp. 539-559 y Merzenich, M. y Harrington, T. (1969). Op.cit.

${ }^{48}$ Ibidem.

49 Toma, S. y Nakajima, Y. (1995). Op.cit.

${ }^{50}$ Calne, D. y Pallis, C. (1966). Vibratory Sense: A Critical Review. pp. 723-46. Ver también más adelante el sitio de la empresa Clark Synthesis

${ }^{51}$ Collins, D. y otros. (2005). Cutaneous Receptors Contribute to Kinesthesia at the Index Finger, Elbow, and Knee. pp. 1699-1706

${ }^{52}$ Watabe, Y. y otros. A study of bone conduction and its applications for audio signal transmission. pp. 3330

${ }^{53}$ Murfee, W. y otros. (2005). Op.cit.

${ }^{54}$ NASA. (2001) Good Vibrations. A new treatment under study by NASA-funded doctors could reverse bone loss experienced by astronauts in space. En línea.
} 
que: a) la mano humana posee sensibilidad a la vibración entre los 8 y los $160 \mathrm{~Hz},{ }^{55}$ b) los huesos del cráneo humano conducen vibración recibidas por vía aérea en el rango experimentado de los 1000 a los $8000 \mathrm{~Hz},{ }^{56}$ c) la máxima sensibilidad del sistema mano-brazo está comprendida entre 12 y $16 \mathrm{~Hz},{ }^{57} \mathrm{~d}$ ) "la resonancia del subsistema cabeza-hombros está en el intervalo de 20 a $30 \mathrm{~Hz}$." ${ }^{58}$ y e) puede observarse "un efecto de resonancia en la mandíbula inferior y el subsistema craneal en el intervalo de 100 a $200 \mathrm{~Hz}$." 59

La Norma ISO 2631 trata esencialmente de las vibraciones transmitidas al conjunto del cuerpo por la superficie de apoyo, que puede ser los pies o la pelvis. Su campo de aplicación se centra en las vibraciones transmitidas al cuerpo humano por superficies sólidas en un rango de frecuencias entre $1 \mathrm{~Hz}$ a $80 \mathrm{~Hz}$, para vibraciones periódicas, aleatorias, o no periódicas de espectro de frecuencia continuo. ${ }^{60}$

Varias empresas ofrecen a la venta transductores táctiles; dispositivos que transforman audio digital en vibraciones transmisibles a sillones y pisos a los que se los adosa. Clark Synthesis, fabricante de uno de estos productos, alega en su sitio de internet que como resultado de sus investigaciones el "ancho de banda táctil humano abarca desde lo subsónico, $20 \mathrm{~Hz}$ y por debajo, y lo sónico hasta los $800 \mathrm{~Hz}$ para la mayoría de los individuos, y hasta los 2 o $3 \mathrm{kHz}$ para individuos impedidos auditivos. ${ }^{~ 61}$ La misma fuente afirma que sus productos aprovechan la conductividad ósea de las vibraciones en el rango comprendido entre los $20 \mathrm{~Hz}$ y los $20 \mathrm{kHz}$. Los límites mencionados no parecen depender de una característica de la estructura ósea humana sino que la redacción sugiere que este está determinado por el dispositivo ofrecido. No se citan investigaciones que avalen el rango publicado.

En otro párrafo se menciona que "Estudios han mostrado que la mayoría de los individuos son muy sensibles al sonido táctil y pueden detectar un cambio tan pequeño como 2 Hz. Esta sensibilidad se aproxima a la del oído humano la cual puede detectar cambios de 1 Hz." ${ }^{, 62}$

De modo similar, en un experimento de diferenciación de frecuencias por contacto de la mano con un objeto vibrante, sujetos con hipoacusia severa congénita -además de demostrar un mejor desempeño que aquellas con audición normal- pudieron detectar fluctuaciones azarosas de la señal estable de referencia $(250 \mathrm{~Hz})$ menores a $1.1 \pm 0.3 \mathrm{~Hz}(2.3 \pm 0.1 \mathrm{~Hz}$ para los sujetos

\footnotetext{
${ }^{55}$ Morioka, M. y Griffin, M. (2006). Magnitude-dependence of equivalent comfort contours for fore-andaft, lateral and vertical hand-transmitted vibration. pp.633-648

${ }^{56}$ Von Gierke, H. y Nixon, C. (1959). Op.cit.

57 Aguila Soto, A. Procedimiento de Evaluación de Riesgos Ergonómicos y Psicosociales. En línea.

${ }^{58}$ Urias, C. (2007). Op.cit.

59 Ibidem.

${ }^{60}$ Aguila Soto, A. En línea. Op.cit.

${ }^{61}$ Sitio de la empresa Clark Synthesis. En línea. Op.cit.

${ }^{62}$ Ibidem.
} 
oyentes) ${ }^{63}$ La coincidencia entre los datos experimentales de los estudios mencionados, y lo publicado en el texto promocional de los productos de Clark Synthesis le confieren a este último alguna credibilidad; es posible pensar que los rangos publicados por esta empresa se basen en investigaciones científicas no detectadas por quien suscribe el presente proyecto. De cualquier modo, este hecho último sugiere poca investigación en el área.

Resulta también notoria la coincidencia que puede encontrarse entre los datos vertidos en párrafos anteriores y los resultados de uno de los numerosos trabajos que investigan la vibración de cuerpo entero ("whole-body vibration"). Sujetos expuestos a la vibración de dos sinusoides simultáneas de 10 y $8 \mathrm{~Hz}$, fueron más sensibles al estímulo que cuando se les presentaron las dos ondas de modo independiente.

La explicación probablemente puede ser encontrada en el fenómeno de batimento [...] Las señales sumadas de 8 y $10 \mathrm{~Hz}$ se repiten cada $0.5 \mathrm{~s}$, i.e.: con una frecuencia de $2 \mathrm{~Hz}$. La sensibilidad debida a la contribución de los $2 \mathrm{~Hz}$ combinada con el incremento de la amplitud de picos hace fácil la detección de la vibración. ${ }^{64}$

Cabe preguntarse aquí si las frecuencias diferenciales generadas por batimentos de frecuencias más altas (audibles) son plausibles de ser percibidas por la vía audiotáctil. De ser así, no estaría fuera de lugar suponer que este tipo de estímulo pueda generarse a través de la música. Dadas estas coincidencias, también resulta posible suponer una vía compartida de sensibilidad tanto para las vibraciones que impactan la piel por vía aérea, como para aquellas que alcanzan el cuerpo humano por vía sólida, provoquen o no éstas o aquéllas resonancias en los diferentes huesos, cavidades y tejidos constituyentes. ${ }^{65}$

Los múltiples métodos y rangos estudiados, como así también las diferentes condiciones en las cuales se realizaron los experimentos, han determinado diferentes resultados. Se destaca que en su conjunto, estos estudios dan prueba de la incidencia de la vibración en huesos y tejidos del cuerpo humano. Así también, no se han detectado estudios que exploren esta incidencia por vía aérea en todo el rango de frecuencias perceptibles de modo audiotáctil, ya sean estas originadas por ondas de baja frecuencia de primer orden (entre otras, sinusoides de baja frecuencia) o por ondas de baja frecuencia de segundo orden (por ejemplo, frecuencias diferenciales originadas por la interferencia de ondas de frecuencia de rangos superiores).

\section{Ámbito musical, contexto social y experiencias personales}

Las características del fenómeno social contemporáneo comúnmente conocido como "raves" o "fiestas electrónicas", caracterizados por la presencia de altos niveles de presión

\footnotetext{
${ }^{63}$ Levänen, S. y Hamdorf, D. (2001). Feeling vibrations: enhanced tactile sensitivity in congenitally deaf humans. pp. 75-77

${ }^{64}$ Ljunggren, F., Wang, J. y Ågren, A. (2007). Human vibration perception from single- and dualfrequency components. pp.13-24. Véase también Levänen, S. y Hamdorf, D. (2001). Op.cit.

${ }^{65}$ Ver supra Mowbray, G. y Gebhard, J. (1957). Op.cit.
} 
acústica, han dado lugar a que algunos asistentes concurran a los mismos munidos de protectores auditivos. Estos individuos, por el mismo hecho de proteger su sistema auditivo, dan prueba de ser conscientes del riesgo sanitario que acarrea asistir y aún así, lo hacen.

Digno de mención, algunos de estos eventos incluyen -en sus afiches promocionales y en carteles en el mismo local de realización- leyendas que advierten sobre altos niveles de presión sonora tales como "120 dB. Asistencia a su propio riesgo" [ver Ref.Biblio.2] nocivos para la salud. Frente a preguntas directas por parte de quien suscribe, numerosos asistentes a este tipo de eventos han brindado respuestas que implican la presencia de sensación táctil. Además de advertir sobre los futuros problemas de salud pública a los que deberá enfrentarse el conjunto de nuestra sociedad, el mismo uso de estos dispositivos constituye una de las pruebas de que las vibraciones generadas por la música son capaces de producir sensaciones táctiles y audiotáctiles.

La amplia mayoría de estos testimonios se han detectado en eventos con presencia de la llamada "música electrónica de baile". Por esta razón, se circunscribe el presente proyecto a los contextos donde se presentan este tipo de músicas reforzadas electroacústicamente. Si bien algunos instrumentos acústicos son capaces de alcanzar los niveles de presión acústica que $-a$ priori- parecen necesarios para la generación de sensación táctil o audiotáctil, en los contextos mencionados dicha presión es no solo alcanzada sino también sostenida con continuidad durante horas.

Se sopesó también la posibilidad que estas músicas ofrecen de repetir el estímulo un sinnúmero de veces; permitiendo a futuro tanto la repetición exacta de la experiencia pasada como la modificación de solo algunas variables.

En el transcurso de años pasados -antes del trabajo sistemático de campo- se realizaron experiencias personales que consistieron en la asistencia a locales bailables del tipo referido, y que incluyeron consultas directas a los asistentes y trabajadores de dichos locales y percepciones personales. Dichas experiencias han suministrado indicios de que:

a) las cualidades de la sensación táctil o audiotáctil dependen principalmente de la frecuencia, intensidad, duración y espectro de la vibración acústica presente.

b) vibraciones de baja frecuencia -y gran intensidad- resultan más efectivas para la generación de sensación táctil y audiotáctil.

c) existe sensación a nivel cutáneo, y ésta se torna más intensa (al menos en la piel de antebrazos) si sobre la piel se antepone una capa de ropa liviana en contraposición a la piel desnuda (se experimentó con tejido de algodón). Una explicación a priori de este hecho podría encontrase en que la ropa ofrece más resistencia al frente de onda por poseer una superficie mayor que la de los vellos de los brazos en su conjunto. Las 
vibraciones del tejido son transmitidas a los vellos y estos las transmiten a los mecanoreceptores táctiles cutáneos.

d) existe sensación táctil a niveles corporales más profundos como en huesos, estómago, piernas, cráneo, cavidad pulmonar y órganos internos (en este último caso, de más difícil localización). En algunos casos, sonidos de muy baja frecuencia producen lo que parecería ser atonía en la musculatura de las piernas. Varias personas han manifestado que las piernas se les aflojan en momentos determinados de piezas musicales.

\section{Distribución y desarrollos geográficos e históricos de la música electrónica de baile}

El desarrollo histórico y geográfico de la música electrónica de baile a nivel mundial ha sido expuesto con gran detalle y proliferación de anécdotas por Simon Reynolds en su extenso Energy Flash. ${ }^{66}$ Disponible en español desde 2014, su edición actualizada permite recorrer desde los orígenes de la especie hasta la actualidad, incluyendo multiplicidad de referencias a ejemplos musicales y entrevistas a los protagonistas (principalmente norteamericanos y británicos) de cada momento histórico.

Para el desarrollo local de las primeras vanguardias remitimos a los aportes de la publicación digital e impresa de 2011 de la Secretaría de Cultura de la Nación derivada del Festival internacional "La música en el Di Tella. Resonancias de la modernidad"67 y del libro Conversaciones en torno al CLAEM. Entrevistas a compositores becarios del Centro Latinoamericano de Altos Estudios Musicales., ${ }^{68}$ coordinado por Hernán Vazquez y basado en entrevistas realizadas en oportunidad del festival.

Una síntesis del desarrollo histórico local de las músicas electrónicas utilizadas para el baile social ha sido tratado por Victor Lenarduzzi en su libro Placeres en movimiento, dedicando la mayor parte de su tercer capítulo al tratamiento del tema. Valga decir también que en esta misma obra Lenarduzzi propone ciertos recorridos posibles para comprender la evolución de la música electrónica de baile a nivel global.

Por fuera de los trabajos mencionados en nuestro país existe muy poca información, la mayoría de la cual se encuentra desperdigada en la forma de entrevistas periodísticas fragmentarias en video a artistas locales; como en los casos previos, mayoritariamente centrados en artistas residentes u originarios de la Ciudad Autónoma de Buenos Aires. No siendo el foco central de nuestro trabajo, en cuestiones vinculadas a los desarrollos históricos y geográficos remitimos a las fuentes mencionadas. Donde sea posible y pertinente, sin apartarnos de nuestro tema central intentaremos realizar un aporte a esta cuestión.

\footnotetext{
${ }^{66}$ Reynolds, S. (2014). Energy Flash. (edición en español).

${ }^{67}$ Castiñeira De Dios, J.L. (2011). Op.cit.

${ }^{68}$ Vazquez, H. G. (2015) Op.cit.
} 


\section{Corolario, aportes y aplicaciones posibles de la investigación propuesta}

Numerosos estudios han abordado la relación entre la percepción auditiva y táctil, demostrando la estrecha relación que existe entre ambas. Sin embargo no hay estudios musicológicos que exploren este tema en un contexto musical.

La sensibilidad de la piel humana a las vibraciones ha sido probada en numerosas investigaciones. Muy pocas lo han hecho para vibraciones transmitidas por vía aérea y ninguna desde un punto de vista musical.

Quizá tantos como los dedicados a la piel, estudios que exploran la conductividad de vibración a través de los huesos han arrojado resultados positivos tanto para el conjunto del cuerpo humano como para segmentos del mismo. Todos, a excepción de uno, exploran la vibración por contacto directo y ninguno desde perspectivas musicológicas.

Fuentes secundarias y algunos análisis de experiencias asistemáticas personales, realizados desde la perspectiva de partículas, sugieren que oscilaciones/alternancias de baja frecuencia de primero o segundo orden pueden incidir de algún modo sobre la sensación táctil y audiotáctil generada. Las cualidades de estas oscilaciones es uno de los aspectos a explorar. Su frecuencia, la presión acústica necesaria y el espectro de frecuencias de sus componentes son algunos de estos aspectos.

La experiencia realizada por Merzenich y Harrington ${ }^{69}$ sugiere que la cualidad de la sensación audiotáctil en una determinada pieza musical podría depender -en parte- de oscilaciones/alternancias de segundo orden presentes en dicha pieza. Los efectos audiotáctiles originados a partir de estas oscilaciones podrían explicar alguna de las dimensiones táctiles del timbre. $^{70}$

La comparación de resultados según las perspectivas de onda y de partículas puede suministrar datos acerca de las condiciones necesarias para la generación de sensación audiotáctil.

La detección de sensaciones audiotáctiles generadas por la música puede abrir un campo de experimentación sumamente novedoso y completamente inexplorado tanto para la composición, como para la instrumentación, la síntesis sonora y la educación musical en general. Así también, puede suministrar una nueva herramienta de análisis musicológico y una nueva perspectiva para evaluar los fenómenos de los cuales se ocupan las disciplinas antes mencionadas.

La industria del audio, con todos sus campos de aplicación (i.e.: música, cine, videojuegos, etc.), también podría hacer uso de los resultados del presente trabajo.

Por otra parte, el análisis de los datos estadísticos referidos a rangos de frecuencias e intensidades presentes en los locales bailables se configura como fuente de evaluación posible

\footnotetext{
${ }^{69}$ Merzenich, M. y Harrington, T. (1969). Op.cit.

${ }^{70}$ Basso, G. (2001). Op.cit. y Štěpánek, J. (2006). Op.cit.
} 
para determinar la incidencia de los mismos en la salud auditiva de la población que asiste a eventos electrónicos. Conocer las condiciones necesarias para la producción de sensación táctil y/o audiotáctil permitirá determinar si es posible reducir los efectos nocivos que presenta la presión acústica en estos locales bailables sin reducir la sensación corporal que parecen procurar los asistentes. Objetivo que probablemente requiera estudios más allá de los planificados como parte de la presente tesis, los datos que ésta suministre podrán utilizarse como fundamento para procurar mejoras que los transforme en espacios menos agresivos para la salud auditiva.

Más allá de las aplicaciones en el campo musical y musicológico, determinar los rangos de frecuencias e intensidades necesarios para la generación de sensación audiotáctil y táctil pueden aportar datos que permitan, entre otros: mejorar y diseñar dispositivos de asistencia para personas visual y/o auditivamente impedidos; hacer más eficaces tratamientos médicos donde estén involucrados dispositivos vibrantes; rediseñar parcial o totalmente herramientas de trabajo para reducir la transmisión de las frecuencias que mayor incidencia tengan en el cuerpo humano; mejorar el diseño de dispositivos antivibratorios; determinar con más precisión que materiales y dimensiones son los apropiados para la construcción de estructuras antivibratorias y que rangos de frecuencias deben atenuarse más; mejorar el aislamiento acústico de un local.

Por último, fuera de los campos ya citados, los resultados de este trabajo pueden aportar datos útiles en campos de aplicación tan dispares como Biología (cod.0200), Física Acústica (0301), Biofísica (0302), Física Médica (0308), Ingenierías Civil (1700) y Acústica (1801), Computación (1802), Ingeniería Industrial (2000), Ingeniería Mecánica (2200), Hábitat, energía y ambiente (2906), Ciencias de la Salud (3000), Medicina Dermatológica (3209), de Rehabilitación (3220), del Trabajo (3221), Otorrinolaringología (3230) y Salud Pública (3237), Pedagogía (4308), Ciencias de la Información (4600), Lingüística (4700), Teatro (4806), Diseño Audiovisual (4808) e Industrial (4811), Psicoacústica (4999) y Sociología (5000).

\section{Advertencia a modo de delimitación del objeto de estudio}

Nuestro objeto de estudio y su contexto/fuente de ocurrencia se configuran como un acontecimiento multidimensional de un alto grado de complejidad. La generación de sensación táctil o audiotáctil a partir de músicas electrónicas utilizadas para el baile social involucra la ocurrencia simultánea de múltiples relaciones complejas entre dos entidades que resultan en sí mismas complejas. En el objeto de estudio, en su contexto/fuente y en las relaciones que entre ambos se establecen, convergen y se interfieren cuestiones culturales, sociales, cognitivas, perceptivas, estéticas, físico-acústicas, electroneurofisiológicas, de movimiento o baile y muchas otras.

Por otra parte, mientras la sensación táctil y/o audiotáctil se presenta como un objeto donde prima casi con exclusividad la innovación y donde la ausencia de categorías exige construir incluso el sistema a utilizar para su análisis, las músicas electrónicas utilizadas para el 
baile social ${ }^{71}$ se incluyen al interior de los estudios de músicas populares, de músicas de base tecnológica y de músicas vinculadas al movimiento y al baile; todos campos de estudio novedosos, recientemente surgidos y donde se detectan muy pocos trabajos científicos que los indaguen. ${ }^{72}$

Tal es la novedad e innovación inherente al estudio de nuestro objeto ${ }^{73}$ que nuestro trabajo aporta una perspectiva que trastoca la base misma sobre la que se asienta nuestra comprensión de los acontecimientos que denominamos tradicionalmente con los términos "sonido" y "música". Dadas estas características, su estudio no puede resultar una tarea ni sencilla ni breve y excede el marco acotado que brinda una tesis doctoral.

Por lo expuesto, advertimos que el trabajo que sigue es una búsqueda necesariamente incompleta. En la etapa inaugural que caracteriza a este trabajo, los desarrollos teóricos resultarán siempre parciales y truncos, y los análisis de obras, situaciones o ejemplos hipotéticos paradigmáticos presentarán múltiples y diversas vacancias.

Entiéndase entonces a cada uno de los trabajos y desarrollos mencionados como el inicio de un camino de análisis y reflexión destinados a cubrir aquellas áreas que, por su extensión, debieron quedar fuera de la órbita de esta tesis, ya de por sí extensa.

\section{Consideraciones en relación a las fuentes documentales y metodología}

Quizá por tratarse de expresiones tan recientes y en constante y veloz cambio, ${ }^{74}$ la mayor parte de la información vinculada al tema se halla en la forma de documentos escritos y audiovisuales, entrevistas en video, ejemplos musicales y otros contenidos en línea. Este hecho vuelve a internet la fuente documental por excelencia, por lo que en la bibliografía proliferan referencias de este origen.

Si bien algunas podrían ser consideradas informales, esta impresión inicial (falsa a nuestro entender) se diluirá al avanzar la lectura. Dicha documentación ha sido incluida principalmente en tanto material sobre el cual se realizó un análisis de significaciones y simbolismos subyacentes. En este sentido han sido incorporadas muchas de las entradas de la enciclopedia en línea y de creación colectiva Wikipedia. Dicha fuente se ha vuelto -para el tema que nos ocupa- un centro de referencia donde se encuentran expresadas las ideas y concepciones de los diferentes actores que integran lo que hemos llamado la comunidad electrónica. ${ }^{75}$

\footnotetext{
${ }^{71}$ Más allá de su necesario establecimiento como una nueva categoría.

${ }^{72}$ Como fuera mencionado con anterioridad, para contar los estudios en sensación táctil y/o audiotáctil (según la definiéramos) alcanzan los dedos de una mano. De las demás áreas, si bien los desarrollos son substancialmente mayores, continúan siendo campos de estudio (sin lugar a dudas) incipientes.

${ }^{73}$ Estudio en contexto que, como dijéramos en párrafos previos, involucra además el estudio de su contexto.

${ }^{74}$ Las fuentes consultadas coinciden en datar los orígenes de la música electrónica de baile hacia fines de la década de 1960 y su primer auge en los primeros ' 80 s y ' 90 s.

${ }^{75}$ Para el sentido asignado a esta y otras expresiones véase nuestro Glosario.
} 
Las fuentes multimediales permitieron y permiten también experimentar la vivencia siempre subjetiva- de la sensación audiotáctil que sonido y música provocan. Por las características sui generis del tema y por tratarse de una investigación en arte, dicha vivencia resultó un primer paso absolutamente necesario. Ha sido de suma importancia para esta pesquisa, hechos como sentir en el propio cuerpo cómo vibra la música; aprender (y aprehender) en la propia carne, huesos, cavidades pulmonares, etc. cómo vibran el aire y los objetos que nos circundan; percibir de modo audiotáctil fenómenos vibratorios sonoros y subsónicos ${ }^{76}$ originados en obras fundantes y fundamentales para la Historia de la música como Despertar de una ciudad ${ }^{77}$ de Luigi Russolo o La expresión de Zaar $^{78}$ del compositor egipcio Halim El-Dabh, así como los conocimientos teóricos adquiridos en el Doctorado en Artes de la Facultad de Bellas Artes (Universidad Nacional de la Plata).$^{79}$ En este sentido es que hemos incorporado numerosos ejemplos de videos en línea accesibles en el sitio YouTube.

Otras fuentes en línea permitieron también acceder a registros de vivencias y experiencias del pasado reciente vinculados al desarrollo tecnológico, musical, artístico, político y social; esferas o campos de la existencia humana estrechamente vinculados al universo de tabúes y construcciones simbólicas que inciden sobre las propiocepciones corporales individual y colectiva. Derivados de tradiciones y folklores (de orígenes diversos aunque) primordialmente occidentales, estos tabúes y construcciones simbólicas podrían apuntarse como los responsables de la invisibilización de la sensación táctil. Aún cuando la misma puede detectarse en aconteceres musicales y sonoros que acompañan a la Humanidad desde el principio de los tiempos, múltiples represiones invisibilizaron e invisibilizan al cuerpo del sujeto perceptor quien, carente de materia, se vuelve oyente puro cerebro y todo oídos de una música y sonido incorpóreos. ${ }^{80}$

A pesar de lo dicho, no todas las fuentes consultadas exponen una investigación subyacente con la sistematicidad y seriedad necesarias como para que los datos aportados puedan ser considerados genuinos sin un análisis crítico previo. Esta falencia se contrarrestó entrecruzando sus datos con diversas y numerosas fuentes documentales tradicionales, asistiendo a múltiples eventos con presencia de músicas electrónicas utilizadas para el baile social, con entrevistas realizadas en persona y por teleconferencia a protagonistas directos de la

\footnotetext{
${ }^{76}$ Tres formas de describir el mismo acto complejo de percepción audiotáctil, acción casi imposible de ser descripta en una única oración simple.

77 Presentada por primera vez en $1913-14$, es la primera pieza musical en utilizar instrumentos no convencionales (los intonarumori, fabricados por el propio Russolo y su hermano Antonio) de la que se tenga registro. Luigi Russolo - Risveglio di una Città. Subido por Jack OneEyed. Accesible en https://youtu.be/IC3KMbSkYNI [04102016]

${ }_{78}$ Mejor conocida actualmente como Wire recorder piece, se considera la primera pieza musical en utilizar material sonoro pre-grabado. Halim El-Dabh - "Wire Recorder Piece" (1944). Subido por Razor Edge. Accesible en https://youtu.be/j_kbNSdRvgo [04102016]

79 Advertimos que -para concretar la mencionada vivencia- es necesario que las piezas sonoras y musicales se reproduzcan en sistemas de amplificación que permitan elevadas presiones acústicas y rangos extendidos de frecuencias, especialmente hacia el registro grave.

${ }^{80}$ Para más detalles véase nuestro Anzil, I. (2012). Des-limitados. pp. 7-8
} 
comunidad electrónica local, componiendo ejemplos sono-musicales donde pudieran apreciarse aspectos puntuales del fenómeno vibratorio asociado a la sensación táctil y construyendo dispositivos que permitieran visualizar y percibir de múltiples maneras los efectos de la vibración sobre medios elásticos (i.e: los efectos del sonido sobre toda materia: aire en sistemas abiertos y cerrados, carne, líquidos, huesos, etc.).

Ha sido también de gran ayuda percibir de modo audiotáctil fenómenos vibratorios del entorno cotidiano. Disponer la atención a la detección consciente de sensación táctil o audiotáctil de -a modo de ejemplo- medios de transporte (subtes, aviones, autos, colectivos, etc.), explosiones (fuegos de artificio, disparos, escapes "liberados", etc.), impactos sonoros (de maquinaria pesada, containers, etc.) o expresiones musicales callejeras (desfiles con ensambles de músicos, grupos musicales informales en manifestaciones públicas, etc.) brindó un panorama algo más acabado de las conformaciones espectrales y de envolvente de intensidad que favorecen la generación de dicha sensación.

Hacer lo descripto en el párrafo previo obturando parcialmente la audición con protectores auditivos intraurales favoreció el proceso de familiarización con la sensación táctil. Esto a su vez repercutió en un incremento en la sensibilidad a dicho estimulo, favoreciendo al proceso de percepción audiotáctil. Solo como ejemplo y basando nuestra afirmación en numerosas apreciaciones subjetivas, bombos graves (de marcha) percutidos con un fragmento de manguera de goma generan una sensación táctil más fácilmente detectable que los excitados con maza de cabeza de fieltro. ${ }^{81}$ Atribuimos esta diferencia a que la mayor dureza y área de contacto de la manguera generan un ataque más pronunciado y una extinción más rápida que la provocada por la maza de fieltro, lo que resulta en un consecuente mayor ancho de banda. ${ }^{82}$ Esto provocaría una envolvente de intensidad más pronunciada a la vez que concentraría la presión acústica en un lapso menor de espacio-tiempo. ${ }^{83}$

Más allá de las extensas reflexiones teóricas que siguieron a la revisión de las diversas fuentes documentales, a partir de aquéllas y de las múltiples experiencias descriptas supra procedimos a modelizar lo que (hoy) consideramos las condiciones paradigmáticas e ideales que

${ }^{81}$ El fenómeno se detectó en varias ocasiones callejeras: durante los festejos del último mundial de futbol en las inmediaciones del obelisco de la ciudad de Buenos Aires y durante dos marchas de carácter político, también en Buenos Aires. En las tres oportunidades fue posible contrastar la sensación generada por un mismo bombo (tres en total, uno diferente en cada caso), ejecutado por un mismo instrumentista, con uno y otro medio de excitación, en inmediata sucesión uno con otro.

${ }^{82}$ Relación descripta por el principio de incertidumbre acústico, en breves palabras establece que la definición de su altura tonal es dependiente de la duración en una relación directa. Basso, G. (2000). "Nuevas tendencias en acústica musical" en: Revista Arte e Investigación. pp. 97

${ }^{83}$ Esta envolvente de intensidad sería más coincidente con la necesaria para la generación de un fonón. Fenómeno que, en principio, presenta las características ideales para la generación de sensación táctil al ser un acontecer vibratorio de gran ancho de banda, con componentes graves/sub-sónicos y de gran presión acústica. Por tratarse de un sonido impulsivo (ataque y extinción virtualmente instantáneos) todo lo anterior se concentra en un muy breve espacio-tiempo. De este modo alcanza el cuerpo del sujeto perceptor, impactándolo en la forma de "pared de presión acústica" que literalmente lo atraviesa deformando efímeramente su materia cárnica. 
la oscilación de la presión acústica debe cumplir para optimizar y/o maximizar la generación de sensación táctil o audiotáctil. Finalizado este trabajo, aplicamos el modelo en el análisis de numerosas piezas pertenecientes a las músicas electrónicas utilizadas para el baile social.

Por último, se realizaron mediciones y registros dinámicos espectrales y de nivel de presión sonora hallables en las músicas electrónicas utilizadas para el baile social presentes en locales bailables. Simultáneamente (a dichas mediciones y registros) realizamos encuestas a asistentes a dichos locales. Se procuró lograr algún grado de intersubjetividad cotejando los datos objetivos del estímulo musical en correlación con las respuestas subjetivas brindadas por los asistentes. Este método permitió evaluar, entre otros, el nivel de detección consciente de sensación táctil en dicho contexto acústico y algunas relaciones posibles entre las variables del estímulo y las cualidades de la sensación.

Así entonces, yendo específicamente al desarrollo de la presente tesis, en la Introducción del Capítulo I exponemos algunos antecedentes, el contexto de surgimiento y el devenir histórico de la música electrónica de baile. Analizamos luego (en el mismo capítulo) a esta especie musical, en tanto aquella alrededor de la cual se configura un contexto y una comunidad donde detectaríamos la amplia mayoría de testimonios respecto de que sonido y música generan sensación táctil. En el análisis desagregado de cada uno de los componentes de la expresión, desarrollamos las perspectivas teóricas para el análisis tanto de la especie musical como de la ocurrencia de sensaciones táctil y audiotáctil a su interior (i.e.: a partir de piezas que pertenecen a aquélla). Así también, procuramos establecer nexos entre diferentes músicas históricas y la actualidad de una especie (las músicas electrónicas utilizadas para el baile social) al interior de la que realizamos nuestros análisis audiotáctiles.

Nos vimos obligados a llevar a cabo una exposición acotada de los desarrollos que hicimos acerca de las implicancias filosóficas y que para la práxis musical y musicológica presenta la incorporación de la sensación táctil al interior de los complejos conceptualesvivenciales de sonido y música. Desarrollos realizados con anterioridad y que han sido incluidos en diversas publicaciones científicas, se encuentran disponibles para su consulta pública. ${ }^{84}$ Esta disponibilidad nos condujo a priorizar la cobertura de otra vacancia; un desarrollo que nos resultaba necesario y que sí incluimos en el presente trabajo: el estudio de las cualidades inherentes a las músicas electrónicas utilizadas para el baile social. Apoyándonos principalmente en los análisis incluidos en los anexos II y III, finalizamos el mencionado Capítulo I proponiendo una definición de dicho concepto.

El Capítulo II lo dedicamos por entero al análisis de las condiciones contextuales y de las cualidades sono-musicales que consideramos necesarias y más relevantes para la generación de sensación táctil. Aplicamos aquí lo que hemos denominado una perspectiva audiotáctil para

\footnotetext{
${ }^{84}$ Tres ensayos donde nos ocupamos específicamente de la sensación táctil y audiotáctil originada en sonido y música pueden descargarse accediendo a https://unlp.academia.edu/IvanAnzil [19102016].
} 
el análisis musical. A partir de desarrollos teórico-prácticos e incluyendo análisis concretos de obras, explicamos y ejemplificamos a) las conformaciones sono-musicales responsables de la generación de sensación táctil y audiotáctil, b) las cualidades que consideramos necesarias en dichas conformaciones, c) los modos en que dichas conformaciones ocurren en las músicas electrónicas utilizadas para el baile social, d) las interacciones complejas al interior de estas conformaciones en el mencionado contexto musical, e) las maneras en que dichas conformaciones interactúan con el cuerpo de los sujetos perceptores para generar sensaciones táctiles y/o audiotáctiles, f) las relaciones que se establecen entre dichas conformaciones y los diferentes sistemas y sub-sistemas corporales y g) las diversas cualidades que asumen las sensaciones táctiles y audiotáctiles generadas.

En los Resultados y conclusiones sintetizamos los hallazgos enunciados en las diferentes secciones y analizamos las prospecciones y derivas que el tema sugiere.

Acompañando al cuerpo principal, el Anexo I expone el desarrollo, datos recabados y análisis de los resultados de nuestras Experiencias de campo.

Los Anexos II y III son necesarios para comprender la complejidad inherente a las músicas electrónicas utilizadas para el baile social, cuestión relevante dado que alrededor de éstas se organiza el contexto paradigmático para el acontecimiento de sensación táctil y audiotáctil. En el Anexo II tratamos lo que hemos denominado El problema de los géneros de la música electrónica de baile. En el Anexo III, mediante análisis y descripciones realizados desde perspectivas próximas a las tradiciones musicológicas, procuramos establecer un nexo entre las categorías musicológicas históricas y las surgidas al interior de nuestra perspectiva audiotáctil. Intentamos de este modo brindar un anclaje más familiar para comprender las continuidades y rupturas tanto inherentes a nuestra propuesta como hallables, a nuestro modo de ver, en numerosas piezas de la especie músicas electrónicas utilizadas para el baile social.

El Anexo IV describe someramente a los diferentes actores involucrados en la comunidad electrónica y a algunas dinámicas y relaciones que se establecen entre éstos. Presentando cualidades novedosas respecto de otras comunidades musicales, permite comprender ciertas particularidades que asume un conjunto de piezas de la especie y brinda sustento a ciertas razones esgrimidas acerca de por qué las músicas electrónicas utilizadas para el baile social condujeron a la visibilización de la sensación táctil y audiotáctil.

El Anexo V describe brevemente las características que presentan los diferentes dispositivos tecnológicos utilizados en la producción de músicas electrónicas, junto a las capacidades de control y modificación sonora que ofrecen. Cuestiones centrales para las cualidades que exhiben las músicas electrónicas utilizadas para el baile social, este conocimiento resulta complementario para comprender los desarrollos expuestos en el cuerpo principal del trabajo. 
AGRADECIMIENTOS

Deseo agradecer el aporte desinteresado de los profesores de grado y posgrado quienes, a pesar de la excentricidad del tema, me estimularon a perseverar en mis perspectivas no convencionales.

A Gustavo Basso, director de tesis, por los constantes apoyos, ayudas, guías, lecturas y relecturas del texto de tesis, contactos, datos y opiniones. Sin ellas hubiera sido imposible llegar a buen término. ( $¡ T e$ deja preguntándote de dónde saca tanto tiempo! Gracias Gustavo.)

A Carlos Mastropietro, co-director de tesis, y al equipo de investigación de las cátedras de Instrumentación y Orquestación e Historia de la música. Su particular visión y las reuniones dedicadas a discutir la problemática que es objeto de esta tesis aportaron claridad al tema.

A la comunidad de usuarios del grupo Argensynth (facebook) por su gran ayuda suministrando información relativa a tecnología musical, actores de la escena electrónica local y demás cuestiones relacionadas al universo de las músicas electrónicas.

A quien, prefiriendo permanecer anónimo, nos facilitara el acceso a los locales de baile donde se realizaran las experiencias de campo; actividad esencial para comprender las condiciones en que se produce y detecta sensación táctil y audiotáctil.

A los compañeros y compañeras que gentilmente ofrecieran sus cuerpos durante las expediciones a locales de baile. Fede, Flor, Juli, Lei y Nacho: sin su buena disposición hubiera sido imposible realizar los relevamientos en tiempo y forma. ¡Gracias!

A Pablo Kogan Musso por aportar sus conocimientos en los temas compartidos entre nuestras respectivas tesis y por su disposición a debatirlos.

A Luis Campos por el intercambio de conocimientos relativos a sus experiencias con hipoacúsicos y percepción cutánea de sonido.

A Silvia, Matías y Fede. Ex compañeros de banda en Sonocroma con quienes debatiera en los momentos de gestación de la idea. Su forma de entender la música subyace a este documento.

A Javier Cardozo, Walter Bohmer y demás músicos, deejays, amigos, conocidos y entrevistados circunstanciales que desinteresadamente ofrecieron el resultado de años de experiencia a este trabajo. Imposible mencionarlos a todos pero, ¡Gracias también por su arte en largas noches audiotáctiles compartidas!

A mi familia directa y -en especial- a Florencia, quienes debieron soportar cotidianas locuras, obsesiones y rayes durante un tiempo más que considerable... los extrañé mucho este tiempo. ¡Gracias también por las revisiones del texto!

Finalmente, agradezco al proyecto nacional, popular, democrático y latinoamericano que condujo los destinos de nuestro país hasta hace un año y algunos días. Fueron 12 bellísimos años donde, además de mejorar la vida a los argentinos en muchas formas, se apoyó al sistema científico que me brindó la ayuda económica con la cual completé este trabajo. 
Probablemente me olvido de muchos amigos, amigas y colegas que realizaran aportes esenciales para este trabajo. Ojalá sepan disculpar mis falencias (quienes me conocen saben de mi pésima memoria). No faltará ocasión de agradecerles en persona.

El origen de la idea que motivó esta tesis doctoral se remonta al primer recuerdo de mi vida que no presenta carácter onírico: la explosión de una bomba que las fuerzas paramilitares hicieran estallar en la casa de mi infancia a finales de los años 1970s. Esa experiencia determinaría incluso (quizá inconscientemente) que me dedicara a las artes vinculadas al sonido y la música. Por esta razón, este proyecto se relaciona íntimamente con las luchas de los diferentes organismos de Derechos Humanos de Argentina y, por extensión, con las luchas de todos los Pueblos del mundo por su emancipación.

Dedico entonces este trabajo a Madres y Abuelas de Plaza de Mayo, a H.I.J.O.S., a los demás organismos de DDHH y a los militantes del campo nacional y popular. Un mejor mundo es posible.

Lo dedico también a la memoria de Mariano Etkin, maestro que me hiciera el compositor que soy. Sin su particular perspectiva esta tesis no existiría. 


\section{CAPÍTULO I}

\section{Música electrónica de baile. MARCO TEÓRICO}

\section{Introducción}

Desde fines del siglo XIX la Humanidad produce y vive los efectos de una revolución tecnológica que, entre muchas otras transformaciones, ha hecho posibles (a) el dominio y control de la energía eléctrica, (b) el registro, almacenamiento y reproducción posterior de fenómenos físicos y (c) la cuantificación y digitalización de dichos fenómenos. ${ }^{85}$ Estas transformaciones impulsaron e impulsan profundos cambios estéticos y técnicos en todas las esferas de la existencia humana. Basta pensar en el dispositivo que hoy llevamos muchos en el bolsillo (y en sus capacidades multimediales) para comprender el vinculo de extrema y estrecha proximidad que une hoy a la tecnología con el arte y para lograr conciencia plena de la transformación que ha acercado y acercan al hombre (o mujer, niñ@, trans-género o quien sea en tanto especie humana...) a su expresividad diversa. Tanto se han aproximado que, en algunos casos, resulta virtualmente imposible determinar la frontera entre arte y ciencia, entre razón y sinrazón.

Basta imaginar cómo era la vida antes de que la Humanidad controlara la electricidad (o recordar cómo era antes de la existencia de internet) para dar dimensión a los profundos y numerosos cambios que asientan sus bases en estos avances técnicos. Donde sea que se encuentre, cualquiera puede hoy grabar un sonido, capturar una foto, filmar un video, escribir un poema o iluminar las hojas para maravillarse ante el reflejo de la luz en el brillo perfecto de las lentes pulidas de los tricomas... y luego compartir sus experiencias en las redes sociales. ${ }^{86}$ Pulsando un botón tenemos luz, viento, calor, frío, cultura de regiones lejanas del planeta, supernovas de regiones lejanas del Universo o sonidos de lugares inaccesibles por tóxicos y mortales. Controlar flujos de electrones ha permitido a la Humanidad conquistar la noche y conocer de profundidades oceánicas, cavernas estrechas, intimidades cerebrales y de posibles orígenes violentos e inflacionarios de nuestro Universo. La propia existencia ideo-material humana se ve hoy atravesada, transformada y cuestionada por los avances tecno-científicos: ya no sabemos si somos información o materia, si matemáticas o energía, si existimos aquí o en la superficie bi-dimensional de un Universo/Multiverso holográfico... o si somos todo ello y más.

La música no ha quedado para nada ajena a este proceso. Los cambios producidos tanto en la cotidianeidad como en la "trascendentalidad" se aprecian también en las músicas de los nuevos siglos. Realizadas con o sin ella, nuevas maneras de hacer músicas surgieron a partir de la tecnología. Desde la fecha de invención del dispositivo que creó la posibilidad de re-producir

\footnotetext{
${ }^{85}$ Es decir, cuantificación y digitalización, entendidos como el registro, almacenamiento y reproducción de la información de dichos fenómenos.

${ }^{86}$ Cualquiera también, en cualquier momento y lugar, puede resultar inadvertidamente grabado, filmado, fotografiado o descripto en el poema de otro.
} 
(i.e.: presentizar) un fragmento de pasado sonoro, ${ }^{87}$ hasta la concientización de la verdadera cualidad dual subyacente de posibilidad/imposibilidad relativístico-cuántica de dicho fragmento, las tecnologías eléctrica y electrónica (análoga y digital) revolucionaron y revolucionan la música tanto en sus prácticas como en los modos de concebir todo lo vinculado a su universo de influencias.

En la Europa en crisis de principios del siglo XX (próxima a sufrir dos de sus peores guerras intestinas) la necesidad de encontrar algún modo de comprender y asimilar los profundos cambios y desequilibrios sociales originados en la Revolución Industrial desembocaría en el Futurismo: movimiento político, artístico y filosófico que promovería una actitud revolucionaria basada en el avance tecnológico. Sus integrantes pretendían construir un "mundo nuevo" a costa de la destrucción del "antiguo". Su radicalismo los llevaría a impulsar actitudes violentas e, incluso, a participar en la llamada Primera Gran Guerra europea. En esta tónica, el (inicialmente no-músico) pintor italiano Luiggi Russolo construiría su orquesta de intonarumori $^{88}$ y compondría (lo que a los ojos de hoy quizá son) las piezas musicales más revolucionarias del siglo XX. Sonidos tan nuevos, organizaciones tan innovadoras que a la comunidad musical le llevaría cinco décadas incorporarlas al universo de posibles de la música.

Con el transcurrir del siglo y paralelamente al surgimiento y desarrollo de nuevos dispositivos musicales de base tecnológica ${ }^{89}$ en diferentes regiones del planeta, se incorporarían al universo musical nuevos ritmos, timbres y formas de distribuir los sonidos, nuevos materiales a elaborar y modalidades de elaboración, nuevas musas para la inspiración, temas a tratar y dimensiones del sonido para manipular, nuevas formas colaborativas de componer, nuevos software, hardware e instrumentos, nuevos actores, expresiones, espacios y públicos entre otros. En síntesis, surgirían nuevas formas de componer, interpretar, percibir y concebir música.

En el terreno estrictamente técnico, los cambios mencionados se reflejaron en el surgimiento paulatino de numerosos dispositivos generadores, modificadores y de control del sonido. Dispositivos que, al mismo tiempo, transformaron las cualidades y variables del sonido (plausibles de ser trabajadas con fines estéticos) de maneras hasta entonces nunca oídas ni vistas. Sus consecuencias sin embargo llegarían mucho más allá, alcanzando ya no solo a la técnica sino al universo musical todo. Permitiendo escuchar lo in-escuchado e in-escuchable la tecnología adentró a la Humanidad en la era del presente continuo, de la máquina y del abismo del salto cuántico. Presente, pasado y futuro se fundirían en la eternidad re-productiva que la máquina posibilitó y, al mismo tiempo, la interrupción de cada re-producción evidenciaría el

\footnotetext{
${ }^{87}$ El fonógrafo de cilindro. Patentado por Thomas A. Edison en 1878. Ya en 1887-8 Emil Berliner desarrollaría el fonógrafo de disco o gramófono. Fuente: Wikipedia, múltiples entradas.

${ }^{88}$ Dispositivos que por medios mecánicos generaban un abanico diverso de sonidos complejos (chirridos, rugidos, roces, trepidares, etc.). En tanto "máquinas" y generadores de oscilaciones, algunos autores los consideran los antecesores no electrónicos de los modernos sintetizadores.

${ }^{89}$ Sintetizadores, samplers, secuenciadores y cajas de ritmo, controladores MIDI, consolas, parlantes, ecualizadores, compresores, espectrógrafos, procesadores, amplificadores, grabadores multipistas y software de edición y mezcla entre muchísimos otros.
} 
abismo de discontinuidad entre cada instante de Tiempo. La máquina hizo su aparición expresándose a sí misma.

Hasta los años 30 del siglo XX el desarrollo sería lento, caracterizado por la aparición esporádica de algunos dispositivos electromecánicos y eléctricos primitivos que, por diversas condiciones vinculadas al contexto, ${ }^{90}$ generarían un impacto (musical y social) limitado. Desde entonces y hasta la década de 1960 la invención de la válvula audión, ${ }^{91}$ el surgimiento de la electrónica, y luego el transistor y la ciencia del cómputo darían origen a lo que llamamos hoy música electrónica o electroacústica: estilo o especie donde el protagonista ${ }^{92}$ es ese aspecto que suele denotarse con las palabras "electrónico", "sintético" o "procesado"93. Nunca escuchados hasta la invención de los dispositivos con los que se la realiza, los sonidos y timbres electrónicos imposibles e impensados (a) crearon la realidad sonora sintética, (b) posibilitaron la presentación fragmentaria de realidades sonoras preexistentes ("acústicas" o "no-electrónicas"), (c) presentizaron y localizaron fragmentos de pasado y lejanía sonoros, (d) materializaron la realidad matemática, (e) maximizaron lo mínimo/ minimizaron lo máximo e (f) hicieron posible la expresión maquinal (i.e.: crearon la expresividad de la máquina). Timbres que evidenciaron corrientes de electrones, formas de onda que manifestaron la subyacencia de esta tecnología se escucharon por primera vez en el planeta Tierra y en la Historia de la Humanidad: el timbre de las matemáticas en los sintetizadores, el ritmo de la máquina en su precisión y complejidad, la

\footnotetext{
${ }^{90}$ Véase, por ejemplo, el caso del Dynamophon o Telharmonium de Thaddeus Cahill. Patentado en 1897, resultó estrictamente el primer sintetizador de la historia. Los masivos volumen y consumo de energía, sumados a los problemas técnicos que presentaba, llevaron al proyecto al fracaso comercial en breves años (1908). Holmes, T. (2008). Electronic and Experimental Music. Technology, Music and Culture. Tercera edición. pp. 27-29

${ }^{91}$ Primer válvula electrónica de tipo triodo. Inventada por Lee De Forest en 1908, permitió la amplificación de señales electrónicas.

${ }^{92}$ Lo que se jerarquiza y se vuelve pregnante a la percepción.

${ }^{93}$ Redefinimos al aspecto como la forma o apariencia que asume una parte del todo o alguna/s parte/s de cada todo. En el caso musical, la forma que asume una parte del total musical que constituye cada pieza concreta, una parte de "todo lo que suena" o, también, ciertas características de cada parámetro musical tomados como diferentes todos (partes de partes). Las cualidades mencionadas -que llamaremos simplemente "electrónicas"- pueden detectarse tanto circunscriptas a rasgos o parámetros musicales concretos como en comportamientos temporalmente o conformaciones complejas que exceden estas categorías. Procurando abarcar todos los casos hemos optado por utilizar el vocablo "aspecto". En algún sentido, el uso que le asignamos es semejante al que se les ha dado en entornos músico-eruditos a "manera" o "estilo"; por lo menos en lo que respecta al carácter totalizador, donde la "maniera" no se encuentra en un rasgo preciso sino que son las cualidades difusas que describen parcial y nunca completamente la forma que asumen los parámetros, rasgos, comportamientos y conformaciones (i.e.: nuestros aspectos) de una determinada pieza musical concreta. Como consecuencia, ninguna pieza asume un aspecto completamente electrónico y siempre posee rasgos provenientes de otras especies. Estas cualidades fluyen e influyen transversalmente y se ponen de manifiesto en todos (o en muchos de) los aspectos vinculados a la música. Sin pretender sistematicidad ni exhaustividad, algunos son: timbre, ritmo, uso del registro, instrumentación, diseño melódico, distribución energética o impulso, cadencia, periodicidad, referencialidad a la fuente sonora y fragmentación, etc. Buscando claridad de ideas y discurso, englobaremos la totalidad de estos aspectos en los conceptos (o complejos conceptuales-vitales) de "sonidos" y "timbres". El hecho de que sonido y timbre sean dos conceptos musicales difusos y totalizadores (a veces utilizados como sinónimos) permite a la vez englobar la inmensa complejidad subyacente como reflejar la profunda influencia que la tecnología tiene sobre la música. En adelante utilizaremos esta expresión para referirnos sintéticamente a la multiplicidad de dimensiones musicales donde pueden detectarse rasgos calificables como "electrónicos", "sintéticos" o "procesados".
} 
textura de lo microscópico en las nubes sonoras, sus "voces" en los vocoders, flangers y chorus, sus duraciones imposiblemente cortas e inhumanamente veloces, sus sonidos imposibles en las reproducciones fragmentarias, la omnipresencia de su existencia en la transformación infinita de sonidos provenientes del entorno acústico, ${ }^{94}$ sus parlantes y sistemas de amplificación, su rango extendido de frecuencias e intensidades,... todos nombres (entre los muchos posibles) de la huella electrónica en la música. ${ }^{95}$

La música electrónica o electroacústica (y sus dispositivos) alcanzaría los años '50s con desarrollos e investigación en laboratorios. Hasta principios de la década siguiente -y según el relato que asumen como propio diferentes fuentes especializadas- el alto costo de los equipos y los conocimientos necesarios para su control (y el del sonido) la mantendría confinada a esos entornos y disponible solo para los pocos expertos que pudieran acceder a los mismos. Ariel Martínez relata que "Ahora, para hacer música electroacústica cualquiera puede comprar una computadora y tener su laboratorio. En aquel momento, el acceso a alguno de los pocos laboratorios del mundo era pura fantasía." ${ }^{16}$ Fantasía que no se encontraba impulsada por la ampulosidad del equipamiento ya que agrega que "El [laboratorio de sonido] del CLAEM no se distinguía por su riqueza ni por su actualización." ${ }^{97}$ Quizá esta situación (identificable con la práctica tecno-científica) influyera también en que estas músicas fueran percibidas (e incluso definidas) por los propios actores y el público del momento como "experimentales". Músicas

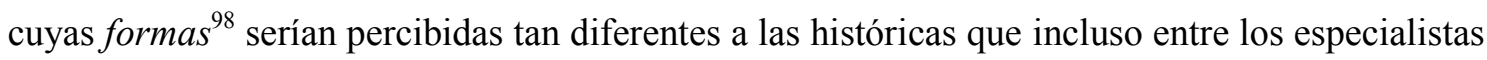
se realizaría una distinción: los compositores dedicados a estas prácticas -como así también las piezas musicales compuestas mediante estos dispositivos- serían adjetivados con los términos "experimental", "electrónico" (primero) y "electroacústico" (luego). Tal sería el extrañamiento provocado que sus cualidades resultarían estereotipadas como músicas de "lo extraño" o "lo distante": numerosos filmes de ciencia ficción, de monstruos y/o del género fantástico de la edad de oro de Hollywood incluyen piezas electrónicas. Los silbidos y glissandos del theremin ${ }^{99}$ se constituirían en el paradigma (y cliché) del timbre y expresividad electrónicos de la época.

\footnotetext{
${ }^{94}$ Entiéndase como "no-electrónico". Si bien todo fenómeno sonoro es "acústico", utilizaremos el término para referirnos a aquellos sonidos que se producen sin mediar dispositivos eléctricos ni electrónicos sino por medios acústicos (i.e.: un sonido de contrabajo o de dos piedras golpeándose).

${ }_{95}$ Poco ilustrativo intentar una definición, esta lista (aunque incompleta) brinda una aproximación mejor a lo que hemos caracterizado como el aspecto electrónico.

${ }^{96}$ Vazquez, H. G. (2015). "Ariel Martínez" en Conversaciones en torno al CLAEM. Entrevistas a compositores becarios del Centro Latinoamericano de Altos Estudios Musicales. pp. 186. Ariel Martínez fue becario en el Instituto Di Tella en los años 1969-71

${ }^{97}$ Ibid.

${ }^{98}$ Utilizamos este concepto en sentido amplio, no para referirnos al concepto musical restringido de forma sino extendiéndolo a sus timbres, procedimientos compositivos y texturas, entre otros aspectos de la música. Para un desarrollo exhaustivo de este uso véase nuestro Anzil, I. (2013). Ideo-materialismo musical. Crítica a los conceptos tradicionales de "sonido" y "música". Bajo el foco de la sensación táctil. pp. 16 y sgtes.

${ }_{99}$ Creado por Lev Termen alrededor de los años 1919-20, es quizá el primer instrumento electrónico que (para los estándares de la época) alcanzó cierto grado de "masividad".
} 
En cierto sentido a modo de paréntesis, resultan muy interesantes los dichos de Mariano Etkin al respecto del citado uso del término "experimental" para referirse a la música electrónica. Independientemente de que acordemos o no con ellos, resulta útil el modo en que desacopla al término de la generalidad de la música electrónica (con la que se establecía un vínculo casi de sinónimos). Retrospectivamente, durante una entrevista realizada en 2011 la considerará...

[...] una palabra que hoy sigue siendo complicada. ¿Dónde empieza y dónde termina lo experimental? ¿Cuando algo deja de ser experimental? Recuerdo lo que decía Varèse. Como le irritaba mucho cuando le decían que hacía música experimental, respondía 'Yo a los experimentos los tiro a la basura. Lo que queda, después de los experimentos, son las obras'. Entonces, ¿cómo podemos definir la palabra experimental? Tal vez, diciendo que es aquel compositor que arriesga algo, que va en contra de la historia, de las prácticas habituales, de las convenciones. ${ }^{100}$

Y agrega:

Para mí, un compositor experimental fue Morton Feldman con sus piezas para piano de los años cincuenta. Era una locura hacer esa música en ese momento. En esa época sí se podía hablar de música experimental, después fue mucho más difícil. ${ }^{101}$

En su respuesta a la siguiente pregunta Etkin cierra su idea diciendo:

Era imposible separarse de la idea de que estábamos a la vanguardia. Porque había un concepto de vanguardia. Vanguardia era el riesgo, los que hacían algo distinto al mainstream, la corriente principal. ${ }^{102}$

Autodefiniéndose como alguien que nunca tuvo una relación "fluida" con la música electrónica, Etkin vincula una y otra respuesta mediante el término "riesgo". De este modo restituye la aplicabilidad del concepto "experimental" a las músicas acústicas (o instrumentales, o no-electrónicas) y le devuelve su independencia perdida.

En el momento de su aparición, los timbres (literalmente) nunca escuchados generados por los dispositivos electrónicos provocaron inmenso impacto y dejaron una impresión muy fuerte en la generación que los experimentó por primera vez. Quizá este impacto se constituyera en el factor determinante para que no pocos individuos incurrieran en un error muy común y que aún hoy persiste: la asociación directa entre el instrumental electrónico y la especie musical homónima; el error de creer que la única condición que una pieza musical debe cumplir para ser considerada música electrónica o electroacústica es ser producida con instrumental de este tipo. Quienes cometen este error desechan -al mismo tiempo- las infinitas transformaciones técnicoestéticas posibilitadas por este instrumental; transformaciones que (junto a las provocadas por la

\footnotetext{
${ }^{100}$ Vazquez, H. G. (2015). "Mariano Etkin" en Op.cit. pp.108

${ }^{101}$ Ibid.

${ }^{102}$ Ibid.
} 
incorporación de las cualidades electrónicas al timbre) creemos constituyen la principal huella electrónica, el aspecto del que hablábamos antes.

Al mismo tiempo que determinaron muchas cualidades sonoras y musicales que exceden al timbre, los dispositivos electrónicos ofrecieron a la música modalidades de control ausentes en todo el instrumental preexistente. Con sus perillas, deslizadores, botones, controles de cinta, micrófonos aéreos y de contacto, aceleración y ralentizado del tiempo, parametrización del sonido, representaciones gráficas, (y luego) sensores infrarrojos, pantallas táctiles, guantes interactivos, capturadores de movimiento, auriculares, análisis espectral, edición no lineal y automatización (solo por nombrar algunas) los dispositivos electrónicos musicales inyectaron una batería de recursos que permitieron y permiten controlar y modificar sonidos y timbres en modos que (antes de su invención) resultaban imposibles. Esto nuevamente repercutiría incluso en músicas que no hacían uso de las nuevas tecnologías. Texturas de puntos, perspectivas espectralistas y microafinación son solo algunas posibles herencias electrónicas hallables en músicas no electrónicas... pero algo de esto llegaría más adelante en el desarrollo tecnológico.

En 1963 y 64 fueron concebidos y fabricados los primeros sintetizadores portátiles. Comparados con los grandes sistemas modulares que resultaban ser la norma del momento y que ocupaban paredes enteras, estos dispositivos resultaban mucho más baratos a la vez que permitían su transporte y ejecución sin grandes complicaciones. Los sintetizadores estuvieron disponibles entonces para ser interpretados en escena, en situación de concierto y recital. Esta situación derivaría en la paulatina adopción de este tipo de instrumental por cada vez más y más músicos y grupos musicales tanto experimentales como populares. Coincidente con el crecimiento exponencial del mercado de consumo, de la mercadotecnia orientada a grupos sociales y etarios diferenciados y (entre otros) con la identificación de la juventud como objetivo de mercado, la fabricación en serie de estos dispositivos favorecería la "electrificación" de las músicas orientadas al público joven. No siempre asociados al baile, los 70s se inscribirían en el relato mítico como el período de los pioneros de la música electrónica de baile. El rock, el disco, el funk y otros géneros verían modificada y ampliada su paleta de conformaciones posibles a partir de la incorporación de dispositivos generadores de timbres y texturas novedosos. Bajo la influencia del LSD surgiría la etapa psicodélica y un período de mucha experimentación en el ámbito de las músicas populares orientadas a esta audiencia. Kraftwerk, Giorgio Moroder, Tangerine Dream, Throbbing Grisle y otros acercarían las tecnologías y timbres electrónicos al público masivo.

En América Latina -logrando sortear el aislamiento del resto del mundo provocado por las restricciones que imponían por la fuerza las dictaduras instauradas para entonces- un lugar similar lo ocuparían grupos como La máquina de hacer pájaros, Los abuelos de la nada o Seru 
Giran. ${ }^{103}$ El compositor brasileño Jorge Antunes afirma que "Los Mutantes utilizaron un theremin en ese mismo período, creo que en el festival de 1967. Es decir, en ese momento los sonidos electrónicos se incorporaban a algunas canciones y arreglos de las piezas." 104 Así también, similar camino al de los Estados Unidos y Europa recorrió en Jamaica el reggae. En los mismos años y aprovechando las nuevas tecnologías musicales, sus productores tomarían material previamente grabado para reutilizarlo en nuevas músicas. Mediante la técnica del remix el reggae derivaría en el $d u b$. Este género es reconocido hoy como una de las principales fuentes de la música electrónica de baile.

Para los años 80's -las mismas fuentes especializadas dirán que- el desarrollo de la electrónica y la computación, su miniaturización y la consiguiente popularización de esta tecnología desembocaría en el surgimiento de lo que se ha dado en llamar "música electrónica de baile". Nutriéndose de diferentes especies musicales populares -entre las que se cuentan el disco, el funk y el jazz- la música electrónica de baile se diferenciaría paulatinamente de los géneros que le dieron origen y forjaría sus propias formas, actores y público, sus propios ámbitos y circuitos de distribución y disfrute. Poco a poco, sus cualidades diferenciadas se harían más evidentes y acusadas. Una compleja dinámica entre diferentes actores sociales, económicos y de diversas otras índoles -cuyos orígenes algunos autores remiten hasta los primeros '70s- harían sus aportes para que, paulatinamente y con el paso de los años, ciertas cualidades estéticas cristalizaran en esta nueva especie. De un único apelativo inicial surgirían múltiples estilos o géneros: englobados primero como simples house o techno, surgirían luego el electro, garage, dance, ambient, trance, goa, jungle, dubstep y muchos otros. Las generaciones jóvenes bailarían en los "boliches" argentinos a Depeche Mode, Erasure, MC Hammer y a los locales Jazzy Mel y Los encargados, entre muchos otros.

Para los primeros años de la década del 90 la especie se masificaría de la mano de "raves" y festivales como Creamfields, alcanzando su auge en eventos donde participaron decenas de miles de personas. Derivando de una región del planeta a otra y replicando una y otra vez clichés (hasta el punto de invertir o neutralizar la carga negativa de este apelativo) se gestó tanto la especie musical como su aspecto electrónico y el contexto diferenciado en que estas músicas se presentaron y presentan. Omnipresente en los 5 continentes, surgida al compás del desarrollo de las tecnologías de comunicación e internet, esta expresión quizá pueda ser considerada como el primer caso de especie musical global. Quizá éste puede rotularse como el

\footnotetext{
${ }^{103}$ Resulta notoria la total indiferencia hacia estas expresiones encontrada en los relatos míticos acerca de las músicas electrónicas de baile. No se ha encontrado un solo sitio o documento que tome en consideración los aportes realizados por América Latina a esta música. Como extensión del discurso y proyecto colonial europeo-norteamericano, África apenas si se menciona en tanto "cuna ancestral" de las músicas de origen afronorteamericano que (estas sí) aportaron rasgos. Especularmente, los países asiáticos ingresan al relato en los últimos años y en el rol de "versiones orientales de experiencias occidentales".

${ }^{104}$ Vazquez, H. G. (2015). "Jorge Antunes" en: Op.cit. pp. 49. Los Mutantes (Os mutantes en portugués) fue un grupo brasilero formado en 1966 por Rita Lee, Sérgio Dias y Arnaldo Baptista.
} 
período en el cual las cualidades distintivas se hicieron lo suficientemente claras como para que la especie se independizara de los géneros que le dieron origen. Si bien guardan características de aquellos y sería de necios negar sus herencias, ejemplos de estos años son quizá los primeros que no permiten ser catalogados claramente dentro de los géneros populares históricos que dieron origen a la música electrónica de baile. Para fines de la mencionada década la especie tendría su segundo momento de auge en nuestra región. Fiestas masivas como las de Parque Sarmiento, el club Ferro o la discoteca Cemento se realizarían en Buenos Aires; allí se presentarían deejays y productores como Javier Zuker, Carla Tintoré, Hernan Cattaneo o Carlos Shaw. ${ }^{105}$ Desde entonces, con altibajos, mantiene su presencia como industria-artesanato cultural argentino.

En la primera década (y media) del siglo XXI, motorizado por el surgimiento de nuevos dispositivos de control y generación sonora, y de control del proceso de producción musical, los géneros históricos de la música electrónica de baile continuaron experimentando fuertes derivas que resultaron en a) una mayor diversificación estética de los géneros originales, b) el surgimiento de nuevos géneros y c) el retroceso en la popularidad de géneros alguna vez centrales. Además de las derivas originadas desde el interior mismo de la especie (i.e.: las de origen tecnológico y las inherentes al hacer musical mismo, que poseen un peso específico por sí mismas), factores exógenos aportaron al incremento de la diversidad estética de la especie. Quizá a un ritmo menos agitado, músicos de todas partes del mundo y de diferentes extracciones sociales comenzaron a hacer propias sus cualidades y a mixturarlas con (entre otras influencias menos populares) géneros y especies locales y folklóricos. Así surgirían en nuestra región -además de las versiones locales de géneros foráneos- remixes electrónicos de temas de rock, pop y otros géneros, y las expresiones de tango electrónico, folklore electrónico y cumbia electrónica (o electrónica tropical). Este proceso de diversificación se encuentra en desarrollo actualmente a nivel global. No solo se reconocen cualidades estéticas divergentes al interior mismo de la mayoría de los géneros de la música electrónica de baile sino que piezas de cualidades aún más divergentes -por incorporar elementos exógenos a la especie (i.e.: locales, folklóricos, etc.)- se incluyen en sus ya históricos circuitos y locales de presentación. Esto condujo a preguntarnos si en la actualidad no es más acertado hablar de "músicas electrónicas de baile". El plural quizá refleja mejor el crecimiento exponencial de la diversidad estética que la especie (como mencionáramos, muy diversa desde su origen) experimenta en los últimos años. ${ }^{106}$

\footnotetext{
${ }^{105}$ Véase por ejemplo Guerreiro, L. (1998). "Raves. Las fiestas interminables." en Revista La Nazión, 20 sept 1998, ed. impresa. Accesible en http://www.lanacion.com.ar/212024-raves-br-las-fiestasinterminables. [04102016]

${ }^{106}$ Solo por ahora (y hasta tanto tratemos este tema específico) reservaremos la expresión en singular para referirnos -en sentido restringido- al concepto "histórico" o "vulgar" que sostienen los relatos más difundidos acerca del tema, y el plural -en sentido extensivo- cuando nos refiramos a lo que podemos llamar "la actualidad" de las músicas electrónicas de baile. Siendo esta apenas la primera de una serie de
} 
Esta pluralidad y diversidad se refleja también en la enorme cantidad de músicos electrónicos y deejays actualmente activos en nuestro país. Similar aunque no igual a sus colegas de la academia, a los compositores electrónicos del campo popular se los denomina con un término diferente. El concepto de "productor" no indica tanto diferencias entre el hacer de unos y otros sino que quizá remite más al rol diferenciado que cada uno juega en sus contextos respectivos. ${ }^{107}$ Sin embargo, subyacen concepciones muy diferentes en relación al vínculo que entablan con la música; tan diferentes que no pocos músicos "convencionales" consideran que los DJs y músicos electrónicos no son intérpretes sino que apenas "pasan música". ${ }^{108}$ Los artistas de la electrónica de baile -a diferencia de los "ídolos" del rock- llegan a ser anónimos, se ocultan tras identidades ficticias y en general se consideran apenas los promotores de una velada donde los protagonistas son el baile y la masa de bailarines en su conjunto. En la misma dirección, la originalidad de ideas (musicales) es en gran medida reemplazada por una cultura que ha sido denominada como del "reúso" por algunos autores y que se caracteriza por la reelaboración constante de materiales musicales. ${ }^{109}$ Incluso la enseñanza de esta música (o, al menos, de estas prácticas) se realiza no pocas veces en instituciones especializadas.

Así arribamos al momento más difícil de esta introducción...

¿Cómo describir la profundidad del cambio, el abismo que esta especie ha abierto en el devenir de la Historia de la Música? ¿Cómo explicar en breves palabras la incapacidad de la comunidad musical toda de ver este abismo? ¿Cómo fundamentar el hecho de que dicha comunidad no tome conciencia de lo que sucede desde hace por lo menos cuatro décadas? El lenguaje evidencia no solo sus limitaciones (como aquí) sino también (como veremos) herejías, herencias y prejuicios propios y ajenos.

Con algunas de sus cualidades heredadas de su predecesora experimental inmediata, otras tomadas de las especies populares que fueron su base y unas terceras que se presentan como rasgos sui generis, las músicas electrónicas de baile han sido y son uno de los principales motores de una transformación estética sin precedentes en el campo sonoro y musical. Con implicancias no solo musicales sino también filosóficas, políticas y sociales que aún no se

redefiniciones parciales que aplicaremos al concepto, amplía su territorio al contener también a estéticas algo mas divergentes y que pueden incluir elementos exógenos reconocibles y provenientes de diversos folklores (i.e.: los mencionados tango, folklore, cumbia, rock y pop nacionales, etc.).

${ }^{107}$ Quizá también puede pensarse que en esto influye el modo en que dicho hacer es percibido por los aficionados a esta expresión artística.

108 Son popularmente conocidas las expresiones que Norberto "Pappo" Napolitano utilizó para caracterizar a "DJ Deró" en el programa "Sábado Bus" hace algunos años. Respondiendo a los dichos de Deró en los cuales manifestó que en una fecha próxima "tocaría" música electrónica, Pappo cerró una sentencia despectiva con un "Andá a laburá' pibe".

${ }^{109}$ Llevado al extremo, este principio se generaliza con la reutilización de aquellos materiales que (valga la redundancia) más usos han tenido. Las mismas melodías, armonías, timbres, ritmos, entre muchos otros que dan forma a las piezas más difundidas o "exitosas" de la especie vuelven a escucharse en numerosas nuevas piezas. Este comportamiento provoca el extraño fenómeno de que aquello que en otras especies puede leerse como cliché, en el caso de la electrónica es expresión de homenaje e incluso ritual de idolatría tanto del material revisitado como del mismo reúso. 
aprecian ni comprenden en su totalidad, su inmensa influencia transformadora -incluso sobre músicas que no hacen uso de estas tecnologías- resulta hoy casi por completo desestimada en tanto campo de estudio válido. Este trabajo pretende entonces, entre otros objetivos, evidenciar la importancia que las músicas electrónicas de baile tienen para el devenir musical histórico. Sentamos aquí entonces el núcleo central e hipótesis de nuestro planteo, que al mismo tiempo resulta lo que consideramos el aporte principal de estas músicas al universo de la música en general:

\section{Las músicas electrónicas de baile y el contexto en el cual se desarrollan han puesto y ponen en evidencia que tanto música como sonido poseen una dimensión táctil.}

Pero... ¿cómo es posible que un avance técnico incidiera tanto en aspectos estéticos, creativos y filosóficos? Los dispositivos antes mencionados son capaces de generar un contexto acústico esencialmente diferente a todos los escuchados por la Humanidad hasta su aparición. Además de permitir la manipulación del tiempo, explicitar dicha manipulación y todo lo dicho con anterioridad, las músicas electrónicas de baile se han desarrollado en un contexto donde convergen numerosos factores (sociales, culturales, políticos, narcóticos, acústicos, tecnológicos, etc.) que propiciaron y favorecen la generación de sensación táctil. Los niveles monstruosos de presión acústica mensurables en los locales donde se la presenta, los rangos de frecuencias extendidos que esta música utiliza (sobre todo hacia las frecuencias graves), ${ }^{110}$ la ingesta de sustancias psicoactivas, un período socio-político caracterizado por la apertura hacia el cambio (al menos en el contexto local) entre otros factores, parecen haber interferido mutua y sinérgicamente al punto de transformar la esencia musical más profunda... su materia.

Las músicas electrónicas de baile lograron correr el límite de los conceptos de "sonido" y "música" hasta incluir la sensación táctil al interior de sus territorios. El aire ha dejado de ser mero medio de propagación para tornarse sustrato material de las artes que involucran sonido y/o música. El cuerpo de los oyentes musicales (hasta entonces ausente-en-presencia) ${ }^{111}$ se ha vuelto el efímero contenedor y sustrato material último de las vibraciones generadas por aquellos. Por todo esto, lo que los artistas sonoros y musicales realizan (realizamos) al presentar su (nuestro) arte son efimeras esculturas eólicas y propio-óseo-cárnicas que vuelven difusos los límites entre los cuerpos de los sujetos perceptores audiotáctiles y su entorno. A partir de allí ya no es nuestra la materia: tomando esa energía, serán los propios bailarines quienes transformen su cuerpo en danza; en calor, movimiento corporal y conexión con lo uno y lo otro, con sus yos respectivos y la otredad.

\footnotetext{
${ }^{110}$ Ambos posibles solo gracias a los modernos sistemas de amplificación sonora surgidos hace menos de medio siglo.

${ }^{111}$ Véase nuestro ya citado Anzil, I. (2012). Des-limitados. pp. 10
} 
Estas músicas son tan diferentes a todas las precedentes que la amplia mayoría de sus ejemplos solo pueden apreciarse en su completitud en locales dedicados y preparados para este fin. El equipamiento técnico que estos locales poseen permite y favorece la experiencia audiotáctil que subyace al trabajo (muchas veces sub-o inconsciente) de los productores de músicas electrónicas de baile. Por una parte, dicho modo perceptivo no puede ser generado por la mayoría de los equipos de audio hogareños; por otra, estas músicas han sido concebidas para ser experimentadas en el movimiento corporal y en un contexto de baile social y comunitario. Experimentarlas en otra situación suele desvirtuar sus cualidades y conducir a una apreciación errónea o equívoca. El cuerpo, el movimiento, el entorno y el otro danzante son elementos inherentes a estas músicas y necesarios para la realización de la experiencia completa. La referencia en el cuerpo del otro, la comunidad de cuerpos atravesados todos por la misma vibración y emotividad (no pocas veces narcotizada) y el rito dionisíaco, efímero y post-sexual, son cualidades asignadas por Lenarduzzi a la escena (o "escenio") electrónica. ${ }^{112}$ En su libro Placeres en movimiento, describe a la danza que se desarrolla en este ámbito como individualcolectiva: liberada de la tarea de seducción de un otro pareja, el baile se transforma en un goce individual-colectivo compartido con todos los demás bailarines; un trance donde la sensorialidad de todos resulta atravesada por múltiples estímulos compartidos. Continuando desde sus palabras podemos sintetizar que a) la empatía -con todo y con todos- provocada por la frecuente ingesta de sustancias psicoactivas, b) los movimientos corporales típicos asociados a estas sustancias y a esta especie musical, c) los sonidos y clichés de la música y d) la vibración mecánica del aire provocada por esta última y transferida a todos los cuerpos (i.e.: la sensación táctil propiamente dicha), son quizá los principales factores que propician la sensación de "comunidad" que los aficionados a la especie describen como propia de estos ámbitos y de la danza en eventos electrónicos.

Este jardín y los caminos que se bifurcan es lo que intentaremos recorrer con éxito. Y si no llegamos a destino, al menos habremos apreciado miles de flores.

\section{Perspectivas teóricas actuales}

Por la novedad del concepto "música electrónica de baile" y por la complejidad intrínseca a su universo no resulta sencillo encontrar definiciones precisas y que permitan abarcar dicho fenómeno en su totalidad. Por diversas razones, algo similar sucede con las correspondientes a los diferentes componentes de dicho concepto. Así encontramos (a modo de ejemplo) definiciones de "música electrónica" que se circunscriben a caracterizar dicha rama del arte musical a partir de un criterio estrictamente instrumental. Para dichas fuentes y rayando lo tautológico: "música electrónica es aquel tipo de música que emplea para su producción e interpretación de instrumentos electrónicos y tecnología musical electrónica." ${ }^{113}$ Textos de

\footnotetext{
${ }^{112}$ Lenarduzzi, V. (2012b). Placeres en movimiento. pp. 83.

${ }^{113}$ Wikipedia [en línea] https://es.wikipedia.org/wiki/Música_electrónica [06042016]
} 
investigación y tesis doctorales, libros digitales, documentales en video sobre el tema y entrevistas a deejays o actores vinculados a estas músicas presentan problemas similares. Éstos pueden resumirse en que la definición de música electrónica de baile o bien se evita, o bien presenta ambigüedades, vacíos, contradicciones y falencias de todo tipo. Procurando una primera aproximación al marco estético de nuestro objeto de estudio recorreremos aquellas que consideramos representativas por su contenido, forma, tipo de acceso y problemática puesta de manifiesto. Veamos entonces en primer término la entrada "Dance" o "Música electrónica de baile" incluida en la versión española de la enciclopedia en línea de creación colectiva Wikipedia:

La música electrónica de baile, $E D M$ (por sus siglas en inglés electronic dance music), música club, música dance, o simplemente dance, es un conjunto de géneros de música electrónica, como el house, techno, trance, eurodance, italo-disco, drum and bass, el híbrido dance-pop, entre otros. Orientada principalmente al baile, se caracteriza por estar realizada con sonidos sintéticos y ritmos bien marcados y repetitivos, con letras pegadizas cuando no es música instrumental.

Es también frecuente, en países no angloparlantes, emplear el término "dance" en un sentido más restrictivo -lo que puede originar alguna confusión- para referirse a un subconjunto de la música electrónica de baile integrado fundamentalmente por los géneros de mayor difusión entre el gran público, como son el dance-pop, el italo-disco, el euro-disco, el euro-dance y el trance. ${ }^{114}$

La definición/descripción de Wikipedia se presenta de un modo que, a nuestra manera de ver, involucra varios problemas.

Primeramente, la música electrónica de baile se encuentra superficialmente descripta y casi en nada definida. No se incluye prácticamente ninguna característica que permita identificarla por lo que, sin conocer estas músicas (y sus géneros) no podemos saber cuándo nos encontramos frente a una pieza de esta especie. Apenas iniciada la caracterización por medio del ambiguo "Orientada principalmente al baile" y de los escuetos "sonidos sintéticos y ritmos bien marcados y repetitivos" concluye, en la misma sentencia, con el contradictorio "con letras pegadizas cuando no es música instrumental".

Por otra parte, su sección definitoria posee un componente tautológico al utilizar la expresión "conjunto de géneros de música electrónica". Como consecuencia queda indefinido el primer componente del concepto (i.e.: "música electrónica"), el cual debería brindar las claves que permitan agrupar a los "géneros". Su indefinición nos deja huérfanos de criterios para concretar lo que en definitiva -según Wikipedia- es esta música: un "conjunto".

Sumado a lo dicho, los géneros no se enumeran exhaustivamente. En las dos oportunidades en que se hace alusión a los mismos se utiliza la partícula copulativa "como", dando a entender que apenas se incluyen algunos ejemplos. Por otra parte, no existe entrada en la enciclopedia que refiera específicamente y en detalle a los géneros de música electrónica de

\footnotetext{
${ }^{114}$ Wikipedia [en linea] http://es.wikipedia.org/wiki/Dance [16102014]. Es oportuno aclarar que a través de los años esta música ha recibido también los nombres (no incluidos en Wikipedia) tecno y house.
} 
baile. Esto agrega más ambigüedad a una (in-)definición ya de por sí difusa debido a que los géneros son muy numerosos y diversos en sus cualidades. En su versión inglesa, para la categoría "música electrónica", Wikipedia reconoce 23 géneros y 173 sub-géneros ${ }^{115}$ mientras que McLeod, en su trabajo sobre este tema específico, dirá:

Metagéneros como el rock and roll pueden haber engendrado el rock, folk rock, acid rock, garage rock, punk rock, y más recientemente el grunge, rock alternativo, postrock, y otras combinaciones semánticas aún no acuñadas, pero la música electrónica/de baile genera esa cantidad de nombres en una fracción del tiempo. Para ilustrarlo, un cuidadoso relevamiento de revistas y CDs que compilan electrónica/de baile publicados en 1998 y 1999 arrojó una lista de más de 300 nombres. ${ }^{116}$

Solo el género House (uno de los que más ha perdurado históricamente) presenta en la enciclopedia en línea 38 subgéneros (y en otros caso de la misma enciclopedia, 51). Por su amplitud estética, este último ha sido caracterizado como "divergente", "irremediablemente fragmentado" y no poseyendo "ningún atributo particular" al punto de que el "house se ha vuelto algo así como un nombre que sirve para todo en música que es dance (no pop!), pero que no cabe en otra categoría de dance." 117

De hecho, todo el sistema de categorización de las piezas musicales concretas en géneros discretos incluye a su interior su propia negación. A modo de ejemplo, la cualidad experimental recorre transversalmente piezas de todos los géneros, constituyéndose a su vez en una especie de género 24 (ref.: los 23 géneros de Wikipedia). Se supone que las piezas experimentales pueden (tienen permitido) por igual tomar cualidades de los diferentes géneros de música electrónica de baile como de cualquier otra música. Esto le permite incorporar elementos, recursos y procedimientos exógenos hacia el interior de la especie. De esta manera las zonas límite compiten con el territorio que podría llamarse "propio" de la especie; territorio propio de cualidades ya de por sí borrosas y difusas. ${ }^{118}$ Este es otro de los argumentos que

\footnotetext{
${ }^{115}$ Wikipedia [en línea] https://en.wikipedia.org/wiki/List of electronic music genres [30032016]

116 "Metagenres like rock and roll may have spawned rock, folk rock, acid rock, garage rock, punk rock, and more recently grunge, alternative rock, post-rock, and other semantic combinations yet to be coined, but electronic/dance music generates that many names in a fraction of the time. To illustrate, a careful scan of electronic/dance-oriented magazines and electronic/dance compilation CDs published or released in 1998 and 1999 yielded a list of more than 300 names." McLeod, K. (2001) "Genres, Subgenres, SubSubgenres and More: Musical and Social Differentiation Within Electronic/Dance Music Communities." en Journal of Popular Music Studies, 13. pp. 60 Esta traducción, como todas las siguientes, son nuestras. ${ }^{117}$ Snoman, R. (2014). The Dance Music Manual. Third Edition. Edición digital. pp.347. La cita completa reza: "The divergence of house music over the subsequent years has resulted in a genre that has become hopelessly fragmented and as such cannot be easily identified as featuring any one particular attribute. It can be funky drawing its inspiration from disco of the 70s; it can be relatively slow and deep drawing inspiration from techno, it can be vocal, it can be party-like or it can simply be pumping. In fact, today the word house has become somewhat of a catch-all name for music that is dance (not pop!), yet doesn't fit into any other dance category."

118 Referimos y referiremos con estos términos a lo que se conoce como "lógica borrosa" o "lógica difusa". En algún sentido opuesta a la "lógica binaria" (donde los opuestos son mutuamente excluyentes), una excelente introducción a la misma la constituye el libro Briggs, J. y Peat, F. (1989). Espejo y reflejo: del Caos al Orden. Guía ilustrada de la teoría del caos y la ciencia de la totalidad.
} 
fundamentan la pregunta acerca de si nos encontramos efectivamente ante una música o varias. Para este tema, lejos se encuentra la enciclopedia en línea de darnos una respuesta.

La expresión "de baile" implica la existencia de música electrónica que no tendría esta finalidad o que no sería danzable. El problema que encontramos aquí es la contradicción directa entre esta perspectiva y las principales líneas de pensamiento actuales de la danza y el movimiento, las cuales sostienen que toda música (e incluso el silencio) son "bailables". ¿Cómo debemos comprender entonces que esta música esté "orientada al baile"? ¿Cómo se concreta dicha orientación? La expresión "de baile" implica e involucra además la complejidad extra de considerar dicho carácter de la especie en tanto vinculación con otros géneros -de danzahistóricos. Con esto nos referimos a géneros que históricamente fueran utilizados para la danza social (i.e.: no profesional). En otras palabras, ¿cuál es el vínculo que une a las músicas electrónicas de baile con las demás músicas de baile? ¿qué cualidades comunes presentan? Ninguna de estas cuestiones se responden en la entrada dedicada a la especie.

En síntesis, la (supuesta) definición de Wikipedia exige para su comprensión que:

1.- Conozcamos con anticipación las cualidades de la música electrónica de baile, debiendo además proveernos de los medios para conocerlas, ya que la descripción da pocas y pobres pistas de cómo identificar ejemplos de esta música.

2.- Tengamos conocimiento de al menos una de sus influencias históricas, la música electrónica. Tarea para la que tampoco brinda referencias por lo que nos pone nuevamente frente al problema de la identificación de ejemplos.

3.- Seamos capaces de reconocer tanto a todos los géneros que componen la especie (cuales son, de entre la totalidad de los géneros musicales contemporáneos) como a las características sui generis del conjunto (i.e.: de la música electrónica de baile) y de cada género. Este problema, refractario (o... ¿complementario?) del primer conocimiento requerido, conduce a un círculo vicioso paradójico: sin conocer las cualidades que permiten determinar si un ejemplo pertenece o no a la especie, ¿cómo hacemos para (re)conocer los géneros que la componen? ...y sin conocer la totalidad de los géneros que conforman la especie, ¿cómo podemos reconocer las cualidades propias que determinan los límites del conjunto y de cada sub-conjunto de piezas musicales? Todo, sin tomar en cuenta ni a nuestro llamado género 24 ni a las piezas que presentan elementos exógenos.

4.- Desconozcamos los desarrollos teóricos que durante el pasado siglo se realizaran en las ciencias que estudian los movimientos de la danza y la expresión corporal o, si decidimos tomar un camino que evite la deshonestidad...

5.- Conocer todos y cada uno de los (históricos) géneros de músicas utilizadas para el baile social y sus cualidades de conjunto. Para ello, como puede suponerse y tal como 
sucede para las músicas electrónicas de baile, debemos conocer las cualidades de cada género.

Como hemos visto, no son pocos los problemas que presenta la (in-)definición de música electrónica de baile de Wikipedia en español. En sus fuentes documentales, los autores explicitan que ésta deriva de la traducción que dicha enciclopedia presenta en su versión inglesa, la cual resume a su vez la extensa exposición que Mark Butler realiza en su tesis doctoral Unlocking the groove: Rhythm, meter and musical design in electronic dance music. ${ }^{119}$ En su trabajo, Butler expone un análisis pormenorizado de rítmica, métrica, textura y forma de varios ejemplos de música electrónica de baile. Sin embargo, contrastando la profundidad del desarrollo, su definición resulta tanto o más acotada que la de Wikipedia, y su objeto de estudio aún más difuso que el propuesto en el sitio. Respecto de los géneros, Butler asume una perspectiva histórica compartida con la amplia mayoría de las fuentes relevadas; pero al mismo tiempo excede esta perspectiva, apartándose de la generalidad de las fuentes. Así dirá (de modo similar a -por ejemplo- Reynolds, Demers y Snoman ${ }^{120}$ ) que House y Techno serán los primeros géneros en surgir y popularizarse, pero también que:

Caracterizo ciertos géneros como "mayores" sobre la base del modo en que los fans y músicos usan los términos (según lo observado en exploraciones de campo, listas de correo electrónico y fuentes periodísticas); los géneros "mayores" son los que ellos utilizan más frecuentemente como categorías amplias. ${ }^{121}$

Butler propone estos argumentos (y otros que veremos luego) como los criterios para determinar a qué género corresponde cada ejemplo concreto. Sin embargo, si bien proclama que su tesis es válida para la totalidad de la música electrónica de baile, en la sección dedicada al análisis musical el autor elige focalizar primordialmente en el Techno ("con solo unas pocas excepciones"). ${ }^{122}$ Una vez más, el problema de los géneros permanece sin resolución, manteniendo la ambigüedad e indefinición de la especie.

Si bien Wikipedia en inglés agrega algunos datos ausentes en su versión española, no difiere demasiado de ésta, preservando tanto sus precisiones como sus vaguedades y prejuicios. Al igual que la definición analizada en primer término, esta tampoco logra abarcar todas las expresiones conocidas que pueden ser incluidas en la especie.

\footnotetext{
119 Butler, M. (2003). Unlocking the groove: Rhythm, meter and musical design in electronic dance music.

${ }^{120}$ Reynolds, S. (2012). Energy flash; Demers, J. (2010). Listening through the noise. The aesthetics of experimental electronic music. y Snoman, R. (2014). Op. cit. Reynolds incluye además al género newyorkino Garage.

121 "I caracterize certain genres as "major" on the basis of the way fans and musicians use genre terms (as observed in field research, internet mailing lists, and journalistic sources); "major" genres are those that they use most frequently as broad categories." Butler, M. (2003). Op. cit. pp. 24

122 ibid. p. 79
} 
Música electrónica de baile (también conocida como EDM, dance, club music o simplemente dance) es un ancho rango de géneros de música electrónica percusiva producida en gran medida para clubes nocturnos, "raves" y festivales. Producida para ser reproducida por disc jockeys (DJs), la EDM es generalmente utilizada en el contexto de una mezcla en vivo, donde un DJ crea una selección continua (o ininterrumpida) de temas mediante la generación de transiciones de una grabación a la siguiente. ${ }^{123}$

El sitio de Wikipedia (en inglés) continúa luego:

Hacia los primeros 2010s el término "música electrónica de baile" y la sigla "EDM" fue impulsada por la industria musical estadounidense y la prensa musical en lo que en gran parte fue un esfuerzo por relanzar la cultura "rave" en dicho país. En el Reino Unido, son más comunes las expresiones "dance music" o "dance". En este contexto, EDM no refiere a un genero específico sino que sirve como paraguas para varios géneros comerciales populares, incluyendo techno, house, trance, drum and bass, dubstep, trap, Jersey club y sus respectivos subgéneros. ${ }^{124}$

Como dijéramos, los mismos problemas se repiten.

[Un paréntesis necesario: los géneros como categorías]

A pesar de lo dicho supra acerca de los géneros, estos poseen en la música electrónica de baile una existencia efectiva que se materializa en el trabajo de los deejays. Demers dirá, de un modo un tanto ambiguo, que:

Los géneros son de suma importancia en cualquier discusión sobre música electrónica, porque los géneros la dominan, dividiendo a los participantes en campos que usualmente perciben como desvinculados entre sí. ${ }^{125}$

Los deejays los utilizan para determinar el carácter que asumirá un evento electrónico o los diferentes momentos o fases que propondrán a los bailarines en el transcurso de una noche. Hay así deejays especializados en uno o pocos géneros, aficionados que dicen disfrutar del Trance pero no del House y conductores de programas de radio especializados que lamentan el camino que tomó la electrónica al mixtura cualidades de distintos "estilos" en el Tech house. ${ }^{126}$

123 "Electronic dance music (also known as EDM, dance music, club music, or simply dance) is a broad range of percussive electronic music genres produced largely for nightclubs, raves, and festivals. Produced for playback by disc jockeys (DJs), EDM is generally used in the context of a live mix, where a DJ creates a seamless selection of tracks by segueing from one recording to the next." Wikipedia [en línea]. https://en.wikipedia.org/wiki/Electronic dance music\#cite note-Definition-4 [30032016]

124 "By the early 2010s the term "electronic dance music" and the initialism "EDM" was being pushed by the U.S. music industry and music press in what was largely an effort to re-brand U.S. rave cultura. In the UK, "dance music" or "dance" are more common terms for EDM. In this context, EDM does not refer to a specific genre, but serves as an umbrella term for several commercially-popular genres, including techno, house, trance, drum and bass, dubstep, trap, Jersey club and their respective subgenres." ibid. [20032016] 125 "Genre is of the utmost importance to any discussion of electronic music, because genre rules electronic music, dividing participants into camps that often perceive themselves as incommensurate with one another." Demers, J. (2010). Op. cit. p.10

${ }^{126}$ Walter Bohmer, periodista especializado en música electrónica de baile. Entrevista realizada por el autor. Registro fonográfico en poder del autor y a disposición. 
Conscientes del camino sin salida que resulta hoy la utilización de categorías, en nuestro Anexo II incorporaremos sin embargo al debate El problema de los géneros. Procuraremos aportar algo de claridad en una cuestión que -en el caso específico de la música electrónica de baile- es más que confuso. Trataremos este tema luego, en el anexo cuyo título hemos mencionado.

[Fin del paréntesis]

Resulta digno de mención que el sitio en línea Cambridge Dictionaries online dependiente de la Cambridge University Press- no posea las entradas "EDM", "electronic dance music", "techno", "tecno" o ni siquiera "electronic music". Incluye sin embargo "dance music" y "house music" (valga también la aclaración, la última entrada bajo el tópico genérico "house", "casa"). En estas omisiones e inclusiones encontramos un nuevo ejemplo de cómo la denominación de los géneros y de la especie se entrecruzan y enlazan saltando de nivel en nivel. Así, Cambridge Dictionaries online presenta definiciones aún más acotadas afirmando que la "música dance" es "un tipo de música con un fuerte 'beat' que gente baila en locales nocturnos"127 y que la "música house" es "un tipo de música electrónica de baile que se originó/desarrolló en los 80s." ${ }^{128}$ Éste es otro ejemplo de la confusión imperante en esta cuestión y de cómo la perspectiva histórica se refleja en los medios no especializados, distorsionando la realidad de la especie.

El Diccionario Espasa Calpe en su edición del año 2000, bajo la entrada genérica "música" incluye breves definiciones para los términos "música concreta" y "música electrónica", pero no hace mención alguna de "música electrónica de baile". ${ }^{129}$

Por último, McLeod presenta una definición que podemos caracterizar de "dual" por incluir otro grado de indefinición en su objeto. El autor dirá que:

Música electrónica/de baile es un término-paraguas utilizado en este artículo para etiquetar un grupo heterogéneo de músicas hechas con computadoras e instrumentos electrónicos -usualmente para el propósito de la danza. Electrónica/de baile es un nombre de metagénero suficientemente vago como para describir la amplia variedad de estilos musicales consumidos por una red vagamente conectada de productores y consumidores. La barra inclinada se utiliza (en lugar del guión) como una designación

\footnotetext{
127 "a type of music with a strong beat that people dance to in a nightclub". Cambridge Dictionaries online. [en línea]. http://dictionary.cambridge.org/dictionary/english/dance-music [30032016] El término "beat" en este contexto tiene una doble connotación como "tiempo" (del compás) y "golpe" o "impacto" (del usual bombo en negras que caracteriza al ritmo que describe el mencionado instrumento en numerosas piezas del género).

128 "A type of electronic dance music that developed in the 1980s". Cambridge Dictionaries online. [en línea]. http://dictionary.cambridge.org/dictionary/english-spanish/house [30032016]

${ }^{129}$ Diccionario Espasa Calpe. (2000). pp.1243
} 
"y/o" debido a que no todas las músicas consumidas por estas comunidades son necesariamente diseñadas para la danza. ${ }^{130}$

Sin incluir en su trabajo referencia alguna a cuales son concretamente aquellas músicas "heterogéneas" que constituyen el objeto, la definición de McLeod presenta falencias similares a las previamente analizadas.

Los inconvenientes que presenta la caracterización de la música electrónica de baile justifica el intento de hallar una aproximación que los elimine, los evite o al menos mitigue. Para ello deberemos antes considerar varias otras cuestiones derivadas de los diferentes elementos que conforman el concepto. Pasemos a dicha tarea.

\section{Determinación conceptual}

\section{Música}

La problematización de este concepto (de este primer elemento) y una aproximación a su definición audiotáctil la debatimos en nuestro Nuestra carne en el espacio. Sensación táctil en la música. ${ }^{131}$ También en Des-limitados. ${ }^{132}$ expusimos ideas centrales y nos extendimos en detalles al respecto. Extendiendo ciertas ideas desarrolladas en el primero (de los trabajos citados) diremos aquí que, a nuestro entender y para los objetivos de la presente tesis, al interior del concepto de "música" resulta incluido:

\section{sonido y sensación táctil ${ }^{133}$ operados por una voluntad organizativa.}

Fuera de contexto este enunciado no evidencia la novedad que implica el mismo para la musicología. Por ello hacemos notar que: todo lo dicho (y lo por decir) al respecto entiende a la sensación táctil y audiotáctil como parte constitutiva esencial de los estímulos tradicionalmente llamados "sonoros" y "musicales". Algunos de los numerosos trabajos científicos que documentan la presencia de sensación táctil (originada en vibraciones mecánicas asociadas a fenómenos sonoros o similares) fueron reunidos por Pablo Kogan Musso en su ya citada tesis Análisis de la Eficiencia de la Ponderación "A" para Evaluar Efectos del Ruido en el Ser

\footnotetext{
130 "'Electronic/dance music' is an umbrella term used in this article to label a heterogeneous group of musics made with computers and electronic instruments - often for the purpose of dancing. Electronic/dance is a metagenre name that is vague enough to describe the broad variety of musical styles consumed by a loosely connected network of producers and consumers. A slash is used (rather than a hyphen) as an and/or designation because not all the musics consumed by these communities are necessarily designed for dancing." McLeod, K. (2001). Op. cit. pp. 60

${ }_{131}^{131}$ Anzil, I. (2011). Nuestra carne en el espacio. Sensación táctil en la música.

${ }^{132}$ ANZIL, I. (2012). Op.cit.

${ }^{133}$ No es posible reducir a la sensación táctil a "sonido" -entre otras razones- debido a que ésta puede originarse en vibraciones subsónicas (inaudibles, ergo: "no-sonido"). Sin embargo, por tratarse de vibraciones detectables en incontables instrumentos musicales, otros dispositivos de creación humana y fenómenos naturales, las consideramos parte de la señal acústica que conforma al fenómeno musical. Para más detalles véase nuestro documento mencionado.
} 
Humano. ${ }^{134} \mathrm{El}$ "estado de la cuestión" se encuentra publicado en nuestro Sensación táctil y/o audio-táctil de vibraciones de baja frecuencia en música reforzada electroacústicamente. Propuesta de tema y plan para la tesis doctoral. ${ }^{135}$

Solo para despejar dudas acerca de qué es sensación táctil recurramos al recuerdo de experiencias vivenciales: recuérdese a usted mismo en un contexto ruidoso (recital, calle de ciudad en hora pico, construcción, manifestaciones públicas, etc.)... ¿no le vibraba el cuerpo? Con cada golpe del tambor grave, ¿no recibía golpes su cuerpo? Ese sonido de bajo "profundo", "gordo", ¿no vibraba en su estómago, en su pecho, en sus piernas? Eso es sensación táctil... y es plausible de ser organizada (repetida, variada, contrastada, etc.) con fines estéticos en diferentes niveles.

Cuando la misma vibración provoca simultáneamente sensación auditiva la interferencia de ambos estímulos (auditivos y táctiles, oseo-cárnico-cutáneos) resulta en lo que denominamos sensación audiotáctil. Las sensaciones táctil y audiotáctil son entonces parte constitutiva de la música, y esta ya no es un arte (meramente) sonoro sino que audiotáctil.

Aclarado esto, agregaremos que -secundariamente y para distinguir a la música del arte sonoro- la operación mencionada en nuestra definición ${ }^{136}$ debe cumplir con al menos una condición: la organización resultante (la macro-forma de la obra) debe tener un mayor grado de autoreferencialidad interna (referencia formal a las formas de la propia obra) que de referencialidad externa (referencia concreta a elementos externos a la obra). ${ }^{137}$

Diremos por último en relación a este tema que: el "acontecer" del "estado de cosas"138 sono-vibratil musical (el "suceso" musical, la música moviendo el aire y vibrando los cuerpos) debe cumplir ciertas condiciones para que la sensación táctil pueda detectarse conscientemente. Las condiciones más evidentes son que la música ${ }^{139}$ a) debe tener una carga importante de contenido de bajas frecuencias $y, b$ ) como un todo debe generar una presión acústica -que en principio parece encontrarse en el orden de ser- igual o mayor a $95 \mathrm{~dB}^{\mathrm{SPL}^{140}}{ }^{14}$ En otras palabras, pareciera que:

\footnotetext{
${ }^{134}$ Kogan Musso, P. (2004). Op.cit.

135 Anzil, I. (2010b). Sensación táctil y/o audio-táctil de vibraciones de baja frecuencia en música reforzada electroacústicamente. Propuesta de tema y plan para la tesis doctoral.

${ }^{136}$ Aunque antes que "definición" preferimos el término "aproximación".

${ }^{137}$ Aquí se puede releer nuestra aproximación a la definición audiotáctil de música.

${ }^{138}$ Deleuze, G. y Guattari, F. (2001). ¿Qué es la filosofía? pp. 119 y sgtes.

139 Para ser estrictos: el mencionado "acontecer" del "estado de cosas" musical. Siguiendo a Deleuze y Guatarí, el "sustrato material" de la música sería el aire vibrando a causa de las oscilaciones provenientes de los instrumentos musicales, sean aquellas audibles o subsónicas y los instrumentos de la naturaleza que sean (acústicos, eléctricos, electrónicos, excéntricos, etc.).

${ }^{140} \mathrm{~dB}$ SPL. Nivel de presión sonora (o "Sound pressure level") expresado en decibeles. Para más datos véase Kogan Musso, P. (2004). op.cit. pp. 112
} 
BREVES INSTRUCCIONES PARA GENERAR SENSACIÓN TÁCTIL EN MÚSICA

1.- Cree, grabe o consiga por cualquier medio (legal) muchos sonidos graves y vibraciones subsónicas.

2.- Componga con ellos una música que suene...

\section{FUERTE.}

Si lo desea, puede agregar algunos sonidos agudos y otros -agudos o graves- suaves..

...como para matizar.

Sin embargo, para la sensación táctil las cosas solo parecen de esta manera. Procurando que se comprenda mejor el alcance de esta transformación veamos algunas formas en las que esta sensación puede aprovecharse con fines estéticos. Con este objetivo en mente, la sensación táctil puede ser comprendida en tanto:

a) cualidad del sonido: similar y estrechamente vinculada al timbre y en algunos casos subordinada a éste, es uno de los criterios posibles para determinar qué componentes en frecuencias deberá tener un sonido de bombo ${ }^{141}$ electrónico, donde se ubicarán los micrófonos al realizar un registro sonoro o qué procesamiento se aplicará a un sonido preexistente;

b) técnicas instrumentales y de instrumentación: ${ }^{142}$ como criterio de organización de los comportamientos y combinaciones del instrumental y de las técnicas asociadas, tanto para conformaciones simultáneas como sucesivas. Se solapa parcialmente con el punto anterior y abarca temáticas que lo exceden como ser, entre otros: distribución registral del instrumental, modos de interacción entre los componentes de la texturatimbre y efectos a aplicar a cada uno de dichos componentes (y configuraciones de los mismos);

c) variable compositiva que incidirá sobre la macro-forma percibida: quizá más fácilmente detectable a partir de una escucha (o mejor, percepción) en movimiento, dan cuenta de ello la gran carga sobre el registro grave detectable en músicas electrónicas de baile, como también la técnica (muy difundida entre deejays y productores) de eliminar las componentes graves de una pieza (por

\footnotetext{
${ }^{141}$ Utilizamos esta expresión para diferenciar el rol asignado a un determinado sonido sintetizado o sampleado ("muestra" o "sample": sonido grabado y reproducido digitalmente), del timbre o fuente concretos que se utilizan en dicho rol.

142 Mastropietro, C. y otros. (2014). Música y timbre: el estudio de la instrumentación desde los fenómenos tímbricos. pp.28 y ssgtes.
} 
uso de filtros pasa-altos o silenciando los canales de instrumentos en ese registro) para provocar pausas o decrecimientos de la activación corporal;

d) variable compositiva que incidirá sobre la micro-forma del material musical utilizado: la iteración -comprendida como lisa y llana repetición de un evento acústico simple o complejo de duración breve (i.e.: presencia de una periodicidad en el estímulo vibratorio)- se establece como un factor que maximiza el estímulo táctil de los cuerpos de los sujetos expuestos a vibraciones. El uso extensivo de la iteración en la música electrónica de baile la recorre desde los moduladores aplicados sobre sonidos diversos, pasando por la repetición (tiempo a tiempo) del sonido que cumple el rol de bombo de batería y (compás a compás) de motivos melódico-armónicos breves, hasta la proliferación de piezas que, por el material musical utilizado, pueden ser descriptas como monotemáticas.

Toda una aventura en territorio desconocido. A pesar de esto -quizá por ignorancia, quizá por desidia- encontramos en las músicas electrónicas de baile numerosos ejemplos que parecieran seguir la fórmula descripta en nuestro "breve manual". Pasemos de inmediato al siguiente componente.

\section{Música electrónica}

En la búsqueda de sus orígenes y de los orígenes de sus características actuales nos vimos obligados a a) retroceder hasta los inicios de la tecnología eléctrica y electrónica y hasta el surgimiento de las primeras vanguardias artísticas y el futurismo y b) recorrer el desarrollo de los dispositivos tecnológicos musicales (electromecánicos, eléctricos y electrónicos), de las teorizaciones y manifiestos al respecto de los mismos y de los cambios estéticos generados o coincidentes temporalmente con estos. Solo así nos fue posible comprender al primero de los componentes de la especie: la música electrónica o electroacústica.

Consultadas diversas enciclopedias y textos especializados, nos encontramos con que la ausencia de definiciones críticas es un hecho que abarca tanto fuentes bibliográficas como en línea. Siendo una materia tan novel, no nos resulta extraño que el debate permanezca abierto. A modo de ejemplo, analicemos primeramente la definición que brinda Joanna Demers en su reciente Listening through the noise. En dicha obra, la autora desarrolla numerosos argumentos alrededor del interrogante "¿Qué es específico de la música electrónica que está ausente en otras prácticas artísticas y medios?"143 y afirma que:

143 "¿What is specific of electronic music that is absent in other artistic practices and media?" Demers, J. (2010). Op.cit. p.5 
La música electrónica no es un único género sino más bien un nexo de numerosos géneros, estilos y subgéneros divididos no solo geográficamente sino también institucional, cultural, tecnológica y económicamente. Como consecuencia de esta amplitud de actividad, ningún participante individual o informante puede hablar sobre toda la música electrónica con igual facilidad. ${ }^{144}$

Procurando una perspectiva estética abarcativa que responda a la producción musical experimental electrónica a partir de 1980, Demers definirá a la música electrónica como:

cualquier tipo de música que hace uso primordial, sino exclusivo, de instrumentos o equipamiento electrónico. Engloba a la música electroacústica, la cual usualmente utiliza instrumentos acústicos junto con electrónicos, tanto como sonidos producidos puramente por electrónica. La música electrónica entonces habita una gran extensión de géneros, estilos y prácticas, ${ }^{145}$

Perspectiva puramente instrumental, no indaga acerca de las fronteras del objeto propuesto, dejando sin respuesta los interrogantes: ¿qué porcentaje de instrumentos electrónicos/acústicos habilita a que una obra pueda rotularse como "electroacústica"? y ¿es "electroacústica" una obra donde un único instrumento electrónico interviene cumpliendo roles (texturales, formales, rítmicos, etc.) idénticos a los históricamente realizados por instrumentos acústicos?

Sin detenerse en estas cuestiones, la autora prefiere avanzar estableciendo tres grandes "meta-géneros" (i.e.: música electroacústica institucional, electrónica y arte sonoro) y seleccionando un subconjunto de "ejemplos individuales" de "géneros electrónicos" sobre los que realizar sus estudios: música concreta, música electroacústica post-schaefferiana, techno, house, microsound, glitch, ambient, drone, dub techno, noise, chill-out, paisaje sonoro y grabaciones de campo.

Respecto del segundo meta-género (electrónica, nuestro objeto de estudio en este capítulo) ambiguamente dirá que:

Electrónica significa diferentes cosas en diferentes contextos pero normalmente aplica a música electrónica comercial que es nominalmente popular, aunque poca electrónica vende un gran número de grabaciones. ${ }^{146}$

Aunque no lo menciona, de la selección de géneros reproducida supra se desprende que con este término se refiere a música electrónica de baile. Sin embargo, respecto del término

\footnotetext{
144 "Electronic music is not one single genre but rather a nexus of numerous genres, styles, and subgenres, divided not only geographically but also institutionally, culturally, technologically, and economically. Because of this breadth of activity, no one single participant or informant can speak about all of electronic music with equal facility." ibidem.

145 "Electronic music is any type of music that makes primary, if not exclusive, use of electronic instruments or equipment. It encompasses electroacoustic music, which oft en enlists acoustic instruments along with electronics, as well as purely electronically produced sounds. Electronic music thus inhabits a large expanse of genres, styles, and practices.". ibid.

146 "Electronica means different things in different contexts but normally applies to commercial electronic music that is nominally popular, although little electronica sells any great volume of recordings." ibid. p.6
} 
"electrónica" ampliará luego que, en relación al sentido histórico en ámbitos "institucionales" (i.e.: académicos):

\begin{abstract}
Música electrónica ha significado tradicionalmente algo muy diferente en la esfera de la música popular, la cual es, por supuesto, no una entidad homogénea sino mejor un difuso conglomerado de rock, psicodelia, ambient y géneros de EDM, junto con música para films. Muchos ganaron su primera exposición a música electrónica popular o electrónica escuchando las principales radios "pop", que canonizaron canciones de actores que van desde Depeche Mode a Radiohead.
\end{abstract}

Esta descripción evidencia un corrimiento de la perspectiva, centrando el concepto en el término "popular" más que en la expresión "de baile": solo basta con escuchar la producción musical de Radiohead para apreciar que -si bien muy influida por la tecnología- aquella difiere en esencia de las cualidades que presenta la música electrónica de baile según se describe en Wikipedia. Por otro lado, Demers utiliza la expresión "EDM" no como sinónimo sino como género al interior de la música electrónica de baile. En este punto, creemos que la autora solo agrega confusión a un tema ya de por sí complejo.

Veamos ahora la que consideramos una excelente aproximación al concepto, incluida en The Grove Dictionary of Music and Musicians. Propuesta por Emmerson y Smalley, dirá que la música electroacústica es:

música en que la tecnología electrónica, hoy en día principalmente basada en computadoras, es utilizada para acceder, generar, explorar y configurar materiales sonoros, en los cuales los altoparlantes son el medio de transmisión primordial. ${ }^{148}$

La perspectiva de estos autores, si bien no tan centrada en la cuestión instrumental, posee puntos de contacto con la de Demers. Estas similitudes, como es de esperarse, conducen a problemas similares:

a) ¿A qué refiere el verbo "explorar"?

Reproducir un sonido de la naturaleza o de algún instrumento musical tradicional (i.e.: acústico, no-electrónico) tal cual fue grabado, ¿está comprendido dentro de esta exploración o deberíamos considerarlo sonido "generado"? ${ }^{149}$

\footnotetext{
147 "Electronic music has traditionally meant something very diff erent in the sphere of popular music, which itself is, of course, not one homogeneous entity but rather a loose conglomeration of rock, psychedelic, ambient, and EDM genres, along with fi lm music. Many gain their fi rst exposure to popular electronic music or electronica by listening to mainstream pop radio, which has canonized songs by acts ranging from Depeche Mode to Radiohead." ibid.

148 Emmerson, S. y Smalley, D. "Electroacoustic Music" En: The Grove Dictionary of Music and Musicians, vol. 8, Londres: Macmillan, 2001. pp. 59-65. Citado en: De Andrade, I. (2013). "La música electroacústica mixta: el intérprete y los desafios de la praxis musical contemporánea." en: Revista Vórtex, Curitiba, n.2 p.49-64. p.49

149 Téngase en cuenta que la mera reproducción introduce cambios. Estos cambios se originan en que el sonido original (la onda de presión acústica, la onda elástica que se propaga por el aire) atraviesa el
} 
b) ¿Qué porcentual de los materiales sonoros utilizados en una pieza musical concreta deben tener este origen para que la pieza pueda considerarse música electrónica? ¿Debe evidenciarse la presencia de esta tecnología? ¿Debe ser detectable su presencia? Y además, ¿cómo deberíamos caracterizar a una pieza musical que, haciendo uso exclusivo de fuentes sonoras acústicas (i.e.: no-electrónicas), es percibida por los receptores como música electrónica? ¿Existe un ejemplo tal? ¿Y el caso opuesto? Piezas que utilizan exclusivamente fuentes electrónicas y que suenan como música noelectrónica son hoy una realidad a la que accedemos cotidianamente; la emulación de fuentes acústicas, con un grado de similitud tal que vuelve virtualmente indetectable la presencia subyacente de tecnología, es un hecho solo posible hoy gracias al desarrollo que la misma ha experimentado en los últimos tiempos. Esta problemática es, como resulta evidente, compartida con la aproximación de Demers.

c) Consideremos ahora la partícula "y". En la redacción resulta poco claro si esta se utiliza en su función coordinante o copulativa. Si el sentido asignado refiere a su carácter de condición necesaria (en otras palabras, que todos y cada uno de los verbos mencionados son condiciones para que una pieza musical pueda ser considerada como música electrónica) numerosísimas piezas designadas como pertenecientes a la especie quedan excluidas. Por el contrario, si el sentido es que las acciones incluidas en la definición resultan opciones, una inmensa cantidad de piezas que suelen describirse como no-electrónicas ingresan a formar parte de ella.

El Diccionario Espasa Calpe realiza la distinción perimida entre "música concreta" y "música electrónica", definiendo respectivamente a una y otra en tanto:

MÚSICA CONCRETA Mús. Tendencia musical que se basa en la producción de sonidos derivados de otros por medio de instrumentos electrónicos. // MÚSICA ELECTRÓNICA Mús. La que se obtiene de las oscilaciones de un generador electrónico. Estas oscilaciones, convertidas en sonido mediante un altavoz, son grabadas en una cinta magnetofónica, sobre la cual el compositor realiza un trabajo de selección de los sonidos. ${ }^{150}$

En su artículo Cinta en reverso de 2008, el venezolano Miguel Noya realiza un análisis crítico de las definiciones halladas en diversas fuentes. Noya basa su argumentación en el establecimiento de tres etapas históricas, signadas por el desarrollo y surgimiento sucesivo de a) las tecnologías analógica y de grabación a fines de los años 40s y comienzos de los 50s, b) la

proceso de conversión a señal de audio (energía eléctrica) y luego de regreso a presión acústica. En este proceso, además, cada componente de la cadena de audio influye sobre las cualidades del sonido emitido durante la reproducción. Por supuesto, no podemos olvidar la cualidad "acusmática" (al decir de Pierre Schaeffer) que asume el sonido reproducido al ser reemplazada su fuente de vibración original por un parlante.

${ }^{150}$ Diccionario Espasa Calpe. (2000) Director: Juan Ignacio Alonso Campo. pp. 1243 
tecnología de la computación a fines de los 60 s y comienzos de los 70 s, y c) la masificación de las tecnologías digitales y de comunicación en la que podríamos llamar la "etapa actual". Para cada uno de estos períodos, el autor establece definiciones que -no solo consideramos apropiadas sino que- son coincidentes con las utilizadas en los años respectivos. Con estas herramientas, arriba luego a una definición incompleta pero que contiene a las previas. Así dirá que:

Si se toma como ejemplo los diferentes conceptos de música electrónica que se han presentado anteriormente, se puede ver que hay una síntesis que coincide en todas las definiciones, que nos dice que "la música electrónica es la que se compone, se ejecuta, se genera y se procesa por medios o instrumentos electrónicos". ${ }^{151}$

Inmediatamente después asume la limitación de esta aproximación instrumental y continúa:

Si se establece como limite sólo a este concepto base de música electrónica, que implica la utilización de medios electrónicos para la creación y ejecución de la misma, se podría pensar entonces que toda la música que se produce y se escucha hoy en día es electrónica, pues sólo en los casos de música ejecutada con medios totalmente acústicos y en eventos en directo es donde no se encuentra la utilización de algún instrumento de esta clase, bien sea eléctrico de generación o registro, o de algún medio electrónico de procesamiento y almacenaje; [...] Los criterios de selección y discriminación en el caso del estudio de los miembros de la comunidad de la música electrónica, están relacionados entonces, no estrictamente con los instrumentos usados nada más, sino también con la intención, conceptos, investigación y procedimientos en los procesos creativos y de realización del compositor, productor o ejecutante, para poder incluirlo en una selección más coherente. ${ }^{152}$

Concluyendo finalmente que:

[...] a la definición anterior se le debe añadir, además, que deben estar contemplados elementos estéticos, planteamientos de desarrollo y estructuras de procesos que definitivamente la diferencien de los procedimientos que utilizan las formas de composición y producción características de los medios no electrónicos, incluyendo los estilos musicales. ${ }^{153}$

En definitiva, como todo otro intento de establecer categorías o límites para lograr una definición, la de la música electrónica o electroacústica presenta enorme complejidades que, de no tratarse con cuidado, pueden conducir a la cadena del sinsentido infinito ("Nunca decimos el sentido de lo que decimos."). ${ }^{154}$ Para los fines de nuestro trabajo estableceremos entonces un concepto complejo, difuso y basado primordialmente en un aspecto perceptivo. En forma sintética, música electrónica o electroacústica será entonces:

\footnotetext{
${ }^{151}$ Noya, M. (2008). Cinta en reverso. pp.5

${ }^{152}$ Ibid. pp. 5-6

${ }^{153}$ Ibid. p. 6 A los interesados, sugerimos la lectura del clarificador ejemplo en relación a The Beatles que luego brinda Noya en su artículo.

${ }^{154}$ Deleuze, G. (1969). Lógica del sentido. p.31
} 
música que subjetiva y multidimensionalmente denota la presencia de tecnología eléctrica y/o electrónica (analógica y/o digital); donde la mayoría estadística (nuevamente, subjetiva) de los aconteceres sonoros que la compone evidencian a la percepción la subyacencia de tecnología eléctrica y/o electrónica. Esta presencia subyacente se manifiesta en la forma de timbres, conformaciones, procesos y/o procedimientos que requieren de alguna/s de esta/s tecnología/s para llevarse a cabo y concretarse en sonido.

Ampliando, clarificando y completando la síntesis previamente expuesta, la pertenencia al género de una pieza se determinará en base a criterios subjetivos multidimensionales. En otras palabras, al igual que Noya creemos que no alcanza con que una pieza utilice exclusivamente fuentes electrónicas para ser descripta como música de este tipo. Muy claramente lo dicen Ricardo Teruel:

[...] si algo se puede hacer instrumental tiene poco sentido hacerlo electrónico y definir eso como música electrónica. Eso es más bien un arreglo o una versión de algún tipo con sonidos electrónicos. ${ }^{155}$

\section{y Adina Izarra:}

El compositor electrónico es alguien que se interesa en la investigación electrónica, no el que simplemente usa un teclado midi para poner una línea que igual se la habría podido poner a un clarinete, yo creo que es alguien que se dedica a música electrónica, es alguien que se adentra en los procesos. ${ }^{156}$

Para determinar la pertenencia de cada pieza concreta al género música electrónica o electroacústica el dato instrumental deberá contrastarse con lo que ocurre en las demás dimensiones bajo análisis (como ejemplo: conformaciones rítmicas, melódicas, armónicas y formales; tipos de procesos aplicados a la transformación del timbre, del ritmo, etcétera; procedimientos de elaboración de los materiales musicales, como también los emergentes sonoros de dichos procesos; entre otros). Clarificadores resultan nuevamente los dichos de Jorge Antunes:

Hoy usan la expresión 'música electroacústica' de modo muy abarcadora. Me parece que hoy consideran música electroacústica a cualquier música que se haga con sonidos electrónicos. Eso me asombró un poco. Para mí la música electroacústica tiene un lenguaje propio. Un arreglo de una obra de Beethoven hecho con sonidos electrónicos por Walter Carlos no tiene nada que ver con la música electroacústica. Es música

\footnotetext{
155 Citado en Noya, M. (2008) Op.cit. p.1 Por "instrumental" Teruel se refiere a instrumentos de naturaleza acústica.

${ }^{156}$ Citada en ibid. p.2
} 
tradicional ejecutada con sonidos electrónicos. En el CLAEM, al conocer el trabajo de Kröpfl en sus clases y las obras de becarios anteriores como Jacqueline Nova, Gabriel Brncic y César Bolaños, u obras de Karlheinz Stockhausen o Andrzej Dobrowolsky, alcancé a conocer lo que llamo el lenguaje de la música electroacústica. ${ }^{157}$

Y si a un cierto procedimiento de identificación de música electroacústica nos referimos: para evitar cualquier tipo de formalización o carácter normativo es deseable que también a partir de criterios difusos y complejos- el analista determine qué dimensiones concretas sopesará en cada análisis. Por supuesto, siempre guiado por las cualidades de cada obra en cuestión. En otras palabras, frente a la pieza analizada, el investigador no arribará a una determinación binaria sino que las conclusiones referirán a que:

a) tales y cuales aspectos poseen cualidades asociables a las prácticas acústicas históricas,

b) otros resultan asociados (o asociables) a las tecnologías y dispositivos eléctricos y/o electrónicos musicales y

c) terceros presentan características neutras, ambiguas o indiscernibles.

Así, de una voz cantando una melodía con texto, que se presenta filtrada en frecuencias, distorsionada y con reverberación podremos decir que:

a) La voz es una fuente acústica y realiza una textura (la melodía) con orígenes históricos, no electrónicos.

b) El timbre de la voz evidencia el procesamiento, la utilización de dispositivos tecnológicos. Concretamente: filtros y distorsión.

c) La reverberación podría presentar cualidades que la vuelvan indiscernible en relación a su origen. Esta podría provenir a) del ambiente acústico en que se registró la voz, b) del registro de la reverberación en un ambiente acústico donde se reprodujo dicha grabación o c) de un dispositivo electrónico que emula las cualidades de espacios acústicos. En cualquier caso, dependiendo de las cualidades sonoras de este aspecto de nuestro hipotético ejemplo, podría suceder que resulte imposible discernir su origen.

Buscando evacuar las dudas que pudieran persistir, y como se desprende del ejemplo previo, explicitamos nuestra posición al respecto de que:

la cualidad electrónica excede los límites de los parámetros del sonido e influye transversalmente sobre todos los aspectos de la música.

${ }^{157}$ Vazquez, H. G. (2015). "Jorge Antunes" en Op.cit. pp. 46 
Contrastar las diferentes dimensiones de análisis seleccionadas en cada ocasión permitiría arribar a una conclusión difusa que brinde aproximaciones acerca de la pertinencia de denominar a una hipotética pieza como música electrónica.

Lamentablemente resulta demasiado extenso para los objetivos de este trabajo realizar un análisis exhaustivo de los aspectos musicales donde pueden detectarse las huellas de los instrumentos, procesos y procedimientos electrónicos. Sin embargo, durante el análisis de diversas cualidades de las (que llamaremos) músicas electrónicas utilizadas para el baile social visitaremos aquellas que sean oportunas al tema tratado en cada ocasión.

\section{Estética electrónica}

Sentimos la obligación de mencionar aquí una consecuencia implícita a nuestra aproximación, la cual consiste en que la música electrónica o electroacústica presenta cualidades estéticas propias, diferenciadas de las demás músicas. Si bien no resulta hasta aquí del todo claro qué cualidades concretas son determinantes y permiten en definitiva catalogar a una pieza como "electrónica", ${ }^{158}$ sí hemos podido hallar numerosos testimonios que dan cuenta de cierta intuición, ciertos indicios que apuntan a que esta estética posee algún grado de independencia respecto de las estéticas acústicas. Sin ser nuestro objetivo específico la definición de este término, veamos algunos de los indicios mencionados.

En el libro Conversaciones en torno al CLAEM, varios de los compositores entrevistados refieren a esta diferencia. Consultado acerca de la impresión de los profesores al encontrarse con un alumno que ya manejaba el lenguaje que ellos enseñaban, Jorge Antunes responde que:

El lenguaje no lo manejaba tanto, manejaba la técnica. La técnica de grabar, de cortar la cinta y empalmar con perfección. Incluso con el cuidado de utilizar el "soplido" más bajo posible. Todo eso ya lo traía, pero el lenguaje no. ${ }^{159}$

Luis Arias dirá que una de las ideas aplicadas en la composición de su obra Fonosintesis I (1965-66) fue "realizar las intensidades de la música electrónica o concreta -como se las dividía en esa época- mediante la orquesta o un grupo instrumental." ${ }^{160}$ Ante una pregunta referida a la inclusión de secciones aleatorias en sus obras, Arias responderá luego que "me impactó mucho la 'Escuela Polaca' y, también, la música electroacústica 'imitable'. Es decir, pretendía buscar en la orquestación ese tipo de resultados." 161

El vínculo en el testimonio de Mariano Etkin es algo más elíptico:

\footnotetext{
${ }^{158}$ Como acabamos de ver, esta adjetivación derivará del análisis del conjunto abierto y difuso de características que se consideren pertinentes para cada pieza concreta.

${ }^{159}$ Vazquez, H. G. (2015). "Jorge Antunes" en Op.cit. pp. 46

${ }^{160}$ Vazquez, H. G. (2015). "Luis Arias" en Op.cit. pp. 66

${ }^{161}$ Ibid. pp.68
} 
Mi relación con la música electrónica nunca fue, digamos, fluida. Sin embargo, fui profesor de música electrónica en la época analógica cuando estuve dando clases en Canadá y, [...] siempre me pareció que le faltaba materia, cuerpo, que faltaba carne y hueso en la música electrónica. ${ }^{162}$

Si bien el testimonio se inicia con ciertas referencias a la situación de concierto y a la presencia escénica del intérprete en la música acústica (recordemos que en el período referido las piezas electroacústicas se presentaban casi con exclusividad grabadas en cinta, sin presencia humana en escena), Etkin luego cambia el foco hacia juicios sobre la materia sonora al decir que:

Todavía me interesa más el sonido bouché de un corno, o de un trombón con sordina plunger tocando en un registro medio que el sonido producido por una máquina. Me sigue erotizando más eso que una máquina. ${ }^{163}$

Eduardo Kusnir lo describe como una cuestión de época:

En ese momento que me tocó vivir, entre 1969 y 1970, con el modernismo o experimentalismo, uno de los criterios de valorización más importante era la novedad. En todo movimiento estético hay una escala de valores. Creo que en este momento no se produce lo mismo. El experimentalismo de los sesenta fue una etapa, se generó un vocabulario y lo importante es cómo eso se emplea. Al principio, con el surgimiento de la tecnología, resultaba novedosa la creación de nuevos sonidos en el ámbito de la música electrónica académica. Cuando la tecnología se hizo masiva, esa novedad de inventar un sonido pasó a la música popular, más allá del vocabulario utilizado. ${ }^{164}$

En este caso, hacemos incapié sobre el uso del término "vocabulario", el cual funciona de modo complementario con el de "sonido". En la respuesta siguiente (con vínculos con la citada) el compositor se refiere al "material sonoro" y a la "organización compositiva", dejando en claro a qué se corresponde cada aspecto estético y término utilizado.

Como puede apreciarse, en los testimonios de exbecarios del CLAEM se referencian cualidades estéticas diferenciadas entre las músicas "instrumental" (o acústica) y electroacústica. Sin embargo, salvo la "novedad" en ninguno de ellos se mencionan las cualidades concretas de dicha diferencia. Involucrando herramientas y procesos tan nóveles e innovadores, y tratándose de testimonios de pioneros en el campo esto no nos resulta extraño.

En su reciente trabajo (ya citado) Listening through the noise, Demers trata extensamente este asunto y afirma que:

Recordar música de centurias previas es de hecho una técnica útil, desde que la premisa de este libro es que la música electrónica es fundamentalmente diferente en carácter y

\footnotetext{
${ }^{162}$ Vazquez, H. G. (2015). "Mariano Etkin" en Op.cit. pp. 111

163 Ibid.

${ }^{164}$ Vazquez, H. G. (2015). "Eduardo Kusnir" en Op.cit. pp. 134
} 
en aspiración de cualquier música que la precedió. Considere que antes del advenimiento de la música electrónica, el sonido de casi cualquier instrumento o voz cantante hubiera alertado a los oyentes en un corto tiempo de que lo que ellos se encontraban escuchando era un sonido musical y no, digamos, un sonido de la naturaleza, azaroso o de una máquina no-artística. Los timbres, ataques, estructura y sintaxis de la música preelectrónica trabajan todos juntos para subrayar el status de la música como un tipo especial de sonido organizado que se separa de los sonidos de la vida cotidiana. No hace falta decir que no todos los oyentes traen el mismo tipo de experiencia o expertise musical a los sonidos que escuchan, y que la experiencia de escucha claramente varía de acuerdo a la historia, cultura y la música misma. Aún así, podemos estar relativamente seguros de que la mayoría de la gente que ha crecido en una cultura particular puede reconocer su música como música aún si no saben nada más acerca de su producción o sentido. ${ }^{165}$

Vemos aquí uno de tantos momentos en los que la autora describe con maestría algunas diferencias que, en varios niveles y dimensiones, son hallables entre la música electrónica y la acústica; en particular aquí, el hecho de que las electrónicas no siempre evidencian su pertenencia a la categoría "música". Adentrada en el desarrollo y procurando diferenciar aquellas tres regiones de la música electrónica que considera sus "meta-géneros" (recordamos: música electroacústica institucional, electrónica y arte sonoro) dirá que:

[...] no podemos dar por sentado definiciones ni de la estética ni de género, como tampoco podemos asumir que los dos existen independientes del otro. Este capítulo se refiere a las relaciones entre la estética y el género: cómo determina la estética nuestra comprensión de los géneros de música electrónica e, inversamente, cómo los géneros afectan nuestra comprensión de la estética de la música electrónica. Argumentaré aquí que lo que motiva el esfuerzo de categorizar y demarcar diferentes géneros es una creciente confusión acerca de la experiencia de escuchar música electrónica. La palabra música podría haberse vuelto inadecuada para describir los extraños sonidos, estructuras y situaciones de este nuevo paisaje acústico. La insistencia sobre distinciones de pequeña escala entre géneros retrasa mayores reflexiones acerca de cómo toda la música electrónica difiere de cualquier cosa que la ha precedido. Aún así, usualmente obviamos similitudes patentes entre formas de música electrónica de otro modo dispares, simplemente porque hemos crecido acostumbrados a la idea de que diferentes esferas de la producción de música electrónica no se relacionan. ${ }^{166}$

\footnotetext{
165 "Remembering music from previous centuries is in fact a useful technique, since this book's premise is that electronic music is fundamentally different in character and in aspiration from any music that preceded it. Consider that before the advent of electronic music, the sound of almost any instrument or singing voice would alert listeners within a short amount of time that they were hearing a musical sound and not, say, a sound of nature, chance, or a nonartistic machine. The timbres, attacks, structure, and syntax of preelectronic music all work together to underscore music's status as a special type of organized sound that is separate from the sounds of everyday life. It goes without saying that not all listeners bring the same sort of experience or musical expertise to the sounds they hear, and listening experiences clearly vary according to history, culture, and the music itself. Still, we can be relatively certain that most people who have grown up in a particular culture can recognize its music as music even if they know nothing else about its production or meaning." Demers, J. (2010). Op. cit. pp. 12

${ }^{166}[\ldots]$ "we cannot take definitions of either aesthetics or genre for granted, nor can we assume that the two exist independently of each other. This chapter addresses the relationships between aesthetics and genre: How do aesthetics determine our understanding of electronic-music genres, and, conversely, how do genres affect our understanding of electronic music aesthetics? I argue here that what motivates the effort to categorize and demarcate different genres is a growing confusion about the experience of listening to electronic music. The word music might no longer adequately describe the strange sounds, structures, and situations of this new acoustic landscape. Insistence on the small-scale distinctions among genres delays larger reflections on how all of electronic music differs from everything that has preceded it. Yet we often disregard patent similarities between otherwise disparate forms of electronic music
} 
El pasaje citado evidencia sin lugar a dudas la posición de Demers respecto de que las electrónicas son músicas esencialmente diferentes de todas sus predecesoras. Consecuente con este punto de vista sostendrá luego que esta requiere una escucha diferenciada, divergente de la que se dedica a las "músicas de centurias previas", y dirá que:

\begin{abstract}
A pesar del hecho de que los tres metagéneros insisten en sus diferencias mutuas, sin embargo, los tres alientan un tipo de escucha que se parece menos a lo que consideramos "escucha musical tradicional" (al menos para la música occidental) [y más] a un movimiento hacia un nuevo tipo de atención, al que llamo escucha estética. ${ }^{167}$
\end{abstract}

En este marco definirá a las diferentes ramas de la música electrónica en términos de signo, objeto y situación y asociará (al menos parcialmente) a cada uno de sus "géneros" en relación a aquellos. Debate que excede los objetivos de nuestro trabajo, sugerimos para más detalles la revisión de este libro. De cualquier modo, en capítulos subsiguientes volveremos a Demers para otras cuestiones.

En una de las entrevistas que realizáramos encontramos respuestas significativas a este respecto: ante nuestra pregunta acerca de si la música electrónica posee cualidades estéticas diferenciadas el músico electrónico Ernesto Romeo ${ }^{168}$ respondió con un tajante "Si, absolutamente". Consultado luego acerca de cuáles serían esas diferencias concretas respondió refiriéndose a:

a) cuestiones rítmicas, texturales y tímbricas -y vinculando de algún modo estas tres dimensiones en una (como veremos más adelante, coincidente con nuestros resultados)y a

b) la generación de fuertes contrastes y discontinuidades "en frecuencia, en color, en amplitud"169 irreproducibles "de manera acústica y que han creado toda una estética propia, que incluso ha renovado el lenguaje de ciertos usos de los instrumentos

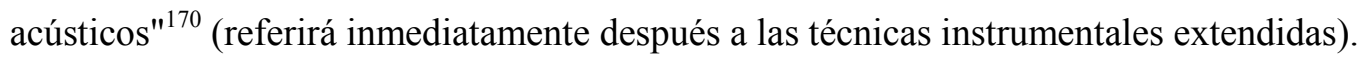

simply because we have grown accustomed to the idea that different spheres of electronic-music production are unrelated." Demers, J. (2010). Op. cit. pp. 135

167 "Despite the fact that the three metagenres insist on their difference from one another, however, all three encourage a type of listening that resembles less what we think to be traditional musical listening (at least in Western art music) than a move toward a new type of attention, which I call aesthetic listening." Demers, J. (2010). Op. cit. pp. 15

${ }^{168}$ Sintetista de larga trayectoria y docente en la materia, Romeo es uno de los dueños de La siesta del fauno, uno de los estudios con mayor cantidad de dispositivos tecnológicos musicales de Argentina.

${ }_{169}$ Ernesto Romeo. Entrevista realizada por el autor. Registro fonográfico en poder del autor y a disposición.

${ }^{170}$ Ibidem. 
Como vemos, es común a todos los testimonios referir a diferencias en términos muy generales. Creemos que esto se debe a la profundidad y vastedad de los cambios impulsados por los diferentes desarrollos tecnológicos que se han sucedido a lo largo del siglo XX. Esta profundidad impulsaría respuestas en términos abarcativos y diversos o, como dijéramos en algunas oportunidades, transversales y difusos.

En otro momento de la charla Romeo haría referencia además a que los dispositivos tecnológicos brindarían la posibilidad de acceder a la cualidad "plástica" del sonido. En otras palabras, a trabajar sobre dicha materia sin estructuraciones establecidas de antemano (siendo un ejemplo de estas estructuraciones la cuantificación del parámetro altura que representan las notas). Para nada una cuestión accesoria, sus últimos dichos ponen de relieve la importancia de la interfase que cada dispositivo ofrece. Siendo las combinaciones de componentes sonoros posibles virtualmente infinitas, serán los controles que el instrumento incluye lo que determinará a cuales tendremos acceso y a cuales no, condicionando las acciones y transformaciones posibles de realizar sobre la materia sonora.

Sirvan entonces los argumentos expuestos como apoyo a nuestra decisión de incluir a las diferencias estéticas como criterio para la determinación de cuando una pieza puede ser considerada parte de las músicas electrónicas. Como enunciáramos durante la introducción y en cierto sentido realizando un recorrido histórico del desarrollo de las diferentes tecnologías involucradas, algunas de estas diferencias son hallables en:

a) Diversas formas de realidad sonora sintética.

Específicamente, sonidos generados a partir de todo tipo de sintetizadores analógicos; dispositivos que crean sonidos a partir de (literalmente) corrientes de electrones. En otras palabras, podemos hablar aquí (con un grado relativamente bajo de metáfora) del sonido de la electricidad, del sonido de la onda eléctrica.

b) Presentización y localización de fragmentos de pasado y lejanía sonoros (de origen no electrónico).

El surgimiento de la grabación sonora posibilitó la posterior reproducción del pasado sonoro almacenado, haciendo presente o presentizando un pasado hasta entonces imposible de acceder. Más allá de lo naturalizado que hoy pueda sentirse, acceder a fragmentos de tiempos pasados es quizá una capacidad que la tecnología ha sustraído a la magia: como sucediera con las películas de los hermanos Lumiere, los primeros oyentes de grabaciones se habrán sentido "en varios tiempos a la vez".

Algo similar sucede con la reproducción de sonidos registrados en lugares tan distantes o inaccesibles (al menos hoy) como el planeta Mercurio. La continuidad/discontinuidad espaciotemporal (dual e integrada) que la posibilidad de acceder a pasados y lejanías sonoras provoca es algo que hoy se refleja en ciertos sentidos incluidos al interior de la 
música electrónica. Aún cuando ya lleva casi un siglo de existencia, para muchos oyentes esta música sigue siendo sinónimo de "futuro" y de "espacio exterior" (Espacio extraterrestre).

c) Presentación fragmentaria de realidades sonoras (preexistentes) de origen no electrónico.

Los sonidos de lo imposible quizá condujeran a que la industria del cine apelara a recursos sonoros electrónicos para sus producciones del género fantástico. Sonidos de fuente reconocible presentados sin su inicio, medio o final; o repetidos sin variación alguna un significativo número de veces; o combinaciones de sonidos de diferentes animales destinadas a reconstruir las vocalizaciones de animales extintos son algunos ejemplos sencillos de aquello que fuera imposible en el período pre-electrónico. Expresión también de lo "monstruoso", "extraño", "antinatural" o "inhumano", también estos sentidos han permeado otros aspectos de la música electrónica.

d) Maximización de lo mínimo/minimización de lo máximo

Enlazado con el punto anterior y parte hasta cierto punto de los sonidos de lo imposible, la tecnología permitiría -para el sonido- lo que podemos llamar un "equivalente" de lo que fuera la invención de las lentes cóncavas y convexas para la imagen. El incremento o decrecimiento de la intensidad de sonidos débiles/fuertes, de la frecuencia de sonidos agudos/sobre-agudos o graves/sub-graves (haciendo audibles incluso fenómenos vibratorios super- o sub-sónicos) o de la duración (expandiendo temporalmente sonidos breves o fases efímeras de estos/comprimiendo a sonidos de mayor extensión temporal) o enfatizando/relegando algunas de las cualidades de los sonidos (por medio de herramientas como la ecualización) son solo algunos ejemplos de las posibilidades abiertas por los dispositivos tecnológicos.

e) Materialización sonora de la realidad matemática.

A partir del surgimiento de la tecnología de síntesis digital sería posible escuchar sonidos cuyas formas de onda se originaran ya no en un acontecer físico sino en pura información. Las oscilaciones del parlante serían (y son) derivas de puros algoritmos matemáticos. Involucrando nuevamente cierto grado de metáfora, los sintetizadores digitales permitirían el acontecimiento sonoro del universo matemático.

Los casos expuestos no agotan las formas en que la huella electrónica se concreta en la música y apenas si se aproximan a esbozar los procesos y procedimientos posibles de ser aprovechados por derivación a partir de esta multiplicidad de herramientas y recursos que la tecnología ha puesto a disposición de los músicos. Apenas una muestra de las muy diversas y revolucionarias maneras en que la tecnología ha ingresado al universo de la música, todas las anteriores son expresión del derrumbe de numerosos límites que las estéticas tradicionales y los 
prejuicios culturales impusieran a la materia sonora. Manifestándose subyacentes a los principios constructivos del instrumental acústico, dichos límites se evidenciarían también en la forma de categorías y dimensiones musicales y cualidades del sonido. Como veremos durante los títulos por venir, muchos de estos límites han sido al menos puestos en cuestión por los desarrollos tecnológicos.

Por último, si bien coincidimos con Ernesto Romeo en que la electrónica no es puramente "música de máquinas" y que -en último término y aunque ciertos desarrollos en inteligencia artificial podrían poner esto en cuestión- siempre habrá detrás un humano que tomara decisiones acerca de uno u otro aspecto, los argumentos expuestos son (al menos en algún sentido) la materialización de la expresión maquinal: de algún modo, en la música electrónica parte de la expresión resulta de la máquina (el proceso físico, las leyes del electromagnetismo) expresándose a sí misma.

\section{La cualidad experimental}

A partir de los argumentos expuestos en los últimos títulos se vuelve evidente el vínculo que se establece entre las músicas electrónicas o electroacústicas y el término "experimental". Mencionado en la introducción, creemos oportuno detenernos un momento a considerarlo brevemente. Postergando su desarrollo para cuando podamos inscribirlo en el marco concreto de las músicas electrónicas de baile, introducir las cuestiones básicas del tema permitirá una mejor comprensión del lugar que esta cualidad ocupa en las músicas electrónicas (en general).

Como viéramos, tanto Etkin como Demers coinciden en caracterizar a la experimentación en términos de "riesgo asumido". Ahora bien, particularmente en las músicas electrónicas la asunción de riesgo resulta en algún sentido intrínseco, debido a la novedad que representa el uso de dispositivos (valga la redundancia) novedosos. Dicha novedad involucra, en algún sentido, algún grado de desconocimiento del instrumental; razón que podría explicar la inclinación que demuestran los productores de las músicas electrónicas de baile a renovar su arsenal de recursos tecnológicos y a intercambiar con sus pares los de su propiedad. Más allá del impulso originado en intereses comerciales, también la transformación continua de componentes e interfases y el surgimiento constante de nuevos dispositivos podría encontrar parte de su razón de ser en la satisfacción de este ansia por novedades tecnológicas que renueven la sensación de riesgo originada en el desconocimiento (al menos parcial) de las características concretas de cada nuevo diseño instrumental.

Como dijéramos en el título precedente, las interfases condicionarán los aspectos de la plasticidad sonora a los que se tendrá acceso y los modos en los que se podrá acceder a aquellos. Esto determinará a su vez las transformaciones, procesos y procedimientos posibles de aplicar sobre la materia sonora, permitiendo unos al tiempo que dificultando o imposibilitando otros. Como consecuencia, el "simple" reemplazo de la interfase con la que se accede y controla a una 
misma fuente sonora ${ }^{171}$ puede tener un gran impacto sobre el resultado sonoro. Así entendido, el riesgo se vuelve no solo estético sino también operacional y procedimental e involucra decisiones poéticas, estéticas y técnicas. No resulta extraño entonces que a partir del surgimiento de dispositivos tan diferentes de todo instrumento musical preexistente estas esferas del universo musical se vieran modificadas tan profundamente.

Avanzando un paso más en esta cuestión, Demers ofrece una perspectiva donde la variable temporal, histórica, se vuelve esencial para la comprensión del concepto.

Por lo tanto defino experimental como cualquier cosa que se ha apartado significativamente de las normas de su tiempo, pero con la comprensión de que algo experimental en 1985 puede haber inspirado lo que fuera convencional para $1990 .{ }^{172}$

Si llevamos la afirmación de Demers hasta sus últimas consecuencias podemos incluso afirmar especularmente que, si la cualidad experimental es dependiente de los convencionalismos de cada época, lo que fuera convencional para 1990 puede inspirar lo (nuevamente) experimental en 2000.

Finalizamos así nuestra primera aproximación a lo experimental. Algunas otras apreciaciones al respecto en el marco más específico de la música electrónica de baile se incluyen en el Anexo II. El problema de los géneros. bajo los títulos "Un paso más allá: la cualidad experimental como índice transversal" y "Otras formas experimentales".

\section{La diferenciación eléctrico/electrónico}

El análisis multidimensional para determinar la pertenencia de una pieza específica a la categoría de música electrónica permite a la vez salvar un escollo hallado en varios debates acerca del tema: la diferenciación eléctrico/electrónico. Algunos participantes de foros relacionados a estas músicas dirán que es un error considerar que una pieza musical es electrónica por incluir guitarra eléctrica. ${ }^{173} \mathrm{Si}$ bien en términos generales acordamos con esta idea, creemos necesarias varias observaciones.

Subyace al argumento precedente la diferenciación entre instrumentos electrónicos y otros que, sin ser acústicos, podemos denominar (por practicidad) "eléctricos" o "electromecánicos". Subyace también la concepción de que solo es posible utilizar instrumentos electrónicos para concretar estas músicas; como también deja implícito que los instrumentos electrónicos no podrían ser utilizados en músicas no-electrónicas.

\footnotetext{
${ }^{171}$ Por ejemplo, el reemplazo de un teclado con formato de piano por guantes con sensores o una cámara de video que a partir de la posición del cuerpo del intérprete modifique ciertas variables del sonido.

172 "I therefore define experimental as anything that has departed significantly from norms of the time, but with the understanding that something experimental in 1985 could have inspired what was conventional by $1990 . "$ Demers, J. (2010). Op. cit. pp. 7

${ }^{173}$ Refiere a una interpretación de este instrumento utilizando técnicas de ejecución tradicionales: pulsando o rasgando las cuerdas con dedos o plectro-púa.
} 
Como ya explicáramos, desde nuestra perspectiva el tipo de fuentes utilizadas es apenas uno de los factores que determinarán la pertenencia (o no) de la música en cuestión a esta especie. Factor central por supuesto, pero que no deja de ser uno entre varios, solo luego de contrastar esta dimensión con otras y determinar la importancia específica (subjetiva) que cada una tiene en relación a las demás, podrá aproximarse una determinación para una pieza concreta. Así, una obra para guitarra eléctrica (o realizada aplicando alto voltaje a una piedra con alto contenido de óxido de hierro) podrá o no pertenecer a la especie música electrónica, tanto como otras obras cuyas fuentes generen sonido a partir de instrumentos acústicos grabados, circuitos integrados o algoritmos matemáticos.

Por otra parte, en relación a este tema Ariel Martínez nos permite apreciar nuevamente cuán importante se vuelve que los dispositivos utilizados para la creación musical electrónica amplíen las capacidades de control sobre el sonido. En su testimonio respecto de la metodología de enseñanza utilizada durante los años que existió el CLAEM dirá que:

Está claro que un curso de música electroacústica es una empresa muy compleja, en cualquier época. [...] ...cualquier curso de este tipo debe adaptarse al equipamiento disponible. De nada habría valido [por la novedad del tema tratado] hacer un curso sobre el sintetizador de la RCA o sobre el programa MUSIC de Mathews. [...] el curso de Kröpfl [...] era el intento de poner en evidencia la necesidad de desarrollar una metodología de la composición musical que incluyera a las nuevas y vastas capacidades de los medios electroacústicos. Para recorrer ese camino, Kröpfl dedicó la primera mitad del corto curso de 1969 a esbozar un proceso más abstracto que el usado durante mucho tiempo por los compositores. Comenzó explicando la estructura musical como el resultado de la relación entre dos grupos de elementos. El primero de esos grupos comprendía a la materia sonora, por una parte, y a las formas y cualidades del movimiento, por otra. El segundo estaba centrado en los sistemas (se supone que son constructos apropiados para organizar a los sonidos respecto de ellos mismos y del tiempo, pero esta seudodefinición casera es mía, porque no hubo otra), en los que deben ser considerados los elementos, las relaciones y las jerarquías. ${ }^{174}$

Y continúa:

Era un hermoso comienzo, sobre todo por la cantidad de "pelotas" que dejaba picando y que debían ser atrapadas por los alumnos, quienes mayoritariamente no habíamos hecho los cursos de acústica y psicoacústica necesarios. ¿Qué es la materia sonora en términos de esas disciplinas científicas?, ¿qué diferencia hay entre frecuencia y altura, que usábamos indistintamente?, ¿cuáles son las formas y las cualidades del movimiento, de un modo más preciso y formal que el provisto por Aristógenes cuando se refería al cambio?, ¿qué se entiende por sistema? ${ }^{175}$

Como modo de continuar con el ejemplo con que iniciamos el presente título y a modo de posible respuesta a la cuestión planteada en el mismo, sugerimos contrastar las capacidades de transformación del timbre de una guitarra eléctrica con las de un sintetizador: el segundo permite y propicia la creación de conformaciones espectrales mucho más diversas (u opuestas) y

${ }^{174}$ Vazquez, H. G. (2015). "Ariel Martínez" en Op.cit. pp. 188
${ }^{175}$ Ibid. 
facilita transformaciones tan complejas que exceden la perspectiva de los tradicionales parámetros del sonido (i.e.: altura, duración, sonoridad y timbre). En la guitarra en cambio, la misma construcción del instrumento evidencia la concepción paramétrica del sonido subyacente: la producción de sonido se logra casi exclusivamente al pulsar una cuerda; cuerda que proporciona un timbre con altura tonal definida y única, persistente. ${ }^{176}$

\section{Músicas de baile}

Como ocurrió con los componentes previos, aquí nuevamente nos topamos con una adjetivación plagada de prejuicios y problemas. Fundamentamos extensamente esta cuestión en nuestro ya citado Des-limitados, por ello nos limitaremos aquí a sintetizar que: las expresiones tradicionales de música ("a secas", música "pura") y música de baile (adjetivada, evidenciando la presencia del cuerpo en movimiento) implican una valoración que considera a la escucha en situación de concierto (donde cualquier ruido corporal proveniente del público se percibe como molesto) una percepción musical de jerarquía superior; una percepción más "elevada" en relación a la que se realiza en movimiento, en el baile, involucrando al cuerpo. La situación donde el cuerpo no es tenido en cuenta en tanto vía perceptiva es vista (consecuentemente, claro está) como la mejor situación de escucha, la situación ideal para percibir música. Dicho de otro modo, estas expresiones implican que la situación ideal es la mejor para focalizar la atención en lo que la música tiene para dar. Y claro está: si nuestro cuerpo no interviene en la percepción de música (i.e.: si escuchar música consiste solo en "hacerle llegar" al cerebro los estímulos auditivos y que este los aprecie) solo le queda a esta última el ser una idea en el cerebro incorpóreo del oyente.

Como consecuencia directa, estas expresiones subestiman a la música de baile ${ }^{177}$ y la subordinan a la ("Gran") Música ("a secas"). Ven al movimiento y al baile como obstáculos que se interponen y dificultan la percepción de la esencia musical, y a la música de baile como una versión degradada de su hermana mayor ("pura"). Evidente ejemplo de las políticas idealistas (políticas represoras de los cuerpos tanto individual como social) ${ }^{178}$ la subordinación de la categoría música de baile a la de Música continúa en la línea de los históricos relatos reales,

\footnotetext{
${ }^{176}$ Puede cuestionársenos que el instrumento "guitarra eléctrica" se compone además de los pedales o procesadores que transforman el sonido original. Ahora bien, que dichos dispositivos se encuentren como módulos en muchos sintetizadores puede comprenderse como señal de pertenencia o como influencia del instrumental electrónico sobre un instrumento que no forma parte de tal grupo. La segunda interpretación se reafirma por el argumento expuesto en el cuerpo principal: los pedales operan sobre el sonido ya parametrizado que entrega la guitarra; los sintetizadores en cambio se caracterizan por su matriz compleja desde origen para la generación de sonido. Numerosos ejemplos musicales dan cuenta de cómo se "desnaturaliza" y transforma la interpretación de la guitarra cuando proliferan los pedales (i.e.: la interpretación se "sintetiza", las acciones se vuelve las propias de un intérprete de sintetizador).

${ }^{177}$ No solo a su producción musical sino a todo su universo de compositores, productores, intérpretes, etc. ${ }^{178}$ Puesta de manifiesto por ejemplo en la expresión "masa trabajadora", o en el mismísimo "cuerpo social".
} 
imperiales y coloniales europeos y norteamericanos. Herederos estos, a su vez, de la oposición antigua entre idealismo y materialismo. ${ }^{179}$

Por otra parte y como fuera dicho, es un hecho innegable que algunas músicas se conciben y componen efectivamente para la danza. Sus creadores ponen en evidencia su intención compositiva (i.e.: su conciencia y deseo de que su pieza se baile) al reutilizar y reproducir cánones presentes en innumerables ejemplos históricos de músicas de danza; lo mismo sucede en las músicas que hemos llamado "de escucha". ${ }^{180}$ Es justamente aquí, en sus cánones estéticos, donde sus detractores fundamentan su posición: argumentan que las músicas compuestas para el baile son estética y técnicamente inferiores porque son concebidas especialmente para ser percibidas por bailarines, por sujetos en movimiento. Por encontrarse en movimiento los bailarines se encontrarían (al menos momentáneamente) incapacitados para dedicar toda su atención a la música; esto llevaría a los compositores a preferir formas (en sentido amplio) musicales simples por sobre otras más complejas. En otras palabras, pareciera que la complejidad es virtuosa por sí misma. Así surgió el término "música ligera" para denominar (en algo despectivamente) a muchas músicas populares. Sus compositores (como los productores de la electrónica) tampoco se salvan: son considerados artistas menores, creadores tan "ligeros" como la música que crean. Desde este punto de vista -el de la intención compositiva que subyace a cada pieza- podemos resumir y clarificar diciendo entonces que contamos con:

a) músicas de escucha o de concierto (compuestas para ser percibidas en dicha situación por sujetos incorpóreos) ${ }^{181} \mathrm{y}$

b) músicas de baile (compuestas para ser percibidas durante la danza por sujetos de cuerpo pleno).

Pero aquí surge otro problema, esta categorización entra en contradicción con las perspectivas actuales en relación al movimiento. Dichas perspectivas corren el eje del debate al proponer y promover que tanto las músicas que hemos llamado "de escucha" como las compuestas especialmente para la danza son plausibles de ser utilizadas para el baile. En otras palabras, ya no existirían músicas danzables y músicas que no, sino que unas y otras (e incluso

\footnotetext{
${ }^{179}$ El rol que le cabe a la perspectiva audiotáctil en este histórico debate puede ser visitado en nuestro ya citado Anzil, I. (2013). Ideo-materialismo musical...

${ }^{180}$ Por si no se nos comprende cabalmente: queremos significar que tanto las músicas compuestas "para la escucha" como las compuestas "para la danza" siguieron y siguen cánones históricos. Por supuesto, cánones diferentes -al menos en alguna medida- para cada una de estas músicas. Recorreremos los relativos a las músicas de baile en breve.

${ }^{181}$ Desde una perspectiva dualista mente/cuerpo -y procurando mayor precisión en nuestra descripcióndeberemos referirnos aquí a que, si bien la escucha ha sido y será siempre corporizada, en la situación de concierto la tradición occidental demanda a la mente una represión extrema del cuerpo; represión donde la situación ideal será la que más se aproxime a eliminar todo rastro posible de su inevitable presencia y gravitación en el proceso perceptivo. Para más detalles al respecto véase Anzil, I. (2011). Op.cit.
} 
el silencio) se utilizan con fines de escucha o movimiento. Así visto, nuestras categorías se reconvierten respectivamente en:

a) músicas utilizadas para la escucha (o utilizadas para concierto) y

b) músicas utilizadas para el baile.

El criterio para segregarlas ya no es la intención compositiva (muchas veces difícil o imposible de determinar) sino la situación de percepción diferenciada: unas se escuchan con los oídos mientras otras se perciben en el movimiento; las primeras requieren que el cuerpo del oyente esté presente-en-ausencia ${ }^{182}$ mientras las últimas comprometen a aquel en toda su materialidad danzante y perceptiva.

Explicitamos nuestra posición a este respecto: contradiciendo las históricas desvalorizaciones sufridas tanto por las piezas musicales como por los compositores e intérpretes, consideramos a las músicas de escucha y de baile como iguales jerárquicos. Consecuentes con nuestras ideas evitaremos estas adjetivaciones y las reemplazaremos por las expresiones músicas utilizadas para el baile y músicas utilizadas para la escucha. Pero antes de llegar a estas debemos desanudar otra maraña.

\section{Músicas electrónicas de baile}

Como fuera dicho, la adjetivación "de baile" en el caso de la música electrónica pretende al mismo tiempo a) diferenciar a esta especie de expresiones experimentales que le antecedieron históricamente (i.e.: la música electrónica "a secas") y b) dar a entender que los trabajadores culturales que se dedican a este tipo de música (músicos electrónicos, deejays, productores, etc.) desarrollan su actividad conscientes y teniendo en cuenta que sus producciones serán apreciadas en movimiento. En otras palabras, esta adjetivación es simplemente otra manifestación de la diferenciación entre "música" y "música de baile" trasladada al terreno específico de la música electrónica. No es extraño entonces que en los relatos referidos a la música electrónica de baile encontremos todos los problemas y prejuicios evidenciados en el título precedente. Analizando el discurso y las descripciones halladas en sitios y fuentes documentales especializadas podemos incluso ahondar en el sesgo evidenciado supra y detectar algunas posibles derivas del mismo.

Los relatos acerca del origen (mítico) de la música electrónica de baile remiten principalmente a músicas danzables históricas de origen centroeuropeo y norteamericano. ${ }^{183}$ En

\footnotetext{
${ }^{182}$ Véase Anzil, I. (2012). Op.cit. pp. 3

183 Disco, funk, soul, reggae, rock, pop y punk... entre otras. O sea, músicas originadas en los países colonialistas o en sus "descendientes exitosos" (por poseer y detentar poder imperial) los norteamericanos. Con algunas salvedades, hemos detectado alguna referencia a músicas folklóricas africanas en tanto fuentes ancestrales (nunca presentes) de material musical y algunas menciones a músicas de origen afroamericano y mestizo americano. Cabe destacar la ausencia total de referencias a
} 
otras palabras, sugieren que solo quienes utilicen recursos y dispositivos (musicales y tecnológicos) de dichos orígenes geográfico-culturales se encontrarán en condiciones de crear "verdadera" música electrónica de baile (solo quienes figuran en sus orígenes míticos poseen el conocimiento de lo esencial en relación a ellas). ${ }^{184}$ Este recorte de las posibilidades estéticas genera una retroalimentación de dichas cualidades, garantizando en cierto sentido la preeminencia y persistencia de rasgos musicales provenientes de las culturas que se autoarrogan el título de "originarias". De esta manera -sin importar de donde sean los artistas que las creen y por extensión- todas las músicas electrónicas de baile (en plural) se transforman en un nuevo dispositivo de colonización cultural a nivel global.

Surgen así derivas económicas íntimamente enlazadas con el recorte estético descripto: si la música que deseo crear utiliza recursos técnico-estéticos musicales europeos o norteamericanos, ¿qué mejor que un dispositivo de esos orígenes para llevar adelante el proyecto? Quienes figuran en el relato mítico serán los dueños simbólicos de la música tecnológica (y, en definitiva, de la tecnología en sí): ¿a quienes comprar recursos y dispositivos sino a sus dueños? Resulta significativo que incluso páginas web que denotan un trabajo dedicado y a conciencia en relación al tema omitan mencionar (al menos) las numerosas experiencias y desarrollos realizados en el Laboratorio de Música electrónica del Centro Latinoamericano de Altos Estudios Musicales (CLAEM); ${ }^{185}$ o que apenas se mencione a Japón, cuna de la miniaturización electrónica y de algunas de las más importantes empresas dedicadas a la tecnología musical.

\section{Músicas electrónicas de baile social}

De un modo más ambiguo y difuso el relato más difundido remite a los géneros musicales de baile donde la danza es "social"; en otras palabras, donde quienes danzan no son profesionales de esta disciplina sino individuos que desarrollan esta actividad como esparcimiento o contexto para el encuentro. Así, ballets como La consagración de la primavera de Igor Strawinsky (y sus cualidades técnico-estéticas musicales, entre otras) quedan por fuera

músicas de origen sudamericano (ya sean originarias, euroamericanas, afrosudamericanas u otro tipo de mestizaje) en los relatos míticos acerca del origen de las músicas electrónicas de baile o de sus antecedentes musicales. Que no nos extrañe, algo similar puede decirse del desarrollo de la electrónica experimental en nuestra región: los relatos hegemónicos no suelen hacer mención a lo que sucedía por aquí a mediados del siglo XX. Para más detalles al respecto de esto último sugerimos consultar la reciente publicación de la (ex) Secretaría de Cultura de Presidencia de la Nación, Festival internacional "La música en el Di Tella. Resonancias de la modernidad". (2011) Director: José Luis Castiñeira de Dios, como también Vazquez, H. G. (2015). Op.cit.

${ }^{184}$ Este sesgo tendrá una consecuencia ulterior: la utilización del término "tribal" para denominar aquellas piezas que incorporan elementos musicales de origen (primordialmente) africano. Una vez más, África se asocia con rasgos primitivos y pre-civilizados. Escúchese por ejemplo Digital Tribalism [Tribal Psybient Compilation Vol. 1]. Subido por Psybrations. Accesible en https://youtu.be/DOMeAReXICg. [20102016].

${ }^{185}$ El laboratorio funcionó entre 1964 y 1971 bajo la órbita del Instituto Torcuato Di Tella (ITDT) y fue quizá en Latinoamérica el principal motor del período en relación a música y tecnologías. 
de las músicas que (supuestamente) influyeron directamente sobre la especie electrónica de baile. Dicho de otro modo, aún cuando la totalidad de las músicas previas pueden haber influido en uno u otro grado sobre la especie (en cierto sentido consideramos que esto es así), podemos decir que las cualidades estético-técnicas del ejemplo elegido (i.e.: la gran pieza de Strawinsky) no se detectan en la superficie de las músicas electrónicas de baile (i.e.: no son evidentes al menos a primera escucha en la amplia mayoría de las piezas de la especie). ${ }^{186}$

Sabemos qué músicas concretas podemos eliminar de la lista de influencias directas de las músicas electrónicas de baile. Sin embargo persiste el problema de determinar concretamente- con qué especies y géneros históricos de músicas utilizadas para el baile social (de entre la inmensa cantidad que forman el conjunto) tendría relación la especie en cuestión, de qué modo se produciría la asociación y como (o dónde, musicalmente hablando) puede detectarse esta influencia. Podemos reformular nuestros interrogantes de la siguiente manera:

¿Qué cualidades hacen que una determinada pieza sea danzable y social? o... ¿qué generalizaciones podemos deducir a partir del análisis de los géneros danzables y sociales históricos?

Para luego preguntarnos:

¿Qué cualidades de los géneros danzables y sociales históricos persisten en la música electrónica de baile? ¿Experimentaron transformaciones? ¿En qué modos resultaron modificadas?

Considerando las perspectivas actuales que (como ya fue mencionado) establecen la premisa de que toda música e incluso el silencio son danzables, creemos conveniente tomar un camino alternativo para intentar alcanzar algunas definiciones en este asunto: no buscaremos las cualidades técnico-musicales que hipotéticamente harían de una pieza danzable y social sino que, siguiendo el camino inverso, tomaremos como referencias aquellas músicas que históricamente han sido utilizadas para el baile social e intentaremos detectar elementos comunes a todas o a la amplia mayoría de ellas. Esperamos así conformar un perfil de cualidades de las músicas utilizadas para el baile social. En otras palabras, en lo que respecta a la música electrónica de baile no procuraremos identificar sus supuestos (y muy dudosos) orígenes sino que intentaremos una caracterización que nos permita encontrar posibles continuidades y rupturas con las diferentes músicas utilizadas para el baile social pasadas y actuales analizadas.

\footnotetext{
${ }^{186}$ Algo que sí sucede, por ejemplo, en muchas composiciones musicales incluidas en films de los años '50 y '60 de Hollywood.
} 
Simultáneamente, durante el tratamiento de cada cualidad estético-técnica musical analizaremos brevemente algunos modos en los que se las incluye (a estas cualidades) en las músicas electrónicas utilizadas para el baile social, relegando otros para cuando analicemos específicamente aspectos propios de la especie.

Concretamente y para eliminar cualquier duda que pudiera persistir, explicitamos que reservaremos (como antes) la expresión música electrónica de baile para el conjunto al que refiere el relato hegemónico tradicional y reemplazaremos la expresión en plural por la conceptualmente más precisa (y ya mencionada) músicas electrónicas utilizadas para el baile social. ${ }^{187}$

\section{Músicas utilizadas para el baile social}

Listamos a continuación algunos géneros musicales históricos y actuales a los que se les asignó y/o asigna dicha función. No pretendemos aquí una lista exhaustiva ni mucho menos, sino apenas dar una breve muestra de la inmensa cantidad de danzas sociales que pueden hallarse en las diferentes culturas alrededor del planeta. Centraremos nuestra atención especialmente sobre el continente americano, revisando también aquellas otras regiones geográficas que más han influido sobre las músicas locales actuales.

Como forma de acceder a las cualidades musicales respectivas, sugerimos la realización de búsquedas sucesivas (y pacientes) de cada denominación (de cada género) en el sitio YouTube. Los videos incluidos allí permiten escuchar las músicas y, simultáneamente, observar los movimientos de danza asociados. Dichas búsquedas conducirán a un recorrido por un gran número de ejemplos pertenecientes a la categoría y es una forma de replicar la metodología que utilizáramos para el análisis de las mencionadas cualidades. Mediante este recurso es posible aproximarse al recorrido personal que realizáramos en relación a esta cuestión.

Tan numerosos son estos géneros, que el corpus de información que constituyen como conjunto requiere de estrategias de Big Data para ser abarcado. ${ }^{188}$ Tratándose de un tema en algún sentido accesorio a nuestro foco de interés y careciendo de las herramientas necesarias para el procesamiento de la inmensa cantidad de datos, dedicamos a este tema un espacio relativamente breve en nuestro desarrollo y una metodología quizá poco ortodoxa o académica.

Acerca de los datos recabados se hace necesaria una aclaración: por diferencias culturales, en algunos casos no fue posible determinar si el género musical solo es bailado por profesionales o si también se utiliza para danza social. Así sucede por ejemplo con el kecak o kechak de Bali, las danzas del dragón y del león chinas o con la danza hindú bharata-natiam. Todo indica que esta última solo puede bailarse por profesionales, pero su carácter ritual y la descripción hallada en Wikipedia presenta ambigüedades que no pudimos salvar. Hemos optado

\footnotetext{
${ }^{187}$ En títulos por venir trataremos otros argumentos que fundamentan la segunda denominación.

${ }^{188}$ Se denomina así a los estudios que realizan un relevamiento sobre gran cantidad de datos y que, por esta razón, requieren de la asistencia de algoritmos de selección y categorización de la información.
} 
por excluir de nuestro listado los géneros que presentaran problemas de este tipo. También hemos excluido géneros de danza históricos (mencionados en algunos sitios) de los cuales no pudimos encontrar ejemplos audiovisuales o información que confirmara su pertenencia a las músicas utilizadas para el baile social.

Procurando darle algún tipo de organización hemos optado por agruparlos a partir de criterios geográficos, étnicos o de origen. He aquí la lista.

a) Del folklore sudamericano: aire (o aire pampeano), bailecito, bambuco, candombe, capoeira, cielito, cuándo, cuarteto, cueca (en sus numerosas formas), cumbia, chacarera (en todas sus formas), chamamé, chamarra, chamarrita, festejo, forró, galope, galopera, gato, huaino/yaraví, lonkomeo, malambo (argentino norteño y surero), marcha, media caña, milonga, pericón, polka, samba, tango, tinku, triunfo, zamba, zamacueca, ...

b) Del folklore centroamericano y caribeño: bachata, bolero, bunde, cha cha cha, chuchumbé (son de), habanera, malambo (colombiano y venezolano), reggae, rumba, salsa, son, vallenato,...

c) De origen norteamericano: boogie, country dance, disco, funk, danza jazz, pop, rock, rock\&roll, soul, swing, twist, ...

d) De origen europeo: allemanda, bacchu-ber, badinerie, baile de la Era o danza de Larrain o soka dantza, baile de romería, baja danza, bergamasca, bourrée, branle, country dance, courante, cuadrilla, cracoviana, chacona, csárdás, danza irlandesa, galop, gavota, giga, mazurka, minuet, oberek, pavana, polka, sardana, schottisch o chotis, tarantela, vals, zarabanda ${ }^{189}, \ldots$

Como antes, en la enciclopedia en línea Wikipedia encontramos varias listas de géneros de danza; una búsqueda de la entrada "Géneros y formas musicales de danza" arroja que las páginas conteniendo esta categoría son:

Acto de ballet, Aire (danza), Alemanda, Anapalé, Bacchu-ber, Badinerie, Baja danza, Danza balinesa, Ballet, Ballet moderno, Bambuco, Bergamasca, Bharata natiam, Bourrée, Branle, Bunde (Panamá), Carpea, Chacona, Chuchumbé, Cielito, Contradanza, Corranda, Courante, Cracoviana, Creuzpolka, Csárdás, Cuadrilla (danza), Cueca, Cuándo (danza), Dabke, Danza de los funerales, Danza de pareja enlazada, Danza del torito pinto, Danza medieval, Danza Morris, Danza renacentista, Danzón, Diablada,

\footnotetext{
${ }^{189}$ El caso de la zarabanda resulta algo ambiguo. Colegas han expresado su creencia de que su origen es americano con influencias africanas, y que solo luego se trasladaría a Europa. Sumaron a esta información el hecho de que allí, en algún momento del pasado, se la prohibiera por ser una danza "demasiado sensual". Sin ser especialistas y honrando la sinceridad agradecemos el aporte de la información suministrada incluyéndola aquí.
} 
Diablada de Oruro, Escarramán, Escocesa, Estampie, Figura (baile), Folias, Forlane, Gallarda, Galopa misionera, Gavota, Giga (danza), Guabina, Guaguancó, Guaracha santiagueña, Habanera, Haka, Harlequinade, Hoko (Rapa Nui), Hornpipe, Huella (danza), Jerk (baile), Jive, Ka Mate, Krakowiak, Kuchipudi, Ladja, Lakalaka, Landler, Loncomeo, Loure, Lundu, Machicha, Malambo (danza), Mascarada, Matamuerte, Maxixe, Mazurca, Musette, Oberek, Odissi, Ostendesa, Pasodoble, Paspié, Pavana, Pericón (danza), Pesindhèn, Polca, Polonesa, Rasguido doble, Refalosa, Rigodón, Rondón (baile), Rueda de casino, Saltarello, Sau sau, Singuili, Sirtaki, Tamunangue, Tango, Taquirari, Tarqueada, Triunfo (danza), Tunantada, Turdión, Vals, Vals en México, Zamba, Zarabanda, Zarambeque, Zorcico ${ }^{190}$

Sugerimos también consultar las entradas "Dance music" de la versión inglesa de Wikipedia. Esta incluye, entre otras, una categorización de la música electrónica de baile "occidental" ( "western" en el original) en géneros y subgéneros, evidenciando la pertenencia de la especie a la línea histórica de "música compuesta específicamente para facilitar o acompañar la danza". ${ }^{191}$

Mencionamos a continuación algunas danzas originarias de diversas regiones de África (Congo, Sambo y demás) que relegáramos por requerir ciertas aclaraciones previas. La importancia de este acervo cultural reside en la enorme influencia sobre la mayoría de los géneros musicales sudamericanos y americanos (i.e.: zamba, chamamé, milonga, son, etc) como también sobre la música electrónica de baile.

La inmensa riqueza cultural de estas músicas se mestizó con las locales y europeas en la interacción de las personas que fueron arrebatadas y traídas esclavizadas a las -en cierto sentido, también esclavizadas- colonias de América. En su amplia mayoría conteniendo polirritmias, muchas danzas en la cultura africana contienen aportes sonoros de parte de los mismos bailarines (golpes en el piso, percusiones, aplausos y exclamaciones), dificultando la separación entre los roles de bailarín-músico y entre movimiento de baile-movimiento musical instrumental. Desearíamos presentar la información con más detalle, pero no hemos sido capaces de acceder a material teórico al respecto. Agradecemos el aporte de Alex Valentine, ciudadano sudafricano y amigo quien, desinteresadamente, aportó información de músicas utilizadas para el baile en su país. La lista:

\footnotetext{
${ }^{190}$ Wikipedia en español [en línea]. Categoría "Géneros y formas musicales de danza". Accesible en http://es.wikipedia.org/wiki/Categor\%C3\%ADa:G\%C3\%A9neros_y formas musicales de danza [16042016]

${ }^{191}[\ldots]$ "music composed specifically to facilitate or accompany dancing".Wikipedia en inglés [en línea]. Accesible en https://en.wikipedia.org/wiki/Dance music [16042016]
} 
Adowa, adumu, agahu, agbaja, agbekor, agwara, akogo, amaggunju o magunju, assiko, bikutsi, bottle dance, bwola, coupé-décalé, ding ding, ekitaguriro, ekizino, entog, entogoro, gombey, indlamu o ndlamu, kete, kakilambe, kwassa kwassa, kpanlogo, lamban, larakaraka, makossa, macru o makru o makrou, mapouka, mbende, mohobelo, moribayassa, muchongoyo, mwaga, nama riel, ndombolo, owaro, runyege, sabar, sunu, tamenaibuga, umteyo, yankadi, zouglou $\ldots{ }^{192}$

Lamentamos la casi total ausencia de información a este respecto proveniente de países de oriente. A pesar de no contar con herramientas teóricas que nos permitan evaluarlas con cierto grado de certeza, hemos intentando incluir ejemplos de medio oriente y oriente a nuestro corpus de músicas utilizadas para el baile social. Así, pudimos acceder a través de la (misma) plataforma que brinda YouTube a ejemplos provenientes de Palestina, China, Siria, India y otros países de la citada región. Valga decir que las cualidades musicales de los géneros hallados no difieren sustancialmente de los de otras regiones del planeta; temiendo equivocarnos, a primera escucha pareciera que los postulados válidos para occidente son aplicables también para oriente. $^{193}$

\section{Características comunes del universo de músicas utilizadas para el baile social}

En los relatos más difundidos, solo algunos pocos de los géneros musicales nombrados se mencionan entre los que aportan cualidades a la música electrónica de baile. Sin embargo, todos los géneros musicales que conforman la lista previa son o han sido utilizados para el baile social. La música electrónica de baile se encuentra vinculada a aquellas al menos a nivel de lenguaje, ${ }^{194}$ como uno de los elementos que pertenecen a esta categoría ${ }^{195}$ desde la cual pensar la música. Es entonces posible suponer que podemos hallar algunas características técnicas musicales y rasgos estéticos básicos que sean comunes a todas.

Sin ser el foco del presente trabajo y tratándose de un repertorio que -por su extensiónresulta humanamente inabarcable (al menos que, como dijéramos, recurramos a algoritmos matemáticos y sistemas robotizados de búsqueda), nos propusimos realizar un rápido repaso de ejemplos y relevamiento de las cualidades mencionadas, procurando detectar las generalizaciones que nos resultaran subjetivamente razonables. Por supuesto, debe

192 Wikipedia en inglés [en línea]. Categoría "African dances". Accesible en https://en.wikipedia.org/wiki/African_dance [19092016]. Al respecto sugerimos también el documental (en idioma inglés) Dances of Southern Africa. Subido por Penn Museum. Accesible en https://youtu.be/FvzHCMlgkvA [19092016].

${ }^{193}$ Véase a modo de ejemplo el video de danza yangge (China) Yangge Dancing in Shenyang. Subido por Danwei TV. Accesible en https://youtu.be/EXLUTxldQ_g [19092016].

194 Nos referimos aquí al lenguaje hablado, y no al llamado "lenguaje musical".

${ }^{195}$ Una de las especies musicales que conforman el conjunto. 
comprenderse que estos relevamientos y análisis fueron realizados bajo una lógica difusa ${ }^{196}$ tanto en lo que respecta al número (reducido) de ejemplos musicales de cada género escuchados ${ }^{197}$ como a la pertenencia o no de dichos ejemplos al género enunciado en la fuente documental consultada. Confiamos para lo último en el emisor del mensaje. ${ }^{198}$ Confiamos además nuestro éxito al alto número y diversidad de géneros revisados, relegando la exhaustividad a otros.

Por las razones expuestas y por recurrir también a nuestras experiencias profesionales a lo largo de años, la lista de ejemplos visitados resultaría tan inconducente e incompleta como cualquier lista que pretendiera expresar la diversidad de experiencias de toda una vida musical. Basta con realizar búsquedas de estos géneros en los sitios con contenido musical ya mencionados (YouTube, Bandcamp, Soundcloud, Google, etc.) para acceder a material del tipo consultado. Sin intención enciclopedista y desconfiados del determinismo, exponemos a continuación las cualidades detectadas, esperando que se las considere siempre bajo el manto de la "porosidad" y la lógica borrosa.

\section{Previsibilidad}

Quizá la cualidad principal y por excelencia, se pone de manifiesto de diversas formas, en numerosos aspectos y niveles musicales. Tiene su principal y más probable razón de ser en que solo a partir de la posibilidad de anticipar lo que sucederá en la música podemos sincronizarnos con ella. En otras palabras, esta es una de las formas en las que se expresa la cualidad social de estas músicas: el encuentro pareciera expresarse corporalmente en el movimiento sincrónico compartido, en el acuerdo rítmico colectivo.

Además de la evidente utilidad para la sincronización coreográfica, es más sencillo identificarnos con un otro/otra a quien vemos moverse a nuestro ritmo. Por otra parte, es un hecho comprobado que ciertos ritmos fisiológicos (respiración, ritmo cardíaco, presión sanguínea, etcétera) se modifican por diferencias en el tempo/densidad cronométrica. ${ }^{199}$ Descriptas ambas dimensiones musicales casi sin excepción por la velocidad de paso del pulso, vemos aquí una razón que apoya su presencia y constancia en las músicas utilizadas para el

\footnotetext{
${ }^{196} \mathrm{Si}$ bien la lógica difusa tiene una definición estricta desde el punto de vista matemático, aquí la utilizaremos por oposición a la lógica binaria aristotélica donde las proposiciones solo tienen valor binario verdadero o falso. En la lógica difusa o borrosa, las proposiciones tienen un valor porcentual de verdad.

${ }^{197}$ Muy desigual entre los diferentes géneros además.

${ }^{198}$ Recurrir para este tipo de tareas a sitios como YouTube, Bandcamp, Soundcloud, Mixcloud, etc. hoy es ineludible. Se comprenderán entonces las imprecisiones que pueden surgir de la multiplicidad de usuarios que suben contenido multimedia a estas plataformas. De cualquier modo, este incompleto e imperfecto relevamiento aún permite hacerse con una idea más o menos aproximada (nuevamente la lógica difusa) de lo que las músicas utilizadas para el baile social poseen en común alrededor del planeta y musicológicamente hablando.

199 "Music and the heart" en revista Circulation. Journal of the American Heart Association. Dic 11, 2007. pp. f139-f140. Accesible en http://circ.ahajournals.org/content/circulationaha/116/24/F139.full.pdf [27092016]. Volveremos a este asunto luego.
} 
baile social. De cualquier manera, la previsibilidad no se restringe a la presencia de una pulsación constante.

Que las músicas ofrezcan un alto grado de previsibilidad brinda también un marco para la estabilidad emocional que (al menos en teoría) facilitaría una actitud positiva hacia la situación y ocasión donde se las presenta. Si bien no podemos hablar de una relación lineal, saber qué sucederá en la música -y cuándo- libera nuestra atención a otros estímulos y actividades: cuando la finalidad es el encuentro (aunque resulte redundante, "social"), el momento compartido, esta cualidad parece más que deseable. ${ }^{200}$

En lo vertido en el párrafo precedente quizá encontramos otro tipo de previsibilidad que se encuentra presente en estas músicas. Es el caso de aquellos géneros que forman parte del acervo cultural de una sociedad o comunidad determinada, donde sus individuos (músicos y bailarines sociales) poseen un conocimiento compartido en relación a aquellos. Este conocimiento compartido permite salvar (en términos coreográficos) cambios musicales que, de otro modo, dificultarían la continuidad de la danza.

Probablemente puedan hallarse más razones que expliquen esta cualidad. Su omnipresencia en las músicas utilizadas para el baile social así lo sugiere. Tememos extendernos en cuestiones teóricas, por lo que pasaremos a analizar algunos modos en los que la previsibilidad se expresa en términos sonoros y musicales concretos.

\section{Previsibilidad en la organización musical}

La contemporaneidad recuperó para la música diferentes grados de libertad en lo que se refiere a las formas de organización posibles. El abandono de principios estéticos hegemónicos y su reemplazo por el paradigma de la libre elección, en consonancia con la inconmensurable plasticidad que los métodos de control electrónico de la materia sonora aportaron a los músicos, abrieron un campo exploratorio en relación al cual aún nos encontramos en las puertas de entrada. Las estéticas vanguardistas del siglo XX dieron rienda suelta a la imaginación en muchos de los aspectos plausibles de ser trabajados en la música. En una síntesis apretada, podemos resumir esta revolución en términos de liberación de la duración y el ritmo, de la altura y el timbre. En general, esta liberación resultó en/derivó de la incorporación de la diversidad y los extremos.

Sin embargo, en la amplia mayoría de las músicas utilizadas para el baile social actuales persisten formas de organización detectables en ejemplos de los siglos previos. Sus cualidades se encuentran tan omnipresentes que se vuelven definitorias del conjunto de estas músicas. Nos referimos a sus formas, las cuales se caracterizan por distribuir los cambios en el tiempo de

\footnotetext{
${ }^{200}$ Afirmación válida aún cuando este saber es en realidad una ilusión de conocimiento, una creencia, ya que la música siempre puede sorprendernos quebrando nuestra expectativa. Para una mejor comprensión de nuestra perspectiva teórica integradora acerca de la relación entre "saber", "creer" y "crear" sugerimos la lectura de nuestro ya citado Anzil, I. (2013). Ideo-materialismo musical...
} 
manera periódica y regular. Veamos de qué maneras y en qué niveles estas cualidades se ponen de manifiesto.

\section{Pulsación regular subyacente}

Todos los ejemplos escuchados -sin excepción- incorporan algún tipo de métrica basada en la división isócrona del continuo temporal. El establecimiento de una grilla que determina los ritmos posibles e imposibles, que ordena en qué momentos pueden ocurrir eventos musicales y cuando no, ${ }^{201}$ brinda una referencia temporal fija y precisa que se manifiesta explícitamente en la música. ${ }^{202}$ Esta cualidad, que en algunos ámbitos puede percibirse inicialmente asociada al concepto de "simpleza" o a ideas musicales retrógradas, se complejiza a partir de un amplio espectro de estéticas donde (a pesar de compartir la propiedad de dividir al tiempo en partes iguales) las rítmicas utilizadas resultan muy diversas. Encontramos casos que van desde:

a) Muy sencillos

Donde un pulso único, estable, invariante y evidente domina la totalidad (estadística) de las conformaciones rítmicas. Es usual en estos ejemplos que al pulso lo acompañen otras maneras regulares e invariantes de determinar las formas rítmicas, ordenadas en diferentes niveles jerárquicos (compás, división y meta-compases); ${ }^{203}$

b) Medianamente complejos

Aquellos en los que, si bien puede detectarse un pulso único, este se encuentra oscurecido a la percepción. Ya sea por la proliferación de rítmicas sincopadas, por la utilización de tempos veloces y rítmicas cambiantes, por la inclusión de acentuaciones o agrupamientos que lo contradicen o debilitan, por la utilización de compases de amalgama, o aditivos (con pulso variable pero división estable), polirritmias u otros;

c) Muy complejos

\footnotetext{
${ }^{201}$ Ordena sobre todo en qué momentos pueden iniciarse nuevos eventos musicales. En algún grado también ordena en qué momento pueden finalizar; aunque su influencia sobre este aspecto se ve debilitada o difuminada por la ocurrencia de sonidos con extinción gradual.

${ }^{202}$ Recordemos que la música, en el más básico de los sentidos, es en esencia ritmo (o ritmos, en plural), es distribución de la energía en el espacio-tiempo. Entre otros, se conforma por los micro-ritmos concretos (del acompañamiento, de la melodía, de las acentuaciones, etc.), por lo que podemos llamar "ritmos de nivel medio" (armónico, de frases melódicas, de versos literarios cantados, etc.) y por el o los macro-ritmos (o coeficientes) de cambio en diferentes dimensiones (el ritmo de paso de las partes o secciones de una pieza, el de aparición y modificación de los elementos de la textura, el de aparición, modificación y reemplazo de los instrumentos o timbres que componen la resultante tímbrica de una pieza en cada momento, etc.).

${ }^{203}$ Nos referimos aquí a los tradicionales compases de 2, 3 y 4 tiempos binarios y ternarios, como a otros (menos tradicionales) pero donde la pulsación regular y constante persiste (por ejemplo, compases de 5/4 y $7 / 4)$.
} 
Donde pueden presentarse pulsos isócronos diferentes y simultáneos (sobre todo en ejemplos que presentan rasgos heredados de tradiciones africanas), modulaciones rítmicas, o ritmos basados en pulsos o divisiones difusos o medidos de manera laxa (no nos referimos aquí al tempo rubato sino, por ejemplo, al tipo de división difusa binaria-ternaria que presentan algunos géneros bailables del altiplano sudamericano y al denominado "swing" de músicas de origen afronorteamericano).

A lo antedicho debemos agregar diferentes grados de complejidad que aportan a) los cambios de tempo, b) cambios de compás, c) valores agregados o d) estratos texturales que aún simultáneos a los medidos que describimos- presentan ritmo no medido. Estas características últimas han sido halladas en ejemplos que (en lo general) pueden ser descriptos en los términos de la clasificación que antecede a este párrafo.

Todas y cada una de estas rítmicas ocurren en las músicas utilizadas para el baile social. Veremos este tema en detalle cuando desarrollemos las cualidades específicas de la especie.

\section{Formas simples de niveles medio y macro}

Estructuras rápidamente reconocibles generan previsibilidad a niveles mayores al de la pulsación. Patrones breves, estrofas, estribillos y otras formas medianamente fijas, usualmente periódicas, regulares, equivalentes y recurrentes (divisibles a su vez en fragmentos menores, también periódicos, regulares, equivalentes y recurrentes) organizan la percepción en segmentos que aún oídos sin formación musical sistemática pueden identificar.

Las formas musicales simples de nivel medio ${ }^{204}$ generan previsibilidad sin importar si son o no conocidas previamente por los bailarines sociales o acordadas con estos. ${ }^{205}$

\footnotetext{
${ }^{204}$ Nos referimos con esta expresión a frases musicales de pocos segundos de extensión, abarcables en un fiato o respiración.

${ }^{205}$ Hemos elegido redefinir estos términos para facilitar la sintaxis. 1. "Conocidas previamente" (o simplemente "conocidas"): los bailarines sociales poseen conocimientos previos de ciertas formas simples concretas. Su reconocimiento se facilita cuando los rasgos musicales forman parte del acervo cultural de la sociedad a la que pertenecen ambos: música y bailarines sociales. Así, un individuo reconocerá las formas presentes en un determinado ejemplo por su similitud con las formas detectadas en otro escuchado con anterioridad; sobre todo cuando este pertenece al mismo género. Por esta razón, la fuerza de este principio (no se circunscribe pero) es mayor dentro del área de influencias (geográfica y social) de dicho cuerpo de conocimientos culturales y tiene su base en los usos y costumbres populares transmitidos (usualmente) por vía oral de generación en generación. Con el advenimiento de internet y de la posibilidad de acceder a ejemplos de culturas diferentes, las mencionadas "áreas de influencias" han perdido al menos parte de su anclaje geográfico. 2. "Acordadas": si bien los bailarines sociales pueden no estar familiarizados con los rasgos de las formas simples presentadas en un ejemplo concreto, y este ejemplo puede no ser parte del acervo cultural de su sociedad de pertenencia, la similitud de los rasgos de una forma simple concreta (o de la función que esta desempeña en la macro-forma musical) con las detectables en ejemplos musicales pertenecientes a su propio acervo cultural le permiten la operación de
} 
Racional o intuitivamente ${ }^{206}$ los bailarines poseen datos que los ayudan a prever el final de una parte y el comienzo de la siguiente. El elevado grado de sencillez y claridad ${ }^{207}$ y/o las similitudes evidentes con ejemplos previamente escuchados que presentan estas formas, propician y facilitan una estructuración casi instantánea de lo percibido. Casi instantánea ya que la mencionada estructuración puede incluso completarse antes que la primera forma de nivel medio o macro finalice. Esto resulta válido tanto para las formas simples ya escuchadas o en desarrollo como para (al menos en algún grado) las que las suceden.

Para numerosos géneros es común que las estructuras musicales sean conocidas con anterioridad por los bailarines sociales. Para muchos géneros es también común que a dichas estructuras les correspondan formas coreográficas que abarcan períodos temporales equivalentes (mensurable en compases o tiempos). ${ }^{208}$ En muchos casos, estas estructuras coreográficas son también conocidas por los bailarines sociales. En esta categoría entran, por ejemplo, las formas de nivel medio del género folklórico argentino chacarera: la amplísima mayoría de piezas del género presentan la misma cantidad de partes, en el mismo orden y con la misma longitud (relativa a las demás partes, medida en cantidad de compases o tiempos). En otras palabras, podemos decir que al menos hasta cierto punto: habiendo escuchado una chacarera... hemos escuchado todas. Aquellos ejemplos que divergen suelen denominarse "aire de chacarera". ${ }^{209}$

Las músicas electrónicas utilizadas para el baile social hacen un uso tan prolífico de estas formas que numerosas piezas se componen exclusivamente de formas simples de nivel medio y la macro-forma resulta un emergente de las interacciones entre estas.

\section{Fórmulas anticipatorias de cambios}

Fórmulas breves que de algún modo se diferencian de la generalidad estadística presentada hasta entonces permiten anticipar cambios, pausas o el final de una sección e inicio de la siguiente/repetición de la anterior. Cambios en las regularidades presentes hasta entonces (rítmicas, melódicas, armónicas, etc.) convocan la atención de los

reconocimiento por analogía de la función desempeñada por la forma simple en cuestión. En el mismo acto de reconocimiento de dicha función, compositor (a través de su música) y bailarín social "acuerdan" (racional o intuitivamente) que cada aparición de estas formas simples desempeñarán la función antes detectada. Por supuesto, esta operación no está libre de posibles errores de interpretación. Una aclaración final: el límite entre lo "acordado" y lo "conocido" es (como seguramente puede suponerse) difuso.

206 Por ejemplo: apoyados en el contenido literario de las piezas que incorporan canto, por un conocimiento intuitivo de los códigos de la armonía tonal, por indicios derivados de los arcos de evolución melódica, por cuestiones rítmicas, etc.

${ }^{207}$ En otras palabras, cuando las partes presentan conformaciones internas simples y los límites con partes adyacentes son suficientemente claros como para permitir un rápido reconocimiento perceptivo.

${ }^{208}$ Mientras los primeros son utilizados por músicos, el uso de "tiempos" para "contar" y medir las estructuras musicales está más difundido entre bailarines profesionales.

${ }^{209}$ La pieza así adjetivada no se considera $100 \%$ una chacarera. No tiene el "derecho" de ser llamada así por no respetar los cánones formales pre-establecidos del género. 
bailarines sociales. Usualmente periódicos, estos desvíos de la previsibilidad en el nivel micro-formal (en algo asimilables a lo que la tradición europea llama "fórmulas cadenciales") anticipan articulaciones formales o desvíos mayores a nivel macroformal. ${ }^{210}$

Ocupando apenas fragmentos menores a un tiempo o durando un número considerable de compases ${ }^{211}$ estas fórmulas se presentan como a) variaciones de los eventos que conforman el estrato textural que cumple la función de acompañamiento de la pieza musical $^{212}$ o b) elementos texturales novedosos que se superponen a los preexistentes. Grupos rítmicos diferenciados y reconocibles, densificaciones cronométricas, giros melódicos cuyas características se reservan al cumplimiento de esta función, crescendos de sonoridad, pausas breves (llamadas "cortes" o "breaks" en la jerga), cadencias armónicas diferenciadas, cambios o anticipaciones de instrumentación, entre muchas otras, son las innumerables formas que pueden asumir estas fórmulas anticipatorias.

Conocidas por o acordadas con los bailarines sociales, su identidad y reconocimiento por parte de aquellos (como también su eficacia) se basa justamente en la función anticipatoria que estas fórmulas desempeñan. Por lo antedicho podría pensarse que su importancia será mayor o menor (desde el punto de vista de la sincronización coreográfica) dependiendo de si el género musical implica o no una coreografía fija, pero su detección en géneros que cumplen con esta condición tira por tierra esta suposición. Además de su función de renovación del material musical, su presencia en el contexto referido podría comprenderse también como una ayuda extra o indicio intertextual para que aquellos bailarines sociales que desconocen el género musical puedan realizar la necesaria operación de reconocimiento por analogía que les permita el acuerdo. ${ }^{213}$ Vale la pena aquí recordar lo ya dicho: las músicas utilizadas para el baile social tienen como una de sus finalidades principales operar como marco para el encuentro social; encuentro que, además, se realiza en movimiento. La estabilidad emocional asume aquí nueva importancia.

\footnotetext{
${ }^{210}$ Preferimos el término "desvío" por sobre el de "ruptura" debido a que estas fórmulas suelen inscribirse dentro de la grilla planteada por las estructuras métricas antes descriptas (pulso, compás y meta-compás). Dichas estructuras no solo se mantienen inalteradas en la amplia mayoría de los casos sino que resultan fortalecidas y reforzadas por estas fórmulas (de modo similar a como resulta reforzado el tiempo fuerte de un compás por los levares, o por cómo se reafirma la fuerza cadencial del acorde de dominante cuando le antecede el $2^{\circ}$ grado efectivo o sensibilizado en su rol de dominante secundaria). De hecho, es justamente esta cualidad la que permite a los bailarines anticipar el cambio a nivel macro-formal y sincronizar su movimiento con el mismo.

${ }^{211}$ En las músicas electrónicas utilizadas para el baile social estas fórmulas pueden incluso rivalizar en duración con las formas simples de nivel medio, llegando en casos a establecerse como verdaderas secciones intermedias que -como mamuskas rusas- contienen en su interior nuevas fórmulas anticipatorias que (valga la redundancia) permiten prever su fin (y comienzo de la sección siguiente). Muy propio de la especie y de la cultura del remix, lo mínimo se amplifica y reproduce hasta mutar en otra identidad.

${ }^{212}$ Estrato que en el léxico de las músicas populares suele denominarse la "base" de la pieza.

213 "Acuerdo" en el sentido que hemos redefinido; acuerdo con el compositor por intermedio de su música.
} 
En el marco de las músicas electrónicas utilizadas para el baile social el uso de formulas anticipatorias se encuentra muy extendido, resultando para algunos géneros una de sus características definitorias.

\section{Previsibilidad en los principios compositivos preferidos}

Repetición, variación y contraste son los comportamientos paradigmáticos básicos y generales a partir de los cuales se analizan y describen tradicionalmente los métodos y procedimientos utilizados en la composición musical. A partir del análisis retroactivo de los grados de diferencia y similitud que presentan entre sí las secciones y partes de una pieza musical arribamos al resumen y síntesis (de la pieza completa) que constituye la macro-forma. Por tratarse de un análisis multi-nivelado, la macro-forma pone también de manifiesto las micro-formas contenidas en cada sección y parte que la componen.

En el análisis de la macro-forma de una pieza concreta, entre otras acciones se pueden observar las relaciones de duración entre sus secciones y partes, los modos en que estas articulan el devenir musical y temporal, y las maneras en que aquellas se relacionan entre sí. También es posible realizar observaciones respecto de la claridad con que dichas articulaciones se presentan a la percepción. Como en el título precedente, aquí también las macro-formas de las músicas utilizadas para el baile social actuales presentan cualidades que -en términos generales y en su amplia mayoría- pueden rastrearse hasta músicas de siglos pasados: en breves términos, desestiman casi por completo la complejidad formal de ciertos desarrollos musicales del siglo XX y XXI tanto en lo que se refiere a la cantidad de secciones diferenciadas contenidas en una única pieza como a la complejidad en las inter-relaciones mutuas y/o a la posibilidad de configurar fronteras difusas entre secciones adyacentes. ${ }^{214}$ Las músicas utilizadas para el baile social presentan entonces: pocas identidades diferenciadas (usualmente no más de 2 o 3 secciones o partes formalmente diferentes), ${ }^{215}$ secciones o partes con identidades relativamente sencillas de reconocer perceptivamente (y que usualmente se presentan repetidas un cierto número de veces) y articulaciones formales (las fronteras entre secciones o partes) fácilmente discernibles. Algo abarcamos este tema en el apartado previo, en cierta medida retomamos a continuación ese desarrollo.

\section{Repetición y variación. Repetición textual y variada}

Las músicas bajo estudio -a diferencia de otras- recurren casi exclusivamente y a todo nivel a la repetición tanto textual como variada. Si bien este método compositivo es

\footnotetext{
${ }^{214}$ Tómese como ejemplo de complejidad la producción destacada de Igor Strawinsky, Olivier Messiaen y otros compositores del período.

${ }^{215}$ Esquemáticamente, no más de 2 o 3 temas melódicos, armónicos o melódico-armónicos. Veremos luego que algunos de los materiales utilizados en las músicas electrónicas utilizadas para el baile social impiden una relación lineal entre sus "temas" y los "históricos".
} 
hallable a niveles micro-formales (i.e.: de célula rítmica o melódico-rítmica) su omnipresencia se hace más evidente a niveles medios (i.e.: entre semi-frases o frases) y macro-formales (i.e.: las piezas se organizan en estrofas o estrofas y estribillos que se presentan repetidas veces). Pareciera que la complejidad que aporta el desarrollo (esquemáticamente: consecuencia del trabajo compositivo centrado en el contraste) se considera excesiva para el contexto social en que estas músicas se presentan. Ante este dato no carece de lógica pensar que quienes seleccionan piezas para bailar o para que otros bailen (deejays, músico electrónicos, etc.) tienen en cuenta los métodos compositivos que dichas piezas incorporan. El criterio general subyacente podría expresarse de la siguiente manera: demandar a los bailarines demasiada atención demandar una escucha destinada a determinar qué está sucediendo en la música- reduce el espacio mental plausible de ser dedicado a la danza, a la sincronización, al acuerdo y al encuentro. ${ }^{216}$

Tanto la repetición como la variación remiten a la primera aparición del material musical repetido/variado. Las cualidades formales de esta primera presentación se establecen como un anclaje a la percepción y operan como referencia de lo que sucede y sucederá en la pieza de allí en más. ${ }^{217}$ El reconocimiento consciente o intuitivo de todas las formas musicales que se reiteran a diferentes niveles formales (i.e.: ritmos, giros melódicos, secuencias armónicas, acompañamientos, partes, secciones, estrofas, etc.) es otra manera en que se conforma la previsibilidad. Quizá aquí pueda detectarse otra razón para la elección de los métodos compositivos: la variación puede comprenderse como "repetición con un grado de previsibilidad menor". El juego compositivo en relación a las expectativas estaría dado en estas músicas entre repetición textual y variada, respectivamente entre previsibilidad (casi) total $^{218}$ y previsibilidad parcial.

\footnotetext{
${ }^{216}$ Sin embargo, a diferencia de lo que puede suceder en otras especies y en el transcurso de las varias horas que dura un evento de músicas electrónicas utilizadas para el baile social, como veremos luego la complejidad efectivamente emerge y lo hace precisamente a partir del trabajo del deejay.

${ }^{217}$ Para ser exactos debemos decir que su rol de referencia dependerá de la duración total de la pieza concreta. Sin embargo, la brevedad perceptiva (relativa y estadística) que caracteriza a las piezas pertenecientes a las músicas utilizadas para el baile social hace que esta afirmación pueda ser tomada como válida. Aclaramos cualquier duda que pudiera persistir: en músicas de duración más extensa y/o desarrollos complejos, el rol de referencia de una determinada sección o parte puede reducirse, volverse difuso o diluirse en el devenir musical. Si bien muchos ejemplos de músicas electrónicas utilizadas para el baile social poseen duraciones totales que van más allá del doble o triple de la mayoría de las demás músicas utilizadas para el baile social, esta mayor duración se contrarresta por el hecho de que (aquellas) son en su amplia mayoría monotemáticas, presentan un grado mucho mayor de repetición y (siempre en términos generales y difusos) sus coeficientes de cambio describen arcos más largos y paulatinos. A esto específicamente nos referíamos cuando describíamos a la brevedad perceptiva como "relativa" y "estadística": la mayor duración objetiva de las músicas electrónicas utilizadas para el baile social se ve compensada por el mayor grado de repetición que las piezas de la especie presentan. Veremos luego otros factores que también intervienen en esta cuestión.

${ }^{218}$ Nunca podrá ser total ya que siempre nos acompañará la posibilidad de ruptura con la expectativa. Y aquí debemos incluir también la posibilidad de una falla técnica que interrumpa la reproducción (si es el caso) de una pieza grabada.
} 
En otro orden de cosas, la tensión (que en las músicas de escucha se construye solo entre las cualidades musicales y las estructuras mentales que el oyente organiza a medida que atiende a la pieza) se establece aquí entre las formas que presenta la pieza musical y la capacidad del bailarín social de prever cuales serán los movimientos más apropiados para sincronizarse con aquellas. La presencia del movimiento como un tercer nivel o dimensión formal (formas musicales-representación mental de las formas musicales-movimiento sincrónico) complejiza la relación del oyente con la música; lo que podría justificar la idea (muy extendida) de que estas músicas presentan un grado mayor de simplicidad en relación a las utilizadas para la escucha.

Claro está que existen muchos ejemplos donde el desarrollo está presente pero, en términos generales, este se encuentra enmarcado en un contexto donde lo que impera casi con exclusividad es la repetición. Esta última no pierde entonces su rol de referencia a partir del cual evaluar el resto de los sucesos musicales (incluido el desarrollo). Por esta razón última, la identidad de las secciones y partes rara vez se aparta demasiado de las formas que presentaron durante su primera aparición. La reiteración (textual o variada) de formas ya escuchadas puede ser comprendida como otro modo de facilitar el encuentro, el acuerdo y la sincronización.

Por último, cabe destacar que las variaciones operadas sobre los materiales muy rara vez influyen sobre la duración de las secciones o partes. La repetición de una parte o sección implica entonces el establecimiento de una periodicidad y regularidad (dada por la repetición de la duración de esta) a niveles medio y macro-formal. Esta resulta otra forma de generación de previsibilidad.

La repetición (en todas y cada una de las formas que pueda pensarse) reina indiscutidamente en las músicas electrónicas utilizadas para el baile social. Tan numerosas son las formas y los niveles en que permea sus materiales, procesos y demás dimensiones, que durante el desarrollo del presente trabajo será el tema que más veces veremos surgir.

[Paréntesis anticipatorio: la cultura del remix, la idolatría de la repetición]

La preferencia por métodos compositivos que involucran repetición nos permite anticiparnos a exponer un fenómeno que consideramos más que interesante. En la escena electrónica o (mas precisamente) en el "escenio" ${ }^{219}$ de la música electrónica de baile se detecta un comportamiento social que condujo a la repetición hasta el altar del ídolo. En este contexto

\footnotetext{
${ }^{219}$ Lenarduzzi, V. (2012a) No puedo tomar notas mientras bailo. pp.12 Según lo entiende Lenarduzzi siguiendo a Brian Eno: el "scenius" electrónico es el entorno cultural donde se presenta la música electrónica de baile. Síntesis de "genio" y "escena", entiende a todos aquellos que participan de este entorno (deejays, bailarines, productores, etc.) como actores, como participantes activos que aportan a la creación artística.
} 
se desarrolla lo que se ha dado en llamarse la "cultura del remix": materiales y recursos musicales provenientes de piezas preexistentes (samples, ${ }^{220}$ timbres y tecnologías característicos, células rítmicas, melodías, "vocales", 221 etc.) se reutilizan una y otra vez en incontables nuevas composiciones.

De entre los materiales que se reutilizan nos interesa especialmente el caso del sample: la reproducción de un sonido pasado, repetición del pasado sonoro. Sonido que ya en su contexto original (el contexto donde la grabación se utilizó originalmente, la pieza musical de origen) es una re-producción, ${ }^{222}$ vuelve a presentarse (se repite) repetidas veces en numerosos nuevos contextos musicales. Contextos que, además, presentan un alto grado de repetición en otros aspectos y niveles. Repetición de la repetición y repetición sobre repetición son percibidas por la comunidad electrónica como marca de pertenencia y calidad artística. Ya sea en su forma original o variada, algunos materiales se re-utilizarían tantas veces, por tantos artistas y en tal número de piezas que terminarían originando incluso nuevos géneros de música electrónica de baile. ${ }^{223}$ La apropiación del material en cada oportunidad es tal, que los conceptos de "autor", "espectador" y "original" llegan a perder sentido y aplicabilidad... y esto es visto con agrado por una comunidad que presenta otras des-individualizaciones varias. ${ }^{224}$

Re-creación sobre re-creación continua vuelven difusa la frontera entre quien pone y quien produce música, entre el deejay que se limita a reproducir en el local de baile una pieza grabada y el productor que compone (o el músico electrónico que interpreta en tiempo real) material (¿original?). ${ }^{225}$ Es virtuoso aquel productor que -como el deejay- utiliza material sonoro o musical de otros para realizar su arte pero (al contrario de lo que podría suponerse) este re-uso excede el homenaje y la música de citas: aquel artista que tenga la valentía suficiente como para atreverse a re-utilizar lo que es "de todos y todas", lo que todos usaron e hicieron propio, lo que el escenio eligió como ídolo del momento, pasajero y efímero... será merecedor del aliento de los bailarines, de los brazos en alto y las bocas en grito, será venerado como conocedor de lo esencial, de lo definitorio del género (sea el género que sea de entre las músicas electrónicas utilizadas para el baile social), será en resumen un iniciado en la poética que permite el

\footnotetext{
${ }^{220}$ Fragmentos breves de audio extraído de grabaciones preexistentes.

221 En la comunidad electrónica, samples de voces extraidos de piezas preexistentes; fragmentos usualmente reconocibles y de cantantes reconocidos.

${ }^{222} \mathrm{O}$ sea, al menos en cierto sentido y si bien no son equiparables, también una repetición.

${ }^{223}$ Véase por ejemplo el breve documental de 2006 sobre la historia del sample de batería del tema de 1969 "Amen brother" del grupo musical The Winstons, Video explains the world's most important 6-sec drum loop. Subido por el usuario Landon Proctor. Accesible en https://youtu.be/5SaFTm2bcac [04102016]

${ }^{224}$ Para más detalles al respecto véase Lenarduzzi, V. (2012b). op. cit.

225 Simplificación extrema, entre estos extremos una amplia gama de intervenciones más o menos profundas sobre el material musical provoca una gradualidad entre las figuras y roles desempeñados por los músicos electrónicos y deejays. Mientras que algunos artistas encuentran su modo de expresión afectando directamente la estructura del original, otros la encuentran generando cambios menores o medianos, y unos terceros "acariciando" apenas la superficie. Todas actuaciones válidas, superadoras del supuesto conflicto músico-que-toca/deejay-que-pone-música, el escenio electrónico es un entorno lo suficientemente diverso como para contenerlas sin excepción.
} 
establecimiento de un vínculo que no pocos individuos experimentan como trascendente, que viven como místico y mágico, inexplicable y sobrenatural. ${ }^{226}$

Es en este sentido y en este vínculo de validación y premiación que los bailarines construyen y crean el escenio, que se vuelven participantes activos de la creación musical. Con el premio en movimiento y vítores devuelven al deejay sus aciertos en la elección musical; con caras de hastío, desgano al bailar o abandono de la pista castigan sus desaciertos. Mediante estas señales y acciones los bailarines determinan las músicas que alcanzan éxito y popularidad... y no olvidemos: las piezas exitosas y populares son aquellas de las cuales se tomarán materiales a ser re-utilizados.

No son pocos los deejays que condicionarán sus elecciones a las respuestas "de la pista". Considerando el contexto, esto resulta mucho más que lógico: en definitiva, son precisamente los bailarines los destinatarios últimos del arte de productores, músicos electrónicos y deejays. Desde la perspectiva de aquellos, la tarea específica de estos consiste en conquistarlos y brindarles el estímulo musical apropiado para una noche de encuentro y placeres en movimiento. Solo entonces se realiza el rito que muchos esperan encontrar en los eventos electrónicos, solo entonces las relaciones que se establecen entre los actores involucrados asumen la carga mítica antes descripta.

Por si esto fuera poco, un factor económico se suma a los anteriormente mencionados: solo alcanzando este objetivo tendrá el deejay asegurada la continuidad de su trabajo. Una pista de baile llena es, para los empresarios del espectáculo, sinónimo de éxito artístico (el deejay es visto como bueno en lo que hace), comercial (las arcas del empresario se llenan del dinero proveniente de las entradas) y de ventas (más movimiento en la pista de baile equivale a más movimiento en la barra de venta de bebidas).

De hecho, si algo caracteriza a las músicas electrónicas utilizadas para el baile social es el hecho de que la música se configura durante cada evento como un fluir continuo e ininterrumpido; cualidad que tuvo como origen el objetivo de evitar que los bailarines abandonaran la pista por las pausas entre pieza y pieza (que caracterizara las etapas históricas previas de las discotecas), implica que el éxito de un determinado deejay puede medirse en términos del porcentaje de asistentes que permanecen bailando en la pista. No resulta extraño entonces que muchos deejays estimulen el establecimiento de este tipo de relaciones místicas y "trascendentes" con su público.

\footnotetext{
${ }^{226}$ No pocas veces, pero tampoco todas, las cualidades e intensidad de esta vivencia podrían explicarse -al menos parcialmente- en estados alterados de conciencia incitados por el consumo de sustancias psicoactivas. Consumo que, valga decirlo, nunca alcanzó las cantidades que los relatos periodísticos míticos -asociados a las músicas electrónicas de baile- pretendieron construir como verdad. Como a todos los movimientos (primordialmente) juveniles que incluyeron algún tipo de discurso libertario en algún sentido, los medios representantes de los poderes fácticos concentrados procuraron demonizarlo asociándolo a la nueva droga del momento. Es cierto que las drogas circulan en la comunidad electrónica... pero tanto como los hábitos y filosofías de vida naturistas y muchas otras experiencias humanas constructivas y exploratorias.
} 
En este marco y similar a lo que fuera dicho respecto de las fronteras difusas entre los roles de deejays y productores o músicos electrónicos, también los límites de la obra musical única se desdibujan: por la forma de presentación que describiéramos en el párrafo previo, esta se abre a una potencial transformación al infinito en manos de (también infinitos) artistas anónimos. Repetida parcialmente en un nuevo contexto (usualmente repetitivo), la obra abandona su unicidad para fundirse en el continuo musical que el deejay construye noche a noche (y noche a noche diferente) al superponer entre uno y dos tercios de su duración total con otras dos piezas. ${ }^{227}$

Por supuesto, incluso la calidad artística de cada material apropiado se ve cuestionada al recibir tratamientos muy disimiles a manos de artistas de muy diversas extracciones y formación. Y es que no es este el criterio con el cual la comunidad electrónica selecciona sus favoritos. La idolatría de la repetición tiene su origen sin lugar a dudas en diversos factores culturales, ninguno sencillo de describir o aislar. Sin embargo, creemos detectar aquí al menos uno que cae dentro de la esfera de objetivos del presente trabajo y que se vuelve relevante para el mismo al proponer una posible línea de continuidad entre las músicas utilizadas para el baile social tanto históricas como electrónicas.

Como fuera dicho, las expresiones históricas de las músicas utilizadas para el baile social hacen uso prolífico de la repetición y de la periodicidad en todas sus formas. Ahora bien, su versión electrónica ha llevado esta proliferación hasta un grado que podemos describir como de "idolatría". Al mismo tiempo, los cultores de esta especie idolatran a la tecnología y a sus dispositivos e instrumentos. $\mathrm{Y}$ es aquí, en esta doble "adoración" donde encontramos uno de los posibles fundamentos de la proliferación de la repetición: las músicas electrónicas utilizadas para el baile social tienen a la repetición como método compositivo favorito no solo por ser herederas de la tradición de las músicas utilizadas para el baile social sino también por la repetición de la repetición involucrada en la tecnología de la grabación sonora y en la utilización de sonidos grabados (i.e.: en la utilización de samples). Las músicas electrónicas utilizadas para el baile social repiten lo que sus antecesoras históricas hicieron, y lo hacen (entre otros recursos) repitiendo fragmentos de pasado sonoro. La "cultura del remix" puede rastrearse hasta la base tecnológica misma de estas músicas: si para crear una pieza "original" hacemos uso de material sonoro, pre-musical, apropiado de otras situaciones (i.e.: samples) no resulta extraño que los artistas de esta comunidad se sientan libres de apropiarse también de material musical originado en otras situaciones (en otras piezas musicales).

\footnotetext{
${ }^{227}$ Es la práctica más común que (de una pieza musical de, a modo de ejemplo, 6 minutos totales de duración) el primer sexto o tercio ( 1 o 2 minutos) se sincronice y presente al público con el final de la pieza que sonó previamente y que el último sexto o tercio se presente simultanea y sincrónicamente con la pieza que sonará después. En otras palabras, apenas uno o dos tercios de las piezas musicales suenan tal cual fueron compuestas y sin intervención por parte del deejay. Esto último resulta válido solo en los casos en los que el deejay no acostumbre intervenir las piezas en formas complementarias a las mencionadas; casos donde la transformación será más acusada aún.
} 
Por otra parte, el uso de samples podría explicar la persistencia y proliferación de otro tipo de repetición detectable en las músicas electrónicas utilizadas para el baile social: el de la repetición de la duración o periodicidad. Siempre que se presenta un sonido grabado determinado, este tendrá la misma duración; al menos en principio y cuando estos se utilizan en su forma original. Si además se lo utiliza reiteradas veces y en sucesión, la repetición de la duración determina el establecimiento de una periodicidad. Esta es la manera precisa en que se los utilizó en las músicas concretas de vanguardia, época en la cual los procesos que podían aplicarse a estos sonidos encontrados ${ }^{228}$ eran muy limitados. ${ }^{229}$ Una limitación tecnológica determinó una cualidad poético-estética compartida entre músicas que, en principio, podrían pensarse muy diferentes. En otras palabras, las dos principales fuentes que han dado origen a las músicas electrónicas utilizadas para el baile social presentan formas de repetición y periodicidad: las músicas utilizadas para el baile social en la búsqueda de facilitar el encuentro, el acuerdo y la sincronización, y las músicas electrónicas ${ }^{230}$ de vanguardia como consecuencia derivada de los modos de funcionamiento de las tecnologías utilizadas para su concreción durante su período fundacional.

Si bien estas dos expresiones se ubican tradicionalmente en los extremos opuestos de un hipotético eje estético, en las músicas electrónicas utilizadas para el baile social han sabido hallar su lugar de encuentro. Resulta menos extraño entonces encontrar piezas de una y otra vertiente en proyectos (percibidos como) de música popular como Kraftwerk, o que artistas identificados con las vanguardias como Pierre Henry compongan piezas electrónicas de baile. Y es que las músicas electrónicas no discriminan (desde sus orígenes) material musical (y "nomusical") alguno. Nacidas contemporáneas, la experimentación que caracterizó al período histórico de su surgimiento no sabe de "academia" ni de "popular", no entiende de música "seria" ni "ligera". Tomando de uno y otro universo de posibles -y combinándolos indiscriminadamente- destruyó en la práctica categorías tales como "experimental",

\footnotetext{
${ }^{228}$ Para evitar cualquier ambigüedad y previendo su uso posterior, nos referimos con esta expresión a lo que se denominan "tomas de campo": grabaciones de eventos sonoros (musicales o no), provenientes de la cotidianeidad, la naturaleza o de actividades humanas que pueden no tener como finalidad específica la generación de sonido.

${ }^{229}$ Véase por ejemplo los 5 etudes de bruits (1948) de Pierre Schaeffer y compárese con el trabajo sobre el sample de voz del tema house de David Morales "Needin'U" (1998), especial y aproximadamente a partir de los 3'11" de iniciada esta pieza. Pierre Schaeffer -- Études de bruits (1948). Subido por $d S$. Accesible en https://youtu.be/CTf0yE15zzI. David Morales Presents The Face Needin' U (Original Mistake).mp4. Subido por revistauay. Accesible en https://youtu.be/ZpWbT6jEVWg. [04102016]

${ }^{230}$ Frente a ciertas ambigüedades preferimos este término al de "electroacústicas". De cualquier manera lo utilizamos en sentido amplio, abarcando también las músicas que históricamente recibieron el nombre de "concretas". Respecto de este tema, algo similar puede decirse también de las "músicas electrónicas" en el sentido histórico (restringido): el uso extendido de sequenciadores y secuencias provocó un fenómeno paralelo muy similar al de los samples. Si bien son sonidos de sintetizador (i.e.: "nuevos"), estos se presentan en una (o varias) secuencias de eventos que se reiteran una y otra vez generando periodicidad. Por si fuera poco, utilizando la mayor de las veces eventos de valores iguales (pulsación). Aquí también repetición sobre repetición, timbres y secuencias de sintetizador característicos serán apropiados e incluidos en nuevas piezas musicales generando una forma diferente (pero similar) de repetición de la repetición.
} 
"conservador", "de vanguardia" y "retrógrado". Recorreremos algo más de esta cuestión en títulos por venir.

[Fin del paréntesis]

\section{Sencillez}

Economía de recursos, brevedad y repetición (textual y variada) se combinan en las músicas utilizadas para el baile social y son, al mismo tiempo, manifestaciones y emergentes de una búsqueda por establecer conformaciones que se presenten a la percepción como sencillas. En sí mismos y en interacción recíproca, estos tres factores propician agrupamientos, figuras y gestos musicales rápidamente asimilables e identificables que, al menos en apariencia, construyen experiencias que suelen describirse como "simples" o "sencillas".

Gestos breves antes que extensos, repetición y variación antes que desarrollo y grupos (melódicos, rítmicos, armónicos) constituidos por pocos elementos similares -antes que por numerosos elementos diversos- son algunas de las maneras en las que en estas músicas se prioriza la sencillez sobre la complejidad. En otras palabras, agrupamientos que presentan y se originan en cualidades asociables a las expresiones musicales de los principios de buena forma y destino común (propuestos por la teoría de la Gestalt) generan identidades perceptualmente segregables de otras y fácilmente recordables.

Ahora... ¿qué pretendemos significar con el término "sencillo" o "simple"? Antes de continuar debemos revisar algunas relaciones que se establecieron históricamente entre "lo simple" y la música.

La sencillez es una cualidad que en la Europa de siglos pasados se asoció con las músicas utilizadas para el baile social y sirvió como argumento para disminuir la jerarquía de éstas en relación a otras (músicas). Dicha disminución se basó (y basa) en el prejuicio de que las músicas utilizadas para el baile social constituyen un tipo de expresión musical "simple" y que requiere poco trabajo; en los casos en que se le aceptara su condición artística sería apenas un arte "menor", uno que puede lograrse sin mayores esfuerzos. Oponiéndose al juicio estético de las mayorías, este prejuicio sería una forma más en la que se manifestaran (y manifiestan) las políticas represivas sobre el cuerpo. ${ }^{231}$ Considerando superior a la idea y a la mente -en contraposición con la inferioridad de la materia y el cuerpo-, el proyecto colonial europeo impondría esta visión donde fuera que estableciese su dominio. Aún hoy persiste esta visión en amplias regiones del planeta, donde la simplicidad es casi sinónimo de "tonto", "naif", "inocente" o "inexperto".

\footnotetext{
${ }^{231}$ Para un desarrollo de estas ideas véase nuestros ya varias veces citados (2012). Des-limitados e (2013). Ideo-materialismo musical...
} 
Disentimos con esta perspectiva considerando que, de ser objetivos a alcanzar, tanto sencillez como complejidad demandan grados de reflexión y elaboración equiparables. Disentimos también con las asociaciones mente-complejo y cuerpo-sencillo, considerándolas sin lugar a dudas preconceptos sin base sólida y teñidos de ideologías provenientes de una visión de la realidad sesgada e interesada.

Por otra parte, consideramos también que el desprecio y baja estima que las músicas utilizadas para el baile social sufrieran y sufren se debe -no directamente a sus cualidades particulares sino- tanto a ciertas limitaciones y sesgos de los análisis como a las intenciones políticas de sus críticos: su caracterización como música "menor" deriva de que la complejidad resulta en algún sentido difícil de detectar por localizarse en la relación compleja entre las variables musicales y las interpretaciones en movimiento de los bailarines. Como dijéramos con anterioridad, formas que pueden resultar simples a la escucha se complejizan en su relación con el movimiento. Como reza uno de los lemas principales del escenio electrónico (cita de la anarquista-feminista lituana Emma Goldman):

"Si no lo puedo bailar, no es mi revolución."232
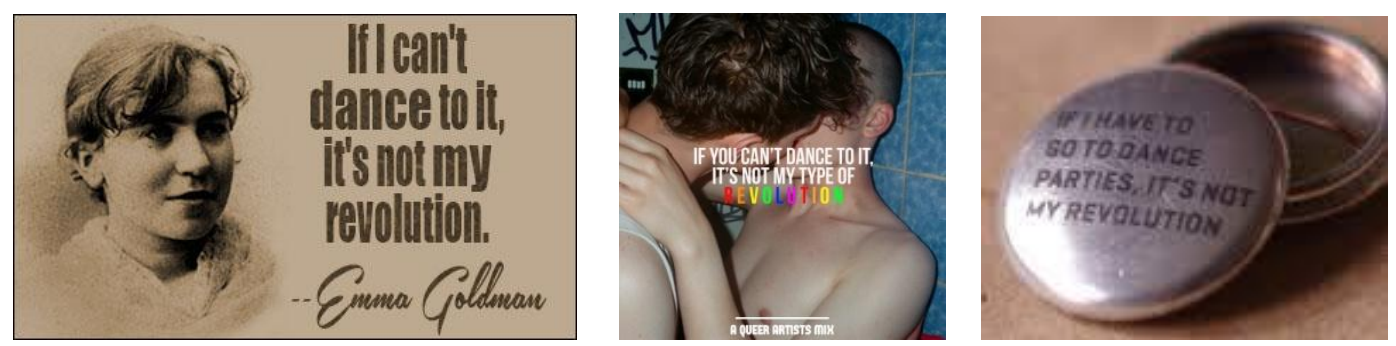

La frase atribuida a Emma Goldman y dos paráfrasis de la misma.

Ahora bien, la simplicidad a la que referimos no puede ser denominada lisa y llanamente así sino que requiere adjetivación; adjetivación que tiene su origen en un término que quizá pasara desapercibido en los párrafos precedentes: la apariencia. En el caso que nos ocupa la simplicidad es perceptiva. Queremos significar con esto que los materiales utilizados, los procedimientos aplicados y los procesos descriptos por la música pueden consistir en aconteceres complejos, siempre y cuando estos resulten sencillos perceptualmente. En otras

${ }^{232}$ La frase hace alusión a la libertad del cuerpo en acción y a la igualdad jerárquica de cuerpo y mente. Además, tomando en cuenta la condición femenina de la emisora, el sentido de cada elemento involucrado adquiere mayor relevancia. En el contexto de la música electrónica de baile, vinculada en sus orígenes $\mathrm{y}$ en algunos casos con comunidades doblemente discriminadas (afronorteamericanas y homosexuales), la frase toma una significación doblemente apropiada: los contextos de diversos niveles donde el relato mítico sitúa los orígenes de esta música (crisis económicas y sociales, discriminación racial y por elección sexual, pobreza, etc.) hicieron de los locales de baile donde se la presentara (muchas veces clandestinos) espacios de resistencia a los poderes opresivos del momento. "Bailar lo prohibido" (siendo "lo prohibido"... múltiple) sería entonces revolucionario. En algún sentido, ciertos ámbitos del escenio electrónico actual mantienen este espíritu. Lenarduzzi trata con gran profundidad esta cuestión en su ya citado (2012b). Placeres en movimiento. Volveremos luego a esta cuestión. 
palabras, mientras aparenten simplicidad (mientras la impresión perceptual las caracterice como "sencillas") las piezas podrán presentar todas las complejidades que el autor desee.

Por supuesto, tanto uno como otro término ("sencillez" y "complejidad") son dependientes del contexto cultural. Por esta razón, no resulta posible realizar generalizaciones acerca de qué configuraciones concretas generarán una y otra impresión. Según la cultura en que una pieza se inscriba tanto complejidad como sencillez asumirán una u otra forma, se establecerán en diferentes grados y se localizarán en diferentes dimensiones musicales. Sin embargo, en las músicas utilizadas para el baile social (pertenecientes a acervos culturales diversos) que releváramos, la simplicidad puede resumirse en los términos generales con que la describiéramos al inicio del presente título. Continuemos entonces con dicha caracterización.

En su amplia mayoría monotemáticas, en las músicas utilizadas para el baile social la sencillez opera también en función del encuentro y, como fuera mencionado, puede ser comprendida también en el marco de la generación de previsibilidad. Conformaciones complejas demandarán más espacio mental (y tiempo objetivo) para su aprehensión auditiva, postergando la asimilación en movimiento y la sincronización. Recordando que una gran parte de la apreciación musical se realiza (en el contexto que nos ocupa aquí) en movimiento y que los receptores modelo son sujetos no-iniciados ni en música ni en danza, cualquier factor que dilate pasar al cuerpo las cualidades detectadas en la música puede convertirse a su vez en un generador de incomodidad y frustración, emociones que obstaculizan el encuentro.

El mismo rol y justificación tienen la brevedad y la repetición. Por una parte, una pieza de mayor duración demandará mayor reelaboración del material, con la consiguiente imprevisibilidad que acompaña al surgimiento de nuevas formas y materiales musicales. Por otra, cuanto mayor sea el grado de contraste entre diferentes materiales musicales, mayor será la duración que dicho material musical demande para su desarrollo, dando origen (nuevamente) al surgimiento de mayores grados de imprevisibilidad. La solución a todos estos posibles inconvenientes (al menos en apariencia) ha sido recurrir a la sencillez.

El algún sentido quizá las músicas electrónicas utilizadas para el baile social constituyen una excepción a algunas de las cualidades de la regla enunciada en el párrafo previo. Como dijéramos, de mayor duración relativa que todas las demás músicas utilizadas para el baile social, mediante el recurso que describiéramos como proliferación de la repetición sus productores han evitado los problemas derivables de su (generalizada) mayor extensión temporal. Este recurso ha hecho a la especie merecedora del adjetivo "repetitiva" como cualidad descalificativa. Sin embargo, ciertas prácticas ausentes para otras especies hacen de ésta un caso particular que requiere y merece ser tratado.

Como fuera mencionado y veremos en títulos próximos, en las músicas electrónicas utilizadas para el baile social tanto al interior de una única pieza como en el transcurso de una noche completa la complejidad resulta usualmente más un emergente de la combinación de 
elementos diversos y menos la cualidad de un elemento individual. Concebidas para ser recombinadas con otras y para ser bailadas, las piezas de las músicas electrónicas utilizadas para el baile social dejan espacio a las infinitas (e imprevisibles) posibles formas de intervención futura y para la expresión en movimiento de los bailarines. Formas solidarias, abiertas y de creación colectiva, las piezas de la especie se constituyen en la sublimación tecnológica del músico improvisador bien dispuesto hacia sus compañeros de conjunto: el productor, poniendo en juego todo su potencial durante sus solos en el estudio, cede frente al público el rol protagónico (a favor del deejay) para aportar con sus acciones los elementos de la "base"; elementos necesarios para que sus pares tengan también la posibilidad de expresión a solo que estos le concedieron en primer término.

Se evidencia aquí nuevamente la jerarquía de iguales y el rol de actores (más que de espectadores) que reciben los bailarines en el escenio electrónico. Vemos también aquí concretarse la igualdad de concepción que aúna a la interpretación musical y en movimiento (una concepción del movimiento como "actividad musical"). Aquí residen las razones que llevan a muchos aficionados a escuchar músicas electrónicas utilizadas para el baile social solo en contexto de movimiento y a muchos no-iniciados a evaluar (a nuestro parecer) erróneamente las cualidades de estas músicas: el carácter repetitivo que se les suele asignar -en tanto cualidad negativa- pierde de vista que las piezas de la especie son formas abiertas a la intervención sonora y en movimiento. Escucharlas inmóviles y una pieza a la vez ( $\sin$ combinarlas y sincronizarlas simultáneamente con otras piezas) es entonces una manera de distorsionar sus formas, equiparable a escuchar una pieza del repertorio clásico en un entorno muy ruidoso y con diversos estímulos sensoriales que originen distracciones.

\section{Claridad}

Otro factor más que configura y facilita la previsibilidad lo constituye la claridad formal perceptible. Las músicas utilizadas para el baile social presentan en su amplia mayoría articulaciones formales claras (los momentos de articulación formal difieren sin ambigüedades de aquellos en los que se desarrolla cada parte o sección) como también precisas y previsibles (respecto del momento y duración de su ocurrencia, relativo a los períodos en que las partes o secciones acontecen). En conjunción con la utilización de formas simples de nivel medio, de fórmulas anticipatorias de los cambios y de distribuciones periódicas y regulares de los cambios -y, al menos en parte, consecuencia de su uso- las articulaciones sin ambigüedades entre partes o secciones de diferentes niveles generan un contexto general de claridad formal aprehensible para oídos no iniciados en teoría musical.

Como dijéramos, esta característica nuevamente se encuentra en función de la previsibilidad y del encuentro. En la generalidad de los casos, en las músicas utilizadas para el baile social la novedad o sorpresa suele presentarse más en la forma de contrastes entre una 
parte o sección y otra, preservando casi sin excepción la periodicidad y regularidad del momento en que la articulación ocurre (relativo a la duración de las partes o secciones). Además, en los casos en que una sección presenta algún tipo de contraste con la precedente (de carácter, de configuración rítmica u otros), el momento de articulación formal y algo de aquello que constituye el contraste suele ser anticipado y presentado por las mencionadas fórmulas anticipatorias de los cambios; dicha presentación anticipada le brinda al bailarín los indicios que le permiten (de no conocer la pieza o el género) aproximar una estimación de lo que resulta posible en el contexto musical concreto (cualquiera sea este).

Por supuesto, lo dicho en el párrafo precedente no cubre todos los casos y en las músicas utilizadas para el baile social existen numerosos ejemplos de contrastes entre secciones donde la música demanda que los bailarines posean como capital cultural el conocer el género y algunas de sus características. Un ejemplo lo constituye el tango: en muchas piezas pertenecientes al período que se conoce como de la "guardia vieja", la sección media -más lenta que el comienzo y final- no puede ser prevista salvo que se conozca (al menos) que dicho género se caracteriza por la alternancia de tempos mencionada. Aún así, en no pocas piezas de dicho conjunto la primera sección finaliza con un rallentando o ritardando (una disminución del tempo) que, coincidente con el final de una secuencia coreográfica y al menos hasta cierto punto, permite a las parejas acomodar su danza al próximo movimiento o tempo.

Por supuesto, no implicamos en nuestros dichos que secciones o enlaces entre secciones puedan presentar características o identidades difusas y poco precisas. Como viéramos, en las músicas electrónicas utilizadas para el baile social el flujo musical continuo se consigue haciendo sonar simultánea y sincrónicamente ("mezclando") dos piezas diferentes. El incremento paulatino del volumen de la pista (i.e.: "track") ${ }^{233}$ que ingresa mientras, al mismo tiempo, se disminuye el de la que la precede, genera consecuentemente períodos donde las identidades se mixturan y transforman progresivamente. En otras palabras, en esta especie se alternan continuamente segmentos de identidades claras con otros donde se desarrollan transformaciones graduales. Si bien la temporal imposibilidad de prever lo que ocurrirá en la música suele provocar cierta indefinición en el movimiento de los bailarines, en el caso concreto de las músicas electrónicas utilizadas para el baile social dicha consecuencia se mitiga con la sincronización de los tempos de ambas piezas. Aún cuando en algunos casos no hay forma de que el bailarín pueda prever el tipo de configuración rítmica que la pieza que ingresa ofrecerá al movimiento, la persistencia del tempo posibilita al menos sostener la cantidad de activación corporal y el período global que describirán los mismos.

\footnotetext{
${ }^{233}$ Con el término "pista" referimos a una forma musical propia de la especie y diferente a los "temas" o "canciones" populares. Para detalles al respecto véase el Glosario.
} 


\section{Estabilidad}

Como anticipáramos en los títulos precedentes, la sincronización entre música y movimiento tiene una importancia central en la actividad social que rodea a las músicas utilizadas para el baile social. Esta razón conduce a que los tempos sean aún otro factor que aporta a la posibilidad de prever lo que ocurrirá en la música en tanto estímulo que normaliza y pone en común los movimientos, por lo que nos hubiera sorprendido encontrar algún ejemplo de músicas utilizadas para el baile social que presentara constantes y/o imprevisibles cambios en la variable que nos ocupa; este no ha sido el caso.

El tempo permanecerá estable en la amplia mayoría de las piezas $\mathrm{y}$, de presentar cambios, éstos se darán de formas y en momentos previsibles y/o acordados. Siendo muy pocos los géneros en que detectáramos ejemplos con modificaciones en esta dimensión, los mismos suelen sobrevenir coincidentes con articulaciones formales. Similar al del tango, un caso de los últimos lo constituye el tinku: género folklórico originario del altiplano sudamericano que suele interpretarse en las sikuriadas, ${ }^{234}$ de ocurrir cambios de tempo (acordados con la comunidad de pertenencia), estos no solo coinciden con articulaciones formales sino que en cierta medida son un factor de demarcación de las mismas. En estas músicas, luego de reiterar un cierto número de veces una misma sección puede suceder una de las cuatro opciones que siguen:

a) se volverá a presentar la misma sección a un tempo sustancialmente mayor (al doble o incluso más),

b) se reiterará la sección iniciando un proceso de aceleración gradual (que alcanzará los mismos resultados descriptos en el apartado previo pero paulatinamente),

c) se presentará nuevamente la sección pero a un tempo mucho más lento (la mitad o menos) para luego de una o varias presentaciones retornar al tempo original o

d) se presentará la sección a un tempo lento y se acelerará paulatinamente hasta el tempo original o incluso más allá. ${ }^{235}$

En las músicas utilizadas para el baile social los cambios repentinos de tempo suelen además involucrar el establecimiento de relaciones matemáticas relativamente simples entre las velocidades de paso de las unidades de medición activas en cada una de las secciones o partes involucradas en el contraste. Dadas dos secciones, sus tempos divergentes generarán que la diferencia en la duración objetiva de cada pulso presente razones matemáticas simples del estilo y orden (a modo de ejemplo) de 3:4 o 3:2. En otras palabras, con un tempo de 120 pulsos de

\footnotetext{
${ }^{234}$ Ensambles circunstanciales de un número indeterminado de ejecutantes que se reúnen a interpretar piezas tradicionales para sikuris (flauta de pan del altiplano). Con secciones durante las cuales se entonan versos, suelen acompañarse de bombo como también, en algunas ocasiones, redoblantes y charangos.

${ }^{235}$ Escúchese el ejemplo en línea MARKASATA / FLOR DE CACTUS, CARAMBA CHIQUITA, UN CORAZON COMO EL MIO. Hacia los 5'30" presenta un incremento en el tempo. Subido por Bolivian $M T V$. Accesible en https://youtu.be/8xfck2huoZc. [26092016]
} 
negra por minuto cada pulso durará 500 milisegundos, por lo que 3:4 de esta duración resultará en un tempo de 150 ppm y una duración de negra igual a 375 milisegundos (en otras palabras, la figura de negra durará lo que la corchea con punto precedente); por su parte, 3:2 resultará en un tempo de 90 ppm y una figura de negra que durará 750 milisegundos (negra igual a la negra con punto precedente). En las músicas electrónicas utilizadas para el baile social es quizá en piezas del (llamado) género Dubstep el que más claramente presenta cambios de este tipo, siendo 2:1 la relación más común (en un determinado momento el tempo se reduce a la mitad o, según el caso, se duplica).

A pesar de los casos descriptos y como dijéramos, en la amplia mayoría de las músicas utilizadas para el baile social -antes que cambios de tempo- se preferirán otras formas de modificación de la activación. Mediante incrementos en la densidad cronométrica o recurriendo a diferencias en los agrupamientos rítmicos, se buscará producir contrastes similares (aunque no idénticos) a los que se alcanzan mediante cambios en el tempo. Este es el caso más común en las músicas electrónicas utilizadas para el baile social. Aprovechando ciertas polimetrías hallables en la especie y los ritmos "diatónicos" (que trataremos en el Anexo III), sus productores buscarán provocar un efecto similar a un incremento del tempo. Superpondrán ritmos que describen lo que podemos llamar cuasi-pulsos algo más veloces que el pulso propiamente dicho. Al establecer cuasi-regularidades más veloces, estos ritmos provocan una densificación cronométrica que -sin serlo- genera la sensación de que el tempo se acelera. Siendo clara herencia de tradiciones africanas, tomando como valor-unidad a la figura de semicorchea, en un compás de 4/4 el ritmo más veces hallable se corresponde con el agrupamiento (llamado "aditivo" en la tradición musicológica occidental) $3+3+3+3+4$.

Por último, otro recurso lo constituye la ejecución con swing. Manifestándose principalmente en la sección rítmica (o de percusión) y nuevamente herencia de tradiciones de origen africano, una anticipación de unos pocos milisegundos en el momento de ocurrencia de algunos ataques (por ejemplo, del redoblante) provoca un efecto perceptivo de gran impacto, dinamizando e impulsando con gran eficacia al ritmo "hacia adelante". ${ }^{236}$ Presente en muchas de las músicas utilizadas para el baile social del continente americano, el efecto opuesto se logra mediante mínimos retardos en eventos del mismo o diferente tipo.

[Paréntesis a modo de descanso: paradas o bajones]

En las músicas electrónicas utilizadas para el baile social, otras formas de reducir la activación la constituyen ciertos momentos que publicaciones españolas llaman "parones" o "bajones", que inglesas denominan "breakdowns" y que nosotros nombraremos con el término "paradas". Como los términos sugieren, en el marco del fluir musical continuo que caracteriza a los eventos de músicas electrónicas utilizadas para el baile social, estas secciones funcionan

\footnotetext{
${ }^{236}$ En otras palabras, generando una sensación de aceleración del tempo.
} 
como una invitación al descanso o a una reducción de la activación de movimiento, y reemplazan a la pausa entre tema y tema característica de eventos con presencia de otras especies musicales.

Pudiendo presentar muy diversas duraciones que abarcan desde algunos pocos compases a varios minutos, es muy común que durante estas secciones se eliminen los elementos texturales de la región grave/sub-grave (como veremos, esencialmente los sonidos de bombo y bajo). ${ }^{237}$ Cuando no desaparece por completo, suele también disminuir sustancialmente la densidad de elementos de la sección rítmica. En síntesis, suelen eliminarse muchos de aquellos elementos que pueden asociarse con la promoción del movimiento. ${ }^{238}$ No existiendo regla alguna, estos cambios suelen ir acompañados también de diferencias texturales, armónicas, tímbricas y de cualquier otra índole que el artista determine.

Como veremos durante el análisis audiotáctil de la altura, el registro grave/sub-grave es depositario del rol cuasi-tonal de distensión y reposo, por lo que la ausencia de elementos en esta región se constituye también para los aficionados a la especie en señal de inestabilidad y de cierta imprevisibilidad. La menor definición que caracteriza a los movimientos que los bailarines desarrollan durante estas secciones probablemente puedan asociarse también con esta cuestión.

Como podrá suponerse, la eliminación de los elementos descriptos genera también una reducción de la densidad vertical, con una consecuente reducción de la presión acústica. Durante nuestras experiencia de campo registramos una diferencia de aproximadamente $-44 \mathrm{~dB}$ SPL, presentando estas secciones un valor aproximado de $80 \mathrm{~dB}$ SPL. ${ }^{239}$ Encontramos en las dos cualidades descriptas (ausencia de elementos graves/sub-graves y reducción de la presión acústica) dos indicios que permiten asociar la reducción en los movimientos de danza (al menos, menor definición y amplitud) con la disminución de la sensación táctil.

Esencialmente, lo que los bailarines atenderán expectantes durante el desarrollo de la parada es -en primer término- el retorno del bombo y -secundariamente- el de otros elementos en el registro grave/sub-grave. En otro orden de cosas podemos anticiparnos y decir que lo que

\footnotetext{
${ }^{237}$ Sonido de...: utilizaremos esta expresión para diferenciar el rol asignado a un determinado sonido sintetizado o sampleado del timbre o fuente concreto que se utiliza en dicho rol. Para más detalles ver el Glosario.

${ }^{238}$ Como veremos en títulos próximos, la principal función del bombo (y de la región grave/sub-grave del espectro) es efectivamente la enunciada en el cuerpo principal. Consecuentemente, la eliminación de los elementos que ocupan dicha zona -para los aficionados a la especie- constituye una clara señal de "detención" o "disminución" del movimiento o activación musical. Consecuentemente y como también ya fuera mencionado, el baile se vuelve dubitativo y los movimientos menos definidos. Accesoriamente encontramos aquí un argumento no convencional y novedoso que vincula de forma directa la cantidad de actividad musical con la activación en movimiento; si bien no podemos afirmar que su vínculo resulta lineal en toda ocasión y estética, sí vemos (a partir de los comportamientos concretos que hemos presenciado en incontables ocasiones) que la presencia de aquellos elementos que estimulan al cuerpo por vías táctiles (en otras palabras, aquellos que literalmente lo mueven) se asocian (en el contexto de las músicas electrónicas utilizadas para el baile social) con una "invitación" a la danza.

${ }^{239}$ Para más datos véase nuestro Anexo I. Experiencia de campo.
} 
también esperan es el retorno de la presión acústica mayor (o máxima) y de la sensación táctil (de persistir durante la parada, de mayor intensidad). Dicho retorno será anticipado y preparado (durante la misma parada) por una batería de recursos diversos de diferente índole; recursos que, en algunos casos, determinan la pertenencia de la pieza a uno u otro género. Esquemáticamente y a modo de ejemplo, las piezas que se identifican como pertenecientes al género trance se caracterizan por presentar redobles y otras densificaciones cronométricas que paulatinamente incrementan la cantidad de ataques por unidad de tiempo. Comúnmente redobles descriptos por sonidos de percusión (usualmente redoblante $\mathrm{y} / \mathrm{o}$ bombo), el retorno de los elementos eliminados suele sobrevenir solo luego de que estos alcanzan una densidad de ataques tal que se vuelven incontables.

Las paradas presentan tres diferentes orígenes posibles:

a) se construyen en tiempo real por el deejay o músico electrónico mediante diferentes recursos disponibles en los dispositivos tecnológicos (filtros pasa-altos, silenciamiento de los canales donde los elementos que se pretende eliminar se encuentran almacenados, etc.),

b) son parte constitutiva de la pista que el deejay ha puesto a reproducir (en otras palabras, la parada ha sido producida previamente en el estudio y forma parte constitutiva de la macro-forma de la pieza reproducida) o

c) es una mixtura de ambas (la parada es parte de la pieza pero el deejay la interviene, pudiendo prolongarla, acortarla o modificarla de numerosas maneras).

El trabajo en tiempo real sobre las paradas brinda al deejay la flexibilidad de interactuar y "jugar" con las expectativas de los bailarines. Mediante diversas herramientas, técnicas y procesos, el deejay estimulará la ansiedad de estos para potenciar el efecto que provoca sobre su ánimo el retorno del bombo (y demás elementos en el registro grave/sub-grave). Cuando finalmente dicho retorno se consuma, si la construcción de tensión por parte del deejay es percibida como eficaz y si el retorno es eficiente para satisfacer las expectativas creadas (en síntesis, si el proceso completo cumplió con lo que se espera en ese contexto y género concreto) los bailarines se lanzarán a una danza más enérgica, alzando los brazos en el aire, exclamando vítores de satisfacción y demostrando su aprobación al deejay por cumplir la tarea satisfactoriamente.

Volveremos en varias oportunidades a las interacciones entre el deejay y los bailarines y al rol e influencia de cada uno sobre el universo relativo a las músicas electrónicas utilizadas para el baile social. Téngase presente entonces lo dicho en este paréntesis. ${ }^{240}$

\footnotetext{
${ }^{240}$ Algunas otras características de las paradas se incluyen en nuestro Anexo IV. Actores involucrados en la escena electrónica, bajo el título Bailarines.
} 
[Fin del paréntesis]

\section{Percusividad}

Esta cualidad resulta quizá más elusiva que las precedentes por involucrar diferentes aspectos y cualidades musicales. Pudiendo asociarse con cierta característica general de claridad rítmica y formal, gravita sobre las dos dimensiones mencionadas como también sobre la articulación, la textura, las duraciones, la conformación fraseológica, el timbre y la sonoridad. Además, es aún otro factor que promueve la repetición sobre el contraste. Siendo una cualidad que ha proliferado (y prolifera) en las músicas electrónicas utilizadas para el baile social trataremos aquí sus propiedades básicas y relegaremos el tratamiento de otros aspectos para cuando nos encontremos en dicho marco específico. Es posible que al finalizar la lectura del presente título no se vislumbre aún ni la importancia ni las profundas implicancias que las diferentes formas de percusividad presentan para la música en general y para nuestro tema en particular.

En primer término, la cualidad percusiva puede ser comprendida como una envolvente de intensidad de cualidades precisas. Como tal, se constituye en un conjunto de características que describen la evolución temporal de la sonoridad de un evento sonoro único. Dicha envolvente presenta un ataque impulsivo, carece de sostenimiento y finaliza con una liberación (relativamente) rápida. ${ }^{241}$

Contrapuestos a sonidos de evolución paulatina (especialmente en su ataque), los sonidos percusivos favorecen la precisión rítmica y facilitan la detección del momento en que el evento musical ocurre. Al favorecer la precisión rítmica, la percusividad repercutirá directamente sobre la capacidad de sincronización, permitiendo a los bailarines (no-iniciados en teoría musical) ordenar sus movimientos al facilitarles el reconocimiento (intuitivo) de todo tipo de patrones y conformaciones rítmicos.

Simultáneamente, la misma precisión rítmica incidirá sobre la articulación formal, favoreciendo (y siendo una de las variables que determinará) su claridad. Al facilitar el reconocimiento del instante preciso en que una parte o sección finaliza y otra inicia, las articulaciones formales se tornan más sencillas de aprehender y prever, facilitando nuevamente la sincronización del movimiento y la anticipación de los cambios.

Pero para que lo dicho en los párrafos precedentes acontezca efectivamente, los sonidos percusivos deben preponderar por sobre los de cualidades opuestas. Si bien no hemos realizado un estudio específico al respecto, a partir de nuestras extensas sesiones de escuchas de músicas utilizadas para el baile social y de los argumentos que siguen, nos encontramos en condiciones

241 De aquí la denominación que le asignamos, "percusiva" por presentar cualidades típicas de las envolventes de sonoridad de los instrumentos de percusión. 
de afirmar que (en general) estas músicas presentan mayor porcentaje estadístico de sonidos percusivos y mayor densidad cronométrica que la mayoría de las músicas utilizadas para la escucha. ${ }^{242}$ Nuestra afirmación se basa también en el hecho de que -debido a las cualidades inherentes a la envolvente de intensidad que describiéramos- los sonidos percusivos tienden a presentar duraciones breves, lo que involucra hasta cierto punto un grado mayor (siempre relativo) de densidad cronométrica. ${ }^{243}$

Considerando a la proliferación de sonidos percusivos un hecho, podemos afirmar que la incidencia de esta cualidad excede a la que (mencionáramos) tiene sobre las envolventes de intensidad de un evento único. En otras palabras, por el mismo hecho de utilizar mayoritariamente sonidos percusivos, la evolución temporal de la sonoridad general del elemento y/o estrato textural que los contiene presentará un perfil de sonoridad que también puede ser descripto como percusivo; y esta cualidad puede aplicarse tanto a cada elemento y estrato textural como a la textura general de la pieza.

Explicitamos entonces que, en segundo término, también a estas dos características las consideramos parte de la cualidad percusiva. Compuesto principalmente por sonidos percusivos, comprendemos al perfil de sonoridad de cada elemento y estrato textural y de la textura general, como dos nuevos niveles de análisis donde la cualidad se manifiesta y puede ser observada: ya no como la característica de un evento sonoro único, sino como una forma en la que evoluciona la sonoridad -de un elemento y/o estrato textural y de la textura general- de una pieza, la cual puede comprenderse (y esta es la perspectiva que asumiremos luego) como un tipo de iteración a escala macro. Veremos en detalle esta cualidad en el marco de las músicas electrónicas utilizadas para el baile social, contexto donde su proliferación resulta estructurante.

Ahora bien, cuando una mayor densidad cronométrica sucede en un contexto de periodicidad y regularidad multinivelada como el que caracteriza a las músicas utilizadas para el baile social (y por ende, en un contexto donde prepondera la re-iteración), dichas periodicidades y regularidades resultan explicitadas en los ritmos y duraciones -repetidos- de los eventos (nuevamente, organizados en diversos niveles) que las tres cualidades conforman. La reiteración de cualidades propias de eventos únicos y de conformaciones de niveles mayores (compuestas por conjuntos de eventos, aún en instrumentos que no generan una envolvente estrictamente percusiva) derivará en que el elemento o grupo reiterado concluirá operando del mismo modo que describiéramos en los párrafos precedentes. En otras palabras, resultará en una periodicidad, en una iteración (más o menos) regular; ergo, en una percusividad. La reiteración de un mismo

\footnotetext{
${ }^{242}$ En el caso de las músicas electrónicas utilizadas para el baile social podemos afirmar que esto resulta efectivamente así.

${ }^{243}$ Téngase en consideración que solo a partir de la segunda mitad del siglo XX -y principalmente a partir de la obra 4'33" de John Cage- el silencio adquirió su status musical. Hasta entonces la música se trató específicamente de "hacer sonar sonidos"; y si de hacer música con sonidos breves hablamos, para ocupar con sonidos breves un mismo período de tiempo serán necesarios más ataques que si utilizáramos sonidos largos. Esta es precisamente la definición de "mayor densidad cronométrica".
} 
evento sonoro único (simple o complejo) o de un grupo breve de eventos sonoros diferenciados (simples o complejos) presentados en el mismo registro, como cualquier otra recurrencia relativamente periódica de un evento único o de una secuencia breve -como oposición a una cualidad más cambiante o evolutiva que podríamos caracterizar como "melódica" o "armónica" "lineal"- establecerá una nueva periodicidad, a nivel mayor que las descriptas en párrafos precedentes.

Resultan incluidos en esta descripción desde simples pulsaciones conformadas por ataques breves reiterados, hasta conformaciones rítmicas complejas interpretadas por secciones de percusión completas, (semi-)frases melódicas y/o secuencias armónicas de período (aproximadamente) igual a uno o dos compases. Incluimos también a ciertos elementos que, aunque por anacrúcicos parecerían contradecir una cierta periodicidad ya establecida, refuerzan la percepción de una pulsación regular o acento periódico (por ejemplo: un levare con duración de semicorchea hacia el $1^{\circ}$ tiempo fuerte del compás).

Antes de continuar y por la transversalidad que la caracteriza, preferimos resumir lo que (hasta aquí) consideramos la cualidad percusiva:

a) La propiedad de un evento sonoro único. Se manifiesta en su envolvente de intensidad con un ataque impulsivo, sin sostenimiento $\mathrm{y}$ con decaimiento (relativamente) breve.

b) La propiedad del perfil de sonoridad de cada elemento y estrato textural y de la textura general de la pieza. Pudiendo describirse como (re-)iterado, este perfil de sonoridad deriva de la preponderancia y proliferación de eventos con envolvente de intensidad percusiva.

c) La cualidad de la evolución temporal general de la pieza. Caracterizada por presentar repeticiones periódicas (antes que un carácter evolutivo), puede comprenderse como una iteración de período comprendido entre (aproximadamente) el valor de (sub)división y el de (meta-)compás. ${ }^{244}$

En algunas músicas de raíz europea de fuerte carácter melódico (por ejemplo: polka, chamamé o milonga) la periodicidad del tipo descripto en el apartado $c$ se establece a partir de la recurrencia (en la melodía y/o el acompañamiento armónico) de formas rítmico-registrales medianamente fijas donde -mientras el ritmo y los registros permanecen inalterados en su

\footnotetext{
${ }^{244}$ Como pudo apreciarse en nuestra descripción, las cualidades descriptas en los apartados $b$ y $c$ parecen solaparse y su diferencia reducirse a una cuestión de escala temporal. Sin embargo, consideramos que la principal diferencia radica en que mientras en el apartado $b$ asumimos una perspectiva más próxima a un análisis tímbrico o espectral, en el apartado $c$ en cambio tomamos en consideración ciertas cualidades que podemos describir como micro-formales, ausentes en el primero.
} 
ordenamiento- lo que cambia (siguiendo la evolución de la armonía) son las alturas concretas. ${ }^{245}$ Mediante estos ejemplos pretendemos significar que, pudiendo definirse al ritmo como la distribución en el tiempo de la energía acústica: dada cierta permanencia registral de los elementos que conforman la textura en un pasaje o sección determinado, el cambio de las alturas concretas que acontezca en cada momento puede ser (hasta cierto punto) desestimado durante el análisis de la percusividad.

Para finalizar la descripción de esta cualidad y en otro orden de cosas vale decir que, en su instrumentación tradicional, los géneros citados en último término suelen carecer de instrumentos de percusión. Sin embargo, si bien es relativo a cada cultura, son muy numerosos los géneros de músicas utilizadas para el baile social que incluyen elementos percusivos (ya sea en la forma de instrumentos o de sonidos sintéticos con envolventes de intensidad de este tipo) como parte o centro de su textura/motor musical. Mencionamos esta cuestión porque consideramos necesario dejar en claro que el grado de percusividad que una pieza concreta puede presentar resulta hasta cierto punto independiente de la inclusión o ausencia de sonidosinstrumentos $^{246}$ de este tipo.

\section{Concordancia directa entre tempo, densidad cronométrica y activación de movimiento}

La relación expresada en el título refiere al fenómeno apreciable en la virtual totalidad de eventos que incorporan música utilizada para el baile social y consiste en que, frente a un tempo más rápido o a mayor densidad cronométrica en la música, la respuesta en movimiento se caracterizará por presentar un incremento en la activación. Del mismo modo, una disminución en una o ambas variables musicales redundará en una consecuente reducción de la activación de movimiento. Tomando en consideración que, dado un material invariante, un tempo más veloz repercutirá en mayor densidad cronométrica, podemos incluso sintetizar el enunciado y afirmar que: cuanto mayor o menor sea la densidad cronométrica mayor o menor será la activación en el movimiento corporal. ${ }^{247}$

${ }^{245}$ Véase por ejemplo la interpretación del acordeón de la melodía de los diferentes estribillos en Kilometro 11. Tránsito Cocomarola. Subtitulada. Subida por Pancho Vertigen. Accesible en https://youtu.be/VUYdnu0B9hM [26092016].

${ }^{246}$ Referimos así a elementos texturales que permiten su segregación e identificación perceptual a partir de a) analogía con ciertos roles asignados a instrumentos acústicos, b) remitir a un determinado instrumento a partir de cierta similitud tímbrica con este o, c) una combinación de los dos factores previos. Hablamos así del "sonido-instrumento redoblante" para referir (a modo de ejemplo) a un timbre sintetizado o sampleado que cumple el rol asignado en otras músicas a dicho cuerpo de la batería acústica.

${ }^{247}$ Que no se nos malinterprete, no implicamos aquí que la diferencia en la cantidad de activación de movimiento será proporcional al cambio acaecido en la música (ni que pueda siquiera establecerse algún tipo de proporcionalidad entre una y otra actividad) sino que la dirección (del cambio) se corresponderá de forma directa. Sin embargo, mayores cambios en las variables musicales suelen acompañarse por mayores cambios en la activación de movimiento. Sin haber realizado estudios específicos en este aspecto de la relación, a partir de numerosas observaciones creemos posible afirmar que, al menos hasta cierto punto, una relación del estilo se establece entre música y movimiento. 
Según nuestra experiencia docente en el Departamento de Artes del Movimiento de la Universidad Nacional de Artes (UNA, ex IUNA), el fenómeno no se restringe a los ámbitos mencionados sino que se extiende en general a todo tipo de movimientos que consistan de algún modo en la reacción o respuesta a un estímulo musical. Independientemente de lo que suceda en otros contextos, específicamente al interior de las músicas utilizadas para el baile social la relación se cumple en casi todos los casos.

La dependencia que la activación de movimiento presenta respecto del tempo deriva directamente de la sincronización a los ritmos organizados a partir de la ocurrencia de músicas que hacen uso de rítmica medida. En nuestro transcurrir cotidiano por espacios públicos todos hemos experimentado alguna vez cómo nuestras acciones (por ejemplo, el ritmo del caminar) se sincronizan involuntariamente con las músicas presentes, requiriendo incluso un esfuerzo consciente (no siempre exitoso) para lograr la des-sincronización. Esto conduce a que casi como un automatismo nos sincronicemos con el tempo de una pieza y la activación de movimiento presente una relación lineal con el mismo.

La única excepción (y quizá ni siquiera podamos llamarle así) la constituye la posibilidad de movernos "a la mitad" (o en otra relación simple) de la velocidad de paso del pulso. Relación entre música y movimiento hallable en la danza que acompaña al género llamado dubstep, es expresión de una cierta mutitemporalidad que caracteriza a las músicas electrónicas utilizadas para el baile social. Una de las formas en las que en la especie se manifiestan propiedades asociadas a la heterofonía, ${ }^{248}$ numerosos ejemplos presentan componentes que pueden comprenderse como inscriptos en temporalidades que avanzan a diferentes velocidades.

Más allá de los cambios de tempo, en todos los ejemplos visitados de músicas utilizadas para el baile social detectamos que diferencias en la densidad cronométrica -alcanzadas en la música mediante cambios rítmicos- se acompañan con cambios en la misma dirección en la activación de movimiento. ${ }^{249}$ La distribución temporal de la energía acústica que constituye en definitiva el acontecer musical parece invitar a los bailarines a realizar movimientos que

\footnotetext{
${ }^{248}$ Habiendo sido utilizado este mismo término para referir también a ciertas texturas de origen oriental (i.e.: aquellas que ocurren en los grupos de gamelan balinés) preferimos aclarar que nos referimos aquí a la heterofonía por carencia de relación utilizada para describir piezas donde los diferentes elementos o estratos texturales divergen en sus cualidades estructurales y se presentan desvinculados. Como compartimentos estancos, las propiedades idiomáticas de unos y otros no influyen sobre las de los demás. Ejemplo posible es la pieza de 1917 The tides of Manaunaun del compositor norteamericano Henry Cowell, donde la oposición tonal-atonal se concreta en la ocurrencia simultánea de un estrato textural armónico-melódico y otro conformado por clusters de notas graves ("racimos" de gran cantidad de teclas a intervalo de semitonos articuladas juntas). Puede escucharse en Henry Cowell - The Tides Of Manaunaun. Subida por Tal Grünberg. Accesible en https://youtu.be/bgNTWJwsG_E [12082016]

${ }^{249}$ Nos referimos aquí a aquellos videos de músicas utilizadas para el baile social que incluyen imágenes de individuos o grupos de individuos bailando. En los casos en que desconocíamos al género de danza o si este pertenecía a las músicas utilizadas para el baile social, las imágenes fueron (junto con otras fuentes) otro modo de comprobar o refutar dicha pertenencia. Confirmada la condición de pertenencia, los videos resultaron la principal fuente para estudiar tanto la relación que nos ocupa como otras que se establecen entre música y movimiento.
} 
presentan algún tipo de analogía con dicha distribución. Quizá debido a vinculaciones con los ritmos corporales, a cuestiones de aprendizaje, a cuestiones evolutivas, o a herencias animales ancestrales que subyacen a nuestros comportamientos básicos, la condición humana parece involucrar una tendencia a configurar este tipo de analogías.

Similar a la sincronización involuntaria que experimentamos frente a la presencia de música (y que mencionáramos supra), relaciones entre los estímulos musicales y la agitación de los cuerpos de los músicos al tocar constituyen el campo de estudio del Laboratorio para el estudio de la experiencia musical ${ }^{250}$ donde se encuentra radicada la presente tesis. En la edición de diciembre de 2007 de la revista norteamericana Circulation, el investigador italiano Luciano Bernardi explicó que su estudio, realizado sobre 24 voluntarios (12 con extenso entrenamiento musical), permitió probar los efectos del tempo musical sobre diferentes variables corporales. Entre otros resultados relevantes para la relación entre música y ritmos corporales, el científico expresó allí que:

[...] solo 1 factor medió el efecto psicológico de escuchar música: el tempo. Música rápida, ya sea clásica o techno, causó incrementos en la presión sanguínea, el ritmo cardíaco y de respiración y redujo la sensibilidad barorrefleja. Música lenta, por otro lado, ya sea clásica o de estilo reggae [interpretada] en sitar, causó una significativa caída en el ritmo cardíaco y en la frecuencia respiratoria comparada con la base. El Dr. Bernardi dijo "Descubrimos que tanto los [sujetos] control como los músicos se comportaron del mismo modo cuando escuchaban música. Más rápido el tempo, más rápida la respiración, el ritmo cardíaco, la presión sanguínea y demás. Cuando la música era más lenta, tuvo un efecto de ralentización." 251

Estos efectos se documentaron a partir de la siguiente configuración:

Las muestras musicales utilizadas en el estudio vinieron de piezas de Beethoven, Vivaldi, los Red Hot Chili Peppers (una banda popular actual), música de sitar de Deborah Caudhuri, un trabajo orquestal dodecafónico y música techno. Estas 6 muestras de música sonaron por 2 minutos cada una, en orden aleatorio, sin pausas, y luego se repitieron en un orden aleatorio diferente por 4 minutos cada una. Además, la secuencia incluyó un período de 2 minutos de silencio. A diferencia de estudios previos, este

\footnotetext{
250 Las diversas e intensas actividades del laboratorio puede conocerse ingresando en http://fba.unlp.edu.ar/leem/ [27092016]

${ }^{251}[\ldots]$ "only 1 factor mediated the physiological effect of listening to music: tempo. Fast music, whether classical or techno, caused increases in blood pressure, heart rate, and breathing rate, and reduced baroreflex sensitivity. Slow music, on the other hand, whether classical music or reggaestyle sitar music, caused a significant fall in heart rate and breathing frequency compared with the baseline. Dr Bernardi says, 'We discovered that controls and musicians all behaved the same way when listening to music. The faster the tempo, the faster the respiration, heart rate, blood pressure, and so on. When the music was slower, it had a slowing effect."'. "Music and the heart" en revista Circulation. Journal of the American Heart Association. Dic 11, 2007. pp. f139-f140. Accesible en http://circ.ahajournals.org/content/circulationaha/116/24/F139.full.pdf [27092016]. Valga recordar aquí lo que dijéramos en párrafos previos respecto de la relación entre tempo y densidad cronométrica. Si bien el estudio refiere a los tempos, los mismos son una de las variables que determinan la densidad cronométrica que presentan los eventos sono-musicales, por lo que nuestros dichos mantienen su validez.
} 
estudio no encontró efectos del estilo o preferencia musical en ningún parámetro cardiovascular. ${ }^{252}$

Luego de los estudios citados y considerando que regiones muy próximas y parcialmente compartidas de la corteza cerebral procesan los estímulos auditivos, táctiles y cuestiones hápticas múltiples, no debería resultarnos extraño que cambios en los estímulos auditivos y/o táctiles provoquen reacciones análogas en el movimiento.

Para finalizar, téngase en cuenta que una mayor densidad cronométrica en la música implica utilizar sonidos cortos y en mayor cantidad. Consecuentemente, dichos sonidos presentarán necesariamente una envolvente de intensidad percusiva $\mathrm{y}$, como viéramos (y veremos), por sus implicancias audiotáctiles esta cualidad estimula la agitación corporal. En otras palabras, es razonable suponer que aquí reside aún otro vínculo entre música y la activación de movimiento.

\section{Músicas utilizadas para el baile social y movimiento}

Aspecto en que los géneros resultan quizá más divergentes, algunas de estas músicas interactúan con danzas grupales, otras con bailes de a pares, otras individuales y, las músicas electrónicas utilizadas para el baile social, individuales-colectivas.

Las diferentes danzas pueden también categorizarse según la coreografía involucrada consista en pasos completamente preestablecidos, presente fases semi-pautadas o resulte en movimientos libres. El caso de la especie que nos ocupa se corresponde con esta última, aunque se han detectado ciertos movimientos característicos como, por ejemplo, el que consiste en elevar (alternada o conjuntamente) los brazos extendidos por el frente del cuerpo. Este movimiento ha sido asociado por algunos usuarios de la sustancia psicoactiva éxtasis o mdma (3,4-metilendioximetanfetamina) a una sensación de "cosquilleo" en las axilas, percibida como provocada por la música cuando se hallan bajo los efectos de la mencionada droga. La ejecución de dicho movimiento es referida como "fuente de placer" por los mismos individuos.

Sin ser un punto central en nuestro trabajo y habiendo Lenarduzzi tratado extensamente y en profundidad el caso particular de la música electrónica de baile, remitimos en esta cuestión a su ya citado título Placeres en movimiento. ${ }^{253}$

\footnotetext{
252 "The musical samples used in the study came from pieces by Beethoven, Vivaldi, the Red Hot Chili Peppers (a currently popular band), sitar music by Deborah Caudhuri, a dodecaphonic orchestral work, and techno music. These 6 samples of music played for 2 minutes each in a random order without pauses, and then repeated in a different random order for 4 minutes each. In addition, the sequence included a 2 minute period of silence. Unlike earlier studies, this study found no effect of musical style or preference on any cardiovascular parameters." Ibidem.

${ }^{253}$ Lenarduzzi, V. (2012b). Op. cit.
} 
Globalismo e hibridaciones. Una aproximación al concepto de músicas electrónicas utilizadas para el baile social.

Como refiriéramos en diferentes momentos de nuestra exposición, mediante la invisibilización de sus cualidades locales el relato impulsado por los países centrales y coloniales pretende que comprendamos a la música electrónica de baile como el primer ejemplo de especie musical global. A pesar de esta pretensión, los numerosos localismos presentes en sus diferentes índices ${ }^{254}$ históricos son innegables y han sido descriptos en detalle -no por nosotros sino- por nuestros autores de referencia. Los contenidos culturales incluidos en las expresiones históricas de la especie no son ni pueden ser comprendidos como culturalmente neutros; la especie es, sin lugar a dudas, local. ${ }^{255}$

Sin embargo, el surgimiento de la música electrónica de baile coincidió con el desarrollo de internet y de la posibilidad de acceder a información de todas partes del mundo (basten como prueba los dichos respecto de los orígenes de las músicas presentadas en The Warehouse o Paradise Garage que incluyéramos en el Anexo II. El problema de los géneros). Similar al cine -nacido moderno-, la música electrónica de baile surgió post-moderna. ${ }^{256}$ Como tal, la especie presenta como característica propia la cualidad de abierta: ésta posee un mecanismo que le permite incorporar a su interior cualidades musicales que en principio pueden ser ajenas (véase nuestro debate en el Anexo II. El problema de los géneros en relación al sentido del término "House") o incluso cualidades y sonidos que desde perspectivas tradicionales son considerados "no-musicales". Expuesto brevemente y de modo esquemático: en los materiales musicales concretos se combinan fuentes locales y exógenas mientras que en los procedimientos y procesos aplicados se expresan más claramente los localismos o las formas locales de ideas universales/universalistas ${ }^{257}$ o exógenas apropiadas. Y en esta apropiación de procedimientos y procesos resultan (consecuente y nuevamente) también apropiados los materiales de origen exógeno.

Este mecanismo presenta otra característica que, si bien se parece mucho a la cualidad previamente descripta (al punto de casi identificarse mutuamente) es en algo diferente. Nos referimos a que la mencionada porosidad que la especie posee (por tratarse de un conjunto abierto y por presentar elementos exógenos) la convierte simultáneamente en una especie totalizadora. Más que cualquier otra música:

\footnotetext{
${ }^{254}$ Para el sentido del término "índice" y su relación con los (antes denominados como) géneros ver el Anexo II. El problema de los géneros.

${ }^{255}$ El singular aquí deriva de que nos expresamos conceptualmente. En términos concretos queremos significar que la música electrónica de baile consiste en diferentes localismos (Estados Unidos de América, Reino Unido, Alemania, Japon, Francia, etc.).

${ }^{256}$ Usamos este término de modo laxo, más allá de los interminables debates alrededor del mismo, de sus componentes y de su ocurrencia efectiva actual (o no).

${ }^{257}$ Pensamos aquí, por ejemplo, en el ideario del futurismo italiano puesto en obra por artistas norteamericanos.
} 
la música electrónica de baile se encuentra especialmente preparada para incorporar, al interior de su universo de posibles, cualidades poético-estéticotécnicas musicales y meta-musicales exógenas (provenientes de otros géneros y especies) y volverlas -siempre parcialmente- propias.

Dicho de otro modo: mientras contenga -o permita la mixtura con- aspectos electrónicos y de baile... en esta música pueden estar todas las músicas. Consecuencia directa de su cuna post-moderna, la música electrónica de baile es el primer caso de fagocitosis musical del que tenemos registro.

Estas cualidades particulares (y el impulso colonial de sus países de origen) pueden ser vistas como los factores principales que le permitieran permear en los vastos y muy diversos territorios y culturas en los que hoy se encuentra presente: son sus cualidades abierta y totalizadora lo que facilita su hibridación con otros géneros y especies; géneros y especies tan locales como la misma música electrónica de baile.

Son también estas cualidades las que facilitan la inversión de sentido que impulsan los poderes centrales en los territorios y culturas en las que pretenden incrementar su poder e influencia. Son sus cualidades abierta y totalizadora, y los contenidos culturales exógenos (a las culturas coloniales "de origen") incluidos a su interior, lo que permite a los poderes coloniales disfrazar a esta música (siempre local) y presentarla como "global". Son esas músicas extranjeras apropiadas lo que le brinda a la música electrónica de baile su apariencia de global. Pero -preferimos insistir y remarcarlo- su globalidad es solo una apariencia.

La música efectivamente global es (o será) en realidad la que seleccionáramos como marco estético para el objeto de nuestro estudio. La música realmente global es (o será) aquella que surge del proceso de hibridación entre la música electrónica de baile y otras diferentes músicas locales. Como evidenciáramos durante los análisis de diversos aspectos musicales, estamos convencidos de que este nuevo cuerpo de cualidades aún más abarcativo merece un nuevo y más apropiado nombre que lo identifique y diferencie de la más restringida y culturalmente sesgada música electrónica de baile. Requiriendo que su denominación denote una mayor apertura, límites más difusos y una cualidad aún más abierta y totalizadora hemos llamado a esta especie por el nombre de:

\section{músicas electrónicas utilizadas para el baile social.}

Definida finalmente una categoría que utilizáramos hasta aquí como un boceto borroso, y procurando evitar ambigüedades, preferimos explicitar que este cuerpo de obras:

a) contiene a la música electrónica de baile -al incluirla a su interior- y 
b) la excede al incluir también áreas de aquellas otras con las que la primera se mixtura.

En otras palabras, nos encontramos ante una sublimación y ampliación del concepto y del territorio de la música electrónica de baile. Los géneros exógenos se incorporan en tanto nuevos índices, sumando sus (originalmente excluidos) procedimientos, procesos, materiales, recursos, cualidades y sentidos diversos al universo de posibles poético-estético-técnicos de la especie. Recíprocamente, el índice música electrónica de baile (por medio y en la forma de todos y cada uno de sus índices propios) se incorpora parcialmente como una nueva área del concepto y territorio correspondiente a cada especie y género exógenos con los que se hibrida.

Mayores detalles son necesarios. La decisión de optar por una nueva denominación resulta de que consideramos que no podemos hablar aquí de un crecimiento dentro de la misma especie (música electrónica de baile) debido a que nos encontramos frente a:

a) una ("nueva") apropiación -por parte de individuos provenientes de culturas excluidas del relato hegemónico- que modifica las cualidades identitarias de la especie al expandir sus fronteras $y$,

b) una re-apropiación simultánea de esta nueva especie en y durante el proceso mismo de expansión -por parte de individuos de las culturas que dicho relato considera como "de origen"-.

Resulta digno de mención que la apropiación de la música electrónica de baile por parte de individuos que no pertenecen a las culturas "de origen" (mítico) es doble. Se produce -por una parte- la apropiación de los elementos propios ("locales") de la cultura "de origen" de la música electrónica de baile y -por otra- la apropiación "de segunda mano" de aquellos materiales que en la cultura "de origen" eran ya exógenos apropiados (de aquí nuestra utilización del término "nueva" en el apartado a).

Por su parte, la re-apropiación en las culturas "de origen" puede ser también caracterizada como doble. Cualidad propia e indiscutiblemente post-moderna, no solo se adoptan los nuevos procedimientos y materiales -provenientes de las especies y géneros localesrecientemente incorporados por hibridación sino que también se adopta como cualidad propia la capacidad de (valga la redundancia) apropiación de nuevos procedimientos y materiales $a$ futuro. En otras palabras, se profundiza y extiende el alcance de la cualidad totalizadora que la especie presenta desde su nacimiento (esta razón motivó el uso de las partículas "en" y "durante" en el apartado b).

Véase con cuanta claridad se expone esto en la reciente publicación de la empresa alemana Native Instruments. Fabricantes de numerosos dispositivos musicales fisicos $y$ 
virtuales $^{258}$ de vanguardia destinados a la producción e interpretación de música electrónica, dedican la edición del 5 de julio de $2016^{259}$ de su boletín de noticias a compartir un desarrollo comunicacional que involucra diferentes piezas audiovisuales (documentales y otros) y una extensa selección musical de electrónica tropical o Global Bass. Material que probablemente llevara un tiempo considerable reunir, lo introducen del siguiente modo:

\begin{abstract}
¿QUÉ ES EL GLOBAL BASS?
De Lisboa a Lima, de Ciudad del Cabo a Ciudad de México, y más allá: ciudades de todo el mundo están dando mucho que hablar con sus estilos únicos y su cultura musical electrónica. Ya sea cumbia digital, trap, moombahton, UK grime o kuduro, todos estos géneros amplían las fronteras musicales combinando tradición con técnicas modernas de producción, y toman la inspiración de sus propios entornos únicos. ${ }^{260}$
\end{abstract}

Creemos que aquí sí, el plural es sin dudas aplicable y tiene su razón de ser. A diferencia de a) las dudas (que mencionáramos al pasar) acerca de la unicidad de la especie "original" y b) contrariamente a la impresión de homogeneidad que pretende construir el relato hegemónico alrededor de esta: el plural de nuestra nueva denominación no pretende ocultar la diversidad estética y de orígenes (i.e.: sus particularidades culturales locales) sino que, por el contrario, busca ponerlas de manifiesto haciendo honor al multiculturalismo inherente a cualquier categoría que se precie de ser realmente global (o, como dijéramos en el prefacio, "glocal"), abierta y totalizadora.

En las músicas electrónicas utilizadas para el baile social las expresiones "utilizadas para" y "social" se encuentran en relación íntima mutua y denotan la función (o intención) que se le da a este cuerpo de obras. Pero... que no se nos malinterprete: el primero de los términos independiza a las músicas electrónicas utilizadas para el baile social de las intenciones de sus creadores al referir a un "uso" por parte de sujetos indeterminados que pueden o no coincidir con el preferido por quienes crean las piezas artísticas. Nos ponemos así en línea con las perspectivas de la danza que hemos mencionado en oportunidades previas.

Previamente al presente desarrollo hemos utilizado esta denominación y categoría. En esas oportunidades nos ha sido útil para diferenciar a la música electrónica de baile de este "nuevo" cuerpo de obras y cualidades. Ahora si, finalmente contamos con las herramientas y

\footnotetext{
${ }^{258}$ Los cotidianamente descriptos como "hardware" y "software".

${ }^{259}$ Dato anecdótico pero que demuestra la actualidad del tema: el mismo día en que nos encontramos redactando el presente título.

${ }^{260}$ Servicio de noticias periódicas en línea enviadas por correo electrónica de la empresa Native Instruments. (2016). Accesible en http://www.native-instruments.com/es/specials/tropicalfrequencies $/$ ? content $=3531 \& u t m \_$source $=$newsletter\&utm medium $=$email\&utm campaign $=$TROPICAL + FREQUENCIES $+\mathrm{c} \%$ 3DGlobal_Bass Tropical_Frequencies $+\mathrm{b} \% 3$ DMaschine $+\mathrm{t} \% 3 \mathrm{DV}$ ideo PD $+\% 28 \mathrm{es}$ \%29 Sugerimos visitar también el video en línea al que esta publicación refiere, accesible en https://youtu.be/nMiTKhFfiHA. Ejemplos musicales en línea de la estética son la pieza "Simiolo" (2012) del proyecto peruano Dengue Dengue Dengue! (Dengue Dengue Dengue! - Simiolo. Subido por Dengue DengueDengue. Accesible en https://youtu.be/Zi49IeO01lk) o "ZZK Mixtape 17 El Remolon Selva" (2014) del proyecto argentino Zizek (ZZK Mixtape 17 El Remolon Selva. Subido por zzkrecords. Accesible en https://youtu.be/76c0LIXn_P0). [05072016]
} 
conocimientos como para definirlo. Por tratarse de un concepto más abarcativo, la música electrónica de baile resulta entonces incluida al interior de las músicas electrónicas utilizadas para el baile social. Lógicamente, siendo la primera un concepto más restringido, la segunda resultará excluida cuando hagamos uso de aquélla expresión.

Problematizado cada aspecto del concepto, conjugados los argumentos vertidos con antelación con aquellos debatidos en nuestro Anexo II. El problema de los géneros y recorridas las cualidades técnico-estéticas musicales en nuestro Anexo III. Características identitarias generales de la música electrónica de baile y de los índices asociados a sus géneros "mayores" creemos encontrarnos en condiciones de realizar una aproximación a la definición del marco estético en que analizaremos nuestro objeto de estudio. Proponemos entonces que:

músicas electrónicas utilizadas para el baile social son aquellas expresiones musicales diversas, multiculturales, de límites difusos y en constante y veloz cambio que -a partir de combinar materiales, procesos, procedimientos, cualidades y herramientas procedentes de la música electrónica o electroacústica (en sentido amplio) y de las históricas músicas utilizadas para el baile social- han derivado en la conformación de una especie que preserva huellas de sus antecesoras y -simultáneamente- presenta algunas características poético-estético-técnicas sui géneris. Siendo la llamada "música electrónica de baile" una de sus fuentes principales de características, toma de esta sus cualidades esenciales de abierta, totalizadora y global (o glocal). Para su realización, la especie requiere además de instrumental de base tecnológica y que su uso se evidencie a la percepción. 


\section{CAPÍTULO II}

\section{Músicas electrónicas utilizadas para el baile social. APLICACIÓN PRÁCTICA}

\section{Análisis audiotáctil de las músicas electrónicas utilizadas para el baile social}

La evolución y desarrollo simultáneos de los dispositivos tecnológicos y su influencia sobre aspectos estéticos musicales, la influencia sobre estos últimos ejercida por sucesos sociales y geopolíticos de relevancia mundial, la transformación de las condiciones de disfrute $y$ percepción por incidencia tanto de las tecnologías como de los hábitos sociales, como así también la influencia que sobre éstos y otros factores han tenido y tienen cuestiones que podrían ser consideradas "periféricas" o "tangenciales", son solo algunos de los factores que provocaron el surgimiento de una especie musical que se diferenciaría tanto de sus predecesoras, que llegaría al punto de volverse la pieza clave en el proceso de visibilizar (o como dijéramos, "tactibilizar") la sensación táctil originada en vibraciones mecánicas transmitidas principalmente- por vía aérea y -secundariamente- por vía sólida. Proceso subyacente donde apenas si se detectan menciones e indicios aislados, en los actores involucrados en la especie se aprecia una conciencia elusiva y siempre parcial del trabajo realizado por ellos mismos en relación a la sensación táctil y/o audiotáctil mencionada. ${ }^{261}$ Sin embargo y como veremos en el desarrollo que sigue, resulta evidente que estas sensaciones juegan un rol para nada secundario (quizá resulte excesivo decir "central") en el establecimiento de numerosas y muy diversas cualidades particulares que asumen las piezas de las músicas electrónicas utilizadas para el baile social.

Recorreremos aquí entonces dichas cualidades, asumiendo para su análisis un punto de vista audiotáctil; perspectiva que tanto las pone en evidencia como permite apreciarlas mejor. En otras palabras, estudiaremos a las músicas electrónicas utilizadas para el baile social considerando en nuestro análisis a las sensaciones táctiles que se originan en las vibraciones que se establecen a partir de las particularidades poético-estético-técnicas musicales que la especie presenta. Examinaremos dichas particularidades haciendo foco especialmente en las sensaciones corporales (y no tanto auditivas), en los efectos táctiles que las conformaciones musicales propias de la especie originan. ${ }^{262}$

Tomaremos para ello una perspectiva que podemos llamar "acústica", focalizando principalmente en las cualidades del sonido. En otras palabras, aunque sin descuidar las conformaciones establecidas con fines estéticos (i.e.: "musicales"), haremos especial hincapié en las características pre-musicales que presenta la especie. Creemos que este punto de vista es

${ }^{261}$ Cuáles son estos actores y qué relaciones se establecen entre ellos es el contenido del Anexo IV. Actores involucrados en la escena electrónica.

${ }^{262}$ Como fuera anticipado en la Introducción, con el objetivo de brindar un marco de referencia algo más claro a este análisis sui generis hemos realizado además algunos análisis complementarios de la especie desde una perspectiva musicológica más próxima a la tradicional. Descripciones de diferentes aspectos musicales (y aún otros análisis audiotáctiles) se incluyen en el Anexo III. Características identitarias generales de la música electrónica de baile y de los índices asociados a sus géneros "mayores". 
el mejor para comprender al universo acústico (i.e.: tímbrico, registral, etc.) que las músicas electrónicas utilizadas para el baile social ofrecen y configuran. Al mismo tiempo, esta perspectiva pondrá en evidencia las implicancias táctiles y audiotáctiles de las cualidades y conformaciones musicales que estas músicas presentan. En el transcurrir de este desarrollo veremos surgir diversas categorías, como también jerarquizarse ciertas variables musicales hasta hoy desestimadas en los análisis musicológicos.

Como dijéramos en nuestra introducción, la principal característica por la que se identifica a la especie se rige por criterios instrumentales. Esta cualidad ha sido histórica y usualmente comprendida como sinónimo de cierta tímbrica a la que se ha denominado "electrónica" (a partir de la tecnología que la hiciera posible) o "sintética" (a partir de la síntesis sonora; denominación que, a pesar de excluir a los samples o sonidos grabados, no deja de tener cierta pertinencia). La concepción subyacente a los instrumentos acústicos y el impacto que los instrumentos electrónicos provocaran en oportunidad de su surgimiento (en particular sus timbres) influiría en la lógica que la sociedad de la época aplicaría para comprender la extrema novedad que la música electrónica toda presentara entonces y hoy. El enorme peso de la novedad tímbrica generaría la falsa impresión de que aquí -y solo aquí- reside la propiedad sui géneris de la música electrónica.

Esta forma de entender al criterio instrumental resulta extremadamente limitada respecto del sentido que en la especie asume dicho concepto. Sin embargo, la falacia de que los timbres son lo único que distingue a la electrónica de las demás músicas se encuentra aún muy extendida, incluso entre los miembros de la comunidad de pertenencia. Contradiciendo esta creencia sostenemos que la influencia de los dispositivos musicales de base tecnológica alcanza mucho más allá que al territorio ocupado por el concepto de timbre (al menos en su acepción tradicional y desestimando su cualidad totalizadora de las demás cualidades del sonido).

Es posible enunciar brevemente las dimensiones que resultaran subvertidas por la aplicación de la tecnología electrónica a la música; en simples términos, el surgimiento de los dispositivos tecnológicos (y de sus peculiaridades y diferencias en relación al instrumental acústico) crearía las condiciones de posibilidad para la existencia de una música que presenta novedad, innovación y cualidades sui géneris en:
a) su materia sonora,
b) los procesos a los que se somete a dicha materia,
c) las transformaciones que la materia experimenta y
d) la poético-estético-técnica musical resultante de la interacción entre las novedades, innovaciones y cualidades sui géneris mencionadas previamente. 
Recorreremos estas cuestiones desde la perspectiva de las peculiaridades que presentan la materia sonora electrónica y los procesos electrónicos aplicados a esta. Para comprender las implicancias últimas de esta materialidad, en algunas ocasiones trazaremos paralelos con la materia sonora y musical de origen puramente "acústico" y con los procesos asociados a esta.

\section{Sonoridad}

La novedad que la especie presenta en relación a esta cualidad depende de la utilización que la misma hace de sistemas de refuerzo acústico o amplificación. Surgidos hace aproximadamente 50 años, los "PA" ("Public Adress", como se los conoce entre los equipos técnicos de apoyo) han ido creciendo en su capacidad de generación de presión acústica, reduciendo en cada etapa de su desarrollo las limitaciones y deficiencias que presentaran en origen. Con mucho menor potencia que en la actualidad, estos sistemas estarían inicialmente cargados de ruidos parásitos de funcionamiento, altos grados de distorsión armónica (sobre todo al reproducir altas intensidades) y rangos de frecuencia de reproducción limitados. El desarrollo de diferentes soluciones tecnológicas mejoraría y ampliaría sus capacidades alcanzando el nivel actual, en el que contamos con equipos de amplificación sonora que han hecho posible disfrutar con grados de fidelidad suficiente de espectáculos musicales masivos en locales cerrados de grandes dimensiones, estadios y espacios completamente abiertos.

Al ritmo de este desarrollo tecnológico surgiría la música electrónica de baile. Solo con la posibilidad de amplificar las mínimas tensiones electrónicas producidas por (a modo de ejemplo) micrófonos y sintetizadores sería posible disfrutar de una música que depende de estos sistemas para ser escuchada. ${ }^{263}$ Solo a partir del desarrollo de sistemas esencialmente libres de ruidos parásitos y con bajos niveles de distorsión armónica, los PAs se volverían "aptos" para una música centrada en el timbre y donde sus creadores presentaban y presentan un especial interés por la fidelidad de reproducción de los más mínimos detalles sonoros. ${ }^{264}$ Solo con el incremento de la potencia sonora disponible y la extensión del rango de frecuencias plausible de ser reproducido sería posible que la música electrónica de baile tomara su forma actual.

\footnotetext{
${ }^{263}$ Queremos significar que, mientras que una guitarra eléctrica puede al menos escucharse mínimamente sin amplificación, un micrófono o sintetizador no producirán ni el más mínimo sonido sin la ayuda de un parlante.

${ }^{264}$ No resulta extraño que aún hoy exista un especial interés entre los productores por la fidelidad sonora: al igual que con el mito alrededor del timbre que se construyera en la sociedad en oportunidad del surgimiento de los dispositivos tecnológicos, en las etapas iniciales de la música electrónica, evitar la incorporación de ruidos parásitos era una de las ocupaciones técnicas centrales. A partir de las mejoras en este campo, dicha ocupación se ha transformado en una pre-ocupación o ideal de belleza.
} 

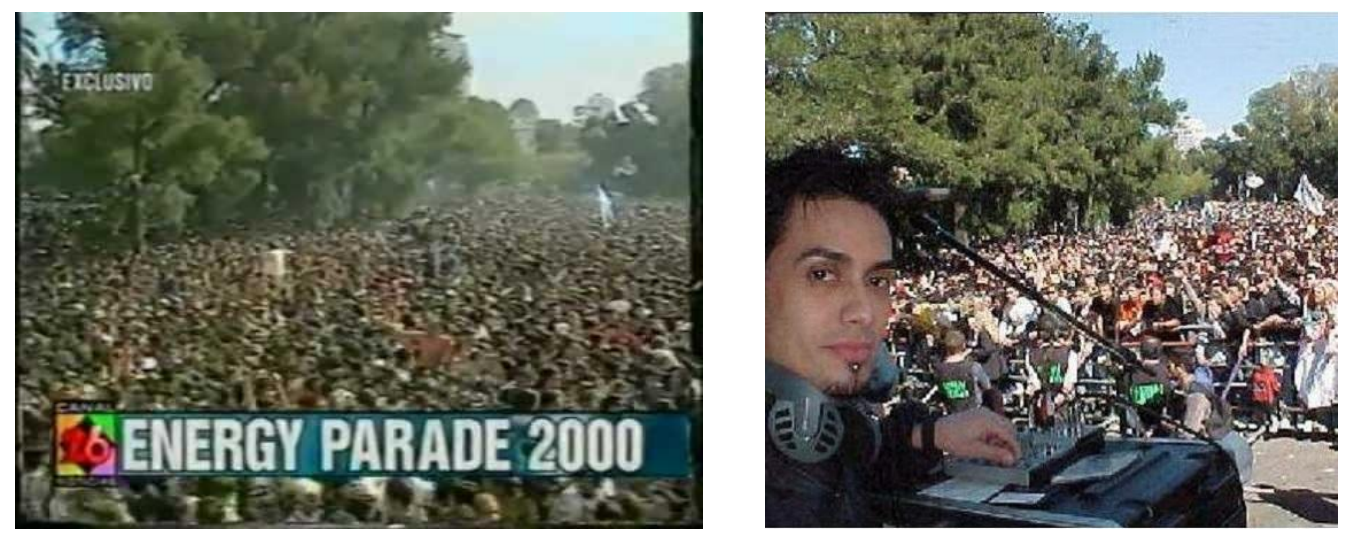

Energy Parade. Varias fiestas electrónicas serían organizadas en años sucesivos por la radio Energy 101.1, especializada en música electrónica de baile. Las fotos se corresponden con las ediciones 1999 y 2000. En la última foto, el deejay y productor Carlos Shaw, pionero de la especie en la Argentina, durante su presentación. ${ }^{265}$

Si bien no es privativa de ésta y casi todas las músicas actuales hacen uso hoy de algún tipo de amplificación, en la especie ocurren los niveles de presión acústica continuos más elevados de los que se tenga registro para un evento musical. Alcanzando en locales de baile valores superiores a los $120 \mathrm{~dB}$ SPL, debido al constante flujo musical que caracteriza a la forma de presentación de las músicas electrónicas utilizadas para el baile social, en el transcurso de una noche de fiesta electrónica los niveles raramente descenderán por debajo de los $80 \mathrm{~dB}$ SPL. ${ }^{266}$

Snoman corrobora esta tendencia hacia la mayor sonoridad posible al explicitar el compromiso que debe asumir y resolver el productor al momento de finalizar y darle los retoques técnicos finales a sus creaciones:

Los habitués de clubes, tu potencial audiencia, gustan [del sonido] fuerte[;] por [esta razón] tienes que asegurarte de que tu pista se pare hombro con hombro con las demás pistas mientras que, al mismo tiempo, no se sacrifica demasiado rango dinámico de la música. ${ }^{267}$

${ }^{265}$ Información y videos de algunas de las tantas fiestas organizadas por la radio pueden consultarse accediendo a https://faunanrg.wordpress.com/category/fiestas-y-raves-nrg-baires/. Uno de varios videos en línea de la edición del 21 de septiembre de 2000 puede verse en Bs As Energy Parade 2000 Parte 1/3. (2012). Subido por Robert Quinteros. Accesible en https://youtu.be/VGm3vWk67qc. En el siguiente video promocional se alega que la edición de 1999 congregó a más de 100.000 personas, instalándose como una de las fiestas electrónicas (o "raves") más masivas del mundo y la mayor de América Latina. BUENOS AIRES NRG PARADE 2000. (2012). Subido por djsebaparatodos. Accesible en https://youtu.be/TcYQy0lM6kg. [18072016]

${ }^{266}$ Datos relevados durante nuestras experiencias de campo, pueden verificarse en nuestro Anexo I. Experiencia de campo. Como veremos durante desarrollos posteriores, estas diferencias tendrán una incidencia fundamental en la generación de sensación táctil y en la incitación a la danza.

267 "Clubbers, your potential audience, like it loud so you must ensure that your track stands shoulder to shoulder with further tracks whilst at the same time not sacrificing too much of the music's dynamic range." Snoman, R. (2014). Op.cit. pp. 409 Debido a que el contexto podría generar ambigüedades preferimos aclarar que utilizamos aquí el término "pista" en el sentido que diéramos en capítulos previos, como traducción del inglés "track". 
Tanto gustan los aficionados del sonido fuerte (o tanto se los ha acostumbrado) que es posible establecer cierto paralelismo entre la mayor presión acústica y la incitación al baile. Restando aún exponer algunos datos para tratar este tema, nos limitaremos a decir aquí que en las músicas electrónicas utilizadas para el baile social a) al sonido de bombo se le asigna la mayor cantidad de energía acústica y b) el bombo es el principal motivador y promotor del baile. Las presiones sonoras presentes en los locales de baile son tan altas y nocivas para el sistema auditivo humano, que merecen que les dediquemos al menos un breve comentario.

La costumbre de consumir música a niveles de presión sonora o acústica tan elevados provoca desde hace décadas generaciones de jóvenes que experimentan o experimentarán problemas de pérdida auditiva. A partir de disposiciones gubernamentales claramente insuficientes y que no se encuentran acompañadas de políticas educativas que informen y formen a la población en el cuidado de su sistema auditivo, resulta común encontrar en el ingreso a los locales de baile donde se presentan músicas electrónicas utilizadas para el baile social diversos estilos de carteles advirtiendo que "Los niveles sonoros en este local pueden provocar pérdidas auditivas permanentes." Desentendiéndose de las acciones necesarias para resolver un serio problema generalizado de salud pública, el Estado se retira del control justificando su ausencia con un simple cartel que (valga también decirlo) pocas veces se encuentran instalados en lugares de fácil acceso y alta visibilidad. Esta costumbre, sumada al uso generalizado de auriculares (dispositivos sobre los que se han realizado innumerables estudios que prueban su relación con pérdidas y problemas auditivos) enfrenta a la sociedad toda con una situación de salud pública presente que consiste en un amplio grupo de individuos con falencias de audición. De no realizarse campañas de educación al respecto este problema solo puede incrementarse y amplificar sus efectos nocivos.
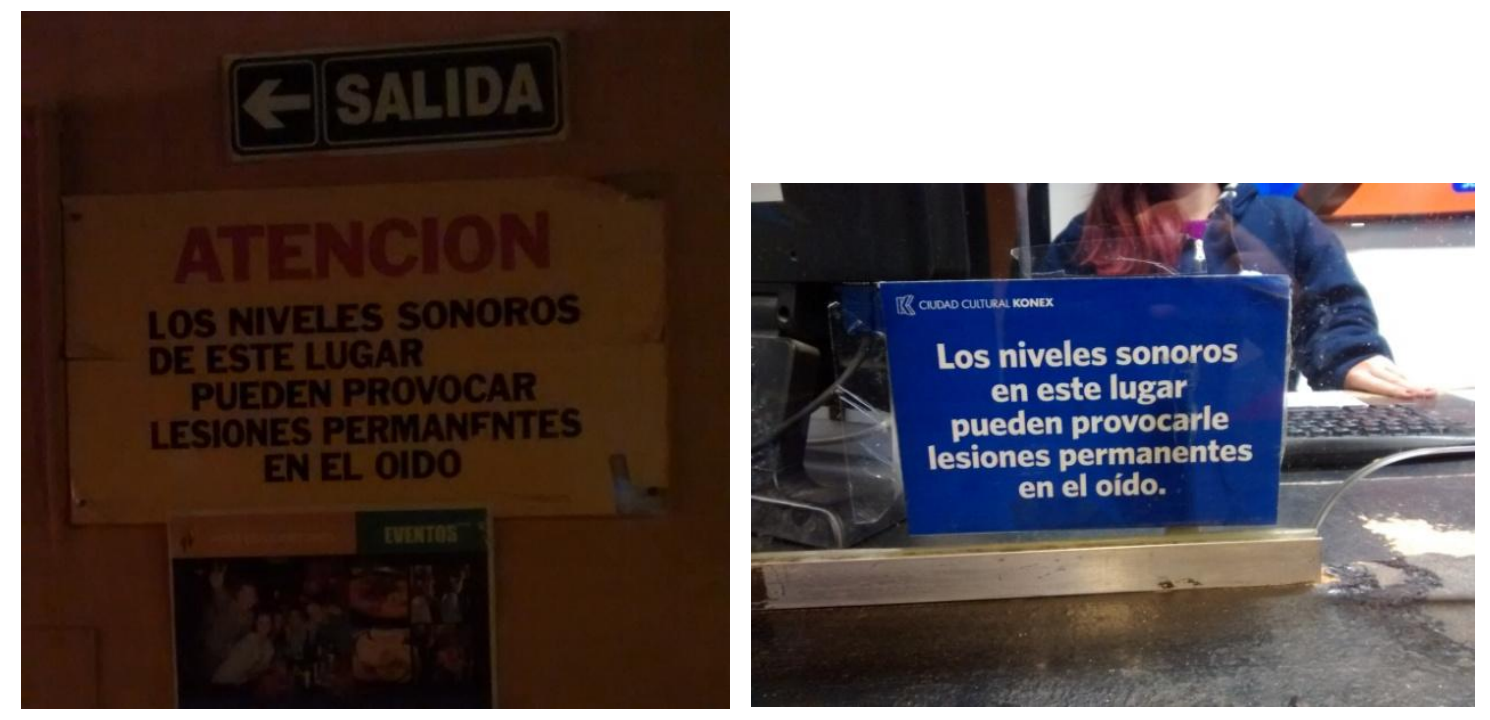

Carteles advirtiendo sobre los riesgos para la salud auditiva. Locales donde, entre otras actividades, se presentan músicas electrónicas utilizadas para el baile social. Nótese la escasa iluminación sobre el primero. Imágenes tomadas en la Ciudad Autónoma de Buenos Aires en los meses de junio y agosto de 2016. 
Las músicas electrónicas utilizadas para el baile social suenan fuerte, muy fuerte. Las músicas electrónicas utilizadas para el baile social se disfrutan (y "deben ser" disfrutadas) muy fuerte. El relato anecdótico de uno de los principales disparadores que nos llevaran a visibilizar en nuestro fuero íntimo a la sensación táctil (en tanto fenómeno independiente y como posible variable a ser trabajada con fines estéticos) nos será útil para ilustrar esta cuestión (sobre todo) a quienes no han asistido nunca a eventos o locales de este estilo.

Aproximadamente a finales del año 2007 asistimos con un grupo de amigos a una noche de música electrónica en un local de baile en la zona céntrica de la Ciudad Autónoma de Buenos Aires. En un momento de la noche notamos a nuestro lado a una chica que bailaba munida de algo extraño en sus oídos. Tocamos uno de sus hombros y mediante gritos (por el nivel sonoro del local) le consultamos qué era aquello. Se quitó uno de sus protectores auditivos moldeables de silicona y nos lo mostró. Frente a nuestra pregunta acerca del porqué de su uso nos respondió con la simple frase "Por la música...", girándose inmediatamente después. Asombrados, su respuesta disparó la vaga intuición de que algo profundamente íntimo había comenzado a cambiar en nuestra relación con la música. La enorme contradicción se materializaba en la pregunta (que nos repetimos durante días):

¿Qué lleva a una persona a asistir a un evento -donde se va esencialmente a disfrutar y experimentar música- munida de semejantes dispositivos? ${ }^{268}$

La respuesta de la joven, completamente lógica, no tardaría en dar forma al objeto que hoy tratamos en nuestra tesis doctoral:

los enormes niveles de presión sonora que hoy se experimentan en los locales de baile generan no solo sensación auditiva sino también sensación táctil.

A partir ya no de las palabras sino de la actitud de nuestra interlocutora ${ }^{269}$ y de nuestra experiencia personal como participantes de la comunidad electrónica -en carácter tanto de productor como de músico electrónico y bailarín- nos arriesgaremos a realizar aún otra afirmación.

Si bien nos basamos apenas en una serie de indicios y testimonios al respecto de la presencia de sensación táctil, creemos que los aficionados a las músicas electrónicas utilizadas para el baile social no asisten a estos eventos en busca de disfrute puramente auditivo, sino que lo hacen en procura (quizá subconsciente) de una experiencia que también involucra a aquel

\footnotetext{
${ }^{268}{ }_{i}$ Dispositivos creados precisamente para obturar el sistema que permite dicho disfrute!

${ }^{269}$ A quien ojalá alguna vez tengamos la oportunidad de agradecer la motivación que -desprevenida- nos regalara.
} 
sentido. Además de la anécdota relatada, numerosas referencias pueden hallarse en el discurso de productores, músicos electrónicos, deejays y participantes de la comunidad electrónica como bailarines.

En nuestra desempeño profesional escuchamos de músicos y productores que "el bajo está muy gordo" (denotando exceso de graves), que los platillos están "filosos" (denotando exceso de componentes agudos) o les falta "corte" (por debilidad de las mismas frecuencias), que un determinado bombo es "redondo" (por poseer poca cantidad de agudos en el ataque) o que "no patea" (por carencia de componentes graves), que un redoblante tiene poco "cuerpo" (ilustrando la carencia de componentes graves) o que tal o cual sintetizador presenta un timbre "rugoso" (al contener componentes que lo vuelven iterado).
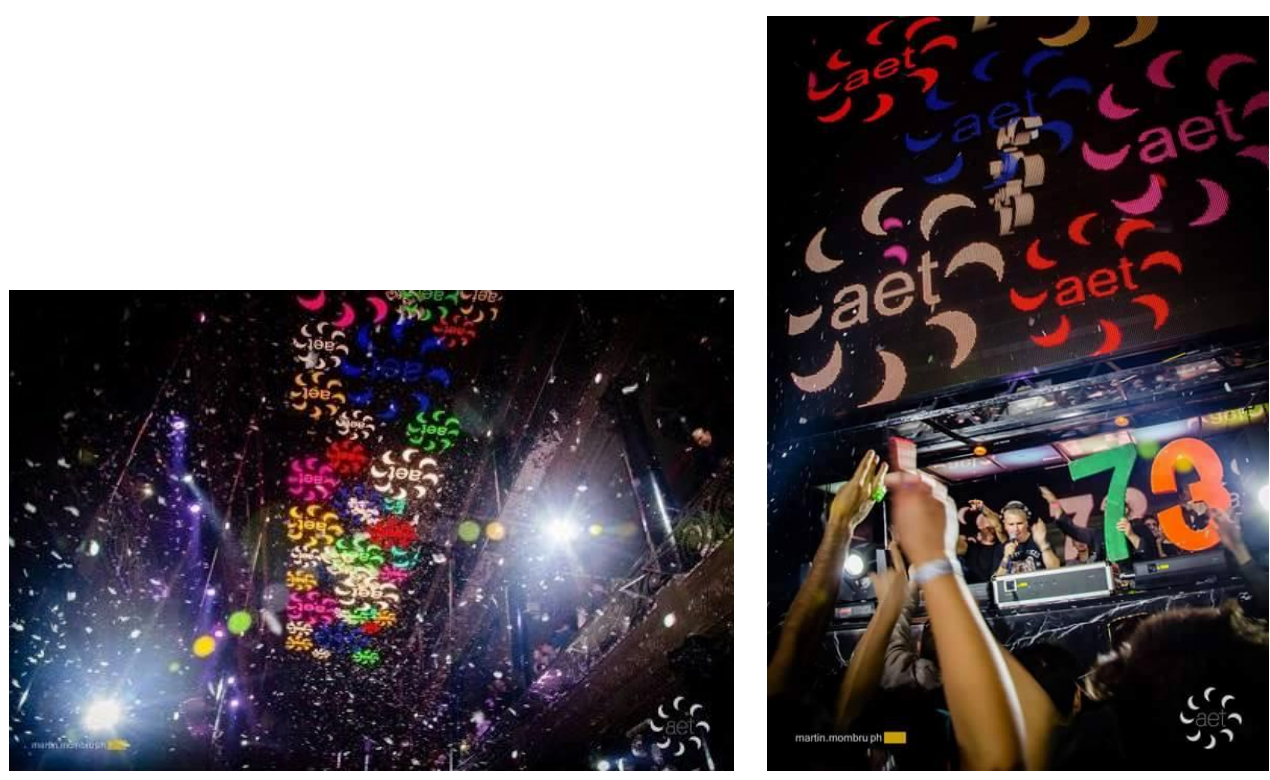

AET. Con más de 70 ediciones en diferentes locales de baile de la Ciudad de Buenos Aires, es hoy una de las mayores fiestas electrónica del país. Fotos de la edición No73. 2015.

En una cadena de conversaciones en el grupo Argensynth de la red social facebook, un reconocido deejay afirma que, al hacer sonar sonidos graves desde un clon del sintetizador ARP 2600 (en ocasión de celebrarse una fiesta electrónica de la cual es deejay residente) incluso las columnas que sostienen la cabina (de deejay) vibraron. En el mismo momento nos encontrábamos realizando una de nuestras experiencias de campo; oportunidad donde registramos presencia de sensación táctil, incluso en el momento al que el deejay refirió con su comentario.

En nuestras entrevistas personales, los músicos Esteban Fangi Boggia, Sebastián Duarte y Facundo Locaso Olivi afirmaron experimentar vibración "en todos lados" (del cuerpo) a partir de un sonido "grave" en un recital del conjunto Jamiroquai. ${ }^{270} \mathrm{Si}$ bien la producción del artista no se limita por completo a la especie que nos ocupa, su música presenta gran influencia del

\footnotetext{
${ }^{270}$ Registro fonográfico en poder del autor y a disposición.
} 
disco y el funk (géneros que, como puede verse en nuestro Anexo II. El problema de los géneros, ejercen una gran influencia sobre la especie) e incluye un número considerable de piezas que pertenecen a las músicas electrónicas utilizadas para el baile social.

Paloma Garay Santaló (aficionada a la especie como bailarina) expresó también en la entrevista que le realizáramos que en eventos con músicas electrónicas utilizadas para el baile social experimentó vibración en su nuca, hombros, cabeza y pecho (entre otras, estas son localizaciones corporales donde releváramos sensación táctil durante nuestras experiencias de campo). ${ }^{271}$

Muy ilustrativo es el testimonio que nos diera el periodista Baltasar Lafarga, aficionado a la especie quien expresó en nuestra entrevista que en las músicas electrónicas utilizadas para el baile social posteriores a los años 2000 "el sonido del bombo se hizo más duro", "es un golpe con mucha más fuerza" y "golpea más fuerte", mientras que el utilizado durante la década del 90 "era más suave" y "apenas golpeaba". Consultado respecto de las cualidades de uno y otro sonido de bombo y de su opinión respecto de las razones que llevaron a esta mayor "dureza" respondió que el bombo más moderno presenta "más carga de graves" y que "debe tener que ver con la producción musical para las pistas de baile y para las grandes fiestas". Consultado a su vez sobre esta asociación dio como razón "el impacto que tiene que generar en la gente que está bailando el golpe de la música" y continuó "el golpe de la música cuando estás en una fiesta electrónica... el golpe, el beat, el bpm,... lo tenés que sentir para que te genere algo en tu cuerpo, para que te genere la predisposición a bailar, la predisposición a saltar o para ponerte eufórico."

En las fuentes consultadas hemos hallado también numerosas referencias a cuestiones vinculadas a la corporalidad o directamente táctiles. A modo de ejemplo, respecto del disco Black Secret Technology de 1995 de A Guy Called Gerald, Blánquez dirá: "bañada en soul, dub, ambient y sonidos profundos que dejó muy alto el pabellón del ingenio: pocos discos, pueden presumir, de verdad, de ser un auténtico universo paralelo, una demostración de música táctil"272

Respecto del tema de 1976 Love in C Minor dirá Ariel Kyrou en su Techno rebelde que "Cerrone y Moroder innovan debido a la exagerada simplicidad de su pulsión rítmica: un bombo poderoso, enorme, que golpea, golpea y golpea cada vez de forma más rápida (¡120 bpm!, para los amantes de los números)." 273

En el capítulo dedicado a la síntesis sonora, Snoman dirá que la onda sinusoidal "comúnmente se mezcla con otras formas de onda para introducir cuerpo o poder a un sonido." ${ }^{274}$ En otro pasaje vinculará directamente intensidad con sensación táctil al decir que:

\footnotetext{
${ }^{271}$ Para más detalles sugerimos ver nuestro Anexo I. Experiencia de campo.

${ }^{272}$ Citado en Lenarduzzi, V. (2012b). Op.cit. pp. 139

${ }^{273}$ Kyrou, A. (2006). Techno rebelde. Un siglo de músicas electrónicas. pp.144

274 "Consequently, the sine wave is [...] commonly mixed with other waveforms to introduce body or power to a sound." Snoman, R. (2014). Op.cit. pp. 73
} 
En la EDM, el bombo provee el elemento rítmico principal de la música que golpea al oyente en el pecho, y aquella energía es un resultado directo del grado en que mueve a los conos de los parlantes de los monitores. Más se mueve físicamente el cono del parlante, mayor será el impacto del bombo. ${ }^{275}$

En síntesis, a partir de estos datos (que ofician de ejemplo de otros que obviamos en honor a la brevedad) creemos razonable considerar que:

los aficionados a la música electrónica de baile asisten a eventos de la especie en procura de una experiencia que excede lo auditivo y puede ser descripta como audiotáctil.

En la generación de los niveles extremos de presión sonora mencionados influye también la capacidad de los sistemas de amplificación de reproducir frecuencias que han sido históricamente obviadas en los estudios acústicos relativos a la música. Los extremos grave y agudo que los actuales PAs son capaces de reproducir se encuentran presentes en una multiplicidad de instrumentos acústicos. Frecuencias (incluso) sub-sónicas y elevada presión acústica son emitidas al menos por instrumentos de percusión; $;{ }^{276}$ sin embargo, éstos no alcanzan las grandes intensidades, la gran cantidad de energía que los sistemas de amplificación y las conformaciones musicales de las músicas electrónicas utilizadas para el baile social permiten concentrar en un muy breve espacio-tiempo.

A modo de ejemplo, en el acontecer de un sonido de bombo electrónico y demás elementos de la textura musical (que pudieran presentarse sincrónicamente a aquel):

casi instantáneamente y en muy breves milisegundos la presión del aire -en una región espacialmente muy reducida- se eleva a enormes niveles, alcanzando las condiciones necesarias para la generación de sensación táctil.

Este acontecer configura sin lugar a dudas un fonón o sonón que rápidamente alcanza al sujeto perceptor, impactando y habitando brevemente su cuerpo. Aunque deformándolo efímera y fugazmente, no por ello resulta menos perceptible que el aspecto auditivo del estímulo.

\footnotetext{
275 "Within EDM, the kick drum provides the main rhythmical element of the music that thumps the listeners in the chest and that energy is a direct result of the degree it moves the monitor speaker's cones. The more the speaker cone is physically moved the greater the punch of the kick is." Snoman, R. (2014) Op.cit. pp. 129

${ }^{276}$ Hemos experimentado sensación táctil en proximidad de "cuerdas" de percusión de candombe o samba y al hallarnos cerca de grupos de percusión en manifestaciones políticas callejeras. En algunas de estas situaciones consultamos a allegados que se encontraban también próximos a los ensambles, recibiendo confirmación de que la experiencia era compartida. Situación sencilla de reproducir, son esencialmente los bombos graves los que provocan la sensación.
} 
[Digresión: el fonón o partícula acústica]

Equivalente acústico de la partícula electromagnética fotón, la hemos utilizado en trabajos previos y la utilizamos aquí para graficar la cualidad material que sonido y música asumen. Tradicionalmente concebidos en términos de ondas, sonido y música pueden comprenderse también desde la perspectiva de partículas. Con algunas diferencias respecto de la dualidad onda/particula que presenta la luz, la mencionada perspectiva nos resulta útil sin embargo para evidenciar que sonido y música literalmente esculpen formas en el aire. Sin involucrar metáfora alguna y (preferimos arriesgarnos a redundar pero dejarlo claro) siendo completamente literales sin excepción:

la forma de onda y la envolvente de intensidad son -literalmente- las formas que la música imprime al aire y que, fugaz y mínimamente, deformarán (i.e.: darán forma) a la piel, carne, órganos internos y huesos del sujeto perceptor.

A partir de los datos recabados en nuestras experiencias de campo fue posible estimar que la traslación que una molécula de aire puede experimentar en los momentos de sonoridades máximas es de aproximadamente un (1) milímetro. Si bien puede parecer a primera vista poco, en términos de física acústica (i.e.: tomando como referencia el diámetro de la molécula de aire) se constituye en otra expresión de la enorme presión acústica presente en estos locales de baile. Combinado con las elevadas presiones acústicas locales (i.e.: al interior del área de influencia del fonón) resulta comprensible la detección consciente de sensación táctil registrada en nuestras experiencias y referidas en nuestras entrevistas. De este modo, nuestra pesquisa en relación a la sensación táctil presenta un resultado que -aún sin ser el foco de nuestro trabajo- es consecuencia directa de este.

En la casi totalidad de las numerosas conversaciones que entabláramos en los últimos años con diferentes integrantes de la comunidad musical, ${ }^{277}$ encontramos que debíamos reiterar la mención de nuestro objeto de estudio para que nuestros interlocutores tomaran consciencia de las implicancias del mismo sobre el universo relacionado con el sonido y la música. Para la ideación de uno o varios eventos musicales, los creadores musicales y de arte sonoro suelen considerar cuestiones técnicas de las fuentes sonoras al imaginar/recordar sonidos. Sin embargo, al medio de propagación se le asigna un rol secundario en el proceso de ideación; en el proceso de concebir y "dar forma" a la idea de la obra futura. En este punto es donde -creemos- la perspectiva audiotáctil contribuye con uno de sus principales aportes para la praxis musical. La incorporación de la sensación táctil al momento de idear el estímulo le brinda al creador la posibilidad de imaginar la forma de onda "en el aire": metafóricamente, "materializar la forma

\footnotetext{
${ }^{277}$ Sobre este tema: compositores, intérpretes, directores de orquesta y coros, educadores, productores, músicos electrónicos, deejays, sonidistas de cine y video, etc.
} 
aérea" de la señal acústica a ser emitida por la fuente. En la mente del músico, la forma de onda se "materializa" en la distribución misma que adoptan las moléculas de aire con el paso de la perturbación acústica. De esta manera, la perspectiva audiotáctil le suministra a los músicos un dispositivo conceptual que puede aplicarse al momento de imaginar, componer, analizar e interpretar los fenómenos y acontecimientos musicales.

[Fin de la digresión]

Nos restan explicitar tres aspectos de la sonoridad, los cuales se expresan en relación al ritmo, a la textura y al timbre. Como veremos más adelante, esta será apenas la primera de muchas formas en las que estas dimensiones musicales se cruzan y entrelazan hasta extremos de identificación mutua.

Las músicas electrónicas utilizadas para el baile social son percusivas, reiterativas e iteradas; y estas son tres formas en las que ritmo, textura y timbre se manifiestan en la sonoridad. Aunque pueda parecer contradictorio o ilógico, como consecuencia de lo anterior, esta es también la forma en la que las tres dimensiones mencionadas -a través de la sonoridadconforman el ritmo. Dicho de otro modo, la distribución en el tiempo de las energías contenidas en los ritmos, la textura y los timbres constituye el ritmo "total", resultante de la pieza musical.

Esta peculiaridad se explica en el hecho de que los dispositivos tecnológicos utilizados en las músicas electrónicas utilizadas para el baile social brindan la posibilidad de transformar a los materiales de modos tan radicales que cualidades históricamente asociadas a una dimensión se reconvierten en cualidades de otra o de varias. Esto establecerá vías de comunicación fluidas y continuas entre las tres dimensiones mencionadas, generando su integración última en la dimensión rítmica (aunque, mejor dicho, esta será una de sus integraciones posibles).

\section{Percusividad}

La amplia mayoría de los eventos sonoros que ocurren en las músicas electrónicas utilizadas para el baile social presentan envolventes de intensidad de inicio impulsivo. Cualidad compartida con las músicas de baile históricas, la mayoría de los sonidos de la especie se inician repentina, casi instantáneamente, generando que muchos sonidos y timbres aporten al ritmo y a la sensación de activación musical. ${ }^{278}$ Son muy numerosos también los sonidos que presentan breve o nulo sostenimiento (i.e.: sonidos que podríamos describir -por analogía- como staccato). Como viéramos en capítulos previos, esto configura una textura, una superficie musical que hemos descripto como percusiva.

\footnotetext{
${ }^{278}$ Sensación de activación, actividad o movimiento percibido en la música. Para más detalles véase el
} Glosario. 
Los sonidos percusivos amplifican la relevancia perceptiva de los silencios (o los niveles relativamente bajos de intensidad) que suceden en los que llamaremos periodos interataques al establecer (y permitir) mayores contrastes de sonoridad: mayor rango dinámico puede conseguirse entre períodos de silencio y la sonoridad máxima de los sonidos percusivos. Estos últimos, como la mayoría de los sonidos en la especie, presentan gran intensidad. En los términos utilizados por Snoman, esta es la situación en la que puede lograrse el mayor recorrido de los conos de parlantes. ${ }^{279}$

En el caso que nos ocupa, la intensidad se ve reforzada por la misma cualidad percusiva de las vibraciones en cuestión. Ampliando lo mencionado en la introducción y durante el tratamiento de la propia cualidad percusiva, el principio de indeterminación acústico describe que cuanto más veloces sean los cambios en intensidad, menor será la definición de la altura tonal. ${ }^{280}$ En otras palabras, el ataque virtualmente instantáneo de los eventos vibratorios que darán origen a sonidos percusivos determina la ocurrencia (en dicha fase de la envolvente de intensidad) de componentes de banda ancha, incluso en regiones sub-sónicas del espectro de frecuencias. Escúchese por ejemplo la pieza 10000 horses can't be wrong del duo británico Simian Mobile Disco, pieza donde esta cualidad (y varios aspectos de las próximas repetitividad e iteratividad) pueden apreciarse claramente expuestos. ${ }^{281}$

Contener en un mismo instante mayor cantidad de componentes, distribuidos en diferentes regiones del espectro, permite que estas vibraciones alcancen mayor presión acústica y entreguen mayores cantidades de energía en un mismo momento (el del ataque). Requiriéndose altas presiones acústicas para la generación de sensación táctil, esta capacidad se vuelve central y quizá uno de los factores principales para la presencia mayoritaria de este tipo de envolventes de intensidad en la especie.

Procurando evitar interpretaciones erróneas, explicitamos que es usual en las músicas electrónicas utilizadas para el baile social (hasta ser casi un lugar común) la variación basada en cambios paulatinos entre articulaciones staccato-legato y entre ataques impulsivos-paulatinos por manipulación de los parámetros de la envolvente de intensidad (recordamos: ataque, decaimiento, sostenimiento y liberación) que la mayoría de los sintetizadores suministra entre sus capacidades de control.

Así también, es usual encontrar ciertos comportamientos de oposición o complementariedad entre estratos texturales compuestos de sonidos percusivos y otros que independientemente de que su ataque sea impulsivo o paulatino- presentan articulación legato

\footnotetext{
${ }^{279}$ Valga decir que el autor considera muy importante esta cualidad. Dedicará un espacio considerable a explicar diferentes técnicas para la aplicación de compresión y compuertas de ruido que reduzcan o eliminen por completo las "colas" de los sonidos, de reverberancias y otros, procurando que dichos finales de los sonidos no se superpongan con el ataque que los sucede.

${ }^{280}$ Para más detalles véase el Glosario y Basso, G. (1999). El principio de indeterminación en acústica musical.

${ }^{281}$ Simian Mobile Disco - 10000 horses can't be wrong. (2009). Subido por SMDTV. Accesible en línea en https://youtu.be/Ko5ryBx65ZM [23072016]
} 
y/o sonidos con sostenimiento. Características (todas) que suelen describirse como pertenecientes a la esfera del timbre, repercuten como vemos en ritmo, textura y en la generación de sensación táctil.

\section{Reiteratividad}

Esta no es la primera ni será la última vez que nos refiramos a las numerosas formas y niveles en que la repetición se hace presente en la especie. Habiendo tratado ya la importancia central de esta cualidad, como también algunas de las razones que podrían explicar su proliferación en la música electrónica de baile, recorreremos aquí las formas en que se manifiesta en la sonoridad, en el marco de la vinculación con ritmo, textura y timbre que enunciáramos previamente. Sin pretender exhaustividad, procuraremos aportar algunos datos extra a los ya vertidos en títulos precedentes.

No cabe duda de que existe -entre los productores de la electrónica- un interés especial por establecer pulsaciones regulares reiteradas sostenidas en el tiempo. Aún en aquellas piezas donde el índice experimental presenta fuerte incidencia sobre el ritmo, batimentos y modulaciones promueven la generación de regularidades y cuasi-pulsaciones. A veces métricamente coincidentes, otras generando polimetrías, $\mathrm{u}$ otras presentando batimentos que conviven desfasados por extensos períodos, en numerosos casos las músicas electrónicas utilizadas para el baile social se componen de lo que podemos denominar "distribuciones isócronas o casi-isócronas de la energía acústica". A modo de ejemplo, escúchense las numerosas y diversas pulsaciones que sostienen e impulsan el desarrollo de la pieza Out of control de los popularmente masivos The Chemical Brothers. ${ }^{282}$

Muchas razones podrían explicar este interés de los productores; de entre las estrictamente técnicas que posiblemente lo promovieran, podemos mencionar aquí los modos que utilizan los históricos secuenciadores por pasos analógicos para estructurar los puntos de ataque y ritmos posibles. ${ }^{283}$ De cualquier modo, independientemente de las razones que impulsaran su proliferación, encontramos en las conformaciones generadas a partir de estos dispositivos una posible herramienta para ejemplificar la repetición que se manifiesta en sonoridad.

Los secuenciadores por pasos han sido (y son) utilizados para la generación de líneas de bajos, rellenos armónicos, líneas melódicas "lideres" y otras conformaciones del estilo. Impulsados quizá por el hecho de que los primeros sintetizadores eran dispositivos monofónicos, la generación de secuencias de ataques de duraciones breves fue la forma que muchos productores y músicos electrónicos encontraron en el período fundacional para

\footnotetext{
${ }^{282}$ The Chemical Brothers - Out Of Control. (1999). Subido por Astralwerk. Accesible en línea en https://youtu.be/6sOpbRL8R4g [23072016]

${ }^{283}$ Véase para más datos el Anexo V. Dispositivos tecnológicos asociados a las músicas electrónicas utilizadas para el baile social.
} 
establecer campos interválicos o para conformar -en el mismo período de tiempo- más de uno de los estratos texturales mencionados (i.e.: lo que se conoce en el entorno académico como "polifonía virtual"). Este uso persiste aún hoy, transformado en una cualidad identitaria de la especie. Nos interesa especialmente aquí de los secuenciadores por pasos dos de sus cualidades:

a) que estructuran los puntos de ataque posibles a partir del establecimiento de una unidad isócrona y

b) que, una vez recorrida por completo la secuencia de ataques, el dispositivo recomienza la misma desde el principio. ${ }^{284}$

De entre las diferentes texturas posibles de configurar a partir de las variables mencionadas, analizaremos aquellas donde el secuenciador ha sido programado para articular todos y cada uno de los puntos de ataque disponibles en su grilla. Situación muy común en la especie, ocurre por ejemplo cuando se les asigna el control de un sintetizador que cumplirá la función textural de relleno armónico arpegiado o en algunas líneas de bajos.

En esta situación paradigmática acaecen dos regularidades en dos niveles diferentes de la organización musical: la primera se ubica en lo que podemos denominar nivel de pulso/de la (sub-) división y resulta en un tren de impulsos breves; la segunda, ubicada en lo que podemos llamar nivel de (meta-)compás, consiste en una estructuración de período mayor al anterior y múltiplo de aquel. ${ }^{285}$

En el ejemplo (hipotético) propuesto, a nivel de pulso/de la (sub-)división, se establece una distribución isócrona de la energía que en numerosos casos puede considerarse incluso como una oscilación compleja de baja frecuencia. En esta serie continuada y sostenida de ataques breves, isócronos y usualmente percusivos, la textura aporta a la sonoridad (energía acústica), a la rítmica (regularidad) y a la tímbrica (componentes de banda ancha).

El aporte concreto a la sonoridad sobre el que pretendemos llamar la atención es precisamente el que realizan los transitorios de ataque. Así la secuencia se constituya de alturas iguales o diferentes, los transitorios de ataque de banda ancha -como viéramos, propios de los sonidos percusivos- suman complejidad al timbre resultante incluso en registros diferentes al de las alturas percibidas. Consecuentemente, suman a la sonoridad total más cantidad de energía acústica de la que aportarían si no contuvieran los mencionados transitorios de ataque. Por otra

\footnotetext{
${ }^{284}$ No tendremos en cuenta en el análisis de este punto la reproducción con orden azaroso que algunos modelos de secuenciadores posibilitan. Sin embargo y como veremos luego, en muchas ocasiones esta capacidad no tendrá una incidencia sustancial sobre el efecto generado, por lo que los argumentos a exponer mantendrán su validez.

${ }^{285}$ Como podrá suponerse, utilizamos estas denominaciones por analogía con las herramientas métricas. Cada nivel ocurrirá aproximadamente en la escala respectiva de las unidades métricas mencionadas e incluso, no pocas veces, los valores duracionales descriptos serán coincidentes con estas.
} 
parte, por tratarse de sonidos percusivos, luego de cada ataque dicha energía decrece hasta nada o cero, provocando el contraste (y recorrido del cono del parlante) que antes describiéramos.

Estos componentes de altura indeterminada conforman una regularidad y repetición efectiva que pasa desapercibida si focalizamos la atención sobre el cuerpo de dichos sonidos (donde, como dijéramos, pueden presentarse variaciones de altura). ${ }^{286}$ Suponiendo que cada ataque acontezca a un período igual a semicorcheas a tempo 120 (conformaciones usuales en la especie), en la repetición de estos componentes de altura tonal no definida (repetición que ocurre por la articulación de todos y cada uno de los puntos de ataque disponibles en la grilla del secuenciador) se configura una vibración de baja frecuencia de período igual a $8 \mathrm{~Hz}$.

Quizá por tratarse de vibraciones sub-sónicas, los componentes que acabamos de describir no han sido considerados usualmente en tanto frecuencias presentes en la música ni por la ciencia acústica tradicional ni en análisis musicológicos. Sin embargo, frecuencias en este rango han sido documentadas por Kogan Musso como generadoras de sensación táctil en la pared abdominal, tórax, abdomen, tabique nasal, pecho y garganta. ${ }^{287} \mathrm{Si}$ bien los documentos indican (al menos en principio) mayores intensidades que las registradas en nuestras experiencias de campo, los componentes de este elemento tímbrico-textural (y la vibración de baja frecuencia en particular) contribuyen sin lugar a dudas a la sensación táctil general provocada por la música en su totalidad.

Creemos no equivocarnos al decir que estas vibraciones son de una cualidad diferente de las que tradicionalmente han sido descriptas como conformando sonidos "musicales". En cierto sentido podemos hablar de vibraciones "fantasmas", de "perfiles" o "siluetas" de ondas cuyas vibraciones no se componen de vibraciones propias sino que toman prestada la energía acústica de vibraciones originadas en otras fuentes. Conformadas por el perfil o envolvente de intensidad que resulta de la interacción de uno o varios elementos constituyentes de la textura,

\footnotetext{
${ }^{286}$ Por supuesto, los componentes de los transitorios de ataque no son completamente independientes de la frecuencia del cuerpo de cada evento y esta no puede ser ignorada por completo. Sin embargo, en experiencias realizadas ad hoc comprobamos la validez de nuestras descripciones al aplicar modulación sobre la intensidad (estable) de, alternativamente, oscilaciones de baja, media y alta frecuencia. Una onda senoidal resultó transformada en una forma de onda compleja y con otros componentes espectrales al ser modulada su intensidad por una onda cuadrada. Alternativamente también realizamos la experiencia con una onda en dientes de sierra, obteniendo resultados generales equivalentes (con las variantes esperables por el cambio en la forma de onda del modulador). Comprobamos allí que frecuencia y forma de onda de la oscilación "base" resultan factores en algún sentido secundarios, ya que su influencia sobre la oscilación resultante termina siendo en cierto grado lateral. En otras palabras, si bien la frecuencia y la forma de onda de la onda "base" repercute en la forma de onda y espectro de frecuencias resultante, mucho mayor es la gravitación de la envolvente de intensidad reiterada que expresa el modulador en su propia forma de onda. Esto sucede precisamente debido a la influencia del principio de incertidumbre acústico. Presentando igual frecuencia y polaridad tanto la onda senoidal modulada como la onda cuadrada, y esta última iniciando su ciclo retrasada (en relación a la senoidal) en un cuarto de ciclo: por el principio de incertidumbre acústico, en cada cambio repentino de la intensidad de la onda cuadrada ocurrirá un brevísimo instante de ruido de altura tonal no definida y registro usualmente grave y/o subgrave. Si bien algo persiste de la onda senoidal en el timbre, la forma de onda y espectro de frecuencias resultante se ve enriquecido y su componente espectral (inicialmente única) resulta acompañada de una iteración en registros donde antes no hubo nada.

${ }^{287}$ Kogan Musso, P. Op. cit. 2004. pp.105-6
} 
denominaremos a estas vibraciones con el nombre de oscilaciones/alternancias de intensidad y las incluiremos en la categoría de oscilaciones de segundo orden; categoría que describiremos en detalle en Iteratividad, título inmediato posterior.

Creemos que aquí puede comprenderse mejor la importancia que asume la repetición en la especie. Solo a partir de la reiteración de las formas acústicas breves que describiéramos -y de la cual los trenes de impulsos originados en los secuenciadores son apenas un ejemplo- los cambios de intensidad describen oscilaciones/alternancias. La repetición resulta esencial para que la intensidad describa rápidas alternancias entre momentos de mínima y máxima presión acústica y así se constituyan oscilaciones/alternancias de intensidad. Cuando la música no presenta repeticiones los cambios describirán apenas la evolución de esta cualidad (i.e.: la sonoridad) en el tiempo.

En estas mismas razones podemos encontrar un justificativo extra para la preeminencia en la especie de rítmicas binarias. ${ }^{288} \mathrm{Si}$ lo que se procura es el establecimiento de una alternancia en dos fases de período igual -tal cual sucede con las fases positiva y negativa de las oscilaciones que originan sonido-, compases de tres tiempos, con división ternaria o (de modo más abarcativo) de duración desigual incidirán de forma negativa y en detrimento del efecto buscado.

Aquí también puede apreciarse la relevancia de los sonidos percusivos. Esta cualidad de los eventos sonoros toma mayor importancia al considerar que sus envolventes de intensidad (a escala micro) son en parte las responsables de que las oscilaciones/alternancias de intensidad (i.e.: envolventes de intensidad percusivas reiteradas a escala media) acontezcan efectivamente. Sin los rápidos ascensos y descensos en la intensidad que este tipo de sonidos permite resulta imposible que la intensidad general de la pieza musical oscile/alterne.

Arribamos así a una posible respuesta que podría explicar parcialmente porqué en la comunidad electrónica se detecta una mayor cantidad de testimonios refiriendo a sensación táctil:

En interacción estrecha con las envolventes de intensidad y otras cualidades propias de cada evento sonoro (como por ejemplo, frecuencia y timbre), las oscilaciones/alternancias de intensidad facilitan y maximizan la generación de sensación táctil al aportar un componente vibratorio extra, ausente en otras músicas.

Para el cumplimiento efectivo de nuestro último enunciado es deseable la coincidencia o sincronía entre las envolventes de intensidad en los diferentes niveles. Las

\footnotetext{
${ }^{288}$ No referimos aquí a la cualidad de la división sino a la conformación en general de agrupamientos en dos partes.
} 
oscilaciones/alternancias de intensidad presentarán un rango dinámico mayor solo cuando los niveles máximos (y mínimos) de intensidad ocurran en el mismo momento en todos los elementos de la textura; como en cualquier fenómeno vibratorio, si un elemento presenta su pico máximo mientras otro describe su valle, sus diferentes intensidades se cancelarán, al menos parcialmente. Esto no significa que todos los componentes texturales deban describir los mismos ritmo y duración; si bien este sería el caso ("científico") ideal, la coincidencia necesaria debe darse principalmente entre sus puntos de ataque (instante en que ocurre el mayor ancho de banda). En casos donde coexistan eventos de duraciones desiguales, en sus puntos de ataque coincidentes (es altamente probable que) acontezcan acentos. ${ }^{289}$

Aquí nuevamente surge otra razón posible para explicar por qué la mayor cantidad de testimonios refiriendo a sensación táctil se presentan en las músicas electrónicas utilizadas para el baile social:

A diferencia de otras músicas, en las electrónicas utilizadas para el baile social es posible controlar en extremo las fases de las oscilaciones, permitiendo maximizar la intensidad de los eventos hasta el nivel micro del timbre y la frecuencia.

De desearlo el productor, en los modernos editores de sonido podrá ampliar la representación gráfica de la forma de onda grabada, desplazarla y/o invertir su fase hasta hacerla coincidir con las demás con una precisión mayor a la milésima de segundo. Práctica común en los estudios cuando se mezcla un mismo instrumento grabado con más de un micrófono, es también un proceso aplicable en este caso.

Las oscilaciones/alternancias de intensidad y la sincronía entre envolventes de intensidad se encuentran en la especie de diversas formas. Así puede comprenderse el patrón de bombo en negras, ciertas conformaciones propias del trance (caracterizadas por breves ataques sucesivos de sonidos graves sobre una misma nota), los ataques a contratiempo del sonido de bajo en este mismo índice (con el bombo articulando en las partes fuertes de cada tiempo), el efecto de "bombeo" que la aplicación de compresión por cadena lateral (conducida por el sonido de bombo) provoca sobre todos o casi todos los demás componentes de la textura

\footnotetext{
${ }^{289}$ Si bien está llena de ejemplos al respecto de este tema, hacia aproximadamente los 3'38" de Out of control (la pieza de The Chemical Brothers mencionada en párrafos previos) ingresa una secuencia que, aún siendo muy similar a otras que la preceden, presenta todas las características que hemos descripto. A partir de ese momento la oscilación/alternancia de intensidad -presente en mayor o menor medida durante toda la pieza- se hace más evidente. Segundos antes del final (aproximadamente a los 4') numerosos elementos texturales se silencian, dejando expuestos varios componentes que describen ritmos de semicorcheas. A un tempo aproximado de 133 pulsos por minuto, dichos ritmos configuran una oscilación/alternancia de intensidad de casi $9 \mathrm{~Hz}(8.86 \mathrm{~Hz})$.
} 
(proceso común a varios índices en la especie), ${ }^{290}$ el patrón "PoumTchak" que veremos en títulos por venir y, en general, todas aquellas alternancias que generan un efecto masivo sobre la intensidad de la forma de onda compleja conformada por la música toda.

También encontramos aquí una posible explicación para el ritmo primordialmente tético del índice hardcore: si la intención del mismo es presentar un carácter agresivo, la mejor opción es sincronizar la mayoría de los ataques y el inicio de las envolventes de intensidad de diferentes niveles; de esta manera se maximiza la presión acústica total al concentrarla en sucesivos instantes únicos (coincidentes con cada ataque homorrítmico), los cuales -consecuentemente- se alternarán con momentos de muy baja presión acústica (en los períodos inter-ataques).

En esta homorritmia -que usualmente describen en este índice elementos texturales segregables y ubicados en registros diferenciados- encontramos un ejemplo (entre muchos posibles) donde puede apreciarse la integración de textura y ritmo a la que hemos referido en varias ocasiones durante este título. La forma de onda oscilando en el aire (el fenómeno resultante de la interacción de todos los elementos presentes en un determinado fragmento) puede comprenderse como la manifestación de lo que podemos llamar la textura total (o timbre total, ritmo total): aquella se configura como un acontecer acústico complejo y en constante y continuo cambio que, momento a momento, presenta cualidades que derivan de la interacción íntima entre la envolvente de intensidad (también "total", emergente de la evolución de la sonoridad de todos los sonidos presentes) y el espectro de frecuencias (como antes, "total", explicitando la composición en frecuencias con que se alcanza cada nivel de sonoridad momento a momento). Herencia conceptual del espectralismo, este acontecer acústico complejo puede comprenderse (en el marco que presentamos) como sinónimo de textura en su desarrollo temporal. Buscando ayudar a la comprensión de una descripción tan acotada agregaremos que este acontecer es el que resulta representado en los espectrogramas (especialmente los tridimensionales). Como describiéramos, estas representaciones permiten la visualización de la evolución temporal de la sonoridad de cada zona de frecuencias. ${ }^{291}$

Como puede suponerse, las variables involucradas en el acontecer del timbre total o textura total son numerosas, y los valores que cada una puede asumir tan grandes como las combinaciones musicales posibles. Procurando darle alguna finalización y tomando lo que

\footnotetext{
${ }^{290}$ La compresión por cadena lateral -según el caso por nosotros descripto- genera que la intensidad de los demás componentes de la textura decrezca cada vez que suena el bombo (de allí que se dirá que la compresión es "conducida" por este sonido). Este decrecimiento y crecimiento alternado de la intensidad suele describirse como "bombeo" (i.e.: de bomba de presión) y es lo que, en nuestros términos y en esta conformación particular, constituye uno de los componentes de la oscilación/alternancia de intensidad (el otro es la ocurrencia misma del bombo).

${ }^{291}$ Como puede apreciarse, esta integración de dimensiones musicales presenta un elevado grado de complejidad. Siendo una concepción que se evidencia muy extendida entre los productores dedicados a la especie, su tratamiento no solo nos resulta ineludible sino que en breve nos será de gran utilidad como herramienta para la descripción de algunos fenómenos. La exposición que realizáramos considérese entonces apenas una introducción de una perspectiva espectral que desarrollaremos paulatinamente en varias secciones por venir.
} 
apreciáramos en los últimos párrafos, retornaremos a nuestro ejemplo sencillo basado en los secuenciadores por pasos para agregar que este fenómeno se complejiza al poner en consideración los diferentes cambios de registros y/o timbres que pudieran incluirse en la secuencia de ataques. Con la reiteración de dichos registros y/o timbres en períodos fijos se configura otra vinculación entre ritmo y textura, esta vez a nivel de (meta-)compás.

Ocurre a nivel de (meta-)compás una simple estructuración periódica que puede asociarse al concepto de (semi-)frase. Con cada ciclo cumplido de la secuencia y en su reiteración, se confirma un período de recurrencia mayor al presentado en párrafos previos, asimilable al que describen los tradicionales compases o meta-compases (a veces menos, según la extensión concreta de la secuencia).

Dependiendo de la conformación interna de la secuencia de ataques -específicamente de la distribución de alturas, registros y timbres- pueden suceder una o varias acentuaciones o jerarquizaciones a su interior. Estas jerarquizaciones pueden derivar a su vez en la conformación de:

a) uno o varios estratos texturales $y / o$

b) pulsaciones u oscilaciones/alternancias de intensidad de nivel intermedio. ${ }^{292}$

La configuración concreta que derive de este conjunto de cualidades será en definitiva lo que permitirá la detección de la recurrencia a nivel de (meta-)compás. Dicha recurrencia, en numerosas piezas de la especie, se manifiesta en la oscilación/alternancia de intensidad otorgándole cualidades que se reiteran en períodos temporales más extensos que el establecido a nivel de pulso/de la (sub-)división. De hecho, lo que en general ocurre en la especie es que como toda oscilación compleja- la oscilación/alternancia de intensidad -que llamaremos "de nivel superior" por presentar un período mayor- puede descomponerse para su análisis en diferentes oscilaciones/alternancias de intensidad simultáneas donde aquellas de mayor período resultan múltiplos de las más breves. Especularmente, otra forma de enunciar esta misma cualidad es diciendo que: variaciones periódicas en ciertas cualidades de las oscilaciones/alternancias de intensidad de período menor configuran oscilaciones/alternancias de intensidad de mayor período.

Creemos aquí oportuno realizar una breve aclaración: independientemente de las formas sintácticas que utilizáramos en un momento u otro para explicar el concepto, consideramos que:

\footnotetext{
${ }^{292}$ Supóngase a modo de ejemplo una secuencia que alterna, ataque a ataque, entre dos registros distantes. Esto puede resultar en el establecimiento de dos estratos texturales "virtuales" y dos pulsaciones (simultáneas y alternadas) de período igual al doble de la duración que el secuenciador utiliza como valor unidad.
} 
la oscilación/alternancia de intensidad es -en y para cada pieza concreta- una única onda compleja que, de modo simultáneo, describe múltiples períodos de oscilación.

A modo de ejemplo, en la oscilación/alternancia de intensidad de Out of control encontramos oscilaciones de período igual a:

a) la subdivisión: esencialmente descripta en cada uno de los ataques del sonido de bajo, por momentos otros elementos (compuestos por sonidos percusivos) se suman a describirla en registros más agudos.

b) la división (quizá la oscilación más débil): establecida principalmente en la interacción entre bombo y hi-hat, ${ }^{293}$ una sutil articulación/acentuación en el bajo parece también incidir en su establecimiento.

c) el pulso: explícitamente configurado por el bombo.

d) dos pulsos: con una relevancia secundaria similar a la de la división, se configura principalmente a partir de la alternancia entre los ataques de bombo y los de bombo+redoblante. En algunas secciones otros elementos contribuyen a su demarcación, aunque su incidencia sobre la oscilación/alternancia de intensidad es despreciable.

e) el compás: el sonido de bajo (aquí en su secuencia completa) es el que describe más claramente este nivel de la oscilación/alternancia de intensidad. De cualquier modo, aquí coinciden también el reinicio de los diferentes ciclos previamente descriptos.

Como puede apreciarse en el ejemplo previo, cada nivel de la oscilación/alternancia de intensidad puede presentar diferentes grados de relevancia. Para una mejor comprensión por oposición, compárese este ejemplo con el tema Setting Sun, del mismo artista. ${ }^{294}$ Obsérvese cuan diferente es en esta pieza la relevancia relativa que asume cada nivel de la oscilación/alternancia de intensidad. Cualidades derivadas principalmente de cuestiones registrales y duracionales (grave, largo y sostenido opuesto a agudo, corto, iterado y repetido), la oscilación/alternancia de intensidad establece un perfil muy claro sobre el nivel de (meta-) compás, resultando en una gran debilidad relativa de los demás niveles. Configurando una cadencia musical de cualidades diferenciadas respecto de Out of Control, luego de la

\footnotetext{
${ }^{293}$ Conscientes de que los individuos no iniciados en músicas electrónicas utilizadas para el baile social pueden no encontrar razones para el establecimiento de esta vinculación, preferimos anticipar que esta interacción prolifera en la especie permeando todos los índices casi sin excepción. Precisamente es esta la unidad a la que (como trataremos luego) Zeiner-Henriksen convertirá en su objeto de estudio y denominará el patrón "PoumTchak".

${ }^{294}$ The Chemical Brothers - Setting Sun. (1996). Subido por Astralwerk. Accesible en línea en https://youtu.be/p5NX1FC-7-w [25072016]
} 
presentación del sonido de bajo al inicio de cada compás es quizá la sección rítmica (y en particular el sonido de bombo) el elemento textural que imprime relieve -en algún grado significativo- en la oscilación/alternancia de intensidad.

Los períodos mayores al nivel de pulso/de la (sub-)división suelen manifestarse en la oscilación/alternancia de intensidad describiendo mayores recorridos de intensidad (i.e.: presentan mayores ascensos y descensos de intensidad). Esta mayor diferencia entre máximos y mínimos (recordamos, diferencia que suele describirse mediante el concepto de rango dinámico) se logra mediante:

a) ataques con mayor sonoridad máxima resultante y/o

b) por diferentes niveles de sonoridad mínima en los períodos inter-ataques.

Los primeros se pueden obtener mediante énfasis de sonoridad (i.e.: énfasis por acentos) o por la convergencia de ataques simultáneos en varios estratos texturales (i.e.: énfasis por instrumentación). El nivel concreto de los segundos dependerá, entre otros, de:

a) la presencia de resonancias de sonidos largos previamente atacados,

b) la presencia de reverberación u otras resonancias derivadas de la aplicación de efectos a los sonidos,

c) la ocurrencia de ataques en elementos o estratos texturales secundarios (i.e.: elementos que, por sus cualidades, provocan baja incidencia sobre la oscilación/alternancia de intensidad),

d) el acontecimiento de "ataques" derivados de la aplicación del efecto de retardo (i.e.: el efecto de "delay" o eco) y/o

e) el mayor o menor impacto de la aplicación de compresión o compuerta de ruido ${ }^{295}$ sobre las "colas" de todo evento sonoro posible (impacto derivado del grado más o menos extremo en que se configuren las variables de dichas herramientas).

De la interacción de esta multiplicidad de factores (entre muchos otros) derivará el perfil último que describirá la oscilación/alternancia de intensidad a nivel de (meta-)compás. Dicho perfil repercutirá a su vez sobre la eficacia de la oscilación/alternancia de intensidad para la generación de sensación táctil, sobre su intensidad, cualidades y distribución temporal. De estos rasgos, al menos para la especie, creemos posible extraer:

a) la cadencia de activación (la longitud y distribución de la energía musical, del impulso musical),

\footnotetext{
${ }^{295}$ Proceso que permite modificar las partes de los sonidos que presentan menor intensidad.
} 
b) el grado de incitación al movimiento (cuan estimulante resulta la pieza para bailar) y

c) los modos sugeridos para el movimiento por la pieza musical (la longitud, cualidades y distribución temporal de los movimientos de danza sugeridos).

Por supuesto no implicamos aquí una relación lineal ni normativa entre música y baile sino apenas la ocurrencia de eventos sonoros cuyas cualidades (entre muchas otras razones, por analogía con el movimiento requerido para su generación a partir de fuentes no electrónicas) parecen sugerir ciertos tipos de movimiento por sobre otros. Las cadencias, los cambios en las diferentes sensaciones de activación (musical) que diferentes secciones de una misma pieza presentan, pueden explicarse (al menos parcialmente) en las músicas electrónicas utilizadas para el baile social analizando los diferentes períodos (multinivelados) y los rangos dinámicos que en cada fragmento presenta la oscilación/alternancia de intensidad. Escúchese a este respecto los caracteres diferenciados que asume la oscilación/alternancia de intensidad en las diferentes secciones del remix realizado por Trentemoller del tema What else is there de Royksopp. ${ }^{296}$

Resulta claro aquí que, hasta cierto punto, hemos descripto las diferentes unidades métricas (o mejor dicho, la manifestación rítmica de estas unidades) desde sus cualidades asociables a la sonoridad. En algún sentido esto ocurre efectivamente así desde que en numerosos casos en la especie (dependiendo de los ritmos concretos) los diferentes niveles de la oscilación/alternancia de intensidad resultan coincidentes con dichas unidades. Esto no puede ser de otro modo desde que este fenómeno depende directamente de la distribución temporal de la energía. Sin embargo, el fenómeno complejo de la oscilación/alternancia de intensidad y su interacción con el movimiento o baile resulta mucho más rico y excede con creces una reducción tal.

Realizamos así un aporte que consiste en una herramienta posible para articular análisis musicales y de movimiento. Existiendo escasa bibliografía al respecto, lo consideramos una valiosa contribución.

\section{Iteratividad}

Hasta cierto punto, es posible describir a la música electrónica de baile como un estudio de la iteración. Esta característica y configuración se incluye a tantos niveles y en tantas formas, que veremos surgir al concepto durante la descripción de casi cada aspecto de la especie que analicemos. Íntimamente relacionada con la reiteratividad, ambas se basan en la repetición inmediata sucesiva de sonidos de cualidades idénticas o similares y (ambas) tienen en la percusividad a (al menos) una de sus condiciones de acontecimiento.

\footnotetext{
${ }^{296}$ Royksopp - What Else Is There (Trentemoller Remix) (HD). (2005). Subido por weihnachtsmann07. Accesible en línea en https://youtu.be/HT5o8s4VKXg. [26072016].
} 
Considerándolas matices del mismo fenómeno, la decisión de presentarlas desagregadas derivó más de una búsqueda de facilitar su descripción que de diferencias reales. Sin embargo, la inclusión de una al interior de la otra no resulta posible: mínimas diferencias cuantitativas provocan importantes diferencias cualitativas que las segrega mutuamente. Algunos indicios de esta vinculación -creemos- hemos dejado traslucir en fragmentos previos.

Como viéramos, en la reiteratividad el nivel inferior se corresponde aproximadamente con el pulso o la (sub-)división. En la iteración en cambio, la duración de cada uno de los eventos del tren de impulsos suele ubicarla más allá de lo cuantificable o mensurable. Al menos en principio podemos decir que, como mamushkas en relación fractal, en la música electrónica de baile la iteratividad es una versión a pequeña/mínima escala de la reiteratividad.

Sin embargo, esta afirmación pierde de vista que las mínimas diferencias cuantitativas y de grado existentes en la dimensión duracional, implican aún otra importante diferenciación cualitativa: mientras la reiteratividad se identifica como una conformación eminentemente rítmica, la iteratividad se ubica en el territorio de las cualidades tímbricas. Mientras la primera adquiere su sentido a partir de su incidencia sobre la rítmica de la pieza que la contiene, la segunda se ofrece a la misma primordialmente en tanto timbre de los sonidos que la pieza incluye. Generalmente por debajo del valor de duración de la subdivisión o en las inmediaciones de este, la iteración podrá hallarse a lo sumo en las fronteras entre lo cuantificable o mensurable de los fenómenos rítmicos y lo cualificable o "plástico", "maleable" del timbre.

Secundariamente, ambas se asocian con la dimensión textural. En la zona gris entre ambos extremos, la iteración interviene simultáneamente como un fenómeno rítmico-tímbrico que dinamiza a la primera de las dimensiones al tiempo que transforma a la segunda. Dependiendo del caso concreto, en esta región surgirá la textura como nexo entre ambas (en la acepción espectral que le diéramos supra y en íntima vinculación con el concepto de oscilación/alternancia de intensidad). Veremos esta vinculación en el análisis que incluimos debajo.

Los casos de iteratividad suelen presentar como característica extra una libertad mayor (que los de reiteratividad) respecto de la necesidad de sincronía con el tempo. Si bien las rítmicas de tiempo medido y no medido conviven en estas músicas y el tratamiento que se les aplica evidencia que sus diferencias no son consideradas generadoras de conflictos necesarios de resolver, las iteraciones suelen presentar menor vinculación con los valores regulares y el tempo que las reiteraciones. Esta mayor libertad probablemente tenga su explicación en la misma calidad micro que acabamos de describir. La identificación mayor de la reiteratividad con cualidades rítmicas (identificación derivada de que, a diferencia de la iteratividad, de esta asociación es de donde obtiene su sentido) y el hecho de que la especie se vincule con el movimiento y la danza, probablemente conduzcan a un mayor cuidado de los productores a la hora de configurar los ritmos en las reiteraciones. Por el contrario, en la determinación de los 
valores de duración de las iteraciones, probablemente se impongan criterios tímbricos y los valores finales y concretos se deriven del timbre que estos proveen. $\mathrm{Y}$ es que, como veremos, del período concreto que describe la iteración dependen los componentes espectrales que se agreguen al timbre "de base".

La iteración consiste en una oscilación de segundo orden. Mediante este último concepto referimos a:

rápidas alternancias en los valores de una o varias de las cualidades de un sonido o conjunto de sonidos. Ciertos procesos, configuraciones y/o comportamientos provocan el acontecimiento de una conformación espectral que describe cambios alternos y reiterados en alguna/s de sus variables (i.e.: frecuencia, intensidad, espectro, etc.). ${ }^{297}$

En el caso de la iteratividad que nos ocupa, dicha oscilación (como dijéramos durante nuestra descripción de la reiteratividad) consiste en rápidos ascensos y descensos en la intensidad. De modo similar a lo que mencionáramos respecto de la textura cuando tratamos la reiteratividad, en algunos casos esta oscilación coexiste con variaciones en otras cualidades (pudiendo incluso éstas originarse en aquéllas). Siendo la oscilación/alternancia de intensidad la única condición necesaria para la ocurrencia de iteratividad, la presencia de variaciones en otras cualidades del sonido no elimina a estos casos de la categoría de timbres conteniendo oscilaciones de segundo orden.

Y es que tanto textura como timbre resultan -en su raíz más básica- la descripción de la evolución temporal de la sonoridad en cada región del espectro. Desde uno y otro concepto es posible describir la importancia relativa de cada una de dichas regiones, sus cualidades y las relaciones que entre sí se establecen (propiedades usualmente asociadas al concepto de textura), como también la totalidad puede describirse en tanto evolución temporal de la intensidad de las componentes en diferentes regiones espectrales (modo en que usualmente se comprende al timbre).

Dando un paso más allá podemos incluso describir al ritmo del mismo modo: con solo considerar el instante de ocurrencia de los eventos sonoros en función de la región concreta del espectro de frecuencias en el que cada uno acontece, el ritmo se torna sinónimo de timbre y textura. Si bien pareciera que hablamos aquí de la incorporación al análisis rítmico de cualidades derivadas de la textura y del timbre -y aunque en algún sentido esto podría resultar efectivamente así- creemos que éste es simplemente uno de los niveles de análisis rítmico posibles y solo otra perspectiva de análisis de un mismo y único aspecto del fenómeno musical. En otras palabras, así como la "imagen" de una textura no se completa sin la incorporación de

\footnotetext{
${ }^{297}$ Para más datos ver el Glosario.
} 
variables duracionales, tímbricas y de otras dimensiones de análisis; así tampoco la "imagen" de un ritmo se completa sin la incorporación de cuestiones registrales, tímbricas y de otras índoles. En algún sentido, la textura se establece como el vínculo que permite enlazar a las dimensiones rítmica y tímbrica. Recíprocamente, la textura-ritmo puede comprenderse como un timbre de baja frecuencia o el timbre una textura-ritmo de alta frecuencia. $\mathrm{O}$ al menos... numerosas conformaciones y procesos aplicados denotan una concepción tal entre los artistas de las músicas electrónicas utilizadas para el baile social. ${ }^{298}$

Nos apartaremos brevemente de nuestra línea argumental principal para exponer un ejemplo que permitirá comprender con mayor claridad la íntima relación que -por intermediación de la reiteración e iteración- se establece en la especie entre las dimensiones mencionadas.

[Paréntesis analítico: Nevermind de Infected Mushrooms] ${ }^{299}$

El enorme caudal y diversidad de fenómenos que se incluyen en la pieza ofrece numerosos ejemplos de reiteraciones e iteraciones (nótese por ejemplo el rol rítmico que se le asigna a algunos casos de las últimas y como estas interactúan de igual a igual con conformaciones descriptas por la sección rítmica). De entre la inmensa cantidad de ejemplos, nos interesa aquí particularmente un fragmento de pocos segundos donde -principalmente- la sección rítmica y -secundariamente- algunos elementos de la textura experimentan un proceso de transformación cualitativa extrema: medianamente escalonada y en etapas, se desarrolla una densificación cronométrica que pone en evidencia la relación fluida que en la especie presentan ritmo, textura y timbre. Si bien consideramos que la pieza del duo israelita genera un grado relativamente bajo de sensación táctil, creemos también que la misma se constituye en un excelente ejemplo para:

a) observar la interacción entre ritmo, textura y timbre y

b) apreciar el rol central que en dichas interacciones tienen las oscilaciones/alternancias de intensidad.

El fragmento bajo análisis comienza aproximadamente a los 4'28" de iniciada la pieza y presenta una textura relativamente simple compuesta de solo dos elementos:

\footnotetext{
${ }^{298}$ Si bien hemos intentado ser lo más claros posibles, las relaciones que se establecen entre estas tres dimensiones -cada una de por sí, compleja- resultan demasiado intrincadas para ser expuestas brevemente. Creemos que sus vínculos recíprocos se comprenderán con mayor profundidad en los sucesivos tratamientos que les daremos con posterioridad (véase por ejemplo el tratamiento dado al tema en los títulos sucesivos Heterogeneidad y complementariedad. El "motor" regular y Relaciones transversales en el patrón bombo-en-negras).

${ }^{299}$ Infected Mushrooms - Army Of Mushrooms Full Album. (2012). Subido por el usuario Frank Aguilar. Accesible en línea en https://youtu.be/uloBD9xxwZ0. [11072016]
} 


\begin{abstract}
a) sección rítmica
\end{abstract}
Conformada únicamente por sonidos de bombo y redoblante, alternan inicialmente sus ataques a ritmo de blanca. En este estrato textural se desarrollará el proceso de densificación cronométrica.

b) dos sonidos de sintetizador

El primero de ellos, inicialmente cumpliendo el rol de bajo, enmascara al segundo cuya presencia se hará paulatinamente más evidente. Este último presenta características asimilables al sonido que provoca la púa sobre los discos de vinilo cuando a estos se les imprimen rápidos y alternados cambios de dirección (i.e.: técnica conocida como "scratching", es una de las formas de utilizar las bandejas tocadiscos como instrumentos musicales). Ambos timbres iterados, presentan una carga considerable de ruido en la zona aguda del espectro. Tanto el bajo (basado en la división binaria) como el sonido similar al scratching (sobre una subdivisión atresillada) describen rítmicas similares y acentuadas -respectivamente- sobre la parte fuerte del tiempo y sobre las corcheas binarias. Sus ritmos pueden resumirse esquemática y respectivamente como la repetición incansable de: bajo: $\bar{\cdots}$ / scratching: $\stackrel{3}{{ }^{-}}$

Un efecto de reverberación envuelve a ambos sonidos de sintetizador en un continuo agudo.

Este estrato textural acompañará las transformaciones de la sección rítmica con dos procesos diferentes de "agudización" de los sonidos: al bajo se le aplicará un filtro pasaaltos que paulatinamente elevará su frecuencia de corte (proceso que resulta en que solo sus componentes agudos suenen) mientras que el scratching describirá un paulatino ascenso en las frecuencias de sus componentes (solo relativa y parcialmente definidos tonalmente).

La reverberación parece recibir el mismo tratamiento por filtro pasa-altos del bajo, pero su escasa sonoridad lo ubica en un $2^{\circ}$ o $3^{\circ}$ plano sonoro, razón que nos impide asegurarlo.

La primera densificación cronométrica se produce a los 4'37" con una reducción a la mitad del período descripto por el ritmo del bombo. Esto modifica la inicial alternancia bombo - redoblante por la nueva bombo - bombo+redoblante.

A los 4'40" se inicia la tercera etapa, esta vez con un incremento en la ocurrencia tanto de bombo como de redoblante. Mientras el segundo reduce a la mitad su período, el primero describe a partir de aquí el mismo ritmo atresillado que el scratching.

Una nueva densificación en la sección rítmica ocurre a los 4'44". Durante los 4" que dura esta cuarta etapa, tanto bombo como redoblante desarrollan una veloz pulsación en semicorcheas de tresillo. Es en este momento cuando la duración de los eventos alcanza la 
frontera de lo cuantificable, y lo que era claramente ritmo resulta parcialmente cuestionado. El nuevo ritmo es acompañado además (durante toda la etapa) por un sutil incremento paulatino de la afinación en ambos sonidos-instrumentos que, creemos, anticipa lo que sucederá inmediatamente después.

La última fase del proceso se desarrolla entre los 4'48" y los (casi) 4'50" y consiste en un tren de impulsos (i.e.: sonido iterado) que asciende en el registro de alturas hasta alcanzar la zona aguda. Su iteración presenta un período estable, algo más veloz que las anteriores semicorcheas atresilladas e imposible de cuantificar a simple escucha. Conteniendo una veloz oscilación/alternancia de intensidad, el sonido se percibe como la culminación y aceleración del proceso hasta entonces descripto por la densificación cronométrica de la sección rítmica y por el ascenso en registro de los sonidos de sintetizador. Su identificación como parte de este proceso es consecuencia de que inicialmente el tren de impulsos presenta una conformación espectral (i.e.: afinación y timbres) muy similar a la que resulta de la textura inmediata anterior, ${ }^{300}$ y a que con posterioridad describe movimientos rítmico-registrales que se inscriben en la misma dirección que los presentados en las etapas previas.

Con un coeficiente de cambio próximo al de una curva logarítmica, el pasaje completo transforma cualidades tradicionalmente rítmicas y texturales en tímbricas. En poco menos de 22" evidencia la relación fluida que existe en la especie entre estas dimensiones sonoras. Ofreciéndose apenas como un ejemplo breve y simple, abre a la exploración y experimentación las fronteras comunes de cualidades otrora concebidas como compartimentos estancos.

En subsiguientes títulos y secciones, continuaremos el tratamiento de diferentes aspectos de esta relación; retomamos ahora nuestra línea argumental principal.

[Fin del paréntesis]

Los veloces cambios de intensidad que constituyen las iteraciones -potencialmente tan pronunciados como los de la reiteratividad- conllevan, como aquellos, la emergencia de transitorios de ataque en regiones del espectro que (al menos parcialmente) no se corresponden

\footnotetext{
${ }^{300}$ Recuérdese que la textura inmediata anterior establece un casi-timbre conformado por el tren de impulsos en semicorcheas de tresillo. Si bien pueden identificarse diferencias tímbricas a partir de escuchas reiteradas, el grado elevado de similitud y la velocidad de los cambios generan una continuidad tal que hacen virtualmente imposible la detección a primera escucha de las diferencias mencionadas. Podemos suponer que la creación de esta etapa particular del proceso involucró una técnica conocida como "resampling" (o "re-muestreo"): técnica que consiste en transformar a un conjunto de fuentes sonoras diversas en un archivo de audio digital único. Contar con la totalidad del material en un único archivo habilita a manipulaciones que de otro modo resultan (al menos hoy) imposibles. Creemos detectar en este caso concreto la aplicación del proceso de "pitch bending"; proceso que permite la modificación paulatina de la afinación (i.e.: glissandos) y que, como mencionáramos, ocurre durante las dos últimas etapas de la transformación analizada (aplicado respectivamente en cada etapa, de manera sutil y extrema).
} 
con el registro de la altura tonal perceptible en el cuerpo del sonido. ${ }^{301}$ Aunque dependiente de múltiples factores, esta propiedad acarrea la posibilidad de que sonidos que se ubican en los registros medio, agudo o sobreagudo presenten componentes en la zona grave o (incluso) subsónica del espectro de frecuencias. Escúchese a modo de ejemplo la segunda mitad de Raise your weapon de deadmau $5 .^{302}$ Nótese la interacción entre la iteración, los sonidos en registros graves y las componentes graves de las iteraciones de sonidos ubicados en registros medios/medio-agudos; nótese también que, a partir de la presencia de iteración, los últimos aparentan ubicarse en registros más graves. ${ }^{303}$

Usualmente vistas en tanto iteraciones o variaciones de su intensidad, los mencionados efectos de las oscilaciones de segundo orden -y más específicamente, de las oscilaciones/alternancias de intensidad- han pasado desapercibidos en los análisis musicales. Focalizada la atención sobre otras propiedades, la distorsión provocada por las perspectivas tradicionales generó su invisibilización. En síntesis, lo que pretendemos significar y poner sobre relieve es que: aún cuando las frecuencias graves han sido identificadas como las principales generadoras de sensación táctil,

elementos texturales en el registro medio, agudo y sobreagudo, interpretados con timbres que presentan ciertos tipos de iteración, propician la generación de/generan sensación táctil a partir de componentes graves/sub-graves derivados de la ocurrencia de oscilaciones/alternancias de intensidad.

Presentado el marco teórico que consideramos apropiado para analizar y comprender este fenómeno, exponemos a continuación contextos en los que ocurren iteraciones del tipo mencionado. Siendo los casos posibles virtualmente infinitos, presentamos de modo genérico aquellos que consideramos principales:

a.- Iteración en el timbre

La iteración en el timbre ocurre, según el caso, en oscilaciones de primer orden que conforman un sonido, en oscilaciones de segundo orden que modulan a las primeras o en ambas.

\footnotetext{
301 Esto es, por supuesto, en sonidos donde sus timbres definen la altura tonal.

302 deadmau5 - Raise Your Weapon. (2010). Subido por Ultra Music. Accesible en línea en https://youtu.be/YnwfTHpnGLY. [26072016]

${ }^{303}$ Este efecto de reducción de la frecuencia es posible de replicar en instrumentos de cuerda frotada mediante la aplicación de mayor presión del arco sobre la cuerda. Dada una determinada presión, el arco detiene la vibración de la cuerda, permitiéndole oscilar en uno de cada dos ciclos y, consecuentemente, generando una frecuencia resultante que se percibe una octava por debajo de la nota -digitada- que se obtiene con presión de arco normal. El mismo efecto hemos conseguido en sintetizadores mediante la aplicación de modulación de intensidad, donde el modulador presenta una frecuencia igual a la mitad de la frecuencia de la onda portadora. Para más detalles véase Modulación (de intensidad) en el Glosario.
} 
i.- Formas de onda

Muchas de las formas de onda utilizadas por los sintetizadores al alcanzar el registro grave se vuelven trenes de impulsos. Las mismas pueden utilizarse tal y como se presentan o, dependiendo de las prestaciones de cada dispositivo, aprovecharse para incidir sobre otras oscilaciones, aportando su iteración. Numerosos sonidos incluidos en los ejemplos musicales citados presentan esta característica. Véase como ejemplo el video demostración ARP 2600 demo by audio Visual Algebra. A partir de los 3'25" puede escucharse un barrido de frecuencias grave-agudo de una onda cuadrada en el legendario sintetizador ARP $26000^{304}$

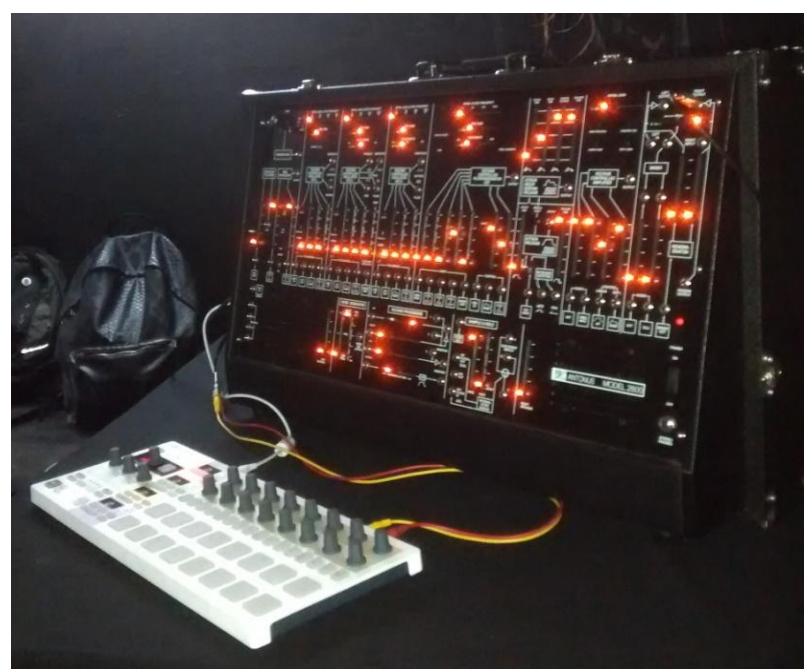

Antonus 2600. Réplica del ARP 2600 fabricada por Antonio Gutierrez. Acompañado del secuenciador Arturia Beatstep, se muestra tal como se lo presentara durante el II Encuentro de Armado de Sintetizadores $y$ otras demencias. Buenos Aires, julio 2016. ${ }^{305}$

\section{ii.- Modulación}

Diferentes métodos de modulación repercuten sobre las formas de onda de maneras que resultan en oscilaciones/alternancias de intensidad. Así sucede -por supuesto- con la modulación de intensidad, como también con la modulación en anillo y la modulación de frecuencia. ${ }^{306}$ En el último caso, dependiendo de

${ }^{304}$ ARP 2600 demo by audio Visual Algebra. (2013). Subido por avalgebra's channel. Accesible en línea en https://youtu.be/iGA86VkFL4Y. [31072016]

305 II Encuentro de Armado de Sintetizadores y otras demencias. Realizado el 28 de julio de 2016 en Espacio Cultural Mi Casa, convocó a diversos fabricantes de dispositivos de la Argentina. Otros datos de los mismos pueden consultarse en el "evento" de la red social facebook. Accesible en https://www.facebook.com/events/1408399509461547/. [31072016]

${ }^{306}$ Simples y breves explicaciones de cada tipo de modulación -incluyendo las lógicas de funcionamiento en la síntesis sonora- pueden consultarse en Gómez Gutierrez, E. Síntesis por modulación (2009). En línea. Accesible en http://www.dtic.upf.edu/ egomez/teaching/sintesi/SPS1/Tema6-Modulacion.pdf [27072016] 
diversos factores, el sonido resultante puede presentar cambios u oscilaciones muy acusadas en su frecuencia, permitiendo originar aquellos sonidos que suelen describirse como "burbujeantes" (por analogía con el sonido producido por burbujas al alcanzar la superficie del agua). Creemos no equivocarnos al decir que tanto la iteración del scratching como la del sonido de la última etapa del proceso analizado en la pieza Nevermind de Infecter Mushrooms, se lograron mediante modulación de frecuencia.

iii.- Batimentos y sonidos diferenciales

Mínimas diferencias de afinación entre dos oscilaciones producen batimentos de frecuencia igual a la diferencia mencionada. ${ }^{307}$ Dependiendo del valor diferencial concreto, dichas oscilaciones pueden presentar características de tren de impulsos. Fenómeno idéntico al que sucede en el entorno no-electrónico entre (por ejemplo) dos flautas, también ha sido detectado al interpretar simultáneamente dos notas con timbres a los que se les ha aplicado intermodulación (i.e.: modulación en anillo) en sintetizadores duofónicos (en concreto, en la edición moderna del legendario sintetizador ARP Odyssey de 1972 recreado por la fábrica Korg en 2015). ${ }^{308}$

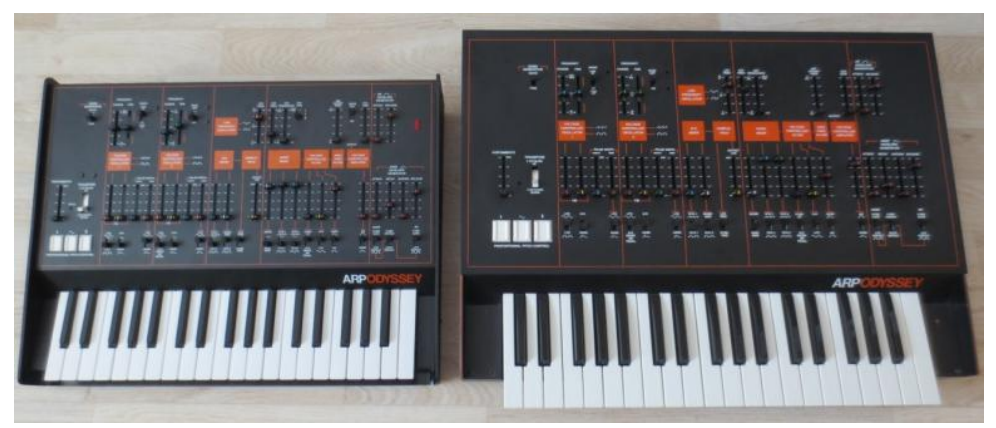

El sintetizador ARP Odyssey (der.) y la reedición de la firma Korg (izq.). Nótese la reducción de tamaño en la versión moderna.

b.- Iteración en el ritmo

Ubicándose en la frontera entre la reiteración y la iteración, la repetición de sonidos en valores extremadamente breves se establece como el nexo entre ritmo y textura. Dependiendo de los valores de duración concretos (i.e.: del período de cada impulso en el tren de impulsos que en última instancia se constituye), conformaciones sonoras de este tipo pueden establecerse también como nexo entre ritmo y timbre. Los dispositivos tecnológicos musicales han abierto la posibilidad de que una reiteración paulatinamente acelerada de sonidos idénticos -o describiendo transformaciónes paulatinas en otras de

\footnotetext{
${ }^{307}$ Como la palabra lo dice, se escucha un "batir" u oscilación.

${ }^{308}$ El desarrollo moderno, como también una breve historia de los sintetizadores ARP, puede consultarse en línea (en inglés) accediendo a http://www.arpsynth.com/en/about/. [28072016]
} 
sus cualidades en un grado que permita la asociación de cada evento con los inmediatos previo y posterior- conduzca, a modo de ejemplo, a que una textura completa de sonidos de batería se reconvierta en el timbre de un sonido con altura tonal definida que describe una melodía. Pudimos apreciar un caso del estilo durante el análisis del fragmento de la pieza Nevermind.

c.- Iteración presente en la fuente original de sonidos encontrados ${ }^{309}$

Sin secreto alguno, nos referimos aquí a la presencia de iteración en el sonido encontrado o "construido" incluido en un sample. Como en todo sonido grabado y como ya dijéramos, el origen de los sonidos incluidos es tan diverso que, consecuentemente, resulta imposible asignarle origen determinado a las iteraciones contenidas en éstos. En resumen, estas iteraciones pueden ser de las categorías previas o provenir de otras actividades humanas, fenómenos naturales, etc.

d) Iteración por la aplicación de procesos destructivos

La técnica conocida como "time stretching" puede traducirse como "flexión temporal" o "compansión temporal" y es una herramienta que permite modificar la duración de eventos sono-musicales contenidos en archivos digitales. ${ }^{310}$ De modo similar a lo que sucede con las formas de onda de los sintetizadores en el registro grave, una expansión temporal extrema aplicada sobre un sample puede llevar a la emergencia de iteraciones: dependiendo de ciertas cualidades que el sonido encontrado o construido incluya, la extensión de su duración puede conducir a que la continuidad sonora original se quiebre en un tren de impulsos. Las cualidades necesarias para la emergencia de iteración a partir de la expansión temporal son dependientes del timbre y consisten esencialmente en la presencia de oscilaciones ricas en componentes agudos. Escúchese como ejemplo el comienzo del "mash up" ${ }^{311}$ de las piezas Robot Rock y Oh Yeah con el que el duo francés Daft Punk iniciara su presentación de 2007 en Buenos Aires. ${ }^{312}$ Incluido en

\footnotetext{
309 Recordamos lo ya dicho: grabaciones de eventos sonoros (musicales o no), provenientes de la cotidianeidad, la naturaleza o de actividades humanas que no tienen como finalidad específica la generación de sonido.

${ }^{310}$ Tomamos prestado para la última traducción la contracción que se utiliza para denominar a aquellas herramientas de control de la sonoridad que permiten -simultáneamente- expandir (i.e.: amplificar) las intensidades mínimas y comprimir las máximas. Al sintetizar en una misma unidad las funciones de compresor y expansor dichos dispositivos han recibido el nombre de "compansores"; por analogía, un "compansor temporal" permitiría comprimir o expandir la duración de eventos sonoros. Sin contar con una traducción apropiada, puede que nuestra propuesta resulte oportuna. En este caso, sin embargo, uno y otro efecto no puede ser aplicado en simultáneo.

311 Siendo su traducción literal "triturar", se denomina con este término a aquellas (nuevas) piezas creadas a partir de mixturar materiales provenientes de dos o más piezas preexistentes.

${ }^{312}$ Daft Punk - Robot Rock - Oh yeah (Official audio). (2007). Subido por Daft Punk. Accesible en línea en https://youtu.be/lVKbF8khsrI. Véase también http://dai.ly/xr5ass [28072016]. Aunque presenta menor fidelidad sonora, el segundo vínculo conduce a un video conteniendo la misma versión de la música e incluyendo imágenes montadas a partir de diferentes filmaciones de asistentes a diferentes recitales de la gira. Realizado por un admirador de la banda, es un homenaje a sus artistas predilectos y registro visual del espectáculo ofrecido. Nótense las numerosas referencias que se incluyen en el despliegue visual a lo
} 
Alive 2007, su segundo álbum en vivo fue grabado en el show de París, durante la misma gira que incluyera Sudamérica. Los primeros dos sonidos son la alternancia de las palabras "Robot" y "Human" procesadas mediante vocoder ${ }^{313}$ y expandidas temporalmente hasta el límite de la inteligibilidad. Nótese que, a pesar de la expansión temporal aplicada y de la aceleración paulatina, ambos sonidos mantienen su afinación original sin cambio alguno. La posibilidad de modificar la duración con independencia de la afinación (y viceversa) es una prestación surgida a partir de las tecnologías digitales y no se encontraba disponible durante el período analógico.

e) Iteración por aplicación de efectos

Multiplicidad de efectos se encuentran disponibles hoy para ser aplicados a cualquier tipo de sonidos. Disponemos actualmente de una inmensa cantidad de herramientas musicales de base tecnológica físicas y virtuales (en constante desarrollo y transformación) que permiten aplicar modificaciones sobre las cualidades de los más diversos sonidos. De entre estas, varias basan su lógica de funcionamiento en la aplicación de retardos sobre la señal de audio original. ${ }^{314}$ Permitiendo diferentes configuraciones, efectos de delay (i.e.: retardo), chorus (coro), flanger (sin traducción sencilla, genera un sonido que puede ser descripto como "metálico"), phaser (fase) ${ }^{315} \mathrm{y}$ otros pueden producir iteraciones y oscilaciones/alternancias de intensidad que presentan las cualidades que son el foco de nuestro interés aquí. Imposibles de abarcar por su vastedad, sugerimos como ejemplo -y como forma de ampliar el imaginario de estéticas posibles contenidos en la especie- la escucha de piezas clásicas del $d u b$. Género derivado del reggae jamaiquino de fines de la década de 1960, se reconoce hoy como uno de los índices de las músicas electrónicas utilizadas para el baile social y es una de las pocas fuentes simultáneamente electrónica y de baile que han influido sobre la especie. ${ }^{316}$

Finalizamos así el tratamiento de la sonoridad en las músicas electrónicas utilizadas para el baile social. Como última cuestión, creemos necesario llamar la atención acerca de una idea que subyace al recorrido que realizáramos en torno a esta cualidad y que emerge de los

\footnotetext{
"no-humano". A nuestro modo de ver, estas se expresan iconográficamente en la forma de cualidades "maquinales", "robóticas" y "divinas".

${ }^{313}$ Para una explicación de este dispositivo véase el Anexo V. Dispositivos tecnológicos asociados a las músicas electrónicas utilizadas para el baile social.

${ }^{314}$ Señal de audio: la corriente eléctrica que incluye información sonora y que el parlante transforma en sonido.

${ }^{315}$ Una breve aproximación a estos modificadores se incluye también en nuestro Anexo V.

${ }^{316}$ Escúchese por ejemplo el uso dado al efecto de retardo en la compilación Best Dub Compilation. Subido en 2013 por el usuario Reggae Box, incluye varios clásicos del género. Accesible en https://youtu.be/7iCxjXZOYsU [28072016].
} 
diferentes aspectos y cuestiones analizados de las músicas electrónicas utilizadas para el baile social.

Cuestión central sobre todo para la composición y el análisis musical, nuestros argumentos demuestran sin lugar a dudas que, contrariamente al tratamiento que ha recibido históricamente:

la sonoridad posee capacidad morfofórica. ${ }^{317}$

Capacidad reconocida para la altura, el ritmo y (más recientemente y de manera restringida) el timbre, fue negada por las perspectivas tradicionales para la sonoridad o, a lo sumo, entendida como una capacidad defectiva y extremadamente rudimentaria. Hallazgo inesperado en nuestra búsqueda de sensación táctil, comprobamos que para reconocerla solo era necesario encontrar los modos en que la sonoridad genera y establece formas. Aspecto secundario en relación a nuestra búsqueda central, lo consideramos sin embargo un aporte de gran relevancia que suministra (aún) otra herramienta novedosa y útil para el análisis y la práctica musical.

\section{Altura}

Como explicáramos someramente al iniciar nuestro tratamiento de la sonoridad, un factor central para el surgimiento de la música electrónica de baile sería el desarrollo de los modernos sistemas de refuerzo electroacústico o de amplificación. No solo porque los dispositivos electrónicos requerían y requieren de parlantes para emitir sus sonidos, sino porque estos debían generar la suficiente presión acústica como para permitir que grandes cantidades de personas, en grandes espacios, pudieran disfrutar de la música a un nivel que se impusiera por sobre los ruidos cada vez más elevados de los entornos urbanos en los que ésta surgió.

Esto repercutiría de maneras impensadas sobre la estética musical, dando origen a una nueva especie de cualidades sui géneris que retroalimentaría el desarrollo de los dispositivos que en primer término hicieran posible su existencia. Forzando sus límites, la música electrónica de baile demandaría año a año mejores y más potentes amplificadores, parlantes y todo componente de la cadena de amplificación de audio. Este proceso socio-tecnológico complejo conduciría en último término al surgimiento de los modernos PAs: sistemas capaces de generar presiones acústicas que superarían con creces a todo el instrumental musical previo, y en rangos extendidos de frecuencias que alcanzan hoy regiones sub-sónicas.

Así como para la sonoridad la utilización de sistemas de amplificación significó una extensión de los rangos de intensidad posibles, para la altura la invención de los sintetizadores y

\footnotetext{
${ }^{317}$ La capacidad de generar forma musical. Para más detalles ver Basso, G. (2006) Percepción auditiva. pp. 149 y 189.
} 
de los mencionados sistemas de amplificación condujo a un corrimiento de los límites en el registro de frecuencias. Ambas extensiones sentarían las bases tecnológicas necesarias para la producción y reproducción electroacústica de frecuencias en los extremos agudo, sobre-agudo, grave y sub-grave, lo que posibilitaría el surgimiento de una estética musical centrada en el cuerpo y el movimiento que promovería la visibilización de la sensación táctil. Si bien estas frecuencias se encontraban presentes ya en algunos instrumentos acústicos pre-existentes, solo mediante la invención de los mencionados sistemas sería posible producir agudos y graves a los enormes niveles de presión sonora que las músicas electrónicas utilizadas para el baile social desarrollan; solo mediante dichos sistemas, y luego de sucesivos perfeccionamientos y mejoras, se darían las condiciones necesarias para la concreción del entorno acústico que pondría literalmente en vibración al cuerpo de los asistentes a los locales de baile donde se los instalara.

La paulatina extensión del registro de frecuencias e intensidades acompañaría y sería impulsado por el desarrollo temprano de la música electrónica de baile. En un movimiento recíproco, a partir de las prestaciones que estas y otras innovaciones tecnológicas musicales ofrecieron, la música que durante los años 1980s se dio en llamar en nuestro país "techno" (hoy "synth pop") transformaría paulatinamente las formas y características de los géneros que le dieran origen. Como sucediera históricamente con el surgimiento de cada nuevo instrumento musical, sus aportes y beneficios se desarrollarían y mejorarían paso a paso.

En el caso concreto de las tecnologías de la amplificación estas mejoras consistirían en los ya mencionados incremento paulatino de su potencia (con el consiguiente incremento en la presión acústica plausible de ser generada), extensión del ancho de banda (i.e.: la extensión del rango de frecuencias posible de ser producidas) e incremento de su fidelidad (por reducción de los ruidos parásitos y distorsiones armónicas). Aún hoy, en una constante interacción, las industrias del audio y de las músicas electrónicas utilizadas para el baile social promueven mutuas transformaciones, abrevan una en la otra y se presentan mutuamente requerimientos y retos a la hora de innovar sus características.

Las músicas electrónicas utilizadas para el baile social incrementaron paulatinamente el uso de los registros extremos, llegando a ser hoy profusas en estas zonas y especialmente abundantes los sonidos incluidos en las regiones grave y sub-grave del espectro. Asociados como viéramos con la incitación al baile, ${ }^{318}$ esta zona de frecuencias se considera -implícita o explícitamente- como la más importante y es a la que se dedica la mayor parte del tiempo durante la producción de una pieza. El mencionado rol de incitación al baile ha conducido a que

${ }^{318}$ Hemos expuesto como, luego de una parada, el retorno del registro grave/sub-grave provoca momentos de euforia y baile más energético y definido en sus movimientos. 
este registro resulte asociado con períodos o secciones (de las piezas) cuyo carácter es interpretado por los aficionados como presentando estabilidad. ${ }^{319}$

La fabricación de sistemas de amplificación capaces de producir frecuencias en los registros sobre-agudo y sub-grave con suficiente fidelidad, libre de ruidos y con mínima distorsión resulta por sí misma una tarea que involucra numerosas complejidades. Cuando esto se combina, además, con la demanda de que dicha producción sea a altos niveles de presión acústica, la complejidad se incrementa exponencialmente. El desarrollo de la industria del audio en los últimos años ha recibido un gran impulso a partir de la industria cinematográfica, pero este impulso no puede compararse con la gigantesca tracción que significa la demanda de la industria musical y de los eventos masivos en estadios y grandes espacios. ${ }^{320}$ Afortunadamente vivimos en una época de grandes avances tecnológicos, los cuales han posibilitado que dicha tarea pueda cumplirse sin mayores sobresaltos. Si bien no se encuentran libres de problemas, los actuales sistemas de amplificación poseen las capacidades necesarias para cumplir el trabajo con eficacia. $^{321}$

Lamentablemente y si bien la oferta existe, en el plano local son aún muchos los locales de baile que presentan PAs deficientes en muchos o todos los sentidos. Los altos costos del equipamiento -problema originado principalmente en que la amplia mayoría son productos de importación- desemboca en que muchos locales de dimensiones pequeñas y medianas no puedan disponer de los recursos monetarios suficientes como para adquirir aquellos que resultarían los más apropiados para su realidad acústica, debiendo contentarse con equipos con menor potencia que la recomendable, débiles en la producción de frecuencias graves o presentando algunos de los problemas mencionados previamente. Si bien en los últimos años el Estado proveyó (en la forma de subsidios y otros) de gran cantidad de fondos para tal fin y la mejora se ha hecho notar a lo largo y ancho del territorio nacional, el esfuerzo ha sido y es insuficiente para los altos estándares que las músicas electrónicas utilizadas para el baile social demandan.

\footnotetext{
${ }^{319}$ Como veremos en breve, esta asociación ha adquirido tanta fuerza que dicho registro cumple hoy una función que puede ser descripta como cuasi-tonal (donde el grave/sub-grave oficia de tónica-reposo y su complementario agudo/sobre-agudo de dominante-tensión).

${ }^{320}$ A modo de ejemplo, las modernas salas de cine presentan sonido envolvente 5.1; donde el "5" identifica a 3 canales frontales (izquierda, centro y derecha detrás de la pantalla) más dos laterales o ambientales, y el ".1" refiere al canal LFE o mejora de bajas frecuencias ("Low Frequency Enhancer" por sus siglas en inglés). A pesar de lo novedoso que puede parecer, sistemas envolventes fueron utilizados en la música electroacústica décadas antes de ser incorporados al cine y el canal LFE resulta oscurecido a la sombra de los inmensos parlantes "sub-woofers" (parlantes de graves/sub-graves) utilizados en los locales de baile para producir las frecuencias graves y sub-graves incluidas en muchas de las músicas actuales.

${ }^{321}$ Los niveles de presión sonora y anchos de banda presentes en locales de baile documentados en nuestras experiencias de campo confirman esta afirmación, al menos para locales de baile orientados a una clase social de poder adquisitivo medio o alto.
} 


\section{Altura relativa y absoluta}

En las músicas electrónicas utilizadas para el baile social el tratamiento de la cualidad sonora altura presenta un grado de diversidad equiparable al de la sonoridad. Consecuencia también de la inclusión de todo tipo de estéticas pasadas y presentes, al interior de la especie las piezas pueden evaluarse como inscriptas en un eje difuso donde los extremos coinciden respectivamente con concepciones de la altura en términos relativos y absolutos.

Próximas al primero de los extremos se encuentran aquellas organizadas a partir de principios tonales o modales -tanto en sentido restringido como extendido (según usos más recientes)- como algunas estéticas atonales. Si bien muy diferentes entre sí, los tres sistemas localizan al sentido musical en el espacio vincular entre las alturas utilizadas, en los intervalos entre las alturas presentadas (intervalos irremediablemente vacíos o plausibles de continuidad; temperados, micro-temperados o relativos según el sistema y el caso particular) y a partir de las relaciones que en dicho espacio vincular se establecen y manifiestan. Expresado de modo sencillo, el sentido musical reside en los intervalos sucesivos (de melodías tradicionales o de timbres) y simultáneos (de armonías tonales, modales o atonales).

Hacia el extremo opuesto, las alturas son comprendidas a partir de su carácter absoluto y los elementos tímbrico-texturales simplemente se distribuyen según sus frecuencias y componentes espectrales en los diferentes registros, ocupándolos, generando actividad en zonas determinadas del espectro. Piezas atonales o que presentan cualidades parciales de tonalidad (ambas en sentido amplio), difieren de las incorporadas en la categoría previa en que el tratamiento que se da al parámetro altura -en particular- y a los eventos completos -en generalse encuentra más próximo a la objetivación u "objeto sonoro" descripto por Pierre Schaeffer en su Tratado de los objetos musicales. ${ }^{322}$ En el caso ideal el sentido musical se localiza en los propios objetos sono-musicales y no en el espacio de relación mutua. Este tratamiento creemos- vuelve conducente incorporar una nueva categoría, a la que llamaremos espectral para diferenciarla de las tres previas.

En las zonas intermedias encontramos casos ambiguos, donde el valor relativo de la altura se ve parcialmente desdibujado o se torna apenas una excusa para (nuevamente) ocupar o generar actividad en diferentes registros. La tonalidad, modalidad o tonicidad pueden presentarse como parcialmente operativos o como meras apariencias. Materiales y/o

\footnotetext{
${ }^{322}$ Schaeffer, P. (1966). Tratado de los objetos musicales. pp. 57-59 Extendiendo el concepto propuesto por Schaeffer, comprendemos al "objeto sonoro" como una conformación sonora de propiedades estables y fácilmente reconocibles y a la objetivación como a aquellos procesos que conducen a que ciertas configuraciones sonoras presenten propiedades estables y fácilmente reconocibles. Estas propiedades provocan que la forma sonora objetivada u objetuada (i.e.: vuelta, por analogía, objeto) hasta cierto punto se desvincule de su contexto y adquiera sentido por sí misma. Como veremos en breve, sus cualidades se aproximan a lo que llamaremos un tratamiento "absoluto" y se alejan de uno "relativo". De este modo y como ejemplo, las notas de una melodía tonal contenida en un sample presentado varias veces pueden ver debilitadas sus relaciones mutuas (valga la redundancia, tonales) por el hecho de que todos los sonidos que constituyen la melodía presentan una completa invariancia hasta en sus aspectos más mínimos. Para más detalles ver nuestro Glosario.
} 
conformaciones tonales, modales o atonales presentan cuestionado su relativismo por el tratamiento que se aplica (o deja de aplicar) sobre ellos y/o por los comportamientos que se les asigna. En los términos con que describiéramos los casos previos, parte del sentido musical se encuentra aquí en el espacio vincular y parte en el carácter parcialmente objetuado u objetivado de los materiales y/o conformaciones, sean estos de la naturaleza que sean. En piezas pertenecientes a esta categoría la fuerza de la oposición tensión/distensión (tradicionalmente generada a partir de las relaciones armónicas) puede ser débil, nula, manifestarse en la altura de modos diferentes a los tradicionales o expresarse en parámetros diferentes a la altura. Como veremos más adelante, ritmo y registro pueden asumir los roles mencionados.

\section{Tratamiento de la altura como cualidad relativa ${ }^{323}$}

Incluimos aquí piezas en las cuales el énfasis está puesto en la oposición de diferencias y en las relaciones que dichas diferencias generan entre los elementos que las contienen. Las cualidades de un determinado material o conformación a utilizar se seleccionan en función de las que presentan los demás, y las de todos (o al menos las de la mayoría) se subordinan a las relaciones que se establecen entre sí. Se configura un cierto número de identidades diferenciadas que, por sus cualidades respectivas, se organizan en relaciones que -al menos hasta cierto puntopodemos caracterizar como de complementariedad. Entre dichas identidades se establece una red de relaciones opositivas que interactúan para organizar y motorizar el devenir musical.

Para el establecimiento de esta red de oposiciones estructurante del devenir musical suele ser necesario que los materiales presenten ciertas propiedades comunes entre sí, por lo que la oposición se realiza dentro de los límites de una única dimensión. Secundariamente, la concreción de la oposición suele demandar también la subordinación de otras dimensiones musicales. A modo de ejemplo, para operar dentro del sistema tonal los sonidos deben presentar timbres tónicos (i.e.: de altura tonal definida), ${ }^{324}$ así, el timbre se subordina a la altura y esta última es la dimensión donde sucede la oposición.

Como consecuencia lateral, la dimensión sobre la que se estructura la oposición suele permanecer como un sustrato subyacente de cualidades invariantes durante el transcurso de toda la pieza. Siguiendo nuestro ejemplo, en el sistema tonal los sonidos no cambian repentinamente sus timbres de altura tonal definida a altura tonal no definida; de suceder algo así, todo el sistema resultaría destruido. En el establecimiento de este continuo subyacente se encuentra una

\footnotetext{
${ }^{323}$ Las piezas incluídas en la lista de reproducción Ultimate EDM Playlist pueden comprenderse como ejemplos de esta categoría. Compilados por Spinnin' Records, ofrecen diferentes grados de tonicidad (en sentido amplio). Accesible en https://youtu.be/gCYcHz2k5x0?list=PLw6eTMMKY24QLYfmrU2rB8x$1 \mathrm{P} 5$ Fas2dY [09102016]

${ }^{324}$ Para mayor precisión, pueden ser suficientes sonidos cuyo timbre presente tonicidad débil, y donde las componentes de ruido se mantengan en un grado tal que no perturben la conformación e identificación auditiva de melodías y armonías.
} 
de las razones que hacen necesaria la cualidad que describimos a continuación y que suele denominarse temporalidad lineal.

Para que el tratamiento relativista de la altura se concrete resulta necesario -además de lo ya expuesto- priorizar la sucesión y secuenciación de materiales diferentes. Esto se debe a que la propia oposición requiere que se sucedan identidades diferenciadas para concretarse. Si a la permanencia cualitativa de la dimensión estructurante se le agrega la persistencia de una única identidad en esta misma dimensión la propia oposición no se concreta, llevando nuevamente al sistema a una crisis que destruye su operatividad. Por esta razón, comportamientos que involucran permanencia o alternancia cíclica (en este caso, solo otro tipo de permanencia) se utilizan solo marginalmente. Continuando nuestro ejemplo, las relaciones tonales ocurren tanto en el intervalo entre alturas como en el intervalo entre las sucesivas armonías o acordes.

Consideramos entonces incluidas en esta categoría a piezas:

a) tonales y modales (en sentido restringido): donde dichos sistemas operan lisa y llanamente sin diferencia alguna con la tradición musical occidental de siglos pasados;

b) tónicas (en sentido amplio): donde tonalidad o modalidad son defectivas y sus principios resultan aplicados (si bien en su mayoría) siempre parcialmente;

c) atonales: donde, si bien los principios estructurantes no se corresponden con los sistemas previos, las alturas (y quizá otras cualidades musicales extras) se organizan alrededor de las relaciones que se establecen entre sí. Ejemplos posibles son piezas que incluyen organizaciones de las alturas que respondan a los principios del dodecafonismo, el serialismo o similares; aun siendo sistemas donde las alturas se organizan en un pie de igualdad ( $\sin$ jerarquizar ningunas por sobre otras), la estructuración se concreta alrededor de las relaciones que se establecen entre las diferentes alturas que se presentan durante el transcurso de las obras que hacen uso de estos sistemas (en nuestros ejemplos, en la serie).

A pesar de lo que pudieran sugerir nuestros ejemplos y como dijéramos al pasar en párrafos precedentes, la pertenencia al último subgrupo no depende del uso exclusivo de sonidos tónicos sino que pueden resultar incluidas en esta categoría tanto piezas que relacionen sonidos de altura tonal definida con sonidos de altura tonal no definida (o de tonicidad débil), como otras que se estructuren exclusivamente en base a la relación entre sonidos de altura tonal no definida y/o tonicidad débil. ${ }^{325}$ Podría pertenecer incluso una pieza hipotética que hiciera un uso continuo del registro de alturas (i.e.: un uso no cuantificado del espectro, como opuesto al

\footnotetext{
${ }^{325}$ En otras palabras, piezas atonales donde (al menos) el sistema dodecafónico no sería aplicable. Si bien no analizaremos casos de esta característica sí veremos manifestaciones parciales que corroboran esta posibilidad.
} 
establecimiento de alturas -tonal definida o no definida- discretas), siempre y cuando se organizara a partir de la relación entre las cualidades de altura de los aconteceres musicales. ${ }^{326}$

En definitiva, independientemente del caso y del modo concreto, lo que define a las piezas de esta categoría es su organización basada en la relación entre alturas. Agregando algún dato final más, ciertos casos que podrían incluirse en el apartado $c$ (y que intentáramos describir en el párrafo precedente) quizá se explican mejor si referimos a una relación entre registros o a una relación mixta entre alturas y registros. ${ }^{327}$

\section{Tratamiento de la altura como cualidad absoluta ${ }^{328}$}

En este modo de concebir la altura, la textura es vista ya no en el sentido tradicional sino en la relación de identificación mutua con el ritmo y el timbre que comenzáramos a esbozar durante el desarrollo del tema sonoridad y que en lo que sigue ampliaremos. Liberada de los preconceptos heredados de la tradición musical europea de siglos pasados, la textura adquiere una plasticidad y fluidez mayormente asociada al timbre, y el total del espectro de frecuencias (audibles e inaudibles) es visto por los productores de las músicas electrónicas utilizadas para el baile social como la superficie de un líquido en reposo plausible de ser excitado en diferentes formas y frecuencias; como un lienzo, tenso y en calma, que resuena al ser expuesto a perturbaciones de diferentes frecuencias, formas e intensidades y que expresa dichas oscilaciones en la totalidad de la superficie. ${ }^{329}$

Consecuente con esta identificación triple (entre textura, ritmo y timbre), los elementos $\mathrm{y}$ estratos texturales se reconvierten en (se identifican con, son concebidos como) los componentes ritmico-espectrales de un timbre total que se corresponde y conforma, momento a momento, con todo lo que sucede en la pieza. El registro donde ocurre cada elemento o estrato textural es entendido entonces como una materia elástica donde resulta posible provocar actividad, como un espacio concreto -de límites flexibles definidos por el propio elemento o estrato- plausible de ser ocupado, una región de un todo continuo dentro de la cual puede

\footnotetext{
326 No hemos detectado una pieza de tales características; sin embargo, algunos comportamientos observados en la especie hacen pensar que un caso así es posible. Expuesto en breves términos, sugerimos como ejemplo una pieza donde todos los aconteceres musicales (ya sean de altura tonal definida, altura tonal no definida, de tonicidad débil o inarmónicos) presentan glissandos o cambios en su afinación.

${ }^{327}$ No encontrando una forma mejor, referimos aquí con el término "registros" a aconteceres musicales que ocupan zonas espectrales relativamente estrechas. Dichos aconteceres también podrían describirse como sonidos (de altura tonal no definida o de tonicidad débil) de banda relativamente estrecha;

${ }^{328}$ Como ejemplificación de las dos categorías que describiremos a continuación sugerimos la escucha de la Lista de reproducción de YouTube que figura bajo la denominación techno/experimental/idm. Subida por el usuario Filip Makara y actualizada en marzo 2015, incluye 81 piezas donde el tratamiento absoluto de la altura prepondera (en diferentes grados según el caso) por sobre el relativo. Entre muchas otras incluye: "Structure" de Shifted, "You against yourself" de Xhin, "Touch it" de Neil Landstrumm con Si Begg, "Chaste down" de Karenn, "Descending" de Function y "We are back" de LFO. Accesible en https://youtu.be/YYX1bH18WMo?list=PLZ1xQmYItdzRi2POf-KkztDo-rOlKqplr [12082016]

${ }^{329}$ Por la "plasticidad" que subyace a esta concepción (y que presentan materiales en algunas piezas incluidas en esta categoría), acompañaremos nuestras descripciones con metáforas que -creemosfacilitarán la comprensión al aportar imágenes mentales que ilustran dicha cualidad.
} 
verterse energía en la forma de complejos rítmico-tímbricos. En una concepción holística, en este todo continuo y fluido del espectro completo de frecuencias, los elementos y estratos texturales pueden ser comprendidos simplemente como aquellas oscilaciones que conforman al mencionado timbre total.

Consecuentemente, antes de pensar en una melodía, sonido único reiterado, drone o textura evolutiva ${ }^{330}$ o cualquier otra opción textural, el productor pensará en la zona concreta del espectro de frecuencias que desea ocupar, pensará en la región en la que desea provocar actividad (o al menos iniciarla). Las alturas seleccionadas o el registro de cierto complejo espectral, según el caso, dependerán aquí de la frecuencia o zona de frecuencias objetivas en las que el productor desee concretar el acontecimiento musical, llegando en muchos casos a precisiones mensurables en centésimos de semitono (o "cents").

Vemos entonces que en esta categoría el foco está puesto en los elementos y estratos mismos que conforman la textura y ya no en su relación mutua. Las cualidades de cada elemento y estrato textural se seleccionan ya no según las cualidades de los demás sino por las propiedades que presentan por sí mismos y en función del aporte en frecuencias concreto que estos hacen al timbre total. En el caso ideal (e irreal) sus identidades resultan subsumidas en la identidad de la totalidad y su razón de ser y presentarse (i.e.: hacerse presente, incluirse o eliminarse de la textura en cada momento) depende en último término pura y exclusivamente de la voluntad del productor.

Antes que de alturas, en muchas de estas piezas resulta más apropiado hablar de frecuencias. Cada sonido es evaluado según los términos expuestos en los párrafos precedentes, por lo que su afinación y timbre serán seleccionados libres de los condicionamientos que operaran en el pasado próximo. Los sonidos de altura tonal definida entonces -en la historia europea elevados al nivel de únicos sonidos musicales- se relacionan en un pie de igualdad con el resto del universo de posibilidades tímbricas (i.e.: los timbre de altura tonal no definida y de tonicidad débil resultan jerarquizados como iguales de aquéllos) y, de modo similar a lo que sucede con los demás sonidos, estos se conciben ya no en tanto notas sino como frecuencias, como conformaciones espectrales de una determinada característica que no es ni mejor ni peor que ninguna otra. Puesto de modo simple, no se piensa en incluir la nota la central en una

\footnotetext{
${ }^{330}$ Se denominan así a sonidos sostenidos de duración y conformación espectral compleja indeterminada plausibles de ser manipulados de diferentes modos. Estas conformaciones acústicas pueden presentar una simplicidad extrema o ser verdaderas y muy complejas texturas en sí mismas. Las posibilidades de modulación que los sintetizadores presentan permiten la automatización de transformaciones en períodos muy largos de tiempo, permitiendo la ocurrencia de muy complejas y diversas conformaciones sin la intervención de operador alguno. Similares evoluciones prolongadas pueden acaecer en ciertos sonidos provenientes del mundo no-musical, y estos pueden ser incluidos en las piezas en la forma de samples. Esta última cualidad es la que seguramente gravitara para que estos elementos recibieran la denominación con la que se los conoce actualmente: "drone", como una entidad autónoma que opera y evoluciona sin la necesidad de intervención humana.
} 
determinada armonía sino en incluir los $440 \mathrm{~Hz}$ (y demás componentes espectrales del timbre concreto que se elige) al total espectral que se presenta en un determinado momento.

En los estratos texturales compuestos de elementos diversos, esta concepción opera tanto para los primeros (i.e.: el estrato como conjunto) como para los segundos (i.e.: cada elemento al interior del estrato). No solo la elección de afinaciones y timbres se realiza para ambos libremente, sino que además conlleva la posibilidad de que un elemento o estrato que se iniciara con un determinado conjunto de propiedades mute hasta perder todas sus cualidades identitarias, transformando consecuentemente a la entidad de nivel superior que lo contiene; y esto puede ocurrir independientemente del contexto en que una u otra entidad se encuentre.

Esto resulta posible debido a que, ya sea que un elemento o estrato textural se conforme de un sonido único -de cualidades únicas e invariantes (como por ejemplo un sonido de redoblante)- o de un conjunto de eventos -de cualidades convergentes o divergentes unos con otros (como en una melodía o en un patrón rítmico)-, ambos serán vistos en tanto formas concretas en sí mismas; ${ }^{331}$ ya no en la relación entre sus elementos (al interior del estrato que los contiene) o entre estratos (de la textura total/timbre total que conforman) sino como parte de la única, aunque compleja, perturbación que acontece en la superficie del líquido-lienzo.

En ciertos casos, incluso los conceptos de elemento y estrato textural pierden aplicabilidad: unos y otros se funden en la totalidad de la continuidad espectral disolviendo a la vez a sus elementos constituyentes. También diluyen sus límites en la fluidez del timbre total, en la capacidad de transformar sus cualidades en otras completamente diferentes. De modo similar al ejemplo que analizáramos en Nevermind, melodías pueden reconvertirse en secciones rítmicas completas, armonías enteras pueden transformarse en timbres de melodías, texturas tradicionales pueden volverse texturas de puntos y cualquier opción imaginable puede recombinarse en cualquier otra. La identidad se vuelve una cualidad pasajera y lábil, una elección libre sujeta en cada momento a los designios del productor.

Esta focalización sobre lo que podemos llamar (siguiendo a Schaeffer) "objetos sonoros" en sí mismos, elimina la necesidad de varias de las condiciones de existencia asociadas a la concepción relativista de la altura. Ubicado el sentido en los eventos musicales en sí mismos, la relación entre estos pierde su razón de ser. El abandono de la cualidad relacional y el tratamiento fluido y continuo del espectro origina una reacción en cadena que disuelve a la textura tradicional en su versión espectral, sinónimo de timbre (a nivel macroscópico). Recorramos este proceso:

a) Se abandona la relación entre alturas $y$, con ésta, toda relación entre elementos y/o estratos texturales

${ }^{331}$ De aquí la relación con los "objetos sonoros" de Schaeffer. 
La importancia y funciones relativas de cada altura particular (y de los elementos y estratos texturales en general), ceden lugar a una lisa y llana coexistencia de entidades para las cuales el fundamento de su presencia en una determinada pieza o sección es el simple deseo del productor. Su aporte, además del descripto en párrafos precedentes, se explica como meras "formas sonoras" a partir del concepto de "objeto sonoro" propuesto por Pierre Schaeffer en su Tratado de los objetos musicales. Allí dirá que:

A fuerza de escuchar objetos sonoros cuyas causas instrumentales están enmascaradas, somos inducidos a olvidar estas últimas e interesarnos por los propios objetos. La disociación de la vista y el oído favorece aquí otra manera de escuchar: la escucha de las formas sonoras, sin otro propósito que el de escucharlas mejor, a fin de poder describirlas a través de un análisis del contenido de nuestras percepciones. ${ }^{332}$

A diferencia de la categoría previa, las relaciones entre elementos y/o estratos texturales que derivan del tratamiento absoluto de la altura son cambiantes, inestables y mutan. Sin forma precisa y donde cada situación concreta propone la propia, en la mayoría de los casos puede ser descripta como (algún nombre debemos darle) carencia de relación causal. ${ }^{333}$ En otras palabras, nos referimos con esta expresión a que en esta lógica los cambios suceden sin razón aparente; a diferencia de los sistemas relacionales, ${ }^{334}$ aquí mucho de lo que ocurre carece de relación causal.

b) El abandono de la cualidad relacional elimina la necesidad de oposición.

La carencia de relación causal provoca que la oposición (condición necesaria para el tratamiento relacional de la altura) pierda su razón de ser. El establecimiento de funciones oponibles se vuelve entonces una elección libre, no solo de ser utilizada (o no), sino libre también de ser aplicada sobre otras variables musicales.

c) La oposición, vuelta superflua, elimina la necesidad de diferencias.

Al no precisarse oposiciones, la generación de entidades de cualidades diferenciadas deja de ser una condición necesaria. Las cualidades de las entidades dependerán de lo que el productor pretenda que cada una aporte al timbre total y, de darse diferencias, serán consecuencias laterales y secundarias de dicho objetivo.

d) La diferencia, vuelta superflua, elimina la necesidad de identidades.

332 Schaeffer, P. (1966). Op.cit. pp.57 Si bien en la cita precedente el autor hace alusión a "sonidos encontrados", su postulado tiene validez para cualquier sonido (sea la fuente que sea). En el contexto, Schaeffer no se refiere a propiedades que podrían encontrarse en los mismos sonidos sino a una actitud particular que puede asumirse durante la apreciación de cualquier sonido.

${ }^{333}$ Esta expresión ha sido utilizada en algunas oportunidades para describir la relación que se establece en piezas contemporáneas donde los diferentes estratos texturales describen recorridos independientes y donde la interferencia mutua se encuentra ausente por completo. Véase Baquedano, M. (2011). Apunte de cátedra de la asignatura Apreciación Musical II. Universidad Nacional del Arte, Departamento de Artes del Movimiento "Maria Ruanova". pp. 3-4

${ }^{334}$ Donde el cambio tiene su causa en la necesidad constante de contraste para construir la oposición de cualidades, y su efecto en las funciones diferenciadas que se establecen en cada identidad. 
Al no ser necesaria la diferencia, no se configuran necesariamente identidades. Entidades inicialmente diferenciadas pueden -en el transcurrir de una misma piezafundirse en una sola o en otras diferentes a las originales, asignando a la identidad un carácter transitivo y lábil. Del mismo modo y sin complejidad extra alguna, una única identidad puede desmembrarse en otras múltiples. Éstos u otros infinitos recorridos son igual de posibles y constituyen la "fluidez" y "solubilidad" de las entidades que enunciáramos antes. Permitiendo transformarse al infinito, mixturarse entre sí, disolverse en nada o en las demás, expresan la continuidad y plasticidad del timbre total en el espectro completo de frecuencias.

f) La eliminación de la oposición como motor del devenir musical elimina la necesidad de una temporalidad lineal

Abandonada la cualidad relacional y, consecuentemente, la oposición de identidades diferenciadas, el establecimiento de una temporalidad lineal se vuelve (como para otras condiciones de existencia previas) una cuestión electiva. En otras palabras, la carencia de relación causal influye y se expresa también en el devenir temporal.

El modo en que la carencia de relación causal se expresa temporalmente resulta en una preponderancia de la permanencia por sobre la evolución, desarrollo o cambio. Los procesos puestos de manifiesto por (y en) los materiales utilizados en estas piezas pueden ser descriptos como estatismo con cambios o estatismos sucesivos y la temporalidad resultante como cíclica. Estas adjetivaciones son el emergente del tipo de tratamiento que se aplica sobre los materiales, tratamiento caracterizado por el uso de la repetición, transformaciones a-direccionales, yuxtaposiciones repentinas de elementos disimiles (involucrando el abandono sorpresivo de materiales y reemplazo por otros sin vínculo que los enlace) y otros. Al quebrar con los constructos culturales tradicionales europeos caracterizados por el establecimiento de relaciones causales derivadas de la oposición tensión/distensión operativa sobre las alturas en la forma de armonías tonales (en sentido amplio), estos tratamientos provocan la carencia de relación causal como sensación emergente del devenir musical.

No negamos la ocurrencia en estas piezas de cambios concretos (hechos innegables por otra parte) sino que nos referimos más bien aquí al constructo respecto de la sensación de activación, a la sensación de actividad musical que emerge en estas piezas a partir del devenir a escala macro-formal. Si bien a nivel de frase la sensación de activación puede resultar elevada, la ocurrencia de los tratamientos mencionados suele generar en piezas de este tipo largos períodos de -a veces aparente, a veces real- nula transformación.

Advirtiendo que es una generalización por demás exagerada y que puede provocar falsas impresiones, preferimos señalar que, como idea general, la permanencia y temporalidad cíclica pueden comprenderse como consecuencia de un alto grado de repetición. 
Comportamiento omnipresente en la especie, en las piezas de esta categoría se expresa a veces en modos evidentes y en otras oportunidades de formas muy sutiles. Recurso compositivo que ha surgido y surgirá durante el tratamiento de muy diversos aspectos de estas músicas, nos interesa aquí el impacto que tiene sobre el establecimiento y estabilización de objetos sonoros. Al respecto, Schaeffer continúa inmediatamente después de nuestra cita previa diciendo que:

\begin{abstract}
A decir verdad, la cortina de Pitágoras no basta para desalentar una curiosidad por las causas, a la que casi instintivamente nos vemos avocados. Pero la repetición, la señal física que permite la grabación, nos ayuda a ello de dos maneras: al agotar esta curiosidad, nos impone poco a poco el objeto sonoro como una percepción digna de ser observada por ella misma; por otra parte, a condición de hacer escuchas más atentas y refinadas, nos revela progresivamente la riqueza de esta percepción. ${ }^{335}$
\end{abstract}

Y quizá la repetición construya las sensaciones de estatismo, permanencia y temporalidad cíclica ${ }^{336}$ debido a que cada repetición evoca la primera ocurrencia del material. En la especie, esto es especialmente cierto si consideramos la repetición armada a partir de samples: siendo ya la primera ocurrencia de un sonido encontrado una evocación y, en alguna medida, repetición del evento original, cada repetición posterior vuelve a hacer presente al fragmento de pasado sonoro contenido entre los límites del sample. Simultáneamente, el abismo (insalvable) que inicio y final del sample establecen con el tiempo presente refuerzan aún más esta suspensión al quebrar con el continuo que la temporalidad lineal supone y exige.

En definitiva, el foco se encuentra en estas piezas en la superficie como todo, en el complejo ritmico-tímbrico-textural total y no en las relaciones entre sus componentes. En la fascinación frente a la complejidad de la oscilación de la superficie del líquido-lienzo el productor se desentiende de las relaciones internas que pudieran presentar los elementos con que fuera configurada la totalidad. Las perturbaciones que la constituyen -plásticas, maleables, informes- cual verdaderos objetos vibrátiles pueden además trasladarse a otras regiones del líquido-lienzo. Su capacidad de superponerse con las demás, fundiéndose momentáneamente para luego reaparecer indemnes, les confiere (tanto a cada elemento y estrato como a la textura general) un cierto carácter "objetual" e indivisible que individualiza a cada elemento y estrato a la vez que lo vuelve uno (único y el mismo) con los demás y con la totalidad. En última instancia, lo que llamáramos el timbre total, la "superficie como todo", el "acontecer musical completo momento a momento", el complejo rítmico-tímbrico-textural total es el objeto sonoro máximo, la forma sonora de mayor jerarquía que se impone a la percepción más allá de las causas (o "fuentes", en palabras de Schaeffer) que determinaron y determinan su existencia.

La altura recibe este tipo de tratamiento únicamente en piezas atonales. Si bien muchas (podemos arriesgar, la mayoría) suelen presentar:

\footnotetext{
${ }^{335}$ Schaeffer, P. (1966). Op.cit. pp.57

${ }^{336}$ A la que también podríamos llamar "sensación de suspensión del flujo temporal".
} 
a) uno o varios elementos o estratos incorporando sonidos de altura tonal definida o de tonicidad débil y

b) los elementos y/o estratos mencionados pueden presentar entre sí relaciones armónicas simples (por ejemplo, aquellas que se establecen en conformaciones triádicas por intervalos de terceras o similares), ${ }^{337}$

...el tratamiento que se les brinda (usualmente invariantes en la totalidad o mayoría de sus cualidades) y las conformaciones que describen (plausibles de ser rotuladas como "pedales" al menos para los sonidos que ofician de bajo) evitan todo tipo de relación tonal o modal (en sentido amplio), lo que permite incluirlas en la categoría de atonales. ${ }^{338}$

\section{Tratamiento de la altura como cualidad mixta (relativa-absoluta)}

Siguiendo los postulados establecidos en los sistemas con lógica difusa, no resulta extraño que la amplia mayoría de las piezas se inscriba en esta región intermedia donde los principios de uno y otro tipo de tratamiento operan solo parcialmente y en interacción con su opuesto. Encontramos en la especie ejemplos en todo el rango difuso que el eje altura relativaabsoluta propone. A modo de ejemplo (las posibilidades son prácticamente infinitas), los exponentes más claramente mixtos pueden incluir:

a) elementos y/o estratos texturales donde la conformación propia denota su pertenencia a una de las dos lógicas de tratamiento de la altura, coexistiendo simultáneamente con otros elementos y/o estratos texturales cuya conformación explicita su pertenencia a la lógica restante. Anticipándonos al tratamiento de la textura podemos identificar a estos casos con el tipo textural histórico que recibiera el nombre de heterofonía. ${ }^{339}$

b) melodías, armonías y elementos armónico-texturales propios de la tonalidad (i.e.: arpegios, acordes, sonido grave cumpliendo función de bajo u otros) pero donde ésta resulta perturbada o cuestionada por los tratamientos que recibe al interior del estrato textural y/o como estrato en sí mismo,

c) pseudo- (o proto-) melodías, armonías y elementos armónico-texturales propios de la tonalidad que por su conformación interna -incompletos, defectivos, parcialmente indeterminados, demasiado breves, realizados con timbres de tonicidad débil u otros- no alcanzan a establecer con claridad las condiciones de existencia que las funciones

\footnotetext{
${ }^{337}$ Esta cualidad resulta menos común que la descripta en el apartado previo.

${ }^{338} \mathrm{Si}$ se quiere, agregando la adjetivación "incluyendo uno o varios sonidos con timbres de altura tonal definida".

${ }^{339}$ Como dijéramos, piezas donde los diferentes estratos texturales divergen en sus cualidades estructurales y presentan independencia mutua. Para más detalles véase Textura en nuestro Anexo III.
} 
armónico-texturales con las que se los podría asociar requieren para ser merecedoras de dicha denominación.

Estos son los tratamientos en que la altura se presenta a la percepción con cualidades parcialmente relacionales y absolutas. En las piezas que presentan esta característica los principios tonales, modales o atonales (relacionales) aún tienen influencia sobre los materiales, pero dicha influencia se ve cuestionada por la interacción con los tratamientos derivados de la concepción absoluta. Ni una ni otra lógica llega a imponerse sobre su opuesta, por lo que ambas operan parcial y simultáneamente.

Las oposiciones relacionales en ciertos casos se transforman en meras apariencias de tonalidad (en sentido abarcativo), en excusas que "popularizan" (i.e.: asocian con músicas populares a) estéticas que de otro modo serían rotuladas sin dudas como "experimentales" o "contemporáneas". Melodías, líneas de bajo y otros elementos asociables con comportamientos musicales tradicionales se ofrecen como anclaje perceptivo, como cualidad reconocible que facilita la identificación emocional de aquellos entusiastas de las músicas electrónicas utilizadas para el baile social menos familiarizados con su faceta experimental.

Un ejemplo posible lo constituye We are back de $L F O{ }^{340}$ La pieza utiliza una escalística que se corresponde con el modo griego mixolidio y la mayoría de los estratos jerarquizan la nota si generando tonicidad sobre ésta; sin embargo, el uso generalizado de timbres de tonicidad débil, duraciones muy breves, cambios texturales repentinos y estatismo armónico (solo por mencionar algunos tratamientos propios de la concepción absoluta de la altura) perturban y cuestionan la operatividad del modo y sus funciones. La atención que demanda la voz sintética remite al género canción, pero su timbre "robótico" y su insistencia sobre una altura única si y algunos ataques sobre do (que resultan en general parcialmente enmascarados por otros elementos de la textura) ponen simultáneamente en duda dicha remisión, reforzando el cuestionamiento mismo. Este cuestionamiento es reforzado, entre otros factores, por el ripieno armónico de acordes sostenidos agudos que -en un segundo plano de sonoridad y con un timbre contrastado con la "suciedad" del resto- parecieran proponer una progresión armónica funcional (modal); sin embargo, la "armonía" apenas resulta sugerida y solo alterna entre dos conformaciones que apoyan el pedal sobre la nota si que otros estratos describen. El único cambio relevante que experimenta es registral y en nada influye sobre los demás estratos. Quizá en el estrato textural "melódico" conformado por un sonido sintético percusivo $^{341}$ es donde se presenta una definición armónica algo más clara, pero ésta también consiste en una alternancia que se manifiesta sobre todo en la aparición de la nota $f a$.

\footnotetext{
${ }^{340}$ LFO - We Are Back (Warp) 1991. (1991). Subido por el usuario partyfreaks.net. Accesible en https://youtu.be/YYX1bH18WMo [20112016]

${ }^{341}$ Para clarificar la referencia: su timbre se asemeja al de una marimba ejecutada con baquetas duras.
} 
Para finalizar esta sección debemos agregar que la importancia dada a la altura en términos absolutos alcanza no solo a las piezas que hemos caracterizado de este modo sino que sus efectos también pueden apreciarse en aquéllas que presentan un tratamiento relativo de la cualidad. El cuidado que los productores ponen en determinar la región de frecuencias concreta donde sucede cada evento -en otras palabras, el interés por lo que llamáramos timbre total- se manifiesta en estos casos en la precisión que las piezas evidencian respecto de la ubicación registral y timbre de cada elemento y estrato incluido en la textura.

Tales cualidades se evidencian como trabajadas con gran nivel de detalle en, por ejemplo, el período de la oscilación que ciertos timbres presentan. ${ }^{342}$ En uno de los numerosísimos casos en los que se dedica a describir detalladamente el diseño sonoro (i.e.: diseño del timbre de un sonido), la microafinación y sus efectos, Snoman explicará que para lograr sonidos "burbujeantes" se debe proceder del siguiente modo:

Desafine uno de estos [osciladores del sintetizador] del otro entre +3 y +12 centésimas [de semitono] y luego configure la envolvente del filtro con un ataque medio, decaimiento largo, liberación media y sin sostenimiento. Haga lo mismo para la envolvente de amplitud pero use un sostenimiento alto y configure la envolvente de los filtros para que module positiva pero suavemente a un filtro pasa-bajos con una frecuencia de corte baja y alta resonancia. Finalmente, asegúrese que el seguimiento de nota del filtro se encuentra activado y module la afinación de uno o ambos osciladores con una forma de onda de ruido o [mediante la función] sample and hold. Esto debería inicialmente ser configurado rápido con profundidad [de modulación] total, pero vale la ${ }_{343}$ ena experimentar con la profundidad y velocidad para producir diferentes resultados.

Nótese la precisión respecto de la microafinación: el autor sugiere un rango de 9 cents y, además, elimina las diferencias de 1 y 2 cents. El resto del fragmento permite apreciar el grado de detalle necesario en la configuración de un sintetizador para conseguir un resultado tímbrico determinado. Lo mismo resulta válido para cada timbre que se pretenda conformar. Tómese en cuenta además que la cita incluida es apenas un fragmento de una explicación mucho más extensa.

El interés de los productores se evidencia en que una publicación como la citada dedica una parte sustancial de la misma a estas cuestiones. Por otra parte, puede comprobarse en el

\footnotetext{
${ }^{342}$ Incluso en aquellos índices y estilos caracterizados por su "crudeza" tímbrica (índices que, como el hardcore, se presentan como la expresión de emociones agresivas, violentas, críticas y, en cierto sentido, "feistas") el resultado se aprecia como "consecuencia derivada de trabajo y cuidado del detalle".

343 "Detune one of these from the other by +3 to +12 cents and then set the filter envelope to a medium attack with a long decay with a medium release and no sustain. Do the same for the amps EG but use a high sustain and set the filters envelope to positively but mildly modulate a low-pass filter with a low cutoff and a high resonance. Finally, ensure that filter key tracking is switched on and modulate the pitch of one, or both, of the oscillators with a noise or sample and hold waveform. This should initially be set quite fast will a full depth, but it's worth experimenting with the depth and speed to produce different results." Snoman, R. (2014). Op.cit. pp. 265
} 
diálogo directo con ellos y en las numerosas publicaciones periódicas que se editan en la materia. ${ }^{344}$

Finalizamos momentáneamente el tratamiento estético-técnico de la altura. Quedan pendientes algunas otras cuestiones que -como el comportamiento de pedal/repetición de una altura única o el uso cuasi-tonal de los registros- se encuentran muy extendidas en la especie. Volveremos a ellas, no sin antes analizar ciertos aspectos acústicos que se imponen como necesarios de observar.

\section{Diferencias de intensidad entre registros}

Exponer algunos de los valores objetivos de frecuencia e intensidad registrados durante nuestras experiencias de campo permitirá comprender con mayor profundidad la enorme influencia que la concepción espectral de altura y textura ha tenido y tiene sobre la estética de las músicas electrónicas utilizadas para el baile social. El cruce de estas informaciones con las cuestiones estéticas que tratáramos previamente y que trataremos a continuación nos será de utilidad también para apreciar el inmenso impacto que la concepción absoluta de esta cualidad musical consecuentemente genera sobre los bailarines y aficionados a la especie.

A los datos extraídos del análisis de los registros digitales de las piezas que se presentaron durante la realización de las experiencias de campo los consideramos un excelente modo de anclar el debate y las disquisiciones a un cuerpo de conocimientos que remiten a fenómenos acústicos concretos y determinados con precisión. Será apenas una descripción por generalización de algunos ejemplos concretos; sin embargo, aún cuando los valores varían de pieza en pieza, consideramos que el perfil general y a grandes rasgos que expondremos resulta una descripción de lo que sucede en la mayoría de las músicas electrónicas utilizadas para el baile social. ${ }^{345}$

En las músicas electrónicas utilizadas para el baile social la mayor cantidad de energía acústica se concentra en el registro grave y sub-grave. De hecho y como dijéramos en oportunidades previas, en relación a otras, las piezas pertenecientes a la especie suelen presentar en general mayores diferencias de intensidad en favor de este registro. En nuestras experiencias de campo pudimos registrar un conjunto de datos que permiten observar las diferencias concretas en valores objetivos:

a) La mayor concentración de energía acústica se ubicó aproximadamente entre los 35 y los $100 \mathrm{~Hz}$. Esta región de intensidades máximas presentó, en relación al resto del espectro, intensidades medias por sobre los $114 \mathrm{~dB}$ SPL (salvo en paradas) y picos

\footnotetext{
${ }^{344}$ Algunas revistas dedicadas a la creación musical con tecnología son Mix, Remix, DJ Mag, Future music y Computer music.

${ }^{345} \mathrm{O}$ al menos esto resultó así en los ejemplos que pacientemente recorriéramos a partir (y con el objetivo) de realizar nuestro estudio de géneros/índices y en nuestra recorrida por las noches electrónicas.
} 
recurrentes (en diferentes frecuencia según el momento y la pieza) de aproximadamente 124 dB SPL. Las intensidades máximas oscilaron entonces en el rango entre 114 y 124 dB SPL.

b) Frecuencias sónicas y sub-sónicas inferiores a los $35 \mathrm{~Hz}$ presentaron un nivel medio de alrededor de $102 \mathrm{~dB}$ SPL. Por momentos, oscilaciones en este registro sub-grave alcanzaron los 114 dB SPL. Entre otras, se registró una banda centrada aproximadamente en $15 \mathrm{~Hz}$ a (aproximadamente) $113 \mathrm{~dB}$ SPL. ${ }^{346}$

c) Los componentes superiores del espectro (mayores a $100 \mathrm{~Hz}$ ) se ubicaron alrededor de los 102 dB SPL o por debajo, alcanzando ocasionalmente intensidades del orden de los $114 \mathrm{~dB}$ SPL.

Además de los datos detallados debemos agregar que las intensidades descriptas (sobre todo) para los registros grave/sub-grave, por encontrarse asociadas casi con exclusividad al sonido de bombo y describir este en casi todo momento un patrón de bombo en negras, es una energía que describió en muchos momentos una oscilación/alternancia de intensidad a nivel de pulso. Este elemento textural resultó acompañado la mayor parte del tiempo por diversos sonidos de bajo, los cuales aportaron también componentes a esta zona del espectro y diversificaron la rítmica resultante. En registros superiores una multiplicidad de elementos y estratos texturales de diversas cualidades se alternaron, muchos de los cuales presentaron envolventes de intensidad percusivas. Resulta también destacable que ocurrieron especialmente pocas secuencias cuyas cualidades pudieran sugerir el establecimiento de oscilaciones/alternancias de intensidad (o el refuerzo de la establecida por el sonido de bombo).

La estética musical seleccionada por el deejay podría describirse como esencialmente perteneciente al índice techno; además, por la influencia de diversos factores presentó un carácter "duro" y "marcial". Los timbres seleccionados presentaron grados relativamente altos de iteración y componentes de ruido, y las envolventes de intensidad de las secciones rítmicas se caracterizaron por curvas pronunciadas (rápidas) de ataque y decaimiento. Esto provocó una preeminencia de timbres de percusión cargados de transitorios de ataques, cualidad que (al menos potencialmente) habilita a generar mayores presiones acústicas. En relación a otros eventos a los que asistimos, el patrón de bombo en negras resultó especialmente continuo y persistente y, en general, las rítmicas resultaron téticas y "regulares" ${ }^{347}$ En resumen, creemos que la estética de esa noche involucró también (parcialmente y en menor medida que al techno) al índice hardcore, lo que nos permite resumirla en hard techno.

\footnotetext{
${ }^{346}$ Espectrogramas, perfiles de intensidad y testimonios asociados a los momentos de ocurrencia de dichas frecuencias e intensidades pueden consultarse en nuestro Anexo I. Experiencia de campo.

${ }^{347}$ Utilizamos aquí el término "regular" en el sentido que le asigna Mark Butler. Para una comprensión más acertada al respecto de la rítmica se puede ver nuestro título dedicado a dicha temática incluido en el Anexo III.
} 
Volviendo al equilibro de intensidades entre diferentes registros, si bien (como dijéramos) no implicamos que el descripto sea un espectro tipo para la especie ni mucho menos, la mayor carga de energía sobre la región grave y sub-grave es una cualidad muy extendida en estas músicas (característica que puede corroborarse mediante la simple acción de observar las curvas que describe un espectrógrafo al analizar piezas de los diferentes índices). Nuestros registros sirven entonces para cuantificar lo expresado antes en términos subjetivos y otorgar valores concretos aproximados a las diferencias de intensidad observadas en numerosas oportunidades.

Las diferentes músicas que constituyen las electrónicas utilizadas para el baile social varían tanto en el uso que le dan a los registros como en las formas en que los ocupan. Sin embargo, contar con una referencia de valores concretos de presión acústica discriminados por frecuencias, originados en ejemplos de cualidades evidentes y explicitadas y en contexto de local de baile, nos permitirá estimar los valores plausibles de ser detectados en los entornos acústicos que cada una de aquellas pueden generar. Analizaremos entonces los modos en que cada zona del espectro de frecuencias se ocupa. Antes de pasar a ello sin embargo, debemos resolver ciertas divergencias detectadas con datos incluidos en fuentes secundarias.

\section{Frecuencias, intensidades y generación de sensación táctil}

En nuestras búsquedas por encontrar fuentes que dieran cuenta de las condiciones necesarias para la generación de sensación táctil nos cruzamos hace varios años con el ya citado trabajo de tesis de Pablo Kogan Musso Análisis de la Eficiencia de la Ponderación “A” para Evaluar Efectos del Ruido en el Ser Humano. Allí pudimos hallar, luego de largas e infructuosas pesquisas, valores concretos de frecuencias, intensidades y -en algunos casos- timbres asociados directamente con sensaciones táctiles de cualidades y localizaciones diferenciadas. Gracias a dicho trabajo pudimos finalmente aproximarnos a construir una idea acerca de las condiciones acústicas que posiblemente fueran necesarias para generar sensación táctil a partir de vibraciones transmitidas por vía aérea. Por años, estos fueron los únicos valores concretos respecto de dichas cualidades del sonido a los que pudimos acceder como referencia para esta cuestión.

Realizadas nuestras experiencias de campo durante la segunda mitad de 2015, contamos hoy finalmente con:

a) un registro de primera mano de los valores objetivos/físicos y cuantificados hallables en el estímulo,

b) valores que refieren además a un estímulo de mayor pertinencia para nuestros objetivos (musical) y donde todas las cualidades son conocidas y accesibles en su totalidad y 
c) con testimonios subjetivos/perceptuales acerca de sensación táctil i) originados en un estímulo pertinente (musical) y ii) plausibles de ser cruzados con los datos recabados acerca del estímulo.

Siendo uno de nuestros objetivos determinar las condiciones necesarias para la generación de sensación táctil a partir de vibraciones originadas en fenómenos musicales amplificados, pretendiendo poner doblemente a prueba nuestras experiencias y honrando la actitud y el método científicos, confrontaremos ahora los valores y testimonios obtenidos en nuestras experiencias con aquellos que se incluyen en el trabajo que por años fuera nuestra guía. Durante el $22^{\circ}$ Congreso Internacional de Acústica que se desarrollara en la ciudad de Buenos Aires entre los días 5 y 9 de septiembre de 2016, el investigador norteamericano Frank Russo expuso un resumen de los trabajos realizados por su laboratorio en el transcurso de una década. En el documento publicado y en otros precedentes que hemos podido hallar, demuestra la capacidad de reconocimiento táctil de diferencias tímbricas, ${ }^{348}$ ciertos modos en que la actividad cerebral "resuena" a partir de los ritmos presentes en la música, ${ }^{349}$ como también argumentos que se suman a los propios para explican la preeminencia del patrón de bombo en negras en músicas de baile. ${ }^{350}$ Trabajos centrales para nuestros objetivos, mediante la realización de una gran cantidad de pruebas Russo ha dado respuesta a un conjunto de problemas que de otro modo hubiéramos tenido que responder por nosotros mismos. Desde una perspectiva puramente acústica nos libera entonces de una fase inicial y nos permite pasar a la siguiente, que incorpora tanto cuestiones de acústica musical como estéticas.

Los valores de frecuencia e intensidad registrados durante nuestras experiencias de campo son coincidentes con muchos de los datos documentados en fuentes secundarias que remiten a la presencia de sensación táctil citadas en la tesis doctoral de Kogan Musso. Sin embargo, ciertas divergencias no pueden ser pasadas por alto; sobre todo cuando éstas consisten en amplias diferencias de intensidad en los estímulos. Bajo la categoría de efectos fisiológicos no auditivos, el autor explicita que:

\footnotetext{
Las vibraciones del tórax y el abdomen, en general, están situadas entre $40 \mathrm{~Hz}$ y $60 \mathrm{~Hz}$ y han podido ser medidas a partir de los $105 \mathrm{~dB}$. En el rango infrasónico entre $4 \mathrm{~Hz}$ y 20 $\mathrm{Hz}$ las vibraciones en pecho y abdomen comienzan a ser perceptibles a partir de los 132 dB (Johnson, 1982). ${ }^{351}$
}

\footnotetext{
${ }^{348}$ Russo, F. A. y otros. (2012). "Vibrotactile Discrimination of Musical Timbre". Artículo breve.

349 Russo, F. A. (2016b). "Understanding music perception from the perspective of oscillation and resonance." Artículo breve.

${ }^{350}$ Russo, F. A. y otros. (2016a). "Synchronizing to auditory and tactile metronomes: a test of the auditory-motor enhancement hypothesis". Artículo breve.

${ }^{351}$ Kogan Musso, P. (2004). Op. cit. pp.105
} 
Además de los aquí citados, en su trabajo Kogan Musso indica otros estímulos de diferentes frecuencias como generadores de sensación táctil. ${ }^{352}$ En dichos casos las intensidades documentadas se encuentra alrededor de los 128-150 dB o mayores; en otras palabras, sustancialmente mayores que las registradas en nuestros trabajos de campo. A pesar de esta gran diferencia, los sujetos experimentales que participaron de nuestras experiencias manifestaron detectar sensación táctil en múltiples localizaciones corporales, muchas coincidentes con las incluidas en el trabajo de Kogan Musso. ${ }^{353}$

La totalidad de los miembros del equipo técnico de apoyo dio cuenta de lo evidente que resultó dicha sensación durante la realización de la experiencia. Ésta se tornó por momentos tan intensa que fue caracterizada como vibración de todo el cuerpo por la totalidad de los sujetos experimentales y equipo técnico.

Transcurrida aproximadamente una hora de iniciada la experiencia, la sujeto experimental B expresó su deseo de marcharse, deseo motivado por el displacer que la sensación táctil le provocaba. Consultada al respecto respondió que se sentía "invadida" por la vibración (i.e.: por la sensación táctil) y que la intensidad de la misma se había tornado molesta al extremo. Denotando además en su tono y expresión facial una evidente incomodidad, expresó que la misma había superado su umbral de tolerancia. Dicha incomodidad refería a la sensación táctil y no al sonido, ya que la sujeto estaba utilizando protectores auditivos de muy buena calidad.

Es posible suponer que las discrepancias tienen origen en las numerosas diferencias entre estímulos. En los trabajos relevados por Kogan Musso se utilizaron tonos puros (i.e.: sinusoides) o ruidos de banda estrecha aislados, por lo que los sujetos experimentales resultaron expuestos a la energía acústica originada en vibraciones concentradas en una única frecuencia o banda de frecuencias. En nuestras experiencias de campo en cambio, el estímulo fue musical y complejo, presentando energía acústica -y entregándola al cuerpo de los sujetos experimentalesen todo el espectro de frecuencias audible e inaudible.

Esta primera diferencia resulta esencial desde que la energía acústica, distribuida en diferentes registros según la serie de armónicos naturales y manteniendo relaciones armónicas simples, repercute reforzando a la frecuencia o registro que se corresponde con la fundamental (o $1^{\circ}$ armónico) de dicha serie. En otras palabras, la energía acústica "faltante" en nuestra experiencia podría comprenderse como distribuida en otras regiones del espectro, lo que permitiría su "restitución" (por los principios acústicos mencionados) como refuerzo de los eventos ocurriendo en el registro grave, por los que se desarrollan en registros superiores.

\footnotetext{
${ }^{352}$ Como fuera mencionado con anterioridad, el autor indica al rango -coincidente con nuestros registroscomprendido entre los 4 y los $100 \mathrm{~Hz}$ como las frecuencias de los estímulos a partir de los que se documentó generación de sensación táctil. Kogan Musso, P. (2004). Op. cit. pp.105

${ }^{353}$ Para más detalles, véase nuestro Anexo I. Experiencia de campo.
} 
Por otra parte, la detección de sensación táctil evidente y a niveles menores a los documentados para frecuencias aisladas, apoya un argumento que expusiéramos en trabajos previos y que aquí aún no hemos mencionado: de encontrarse en relación armónica simple, es razonable suponer que diferentes oscilaciones simultáneas de frecuencias diferentes generadoras cada una de sensación táctil por sí mismas (i.e.: aisladas y en solitario)- podrían reforzarse mutuamente, dando como resultado una sensación táctil emergente de mayor intensidad que la suma de ambas. En el "Estado del arte" de nuestro Plan de tesis sintetizamos ciertos resultados detectados en fuentes secundarias que avalan nuestros dichos:

\begin{abstract}
Sujetos expuestos a la vibración de dos sinusoides simultáneas de 10 y $8 \mathrm{~Hz}$, fueron más sensibles al estímulo que cuando se les presentaron las dos ondas de modo independiente. "La explicación probablemente puede ser encontrada en el fenómeno de batimento"... "Las señales sumadas de 8 y $10 \mathrm{~Hz}$ se repiten cada 0.5 s, i.e.: con una frecuencia de $2 \mathrm{~Hz}$. La sensibilidad debida a la contribución de los $2 \mathrm{~Hz}$ combinada con el incremento de la amplitud de picos hace fácil la detección de la vibración." [Ljunggren y/o, 2007; véase también Levänen y Hamdorf, op.cit.]. ${ }^{354}$
\end{abstract}

Debemos mencionar aún un tercer (cuarto y quinto) argumento que podría haber repercutido incrementando la intensidad percibida de la sensación táctil durante nuestras experiencias de campo.

En primer término, sin posibilidad de ocurrencia en las oscilaciones aisladas que conformaron los estímulos de las fuentes documentales incluidas en el trabajo de Kogan Musso, las oscilaciones/alternancias de intensidad presentes en la forma de onda musical compleja que constituyó nuestro estímulo promovieron la generación de sensación táctil sin incrementar las intensidades registradas en el grabador de sonido digital.

Luego, de ocurrir varias oscilaciones/alternancias de intensidad simultáneamente -algo que a nivel de pulso/de la (sub-)división resulta más que probable en la mayoría de las altamente repetitivas piezas presentadas durante la experiencia- debe considerarse el argumento expuesto en nuestra cita precedente, el cual es también aplicable para estas vibraciones "especiales": es posible suponer que diferentes oscilaciones/alternancias de intensidad simultáneas sean más eficaces para la generación de sensación táctil que cuando cada una se presenta aislada.

Por último, de encontrarse dichas oscilaciones/alternancias de intensidad en relación armónica simple -nuevamente, una relación muy probable dada la estética musical que se presentara en el evento asistido- el fenómeno de refuerzo armónico puede ocurrir también entre oscilaciones/alternancias de intensidad, tornándose aún otro factor de refuerzo de la sensación táctil.

354 Anzil, I. (2010a). Iván Anzil - Propuesta de tema y plan de tesis. pp. 2 Los trabajos citados son iLjunggren, F., Wang, J. y Ågren, A. (2007). Op.cit. pp.13-24 y Levänen, S. y ii- Hamdorf, D. (2001). Op.cit. pp.75-77 
En síntesis, son muchas y muy diversas las razones que apuntan a que las intensidades documentadas en fuentes secundarias, en tanto umbrales mínimos necesarios de alcanzar en los estímulos para que estos generen sensación táctil, podrían encontrarse sobreestimadas. Las razones expuestas parecen indicar que esta sobreestimación, derivada de una exploración de la sensación táctil a partir de estímulos simples y limitados en registro, dificulta su aplicación directa en casos donde el estímulo es una forma de onda musical periódica, compleja y extendida espectralmente.

Creyendo encontrarnos frente a una respuesta posible para una de nuestras hipótesis, intentaremos una síntesis -en la forma de postulado- de los argumentos expuestos. Creemos que, en el mismo acto, expandiremos incluso los alcances de nuestra hipótesis. Consideramos entonces que los indicios expuestos son suficientes para afirmar que:

En locales de baile donde se presentan músicas electrónicas utilizadas para el baile social, ciertas conformaciones acústicas particulares -usuales en dichas expresiones estéticas- determinan que los umbrales de intensidad mínimos que en cada frecuencia o banda de frecuencias deben alcanzarse para generar sensación táctil son menores a los requeridos cuando la generación de dicha sensación se procura a partir de la misma frecuencia o banda de frecuencias aisladas (en laboratorio se utilizan estímulos sinusoidales o de banda angosta, con transición suave).

Esto resulta así debido a que:

La interferencia y refuerzo mutuo que acontece entre los diferentes componentes espectrales que constituyen el estímulo vibratorio musical complejo (i.e.: la pieza de música electrónica utilizada para el baile social completa en un fragmento determinado) modifican las sensaciones táctiles que cada componente espectral es capaz de generar en soledad, amplificándolas más allá de su suma, sobre todo si los registros o componentes simultáneos poseen la misma fase.

Si bien puede parecer una especulación aventurada, recordamos que basamos nuestra aseveración en una serie de argumentos que se desarrollaron para explicar las discrepancias entre intensidades elevadas (detectadas en fuentes secundarias) y una intensa sensación táctil experimentada por la totalidad de los sujetos experimentales y el equipo técnico; experiencia que en un caso superó el umbral de tolerancia de una sujeto experimental. 
Para concluir esta especie de paréntesis nos resta aún resolver algunos conflictos que quizá quedaron enmascarados por las diferentes aristas que el tema tratado presenta. Para ello debemos retornar a uno de los primeros argumentos que expusiéramos como defensa de nuestra experiencia y hacer notar que, como puede extraerse por deducción lógica de la contraposición de nuestros resultados con los relevados por Kogan Musso, de encontrarse los elementos en diferentes registros en relación armónica simple:

los elementos texturales localizados en regiones medias y superiores podrían jugar el rol de refuerzo armónico, entregando energía a la frecuencia fundamental correspondiente -en fase- y contribuyendo así a la generación de sensación táctil a partir de frecuencias graves/sub-graves.

A pesar de lo que pudiera parecer, contrariamente a los diferentes prejuicios (propios y ajenos) con que nos enfrentamos durante los años que llevamos investigando este tema, encontramos aquí un argumento que vuelve relevantes las conformaciones concretas que acaecen en los mencionados registros medio y superiores. En numerosas oportunidades surgieron referencias al registro grave y sub-grave como las frecuencias responsables de la generación de sensación táctil; si bien acordamos en términos generales con que esta es la zona espectral donde debe colocarse el foco principal del estudio, vimos aquí y en títulos precedentes que elementos que se considerarían "por fuera" de dicha zona podrían tener una mayor incidencia que la sospechada y, quizá de forma indirecta, aportarían al menos parte de su energía acústica a las zonas inferiores del espectro. En otras palabras, asumiendo una perspectiva acústica más conservadora podríamos explicar la diferencia entre las intensidades de Kogan Musso y las nuestras a partir del concepto tradicional de refuerzo armónico.

Consideramos entonces necesario exponer posibles variantes a las conclusiones previamente expuestas. Redirigiendo su foco hacia las frecuencias graves y sub-graves, las nuevas versiones ofrecen un anclaje más próximo a la acústica tradicional resultando como siguen:

En locales de baile donde se presentan músicas electrónicas utilizadas para el baile social, ciertas conformaciones acústicas particulares -usuales en dichas expresiones estéticas- determinan que los umbrales de intensidad mínimos que en frecuencias o bandas de frecuencias graves/sub-graves deben alcanzarse para generar sensación táctil, son menores a los requeridos cuando la generación de dicha sensación se procura a partir de la misma frecuencia o banda de frecuencias aislada y con transición suave. 
Y la renovada versión de las causas del fenómeno resulta:

La interferencia y refuerzo que acontece entre los diferentes componentes espectrales que constituyen el estímulo vibratorio musical complejo modifica las sensaciones táctiles que cada componente espectral grave/sub-grave es capaz de generar en soledad, amplificándolos más allá de su suma.

Luego de las razones expuestas creemos no equivocarnos al suponer que lo que en definitiva ocurre es una mixtura y coexistencia simultánea de ambos principios. En lo que refiere a la generación de sensación táctil tanto sucede el refuerzo armónico tradicional (i.e.: donde las frecuencias superiores ceden parte de su energía a las graves/sub-graves) como el refuerzo mutuo (donde las frecuencias que generan sensación táctil, sean estas oscilaciones de primer orden u oscilaciones/alternancias de intensidad, refuerzan mutuamente el aspecto táctil del estímulo). Para el segundo caso, independientemente del registro en que cada frecuencia generadora de sensación táctil acontezca, el hecho mismo de estimular los múltiples sensores táctiles y hápticos del sistema nervioso podría sensibilizar al sistema como todo. Ésta resulta una posible línea a explorar a futuro en la dirección iniciada por Russo. ${ }^{355}$

Independientemente de esta última cuestión, vemos fundamentada la extrema utilidad que presenta la realización de un relevamiento de las conformaciones típicas que en cada registro se presentan en la especie; relevamiento que, siguiendo las dos lógicas expuestas, procure detectar aquellas conformaciones que pudieran contribuir con mayor eficacia a la generación de sensación táctil. Como puede suponerse, será necesario cruzar datos físicos (acústicos) con cualidades estéticas (musicales).

\section{Usos asignados a los registros}

Como sucediera en otras músicas históricas, las conformaciones y funciones que se destinan a cada registro de frecuencias presentan -según el caso- ciertas diferencias entre sí. Las músicas electrónicas utilizadas para el baile social han heredado esta circunstancial diferenciación según la cual, a modo de ejemplo, los sonidos en el registro grave presentan aunque a veces solo en apariencia- cualidades asociadas al cumplimiento de la función de estabilización tonal. En otras palabras, aún cuando -como viéramos- un subgrupo importante de piezas en la especie puede caracterizarse como atonal, el o los sonidos de bajo describen conformaciones similares a las hallables en piezas del período tonal. Esta característica no se limita al registro grave y en numerosas oportunidades y piezas es posible encontrar conformaciones de este tipo en otros registros, en estratos texturales que puede ser descriptos

\footnotetext{
${ }^{355}$ Ver por ejemplo Russo, F. A., Ammirante, P. y Fels, D. I. (2012). Op.cit.
} 
como acompañamientos o ripienos armónicos (que pueden presentarse como arpegios al estilo de bajos alberti), melodías, contramelodías y demás categorías tradicionales.

En otras oportunidades en cambio, la utilización de la altura evidencia tratamientos derivados de estéticas más próximas en el tiempo, donde el grado de integración con las demás cualidades del sonido suele ser mayor y donde las conformaciones -vistas desde la perspectiva de esta cualidad- denotan un interés focalizado más sobre la cualidad tímbrica (entiéndase: en tanto cualidad totalizadora de alturas, duraciones y sonoridades). Consecuentemente, es usual que el tratamiento de los registros se caracterice también por una mayor integración, por lo que las funciones y/o conformaciones asignadas a cada uno contendrán menos o nulas diferencias o particularidades. En estos contextos las prestaciones que sintetizadores y samplers ofrecen pueden y suelen ser mejor y más extensamente aprovechadas, configurando en numerosas oportunidades elementos y estratos texturales imposibles de concretar con instrumental acústico. En otras palabras, en estas ocasiones se evidencia la influencia que sobre la especie tiene la música electroacústica. Texturas de puntos, texturas de masas, nubes sonoras y las transformaciones radicales que describiéramos en títulos precedentes son parte del repertorio de recursos disponibles a partir de estas estéticas.

Así también, como parte del tratamiento integrado de los registros es posible encontrar versiones actualizadas de texturas históricas y tradicionales. Recurriendo nuevamente a un ejemplo que seleccionáramos por su riqueza para el análisis, este es el caso de Nevermind de Infected Mushrooms: sugerimos ahora una nueva escucha durante la cual focalizar la atención sobre los cambios constantes que (casi) ataque a ataque presentan la distribución registral y el timbre, cualidades que inciden directa o indirectamente sobre la altura. Por secciones, todos los elementos texturales ceden parte de su independencia y participan del desarrollo melódicorítmico, el cual abarca todo el registro y todas las variables y cualidades musicales. Alturas tonales definidas aisladas, acordes, ataques de sonidos-instrumentos de percusión de altura tonal no definida, sonidos lisos e iterados, agudos, medios y graves... absolutamente todos los elementos texturales intervienen (al menos circunstancialmente) en las numerosas variaciones de una melodía que, consecuentemente, adquiere propiedades semejantes a una melodía de timbres (i.e.: "klangfarbenmelodie") extendida por todos los registros, tratados indiferenciadamente.

Una posible síntesis de los usos de los registros hallables en la especie quizá pueda realizarse a partir de los siguientes ejes difusos de análisis:

a) Preponderancia o equilibrio de tratamientos absolutos o relativos de la altura.

b) Uso integrado o diferenciado de los registros de frecuencias.

c) Preponderancia o equilibrio de sonidos de altura tonal definida, de tonicidad débil o de altura tonal indefinida. 
d) Preponderancia o equilibrio de alturas fijas o alturas móviles.

e) Presencia o ausencia de categorías texturales heredadas de tradiciones musicales históricas.

f) Características de las categorías texturales heredadas y vínculos con el contexto concreto que la pieza bajo análisis presenta.

Los valores que asuman unas y otras categorías de análisis y la interrelación entre ellas permite la caracterización del modo en que se ocupa el espectro de frecuencias completo, ofreciendo incluso una descripción parcial de la textura. Hemos explorado ya en profundidad los dos primeros, y los dos últimos no acarrean novedad relevante que no fuera tratada con anterioridad por otros autores. ${ }^{356}$ Relegando por el momento el análisis concreto del apartado $c$, consideraremos primero algunas cuestiones aún no revisadas relativas a la movilidad o invariancia de las alturas.

El eje alturas fijas-alturas móviles resulta hasta cierto punto un paso previo a (i.e.: una de las propiedades que permite parcialmente) la determinación de la presencia o ausencia de categorías texturales heredadas. Como viéramos, durante siglos (y aún hoy en numerosos casos) conformaciones basadas principalmente en cambios de la cualidad altura fueron las responsables de albergar parte del sentido musical. No resulta extraño entonces que su invariancia (como toda persistencia en general) provoque un gran impacto sobre las propiedades musicales generales, al punto de cuestionar la aplicabilidad de categorías de análisis musical tradicionales. En este marco, el recorte que hemos denominado "alturas móviles" -cuyo sentido quizá resultara oscurecido por la denominación- consiste simplemente en conformaciones que derivan del tratamiento relacional o mixto de la altura como melodías o secuencias armónicas de diversas cualidades y provenientes de diferentes tradiciones musicales. Contemplando a aquéllas que involucran sonidos de altura tonal no definida, incluimos también en esta categoría a las melodías de timbres recientemente mencionadas.

Mientras tanto, configuraciones basadas en alturas fijas o invariantes alcanzan -desde la perspectiva tradicional- a la ocurrencia de pedales sobre alturas reiteradas y -desde la espectralse relacionan hasta cierto punto con la estabilización de objetos sonoros. Hemos debatido también este punto y las formas en que la neutralización de la altura, en tanto cualidad motorizadora del devenir musical, conspira contra el establecimiento de la temporalidad lineal. Sin embargo esta aparente desventaja, la reiteración presenta como contrapartida una virtud: dependiendo además de otras variables, la repetición de una única altura involucra la posibilidad de generar sensación táctil. Por involucrar otras complejidades relegaremos nuevamente el

\footnotetext{
356 Véase por ejemplo Fessel, P. (1996). Hacia una caracterización formal del concepto de textura. pp.75-93. El autor ha tratado extensamente el tema.
} 
tratamiento de este tema particular; revisar previamente otros aspectos de la altura permitirá una comprensión más profunda del tema.

Según el grado concreto de movilidad en altura que cada caso presente, las pseudo- (o proto-) melodias, armonías y elementos armónico-texturales (que incluyéramos como categorías asociadas al tratamiento mixto relativo-absoluto de la altura) se establecen como los elementos intermedios entre uno y otro caso extremo (i.e.: entre alturas fijas y móviles). Como en los demás casos de tratamientos mixtos, las cualidades particulares determinarán en cada caso el modo en que se interpreten estas conformaciones. En otras palabras, si cada conformación concreta presenta alguna tendencia que promueve el establecimiento de una temporalidad lineal o cíclica/suspendida.

En otro orden de cosas, la inclusión en el análisis de un factor surgido en el seno de la especie pondrá de manifiesto un fenómeno (evidente para los integrantes de la comunidad electrónica) que no ha recibido la atención suficiente por parte de la comunidad académica. Esto es: ciertos comportamientos heredados de músicas pasadas se ven atravesados íntimamente por la extensión registral y en intensidad que los sistemas de amplificación posibilitaran, resultando en una transposición de sus cualidades hacia nuevos aspectos de la música; dicha traslación oscurece la presencia de la mencionada herencia, dificultando su detección.

Como comentáramos, los aconteceres acústicos que presentan y hacen uso prolífico de las extensiones registral (esencialmente hacia el registro grave/sub-grave) y en intensidad involucran la generación de sensación táctil. La inclusión de este factor al interior de la música electrónica de baile ha provocado que las relaciones de tensión/distensión tonales pierdan (al menos parte de) su vinculación con frecuencias y escalísticas concretas y se vuelvan, por el contrario, registro-dependientes. Subvirtiendo la raíz misma del sistema tonal, la transformación experimentada por los comportamientos en cuestión permite su descripción en tanto versión audiotáctil de las relaciones de tensión/distensión tonales.

La influencia de este comportamiento se extiende a un gran número de piezas de la especie y excede al grupo que presenta cualidades heredadas del período tonal, pudiendo incluso considerársela como -al menos una- razón de la jerarquización por intensidad que el registro grave/sub-grave presenta en relación a los demás. Por considerarlo central para la comprensión del tema que nos ocupa aquí, en nuestro análisis de los tratamientos diferenciados que cada registro recibe nos ocuparemos en primer término de esta característica. Por otra parte, el mismo nos será de extrema utilidad al momento de analizar las diferentes rítmicas que se incluyen en la especie; cualidad estética que, junto con las que nos encontramos analizando ahora, constituye quizá el centro y corazón de la vinculación entre el estímulo musical y la sensación táctil. 


\section{Función cuasi-tonal de los registros grave-agudo}

La relevancia de los diferentes registros extremos en la música electrónica de baile se evidencia -entre otros- en el hecho de que el grave/sub-grave se ha vuelto el registro de referencia, aquel que presenta actividad en los momentos "regulares" y "comunes". La presencia de elementos en este registro ${ }^{357}$ es para los aficionados a la especie sinónimo de movimiento y convocatoria al baile. Tanto es así que sólo luego de que una pieza presenta elementos graves/sub-graves los bailarines consideran que la textura de la misma tiene el suficiente grado de completitud como para justificar movimientos de danza definidos y decididos. La ausencia de actividad en este registro suscita, como hemos visto, actitudes y movimientos dubitativos y expectantes.

Hasta cierto punto, la región grave/sub-grave del espectro presenta características similares y puede ser comprendida como la función de tónica en el sistema tonal: de forma análoga al rol de reposo que dicha función cumple allí, elementos en el registro grave/sub-grave convocan en la música electrónica de baile a bailar despreocupadamente y con ánimo relajado. Complementariamente, el extremo agudo y sobre-agudo se encuentra asociado (la mayoría de las veces) con la generación de tensión. Como viéramos en el fragmento analizado de la pieza de Infected Mushrooms, elevadas intensidades en dicha zona del espectro suelen alcanzarse paulatinamente, durante pasajes musicales que construyen expectativa a partir (también) del incremento en la densidad cronométrica y en la frecuencia de los sonidos que se incluyen.

El comportamiento descripto se inscribe como uno de los tratamientos relativos de la altura, constituyéndose en la sublimación de una función relacional que, asignada en tiempos pretéritos a alturas tonales precisas (i.e.: la tónica de la escala), se traslada aquí hacia registros completos. Sin embargo, esta característica refuerza los argumentos que expusiéramos respecto del tratamiento absoluto de la cualidad al transferir la mencionada función, desde frecuencias precisas y discretas, hacia bandas de frecuencias solo parcialmente definidas, difusas y continuas. En síntesis, la altura aquí recibe un tratamiento mixto, donde ciertos comportamientos que denotan concepciones relativas se aplican a cualidades absolutas.

Estos argumentos se ver reforzados por el hecho de que, en numerosas ocasiones, los sonidos que en los momentos de tensión ascienden en registro, presentan un timbre que consiste en (o se asemeja a) ruido blanco. En otros casos, sonidos de cualidades tímbricas similares a las mencionadas se suman a la textura previa y acompañan -con un proceso igual o similar- el incremento en frecuencia de los elementos y estratos texturales preexistentes. Conformado idealmente por todas las frecuencias a igual intensidad estadística y correspondiéndose consecuentemente con el paradigma por antonomasia de la altura tonal no definida, el ruido blanco es interpretado por la comunidad electrónica como la "suma de todas las tensiones".

357 Especialmente del sonido de bombo; razón que -como viéramos- condujo a varios autores a caracterizarlo como el "motor" de estas músicas. 
En numerosas ocasiones hemos sido testigos directos de que los niveles de intensidad que alcanzan estos sonidos y pasajes de tensión superan el umbral del dolor del sistema auditivo. Desde un punto de vista (o mejor, escucha) acústico, resulta posible decir entonces que hay una búsqueda, quizá inconsciente, de equilibrar durante estos pasajes las diferencias de intensidad que en la especie se inclinan en favor del grave/sub-grave. Esta característica podría constituir otro argumento que soporte la identificación respectiva de los registros grave y agudo con las funciones de reposo-tónica y tensión-dominante.

Por supuesto, resulta de suma relevancia en esta cuestión particular que el registro asociado a la situación de reposo sea aquel que promueve el movimiento y el baile. Claro que, tratándose de música dirigida al baile, resultaría muy extraño que esto no fuera así; sin embargo, encontramos aquí una nueva vinculación entre música y danza que merece ponerse de relieve:

Los registros grave/sub-grave han sido y son asociados a la situación de reposo y se interpretan como los principales "momentos destinados al baile" debido principalmente a que la sensación táctil que dicho registro generan estimula y promueve al movimiento y el baile.

O también, especular y dialécticamente:

Por su capacidad de estimular y promover el movimiento y el baile, la sensación táctil ha generado que los fragmentos musicales con presencia de actividad en el registro grave/sub-grave se interpreten en la comunidad electrónica como "momentos destinados al baile".

La sensación táctil ha sido y es un factor central en la determinación de las formas que ha asumido y asume la música electrónica de baile, y este es hoy uno de los principales aportes que dicha especie hace a las músicas electrónicas utilizadas para el baile social. Pasemos ahora a recorrer las -consecuentes- formas en que los productores ocupan los diferentes registros de frecuencias, más allá de la incidencia concreta que cada una pueda tener sobre dicha sensación.

\section{Tratamiento diferenciado de los registros. Registro grave/sub-grave}

Una parte relevante de la identidad particular de muchas piezas en las músicas electrónicas utilizadas para el baile social deriva de las cualidades, los modos de uso y los roles que se le asignan al registro grave/sub-grave en cada caso concreto. Dependiendo de diversos factores que se manifiestan en esta zona del espectro, y de la incidencia que diferentes conformaciones tienen sobre la dimensión corporal de los aficionados a la especie (i.e.: a las cualidades diversas que, dependientes de las conformaciones sono-musicales, asume la 
sensación táctil generada), piezas de un mismo o diferente índice presentarán caracteres que propiciarán su mutua asociación o segregación.

Algunos de estos factores resultan también relevantes en la diferenciación entre índices. Siendo (como dijéramos) la zona espectral que presenta la mayor intensidad objetiva y a la que se le asigna la mayor importancia, algunas conformaciones que ocurren aquí -y sus cualidadesadquieren una relevancia central para el establecimiento de la identidad de algunos índices y para su diferenciación de los demás. ${ }^{358}$ Veamos entonces algunos modos en los que dichas conformaciones diferencian a unas piezas de otras y a unos índices de otros, sin olvidar que nos encontramos analizando la región del espectro que (como mencionáramos en el título precedente) provoca la sensación táctil más evidente. ${ }^{359}$

a) Diferenciación basada en simple jerarquización por diferencias de intensidad La primera diferencia consiste en que algunos índices y/o piezas presentan mayor diferencia de intensidad (que otros) entre el registro grave/sub-grave y los registros más agudos. Si bien todos los índices -en general- jerarquizan por sobre los demás al registro grave/sub-grave, algunos de éstos y algunas piezas ponen mayor énfasis que otros sobre esta diferencia. Hallamos dos formas en que se alcanza la jerarquización mencionada:

a) en la mayoría de las piezas de algunos índices, las diferencias de intensidad (siempre en favor del registro grave/sub-grave) son simplemente mayores $\mathrm{y}$, b) en algunos índices, la diferencia relativa de intensidad se explicita más que en otros debido a una mayor presencia estadística de elementos texturales en el registro grave/sub-grave (i.e.: en estos índices el registro grave/sub-grave es utilizado más tiempo estadístico, llamando la atención sobre la diferencia de intensidad durante más tiempo, más persistentemente).

Esquemáticamente descriptos, el deep house presenta graves/sub-graves con mayor intensidad que el chiptune, mientras que el techno suele presentar mayor cantidad de elementos y con presencia más continuada (en el registro grave/sub-grave) que muchos ejemplos de drum'n'bass.

\footnotetext{
${ }^{358}$ Por supuesto, nos expresamos aquí en términos generales y no negamos la existencia de numerosos ejemplos que presentan cualidades diferentes a las enunciadas. Los argumentos expuestos y los por venir deben ser comprendidos a modo orientativo.

${ }^{359}$ Enlazado íntimamente con cuestiones tímbricas y texturales, nos limitaremos aquí a describir aquellas cuestiones que no se apartan demasiado del tratamiento específico de la altura en tanto cualidad del sonido. En otras palabras, siempre que sea posible dejaremos para más adelante aquellas propiedades que se derivan del trabajo sobre esta propiedad con fines estéticos. Téngase presente entonces que las propiedades completas de las conformaciones que pueden incluirse en cada registro se describirán con el transcurrir de cada tema y en interrelación con los demás.
} 
b) Diferenciación en las conformaciones rítmicas graves/sub-graves

Aquí encontramos una diferenciación que incide más claramente sobre la identidad de diferentes índices. Mientras unos entregan constantemente energía en esta región del espectro, otros la esparcen en períodos mayores, alternando momentos que presentan elementos en dicho registro con otros de nulo o escaso contenido grave/sub-grave.

Ejemplos de uno y otro caso respectivamente encontramos en los índices trance y dubstep. Esquemáticamente descripto, es usual que en el primero bombo y bajo entreguen energía grave/sub-grave en los valores breves y constantemente reiterados del patrón de bombo en negras (bombo) y en la corchea a contratiempo (bajo). En el segundo, el registro grave/sub-grave se hace presente en ataques espaciados del bajo (usualmente coincidentes con el comienzo del compás y de duración igual a un tiempo) que se alternan con períodos en los cuales el contenido espectral se compone primordial o totalmente de frecuencias en registros superiores. En este último índice el bombo suele contener muchas menos frecuencias graves, presentando un timbre mucho más "liviano".

Con mayor o menor grado de regularidad en la aparición del registro grave/sub-grave, los índices basados en samples de breakbeats establecen a través de sus ritmos sincopados $^{360}$ diferentes grados de inestabilidad, conflicto y tensión. La inclusión de ritmos difíciles de prever en los graves/sub-graves de este índice (fenómeno usual en el drum'n'bass) genera expectativa e invita al intento (destinado al fracaso) de sincronizar el baile con la ocurrencia de ataques en dicho registro. Aunque en este caso mediante el desvío, también en este índice los productores recurren a la asociación del registro grave/sub-grave con un reposo análogo al generado por la tónica en el sistema tonal: la imposibilidad de prever los momentos de ocurrencia de eventos en dicho registro provoca el efecto de tensión. ${ }^{361}$

c) Diferenciación por el instrumental asociado al registro grave/sub-grave

En tercer término, mientras unas piezas suelen destinar dicho registro a componentes contenidos en el sonido de bombo, otras le quitan el peso a éste y se lo asignan a sonidos de bajo o a otros elementos o estratos texturales. Sin corresponderse con índices concretos, esta característica puede incluso modificarse en el transcurso de una misma

\footnotetext{
${ }^{360}$ Samples de breakbeats: fragmentos de pocos compases donde solo suena la batería realizando rítmicas sincopadas. Usualmente extraídos de piezas del género disco o funk, su nombre deriva de que en las comunidades asociadas a dichos compases se los llamó y llama "breaks" (i.e.: "cortes"). Para detalles respecto de los índices mencionados y de este y otros tipos rítmicos ver el Anexo III.

${ }^{361}$ Este factor se suma y refuerza a un aspecto que observaremos cuando tratemos las cualidades rítmicas de la especie. En el Anexo III pondremos en evidencia la asociación existente entre el registro grave/subgrave (en particular el sonido de bombo) y las sensaciones de "a tierra" y de "apoyo".
} 
pieza por lo que creemos ver aquí una búsqueda (consciente o inconsciente) de los productores de generar sensaciones (¿táctiles quizá?) diferenciadas.

Algunos ejemplos posibles de elementos que suelen ocupar la región grave/sub-grave del espectro son: bombos de duración corta -y por consiguiente con menor definición de su altura tonal- pero que generan literalmente gran impacto (i.e.: sensación táctil), bombos o bajos con tiempos de decaimiento largos (llamados no pocas veces "resonantes" por analogía con instrumentos acústicos), percusiones graves (con iguales tiempos de decaimiento) que glissan hacia frecuencias aún más graves y transitorios de ataque de componentes texturales de regiones más agudas.

\section{Tratamiento diferenciado de los registros. Registros medio, agudo y sobre-agudo}

Más allá de las peculiaridades que describiéramos para el registro grave/sub-grave y de la oposición grave/agudo como -respectivamente- registros asociados a la generación de reposo/tensión, el uso dado a los registros superiores no presenta características de mayor relevancia; destinados como en otras músicas a la presentación de melodías, rellenos armónicos, arpegios, secuencias, texturas de puntos o de masas, drones, voces habladas o cantadas y demás posibilidades texturales ya tratadas, no ofrecen novedad digna de mención respecto del tratamiento de la cualidad altura.

A pesar de lo dicho, una cuestión que analizáramos desde otro punto de vista y que aquí quizá sí valga la pena recordar -como forma de reafirmar ciertos comportamientos novedosos ya expuestos aplicados sobre la altura- consiste en la plasticidad y fluidez entre registros derivadas de las prestaciones que los dispositivos tecnológicos ofrecen. La capacidad de transformación tímbrica extrema que sintetizadores y samplers poseen origina que las funciones tradicionalmente asociadas a diferentes registros resulten -al menos parcialmente- inaplicables para muchos sonidos-instrumentos utilizados en la especie. Contrariamente a lo que ocurre en otras músicas, la diferencia instrumental que presentan las músicas electrónicas utilizadas para el baile social consiste en que es muy sencillo transformar el timbre de un elemento textural, al punto de que su localización en el registro se modifique sustancialmente. Consecuentemente, las funciones instrumentales y/o texturales (de entre las cuales algunas se encuentran necesaria y tradicionalmente) asociadas a registros específicos se desvinculan de la "necesidad" de dicha asociación. Tomando esta característica en consideración, categorías texturales tradicionales como línea de bajo y melodía principal (las cuales ocurren en la especie y que en otras músicas populares poseen importancia central) ven relativizadas algunas de sus cualidades perdiendo, en algunas ocasiones y al menos momentáneamente, aquellas que las definen.

Las conformaciones que Butler denomina "riffs" se configuran quizá como el caso más común: gestos melódico-rítmicos que usualmente se reiteran de modo constante, en muchas ocasiones se constituyen en los motivos o temas que identifican o permiten el reconocimiento 
de la pieza que los contiene. ${ }^{362} \mathrm{Si}$ bien no son privativos de ningún registro es usual encontrar riffs descriptos por sonidos de bajos. ${ }^{363}$ Es también relativamente común que sobre estos se apliquen paulatinamente filtros pasa-altos que deriven, temporal o definitivamente, en la transformación de su función textural-armónica. Mediante la eliminación de sus componentes graves/sub-graves la función de bajo original se ve reconvertida en otras que podrían ser descriptas como de "voz líder" (i.e.: asimilable en cierta medida a la función que cumplen algunas melodías de guitarra eléctrica o sintetizador en otras músicas populares como el rock o el pop) o -por describir formas similares a arpegios- de ripieno armónico (aún cuando en algunos casos estos elementos pueden no "rellenar" nada y ser la conformación más pregnante). En síntesis, la identidad instrumental en las músicas electrónicas utilizadas para el baile social es tan lábil y circunstancial como las demás identidades que se presentan en la especie.

Quizá la única propiedad relevante y novedosa que solo puede presentarse en registros superiores la constituya la función de refuerzo armónico; refuerzo que, como viéramos durante el tratamiento de la percusividad, asume aquí connotaciones audiotáctiles. En términos generales y en relación a esta función, la ocurrencia de ataques en los registros superiores en simultáneo con ataques en el grave/sub-grave deriva en que los primeros aporten sus componentes al timbre total, posibilitando un ataque general más pronunciado (i.e.: en menos espacio-tiempo, más próximo al ideal de "instantáneo", con mayor cantidad de transitorios). Como viéramos, conformaciones de este tipo permiten la acumulación de mayor cantidad de energía acústica en el instante del ataque, favoreciendo en último término la generación de sensación táctil. ${ }^{364}$

\section{Repetición de alturas tonales definidas, de tonicidad débil y de altura tonal no definida}

Debimos postergar varias veces el tratamiento de estos casos particulares de repetición. A pesar de su aparente simplicidad (i.e.: apariencia que emerge del hecho de ser conformaciones basadas en la neutralización de una de las variables principales de la música, la altura) estos acontecimientos constituyen un conjunto de configuraciones sono-musicales con tan alto grado de complejidad y con implicancias tan estrechas con la sensación táctil y audiotáctil, que solo

\footnotetext{
${ }^{362}$ El sentido que el término recibe en la especie es similar al que se le asigna en la comunidad vinculada al rock. Usualmente ejecutado en guitarra eléctrica, bajo o en ambos, en este género el diseño melódicorítmico del riff suele equivaler a la identidad más definida y pregnante de la pieza. Aún cuando en las músicas electrónicas utilizadas para el baile social puede incluírselos en la forma de samples extraídos de piezas preexistentes, el rol de "aporte identitario" es quizá la cualidad heredada más persistente de estas conformaciones.

${ }^{363}$ Razón que consideramos suficiente para utilizar estos casos como ejemplo de las transformaciones tímbricas y funcionales que exponemos en el párrafo siguiente.

${ }^{364}$ Entran en juego aquí otras variables dependientes de las capacidades de los sistemas de amplificación que limitan la acumulación posible de energía acústica repartida registralmente. La acumulación posible (por supuesto) no es infinita y dependerá de variables como el ancho de banda, la potencia y otros del PA concreto que se utilice para la re-producción del evento musical en cuestión.
} 
ahora -habiendo analizado previamente diversas cuestiones relacionadas- nos encontramos en condiciones de abordarlo en toda su profundidad.

Sin embargo, antes de abocarnos específicamente a la repetición de alturas debemos analizar brevemente uno de los aspectos aún no visitado de la objetivación. Como se verá en breve, ésta resulta un factor central al momento de determinar, de entre las variantes posibles, qué conformaciones sono-musicales concretas pueden finalmente constituirse en repeticiones de alturas y cuáles son los casos relevantes para la generación de sensación táctil. Conscientes de que el contenido de los títulos por venir puede sugerir objetivos diferentes, realizamos entonces la siguiente advertencia: focalizaremos allí sobre los diferentes grados de objetivación que los materiales pueden alcanzar debido a que sólo a partir de contar con este conocimiento será posible luego comprender los alcances que damos al fenómeno de repetición de alturas.

Luego de este breve desarrollo nos encontraremos finalmente en condiciones de analizar aquellas conformaciones que describen repeticiones de alturas. Si antes no, allí se comprenderá finalmente el rol que asignamos a la objetivación.

\section{La repetición como proceso objetivador de materiales musicales}

Los ruidos parásitos y las imperfecciones de reproducción, evitables en numerosas oportunidades, son utilizadas por los productores para evidenciar el artificio del sample. Poner en evidencia el artificio es una de las formas de objetivar a los sonidos encontrados o a los fragmentos musicales extraídos de piezas preexistentes que constituyen a dichos samples. Al denotar ser algo diferente del acontecimiento que originara el sonido (re-)presentado, la artificialidad de dicho sonido se vuelve más evidente al oyente desprevenido y facilita su objetivación.

La repetición es otra forma posible de alcanzar el mismo objetivo. Esta se vuelve especialmente útil cuando se desea evitar recurrir a los aparentes "errores técnicos" descriptos en el párrafo precedente. El proceso de objetivación por repetición puede describirse del siguiente modo:

a) Una determinada conformación musical se presenta describiendo ciertas cualidades. De inmediato y sin variación alguna se reitera un número elevado de veces. ${ }^{365}$ Cada nueva repetición textual permite anticipar aún más repeticiones, haciendo en y con cada nueva presentación del material original, menos y menos probable la variación. Con

\footnotetext{
${ }^{365}$ Escúchese por ejemplo la breve secuencia con que se inicia "Your love" de Frankie Knuckles. Pieza fundacional de la especie, el contexto tonal (defectivo) no impide que su autor sostenga invariante, casi sin interrupciones y sobre diferentes armonías, un arpegio sobre reb mayor. Nótese también como, paulatinamente, a medida que avanzan las repeticiones es posible focalizar sobre una única altura e independizarla del resto de la secuencia. Esta "absolutización" de los elementos es precisamente uno de los efectos perceptivos de la objetivación que estudiara el movimiento minimalista en su expresión musical. Frankie Knuckles - Your Love. Subido por Backintday. Accesible en https://youtu.be/LOLE1YE_oFQ. [07092016].
} 
cada repetición la anticipación se refuerza, debilitando cada vez más la expectativa de cambio.

b) Cuanto menor es la probabilidad de cambio, más se definen y "endurecen" los límites o "bordes" del material repetido. Cuanto más tiempo tenemos para aprehender perceptualmente sus cualidades, más estable se vuelve su identidad sonora; a más oportunidades para apreciarlas, más reconocibles a la percepción resultan, más evidentes se vuelven.

c) Si las reiteraciones persisten, la "materia" de dicho "objeto" (su morfología) se vuelve más y más "sólida", menos "fluida". En términos técnicos, a medida que las repeticiones avanzan y las cualidades se hacen más evidentes, se vuelve cada vez más difícil lograr modificaciones (en cualquiera de ellas) que pasen desapercibidas para los sujetos perceptores.

Se establece así el objeto sonoro. Más allá de las fuentes que le dieran origen y de su forma sonora concreta, éste se presenta como una conformación sonora de propiedades estables y fácilmente reconocibles. Extendemos entonces a estos casos el concepto de "objeto sonoro", asignándole un territorio algo diferente del que Schaeffer le otorgara. Más allá de la forma sonora y de la actitud de escucha que dicho autor considerara necesaria, de estos objetos sonoros concretos es posible acordar sus límites, siempre subjetivos, a partir de un conjunto de variables sono-musicales estables, determinables perceptualmente y que presentan un grado elevado de claridad.

Entendemos entonces que la repetición es un factor central en algunos procesos de objetivación y un comportamiento necesario para la delimitación de ciertos objetos sonoros. Dependiendo de cada caso, factores contextuales y/o intrínsecos al material objetuable pueden incidir sobre el proceso descripto modificando en esencia el resultado final. Desarrollar este tema nos desviaría de nuestro foco principal; confiando en que el siguiente ejemplo permitirá intuir los límites que la objetivación por repetición presenta, damos por finalizado aquí su tratamiento:

Dado un sonido reiterado sobre una altura tonal definida única, su objetivación resultará más o menos eficaz dependiendo de si este proceso se incluye en una pieza que hace un tratamiento relativo o absoluto de la altura. De suceder en un contexto claramente tonal es bastante probable que la objetivación nunca se concrete y que dicha altura repetida se perciba siempre en relación a su función armónica. Dicho de otro modo, como describiéramos antes para la altura en términos generales, también los objetos sonoros se inscriben en la lógica que establece el eje relativo-absoluto de tratamiento de la cualidad altura. 
[Paréntesis breve: la objetivación como articulador de estéticas divergentes]

Hemos ensayado y ensayaremos diversas explicaciones para la presencia tan extendida de repetición en las músicas electrónicas utilizadas para el baile social. La búsqueda por objetivar materiales puede ser vista como una de ellas.

Una especie surgida en el crepúsculo de la hegemonía de los principios tonales (en sentido amplio) y que alcanzara su auge -o al menos el primero de ellos- en los años de la caída del discurso único y el fin de la historia, encontraría:

a) en la inclusión de todo tipo de estéticas y principios formativos, el multiculturalismo que fuera signo de virtud en la época y

b) en la objetivación de materiales diversos, la justificación en sí mismo de cada material, estética y principio diferenciado.

En otras palabras, en una especie extremadamente diversa en términos estético-técnicopoéticos, la imposibilidad de organizar el material musical desde los principios de un sistema único (cerrado y limitado) conduciría en numerosos casos a la objetivación. Ésta se establecería entonces como el dispositivo (abierto e ilimitado) con la capacidad de justificar todo suceso, proceso y conformación musicales en sí mismos y articular sus relaciones recíprocas. ${ }^{366}$ A modo de hipótesis podemos decir entonces que:

la inclusión de la objetivación en la especie puede haberse visto promovida por el hecho de consistir en una forma posible de articular materiales muy diversos en sus principios constructivos.

[Fin del paréntesis]

En este contexto se inscribe el caso que nos interesa aquí: la repetición de una única altura o conformación espectral compleja. La importancia de este caso concreto radica en que, a diferencia de otros, este comportamiento presenta una doble potencialidad de generar sensación táctil y de establecer -simultáneamente- oscilaciones/alternancias de intensidad que generen otras (sensaciones táctiles) y/o amplifiquen la primera. En síntesis:

\footnotetext{
${ }^{366}$ Además, al menos en ese momento histórico concreto, podría decirse que el sistema tonal (uno de los que pueden describirse como "cerrado" y "limitado") se encontraba debilitado frente a otras tendencias atonales en ascenso. Éste podría ser otro factor que facilitara el proceso de incorporación de la objetivación como principio organizativo en la especie.
} 
dada la repetición de una única altura y/o conformación espectral compleja, su combinación con otras cualidades sonoras configurará materiales que pueden ser descriptos como los paradigmáticos para la generación de sensación táctil.

Como en oportunidades previas, ciertos sentidos podrían resultar oscurecidos por nuestros modos expresivos y por la complejidad del tema tratado. Antes de iniciar el tratamiento del tema y para que se comprenda cabalmente cuales son aquellos casos que incluimos en estos aconteceres creemos necesarias algunas aclaraciones.

Repetición de alturas colectivas únicas.

Grupos de alturas y/o bandas de frecuencias, presentadas simultáneamente o en breves y rápidas sucesiones, pueden resultar incluidos en la categoría.

Todo acontecer sono-musical es un fenómeno complejo que involucra diferentes oscilaciones simultáneas. Caído todo sistema que imponga al sonido cualquier tipo de estructuración "desde fuera" (i.e.: por ejemplo, los principios del sistema tonal o modal) y tomando en cuenta lo que fuera dicho respecto de la incidencia de la objetivación sobre el sentido asignado a las configuraciones sono-musicales, es posible afirmar que en algunos casos, conformaciones de varias alturas y/o bandas de frecuencias pueden considerarse como constituyendo un objeto sonoro único. En otras palabras y a modo de ejemplo, por incidencia de la objetivación por repetición, un conjunto de sonidos simultáneos configurando un acorde o timbre complejo podrá ser considerado como una única conformación espectral compleja, en todo equiparable a lo que más arriba indicáramos como "una única altura". La validez de este postulado podrá persistir incluso cuando dichas conformaciones presenten cualidades identificables como provenientes de tradiciones musicales pasadas.

Por otra parte, sonidos sucesivos de pocas frecuencias diferentes y repetidos en períodos suficientemente breves (a modo de ejemplo, en una secuencia), pueden generar el establecimiento de una o varias oscilaciones/alternancias de intensidad simultáneas aunque desplazadas unas de otras- y de diferente frecuencia "portadora". 367

Por último, presentando propiedades derivadas de relaciones simultáneas y sucesivas, breves secuencias de conformaciones espectrales complejas (en otras palabras, un breve número de acordes o timbres diferenciados presentados en sucesión) combinan lo dicho

367 Cada altura concreta que conforma la secuencia (las "portadoras" del cuerpo principal) podrá percibirse independizada o integrada al conjunto de notas rápidamente reiteradas y conformar una oscilación/alternancia de intensidad. La complejidad de la descripción de este fenómeno puede conducir a que aquí no se lo comprenda en profundidad; este inconveniente será mitigado en el desarrollo y recorrida de ejemplos que siguen. 
en los dos casos previos, configurando lo que puede comprenderse como una nueva y consecuente extensión-de-la-extensión (que el presente apartado constituye).

Incluimos entonces como casos de repetición de una única altura colectiva a la repetición de:

a) un único acorde plaqué o una única conformación espectral compleja,

b) breves melodías, secuencias de alturas y/o un único acorde arpegiado y

c) breves secuencias de acordes plaqué diferenciados (armonías) y/o breves secuencias de conformaciones espectrales complejas diferentes entre sí.

En resumen, si las cualidades previamente descriptas se combinan con propiedades percusivas (i.e.: con propiedades similares a las de las secuencias descriptas durante el tratamiento de la sonoridad) estas conformaciones repetidas pueden, por sí mismas, presentar la misma doble potencialidad que enunciáramos en párrafos precedentes. De ocurrir en registros superiores y en sincronía con eventos en el registro grave/sub-grave, pueden además configurar casos de refuerzos armónicos audiotáctiles como los recientemente descriptos.

Retomando el tratamiento en general del tema, preferimos arriesgarnos a redundar y explicitar que similares resultados -aunque con algunos matices de diferenciación- pueden alcanzarse con sonidos de altura tonal definida, de tonicidad débil o de altura tonal no definida. En otras palabras, lo dicho hasta aquí para alturas únicas, melodías y armonías -y que puede haberse comprendido como refiriéndonos a alturas tónicas- resulta también válido para conformaciones que -por estar constituidas por sonidos de altura tonal no definida- presentan cualidades que pueden describirse como meramente "percusivas" o "rítmicas".

Hemos optado por ejemplificar este tema con casos que involucran el registro grave/sub-grave. Si bien conformaciones de los tipos descriptos pueden ocurrir en cualquier zona del espectro y, con diversa eficacia, son capaces de provocar el doble efecto enunciado en párrafos previos, el registro mencionado es el que de modo más sencillo permite la vinculación con la sensación táctil. Como viéramos, este registro suele ocuparse principalmente con sonidos de bombo y bajo, lo que podría conducir a pensar que las objetivaciones por repetición se concretan sobre ambos sonidos-instrumentos. Sin embargo, por razones derivadas de cuestiones instrumentales históricas, esta se hace evidente (y podemos decir incluso: "sucede efectivamente") sólo sobre los sonidos de bajo.

Lo anterior resulta así debido a que, si bien en la especie es una elección libre que el sonido de bombo repita una misma altura, su fuerte referencia al instrumento acústico (i.e.: el bombo de batería) y a sus cualidades (i.e.: la imposibilidad de modificar su afinación durante 
una interpretación) tiene como consecuencia que los casos en los que su afinación presenta invariancia son interpretados como "lo normal" o "natural" para esta función textural. Las cualidades musicales de la especie la inscriben, en la amplia mayoría de los casos, en una red de referencias vinculada a las músicas populares; músicas donde el bombo cumple un rol protagónico innegable. Consecuentemente, los aficionados a estas músicas, ya sea consciente o inconscientemente, poseen como capital cultural un extenso conocimiento y pre-juicios respecto de las cualidades de este instrumento y función textural.

Sin embargo, sentimos la obligación de explicitar que la mayoría de los bombos sintetizados suelen generarse a partir de osciladores sinusoidales; este hecho tiene como consecuencia que: dependiendo tanto de su afinación concreta como de la conformación de los demás estratos texturales, cuando el tiempo de decaimiento alcanza cierta longitud es posible percibir su altura. ${ }^{368}$ Programando modificaciones sobre dicha cualidad es posible entonces que este sonido-instrumento describa desde sutiles y leves cambios (plausibles de ser identificados como modificaciones tímbricas más que de altura) hasta verdaderas melodías. Tanto es así que algunos modelos de cajas de ritmos o máquinas de ritmos ${ }^{369}$ que incorporan secuenciador incluyen entre sus prestaciones (directamente) sintetizadores de bajo o (al menos) ciertas facilidades para configurar líneas melódicas a partir de alguno de sus sonidos-instrumentos. En otras palabras, en las músicas electrónicas utilizadas para el baile social no siempre resulta sencillo diferenciar las funciones instrumentales-texturales de bombo y bajo. ${ }^{370}$

Hechas las aclaraciones necesarias, pasemos al análisis de aquellos casos donde el sonido de bajo describe conformaciones que incluyen una única altura de timbre tónico o de tonicidad débil reiterada; en otras palabras, analicemos ciertos pedales que ocurren en la especie. Con posterioridad, revisaremos casos similares donde se hace uso de pocas alturas próximas en registro y de sonidos de altura tonal no definida.

\section{Repetición de una única altura en sonidos de bajo}

Los bajos que describen conformaciones sobre una única nota repetida son tan comunes en la especie como aquellos que describen movimientos melódicos. Independientemente de las razones que condujeran a los productores a neutralizar una de las dos cualidades del sonido principales asociadas a la función que el instrumento cumple

\footnotetext{
${ }^{368}$ En los sintetizadores, los osciladores son los módulos específicamente responsables de generar la variación eléctrica o señal de audio que en el parlante se transformará en sonido.

${ }^{369}$ En pocas palabras, sintetizadores dedicados a la generación de sonidos asociables a los producidos por instrumentos de percusión.

${ }^{370}$ Muy ilustrativo resulta el video promocional del sintetizador analógico de sonidos de bombo Korg Volca Kick. Nótense las capacidades de transformación en tiempo real de sus múltiples parámetros. Accesoriamente, puede observarse también aquí la labilidad de las funciones instrumentales/texturales (en este caso, de las funciones bombo y bajo). Resulta también digno de mención que en una conversación de facebook de la ya mencionada comunidad Argensynth varios participantes se refirieron a este dispositivo como un "sintetizador de bombo/bajos". KORG volca kick - ANALOGUE KICK GENERATOR. Subido por Korg. Accesible en línea en https://youtu.be/rgs7p17ElOY [02092016]
} 
tradicionalmente en las músicas populares, al optar por la repetición de una única altura, las músicas electrónicas utilizadas para el baile social han dado forma a una serie de configuraciones que -al menos hasta donde podemos deducir de los datos disponibles hoypresentan las propiedades ideales para generar sensación táctil.

Hemos compartido los hipervínculos a numerosos ejemplos donde las cualidades de los sonidos graves coinciden parcialmente con las que nos encontramos a punto de exponer. Sin embargo, para que las implicancias últimas de esta cuestión en particular -y de la generación de sensación táctil en la especie en general- se comprendan en toda su dimensión, creemos más apropiado desarrollar un ejemplo que, aunque hipotético, cumpla con todas y cada una de las condiciones ideales y paradigmáticas que facilitan y maximizan la generación de sensación táctil. Disponiendo de esta herramienta teórica nos será más sencillo luego discriminar cuales de las mencionadas condiciones se cumplen en piezas concretas.

Damos por sobreentendido entonces que en nuestro ejemplo hipotético la frecuencia que el sonido de bajo repite se encuentra dentro del rango grave/sub-grave en que se produce sensación táctil; existiendo innumerables ejemplos donde esta condición se cumple, no vemos inconveniente para asumir esta suposición. Más allá de esta -extremadamente básica- condición y de los innumerables ejemplos concretos que puedan hallarse, en los estímulos que generan sensación táctil una multiplicidad de factores diversos -asumiendo ciertos valores en rangos concretos- interactúan de formas complejas y se interfieren, amplificando mutuamente su incidencia sobre el cuerpo de los sujetos perceptores y, consecuentemente, maximizando la generación de sensación táctil. Revisemos entonces aquellos aspectos ya visitados y recorramos las mencionadas interacciones.

a) Superado un cierto umbral de intensidad, la ocurrencia de eventos en el registro grave/sub-grave -dependiendo hasta cierto punto de la frecuencia concreta- genera de por sí sensación táctil.

b) La cualidad percusiva, por la inclusión de transitorios de ataque que pueden involucrar frecuencias graves/sub-graves, puede incrementar la intensidad de la sensación táctil percibida al permitir que mayor cantidad de energía acústica se concentre en un muy acotado espacio-tiempo.

En este tipo de sonidos breves y por incidencia del principio de indeterminación acústico, resulta probable que la sensación táctil asuma para la cualidad localización corporal un valor igual a vibración en todo el cuerpo. Recuérdese que por la misma brevedad, los cambios rápidos de intensidad provocan que el sonido presente poca definición en frecuencia durante todo su desarrollo; lo que resulta, en definitiva, en un timbre de altura tonal no definida (i.e.: conformado por una banda de frecuencias en una determinada región del espectro). Esta indefinición esparce la energía acústica en la 
banda mencionada y provoca, al menos en teoría, que ninguna frecuencia genere resonancia en un sub-sistema corporal determinado. De detectarse, la sensación táctil se percibe como una autoconciencia del cuerpo como todo o -lo que es lo mismocorporalmente des-localizada. ${ }^{371}$

Sin embargo, aún cuando estos sonidos presentan una duración siempre breve, diferencias de pocos milisegundos pueden generar un gran contraste, permitiendo el establecimiento de oscilaciones periódicas en el estímulo vibratorio. Dependiendo de los valores concretos, resultará posible la detección auditiva de las diferencias espectrales referidas. ${ }^{372}$ No contamos con datos suficientes para asegurarlo, pero al menos en teoría esta situación podría originar que la sensación táctil inicial, deslocalizada, se localizara al ingresar el sonido a su fase tonalmente definida de liberación.

Son necesarias experiencias que exploren los tiempos de estímulo requeridos para generar resonancias localizadas en cada sub-sistema corporal, y que además indaguen en los umbrales de sensibilidad táctil y audiotáctil para este aspecto del estímulo para cada sub-sistema. Estudios equiparables a las curvas de igual sonoridad de FletcherMunson pero que vinculan múltiples sistemas y sub-sistemas complejos (en relación mutua compleja y de respuestas no-lineales), inauguran por sí mismos una línea de investigación y presentan tareas que insumirán décadas de trabajo. ${ }^{373}$

c) La ocurrencia de sonidos de -por una parte- ataque impulsivo y -por otra- con sostenimiento o decaimiento lento (i.e.: "resonantes") puede resultar en una excitación táctil que presente dos fases.

Este fenómeno se inscribe en la misma lógica del apartado previo y describe simplemente aquéllos casos donde la liberación presenta una duración mayor. En primer término, al concentrar mayor cantidad de energía acústica, las componentes de ruido de los transitorios de ataque podrían excitar inicialmente -y quizá con mayor eficacia- al cuerpo del sujeto perceptor como todo (i.e.: impactándolo o golpeándolo, generando una vibración de todo el cuerpo). Esta puesta en vibración inicial podría facilitar luego que el cuerpo del sonido (i.e.: la resonancia posterior, con una menor capacidad de concentrar energía por ser una oscilación periódica) sostenga la oscilación del cuerpo del sujeto perceptor durante el tiempo que dure el estímulo. Aquí surge la necesidad de realizar varias consideraciones:

\footnotetext{
${ }^{371}$ Los estudios de vibración de todo el cuerpo (o "whole-body-vibration") son una rama de la bioacústica prolíficos en cantidad de trabajos y es un tema que ha recibido mucha atención por parte de la comunidad científica. Para mayores referencias de estudios vinculados a nuestra área véase nuestro Anzil, I. (2010a) Op.cit.

${ }^{372}$ En otras palabras, será posible detectar diferencias entre los componentes transitorios de ruido en el ataque y la, hipotética, oscilación periódica durante su extinción.

${ }^{373}$ Ver por ejemplo Russo, Frank A. (2016b). Op. cit.
} 
i.- Para que el cuerpo del sonido pueda sostener la sensación táctil, su frecuencia e intensidad deberán encontrarse dentro de los rangos respectivos donde dicha sensación se produce.

En otras palabras, la sensación táctil se extinguirá tanto si la frecuencia del estímulo no coincide con aquellas que la generan como si la intensidad desciende por debajo del umbral necesario para su generación. Cabe preguntarnos aquí si el ataque impulsivo tiene alguna incidencia sobre dichos umbrales. En concreto: se requieren estudios comparativos de la sensación táctil generada por sonidos de igual frecuencia e intensidad en sus cuerpos pero que alternen ataques impulsivos con paulatinos.

ii.- De cumplirse la condición previa, las cualidades de la sensación táctil se sostendrán o se modificarán dependiendo de la frecuencia, de la intensidad y de la conformación espectral de la oscilación.

Si bien son necesarias experiencias que brinden mayores detalles acerca de los fenómenos siguientes, en fuentes secundarias y en datos recabados en nuestras experiencias de campo existen indicios para afirmar que a partir de sonidos de altura tonal definida:

iia.- La localización corporal depende de la frecuencia principal presente en el cuerpo del sonido que constituye el estímulo.

Como ya expusiéramos, las componentes de ruido del ataque (por tratarse de bandas solo relativamente localizadas y por su veloz evolución) podrían provocar una excitación del cuerpo como totalidad; mientras que las oscilaciones del cuerpo del sonido (siempre que permanezcan estables en su período) generarán resonancia en aquellos sub-sistemas corporales cuyas dimensiones coincidan con las longitudes de onda de sus frecuencias de oscilación. ${ }^{374}$

De presentar variaciones en la frecuencia, es posible que la sensación táctil:

a) se traslade de una localización corporal a otra (recorriendo diferentes regiones del cuerpo del sujeto perceptor $)^{375} \mathrm{o}$

b) desaparezca de una localización corporal para presentarse en otra (describiendo un comportamiento no-lineal)

${ }^{374}$ Para una aproximación a las frecuencias que provocan resonancias en los diferentes sub-sistemas corporales véase Kogan Musso, P. (2004) Op.cit. pp. 105-107

${ }^{375}$ Véase al respecto el testimonio del sujeto experimental B en nuestro Anexo I. Experiencia de campo. 
iib.- La intensidad y profundidad de la sensación táctil dependen de la intensidad del estímulo.

Cuando establecimos las variables de la sensación táctil no supimos a qué variable del estímulo atribuir la dependencia de la cualidad profundidad. Durante el análisis de nuestras experiencias de campo, al cruzar las respuestas de los sujetos experimentales con los datos registrados del estímulo musical, detectamos ciertos indicios que apuntan a que dicha cualidad (de la sensación) podría depender de la intensidad del estímulo y encontrarse en íntima relación con la intensidad de la sensación. Concretamente, mientras la intensidad del estímulo permanece por debajo de un umbral (cuyo valor debe aún determinarse), la intensidad de la sensación resulta "suave" y la profundidad asume los valores de "cutánea" o "superficial". Con el incremento de la intensidad en el estímulo y superado dicho umbral, la intensidad de la sensación se hace mayor y la profundidad experimenta un cambio de fase, volviéndose "profunda". Habiéndola experimentado en persona en varias ocasiones, nos preguntamos qué lugar le corresponde al valor "textil" de la profundidad. ${ }^{376}$

El tratamiento de los componentes espectrales involucra un grado de complejidad y una extensión de desarrollo mayores.

Los dos vínculos expuestos entre el estímulo y la sensación táctil deben comprenderse próximos a hipótesis y -siempre- como esquematizaciones simplificadas. En otras palabras, creemos no equivocarnos al decir que unas y otras variables del estímulo inciden hasta cierto punto en todas las cualidades de la sensación táctil. A modo de ejemplo y a partir de nuestras experiencias podemos suponer que, si bien la localización corporal depende primordialmente de la frecuencia del estímulo, superado cierto umbral de intensidad (también en el estímulo) es posible que la sensación táctil se des-localice. Si bien esto puede parecer contradictorio con los argumentos expuestos, recordamos que las cualidades del estímulo sono-musical y los sub-sistemas corporales se encuentran en relación compleja, por lo que sus respuestas son no-lineales.

De modo similar, consideramos probable que la frecuencia del estímulo incida en algún grado sobre la intensidad y profundidad de la sensación, así como sobre el umbral de intensidad en el que acontecerá el cambio de fase en la

\footnotetext{
${ }^{376}$ Respecto del valor "textil" ver el Anexo I. Experiencia de campo.
} 
última de las cualidades mencionadas (véase apartado c.iib). Este tipo de interferencias e interacciones entre las variables del estímulo han sido extensamente documentadas para la audición y todo parece indicar que fenómenos similares suceden en relación con la sensación táctil.

iic.- La localización corporal y la intensidad de la sensación táctil dependen de la conformación espectral del estímulo.

La presencia de armónicos, parciales inarmónicos y/o componentes de ruido consisten en definitiva en otras frecuencias (algunas periódicas, otras no) que conforman el estímulo. En otras palabras, dichas componentes son energía acústica que acontece en otras regiones (próximas o lejanas) del espectro; estas oscilaciones pueden a su vez presentarse dentro de los rangos de intensidad y frecuencia donde se produce sensación táctil. El timbre del sonido puede ser entonces fuente de otras sensaciones táctiles. En términos más precisos y técnicos, el timbre aporta otros componentes de vibración a la sensación táctil originada en la frecuencia fundamental, aunque aquí es donde dos cuestiones extras a nivel del timbre y/o conformación espectral deben ser tenidas en cuenta.

\section{iic.i.- Refuerzo armónico audiotáctil}

Los elementos $\mathrm{y} / \mathrm{o}$ estratos texturales que se ubican en regiones superiores del espectro de frecuencias modifican a la sensación táctil provocada por las frecuencias graves/sub-graves al incidir sobre dicha oscilación en tanto timbre o componentes espectrales.

Tanto las componentes del timbre del sonido de bajo que nos encontramos considerando, como los elementos o estratos texturales que acontezcan simultáneamente al bajo y se localicen en regiones superiores del espectro, son potenciales refuerzos armónicos de la sensación táctil generada a partir del fenómeno de la reconstrucción de la fundamental de Fourier. ${ }^{377}$

iic.ii.- Oscilaciones de segundo orden de nivel micro o iteraciones

377 Estrictamente hablando, aquí nos vemos condicionados por la perspectiva que asumiéramos inicialmente para describir las relaciones que se establecen en el estímulo durante la generación de sensación táctil, y lo que en concreto ocurre es que las diversas frecuencias que componen al timbre total se interfieren, refuerzan y cancelan mutuamente $\mathrm{y}$, en último término, interactúan como un todo único con el cuerpo del sujeto perceptor. 
La presencia de diversos tipos de iteraciones y oscilaciones/ alternancias de intensidad, tanto en el timbre del sonido de bajo como en los de los elementos y/o estratos texturales localizados en regiones superiores del espectro, podrían acoplarse y/o interferirse mutuamente con las frecuencias de las oscilaciones de primer y segundo orden de cada uno de los componentes que conformen el timbre total de la pieza en el momento concreto en que ocurre la sensación táctil. Como describimos para las oscilaciones de primer orden, las oscilaciones de segundo orden se interferirán, amplificarán y cancelarán -mutuamente y con las oscilaciones de primer orden- derivando en último término en un refuerzo, amplificación y transformación de la sensación táctil generada.

Terminamos así la descripción de uno de los eventos (i.e.: uno de los "ataques", en el sentido corriente que los músicos le asignan al término) del grupo de ataques sobre una única altura tonalmente definida grave repetida que constituye nuestro ejemplo paradigmático. Veamos ahora lo que resulta de las interacciones entre este evento y los que lo suceden. Por la interferencia con las cualidades ya descriptas creemos apropiado continuar aquí con la numeración que precede a este párrafo.

d) Dependiendo de su período, ataques reiterados sobre una misma altura y/o timbreconformación espectral compleja pueden configurar una oscilación/alternancia de intensidad.

Estas conformaciones resultan similares o iguales a las que denomináramos como "secuencias" y que tratáramos durante el análisis de la sonoridad. A diferencia de aquellas, además de no presentar cambios en la altura del cuerpo del sonido (o ser estos mínimos), sus ritmos suelen presentar algún grado más de variabilidad. Dicho en otros términos y para que se nos comprenda mejor: mientras las secuencias presentan un carácter más próximo al "maquinal" (entre otros factores, debido a que sus ritmos suelen limitarse a una única duración reiterada) aquí nos encontramos con configuraciones rítmicas que expresan mayor "humanidad" (i.e.: si bien suelen presentar duraciones reiteradas, su organización suele también responder a estéticas más tradicionales que permiten asociarlas con -como orientación- los conceptos de "frase" o "semifrase").

Sin embargo, unas y otras comparten ciertas cualidades que promueven la generación de sensación táctil. Veamos entonces las variables involucradas: 
i.- Como viéramos durante el tratamiento de la sonoridad, si el período entre un ataque y el siguiente se encuentra próximo al nivel de pulso/de la (sub-) división, la sucesión de ataques establecerá una oscilación/alternancia de intensidad.

ii.- De resultar (por efecto de la duración de cada evento) en un gesto ligado, la alternancia necesaria para que dicha oscilación se produzca puede presentarse (incluso) entre las componentes de ruido de los transitorios de ataque y las frecuencias periódicas del cuerpo del sonido. En otras palabras, dadas las cualidades tímbricas y de envolvente de intensidad necesarias para la articulación de duraciones breves, en estas conformaciones es más probable la ocurrencia (que la ausencia) de una oscilación/alternancia de intensidad.

iii.- En los casos donde uno de estos ataques (y cada uno, por ser repetidos) presenta las cualidades necesarias como para generar sensación táctil, dependiendo de otros factores, la sensación persistirá hasta el siguiente ataque. Como consecuencia, la sensación táctil será continua y -en algunas ocasiones"oscilante". Esta última cualidad dependerá de la posible ocurrencia de alternancia en el estímulo entre las componentes de ruido de las sucesivas fases de ataque y las tonalmente definidas de las liberaciones.

Los "otros factores" mencionados supra resultan ser justamente aquellos que describiéramos en los apartados previos; estos pueden cumplirse -y se cumplensin problema alguno por los sonidos de bajo, y los timbres utilizados en dicha función en las músicas electrónicas utilizadas para el baile social. En definitiva, en las músicas electrónicas utilizadas para el baile social numerosos bajos sobre una misma altura repetida configuran oscilaciones/alternancias de intensidad.

Finalizamos aquí con la exposición de las variables intervinientes y solo nos resta revisar otras relaciones e interacciones entre éstas.

En primer término, lo dicho durante el apartado $c$ para un único ataque -respecto de los refuerzos armónicos audiotáctiles y de las iteraciones-, resulta igual de válido para cada uno de los ataques reiterados del tren de impulsos conformado por el sonido de bajo.

Segundo, de ocurrir variaciones de períodos superiores en uno o varios de los elementos y/o estratos que conforman la textura-timbre total, lo expuesto durante el tratamiento de la sonoridad para las oscilaciones/alternancias de intensidad a nivel de (meta-)compás resulta también igual de válido que en dicha oportunidad. Incluimos aquí al bajo que, a modo de ejemplo, podría describir pequeñas variaciones de altura. 
Tercero, las herramientas tecnológicas musicales actuales permiten hace coincidir con precisión igual a un sample ${ }^{378}$ los ciclos y las fases de todas y cada una de las variables descriptas. En otras palabras, con dicho grado de precisión es posible hacer coincidir el inicio de los ciclos y las fases de:

a) Todas y cada una de las oscilaciones de primer orden de cada uno de los sonidos incluidos en todos $\mathrm{y}$ cada uno de los elementos $\mathrm{y}$ estratos intervinientes simultáneamente en la textura-timbre total. Incluimos aquí no solo a las frecuencias fundamentales de cada sonido o sonido-instrumento sino que nos referimos a cada uno de sus componentes armónicos, inarmónicos y componentes de ruido.

b) Todos y cada uno de los picos máximos (i.e.: los puntos cúlmine de las fases de ataque de cada uno) de los sonidos con ataque impulsivo, en todos y cada uno de los elementos y estratos texturales intervinientes.

c) En los casos de oscilaciones periódicas y como un caso especial de lo descripto en el apartado a, mediante la utilización de alturas en relación armónica simple es también posible sincronizar y sostener la sincronización de los ciclos y fases de las oscilaciones que acontezcan en el cuerpo de todos y cada uno de los sonidos intervinientes en un determinado momento.

d) Todas y cada una de las oscilaciones de segundo orden de cada uno de los sonidos incluidos en todos y cada uno de los elementos y estratos texturales simultáneos. Ya sea en los inicios como (al igual que en el apartado previo) en los cuerpos de cada sonido interviniente.

Por si esto fuera poco, todas y cada una de estas sincronizaciones puede realizarse ataque a ataque sin excepción. En otras palabras:

e) Todas y cada una de las variables previas pueden sincronizarse en ciclo y fase con los ciclos y fases descriptos por cada uno de los niveles de las oscilaciones/alternancias de intensidad.

Esto resulta en la posibilidad de establecer refuerzos armónicos audiotáctiles "perfectos" e "ideales", lo que permite ataques virtualmente instantáneos $\mathrm{y}$, consecuentemente, una concentración de energía acústica de intensidad teóricamente infinita en cada instante de acontecimiento de cada uno de los ataques descriptos.

\footnotetext{
${ }^{378}$ Referimos aquí a la herramienta de digitalización de sonido en el método conocido como PCM (i.e.: "pulse code modulation" o "codificación por modulación de pulsos"). Pudiendo asumir diferentes valores dependiendo de la variable de calidad conocida como frecuencia de muestreo, dicha unidad suele encontrarse actualmente entre los $1 / 44.100$ y los $1 / 192.000$ de segundo.
} 
Por supuesto, la situación real difiere en muchos aspectos de la descripta. En primer término deben considerarse los límites impuestos por la potencia de cada PA concreto: solo cuando ésta permita alcanzar altos niveles de presión acústica los valores de intensidad máximos "ideales" se concretarán en aconteceres musicales capaces de generar sensación táctil. Paralelamente y como viéramos, el sistema de amplificación deberá ser capaz de producir frecuencias graves/sub-graves a altos niveles; de no ocurrir, inútil será configurar refuerzos armónicos audiotáctiles "perfectos".

Sin embargo, las conformaciones descriptas facilitan en gran medida la generación de sensación táctil. En otras palabras, estamos en condiciones de afirmar que:

dado un sistema de amplificación que cumpla las condiciones técnicas necesarias (enunciadas en el párrafo previo), un fragmento que presente las cualidades detalladas durante las últimas páginas -confrontado con otro que presente cualidades opuestas o cumpla solo algunas de las expuestas- generará sensación táctil más evidente e intensa.

En otro orden de cosas, debe considerarse también al cuerpo del sujeto perceptor. Lejos de un ideal, su cuerpo ha sido visto por diferentes autores como un sistema complejo, conformado a su vez por sub-sistemas que se acoplan y desacoplan dependiendo de diversos factores. Cada sub-sistema, según los valores concreto que en cada individuo asumen sus variables, resuena a partir de una frecuencia precisa o en un rango de frecuencias de límites difusos. ${ }^{379}$ Tomando como ejemplo la longitud de los huesos, es probable que las piernas de un sujeto alto resuenen a frecuencias inferiores que las de otro de menor altura. Esto se debe a que la dimensión mencionada resonará según coincida con la longitud de onda presente en el estímulo. Al mismo tiempo, menos diferencias parecen observarse en (nuevamente, como ejemplo) la sensibilidad de los mecanoreceptores de las capas más profundas de la piel. Este hecho podría conducir a sensaciones y percepciones compartidas o al menos parcialmente coincidentes entre individuos. ${ }^{380}$

En síntesis, algunos valores se reiteran entre individuos diferentes mientras que otros varían de persona a persona. Esta situación genera un cuadro donde la experiencia táctil o audiotáctil es compartida en algunos aspectos y diferenciada en otros, provocando que cualquier generalización resulte en una falacia. Sin embargo, los mismos datos sobre los que se basan estos argumentos demuestran que -al menos para algunos aspectos de la sensación- resulta posible realizar aproximaciones a frecuencias o rangos de frecuencias generadoras de sensación táctil. Podemos referir al rango comprendido entre los 40-60 Hz como el más mencionado en

\footnotetext{
${ }^{379}$ Para más detalles véase Kogan Musso, P. (2004). Op. cit. pp. 105-107

${ }^{380}$ Véase Anzil, I. (2010). Op.cit. pp. 2
} 
diferentes estudios; vibraciones en esta región espectral se asocian con la vibración del tórax y/o de la pared abdominal. Cabe destacar que en nuestras experiencias de campo la totalidad de los sujetos experimentales refirió a sensación táctil en esta localización corporal, y que la misma resultó coincidente con picos de intensidad en el estímulo musical en el rango citado supra. ${ }^{381}$

En otras palabras, si bien son necesarios multiplicidad de estudios que permitan precisar con mayor certeza los datos documentados en fuentes secundarias, nuestras experiencias confirman que tales pesquisas pueden ofrecer resultados útiles y que hemos acertado en gran medida en la selección de las variables y valores del estímulo vibratorio y corporales a considerar. No pretendemos la confección de una receta para hacer vibrar una u otra localización corporal; nunca fue esa nuestra intención y pretenderlo hubiera evidenciado un grado extremo de inocencia de nuestra parte. Sin embargo, aún cuando este enfoque no parte de la electroneurofisiología y como puede apreciarse en páginas precedentes, mucho puede decirse de las relaciones que se establecen entre las conformaciones musicales y el cuerpo del sujeto perceptor. Integrar un equipo multidisciplinar donde dicha especialidad se vea comprendida es uno de nuestros objetivos futuros.

Retornando a caminos propios, utilizar el modelo ideal como perspectiva de análisis para el estudio de piezas concretas, demuestra que en cada uno de los índices que conforman la especie proliferan las conformaciones musicales que cumplen, en mayor o menor medida, las condiciones descriptas supra. Procurando contrarrestar nuestras falencias en disciplinas que nos son ajenas, mediante análisis de obras intentaremos entonces cierto grado mayor de precisión respecto de los materiales y conformaciones musicales concretos que ocurren al interior de la especie. Terminada la descripción del primero de los tipos de repetición de una altura tonal única, veamos ahora algunos ejemplos concretos del mismo. Ejemplos que presentan algunas de las cualidades del modelo que describiéramos pueden hallarse en:

i.- "The enemy" de Matador ${ }^{382}$

Pieza que puede asociarse sin demasiados problemas al índice techno, es obra del productor irlandés Gavin Lynch.

Nos interesa especialmente la oscilación/alternancia de intensidad que describe el sonido grave de sintetizador sostenido persistentemente sobre la nota re en el registro grave. Oscilación de segundo orden a nivel de pulso/de la (sub-)división, no se constituye por ataques repetidos sino que deriva de la aplicación de modulación de intensidad sobre un sonido sostenido. Dicha modulación sincroniza su período y fase con el tempo de la pieza y describe una pulsación equivalente a la subdivisión. Modulación de mediana intensidad, solo en ocasiones conforma un tren de impulsos (la

\footnotetext{
${ }^{381}$ Kogan Musso, P. (2004). Op.cit. pp. 105. Véase también nuestro Anexo I. Experiencia de campo.

${ }^{382}$ Matador - The Enemy ft Felix Da Housecat (Original Mix) - The Enemy EP. (2016). Subido por matador. Accesible en línea en https://youtu.be/ma51mUT8NBM. [26082016]
} 
modulación solo a veces reduce a cero a la intensidad del sonido portador). Sin embargo, esta característica no le impide constituirse en la base de la oscilación/alternancia de intensidad del timbre total.

Por utilizar diferentes formas de onda según el momento, la modulación genera sobre el sonido portador evoluciones de su intensidad que en ocasiones pueden describirse como "suaves" y en otras "más pronunciadas". Este hecho provoca que en algunos fragmentos la modulación genere transitorios de ataque, sumando consecuentemente componentes graves/sub-graves al sonido-instrumento -y al timbre total- y reduciendo la tonicidad del timbre del sonido de bajo. Estas mayor o menor continuidad y tonicidad han sido aprovechadas por Lynch como parte de los factores que determinan el carácter diferenciado de (valga la redundancia) diferentes fragmentos de la pieza.

Adviértase también que, sin embargo, otros elementos de la textura ubicados en regiones superiores del espectro son coincidentes en ataque con los picos de intensidad máxima de la oscilación/alternancia de intensidad que el sonido de bajo describe. En ciertos casos dicha coincidencia es incluso casi ataque a ataque. Esto se debe a que algunos de aquellos elementos describen ritmos que constituyen una pulsación de período igual a la oscilación/alternancia de intensidad sobre la que nos encontramos focalizando nuestra atención. En su mayoría sonidos con timbre de altura tonal no definida, al sincronizarse de este modo aportan a la oscilación/alternancia de intensidad "base" la energía acústica de sus transitorios. En otras palabras, pueden ser vistos como constituyendo la función de refuerzo armónico audiotáctil (al menos para la fase de ataque de cada ciclo de la oscilación/alternancia de intensidad).

La oscilación/alternancia de intensidad describe un ciclo de $8.133 \mathrm{~Hz}$ (igual a 4 valores de subdivisión a un tempo de 122 pulsos por minuto) agregando una nueva frecuencia, posible generadora de sensación táctil. Además, una complejización de la oscilación (que opera sobre este y sobre otros sonidos en la textura) deriva del proceso de compresión por cadena lateral (i.e.: "sidechain compresion" o "ducking") 383 controlado por bombo y redoblante. Proceso muy común en la especie, produce en este caso un resultado sutil para oídos no avezados. En cada ocurrencia de los sonidos-instrumentos mencionados, el compresor reduce levemente la intensidad del sonido grave y de otros elementos y estratos texturales, generando que el período de la oscilación/alternancia de intensidad se extienda al menos hasta ser igual al ciclo descripto por estos dos sonidosinstrumentos.

En otro orden de cosas, que el proceso se aplique a varios elementos y estratos texturales ofrece prueba de dos cuestiones descriptas en esta sección y que presentan gran relevancia para la musicología y la filosofía de la música. Al modificarlos de igual

\footnotetext{
${ }^{383}$ Para el sentido de esta expresión ver la nota al pie 290 o nuestro Glosario.
} 
modo, el proceso de compresión por cadena lateral integra a los diferentes elementos y estratos texturales involucrados. Tratando a estelas o corrientes auditivas tradicionalmente consideradas independientes- como un objeto único, simultáneamente y como consecuencia, este proceso:

a) denota la concepción espectral subyacente y

b) efectiviza en un fenómeno acústico concreto lo que llamamos la continuidad del espectro de frecuencias completo.

Descomponiendo la oscilación en sus elementos periódicos es posible afirmar (esquemáticamente) que el bombo aporta una frecuencia de $2.033 \mathrm{~Hz}$ (período igual al pulso) y bombo+redoblante una de $1.016 \mathrm{~Hz}$ (atacando en los tiempos 2 y 4 y correspondiéndose con la figura de blanca en un compás de 4/4).

Estos períodos y el de $8.133 \mathrm{~Hz}$ se encuentran muy próximos a una relación armónica simple con la frecuencia de la nota do $(32.703 \mathrm{~Hz})$. Tomando en consideración la presencia -en cambio- de la nota re grave $(36.708 \mathrm{~Hz})$ podemos observar que, en la interacción entre ambos períodos, los corrimientos de fase derivan en el establecimiento de una frecuencia de $4.005 \mathrm{~Hz}$.

Como consecuencia, por un lado resulta muy significativa la proximidad de este período con el de la división $(4.064 \mathrm{~Hz})$; por otro, la presencia de toda esta red de relaciones de frecuencias aporta mayor validez a nuestro principio de refuerzo armónico audiotáctil. En tercer término y aún más relevante, no nos parece descabellado pensar que Lynch seleccionara específicamente esta altura (re) en función de su frecuencia concreta y/o de la frecuencia resultante por interferencia entre dicho período y los demás involucrados en la pieza de su creación. Dicho de otro modo, es razonable suponer una de las dos posibilidades siguientes:

a) Lynch seleccionó la frecuencia de la nota grave/sub-grave más persistente en función del tempo seleccionado o,

b) definió el tempo a partir de la frecuencia de la nota grave/sub-grave elegida para ser sostenida durante la mayor parte de la pieza.

En cualquier caso, la vinculación e interferencias mutuas entre tempo y frecuencia que hemos puesto en evidencia denota una búsqueda por la sincronización de las fases y ciclos de múltiples oscilaciones simultáneas, multiniveladas y de cualidades diferenciadas; sincronización que, como viéramos, facilita y maximiza la generación de sensación táctil. 
No podemos afirmar que este productor realizara estas elecciones de forma consciente, ni que optara por estas relaciones procurando establecerlas con el objetivo de maximizar la generación de sensación táctil; sin embargo, paulatinamente vemos surgir ejemplos que se establecen como indicios que apuntan a la validez de nuestros postulados más extremos o límites.

\section{ii.- "Queen" de DJ Tonio. Versión remix de DJ Anna ${ }^{384}$}

Pieza de 2016 indicada como progressive techno y nu-trance de la productora de origen brasileño Ana Miranda, en este caso focalizaremos principalmente sobre las secuencias que describe el sonido de bajo y sobre las derivas que se producen a partir de sus cualidades y de su interacción con otros elementos de la textura. Tangencialmente mencionaremos otros elementos.

Con un tempo de 125 pulsos por minuto, la secuencia $A$-de período igual a un tiempo y reiterada cuatro veces por compás- se configura del siguiente modo:

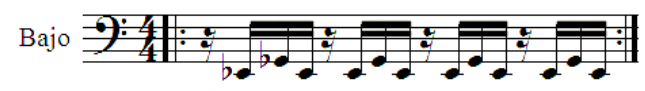

Si bien ésta es la conformación perceptualmente más evidente, hacia los $2^{\prime}$ es posible identificar que también la primera semicorchea se articula sobre el sib grave. Ataque muy disminuido en sonoridad y enmascarado por el sonido de bombo que describe un patrón de bombo en negras, al menos en algunos pasajes la variación resulta como sigue: ${ }^{385}$

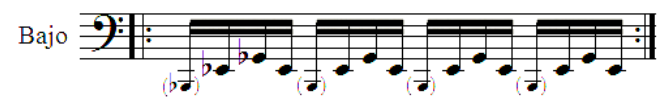

En ciertos momentos (ej.: 2'14") esta secuencia es relevada la secuencia B que, al menos en su primera aparición, se presenta del siguiente modo:

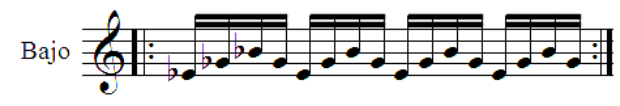

384 DJ Tonio - Queen (ANNA Remix) [Suara]. (2015). Subido por Suara Music. Accesible en https://youtu.be/qTvpcD9giDk. [26082016] Esta pieza ilustra al tema que nos ocupa aquí y -al mismo tiempo- sirve como ejemplo de aquellas secuencias (que tratáramos durante nuestra descripción de la sonoridad) que involucran diferentes alturas y para las cuales no presentáramos análisis concreto.

${ }^{385}$ En la figura, las cabezas de nota de menor tamaño representan una menor intensidad relativa. 
Ambas secuencias, durante el transcurso de la pieza, presentarán modificaciones en sus timbres, las que esencialmente provocan transposiciones hacia registros más agudos. Un ejemplo de este tipo de procesos se configura sobre la secuencia B hacia los 3'23".

Iniciándose en el grave, abarcará un desarrollo de cuatro octavas. En cada registro se presentan diferentes versiones mínimamente variadas de la secuencia; cada una de estas jerarquiza sutilmente una $\mathrm{u}$ otra de las alturas que conforman el arpegio. El paulatino incremento de las componentes agudas se origina (parcialmente al menos) en el aumento gradual de la sonoridad del conjunto; esto pone de relieve la dispar sensibilidad a diferentes frecuencias que caracteriza al sistema auditivo humano y genera como consecuencia que no todos los registros presenten su máxima intensidad al mismo tiempo. Sin embargo, es posible resumir el proceso y las diferentes versiones de la secuencia del siguiente modo:

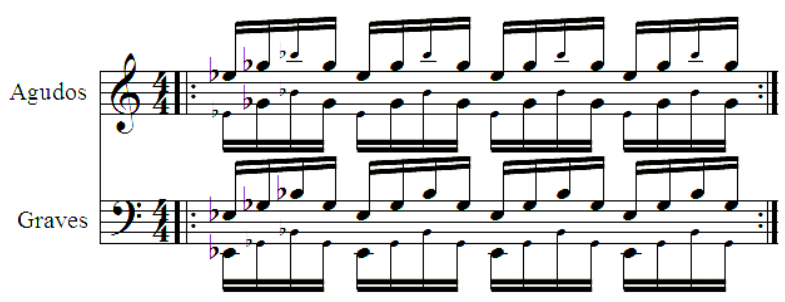

Las variaciones descriptas en el gráfico precedente deben comprenderse como una de entre varias descripciones posibles. Esto se debe a que resulta extremadamente difícil determinar el registro concreto en el que cada jerarquización de notas sucede. Debido justamente al incremento paulatino de la sonoridad, las jerarquizaciones que ocurren en registros superiores se presentan a la percepción como acentuaciones en los registros inferiores. Solo luego de que la intensidad alcanza un determinado umbral, aquellos registros se independizan, evidenciando la zona de frecuencias concreta donde acaecen los agrupamientos percibidos.

Consecuencia directa del fenómeno de refuerzo armónico, es posible suponer que algo similar podría ocurrir en términos táctiles, donde jerarquizaciones en elementos o estratos texturales en registros superiores generen incrementos momentáneos en la (a modo de ejemplo) intensidad de la sensación táctil originada en elementos o estratos texturales incluidos en el registro grave/sub-grave. En este sentido es que llamamos la atención sobre las jerarquizaciones presentes en este proceso: los leves desequilibrios planteados por la disparidad de sonoridades entre alturas en las diferentes versiones de la secuencia ${ }^{386}$ (sumados a la ausencia circunstancial de la referencia temporal que sin lugar a dudas constituye el patrón de bombo en negras en otros momentos) dejan en este

${ }^{386}$ Con el consiguiente "desequilibrio" rítmico que aquellos implican. 
caso expuesto un fenómeno que en otros podría resultar enmascarado por la presencia de la oscilación/alternancia de intensidad (en el registro grave/sub-grave) principal. Cada altura absoluta podría encontrarse generando sensación táctil por sí misma $\mathrm{y}$, al mismo tiempo, aportando (quizá parte de) su energía a la modificación de la oscilación/alternancia de intensidad que describen los elementos que ocupan el registro grave/sub-grave.

Considerando otros factores: aunque no siempre simultáneamente, las secuencias incluidas en esta pieza:

a) presentan perfiles de sonoridad medianamente percusivos.

Cumpliendo con esta y las demás condiciones expuestas durante nuestro tratamiento del tema reiteratividad.

b) presentan versiones de sí mismas que se constituyen en casos de refuerzos armónicos audiotáctiles de aquellas que ocurren en el grave/sub-grave.

Aquí intervienen tanto sonidos de altura tonal definida como de altura tonal no definida; obsérvese como los elementos descriptos interactúan con los demás (los diferentes hi-hats por ejemplo) en los mismos términos que los expuestos durante el análisis de "The enemy".

c) se constituyen en un caso de repetición de una única altura.

Esencialmente consistente en una breve secuencia de alturas tónicas, por momentos puede verse también como varias alturas simultáneas en relación armónica simple. De incluirse en el análisis al resto de los elementos de la textura, esta se vuelve una secuencia de conformaciones espectrales complejas (al incluir elementos de altura tonal definida y de altura tonal no definida)

Considerando únicamente las secuencias de alturas sobre las que originalmente focalizáramos nuestro estudio, respecto del último apartado hallamos entonces repeticiones de período igual a:

a) negra: las secuencias completas de alturas, independientemente de a la que nos refiramos, describen un período igual al pulso de la pieza. Apoyadas y coincidentes con el bombo, configuran una oscilación/alternancia de intensidad de frecuencia igual a $2.083 \mathrm{~Hz}$.

b) corcheas "cruzadas": cada secuencia presenta repetida una de las alturas que la conforman; el mib en la primera, el solb en la segunda. En ambos casos se establece (al interior de cada secuencia) una repetición sobre una única altura de período igual a corchea. 
Sin embargo, dicha oscilación/alternancia de intensidad no se percibe especialmente jerarquizada. Esto se debe a que los eventos que componen la repetición ocurren en la $2^{\circ}$ y $4^{\circ}$ semicorchea del tiempo de negra; en otras palabras, a intervalo de semicorchea de cada evento (acentuado) de bombo. Por ocurrir en las partes débiles del tiempo y por la descripta interacción rítmica (desigual, irregular) con el bombo, las alturas atacadas a contratiempo (en la $3^{\circ}$ semicorchea) resultan jerarquizadas. Esta última jerarquización contradice a la regularidad conformada por la repetición de una misma altura y debilita el establecimiento de una oscilación/alternancia de intensidad a partir de ella.

En definitiva, lo que sucede -y caracteriza de modo audiotáctil a esta pieza- no es tanto una oscilación/alternancia de intensidad en semicorcheas sino una doble oscilación/alternancia de intensidad en corcheas "cruzadas". En otras palabras y a modo de ejemplo, en la primera secuencia, una de las oscilaciones estará conformada por el ataque del bombo y a nota solb (y demás elementos texturales que acontezcan sincrónicamente en las $1^{\circ}$ y $3^{\circ}$ semicorchea de cada tiempo) y la segunda por las dos presentaciones de la nota mib (y demás elementos sincrónicos).

Esta oscilación "cruzada" resulta en un debilitamiento de ambos períodos de corchea, por lo que la oscilación de período igual a negra se ve relativamente fortalecida. Esto puede comprobarse por ejemplo en que, a pesar de presentar una sonoridad que lo ubica en primer plano, el hi-hat a contratiempo no alcanza para imponer el patrón PoumTchak. ${ }^{387}$ La menor sonoridad (o ausencia de ataque) de la primer semicorchea en la primera secuencia podría encontrarse operando también en este sentido.

Esta situación podría también explicar parcialmente el carácter medianamente diferenciado que la pieza asume entre los 2'03" y los 2'18" (y a partir de los 5'22" hasta el final), segmentos donde la secuencia allí presente completa las 4 semicorcheas de cada tiempo. Coincidente con la ocurrencia de una envolvente de intensidad más claramente percusiva, podrían constituirse en factores que fortalecen la oscilación/alternancia de intensidad en semicorcheas que allí se percibe con mayor claridad.

En definitiva, esta oscilación/alternancia de intensidad describe un período de $8.332 \mathrm{~Hz}$.

\footnotetext{
${ }^{387}$ El patrón descripto por el bombo en negras ("a tierra") y un hi-hat articulando todas las corcheas (a contratiempo). Para más detalles véase el desarrollo que realizamos de este patrón particular en el Anexo III bajo el título Heterogeneidad y complementariedad. EI "motor" regular.
} 
La pieza persiste constantemente sobre la nota mib, estableciendo una clara tonicidad sobre ésta. El mib más grave que se incluye se corresponde con los $77.782 \mathrm{~Hz}$. A diferencia de la pieza previamente analizada, para este caso no detectamos correlación alguna entre los períodos determinados por el tempo y aquellos dependientes de la afinación de las alturas seleccionadas.

Creemos sí digno de destacar el rol de refuerzo armónico audiótáctil que realizan los diferentes hi-hats al aportar sus componentes a reforzar las fases de ataque de las secuencias. Uno en corcheas a contratiempo, otro atacando todas y cada una de las semicorcheas y un tercero especialmente relevante que -si bien antes realiza una breve y sutil intervención- se escucha por primera vez con claridad a los 2'18". Presente en numerosos fragmentos, este sonido-instrumento aporta sus componentes a los ataques de las notas repetidas de las secuencias resultando en:

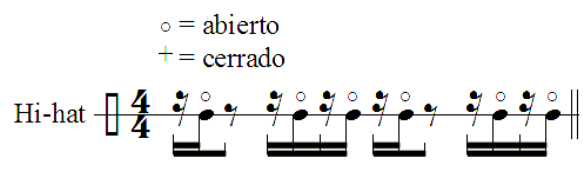

Por último, nótese la iteración del mib grave que, con una liberación lenta ("resonante") articula diferentes secciones al atacar periódicamente. A partir de un proceso de reducción del tempo pudimos detectar que el período de la iteración resultante que describe el timbre total cuando dicho elemento se hace presente se encuentra por momentos próximo al valor de semifusas, mientras que en otros pareciera describir períodos iguales a la mitad de dicha figura. Atribuimos estas variaciones a la interferencia mutua entre el mib grave, sus componentes espectrales y las oscilaciones de primer orden dependientes en cada momento de las alturas presentes en la secuencia. Encontramos un indicio que apoya esta hipótesis en el hecho de que en los períodos coincidentes con las dos ocurrencias de la nota repetida (en nuestro caso la nota solb ya que analizamos la ocurrencia de la nota grave que se presenta al 1'01") la iteración resultante es idéntica, reiterándose en cada repetición de la nota en cuestión.

En estas variaciones hallamos entonces otro indicio que soporta y valida la existencia efectiva de refuerzos armónicos audiotáctiles. Además, el mismo fenómeno es prueba de que tanto las oscilaciones de primero como de segundo orden se interfieren mutuamente, reforzando así a aquellas que se encuentran generando sensación táctil.

Finalizamos el análisis de esta pieza llamando la atención sobre un aspecto que quizá pasara desapercibido: como viéramos aquí, repeticiones de una única altura pueden suceder incluso en el contexto de secuencias conformadas por varias alturas. Siempre y cuando el retorno a una de éstas acontezca a (relativamente) breves períodos de tiempo, 
el establecimiento de una oscilación/alternancia de intensidad basada en una única frecuencia se hace posible.

\section{Repetición de una única altura con timbre de altura tonal no definida}

Como sucede parcialmente con el sonido grave en "The enemy", los dispositivos tecnológicos musicales ofrecen la posibilidad de reconvertir las cualidades de virtualmente cualquier timbre (i.e.: de altura tonal definida, de tonicidad débil o de altura tonal no definida) en otras totalmente diferentes. Al aplicar esta plasticidad a nuestro modelo de análisis surgen nuevos casos y situaciones que resultan variaciones del primero.

Existiendo diferencias que considerar, analizaremos ahora la repetición de un sonido de misma altura y donde el timbre sea (o se aproxime mucho a uno) de altura tonal no definida. Para facilitar la comparación con el caso previo, por tratarse de fenómenos frecuentes en la especie y porque (por enésima vez) es el registro que genera sensación táctil más evidente, continuaremos considerando en particular aquellos sonidos que ocurren en el registro grave. Comencemos entonces, intentando construir un paralelismo punto a punto con el caso previo de alturas tónicas.

El timbre que nos ocupa ahora consiste en una banda de frecuencias de ancho de banda más o menos estrecho y localizada en una determinada región del espectro; esto redunda en que, a diferencia de la situación previa, no tenemos aquí frecuencia con la cual sincronizar ciclos ni fases. Sin embargo, a pesar de la simplicidad que la exposición pudiera sugerir, esta situación presenta otras complejidades, ausentes en el caso previo.

Algunas veces coincidente con la función y timbre del sonido de bombo, en otras ocasiones el sonido que nos ocupa puede diferenciarse de éste, como un elemento o estrato textural independiente de aquél. En otras palabras, en el último caso consiste en un sonidoinstrumento diferente del bombo y que, junto a éste, ocupan el registro grave. En algunas piezas, además, otras de sus cualidades pueden ser interpretadas como "heredadas" de la función bajo, lo que permite asociarlo -siempre parcialmente- a dicha función.

Pudiendo presentar cualidades impulsivas y percusivas, lo dicho antes a este respecto resulta igual de válido ahora sin modificación alguna.

Una de las diferencias principales entre el caso previo y el actual se pone de manifiesto al finalizar la fase de ataque: mientras en aquél el sonido presenta un cuerpo con altura tonal definida, en éste el sostenimiento y/o liberación son de altura tonal no definida. Esta diferencia abre un abanico de (valga la redundancia) posibles diferencias que se manifestarán en este mismo punto del desarrollo de la envolvente de intensidad (o a partir de allí). Aún cuando, como antes, la diferencia principal al interior de cada evento puede detectarse entre el ataque y la fase inmediata posterior, en el caso que nos ocupa ahora puede ocurrir también que no existan diferencias entre las componentes espectrales del ataque y el sostenimiento o liberación. En 
cierto modo anticipándonos al extenso desarrollo que sigue y en post de simplificar la comprensión, creemos oportuno explicitar aquí que de lo dicho se deriva que: aún cuando ataque y cuerpo del sonido consisten en bandas de frecuencias, el cambio en la sensación táctil continúa dependiendo -como en el caso previo- de cuestiones relativas a la altura. Creemos que lo que pretendemos significar se clarificará en las diferentes configuraciones posibles de ocurrir que exponemos a continuación.

De ser coincidentes los anchos de banda y localización espectral en una y otras fases (i.e.: entre ataque y las siguientes), la segunda fase consistirá simplemente en la prolongación del mismo complejo espectral que se presentara durante el ataque; en otras palabras, el mismo estímulo se prolongará en el tiempo. Consecuentemente, cuando la duración (del sonido como todo) resulte más larga, lo que se prolongará será la misma sensación táctil originada en los transitorios de ataque. Dicho de otro modo, una misma y única sensación táctil (temporalmente indiferenciada) decaerá más lentamente.

De resultar divergentes alguna o ambas cualidades (i.e.: ancho de banda y localización espectral), todo dependerá de las relaciones complejas que se establezcan entre una y otra banda de frecuencias. En primer término podemos segregar los casos posibles en dos, donde el criterio para dicha segregación se basará en si la banda de frecuencias del cuerpo del sonido -o al menos una parte de ella- se encuentra dentro o fuera del rango de frecuencias que generan sensación táctil. No caben dudas respecto de que en el segundo caso no ocurrirá sensación táctil. Dada alguna de las situaciones incluidas en el primer grupo, podemos resumir las innumerables situaciones posibles en dos categorías generales:

a) La banda de frecuencias del cuerpo del sonido posee un ancho de banda amplio En el caso paradigmático ocurrirá que las frecuencias presentes abarcan el rango completo de frecuencias que generan sensación táctil. Sea cual sea este rango (son necesarias más experiencias que lo determinen con mayor fiabilidad) y sea como sea la contextura del sujeto perceptor, todo su cuerpo resultará -potencialmente- excitado.

Al distribuirse la energía acústica en un amplio rango de frecuencias es posible que, comparada con un sonido de igual intensidad pero de altura tonal definida, la intensidad de la sensación resulte -subjetivamente- menor. A pesar de lo dicho, es posible también que las menores intensidades locales (en cada sub-sistema corporal) se vean compensadas por el hecho de que la experiencia consiste en una vibración de cuerpo entero y que, por consiguiente, el sujeto describa (i.e.: enuncie, manifieste) percibir una sensación táctil de intensidad igual o mayor. Otra vez, nuevas experiencias son necesarias.

b) La banda de frecuencias del cuerpo del sonido posee uno o varios anchos de banda estrechos. 
Aquí es donde el abanico de posibilidades se abre considerablemente. Por tratarse de bandas estrechas resulta en cierta medida posible determinar la frecuencia alrededor de la cual cada banda se localiza. Según en qué región concreta del espectro acontezca cada banda, los correspondientes sub-sistemas corporales resultarán excitados, provocando allí sensación táctil. En otras palabras, aunque depende del ancho de banda que cada banda de frecuencias presente en cada oportunidad concreta, este caso resulta hasta cierto punto equiparable con nuestro ejemplo constituido por alturas tónicas y puede comprenderse en el mismo sentido: aunque en una relación más débil entre sí (por la imposibilidad de establecer una relación armónica simple entre ellos), los diferentes componentes del timbre total aportan sus oscilaciones (aquí no-periódicas) en diferentes zonas del espectro a la generación de sensación táctil.

Incluidos en estos casos están aquellos donde ciertos componentes en el sostenimiento y/o liberación coinciden con los presentes durante el ataque. Ingresando al terreno de la especulación teórica: en estos la sensación táctil puede presentar ciertos grados de continuidad con la experimentada durante dicha fase.

En definitiva y como mencionáramos, la localización corporal de la sensación táctil mantiene su dependencia de la frecuencia del estímulo. La diferencia es que aquí frecuencia y conformación espectral se funden en una única cualidad. Por esta particularidad la localización corporal en estos casos dependerá también del ancho de banda de cada una de las bandas estrechas que constituyen el timbre total. Esta variable (i.e.: el ancho de banda) se vuelve aquí necesaria para determinar la localización concreta del estímulo en el espectro de frecuencias.

En consecuencia, de ocurrir cambios en la frecuencia del estímulo (de altura tonal no definida), la respuesta en sensación táctil presentará similitudes y diferencias con la que presenta para estímulos de altura tonal definida. Dichos cambios en el estímulo podrán producir (como antes) traslaciones y/o cambios discontinuos en la localización corporal de la sensación táctil. Sin embargo, debido precisamente al ancho de banda (mayor que en el caso previo), es posible prever que ciertos cambios continuos en la localización espectral de una determinada banda de frecuencias que se encuentra generando sensación táctil en un sub-sistema ("A") excite paulatinamente a otro ("B", hasta ese entonces en reposo), generando sensación táctil allí antes de que en el primero se extinga. Cabe preguntarse en este caso hipotético acerca de la continuidad o discontinuidad del cambio en la localización corporal de la sensación táctil.

Respecto de la intensidad y profundidad de la sensación, nada se modifica y para ambas persiste su dependencia de la intensidad del estímulo.

Ciertas relaciones entre las oscilaciones de primer orden y los refuerzos armónicos audiotáctiles se ven modificadas y pierden sentido. Los últimos continuarán aportando sus componentes al timbre total tanto en la fase de ataque como -de existir- en las de sostenimiento 
y/o liberación, por lo que lo dicho a este respecto permanece aún válido. Sin embargo, debido a que nuestra referencia consiste ahora en un sonido de altura tonal no definida, no hay relación armónica simple posible de establecer entre unas y otras oscilaciones. Esta situación conduce a que, a lo sumo, la distribución de alturas tónicas o de tonicidad débil en registros superiores sea tal que refuerce una frecuencia fundamental (ausente como frecuencia aislada pero) comprendida en alguna de las bandas de frecuencias que se presentan en el registro grave/subgrave. Sucederá entonces que dicha banda se percibirá con un grado mayor de tonicidad que el que pudiera presentar por sí misma, ocurriendo (en algún sentido y hasta cierto punto) un fenómeno similar al refuerzo armónico. En otras palabras, esta mayor tonicidad se producirá a partir de las frecuencias diferenciales originadas por la interferencia entre las alturas tónicas incluidas en registros superiores. Más allá de esto, cada frecuencia o banda de frecuencias contará, para la generación de sensación táctil, "solo" con la energía acústica "propia".

Respecto de iteraciones, por las propiedades tímbricas de los sonidos considerados, solo algunas podrán suceder; ${ }^{388}$ aquellas que efectivamente pueden ocurrir, presentarán las mismas relaciones que en la situación previamente descripta, exceptuando que -como puede suponersetampoco aquí son posibles la sincronización de ciclos y fases con el sonido "base" en el registro grave/sub-grave. Sin embargo, por tratarse de oscilaciones cuasi-periódicas nada impide que sus ciclos y fases se sincronicen con los ciclos y fases de las alturas tónicas (i.e.: oscilaciones de primero y segundo orden) que pudieran incluirse en los registros superiores y/o en los refuerzos armónicos audiotáctiles.

El establecimiento de oscilaciones/alternancias de intensidad, como viéramos durante su descripción, resulta independiente del o de los tipos de timbres involucrados. Al igual que en el caso previo, pueden también suceder aquí por la aplicación de algunos de los recursos enumerados durante nuestro análisis de la sonoridad.

Por último, para finalizar la oposición de propiedades nos restan describir las posibilidades de sincronía. En breves y sencillas palabras, como antes, la sincronización puede establecerse entre todas las propiedades que presenten alguna forma de periodicidad. En definitiva, puede establecerse sincronización entre:

a) oscilaciones de primer orden que pudieran encontrarse en registros superiores y que presentasen timbres de altura tonal definida (i.e.: aquellos que en el caso previo describiéramos como refuerzos armónicos),

b) iteraciones u otras oscilaciones de segundo orden que pudieran conformar el timbre total $\mathrm{y}$

\footnotetext{
${ }^{388}$ Los batimentos, por ejemplo, por requerir de la interferencia mutua de dos o más frecuencias aisladas no acontecen en estas conformaciones de altura tonal no definida.
} 
c) los ataques de los diferentes elementos y estratos texturales que pudieran hallarse conformando las -consecuentemente sincronizadas- oscilaciones/alternancias de intensidad de diferentes niveles.

Considerando que los ejemplos analizados para los casos de repetición de alturas tónicas han sido suficientemente ilustrativos y que permiten comprender el punto de vista (o mejor, escucha y tacto) que se debe asumir para observar de modo crítico este fenómeno, nos limitaremos aquí a sugerir experimentar de modo audiotáctil la pieza Ayahuasca del productor búlgaro Pavel Petrov. ${ }^{389}$ Lanzado en mayo de 2016, se asocia con los índices techno y house.

A modo de breve guía, creemos apropiado focalizar la atención menos en la tonicidad que presentan solo algunos sonidos y más sobre los transitorios de ataque y componentes de ruido que incluyen la amplia mayoría. Nótese como, a pesar de su discontinuidad, el sonido de bajo sobre una única altura que se inicia a los 0'37" alcanza a establecer una oscilación/alternancia de intensidad que, sin embargo, no provoca sensación táctil. Este mismo elemento, perdiendo parcialmente su tonicidad a partir de los 2'07" asume el rol de refuerzo armónico audiotáctil de la oscilación aún más grave y continua que allí inicia.

La región grave/sub-grave la ocupan un bombo y otro sonido casi indiscernible, los dos con timbre de altura tonal no definida. En ambos se reconoce cierto grado (mínimo) de tonicidad por la sutil diferencia que presenta cada uno en relación al otro en este aspecto. El último, apenas una banda de frecuencias en la zona más grave del espectro, denota estar expuesto a compresión por cadena lateral conducida por el bombo. De hecho, es justamente el incremento en su intensidad durante la parte débil del tiempo (la $2^{\circ}$ corchea del tiempo de negra) lo que evidencia la presencia de un sonido diferente al bombo en esta región del espectro. Coincidiendo parcialmente con las bandas que componen al primero, configuran entre ambos una oscilación/alternancia de intensidad de período igual a corchea. En una pieza binaria de tempo 120 , estos son $4 \mathrm{~Hz}$.

Secundariamente, creemos que también resulta interesante observar los modos en que en esta pieza interactúan las diferentes iteraciones, reiteraciones y ataques aislados en relación al elemento grave descripto en el párrafo precedente.

\section{Repetición de una única altura con timbres de tonicidad débil}

Como acabamos de ver, bandas de frecuencias pueden combinarse simultáneamente con sonidos de altura tonal definida generando sensaciones táctiles que podemos denominar "mixtas". Estos son casos equivalentes con aquellos donde ocurren sonidos de tonicidad débil y constituyen los puntos intermedios entre los extremos del eje difuso que configuran los timbres

\footnotetext{
389 Pavel Petrov - Ayahuasca (Original Mix). (2016) Subido por Mia Mendi. Accesible en https://youtu.be/2bnZliAjPUk [02092016]
} 
de altura tonal definida y de altura tonal no definida. De hecho, desde la perspectiva espectral no presentan diferencias y pueden resultar divergentes apenas en las localizaciones espectrales concretas de sus componentes de altura tonal definida y de altura tonal no definida del timbre total. Como tales, nada resta por decir, ya que ambos casos resultan idénticos y cumplen con las mismas propiedades y relaciones descriptas durante el análisis de los casos de altura tonal no definida.

Los casos mixtos son los más numerosos en la especie y, como en la casi totalidad de las músicas contemporáneas, escasos aquellos que solo presentan un único tipo de timbres. Particularmente en las músicas electrónicas utilizadas para el baile social, la combinación de sonidos de timbres de altura tonal definida, de altura tonal no definida y toda la gama intermedia es temática. Esto no debería resultar extraño desde que, en músicas que aprovechan las capacidades de trabajo "plástico" sobre la materia sonora que brindan los instrumentos de base tecnológica, el timbre (parcial y total) es el ámbito que (por su multidimensionalidad) mejor permite desarrollar procesos sono-musicales complejos.

\section{Localización espectral grave/sub-grave como ánimo o carácter audiotáctil}

Luego de los numerosos argumentos que hemos expuesto en el transcurso de los últimos títulos creemos que resulta posible proponer como hipótesis que:

al menos uno de los criterios que los productores utilizan para determinar la afinación de los elementos y estratos texturales que se localizan en la región grave/sub-grave tiene origen táctil y/o audiotáctil.

Consciente o inconscientemente, en ciertos momentos del proceso de diseño sonoro (i.e.: configuración tímbrica de los sonidos a utilizar), composición y arreglo de sus creaciones, los productores toman en consideración el aspecto táctil que generan los diferentes elementos y estratos texturales y/o el timbre total.

Este argumento (i.e.: tomar en cuenta la sensación táctil percibida y generada) podría explicar algunos de los múltiples aspectos de las músicas electrónicas utilizadas para el baile social que describiéramos durante los títulos previos. Entre otros, encontramos aquí una explicación (al menos parcial) para:

a) el uso prolífico del registro grave/sub-grave.

b) la jerarquización por mayor intensidad relativa que presenta el registro grave/subgrave por sobre los demás.

c) la proliferación y persistente presencia de elementos texturales graves/sub-graves en aquellos índices más utilizados en locales de baile. 
d) el tiempo y dedicación que se destina al sonido de bombo en general y a su afinación en particular.

e) las numerosas piezas que presentan en el registro grave/sub-grave configuraciones que incluyen repetición rítmica y en altura.

f) la dinámica que se establece con los bailarines y el rol que el registro grave/sub-grave cumple en dicha dinámica.

g) las numerosas piezas que presentan un tipo de repetición tal que permite el establecimiento (y su análisis) a partir de la herramienta que llamáramos oscilaciones/alternancias de intensidad.

h) la proliferación de sonidos de ataque impulsivo y perfil percusivo.

Durante nuestros años en la profesión hemos tenido acceso a publicaciones y entrevistas donde los productores narran los caminos que recorren en su proceso creativo. En muchas notas publicadas en revistas especializadas (que mencionáramos en títulos previos) hemos visto que la mayoría de los artistas suele comenzar a partir de configurar la sección rítmica. Si bien esto no constituye una regla, es quizá el caso más veces descripto. Nada extraño si consideramos los argumentos que hemos presentado en títulos previos; muchos alegan o demuestran además el cuidado particular puesto tanto al seleccionar y configurar el o los sonidos de bombos como al conformar el patrón rítmico básico que dicho sonido-instrumento describirá. ${ }^{390}$

Hemos mencionado también que, en las secciones dedicadas a "géneros" (i.e.: índices) específicos y como parte de su descripción, en su The Dance Music Manual Rick Snoman se dedica a determinar los rangos de frecuencias dentro de los cuales suelen afinarse los bombos para cada género-índice. ${ }^{391}$

En los anteriores argumentos encontramos indicios que podrían agregar nuevos datos a nuestra hipótesis. Creemos plausible afirmar que:

algunos productores seleccionan la afinación de los elementos texturales graves/subgraves según las cualidades que la sensación táctil asume en sus cuerpos. ${ }^{392}$

La repetición o persistencia de una única altura en el registro grave generará un estímulo audiotáctil de cualidades estables. Apelando a un sentido no asociado tradicionalmente con la

\footnotetext{
${ }^{390}$ Incontables artículos de revistas y tutoriales en video en DVD y en línea soportan lo dicho en los dos últimos párrafos. Ejemplos posibles se incluyen en la Lista de reproducción de la revista Future Music en https://youtu.be/RKhUs2wxuE4?list=PLzRVf2noPwEFGdrgQOrurKcZ7sOmctYDC. [28082016] Resulta especialmente explícito el testimonio de Luca Petrolesi respecto de la cantidad de procesos aplicados al sonido de bombo.

${ }^{391}$ Snoman, R. (2009). Op.cit. Véase páginas 238, 255, 275, 316, 333 y 350. Resulta significativo también que en la sección dedicada a la mezcla, el primer instrumento concreto que se menciona sea el bombo (pags. 382 y sgtes.).

${ }^{392}$ Principalmente, su localización corporal.
} 
música, no resulta extraño que en la primera especie que lo visibiliza (o, como dijéramos en oportunidades previas, tactibiliza) se procure la generación de sensaciones claramente reconocibles. Encontramos aquí una analogía posible con el período de establecimiento del sistema tonal; ahora, como entonces, se buscaron y buscan las conformaciones que menos ambigüedad presentan respecto de la generación de las sensaciones deseadas. Lo que en siglos pasados fuera el establecimiento de tensiones y distensiones abstractas y culturalmente construidas, es hoy la generación de sensaciones táctiles concretas, materialmente percibidas. La instauración de jerarquías diferenciadas, análogas a las generadas por el sistema tonal, surge en lugares impensados.

Quizá aquí se explica por qué tantas piezas de la especie presentan bajos que -de diversos modos y aún cuando pueden describir movimientos melódicos- insisten y persisten sobre una altura, jerarquizándola en detrimento de otras. Ya sea que estemos en lo correcto y que lo que resulte pregnante sea su localización corporal, o que nos equivoquemos y que dependa de otra cualidad de la sensación táctil, lo cierto es que ésta ocurre y que será tan estable como las variables en la vibración. La repetición de una altura -ya sea de altura tonal definida, de tonicidad débil o de altura tonal no definida- establece una relación clara y estable entre la pieza concreta y una determinada sensación táctil. Al menos durante la presentación de la mencionada pieza, la sensación táctil será reconocible. Quizá a posteriori nuestra memoria corporal, muscular y/o motora preserve un registro de la misma, como parte del recuerdo (racional-emocional, mental-corporal) que la pieza evoca.

Sobre lo que no cabe duda es que las propiedades táctiles de las piezas musicales -o de algunos de sus elementos o estratos texturales al menos- establecen algún tipo de vínculo con el cuerpo del sujeto perceptor. Resulta posible entonces inferir que las propiedades táctiles mencionadas, por medio del mismo cuerpo, inciden en alguna medida sobre los movimientos de baile, la cadencia de movimiento, las cualidades de movimiento que los bailarines describen en cada pieza o segmento de esta.

En este sentido es que resulta posible afirmar que durante el proceso de creación, en la frecuencia del estímulo el productor encontrará un cierto ánimo diferenciado de otros. En cada altura concreta, en cada nota (en principio, independientemente de la escala y modo en que esta se inscriba) el productor detectará cierto carácter que identificará como propio y único de ese período de oscilación. El productor, al elegir (consciente o inconscientemente) la frecuencia de los elementos graves/sub-graves a partir de los valores concretos de sus propias dimensiones corporales, elegiría entonces un determinado ánimo o carácter audiotáctil para la pieza musical en proceso de creación.

Continuando con las analogías, similar a la teoría renacentista de los modos -aunque en este caso no dependiente de una escalística relacional sino de una frecuencia absoluta- cada altura concreta (i.e.: cada nota, independientemente del nombre que reciba) involucraría cierto 
ánimo o carácter. Este ánimo, intrínseco a la altura concreta al menos para la subjetividad de cada productor, resultaría derivado de la sensación táctil que dicho productor percibe en su fuero íntimo a partir de dicha frecuencia. Esto podría incluso condicionar la selección (posterior) de la escalística, timbres, tempo u otras variables musicales que, por ser al menos por ahora solo intuiciones, preferimos no arriesgar, dejándolas para desarrollos futuros.

Por supuesto, resulta muy probable que nos encontremos aquí frente a un fenómeno no lineal. En los párrafos precedentes expusimos muy esquemáticamente la relación principal y, muy por el contrario, estamos convencidos que en el vínculo entre el productor y el estímulo se encuentra activa una red de relaciones dialécticas (en múltiples y muy diversas dimensiones; involucrando factores culturales, personales, biofísicos, etc.) que presentan un alto grado de complejidad.

En títulos previos describimos también la incidencia que sobre la sensación táctil tiene el timbre total (en sentido amplio) del estímulo. Hemos visto como aquella se configura a partir de la interferencia mutua de los diferentes elementos y/o estratos texturales. Si dichos factores inciden sobre (a modo de ejemplo) la oscilación/alternancia de intensidad, no es descabellado considerar a la sensación táctil resultante, como parte de los factores que inciden sobre la voluntad de los productores a la hora de decidir la forma de cada elemento y estrato a incluir.

Del mismo modo puede comprenderse condicionada a la armonía o a las conformaciones espectrales. En gran medida una categoría especial dentro del más general timbre, las armonías más diversas (en su interválica, sistema de organización y distribución registral) se inscriben en la lógica del refuerzo armónico y del timbre total. Lo que -a modo de ejemplo- hacen diferentes conjuntos de notas por sobre una misma altura "base", es aportarle frecuencias más o menos diferentes (con timbres más o menos diferentes) en cada momento, transformando en definitiva la superficie del timbre total.

En esta misma lógica creemos necesario hacer una aclaración acerca de otra relación; aunque ya fuera presentada, ésta puede evidenciar aún nuevas derivas: si la afinación depende en algún grado de la sensación táctil que el productor experimenta, y el timbre total (en sentido amplio) incide sobre la sensación táctil experimentada, entonces el ánimo audiotáctil se encontrará también enlazado -en primera medida- al grado de tonicidad que presenten los sonidos utilizados en el registro grave/sub-grave y -secundariamente- al que presenten los elementos en registros superiores. Si bien -como anticipáramos- la precedente es solo otra forma de referirnos al timbre total, vemos aquí que tomar en consideración su conformación interna pone de manifiesto que el efecto de la sensación (y ánimo) audiotáctil va más allá del registro grave/sub-grave.

Apenas una hipótesis imperfecta, la localización corporal de la sensación táctil depende sin embargo de la relación entre los valores concretos de las frecuencias presentes en el estímulo y de los que asuman las dimensiones del cuerpo del productor. Como viéramos, probablemente 
una sensación en parte individual-subjetiva y en parte compartida-común, nada impide que si la sensación táctil se presenta en el local de baile pueda también ocurrir en un estudio de producción musical equipado con el instrumental apropiado; nada impide que si la sensación táctil resulta un factor activo que opera sobre los bailarines durante la danza, se configure como un factor activo que opera sobre los productores durante la etapa de creación.

Finalizamos así entonces el tratamiento de los vínculos entre la cualidad altura y la sensación táctil. Conscientes de que mucho más puede decirse y de que aún más puede analizarse, creemos sin embargo que hemos expuesto los lineamientos generales y las perspectivas a asumir para la comprensión de las relaciones que pueden establecerse entre los respectivos universos complejos del estímulo y su correlato perceptivo. 
RESULTADO Y CONCLUSIONES

\section{Sensación táctil en las músicas electrónicas utilizadas para el baile social}

Los trabajos realizados permitieron corroborar que es posible operar sobre la música para obtener sensaciones táctiles con fines estéticos. A la vez, los mismos estudios proporcionaron una descripción del sistema complejo involucrado en la generación y percepción de este tipo específico de sensación.

Tanto la totalidad como cada uno de los componentes del sistema, cuentan hoy con modelos que los describen. Se hallaron herramientas que permiten el estudio efectivo de sus cualidades y de las relaciones que se establecen en cada componente y entre componentes. Mediante un análisis exhaustivo se obtuvieron los datos necesarios, a partir de los cuales es posible anticipar en cierta medida el efecto táctil y/o audiotáctil que tendrán las conformaciones sono-musicales organizadas a partir de los criterios mencionados.

En resumen, se obtuvieron los siguientes resultados:

1.- Caracterización de la sensación táctil y/o audiotáctil.

Se determinó la pertinencia de los factores empleados en el análisis de la sensación táctil y audiotáctil. Su identificación incluyó además la delimitación de diferentes valores para cada uno:

Tipo de sensación: táctil o audiotáctil (o auditiva, en ausencia de sensación táctil).

Intensidad: fuerte, media o apenas perceptible.

Profundidad corporal: superficial o profunda; cutánea, ósea, en diferentes cavidades/ órganos o textil.

Localización corporal: (ver punto 4)

Calidad o cualidad de la sensación: golpe, vibración, presión, cosquilleo, entre otros.

Respuesta emotiva: placer, displacer o neutra.

2.- Caracterización del estímulo sono-musical que la origina y modifica.

Se identificaron y describieron las principales variables sono-musicales involucradas en la generación de sensaciones táctiles y audiotáctiles. Se constató también que determinadas modificación temporales de los valores en el estímulo incide sobre las cualidades de la sensación. Algunas de éstas son: intensidad, frecuencia, duración, envolvente de intensidad, oscilaciones de primero y segundo orden, composición espectral general y de sus transitorios de ataque, oscilaciones/alternancias de intensidad, periodicidad, repetición e iteración.

3.- Caracterización de las músicas electrónicas utilizadas para el baile social como la especie y el contexto paradigmático de generación de sensación táctil y audiotáctil. 
Se identificaron características particulares y propias de las músicas electrónicas utilizadas para el baile social que probablemente condujeron a que la especie cumpliera los roles mencionados. Algunas de las propiedades que la diferencian de otras músicas y que pueden indicarse como maximizadoras o facilitadoras de la sensación táctil y audiotáctil percibidas son: el uso sostenido de rangos extendidos de intensidad y frecuencia (especialmente hacia el registro grave/sub-grave), un elevado grado de repetición en diferentes escalas, la presencia en varios niveles simultáneos de oscilaciones/alternancias de intensidad, una tendencia al establecimiento de diferentes pulsaciones y cuasi-pulsaciones simultáneas y el uso extensivo de conformaciones que involucran percusividad, iteratividad y reiteratividad.

4.- Determinación de algunos sistemas y sub-sistemas corporales donde se localiza la sensación táctil.

En primer término, se corroboró la posibilidad de ocurrencia de sensación táctil localizada y no localizada (o vibración de cuerpo entero). En el primer caso, al menos los sujetos experimentales que participaron de las experiencias de campo fueron capaces de distinguir sensación táctil localizada en pies, piernas, pecho, abdomen, tabique nasal, garganta, cráneo, maxilar inferior y axilas. En relación a la profundidad, los mismos sujetos manifestaron percibir sensación táctil en la piel, huesos y órganos y cavidades internos. También se comprobó la ocurrencia de sensación táctil "textil" y -al menos en dos oportunidades- el traslado de la sensación de un lugar a otro.

5.- Determinación de algunas de las relaciones que se establecen entre el estímulo musical generado y la sensación táctil y audiotáctil percibidas.

En este aspecto de la exploración se conjugan la totalidad de las complejidades inherentes a cada componente del sistema de generación y percepción de sensación táctil y/o audiotáctil. Fuertes indicios apuntan a que las relaciones entre el estímulo emitido y la sensación percibida son, esquemáticamente y hasta cierto punto, como siguen:

\begin{tabular}{|c|c|}
\hline Característica del estímulo & Sensación generada/percibida \\
\hline Intensidad & $\begin{array}{c}\text { Tipo // Intensidad // Profundidad } \\
\text { Respuesta emotiva }\end{array}$ \\
\hline Frecuencia // Conformación espectral & Tipo // Localización \\
\hline Envolvente de intensidad & Calidad // Localización \\
\hline
\end{tabular}

\footnotetext{
${ }^{393}$ Durante la redacción de estas conclusiones y a partir de ciertos indicios detectados "entre líneas" al revisar nuevamente nuestras ideas y experiencias de campo (i.e.: al entrecruzar nuevamente los testimonios de los sujetos experimentales con el registro del entorno acústico), surgió la necesidad de reevaluar el grado de incidencia sobre la profundidad corporal que le asignáramos a la frecuencia. En otras palabras, es posible que las frecuencias de resonancia de órganos y cavidades internas incidan en mayor grado y operen sobre el sistema corporal volviéndolo aún menos lineal que lo estimado hasta aquí.
} 
A partir de lo expuesto es posible entonces concluir que:

A.- Dadas ciertas condiciones de intensidad y espectro, todas las variables del estímulo sono-musical inciden sobre la generación de sensación táctil y audiotáctil.

La totalidad de las características que constituyen los sonidos (micro-forma) y los fragmentos musicales breves (forma de nivel medio), en ciertas condiciones, pueden contribuir a generar fenómenos audiotáctiles. Cada una de ellas incide tanto sobre el sistema auditivo como sobre el sistema háptico humano.

B.- Las manifestaciones en la región sub-sónica del timbre, ritmo y textura convergen en la generación de sensación táctil.

Usualmente analizadas desde perspectivas independientes, al integrar en una misma categoría a oscilaciones de primer orden (sónicas y sub-sónicas) con fenómenos rítmicos, texturales y tímbricos, se manifiesta su incidencia concurrente sobre la generación de sensación táctil y audiotáctil.

C.- Frecuencias por sobre el registro grave/sub-grave juegan un rol activo en la generación de sensación táctil.

El registro grave/sub-grave es el principal generador de sensación táctil y audiotáctil, mientras que las frecuencias superiores inciden como refuerzos armónicos audiotáctiles. Transitorios de ataque o componentes tímbricos y texturales localizados en zonas de frecuencias superiores son potenciales generadores de sensación táctil. Contrariamente a la opinión generalizada, en la generación de sensación táctil y audiotáctil se ven involucradas todas las frecuencias presentes en el timbre del sonido y en la textura musical.

D.- Cualidades sui generis de las músicas electrónicas utilizadas para el baile social configuran un contexto acústico especialmente propicio para la generación de sensación táctil y audiotáctil.

Las músicas electrónicas utilizadas para el baile social presentan algunas características ausentes en otros contextos musicales. Las oscilaciones/alternancias de intensidad y los refuerzos armónicos audiotáctiles, en interacción mutua con las elevadas presiones acústicas y los rangos extendidos de frecuencias (especialmente hacia la región grave/sub-grave), se configuran como las principales cualidades maximizadoras de la sensación táctil y audiotáctil. Su inclusión en estas músicas podría explicar por qué en la comunidad electrónica se obtienen mayor cantidad de testimonios que se refieren a sensaciones táctiles. 
E.- Los diferentes tamaños de los sistemas y sub-sistemas corporales hacen que ciertas características de las experiencias táctiles y audiotáctiles sean compartidas parcialmente los sujetos expuestos.

Mientras que parte de los estímulos se perciben de modo audiotáctil de forma diferenciada según el cuerpo de cada sujeto perceptor, otras cualidades de la señal acústica provocan sensaciones compartidas y análogas.

\section{Prospectiva}

De esta manera llegamos al final de un recorrido que, sabíamos, resultaría necesariamente inconcluso y parcial. Siendo mucho más lo que resta por investigar que lo incluido en este documento, consideramos sin embargo que este trabajo permite iniciar un camino que sin dudas ofrece futuros descubrimientos y el desarrollo de herramientas y categorías para el análisis, creación e interpretación de piezas musicales a partir de criterios audiotáctiles.

Tan importante como los resultados mencionados, creemos que esta tesis propone métodos y procedimientos, como las oscilaciones/alternancias de intensidad y los refuerzos armónicos audiotáctiles, aplicables a la práctica musical concreta.

Estudios adicionales son necesarios para determinar el grado de sensibilidad de, por ejemplo, los cambios que pueden operarse entre la fase de ataque de un sonido de bombo y la de su decaimiento. Tan importante como la determinación de límites y umbrales de sensibilidad es la exploración práctica de las herramientas analítico-compositivas musicales mencionadas.

La creación de músicas electrónicas utilizadas para el baile social a partir de criterios audiotáctiles y su puesta en acto frente al público, son algunas actividades que permitirán comprender los verdaderos alcances de esta investigación. 


\section{ANEXO I}

Experiencias de campo.

Sensibilidad táctil a vibraciones originadas en músicas electrónicas utilizadas para el baile social.

Experiencias realizadas durante fiestas electrónicas en un reconocido local de baile del microcentro porteño. Ciudad Autónoma de Buenos Aires, junio y agosto de 2015

\section{Descripción de las experiencias}

Con el objetivo de recabar datos experimentales que dieran cuenta de algunas de las cuestiones relativas al tema de la tesis, se realizaron varias experiencias de campo que consistieron en asistir a fiestas con presencia de músicas electrónicas utilizadas para el baile social. Frente a la ausencia de estudios previos que pudieran tomarse como guía metodológica, fue necesario realizar una serie de ensayos y acciones preparatorias.

Para preparar la expedición el autor a) realizó algunas experiencias en laboratorio sobre su propio cuerpo, b) asistió a eventos en entornos en los cuales hubiera -al menos por momentos- niveles medianamente altos de presión acústica y c) compuso piezas de la especie procurando replicar ciertas características que en principio se presentaban como condición necesaria para la generación de sensación táctil. Estas experiencias permitieron refinar el procedimiento a utilizar y elegir las variables a ser evaluadas. En síntesis, los resultados preliminares fueron los siguientes:

a) en las experiencias en laboratorio fue posible generar sensaciones táctiles débiles, quizá debido a las limitaciones técnicas del equipamiento utilizado (monitores de campo cercano que generan una presión acústica relativamente baja).

b) Algunas sensaciones táctiles fueron detectadas en recitales al aire libre, fiestas en locales cerrados, manifestaciones callejeras (marchas políticas) con presencia de agrupaciones musicales informales (ensambles de percusión y/o instrumentos de la familia de los metales y presentaciones de murgas barriales). La intensidad de las sensaciones percibidas difirió de un evento a otro y en algunos casos fueron caracterizadas como "intensas". Los registros grabados, aunque fueron realizados con dispositivos digitales estándar, permitieron identificar algunas de las posibles causas físicas de la generación de sensación táctil.

c) Ciertos pasajes y materiales de las piezas musicales compuestas provocaron sensaciones táctiles en el propio cuerpo del autor y en allegados que asistieron a las presentaciones (recitales y conciertos didácticos brindados en el transcurso de los últimos años). 
Pasadas las experiencias preliminares, en el primer trabajo de campo formal se realizaron numerosas mediciones de nivel sonoro y anotaciones personales de las sensaciones táctiles percibidas.

El análisis posterior puso de manifiesto la utilidad de entrecruzar registros físicos de la realidad acústica con las respuestas perceptuales que dieran cuenta de las sensaciones audiotáctiles asociadas.

\section{Experiencias de campo}

Se asistió varias veces a un local de baile cerrado de la Ciudad Autónoma de Buenos Aires. El equipo técnico, integrado por cinco personas munidas de protectores auditivos, sonómetro y grabador digital realizó mediciones y registró el entorno acústico en diferentes puntos estratégicos del local. En simultáneo y en las mismas localizaciones, 5 sujetos experimentales (también con su audición protegida) respondieron a un breve cuestionario suministrado, confeccionado específicamente para explicitar las sensaciones táctiles percibidas.

Con el objetivo posterior de cruzar datos, ambas actividades se realizaron en relación a una referencia temporal única.
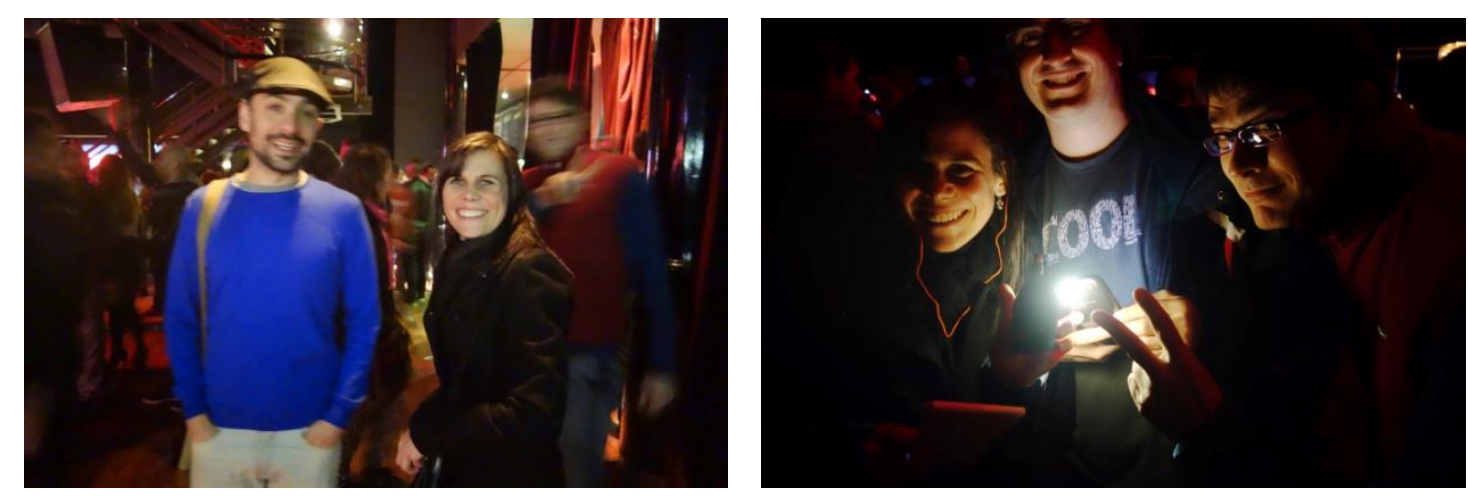

Integrantes del equipo registrando niveles de presión acústica durante una de las experiencias. Local de baile de zona microcentro. Buenos Aires, junio 2015.

Al comprobarse la ineficacia de los micrófonos de contactos sobre el cuerpo de los sujetos experimentales, ${ }^{394}$ se optó por obtener los datos físicos de mediciones de nivel de presión sonora y de la descripción de las características musicales de cada evento. Para los datos perceptuales se recurrió a la ayuda de cinco sujetos experimentales, quienes asistieron por propia voluntad y con el fin específico de formar parte de la experiencia. Su participación consistió en describir sus percepciones audiotáctiles a partir de ciertas variables consignadas.

\footnotetext{
${ }^{394}$ Se barajó la posibilidad de utilizar estos dispositivos como método para medir las vibraciones de los subsistemas corporales de los sujetos experimentales y así contar con datos objetivos que pudieran entrecruzarse con sus respuestas subjetivas. La contaminación de la señal originada en la detección de vibraciones aéreas determinó que se los considerara ineficaces para la función asignada. Evaluadas las opciones, los registros realizados (y que luego se detallarán) se consideraron datos objetivos suficientes para la presente etapa.
} 
Tanto los registros como las anotaciones fueron realizados con una referencia temporal única para permitir el posterior entrecruzamiento de datos. En resumen, se realizaron las siguientes actividades:

a) Mediciones de los niveles de presión sonora en $\mathrm{dBA}$ y $\mathrm{dBC}$ con referencia temporal.

b) Registro de las señales acústicas completas (música) con referencia temporal para su posterior análisis. Entre otros, rangos de frecuencias, perfiles de evolución temporal y diagramas tridimensionales de evolución espectral.

c) Registro de las respuestas perceptuales de los sujetos experimentales con referencia temporal.

Con la finalidad de salvar algunas dudas, ambigüedades e imprecisiones, en los días posteriores a la primera expedición se realizaron algunas entrevistas virtuales complementarias a los sujetos experimentales. Por último, también con posterioridad a la experiencia y con el objeto de recabar datos en relación a los hábitos y experiencias previas de cada sujeto experimental, se les solicitó que respondieran la siguiente encuesta:

\footnotetext{
Datos personales

(Su nombre personal se utilizará solo para asociar sus respuestas a su persona física, el informe será anónimo y se utilizarán denominaciones genéricas del tipo "Sujeto A", "Sujeto B", etc.)

Nombre:

Edad:

Sexo:

Altura:

Peso:

Contextura:

Profesión/ocupación:

Responda todas y cada una de las preguntas contextuales

a. ¿Acostumbra asistir a eventos de música electrónica?

b. ¿Con qué periodicidad? (n veces al año/mes/semana)

c. ¿Y a otros eventos donde haya presencia de música amplificada? ¿Qué géneros musicales suenan en dichos eventos? Rock, indie, cumbia, salsa, folklore, etc.

d. ¿Ha detectado con anterioridad algún tipo de sensación corporal que asociaría como originada en la música? (Responda esta pregunta solo si detectó sensaciones corporales durante la experiencia realizada en conjunto. De lo contrario omítala y pase a la siguiente)

e. Cuando asiste a estos eventos, ¿utiliza algún tipo de protección auditiva? ¿De qué tipo?

f. ¿Sufre de algún tipo de pérdida auditiva? ¿Cuáles son sus síntomas?

g. ¿Realizó la experiencia bajo los efectos de alguna substancia psicoactiva? ¿Cual?

h. ¿Ha consumido substancias psicoactivas en otras ocasiones? ¿Cuáles?

i. ¿Con qué frecuencia aproximada? (n veces al año/mes/semana para cada substancia consumida)

j. ¿Considera que dicho consumo ha influido en su sensibilidad corporal? ¿En qué sentido? (incremento o detrimento de la sensibilidad)

k. ¿Considera que dicho consumo modificó la CUALIDAD de las sensaciones corporales percibidas? ¿Cómo caracterizaría dicha modificación?
} 
Las mediciones y registros acústicos físicos fueron luego cruzados entre sí, dando como resultado una aproximación a las condiciones acústicas a las que hacen referencia las respuestas subjetivas de los sujetos experimentales. El cruce posterior entre dichas condiciones acústicas y las respuestas perceptuales permitió obtener indicios acerca de las relaciones que se establecen entre estímulo y sensación táctil.

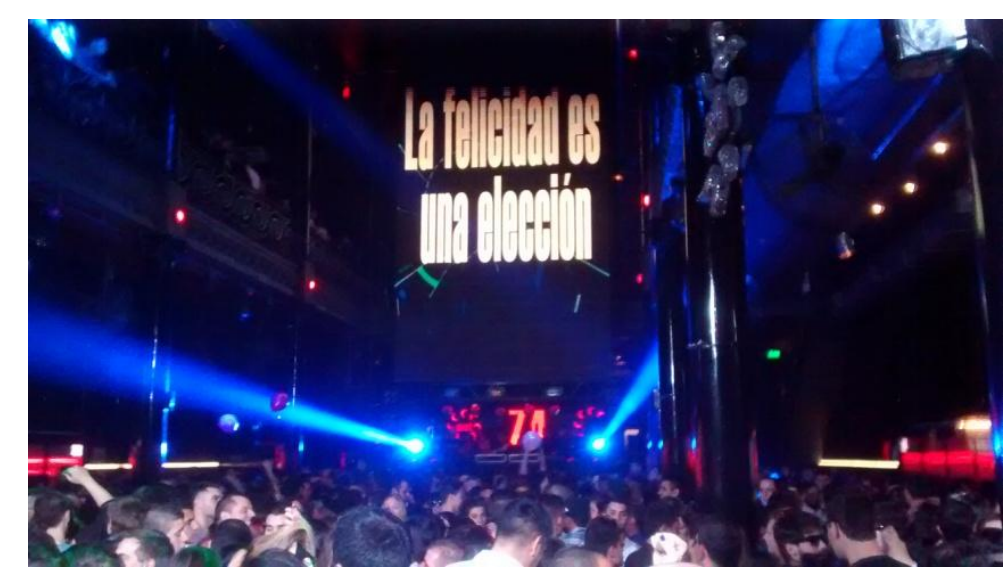

Vista del local de baile, el día del evento.

\section{Contexto acústico arquitectónico}

Características del local. ${ }^{395}$

Edificación modernista de fines del siglo XIX, aún conservan los detalles arquitectónicos propios del estilo. Ubicado en el barrio de Monserrat de la Ciudad Autónoma de Buenos Aires, forma parte de su Patrimonio Histórico y Cultural.

\section{Características}

4 plantas / $2500 \mathrm{mts}^{2}$. Modularidad de espacios. Ascensores de última generación. 60 metros de barras. Amplios espacios de servicios. Amplia capacidad de estacionamiento. Área WI-FI.

Dimensiones: 59,60 x 15,75 metros (según planos descargados del sitio oficial).

Altura estimada: $15 / 20$ metros.

Capacidad: 2500 personas (dato no oficial).

${ }^{395}$ Datos extraídos del sitio web de la empresa. 


\section{Plano del local}
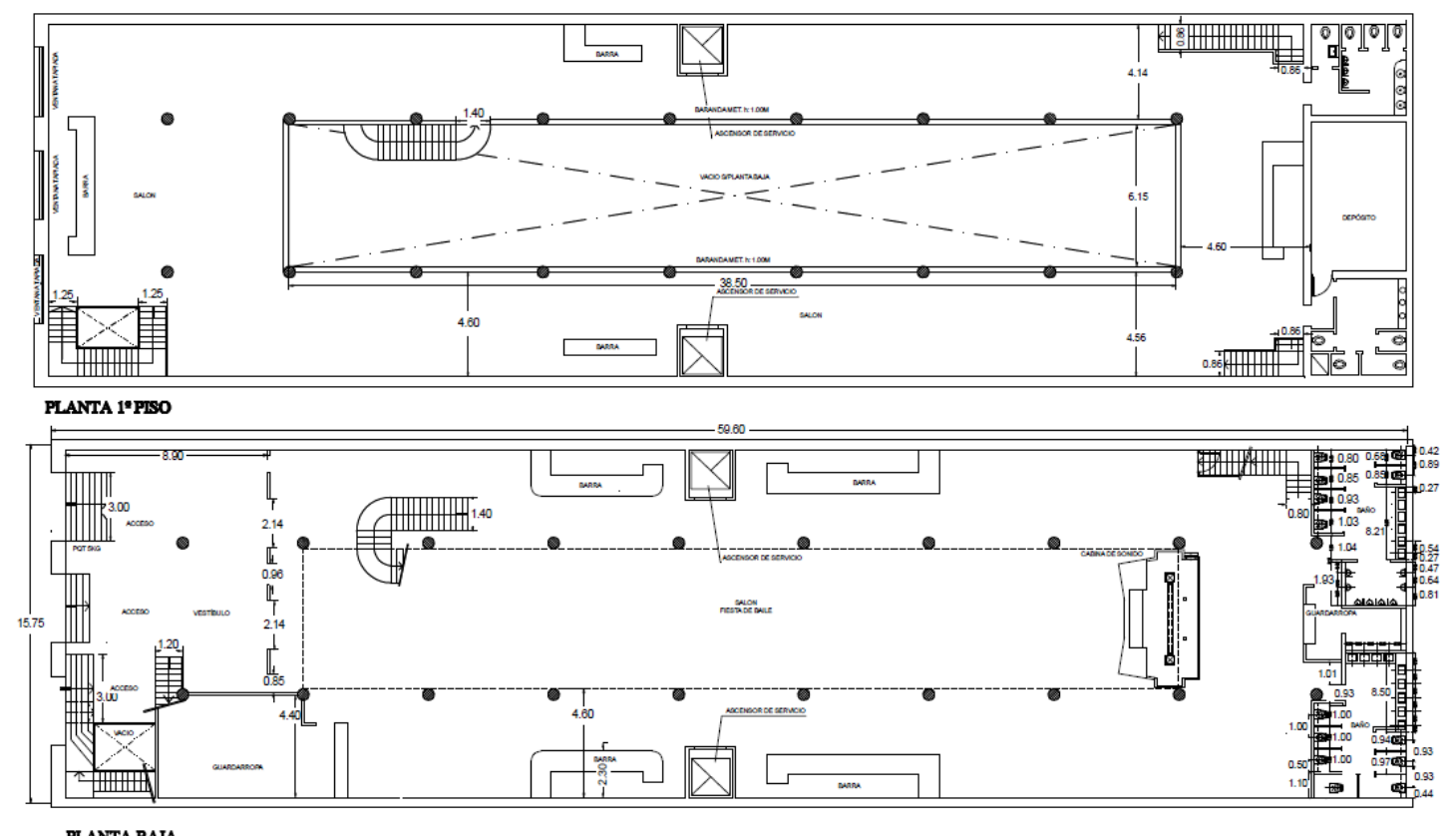

\section{Acústica interior}

De los datos de arquitectura consignados y de valores de tablas de absorción confiables se obtuvieron las siguientes curvas de reverberación en bandas de octava. El resultado más relevante es el primero, con el salón completamente ocupado, pues en esa condición se realizan las fiestas electrónicas y se realizaron las mediciones de nivel sonoro.

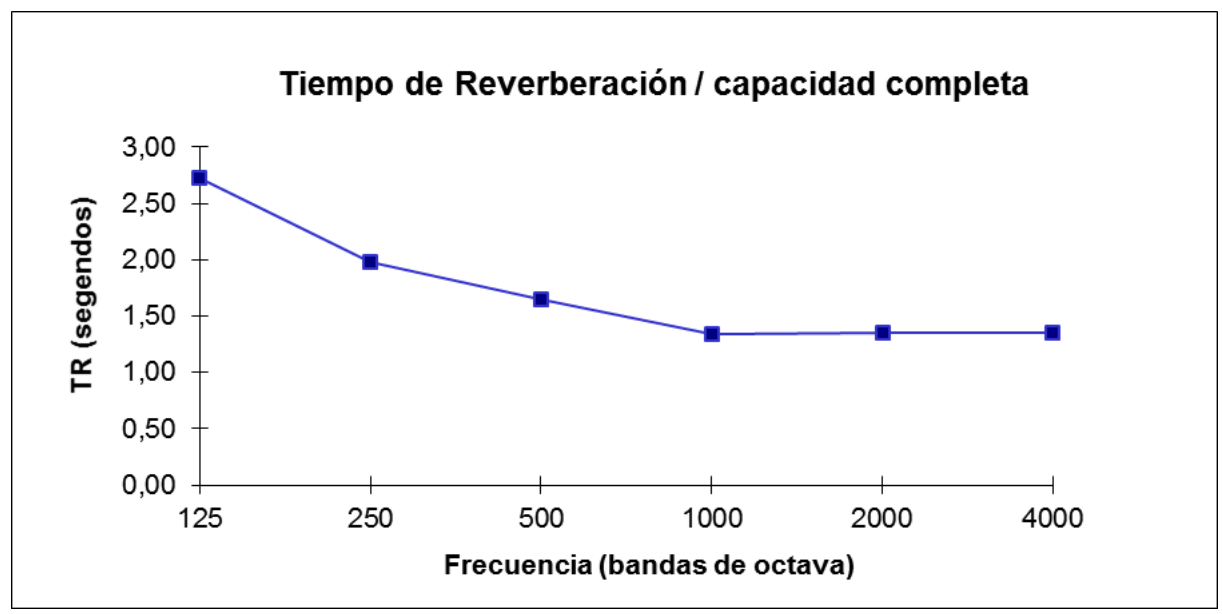



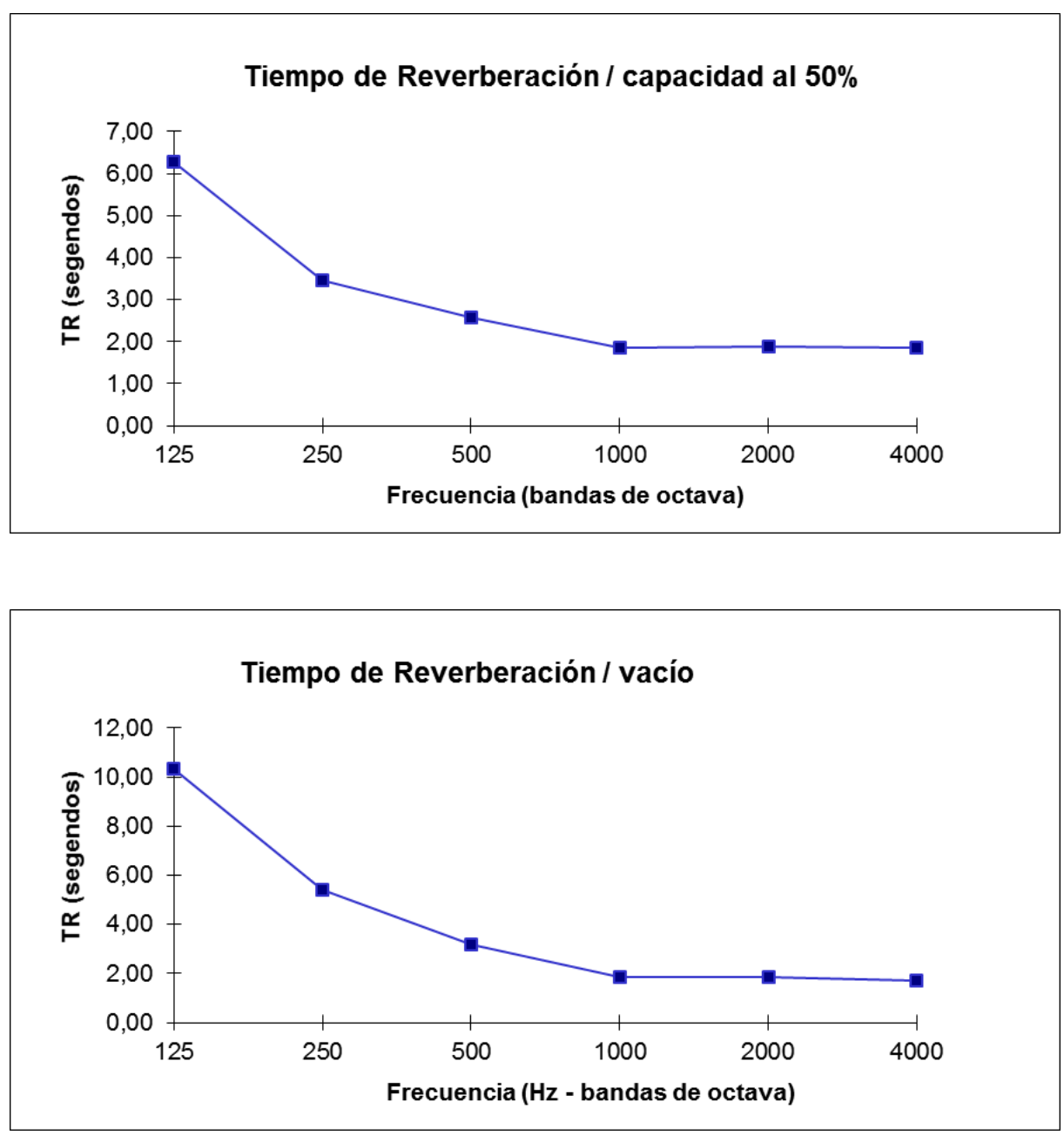

\section{Niveles sonoros en el local}

Los niveles sonoros medidos durante la fiesta fueron muy elevados, en el rango de 115 a $120 \mathrm{~dB}$ equivalentes. Se midieron picos de $124 \mathrm{~dB}$ (datos en el Apendice II). Dichos valores exceden significativamente los recomendados para preservar la salud auditiva de los asistentes.

El espectro de potencia medido típico fue el siguiente:

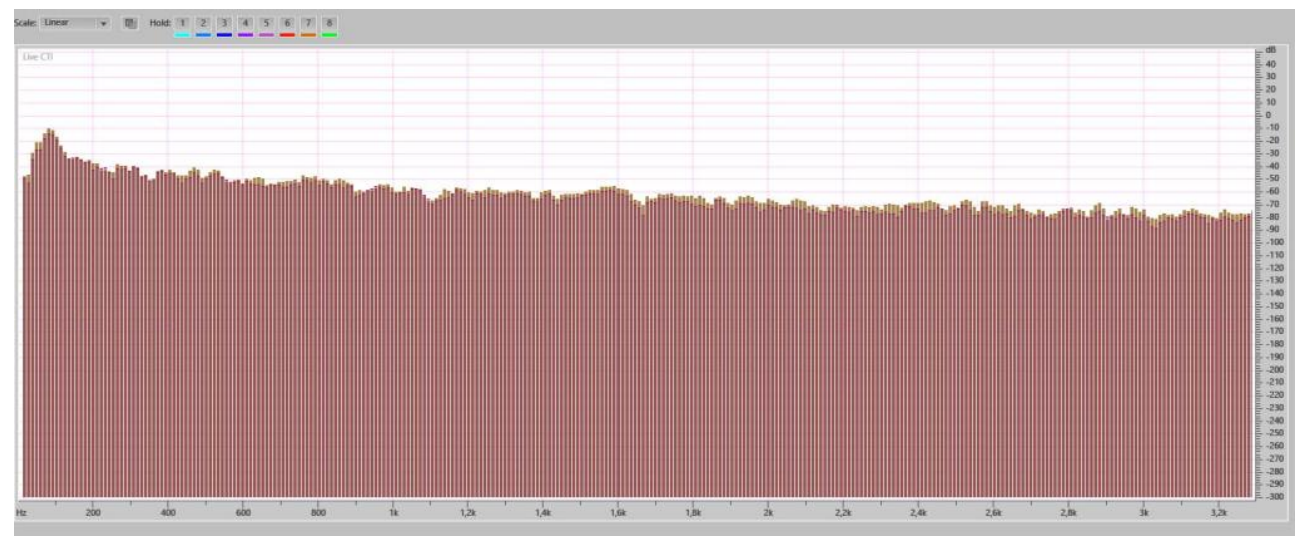




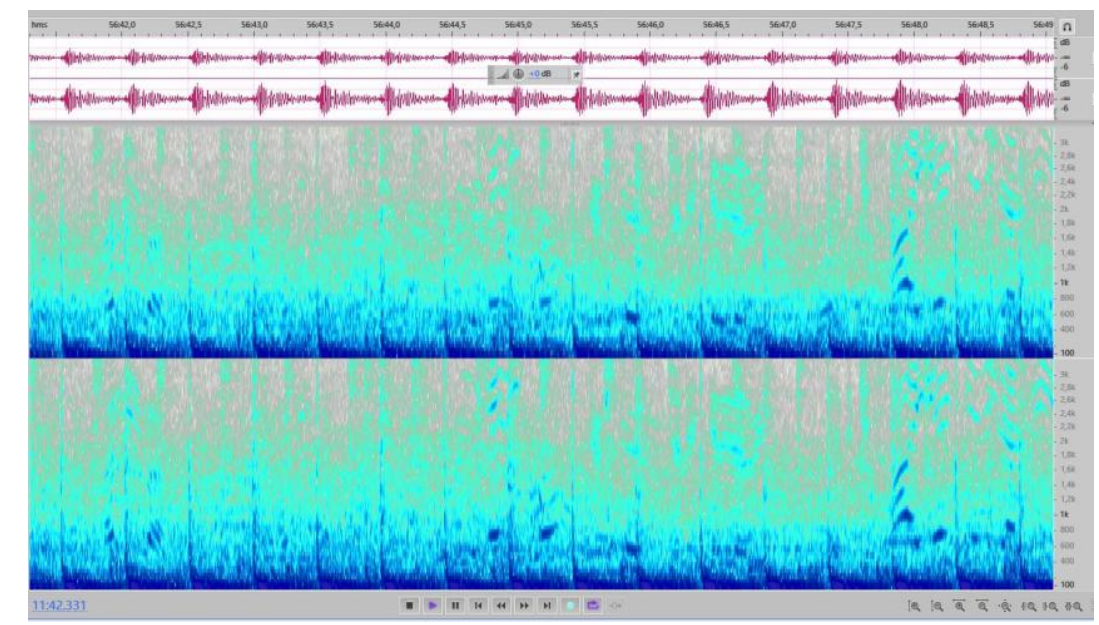

Espectro de potencia y sonograma de una de las señales medidas en la experiencia de campo. Se muestra la banda entre 0 y $3.000 \mathrm{~Hz}$. Es notoria la gran cantidad de energía ubicada en los primeros $120 \mathrm{~Hz}$.

\section{Descripción de la experiencia}

Los sujetos fueron seleccionados por poseer una relación fluida con su corporalidad, como actores y bailarines. A modo de sujeto-control se incluyó también a un individuo de otra actividad, que en esta ocasión resultó ser psicólogo.

Para proteger su audición, a los sujetos experimentales se les suministraron protectores auditivos moldeables de silicona.

A cada uno de los sujetos se le hizo entrega de una guía de preguntas a responder, a la que podían acceder a través de sus teléfonos inteligentes. Por practicidad, también las anotaciones las realizaron en dichos dispositivos: escribir rodeado de una multitud de personas bailando no es tarea fácil. ${ }^{396}$

La guía entregada fue:

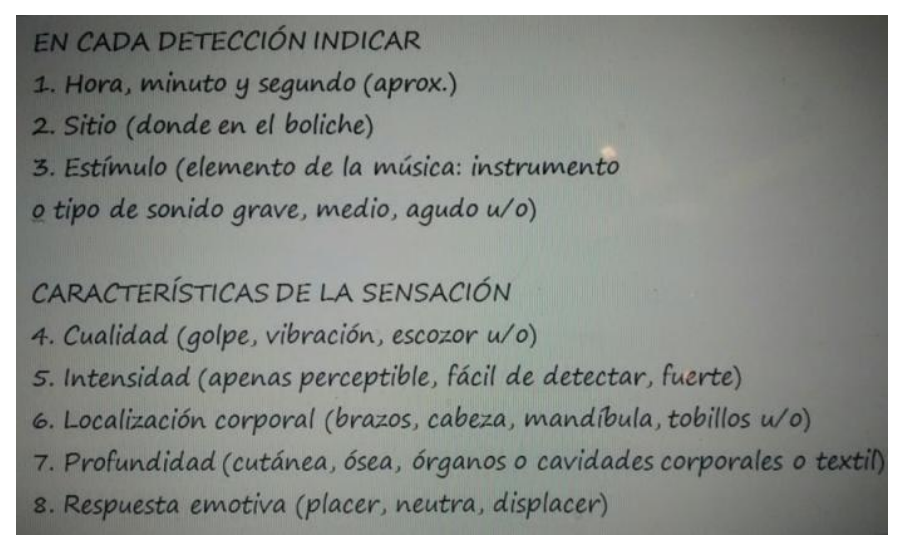

Figura 1. Guía suministrada a los sujetos experimentales.

\footnotetext{
${ }^{396}$ Tan cierta es esta afirmación que ha merecido el artículo "No puedo tomar notas mientras bailo", como parte de los trabajos previos a la tesis doctoral de Victor Lenarduzzi. Lenarduzzi, V. (2012).

No puedo tomar notas mientras bailo. Accesible en

https://www.academia.edu/7379851/VICTOR_LENARDUZZI- 
En los momentos previos al ingreso al local de baile se brindó una breve explicación de cada ítem, en la que se amplió la gama de respuestas posibles para cada uno. Por tratarse de sujetos no iniciados en la disciplina musical, para el punto 3 se amplió la gama de respuestas con términos como "batería", "percusión", "bajo", "base", "acompañamiento", etc. Lo mismo se hizo con los puntos 4, 6 y 7. Para el punto 7 también fue necesario aclarar el término "textil", que refiere a la detección de vibración de la propia ropa que viste cada sujeto, sensación táctil que podríamos llamar "indirecta".

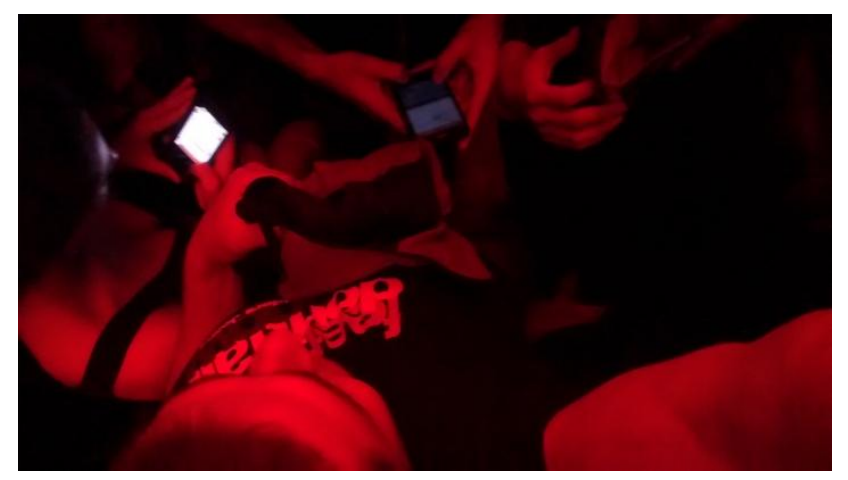

Los sujetos experimentales, respondiendo en sus teléfonos inteligentes.

Se hizo hincapié en que respondieran todos y cada uno de los ítems y se estimuló a no limitarse a los términos sugeridos (por ejemplo, respecto de las palabras para describir la cualidad de la sensación percibida). Esta decisión llevó a que el formato de las respuestas no fuera igual en todos los sujetos y que, en algunos casos, se utilizaran términos no sugeridos. Según lo previsto, esta libertad sumó diversidad a la experiencia, enriqueciendo los datos obtenidos.

Ejemplos de algunas mediciones, anotaciones, entrevistas y encuestas que dan cuenta de los resultados de las experiencias de campo se incluyen en los apéndices al final del presente anexo. Los registros de audio se encuentran en nuestro poder y puede ser facilitado según requisitoria.

\section{Conclusiones iniciales}

1- Todos los sujetos involucrados, sin excepción, experimentaron percepciones audiotáctiles.

2- Todos los sujetos manifestaron que la sensación táctil fue percibida de forma constante y continua. Valga la aclaración: esta respuesta fue dada con posterioridad a la realización de la experiencia ante la pregunta: “¿Sentiste sensación corporal sólo en los momentos que lo explicitaste o también en otros?" En otras palabras y como se verá debajo, 
hubo momentos donde las cualidades de la sensación (i.e.: en este caso concreto la intensidad de la misma) fueron diferentes.

3- Todos describieron a la intensidad de la sensación como alejada del umbral de detección (umbral mínimo). Entre otras, se utilizaron las expresiones "fuertes", "fáciles de detectar" y "muy perceptibles". Esta aseveración se ve reforzada también por los modos en que se expresan otras intensidades mencionadas: "perceptible", "medio fuerte" o "intensidad media" entre otras. De cualquier modo, no es posible descartar momentos en que los sujetos experimentaran el umbral mínimo de la sensación: dado el objetivo consignado de registrar momentos en los que detectaran sensación táctil (y no de identificar "momentos límite" en términos de intensidad de la sensación), resulta razonable suponer que documentaron los momentos donde la sensación se hizo más evidente.

4- Las condiciones presentes durante la experiencia permitieron la detección de cambios en la intensidad de la sensación. Por ejemplo: [en la música] "empieza algo más fuerte que marca mucho la sensación que ya venía sintiendo", "Siento que la vibración es cada vez más fuerte". 397

5- Se detectaron cambios en la localización corporal de la sensación. Tanto en lo que respecta a subsistemas corporales (entre otros, se mencionan detecciones en pies, piernas, cráneo, maxilar, garganta, pecho, esternón, etc.) como a la profundidad de la sensación.

6- La totalidad de los sujetos detectaron sensaciones a nivel superficial (en la piel, cutánea, "textil", al tocarse pudieron percibir en sus manos la vibración de su propio cuerpo y de cuerpos ajenos) y a niveles más profundos (entre otros se mencionan en la garganta, viscerales, esternón, en las cavidades del pecho, etc.).

7- Todos los sujetos describieron sensaciones diferenciadas en lo que denominamos su calidad o cualidad. La calidad fue descripta como sensación de golpe, vibración, resonar, cosquilleo, golpeteo, picazón, taquicardia (inducida, exterior), movimiento (del piso), entrechocar (de los dientes, por vibración del maxilar inferior), retumbar, repiqueteo, ondas y el más poético "Sensación de vacío, aire en todo el cuerpo" (expresión utilizada, entre otros fines y según el sujeto que la esgrimió, para describir una sensación cutánea o soplo sobre todo el cuerpo).

\section{Conclusiones}

\section{Música como arte audiotáctil}

Los puntos 1, 2 y 3 no dejan dudas en relación a una de las hipótesis propuestas: dadas ciertas condiciones, la música genera sensaciones audiotáctiles. No sólo los sujetos

\footnotetext{
${ }^{397}$ En ambos casos, el sujeto experimental B. Valga decirlo, fue el sujeto más vehemente, con mayor facilidad de palabras y más predispuesto a expresar sus impresiones durante toda la experiencia.
} 
experimentales las sintieron sino también la totalidad del equipo técnico y de apoyo que nos acompañó.

\title{
Intensidad de la sensación
}

Los puntos 1, 2 y 3 al mismo tiempo rebaten una creencia o duda del autor con relación a una de las hipótesis auxiliares de esta tesis: que la sensación táctil fuera tan sutil como para que pase desapercibida para quien la experimenta. A partir de la experiencia sistemática realizada podemos comenzar a hablar de percepciones audiotáctiles, ya que las respuestas de los sujetos experimentales no dejan dudas en relación a la detección consciente de dichas sensaciones. ${ }^{398}$

El punto 4 demuestra que al menos la intensidad de la sensación táctil puede ser aprovechada en tanto variable a ser trabajada con fines estéticos, y como tal se la emplea (quizá rudimentaria e intuitivamente) en el contexto de las fiestas electrónicas. Como señalamos en el cuerpo principal del texto, las expresiones de algunos sujetos experimentales parecen ir en esta dirección. El sujeto experimental B dice:

\begin{abstract}
Hay como un tunch tunch también onda bombo que marca el pulso que me hace sentirlo como golpes en el pecho. Un sonido agudo como que pasa de un lado a otro de mi pecho. Los golpes son golpes marcados y el paso del sonido ese es como un cosquilleo que recorre el cuerpo. Sensación placentera. Me genero diversión y alegría, como ganas de moverme.
\end{abstract}

Destacamos también la séptima entrada de este mismo sujeto (ocurrida aproximadamente a los $37^{\prime}$ desde iniciado el registro y citada parcialmente más arriba). Allí pueden apreciarse cambios en la intensidad de la sensación que parecen correlacionados con las diferentes intensidades sucesivas que asumen los componentes graves del estímulo en cada momento.

Cabe aclarar dos cosas: a) este sujeto (27 años, mujer) expresó haber asistido sólo dos veces a fiestas electrónicas y b) ambas oportunidades son coincidentes con las experiencias realizadas para los fines de este trabajo. En otras palabras, este dato es más que relevante ya que es una persona que no acostumbra concurrir a este tipo de eventos. En algún sentido, este argumento apoya la idea de que su deseo de moverse fue provocado por la sensación táctil y no necesariamente por el disfrute del estilo musical electrónico. De hecho, este mismo sujeto expresó luego que en varios momentos posteriores la sensación táctil se le volvió incómoda, generándole displacer.

398 En este marco cobran fuerza los argumentos expuestos en nuestro Ideo-materialismo musical...respecto del tabú y las represiones de la cultura y civilización occidental sobre el cuerpo. Anzil, I. 2013. Op.cit. 


\section{Localización corporal de la sensación}

El punto 5 es más que elocuente al confirmar las perspectivas de otros estudios respecto del sistema corporal como un conjunto de sub-sistemas resonantes. Todo indica que resulta posible trabajar esta variable de la sensación táctil con fines estéticos. Falta determinar las relaciones posibles entre los rangos de frecuencia (y/u otras variables del estímulo) y el subsistema específico en que se detecta la sensación en cada caso. Sin embargo, algunos vínculos concretos han sido establecidos.

Se encuentran anotaciones que refieren tanto a una localización precisada en cierto sistema corporal ("en el maxilar inferior", "en el pecho", etc.), otras donde se señala una indefinición (en otras palabras, la sensación se detecta des-localizada, lo que es lo mismo que decir "en todo el cuerpo") y finalmente, algunas pocas donde se hace referencia a una localización cambiante donde la vibración recorre o atraviesa el cuerpo del sujeto. Lo anterior se puede resumir en que somos sensibles a los cambios en la localización corporal de la sensación; ya sea porque la sensación desaparece de un sub-sistema y aparece en otro, porque se traslada de uno a otro, o porque se transforma de localizada a no-localizada o viceversa.

\section{Profundidad de la sensación}

El punto 6 permite entrever la posibilidad de operar con fines estéticos sobre la variable profundidad corporal de la sensación táctil. En ese sentido, el sujeto experimental A manifestó de forma explícita la asociación de la profundidad de la sensación con su intensidad. Consideramos más acertado hablar de que ambos aspectos de la sensación podrían depender al menos en parte de la intensidad del estímulo vibratorio. Según los dichos del sujeto experimental A, la mayor intensidad de la sensación se traduce (también) en una mayor definición y profundidad de la misma. Creemos comprender que en términos técnicos esto puede expresarse en la forma de la hipótesis provisoria que sigue:

\footnotetext{
Alcanzada una determinada intensidad en el estímulo, la sensación táctil atraviesa una fase y cambia su cualidad, pasando de ser superficial y más débil a profunda y fuerte.
}

Expresado de otro modo se puede apreciar un modo hipotético en que el estímulo opera sobre el cuerpo:

\footnotetext{
Alcanzado un determinado umbral de intensidad en el estímulo, la energía de la oscilación se transfiere a la materia corporal y no sólo resuena en su superficie sino que la penetra, recorre y atraviesa.
} 
Este argumento resulta reforzado también por los dichos del sujeto experimental B cuando dice "La sensación es de golpe dentro del pecho, como si mi caja torácica fuera un tambor"; los del sujeto experimental D al mencionar vibraciones "interiores" y en "huesos" y del sujeto experimental C al referirse a la "sensación de vacío" o "aire en todo el cuerpo". Consultado con posterioridad acerca de esta última expresión, el sujeto experimental C dijo:

lo de aire en todo el cuerpo también tiene que ver con esta liviandad" [...] "podríamos decir que la densidad que nos caracteriza como cuerpos (en tanto a músculos, huesos, vísceras, que es donde [la sensación táctil] más se identifica), de alguna manera para el sistema nervioso se interfiere y se vuelve muy sutil." [...] "probá soplarte la mano... creo que es algo así... pero en el interior".

Describimos como provisoria a la hipótesis enunciada debido al convencimiento de que las relaciones que se establecen entre el estímulo y el cuerpo de cada sujeto perceptor concreto son más complejas. En los casos que nos ocupan creemos prematuro descartar las influencias que frecuencia, espectro y envolvente de intensidad del estímulo pueden tener sobre el cambio en el valor de la variable profundidad.

\section{Calidad o cualidad de la sensación}

El punto 7 es muy claro en relación a este tema. Las diferentes formas que asume la sensación parecen indicar dependencia de diversas variables del estímulo. En numerosas oportunidades las anotaciones dan indicios que permiten asociar al menos a la envolvente de intensidad del estímulo con la forma de la sensación táctil. A modo de ejemplo, a los ítems "Estímulo" y "Cualidad" del cuestionario le corresponden (caso a caso) las expresiones: "percusión electrónica"-"golpe", "chirrido, válvula de escape-vibración", "Sonidos como de bombos"-"golpes en los pies".

A pesar de lo dicho, aquí la cantidad de testimonios resulta insuficiente. Es necesaria la realización de más experiencias que permitan una mejor aproximación que clarifique las relaciones que se establecen entre las cualidades del estímulo y la forma de la sensación. En una de sus anotaciones el sujeto experimental B relaciona "sonidos de bombos" con un "cosquilleo en los pies que llega hasta casi las rodillas". El contexto y la redacción parecieran referir a un sonido que se sostiene (al menos brevemente) en el tiempo y que resuena en el sub-sistema corporal "pierna". Podría pensarse que el presente ejemplo contradice la aseveración inicial, pero el sonido de bombos presente en ese momento posee una resonancia suficientemente larga como para provocar este efecto de "cosquilleo" (es decir una vibración persistente) como opuesto a la sensación de "golpe" (una vibración efímera).

También se encontraron indicios de que la forma de onda en su desarrollo dinámico (entendida en un sentido muy amplio, casi como sinónimo de evolución temporal del espectro) 
parecería esencial para este aspecto de la sensación. Lo mismo puede decirse de las diferentes bandas de frecuencia en su relación compleja con las demás cualidades del estímulo audiotáctil.

\section{Relaciones complejas entre el estímulo y la sensación}

El análisis precedente, dedicado a algunos rasgos (en principio) independientes de la sensación táctil, ha permitido una aproximación los diferentes modos en los que el estímulo vibratorio incide sobre el sistema táctil humano. A pesar de lo dicho, esta aproximación no deja de ser una formalización esquemática de un conjunto de relaciones caracterizadas por un alto grado de complejidad. Como ejemplo, no parece posible aislar completamente cada uno de los parámetros del estímulo, como tampoco los rasgos de la sensación. Parece ser que los resultados que arrojan las experiencias de campo indican que todos los parámetros del estímulo actúan de una forma u otra en la generación de sensaciones audiotáctiles y que en función de los valores de esos parámetros depende la localización corporal de dicha sensación.

Por último, consideramos a priori que, aun cuando son necesarios más datos experimentales, la calidad o cualidad que asuma la sensación táctil depende de la totalidad de las características vibratorias del estímulo. Estamos convencidos que resultará modificada a partir de diferencias en la frecuencia, la envolvente de sonoridad, la duración y el espectro presentes en el estímulo. ${ }^{399}$

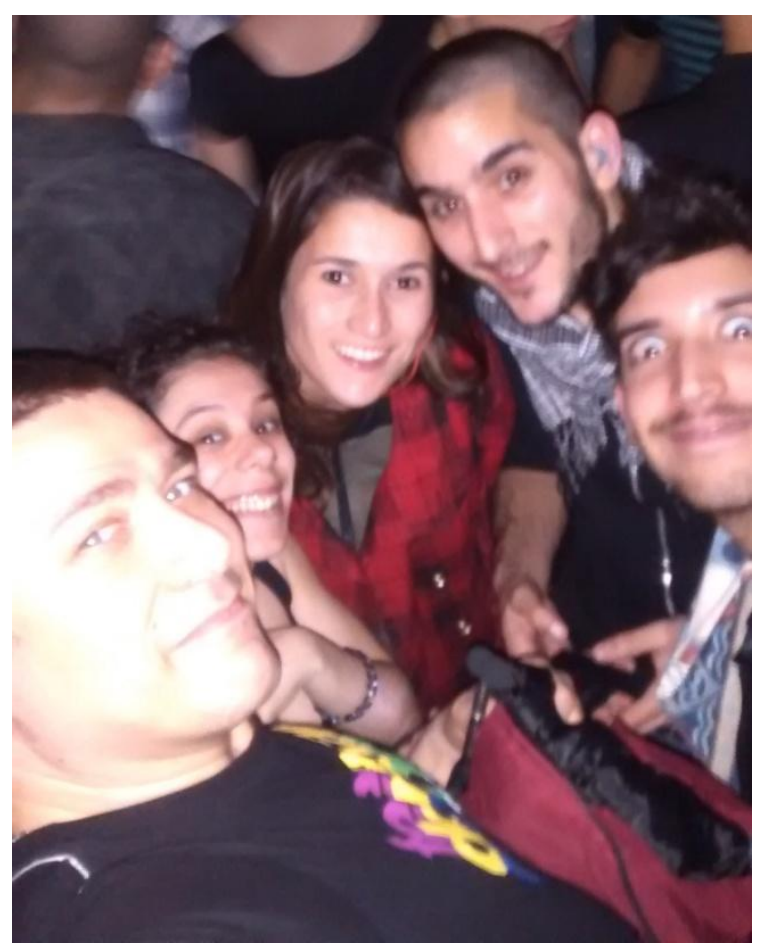

Cuatro de los cinco sujetos experimentales, en momentos de realizar la experiencia.

${ }^{399}$ En otras palabras, de todas y cada una de las cualidades del estímulo. 


\section{Conclusiones finales}

Queda aún mucha información por extraer de los registros y de la documentación obtenida en las experiencias realizadas. El presente trabajo se presenta apenas como una primera aproximación al análisis de los datos y no supone un estudio completo de los mismos.

Consideramos que la metodología ha sido exitosa y permite la observación de muchas otras relaciones aún no exploradas. Permitió corroborar las principales hipótesis, refutar prejuicios y recuperar cierto nivel de objetividad perdida. Los datos obtenidos permiten afirmar que los seres humanos, a través del sentido del tacto, somos sensibles a cambios en la intensidad, frecuencia, duración y composición espectral de los estímulos vibratorios que nos alcanzan por vía aérea y sólida (piso).

Respecto de los rangos de frecuencia analizados, resta decir que de las anotaciones se desprende que, si bien las graves y sub-graves parecen ser las que provocan sensaciones más evidentes, bandas de frecuencias superiores (del rango medio o mayores) resultan posibles generadoras de sensación táctil.

Las experiencias de campo realizadas también han permitido definir un camino a recorrer en el futuro, que posibilitará tanto refinar los datos obtenidos como obtener datos de aspectos no contemplados hasta ahora.

Finalmente, este trabajo confirma que músicos y artistas sonoros, en la práctica de su arte, pueden trabajar:

a.- Aspectos audibles: altura, ritmo, timbre, intensidad, armonía, textura y demás variables tradicionales (pudiendo también concebirlos desde perspectivas novedosas).

b.- Aspectos táctiles: intensidad, localización corporal (incluyendo quizá traslaciones), profundidad corporal y calidad del estímulo.

Dando por finalizado el análisis de los resultados, incluimos debajo los registros de presión acústica y ejemplos de las anotaciones originales realizadas por los sujetos experimentales, acompañados en cada oportunidad por el espectrograma y forma de onda (general) respectivos del momento al que el testimonio refiere. Cuando lo creímos oportuno, incluimos también algunos breves comentarios.

Se incluye luego de las anotaciones, un ejemplo de las entrevistas realizadas con posterioridad. 


\section{Apéndices}

\section{Apéndice 1. Mediciones acústicas}

Fueron realizadas con un Sonómetro Rion NL-27 con un tiempo de integración de 1 minuto.

\section{Resultados}

1. Ubicación del sonómetro: próximo a columna 1 (extremo de los disc-jockeys) ${ }^{400}$ Hora: 2:20 [50' desde inicio del registro sonoro]

Nivel equivalente Leq $=121,9 \mathrm{~dB}$

2. Ubicación del sonómetro: próximo a columna 2 (desde el extremo de los disc-jockeys) Hora: 2:23 [53' desde inicio]

Nivel equivalente $\mathrm{Leq}=114,9 \mathrm{~dB}$

3. Ubicación del sonómetro: próximo a columna 3 (desde el extremo de los disc-jockeys) Hora: 2:24 [54' desde inicio] Nivel equivalente $\mathrm{Leq}=110,5 \mathrm{~dB}$

4. Ubicación del sonómetro: próximo a columna 4 (desde el extremo de los disc-jockeys) Hora: 2:25 [55' desde inicio] Nivel equivalente $\mathrm{Leq}=115,5 \mathrm{~dB}$

5. Ubicación del sonómetro: próximo a columna 5 (desde el extremo de los disc-jockeys) Hora: 2:26 [56' desde inicio] Nivel equivalente $\mathrm{Leq}=116,3 \mathrm{~dB}$

6. Ubicación del sonómetro: próximo a columna 6 (desde el extremo de los disc-jockeys) Hora: 2:27 [57' desde inicio] Nivel equivalente Leq $=117,9 \mathrm{~dB}$

\section{Datos técnicos del instrumental utilizado}

\section{Medidor de nivel sonoro}

Marca y modelo:

Rion NL-27

Serie: 612718

Cantidad: 1

IEC 61672-1:2002

Clase 2

Rango de medición: A-weighting: $30 \mathrm{~dB}$ to $130 \mathrm{~dB}$; C-weighting: $36 \mathrm{~dB}$ to $130 \mathrm{~dB}$ Funciones de medición: Lp, Leq, LE, Lmax 


\begin{tabular}{|c|c|}
\hline Standard compliance & $\begin{array}{l}\text { General-Purpose Sound Level Meter according to Japan } \\
\text { Measurement Law JIS C 1509-1: } 2005 \text { Class 2, IEC 61672-1: } \\
2002 \text { Class } 2 \\
\text { CE mark (EMC Directive 2004/108/EC), WEEE Directive }\end{array}$ \\
\hline $\begin{array}{l}\text { Measurement functions } \\
\text { Processing functions } \\
\text { (normal mode) }\end{array}$ & $\begin{array}{l}\text { Sound pressure level } L_{p} \text {, equivalent continuous sound pressure } \\
\text { level } L_{\text {eq, }} \text { sound exposure level } L_{E} \text {, maximum sound pressure } \\
\text { level } L_{\max } \text {, peak sound level } L_{\text {Cpeak }} \text { (only when peak range was } \\
\text { selected) }\end{array}$ \\
\hline Measurement time settings & $1 \mathrm{~min}, 5 \mathrm{~min}, 10 \mathrm{~min}, 1 \mathrm{~h}$ \\
\hline Microphone & $\begin{array}{l}\text { 1/2 inch electret condenser microphone } \\
\text { Model: UC-52, sensitivity level: }-33 \mathrm{~dB} \pm 3 \mathrm{~dB}(1 \mathrm{~V} / \mathrm{Pa}=0 \mathrm{~dB})\end{array}$ \\
\hline $\begin{array}{l}\text { Measurement level range } \\
\text { (normal mode) }\end{array}$ & $\begin{array}{l}\text { A-weighting: } 30 \mathrm{~dB} \text { to } 130 \mathrm{~dB} \\
\text { C-weighting: } 36 \mathrm{~dB} \text { to } 130 \mathrm{~dB}\end{array}$ \\
\hline $\begin{array}{l}\text { Linear operation range } \\
\text { (A-weighting, } 1 \mathrm{kHz} \text { ) }\end{array}$ & $30 \mathrm{~dB}$ to $137 \mathrm{~dB}$ \\
\hline $\begin{array}{l}\text { Peak sound level } \\
\text { measurement range }\end{array}$ & $65 \mathrm{~dB}$ to $140 \mathrm{~dB}$ \\
\hline Residual noise level & A-weighting: $\max .24 \mathrm{~dB}, \mathrm{C}$-weighting: $\max .30 \mathrm{~dB}$ \\
\hline $\begin{array}{l}\text { Measurement frequency } \\
\text { range }\end{array}$ & $20 \mathrm{~Hz}$ to $8 \mathrm{kHz}$ \\
\hline $\begin{array}{l}\text { Reference frequency, } \\
\text { reference sound pressure level }\end{array}$ & $\begin{array}{l}\text { Reference frequency: } 1 \mathrm{kHz} \text {, } \\
\text { reference sound pressure level: } 94.0 \mathrm{~dB}\end{array}$ \\
\hline Frequency weighting characteristics & A-weighting, C-weighting \\
\hline Time weighting characteristics & $F$ (Fast), S (Slow) \\
\hline Level range & $\begin{array}{l}\text { Wide range: } 30 \mathrm{~dB} \text { to } 130 \mathrm{~dB} \text {, peak range }: 65 \mathrm{~dB} \text { to } 130 \mathrm{~dB} \\
* \text { Peak range is used for peak sound level measurements }\end{array}$ \\
\hline RMS detection method & Digital processing \\
\hline Processing & Digital sampling cycle: $30.3 \mu \mathrm{s}\left(L_{\mathrm{p}}, L_{\mathrm{oq}}, L_{\mathrm{E}}, L_{\max }, L_{\text {peax }}\right)$ \\
\hline
\end{tabular}

\begin{tabular}{|c|c|}
\hline Calibration & $\begin{array}{l}\text { Calibration frequency: } 1 \mathrm{kHz} \text {, } \\
\text { Calibration sound pressure level: } 94 \mathrm{~dB} \\
\text { Japan Measurement Law: electrical calibration with internal } \\
\text { signal source; JIS, IEC: acoustic calibration using NC-74 }\end{array}$ \\
\hline Windscreen & $\begin{array}{l}\text { Unit is compliant with JIS C } 1509-1 \text { Class } 2 \text { and IEC } 61672-1 \\
\text { Class } 2 \text { with and without windscreen }\end{array}$ \\
\hline $\begin{array}{l}\text { Display } \\
\text { (TN positive display, reflective) }\end{array}$ & $\begin{array}{l}\text { Numeric display: } 0.1 \mathrm{~dB} \text { resolution } \\
\text { Bar graph: Scale range } 100 \mathrm{~dB}, 5 \mathrm{~dB} \text { resolution (update frequency } 0.1 \mathrm{~s} \text { ) } \\
\text { Warning indicators: Over (Overload) appears at } 137.4 \mathrm{~dB} \\
(1 \mathrm{kHz} \text { ) Under (Underload) appears from }-0.6 \mathrm{~dB} \text { of lower scale } \\
\text { limit Battery capacity } 3 \text {-stage indicator for remaining capacity }\end{array}$ \\
\hline $\begin{array}{l}\text { Store function } \\
\text { (processing results saved in internal } \\
\text { memory, using manual store) }\end{array}$ & $\begin{array}{l}\text { Number of data: } 199 \\
\text { Stored data can be checked on recall screen }\end{array}$ \\
\hline DC output connector & $\begin{array}{l}\text { DC output: } 3 \vee \text { (full scale), } 25 \mathrm{mV} / \mathrm{dB} \text {, output impedance: } 50 \Omega \\
\text { Load impedance: } 10 \mathrm{k} \Omega \text { or more }\end{array}$ \\
\hline $\begin{array}{l}\text { AC monitor output } \\
\text { connector }\end{array}$ & $\begin{array}{l}\text { AC output: } 1 \text { Vrms }+600-400 \mathrm{mV} \text { rms (at } 110 \mathrm{~dB} \text { ), overload: }+2 \mathrm{~dB} \\
\text { Output impedance: } 600 \Omega \text {, load impedance: } 10 \mathrm{k} \Omega \text { or more, } \\
\text { frequency weighting: } Z \text {-weighting }\end{array}$ \\
\hline USB connector & For transfer of stored data to a computer, using optional USB adapter cable \\
\hline $\begin{array}{l}\text { Power requirements } \\
\text { (size AAA [IEC R03] battery } \times 2 \\
\text { Normal temperature) }\end{array}$ & $\begin{array}{l}\text { Current consumption: approx. } 80 \mathrm{~mA} \text { ( } 3 \mathrm{~V} \text { operation) } \\
\text { Battery life: approx. } 9 \text { hours (with alkaline batteries), } \\
\text { (Wide range) approx. } 3 \text { hours (with manganese batteries) }\end{array}$ \\
\hline $\begin{array}{l}\text { Temperature } I \\
\text { humidity range for operation }\end{array}$ & $-10^{\circ} \mathrm{C}$ to $+50^{\circ} \mathrm{C}, 10 \%$ to $90 \% \mathrm{RH}$ (no condensation) \\
\hline Dimensions, weight & Approx. $120 \mathrm{~mm}(\mathrm{H}) \times 63(\mathrm{~W}) \times 23.5 \mathrm{~mm}(\mathrm{D})$, aporox. $105 \mathrm{~g}$ (including batteries) \\
\hline Supplied accessories & $\begin{array}{l}\text { Windscreen } \times 1 \text {, Windscreen fall prevention rubber } \times 1 \text {, Silicon } \\
\text { cover } \times 1 \text {, strap } \times 1 \text {, AAA [IEC R03] alkaline battery } \times 2\end{array}$ \\
\hline
\end{tabular}




\section{Grabador digital}

Marca y modelo: Zoom H4n

Serie: 230144

Cantidad: 1

Conversión A/D 24 bits Sobremuestreo 128x

Conversión D/A 24 bits Sobremuestreo 128x

Tipo de datos: Formato .WAV

Cuantización: 16 bits (Modos stereo, 4-track), 24 bits (Modo stereo)

Frecuencia de muestreo: $44.1 \mathrm{kHz}$ (Modos estéreo, 4-track), $48 \mathrm{kHz}, 96 \mathrm{kHz}$ (Modo estéreo)

Entradas: conector combinado XLR -entrada balanceada- y phone standard -no balanceada-

Impedancia de entrada -usando la entrada balanceada-: 1 kilohmio balanceado, punta 2 activa, y 480 kilohmios no balanceados -usando la entrada no balanceada-

Nivel de entrada (interruptor INPUT 1 y 2): -usando la entrada balanceada- L -20 dBm (para mic), M -30 dBm (para mic), $\mathrm{H}-40 \mathrm{dBm}$ (para mic) -usando la entrada no balanceada- L -10 dBm -entrada de guitarra, bajo, línea- M -30 dBm (para mic) H -40 $\mathrm{dBm}$ (para mic)

Micrófono estéreo interno: unidireccional de condensador

Ganancia (interruptor del micrófono) $\mathrm{L}+6 \mathrm{~dB} ; \mathrm{M}+20 \mathrm{~dB} ; \mathrm{H}+30 \mathrm{~dB}$

Alimentación fantasma: $48 \mathrm{~V}, 24 \mathrm{~V}$, OFF

En el artículo: "Idoneidad de un grabador digital comercial para su empleo en mediciones acústicas" (Miyara, F., et al., 2010) se presentan los resultados de las pruebas realizadas para determinar la pertinencia de incluir este grabador en un sistema de medición, el mismo fue evaluado en términos de la respuesta en frecuencia, el ruido, la distorsión y la respuesta transitoria a distintas tasas de muestreo. Los parámetros evaluados demuestran que el modelo de grabador digital es adecuado para grabar señales para mediciones.

La respuesta en frecuencia (Figura 1) es adecuada ya que se encuentra por debajo de los límites de tolerancia establecidos en la Norma Internacional IEC 61672-1 para un instrumento clase 1. 


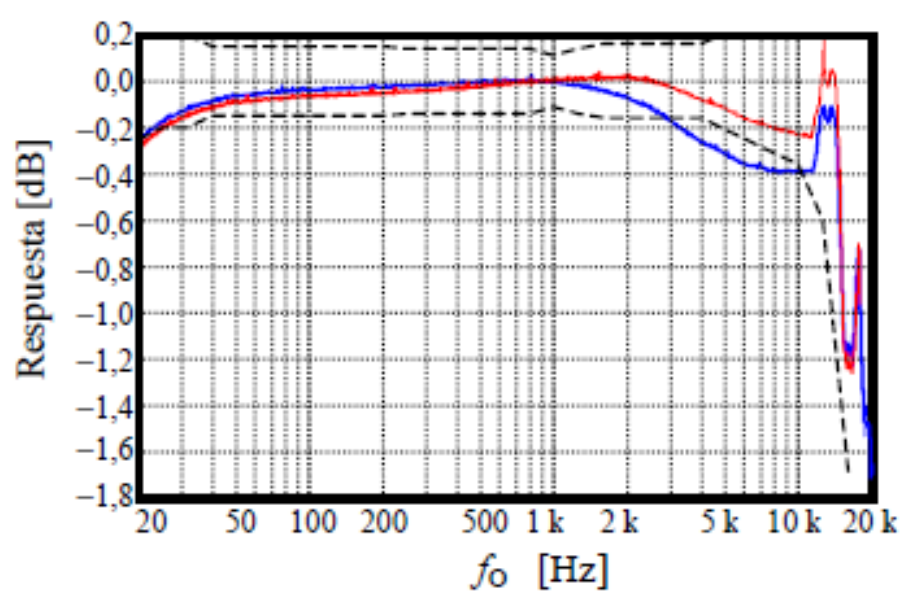

Fig. 1. Respuesta en frecuencia de dos grabadores digitales Zoom H4. Las líneas de trazos muestran 1/10 de los límites de tolerancia inferior y superior mencionados en la IEC 61672-1. [1]

Respecto a la respuesta transitoria se encontró una cota superior del tiempo de establecimiento del $5 \%$. Las respuestas son oscilantes sólo para la tasa de muestreo de $44,1 \mathrm{kHz}$

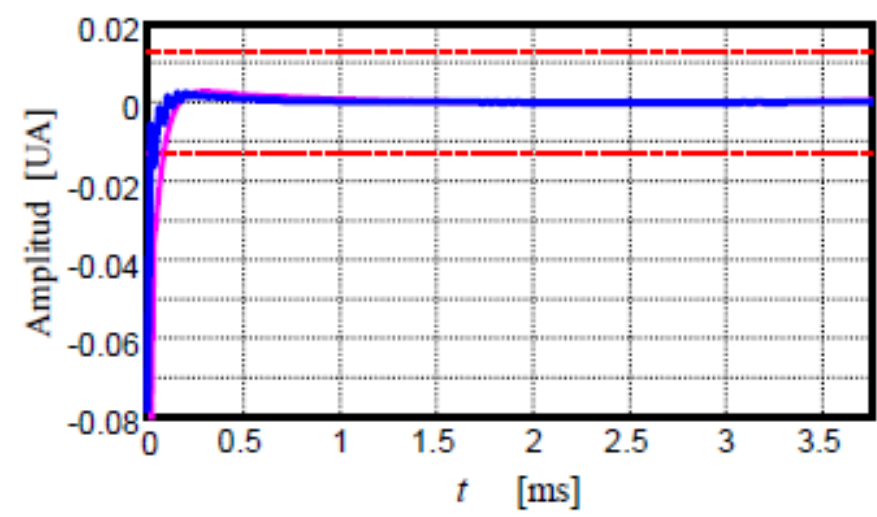

Fig. 2. Respuesta al escalón para 44,1 kHz (azul) y $96 \mathrm{kHz}$ (magenta). Límite del 5\% (rojo). [1]

\section{Bibliografía}

[1] Miyara, F., Accolti, E., et al. (2010). "Idoneidad de un grabador digital comercial para su empleo en mediciones acústicas", Segundo Congreso Internacional de Acústica UNTREF, Buenos Aires, Argentina.

[2] Manual de instrucciones: Handy Recorder H4 Zoom. 


\section{Apéndice 2. Anotaciones y entrevistas}

Para todas las anotaciones se mantuvo la versión original tal cual fuera copiada del correo o mensaje electrónico que se utilizara para su remisión. Se mantuvieron inalterados todos los errores de tipeo como toda otra característica. En el caso de los sujetos experimentales C y D fue necesario reorganizar la información, agrupándola por sujeto, debido a que ambos compartieron un único celular y se turnaron para su uso.

A modo de ejemplo se muestran a continuación algunas de las fichas obtenidas. La totalidad de las mismas se encuentran a disposición según requisitoria.

\section{Sujeto experimental A}

2:18 [48' desde inicio] Adelante, al lado de donde estaba la cabina de DJ. "Batería electrónica" medio alternando con grave. Cualidad: Golpe + vibración. Intensidad: fuerte. Localización corporal: Oídos, omoplatos, mentón. Profundidad: cutánea (oídos, espalda") cavidades corporales (garganta), ósea (esternón ). Respuesta emocional: Placer

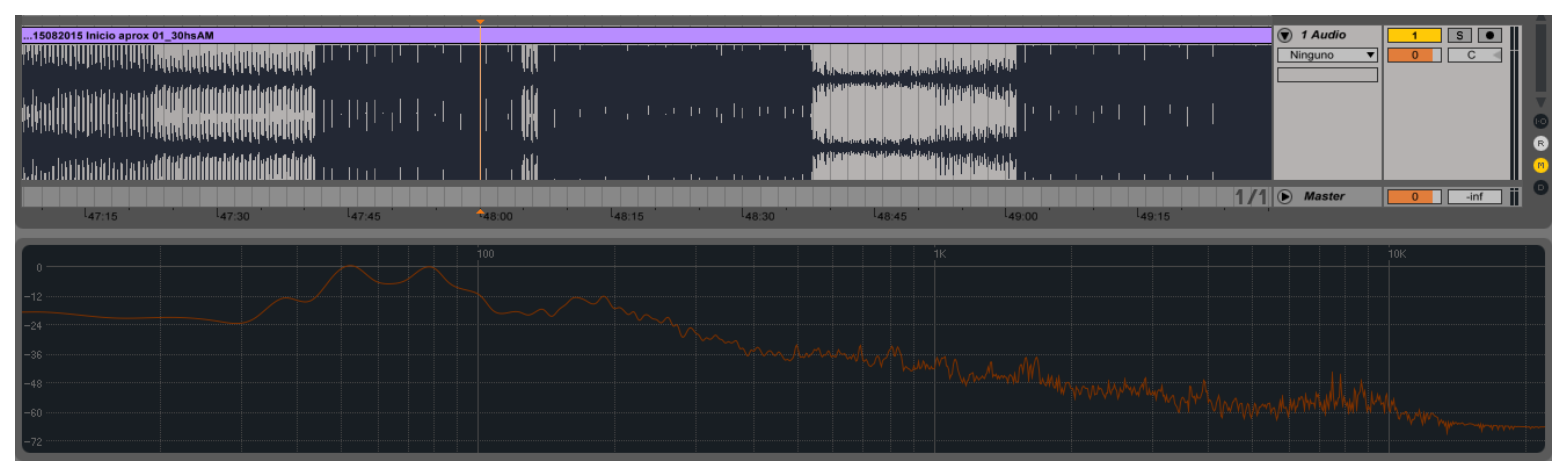

Espectrograma 2

\section{Sujeto experimental B}

02:18 [48' desde inicio] al lado de la cabina del dj. escucho grave nomas. Me golpea el cuerpo, sobre todo el pecho. El piso se mueve, es muy molesto. En este minuto de las 02:19 [49' desde inicio] algo dejo de sonar y alivio mucho la sensacion de golpe. Al rato empezo de nuevo. No me gusta. Sensacion displacentera. Me cuesta respirar con los bombos tan fuertes. Me golpea el pecho y los pies. Se me sienten las tripas. Si me toco yo, vibro tmb. Los sonidos como mas agudos se sienten en la espalda y cuando entran loa graves es en todo el cuerpo, espexialmente pecho, garganta y como en los oidos pero adentro de la cabeza. Tengo acidez.

[Ver Espectrograma 2]

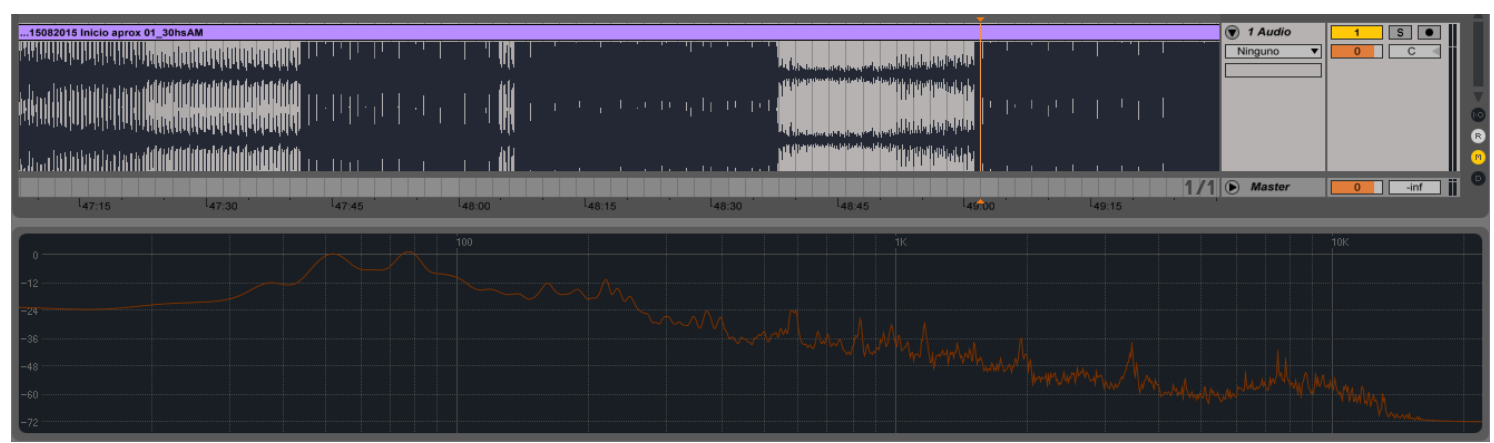

Espectrograma 13 


\section{Sujeto experimental D}

1:02:23 - Debajo de las escaleras. Sonidos de tapon. O gotera que resuena en los oídos. Axilas. Vibración en la ropa. Intensidad media. Neutro.

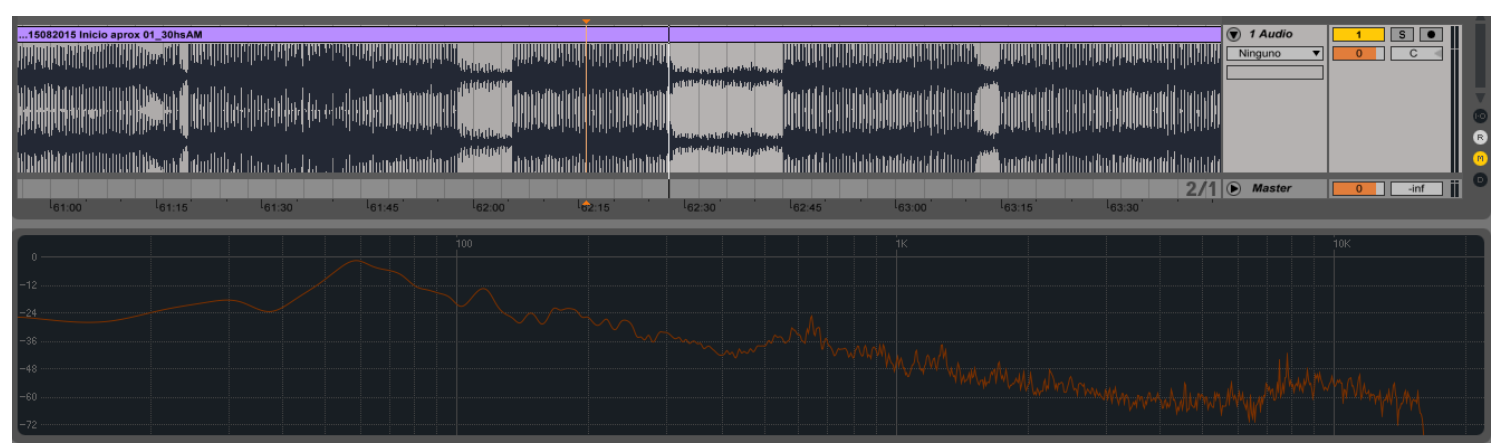

Espectrograma 27

Nota: se advierte una reiterada remisión (por este y otros sujetos) a las "axilas", como localización corporal de la sensación táctil. Detección significativa por hallarse referencias a esta misma parte del cuerpo en otras fuentes (a modo de ejemplo, Lenarduzzi).

\section{Sujeto experimental C}

\section{Entrevista posterior por facebook Messenger (21-08-2015)}

SIA: en una de tus anotaciones hablás de "sensación de vacío" - ¿como es eso? ¿como es esa sensación? ¿podrías describirla un poquito mas? -¿está relacionada con la de "Aire en todo el cuerpo"?

C: creo que lo de vacio lo relacione a la cabeza.

-algo asi como una jaquequa... como una expansion del cerebro... pero que no producia dolor o molestia.

-mas bien cierta liviandad, en este caso en la cabeza.

-algo "atontado"

-lo de aire en tdo el cuerpo tambien tiene que ver con esta liviandad

-podriamos decir que la densidad que nos caracteriza como cuerpos (en tanto a musculos, huesos, visceras, que es dodne mas se identifica) de alguna manera para el sistema nervioso se interfiere y se vuelve muy sutil ..

-proba soplarte la mano... creo que es algo asi... pero en el interior.

SIA: ¿eso lo sentiste como efecto de la música sobre tu cuerpo?

- ¿Estás siendo metafòrico o te referìs a una sensación fisica, corpora?

C: si, si, sensaciones (tal vez lo explique de un modo metaforico pero si son sensaciones. -a ver..enque momento fue y con que sonido

SIA: 00:51:08 Cabina. Sensación de vacío. Aire..en todo el cuerpo. Tono bajo. A nivel muscular. Fuerte. Emotivo: placer. Descanso.

00:54:58 Cabina Golpe. Sin la base. Vacío. Los platillos..cosquillas en las viceras. Nivel medio de intensidad. Muy perceptible.

C: aah bien.

-a nivel emotivo puse placer, descanso, refiriendome a una sensacioncomoda

-creo que hatsapodria definirla de envolvente.

-como de contencion .

SIA: ?

C: La sensacion estaba presente en todo el cuerpo. El tono msucular era bajo asi que estaba relajado, musculos blandos.

-No recuerdo el sonido. pero fue algo que me daba lugar a "descansar en el" ya que me envolvia ... por eso la contencion. La sensacion era hasta suave (aunque el sonido no se si tiene esas caracteristicas)

-¿Qué tal? ¿Fue mejor ahora?¿Se entendió? 
SIA: Si, gracias! Excelente aporte.

C: Tal vez es la costumbre a describir este tipo de cosas con cierto lenguaje que no todos llegan a traducir bien. Trabajamos todo el tiempo con practicas de este tipo.

SIA: Excelente dato me acabás de dar. Los dos han hecho este tipo de experiencias descriptivas antes?

C: Si, Siempre.

-por ahi el lenguaje que usamos es tambien bastante especifico. para nosotros es claro.

SIA: Querés decir que ustedes y yo compartimos terminología?

C: Ah, eso no lo sé. Quise decir que [sujeto D] y yo utilizamos mas que nada para hacer mas rapidos los registros esos terminos. aunquetambien por costumbre.... por eso tal ves no los entiendas. 


\section{ANEXO II}

\section{El problema de los géneros}

La experiencia de un neófito al recorrer la música electrónica de baile intentando reconocer a qué "género" pertenece cada ejemplo escuchado (ya sea que esta escucha se realice en soledad o guiado por un iniciado en el tema) puede resultar frustrante, angustiante e incluso conducir a cierto grado de stress. Así como para un oyente medianamente novel "todo suena igual", para el experimentado "todo suena distinto"... o al menos así parece a ojos (y oídos) del primero.

En la comunidad electrónica se habla de géneros "mayores" y "menores", "puros" y "remixados" (i.e.: hibridados), "subgéneros", "sub-subgéneros" y "estilos". Hay piezas "House", "Trance", "Ambient", "Jungle", "Drone", "Ambient House", "Psy Trance", "Trap", "Moombathon" y una interminable lista de denominaciones diferentes, similares y mixtas que se cruzan, superponen e imbrican aparentemente sin sentido ni criterio. Las denominaciones utilizadas son tantas como similares se le aparecen al no-iniciado las cualidades musicales de piezas a las que se ubica en diferentes categorías y géneros. Sin embargo, a pesar de que esta similitud es real, efectiva, no es menos cierto que estas músicas presentan -al mismo tiempo- un grado elevado y evidente a la escucha de diversidad poético-estético-técnica. Esta combinación y contradicción entre unas y otras (i.e.: entre denominaciones y cualidades poético-estéticotécnicas) suele conducir a dos líneas de preguntas ya "clásicas" para los integrantes de la comunidad electrónica. Estas son:

¿Qué caracteriza a cada género? ¿En qué consiste cada uno y cada uno de sus subgéneros y sub-subgéneros? ¿Qué cualidades determinan a cada una de estas categorías? ¿Cuáles son sus límites? ¿Se encuentran todas al mismo nivel de jerarquía? .... ... ¿En qué nivel se ubica cada categoría? ¿Todas deben comprenderse como "géneros" o algunas deberían ser entendidas como "estilos"?

¿Puede considerarse a la música electrónica de baile como una especie única? ¿Qué grado de cohesión hay entre las vertientes que (supuestamente) la integran? ¿No es más acertado hablar de varias músicas? ¿Qué prima más, las similitudes y puntos de contacto o las diferencias y direcciones divergentes?

Todos los deejays e "iniciados" a quienes consultáramos coinciden en que también ellos atravesaron un proceso similar cuando decidieron interiorizarse respecto del tema. Por si esto fuera poco, es también común (y motivo de risa para los mismos) que -cuando pareciera que finalmente comprendimos lo que define a un género determinado- nos topemos con un ejemplo que contradice todo lo que creíamos esencial del mismo. Así nos sucedió también a nosotros. En 
repetidas y sucesivas oportunidades, creímos comprender alguno de los géneros y vimos frustrada la expectativa. Frente a estas situaciones recurrimos a deejays, músicos y aficionados para que nos explicaran lo que estábamos percibiendo. Cada vez recibimos respuestas diferentes, cada vez nuestras fuentes remitieron a aspectos musicales distintos: algunas veces refirieron al "carácter", otras a un determinado dispositivo o tipo de sonido de sintetizador, otras al tempo, a "la línea de bajo", a que el ejemplo carecía de tal o cual elemento textural, a que en tal género "lo importante son las vocales femeninas", que tal otro es mas "duro", un tercero más "lírico" y un extenso etcétera de remisiones a características muy diversas y divergentes... incluso para un mismo género.

Cada vez que detectáramos cierto grado de permanencia de cualidades, siempre, en todos los casos, para cada género, encontramos luego ejemplos que -si bien los iniciados coincidían en nominarlos como parte del género- no poseían lo que considerábamos (en esas oportunidades) las cualidades descriptas previamente como definitorias. Así la situación y necesitados para nuestros objetivos de cierto marco medianamente firme que nos brindara algún criterio de escucha y selección de ejemplos a ser analizados, emprendimos la trabajosa tarea de otorgarle sentido al problema de los géneros.

\section{Estado de situación}

Como dijéramos, en la música electrónica de baile (o en las músicas electrónicas de baile) proliferan géneros, subgéneros y estilos. Así como Wikipedia en ingles propone para la música electrónica 23 géneros y 173 subgéneros o McLeod menciona el surgimiento de 300 nuevas denominaciones de música electrónica de baile en el término de un año, diversas fuentes documentales enumeran e intentan organizar la información sin siquiera coincidir en cuales (de entre el verdadero zoológico de géneros) son los de mayor jerarquía o "peso específico". Sus autores presentan lo que (ellos) consideran el ordenamiento apropiado de géneros y subgéneros, acompañando a cada uno con una breve descripción de lo que serían sus cualidades distintivas.

Unas fuentes procuran ayudar al lector no iniciado informándolo acerca de cómo se compone la especie, otras pretenden brindar "claves" para la identificación de géneros y subgéneros mientras que terceras intentan ordenar "líneas de tiempo" para su evolución y la de sus géneros. Cuartas presentan disimiles argumentos a partir de los cuales presumen explicar los diferentes orígenes de uno u otro, o el modo/lugar/actor que generó la deriva de tal o cual género en tal o cual otro. Algunas asumen perspectivas de desarrollo histórico mientras otras pretenden conformar una taxonomía de su desarrollo o actualidad en relación a la distribución geográfica. Unas toman como su objeto a la totalidad de la especie mientras otras focalizan sobre uno de sus géneros. Estas últimas, en algunos casos, aplican luego las conclusiones alcanzadas a la totalidad de la especie. Por si esto fuera poco, la amplia mayoría no cita fuente documental alguna. La proliferación y dispersión es tal que -si así lo deseáramos- resultaría 
virtualmente imposible seguir los rastros de origen y destino de numerosos subgéneros sin perderse o dudar en algún momento acerca de su validez y efectiva existencia.

Pareciera que esta misma superabundancia impulsara a que nuevos autores se sintieran en la necesidad de realizar publicaciones que "aclaren el panorama" generando, paradójicamente, el efecto contrario. Creemos que este comportamiento puede comprenderse como otra forma en la que se manifiesta la que hemos llamado "cultura del remix": así como productores reutilizan materiales utilizados ya numerosas veces, así como deejays reversionan piezas en los remixes concretos, así como ambos casi idolatran ciertos dispositivos y debaten interminablemente acerca de si la emulación virtual sufre de la falta de tal o cual calidad sonora que el original ofrece, así como los bailarines se cruzan en apasionados debates acerca de en qué género se inscribe una pieza concreta... así también algunos actores de la comunidad se han visto empujados a explicar "cómo realmente es" la cuestión de los géneros. Muchas veces sin demasiado conocimiento por fuera de la experiencia personal y a partir de fuentes de dudosa procedencia y veracidad, individuos con dispar formación han decidido plasmar su visión acerca de este tema. Y así sucede que estas publicaciones se suman con su número y contenidos a aquéllas dudosas fuentes, aportando al incremento exponencial del problema. Como si de malos remixes se tratara, replicando una y otra vez las falencias de sus fuentes, reforzarán la validez de aquéllos argumentos falaces. En otras palabras, hay tanto -y tanto replicado- debido (en parte al menos) a que los actores de la comunidad electrónica tienen al remix como un comportamiento incorporado ya no solo a la música sino a su vida. Consecuentemente, la primera tarea en esta cuestión ha sido encontrar fuentes que presenten grados mayores de rigurosidad, buceando en un océano de publicaciones-basura. Recorramos el desarrollo de una de las últimas; nos permitirá apreciar los niveles ridículos que a veces alcanzan.

Es al menos "peculiar" la categorización que realizan de la especie los músicos británicos Steve Hillage y Miquette Giraudy a partir solamente de los tempos o "bpm" (i.e.: "beats per minutes") que supuestamente utiliza cada género. Su propuesta es la siguiente:

60-90 bpm - hip hop y dub

90-120 bpm — hip hop "rápido" y big beats/trip hop

120-135 bpm - house

$135-155 \mathrm{bpm}$ - techno

155-180 bpm - drum and bass / jungle

$180+$ bpm - hardcore gabber y más ${ }^{401}$

Esta clasificación se reproduce y cita en un inmenso número de sitios. ${ }^{402}$ A pesar de ello, no pudimos encontrar ni la publicación original ni referencias de la oportunidad o marco en

\footnotetext{
${ }^{401}$ La lista es una traducción (nuestra) de la que se incluye en el sitio Audials dedicado al desarrollo de tecnología digital de audio. Accesible en http://audials.com/en/genres/dance_music.html [27042016]
} 
el que sus supuestos autores concretaron la propuesta. Tampoco encontramos el basamento teórico que los llevó a que jerarquizaran estos géneros por sobre otros o siquiera si dicho basamento existe. Lo que sí queda claro es que el simplismo excesivo de esta perspectiva es algo que no resulta evidente para muchos integrantes de la comunidad electrónica.

Por un lado, es un hecho que en el público de la especie hay gran cantidad de "productores y deejays de dormitorio"; muchos de los cuales coquetean con la ilusión de profesionalizarse. ${ }^{403} \mathrm{Al}$ respecto dirá Butler que:

[...] un porcentaje considerable de la audiencia de un evento dado de EDM tendrá alguna experiencia como DJ y/o productor. Alguno podrá ser "DJ de dormitorio", que nunca toca en público, o productor que crea música en soledad y para su propia entretención. Otros podrán ser ejecutantes amateur que tocan gratis (o por muy poco [dinero]) en eventos locales o regionales. Además, un número de DJ y/o productores semiprofesionales o aspirantes a profesionales pueden estar presentes. Estos artistas habrán comenzado a establecer una reputación fuera de su entorno inmediato y a ganar dinero por sus actividades en la EDM, aunque usualmente mantienen algún otro trabajo para llegar a fin de mes. ${ }^{404}$

Por otra parte, constantemente presenciamos ejemplos de cómo la proliferación de ciertas informaciones, replicadas en numerosos medios de comunicación masivos, genera una "ilusión de validez" para las mismas. Toda información entonces, por efecto de su proliferación e independientemente de su rigurosidad y validez fáctica, tiene mayor penetración en miembros de este grupo, los cuales poseen escasa o nula formación musical sistemática. Así es que en un debate en el foro de la comunidad blizzhackers.cc (comunidad dedicada al debate en relación a la industria del entretenimiento) el usuario Full-Torqe criticará la clasificación de HillageGiraudy y, multiplicando la ridiculez de la propuesta original, propondrá en su lugar la siguiente:

60-120bpm - Downtempo (todo desde hip-hop, trip-hop y chillout)

120-150bpm - Breakbeats

120-140bpm - House

135-160bpm - Techno

130-160bpm - Trance (No escuché ni un ejemplo de goa trance a 160bpm)

140-175bpm - Hardstyle

155-180bpm - Drum'n'Bass/Jungle

${ }^{402}$ Véase por ejemplo la actualización de esta misma lista incluida en la nota Usa diversos tempos para crear beats de diferentes géneros. De muy reciente publicación, resulta accesible ingresando en http://www.futuremusic-es.com/usa-diversos-tempos-para-crear-beats-de-diferentes-generos/ [19092016]. ${ }^{403}$ Lo ponemos en estos términos porque en la mayoría de los casos este "coqueteo" no deja de ser un juego que no incluye el compromiso real necesario para alcanzar dicha profesionalización.

404 "Furthermore, a considerable percentage of the audience at a given EDM event will have some experiencie with DJing and/or production. Some may be "bedroom DJs", who never play in public, or producer who create music solely for their own enjoyment. Others may be amateur performers who play for free (or for very little) at local and regional events. In addition, a number of semiprofessional or aspiring professional DJs and/or producers may be in attendance. These artists have begun to establish a reputation outside of their immediate environment and to make money for their EDM activities, though they usually maintain some other job to make ends meet." Butler, M. Op. cit. (2003). pp. 25 
165-200bpm - Hardcore (Happy Hardcore, Gabber, Trancecore, Freeform, la mierda más mala que hayas escuchado alguna vez)

200-300bpm - Estúpidamente rápido Gabber

300-1000bpm - Speedcore (asombrosamente estúpido)

$1000 \mathrm{bpm}+$ - Xtratone (solamente estúpido $)^{405}$

Creemos necesario aclarar que el tono en que el usuario se expresa en el debate es serio. En otras palabras, si bien otros usuarios utilizan un tono informal y por momentos irrespetuoso, nada de lo dicho por Full-Torqe hace pensar que sus expresiones involucren ironía. ${ }^{406}$ De hecho, en el marco del debate es quizá el "orador" que mejor representa la "voz de la autoridad" y quien asume el lugar de "conocedor iniciado" en el tema. Esto se evidencia sobre todo en dos comentarios previos, en los cuales a) invitará a visitar su sitio http://www.full-torqe.tigerrider.com (hoy "caído") donde afirma tener "una buena cantidad de varias músicas electrónicas" 407 y b) afirmará que los géneros principales de la EDM son: Techno, Trance, House, Breakbeat, Hardcore y Downtempo. Como veremos en breve, tanto los ejemplos incluidos en la lista de los tempos como la que acabamos de citar son selecciones en mucho coincidentes con lo que arrojan nuestras pesquisas.

Nos parece interesante incluir esta anécdota debido a que nos hemos encontrado con esta perspectiva en varias oportunidades. Entre otras, en las entrevistas que realizáramos al deejay y periodista especializado Walter Bohmer y al deejay Javier Cardozo: ante nuestra pregunta acerca de qué caracteriza a los diversos géneros recibimos, como la respuesta que presenta mayor claridad (i.e.: en la que los entrevistados no mostraron ningún signo de duda), una segmentación basada en los tempos. Para ser justos, las respuestas de los entrevistados estuvieron enriquecidas y matizadas con multiplicidad de datos, pero ello no quita que la más clara fuera, sin pausa ni duda, relativa a los tempos. Pero... ¿por qué sucede esto?

El tempo es efectivamente uno de los factores que segmenta al total de las músicas electrónicas de baile, y que surja como el más evidente en las respuestas puede explicarse en el hacer de los deejays. Estos sincronizan y superponen el final de una pista con el comienzo de la siguiente, generando un flujo musical continuo durante toda la noche. Para esto hacen uso de lo que se ha dado en llamar "beat matching". En español, la expresión se traduciría como "hacer coincidir los pulsos" lo que, en otras palabras no es otra cosa que reproducir dos piezas musicales al mismo tempo (en la jerga, a los mismos "bpms") y sincronizar los primeros tiempos de cada compás de ambas piezas. Dominar esta técnica es lo primero que deben resolver incluso quienes apenas desean "jugar" a ser deejays. Esto puede haber conducido a

\footnotetext{
${ }^{405}$ Traducción nuestra como la anterior, se accede al comentario de Full-Torqe en el debate (pág. 3 de 4) en http://www.blizzhackers.cc/viewtopic.php? $\mathrm{f}=162 \& \mathrm{t}=372572 \&$ start $=30$ [27042016]

406 Exceptuando por supuesto la propuesta en sí y los (por ejemplo) "1000bpms", los cuales deberían conducir irremediablemente a la duda.

407 "I have a hole bunch of varios electronic music at my site". Accesible en http://www.blizzhackers.cc/viewtopic.php?f=162\&t=372572\&start=30 [27042016]
} 
muchos al error de creer que esta es la única (o al menos esencial) diferencia entre las diferentes músicas que componen la especie.

La propuesta de Hillage-Giraudy refleja fielmente el mito descripto en el párrafo previo (de que el género de una pieza está determinado solo por su tempo) que circula entre ciertos actores involucrados con la especie. Según nuestra propia experiencia y como dijéramos, esta creencia es más fuerte entre quienes poseen menos experiencia como deejays y/o menos herramientas de teoría musical tradicional. Como se comprenderá a partir del ejemplo desarrollado, en el estudio de los géneros es imprescindible el análisis crítico de los datos contenidos en numerosas fuentes (no siempre fiables).

Llegado este punto creemos conveniente aclarar un par de cuestiones en relación al presente título. No pretendemos aquí realizar ni una taxonomía de los géneros ni organizar mapa o línea de tiempo del desarrollo histórico de la especie, ni de sus géneros o subgéneros. Nuestro intento se centrará en lograr algún tipo de organización o sistema que permita reducir las contradicciones y solapamientos detectados en la amplia mayoría de las fuentes. Intentaremos además este ordenamiento desde las cualidades estético-técnicas musicales, buscando que los agrupamientos resultantes den cuenta de las similitudes y diferencias detectadas en las piezas que conformen cada uno. En definitiva, a partir de los datos relevados en las fuentes, intentaremos encontrar criterios -aplicables en todas y cada una de las etapas históricas que atravesara la especie- que eviten o al menos mitiguen las inconsistencias detectadas hoy. Retomemos ahora el hilo principal.

En el contexto descripto (donde predominan las que llamamos publicaciones-basura) se destacan fuentes en línea y documentos impresos (e incluso una instalación multimedia interactiva) que denotan la subyacencia de extenso trabajo de exploración. Reproducimos a continuación una selección de mapas, líneas de tiempo y organizaciones jerárquicas (de géneros y subgéneros) que resultan ilustrativas de la complejidad del tema y de su estado de situación. ${ }^{408}$

\footnotetext{
${ }^{408}$ Algunas infografías se complementan con la información incluida en sus sitios de publicación, téngase presente entonces que no considerar dichos datos puede conducir a errores al evaluar su relevancia.
} 


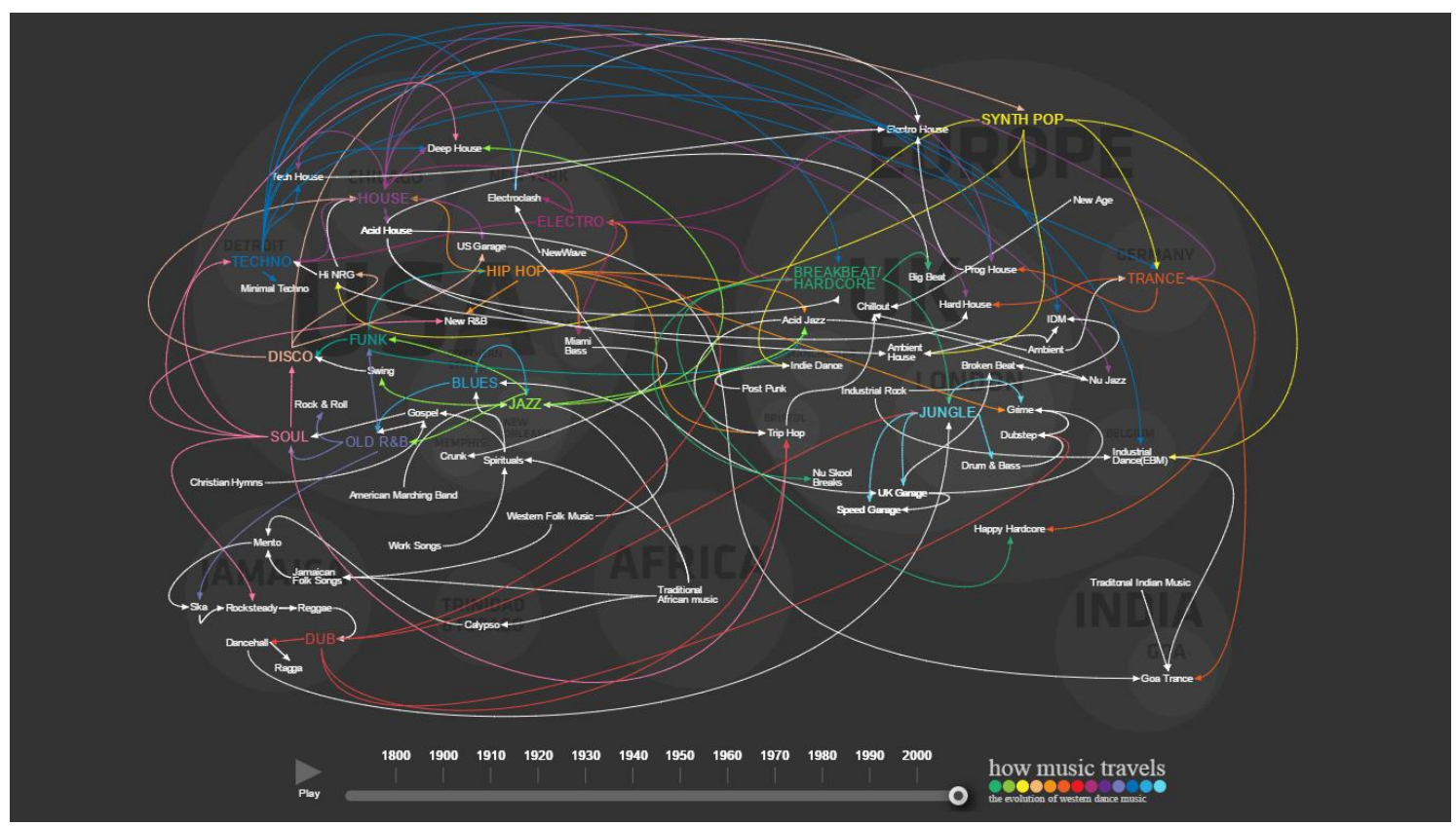

The Evolution of Western Dance Music (Evolución de la música occidental de baile). Accesible en http://www.thomson.co.uk/blog/wp-content/uploads/infographic/interactive-music-map/index.html [27042016]

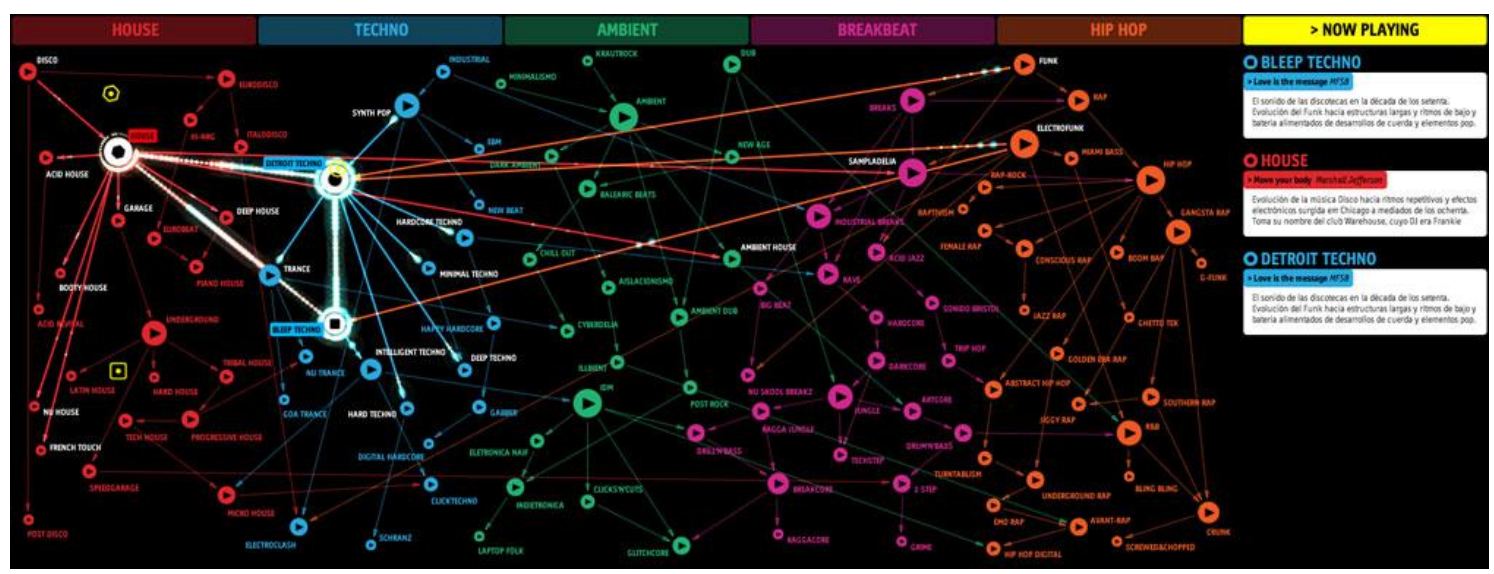

Instalación multimedia interactiva Sync/Lost. Imagen y más información accesible en https://alfazentauro.wordpress.com/2010/02/03/planeta-electronica/ [27042016]

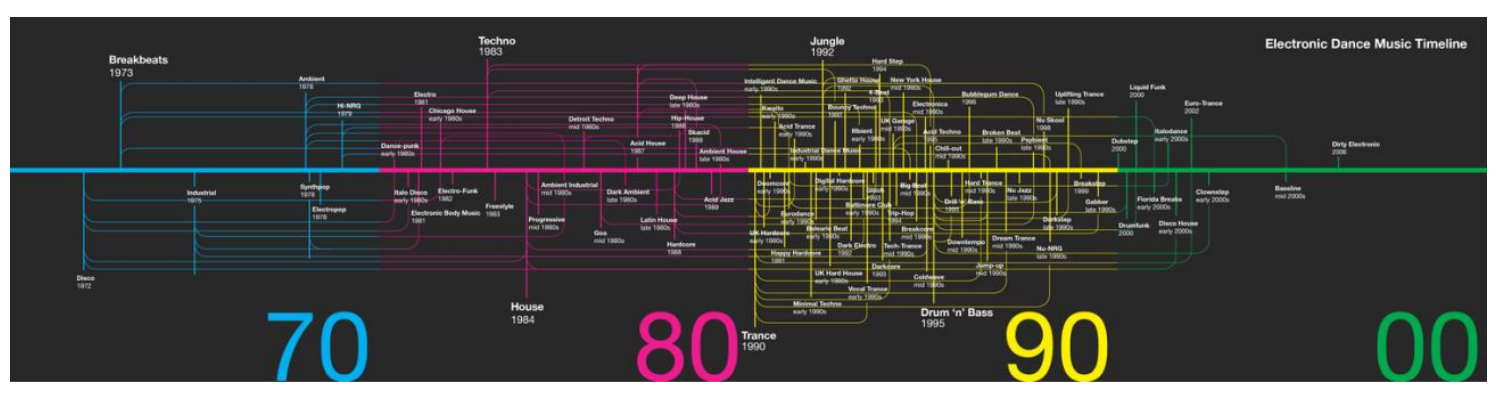

hello janny design edm-cd-project.

Accesible en http://hellojannydesign.com/edm-cd-project [27042016] 


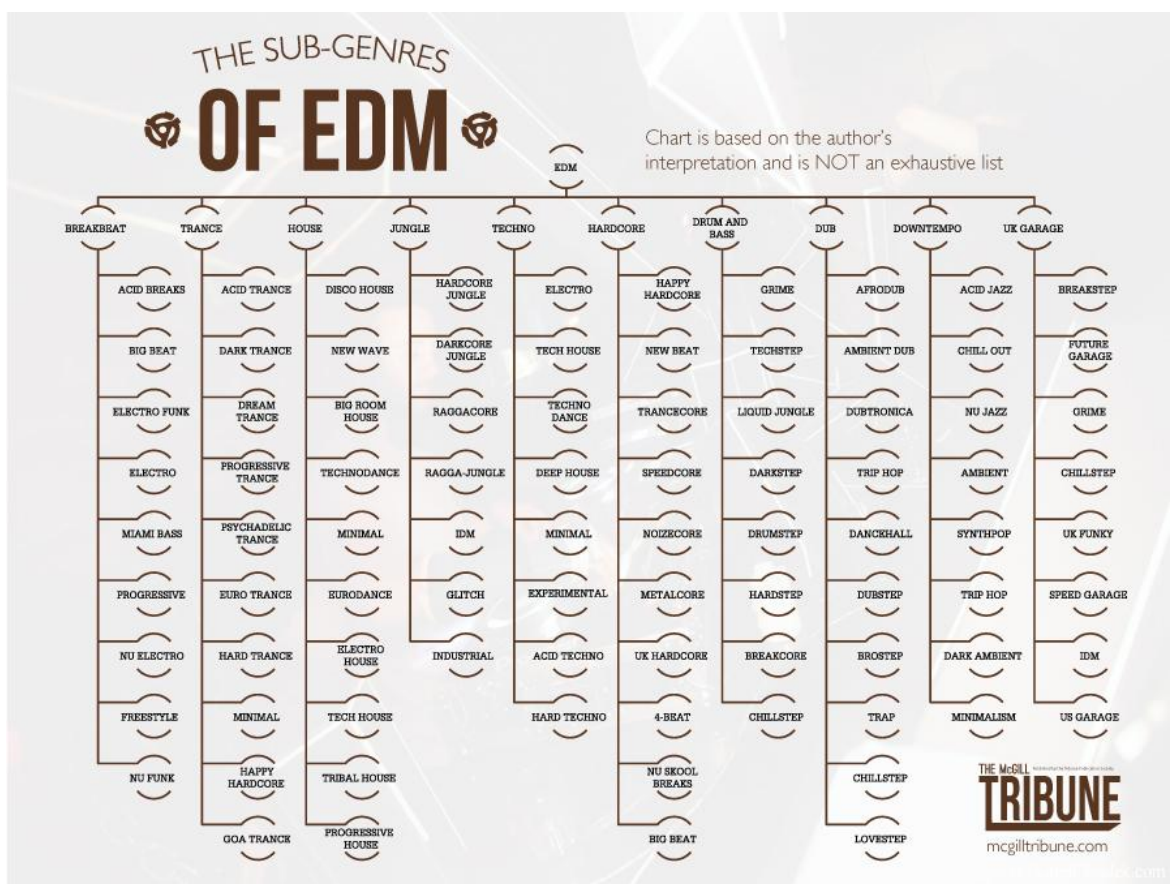

"The proliferation of EDM." Artículo periodístico en The McGill Tribune. Accesible en http://www.mcgilltribune.com/features/the-proliferation-of-edm/ [27042016]

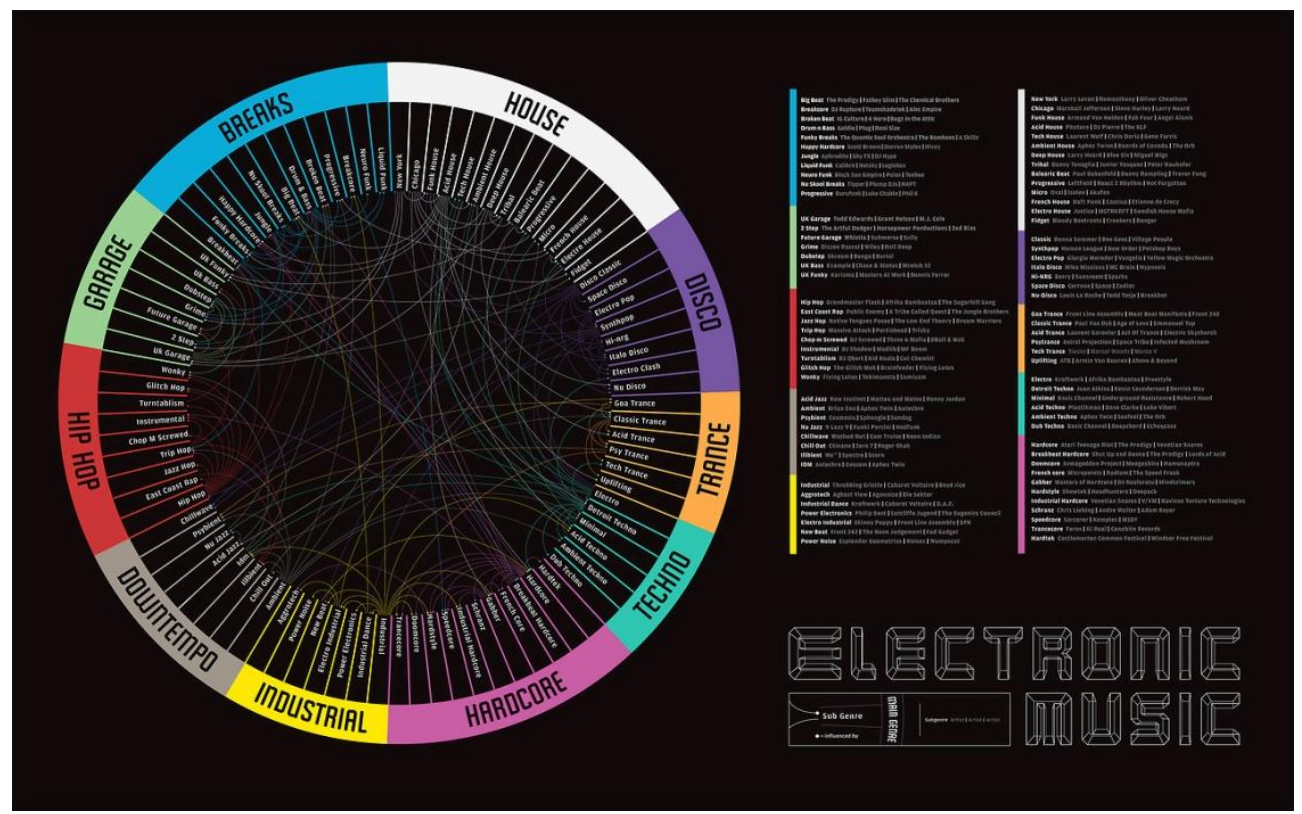

Electronic Music Guide (Music infographics). Accesible en http://www.designinfographics.com/music-infographics/electronic-music-guide\# [27042016] 


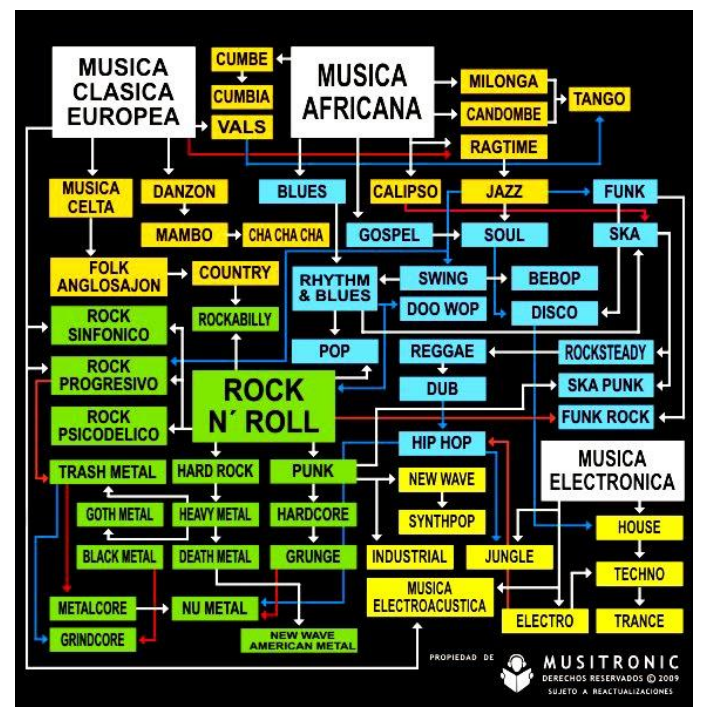

Árbol genealógico de la música moderna. Accesible en

https://soundworkscolombia.wordpress.com/2011/03/10/arbol-genealogico-de-la-musica-moderna/ [27042016]

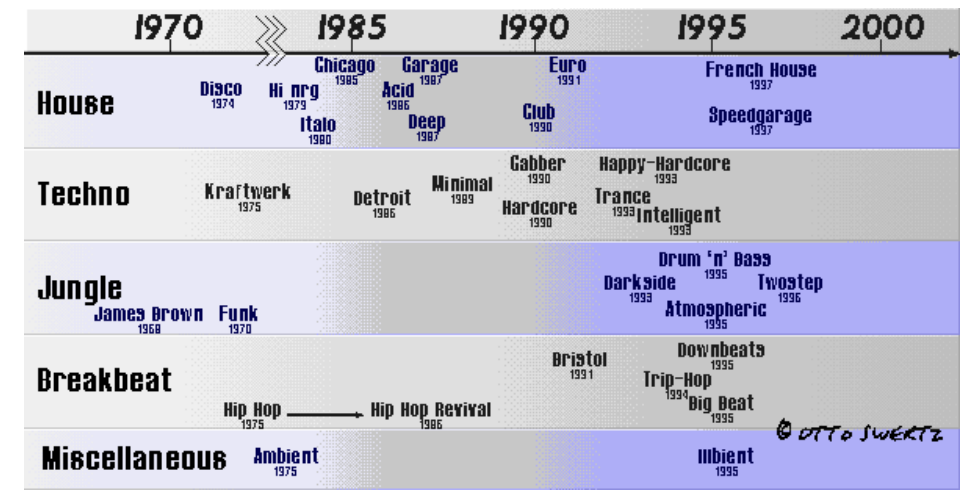

Como diferenciar los distintos géneros de música electrónica. Accesible en http://smallmoments1.blogspot.com.ar/2015/04/como-diferenciar-los-distintos-generos.html [27042016]

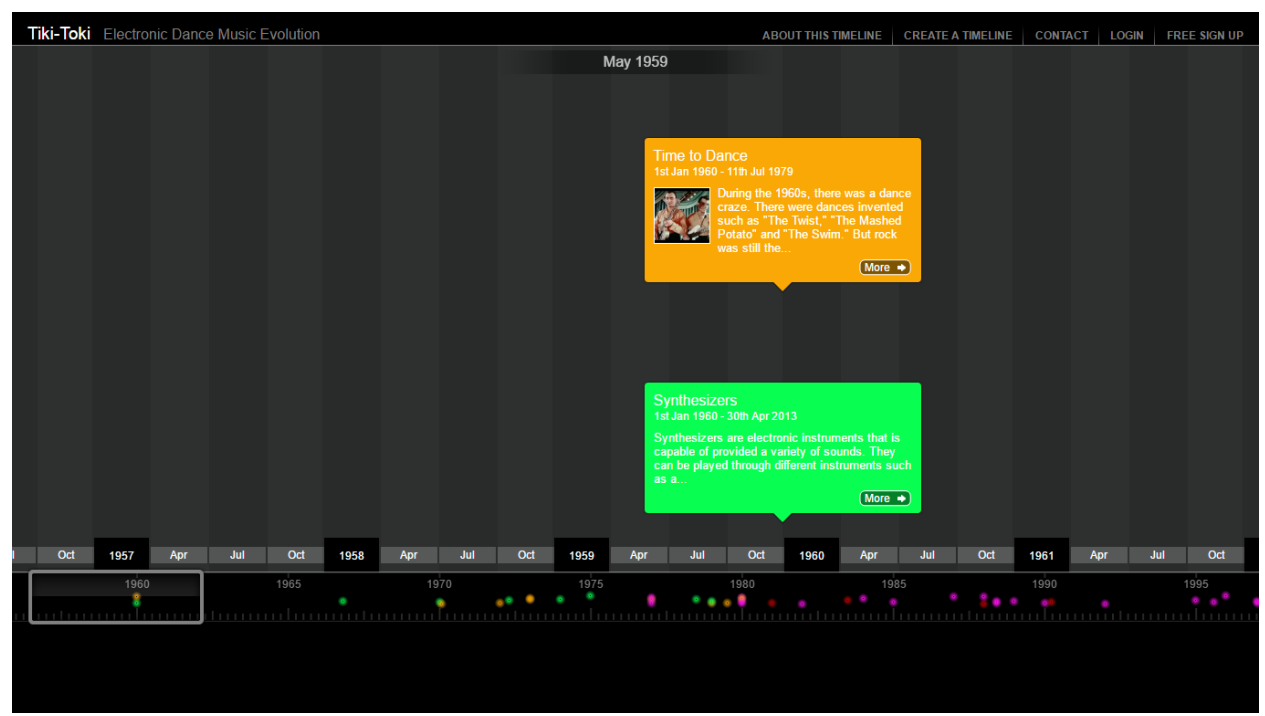

Tiki-Toki Electronic Dance Music Evolution. Accesible en http://www.tikitoki.com/timeline/entry/119994/Electronic-Dance-Music-Evolution\#vars!date=1959-05-13_21:13:42! [27042016] 


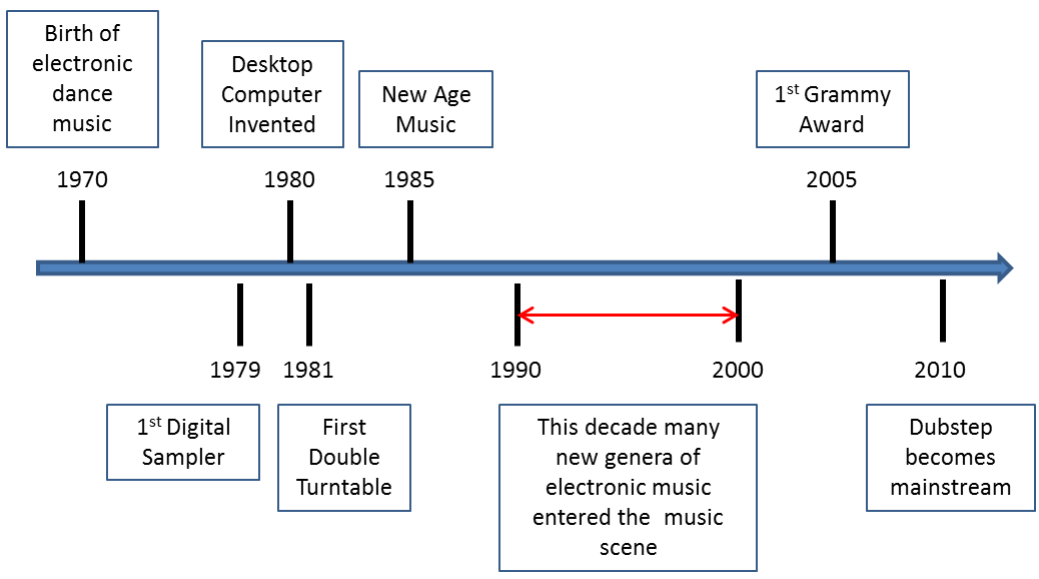

Jeremy Decker's Electronic music timeline.

Accesible en http://ilya.jeremydecker.com/?page id=72 [27042016]

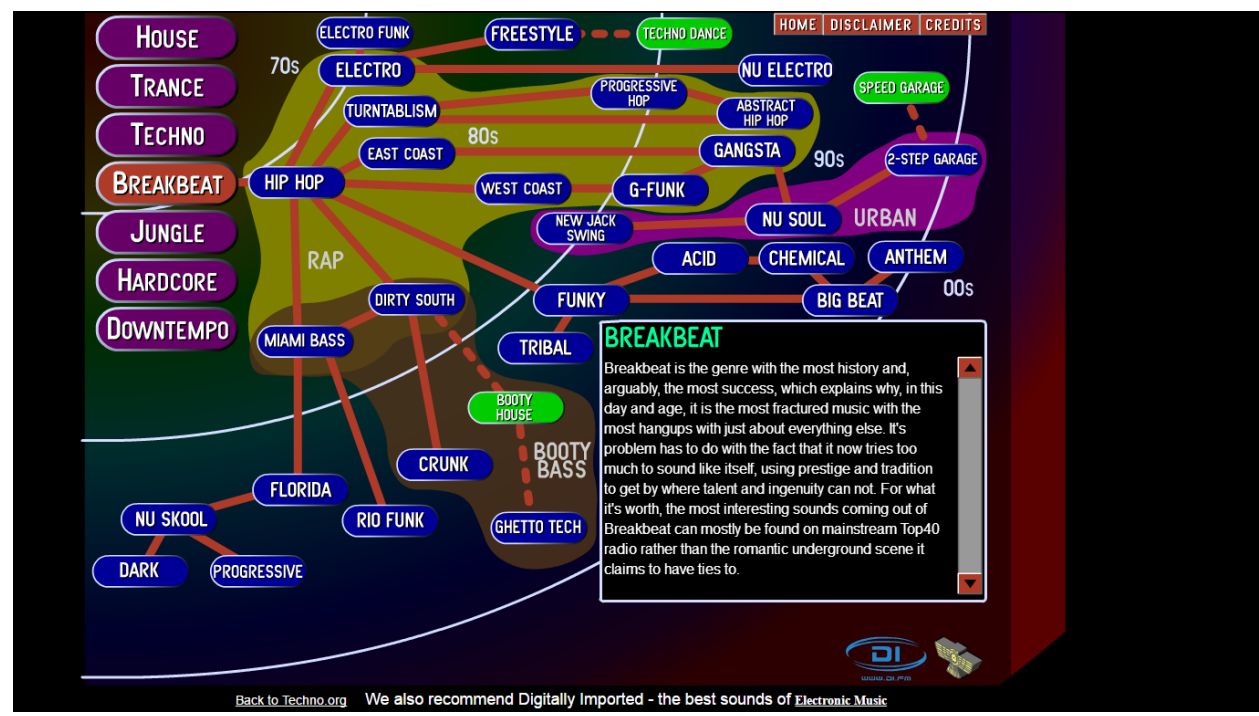

Ishkur's Guide to Electronic Music/Breakbeat (La guía de Música electrónica de Ishkur). Accesible en http://techno.org/electronic-music-guide/ [27042016]

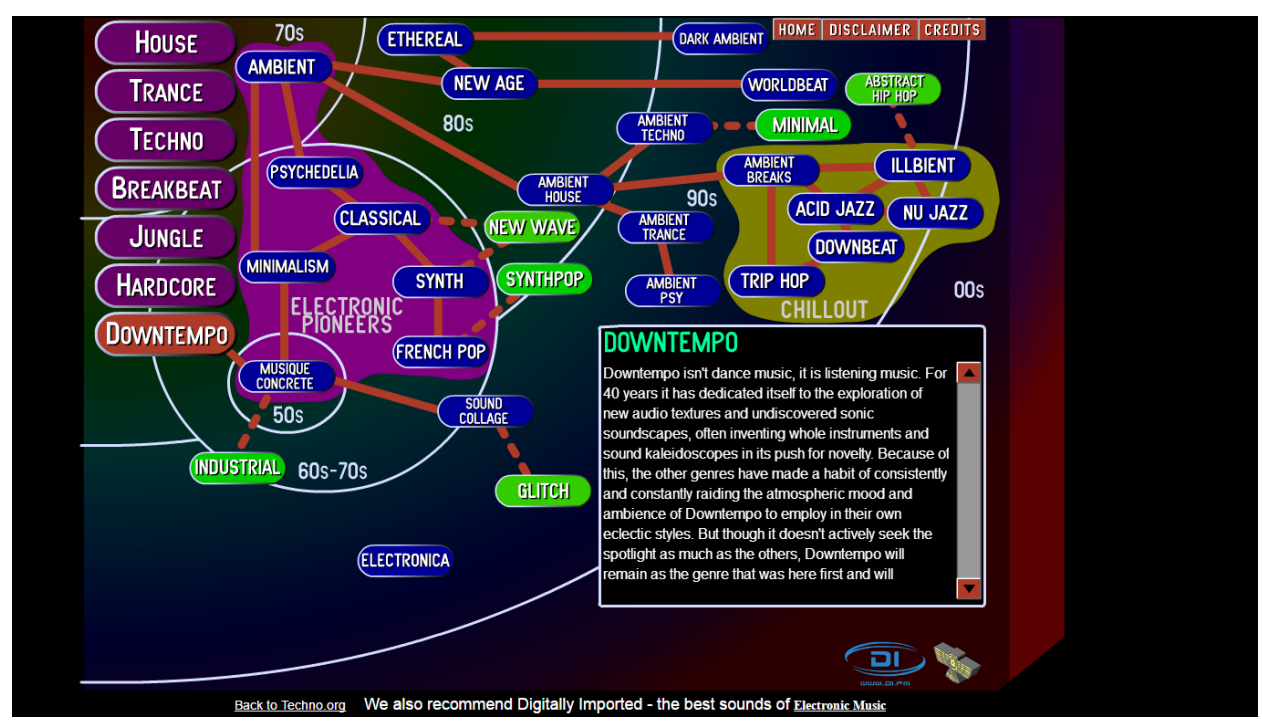

Ishkur's Guide to Electronic Music/Downtempo (véase vínculo en la ilustración anterior) 


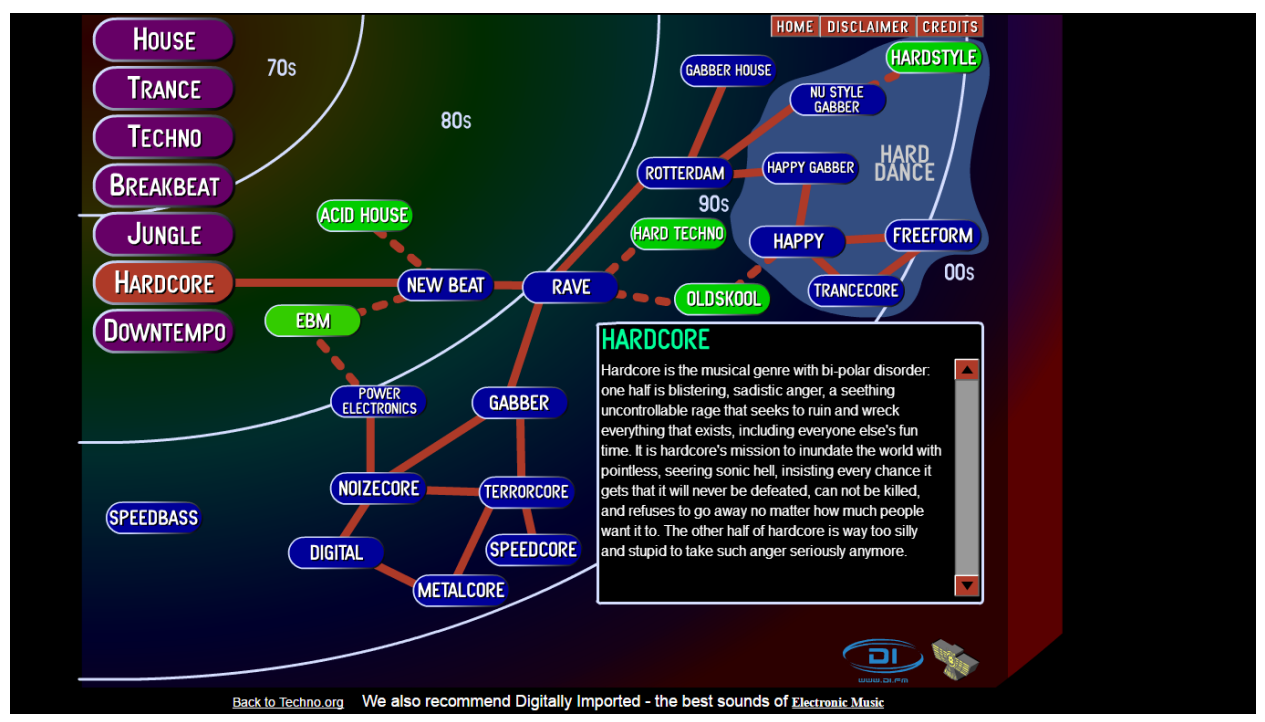

Ishkur's Guide to Electronic Music/Hardcore

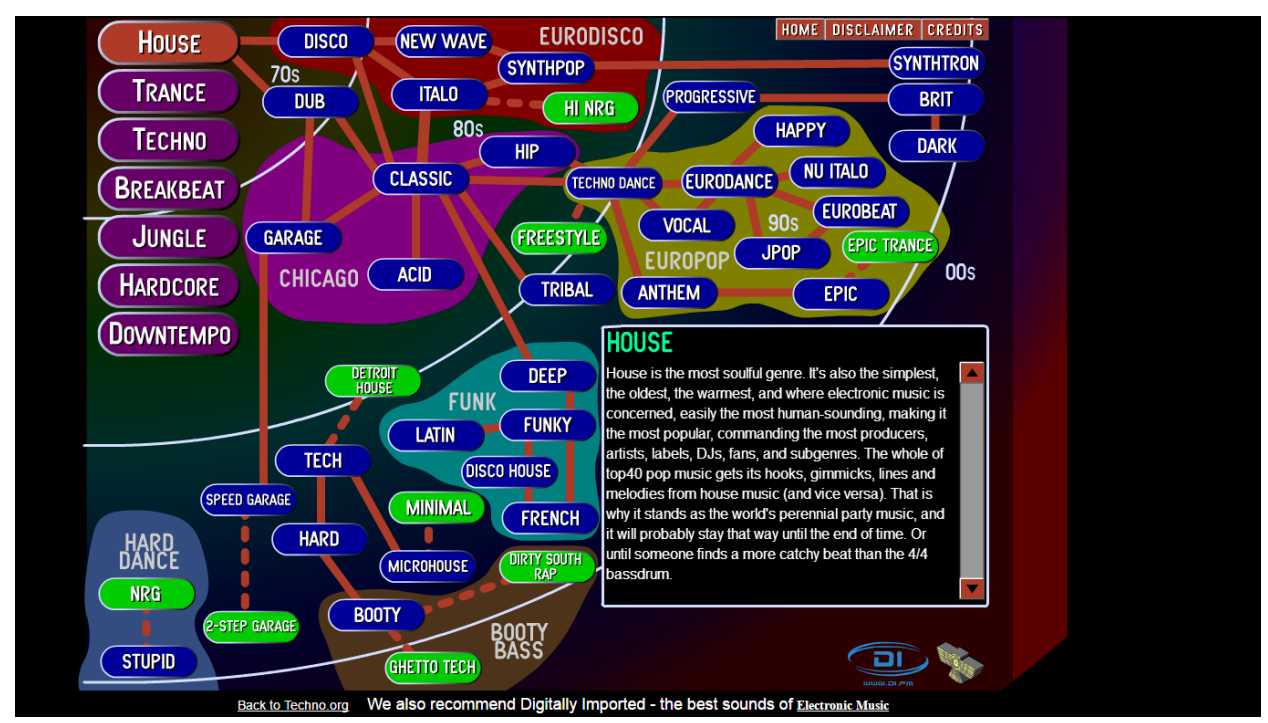

Ishkur's Guide to Electronic Music/House

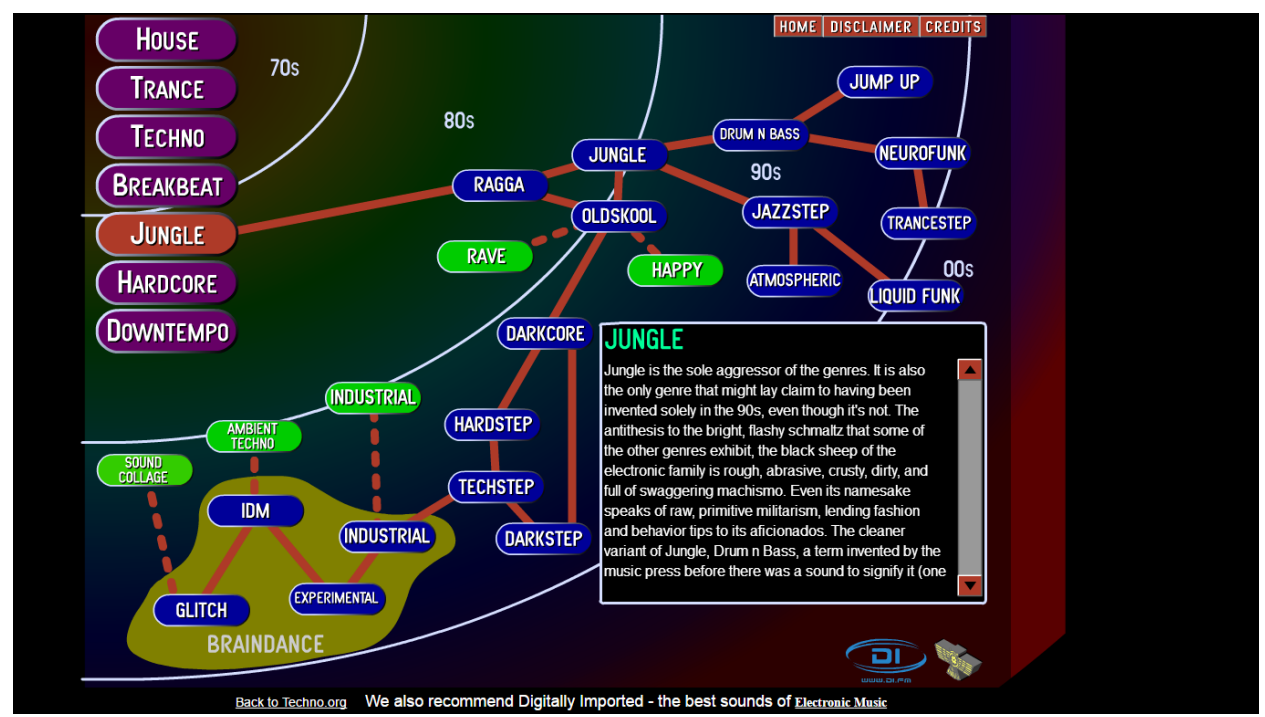

Ishkur's Guide to Electronic Music/Jungle 


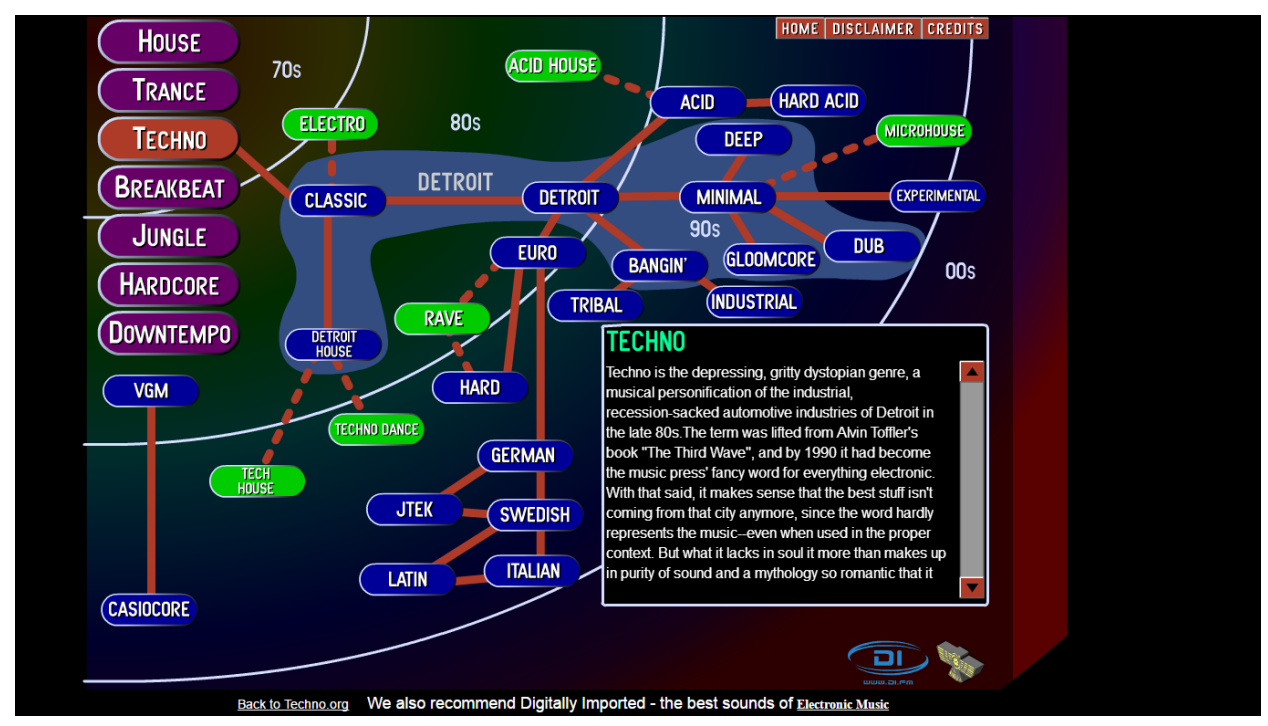

Ishkur's Guide to Electronic Music/Techno

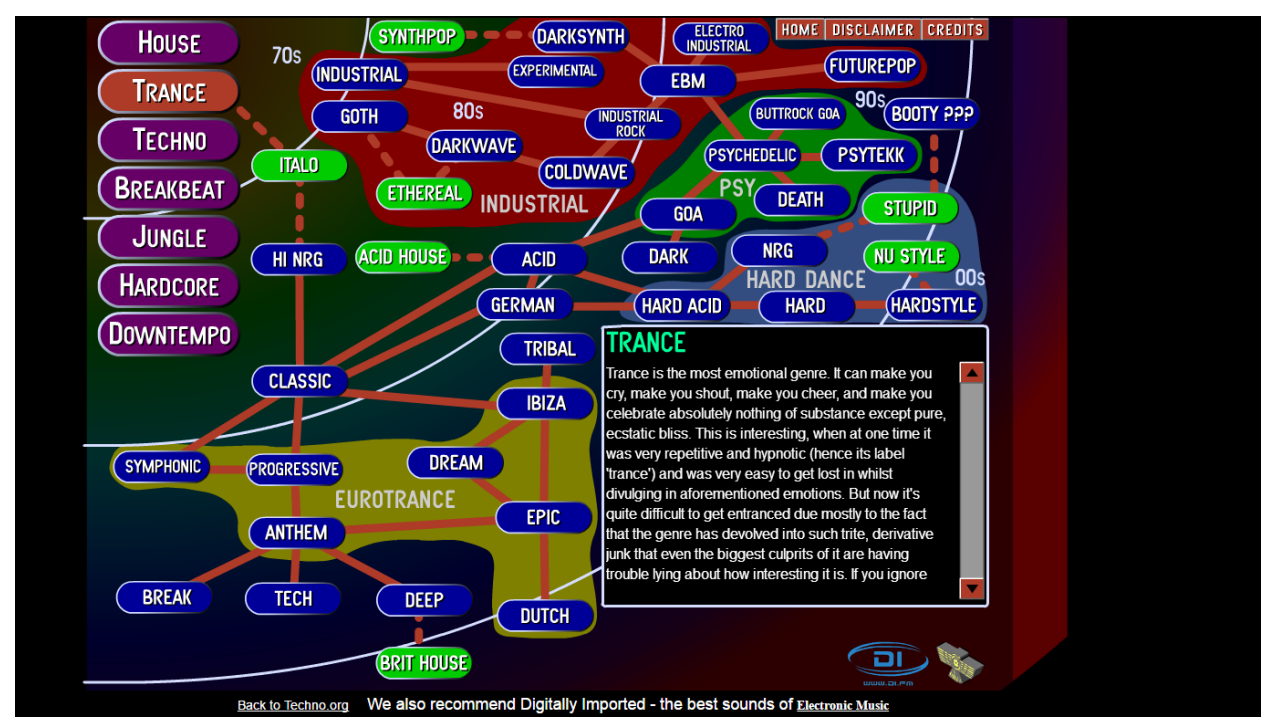

Ishkur's Guide to Electronic Music/Trance

Cada publicación, al mismo tiempo que presenta problemas y ambigüedades a resolver, aporta contenidos valiosos para la comprensión de un objeto que, como puede apreciarse, resulta extremadamente complejo en sí mismo y complejo de representar.

The Evolution of Western Dance Music dice recorrer -en un mapa interactivo que es a la vez línea de tiempo, distribución geográfica y líneas de influencia- la evolución de la música de baile "occidental". De forma similar, Hello Janny Design EDM-CD-Project, Como diferenciar los distintos géneros de música electrónica y Jeremy Decker's Electronic music timeline presentan también líneas de tiempos de diferente nivel de detalle y características y, al mismo tiempo, diferentes formas de ordenar jerárquicamente similares listas de géneros, subgéneros y (a veces, también) estilos.

El Árbol genealógico de la música moderna presenta una aproximación al caprichoso lugar que ocuparía la música electrónica (de baile), en un mapa quizá aún más caprichoso de la "música moderna". También ofrece una idea de su composición en géneros, desde la perspectiva 
de un individuo cuyo universo musical se compone de las tres categorías resaltadas en fondo blanco. Nuestra deformación profesional quizá nos engañe, pero cualquiera puede recorrer todo un Planeta Tierra de culturas y expresiones artísticas más allá de este cuadro (todas a la misma altura jerárquica que las presentadas). Este mapa podría representar la visión, la perspectiva de aquel participante de la comunidad electrónica que podríamos caracterizar como "melómano", "aficionado" a la especie o, incluso, la de algunos de aquéllos que hemos llamado siguiendo a Butler "deejays de dormitorio".

El artículo de The McGill Tribune e Ishkur's Guide... proponen ordenamientos jerárquicos de géneros y subgéneros. La segunda además es otra forma de representar las líneas de tiempo de cada género y las influencias y relaciones múltiples entre los subgéneros a su interior; por otra parte, también propone ciertas categorías difusas que "subyacen" o atraviesan transversalmente a ciertos grupos de subgéneros, agrupándolos. También en Ishkur's Guide... ciertos subgéneros aparecen en más de una categoría, permitiendo apreciar algunos "cruces" entre géneros "mayores" que se concretan en subgéneros que llamaremos "híbridos". Es necesario hacer notar que Ishkur's Guide... es una de las fuentes más citadas y consultadas en relación a la música electrónica de baile.

Similar a Ishkur's Guide... es la información contenida en Electronic Music Guide: esta última forma de representación y organización brinda específicamente la posibilidad de analizar los "cruces" e influencias entre subgéneros que superan los límites de cada género "mayor".

[Paréntesis breve: El sesgo (¿neo-?) colonial]

Una peculiaridad que nuestras convicciones no permiten dejar pasar sin mención es la casi total ausencia de Sudamérica en aquéllos mapas que de algún modo toman en consideración cuestiones geográficas. Apenas si se mencionan a géneros como tango, cumbia o candombe en el Árbol genealógico de la música moderna ${ }^{409}$ Evidentemente, para The Evolution of Western Dance Music la región sur del continente americano se considera menos "occidental" que, por ejemplo, India. A pesar de la innegable temprana actividad desarrollada tanto en nuestra región como en (a modo de ejemplo) Japón, los géneros incluidos son casi con exclusividad originados en los Estados Unidos o Europa ${ }^{410}$ Exceptuando a Jamaica, el sesgo imperio-céntrico se expresa también en el hecho de que músicas originadas en nuestro subcontinente ni siquiera se incluyen como influencias o géneros-origen de las músicas electrónicas, ni como derivas o estilos locales. Este punto resulta digno de mención sobre todo a partir de que nuestro país (Argentina) ha sido y es uno de los centros geográficos donde la especie posee una de las mayores afluencias de participantes del planeta, y el que ha aportado y aporta a la "escena global" numerosos artistas y figuras de renombre mundial.

\footnotetext{
${ }^{409}$ Seguramente esto se deba a que la publicación es de origen colombiano.

${ }^{410}$ Valga decir además que, entre otras industrias, en Japón residen las empresas más grandes dedicadas al desarrollo de tecnología asociada a la música, siendo el gigante Korg uno de sus principales exponentes.
} 
Deejays, productores solistas y agrupados, músicos experimentales e inscriptos en estilos mainstream aportan a una escena que sobrevive siempre incipiente bajo la presión de una industria cultural que, desde los países tradicionalmente coloniales, invade constantemente con un flujo promovido -e incluso a veces sostenido- desde los aparatos estatales y para-estatales de origen; a los que se le suman sus socios estratégicos locales. Como en tantos otros sectores del mercado, el de bienes intangibles como el musical no se salva de la "Guerra Fría Cultural" que aún persiste desde los tiempos de su homónima política y de "inteligencia".

Presentamos debajo una lista parcial e incompleta de algunos artistas, agrupaciones y proyectos (productores, deejays y músicos electrónicos) dedicados a la música electrónica en Argentina. Incluye vínculos a sus materiales y perfiles virtuales como también, en algunos casos, los nombres de sus integrantes.

\section{Artistas electrónicos argentinos. ${ }^{411}$}

\begin{tabular}{|c|c|c|}
\hline Nombre de artista & Vínculos a producción & Integrante/s y otros datos \\
\hline Aguamono & http://soundcloud.com/aguamono & \\
\hline Allan Sin Nada & allasinnada.bandcamp.com & $\begin{array}{l}\text { Ivan Vertki, Bruno Morandi, } \\
\text { Jeremias Calderón, Alan Diaco }\end{array}$ \\
\hline abl & alumbradobarridoylimpieza.bandcamp.com & Nahuel Acosta, Gonzalo Duprat \\
\hline Amapolas & $\begin{array}{l}\text { Www.dulcesamapolas.com } \\
\text { https://soundcloud.com/dulcesamapolas }\end{array}$ & $\begin{array}{l}\text { Daniela Pantano, Federico } \\
\text { Volujewicz, Pablo Paredes }\end{array}$ \\
\hline Ansiosa & $\begin{array}{l}\text { Www.ansiosanet.com.ar } \\
\text { www.ansiosa.bandcamp.com }\end{array}$ & $\begin{array}{l}\text { Mariano Keselman, Pablo } \\
\text { Kaufman }\end{array}$ \\
\hline Ana del Choque & https://soundcloud.com/anadelchoque & Eliana Fernández \\
\hline Apolo Beat & http://apolobeatmusica.bandcamp.com & Gaspar Baldo, Rodrigo Eskinazi \\
\hline Campo Mágico & https://www.facebook.com/CampoMagico & $\begin{array}{l}\text { Mati Be, Willy Azno, Ariel } \\
\text { Pacheco, Javier Pacheco, } \\
\text { Humberto, Mariano Pizarro }\end{array}$ \\
\hline Carlos Shaw & $\begin{array}{l}\text { https://soundcloud.com/carlosshaw } \\
\text { https://www.facebook.com/Carlos. Shaw.Argentin } \\
\text { a/ }\end{array}$ & \\
\hline Chaski Pum & https://www.facebook.com/chaskipum & \\
\hline Charlie Capozzolo & https://www.facebook.com/Capozzolo & \\
\hline Club de Astronomía & http://clubdeastronomia.bandcamp.com & Angelo Paolo, Juan del Campo \\
\hline ConradTwice & https://soundcloud.com/conradtwice & Productor \& DJ. \\
\hline Cosaquitos en Globo & www.cosaquitosenglobo.com.ar & $\begin{array}{l}\text { Maru Pardo Saguier, Sebastian } \\
\text { Cordoves, Diego Lopez }\end{array}$ \\
\hline $\begin{array}{l}\text { Crrraanc!!!! Música } \\
\text { táctil }\end{array}$ & $\begin{array}{l}\text { https://soundcloud.com/crrraanc } \\
\text { https://www.facebook.com/Crrraanc/ } \\
\text { https://www.youtube.com/user/Crrraanc }\end{array}$ & Iván Anzil \\
\hline CRU5H3R & $\begin{array}{l}\mathrm{http}: / / \text { soundcloud.com/cru5h3r } \\
\text { https://www.facebook.com/Cru5h3r }\end{array}$ & \\
\hline Cunnus Cancro & https://cunnuscancro.bandcamp.com/ & Cristiano Monga \\
\hline Dani Perez Audio Buró & https://soundcloud.com/dani-perez-audioburo & \\
\hline Debris & $\begin{array}{l}\text { https://soundcloud.com/debrismusica } \\
\text { https://www.facebook.com/debrismusica }\end{array}$ & $\begin{array}{l}\text { Melisa Blomberg, Alejo } \\
\text { Eremita }\end{array}$ \\
\hline Depuratumba & www.soundcloud.com/depuratumba & \\
\hline Devoto & www.soundcloud.com/devotoduo & Germán Corv \\
\hline Diego Betas & $\begin{array}{l}\text { https://soundcloud.com/diegobetas } \\
\text { http://diegobetas.bandcamp.com// }\end{array}$ & \\
\hline DHD (teama) & http://dhdteama.bandcamp.com/ & $\begin{array}{l}\text { Emiliano Cabral con Nicolas } \\
\text { Campo, Fede Forte, Oscar Pata. }\end{array}$ \\
\hline
\end{tabular}

${ }^{411}$ Fuente: documento del grupo de facebook Argensynth. Accesible (requiere ser miembro del grupo para visualizarse) en https://www.facebook.com/notes/201577609965209/Base de datos m\%C3\%BAsicos Argensynth/623575601098739/ [25062016] 


\begin{tabular}{|c|c|c|}
\hline & & $\begin{array}{l}\text { noise/ psicodelia/ industrial/ } \\
\text { cabeza }\end{array}$ \\
\hline DKL & www.soundcloud.com/dklsessions & $\begin{array}{l}\text { Kevin Sohn, Lucas Mazzei, } \\
\text { Alan Diaco (a veces Jeremias } \\
\text { Calderon) }\end{array}$ \\
\hline Dō & $\begin{array}{l}\text { Www.facebook.com/caminodeldo } \\
\text { https://soundcloud.com/do-visentini-romeo }\end{array}$ & $\begin{array}{l}\text { Dolores Visentini, Ernesto } \\
\text { Romeo }\end{array}$ \\
\hline DobleMoral & https://soundcloud.com/doblemoralesdoblemoral & Pablo Spretz, Blas Finger \\
\hline Duermevela & $\begin{array}{l}\text { http://www.duermevelaweb.com } \\
\text { https://www.facebook.com/duermevelarock }\end{array}$ & Martín Alejo Pensado \\
\hline El Gran Búfalo Blanco & http://elgranbufaloblanco.bandcamp.com/ & \\
\hline Emilio Cardone & $\begin{array}{l}\text { Www.emiliocardone.com } \\
\text { http://emiliocardone.bandcamp.com/ }\end{array}$ & \\
\hline Estupendo & https://www.facebook.com/estupendomusica/ & \\
\hline Ezequien? & $\begin{array}{l}\text { https://soundcloud.com/ezequien } \\
\text { https://www.facebook.com/ezequienoficial }\end{array}$ & Ezequiel Jaroslavsky \\
\hline Fede Manfredi & $\begin{array}{l}\text { https://www.youtube.com/fedemanfredi } \\
\text { https://www.soundcloud.com/fedemanfredi }\end{array}$ & IDM/ Ambient/ Deep Techno \\
\hline Fughu & $\begin{array}{l}\text { www.fughu.com } \\
\text { http://www.youtube.com/channel/UC4up01RlrIZ } \\
\text { Hb-nkIYOIPQ }\end{array}$ & \\
\hline Gabriel Kohout & $\begin{array}{l}\text { http://www.youtube.com/channel/UC4up01RlrIZ } \\
\text { Hb -nkIYOIPQ }\end{array}$ & \\
\hline Gallegher Plus & www.soundcloud.com/gallegherplus & \\
\hline $\begin{array}{l}\text { Gaston Salazar (Gas- } \\
\text { Lab) }\end{array}$ & $\begin{array}{l}\text { https://www.facebook.com/gaslabmusic? fref=nf } \\
\underline{\text { https://soundcloud.com/gas-lab }} \\
\text { http://gas-lab.bandcamp.com/ }\end{array}$ & \\
\hline Gigolo Techno & http://myspace.com/gigolotechno & \\
\hline Gonzalo Wels & $\begin{array}{l}\text { https://soundcloud.com/gonzalowels } \\
\text { https://mixcloud.com/gonzalowels }\end{array}$ & $\begin{array}{l}\text { Productor/ DJ house deephouse } \\
\text { chillout downtempo }\end{array}$ \\
\hline Gramonautas & $\begin{array}{l}\mathrm{http} / / \text { gramonautas.bandcamp.com/music } \\
\mathrm{https}: / / \text { www.youtube.com/user/Gramonautas }\end{array}$ & \\
\hline Gringo... de acá & $\begin{array}{l}\text { https://gringodeaca.bandcamp.com/ } \\
\text { https://www.facebook.com/Gringodeaca/ }\end{array}$ & Iván Anzil \\
\hline Grod Morel & $\begin{array}{l}\text { https://soundcloud.com/grodmorel } \\
\text { http://grod.bandcamp.com// }\end{array}$ & \\
\hline Guido Flichman & www.gflichman.bandcamp.com & \\
\hline Joedesign & https://soundcloud.com/joedesign & $\begin{array}{l}\text { Downtempo/ Dub/ Afrobeat/ } \\
\text { Experimental }\end{array}$ \\
\hline Joorn Bold & https://soundcloud.com/joornbold & Progressive House, DJ/Producer \\
\hline Juan Nanio & $\begin{array}{l}\text { http://propolia.bandcamp.com } \\
\text { https://soundcloud.com/lucescaen/sets/demos }\end{array}$ & \\
\hline Klauss & $\begin{array}{l}\text { https://www.facebook.com/klauss.musica } \\
\text { https://www.facebook.com/pages/KLAUSS- } \\
\text { MUSICA-ELECTRONICA/71396822232?fref-ts } \\
\text { https://myspace.com/klaussmusica }\end{array}$ & $\begin{array}{l}\text { Ernesto Romeo, Francisco } \\
\text { Nicosia, Lucas Romeo, Pablo } \\
\text { Gil }\end{array}$ \\
\hline Krupoviesa & krupoviesa.bandcamp.com & \\
\hline Intranet Data & https://soundcloud.com/patterns-intranet/ & \\
\hline La Galería del Ciclista & https://lagaleriadelciclista.bandcamp.com/ & Ramiro Perez, Pablo Orellano \\
\hline La Rata Terrible & larataterrible.bandcamp.com & $\begin{array}{l}\text { Diego Betas, Joaquin Ledesma, } \\
\text { Guillermo Dorfman }\end{array}$ \\
\hline $\begin{array}{l}\text { La Aventura del } \\
\text { Hombre }\end{array}$ & http://aventuradelhombre.bandcamp.com/ & $\begin{array}{l}\text { Grod Morel, MigMa, Sam } \\
\text { Nacht }\end{array}$ \\
\hline Lesbiano & $\begin{array}{l}\text { http://www.facebook.com/BREAKPOP } \\
\underline{\mathrm{http}: / / \text { lotekrecords.bandcamp.com/album/breakpo }} \\
\underline{\mathrm{p}}\end{array}$ & \\
\hline Macedonio & $\begin{array}{l}\text { https://www.facebook.com/macedonioo } \\
\text { https://macedonio.bandcamp.com/ }\end{array}$ & \\
\hline Malasia & http://malasiamusic.bandcamp.com/ & $\begin{array}{l}\text { Fermín Kehoe, Dan Szenkier, } \\
\text { Risa de Pájaros }\end{array}$ \\
\hline Malhablar & https://malhablar.bandcamp.com/ & Alejandro Suárez Pryjmaczuk \\
\hline $\begin{array}{l}\text { Martin Yo: PLUG DEL } \\
\text { SUR }\end{array}$ & $\begin{array}{l}\text { https://www.facebook.com/thePLUGDELSUR } \\
\text { https://www.youtube.com/user/ThePLUGDELSU } \\
\text { R/videos?spfreload=10 }\end{array}$ & \\
\hline Matias A. Massari & $\begin{array}{l}\text { https://soundcloud.com/matias massari } \\
\text { https://www.facebook.com/matias.a.massari }\end{array}$ & \\
\hline Metanoia Z & metanoiazeta.bandcamp.com & Dimas Stazik, Pablo Choren, \\
\hline
\end{tabular}




\begin{tabular}{|c|c|c|}
\hline & & Camilo Kleinerman \\
\hline Metal Beat & https://metalbeat.bandcamp.com/ & Francisco Demichelis \\
\hline Música Comarca & https://musicacomarca.bandcamp.com/ & Emi Lians \\
\hline Nacho García & https://nachogarcia.bandcamp.com/ & \\
\hline Niños del Parque & https://ninosdelparque.bandcamp.com/ & Tom Tom, Pupi Gonzales \\
\hline Never Susy & $\begin{array}{l}\text { https://www.facebook.com/pages/Never- } \\
\text { Susy/110354001539 }\end{array}$ & Daniel Bargach Mitre \\
\hline Op3rador & $\begin{array}{l}\text { https://soundcloud.com/op3rador } \\
\text { https://www.facebook.com/op3rador/ }\end{array}$ & \\
\hline Paquito Salazar & http://paquitopaquitopaquito.bandcamp.com/ & \\
\hline Pareidolia & http://somos-pareidolia.bandcamp.com/releases & $\begin{array}{l}\text { Javier Bruno, Santiago Bertoni, } \\
\text { Bruno Scucimarri, Nacho } \\
\text { Castellón. Rock Progresivo } \\
\end{array}$ \\
\hline Paribus & http://paribus.bandcamp.com/ & \\
\hline Parque Montaña & http://parquemontana.bandcamp.com & $\begin{array}{l}\text { Canciones con rock y sin } \\
\text { guitarras }\end{array}$ \\
\hline Patokai & https://soundcloud.com/patokai & $\begin{array}{l}\text { Cybersolista, SynthPunk, } \\
\text { Electroclash, Futurepop, } \\
\text { Powered by Central Eléctrica } \\
\text { Discos }\end{array}$ \\
\hline Phienex & $\begin{array}{l}\text { http://www.phienex.com } \\
\text { https://soundcloud.com/phienex }\end{array}$ & \\
\hline Plagio & $\begin{array}{l}\text { https://www.facebook.com/plagiorock } \\
\text { http://www.plagiorock.com }\end{array}$ & Martín Alejo Pensado \\
\hline Pol Walls & $\begin{array}{l}\mathrm{https}: / / \text { soundcloud.com/polparedes } \\
\text { https://soundcloud.com/thepoliceladiestribute } \\
\text { https://soundcloud.com/culebraandtess } \\
\text { https://www.youtube.com/watch?v=JaWOPORu3 } \\
\mathrm{kM}\end{array}$ & \\
\hline POSA Refusilos & https://www.facebook.com/posarefusilos & \\
\hline Posavasos & https://posavasos.bandcamp.com/ & \\
\hline PoSt 4:48 & https://soundcloud.com/post448 & David Porto \\
\hline Programa & www.programa.bandcamp.com & \\
\hline Real Vintage & $\begin{array}{l}\text { https://www.facebook.com/pages/Real- } \\
\text { Vintage/123946894364685 } \\
\text { http://realvintage.blogspot.com.ar/ }\end{array}$ & \\
\hline Rhesus Albert II & https://soundcloud.com/rhesusalbert2 & Pablo Spretz \\
\hline Saggx & https://soundcloud.com/saggx & \\
\hline $\begin{array}{l}\text { Salgado Luciano } \\
\text { Ezequiel (Lucho) }\end{array}$ & $\begin{array}{l}\text { https://www.facebook.com/zellsito } \\
\text { https://www.youtube.com/channel/UCeRT21Uzz } \\
\text { AuECX3EbmR0pNw }\end{array}$ & \\
\hline Sami Abadi & $\begin{array}{l}\text { www.samiabadi.com.ar } \\
\text { http://naturebliss.bandcamp.com/album/amber- } \\
\text { topaz-sami-abadi }\end{array}$ & $\begin{array}{l}\text { solista: violín eléctrico, } \\
\text { procesadores, loops, sequencers } \\
\text { y synthesizers. }\end{array}$ \\
\hline Santiago Szulman & http://parquemontana.bandcamp.com & Tecladista y pianista \\
\hline SHIT!! & www.soundcloud.com/shittechno & \\
\hline Small Elephant & https://soundcloud.com/small elephant & House \\
\hline Sseccuennccia & $\begin{array}{l}\text { https://soundcloud.com/sseccuennccia } \\
\text { https://www.facebook.com/sseccuennccia }\end{array}$ & \\
\hline Synth Surfers Ensemble & $\begin{array}{l}\text { https://www.facebook.com/SynthSurfers?fref=ts } \\
\text { https://soundcloud.com/synthsurfersensemble }\end{array}$ & \\
\hline Tav Ripo & $\begin{array}{l}\text { https://tavripo.bandcamp.com// } \\
\text { https://soundcloud.com/tav-ripo }\end{array}$ & \\
\hline Termotank & www.termotank.bandcamp.com & \\
\hline Tierra de Antílopes & $\begin{array}{l}\text { http://tierradeantilopes.bandcamp.com/ } \\
\text { https://www.facebook.com/tierradeantilopes?fref }=\end{array}$ & \\
\hline Tomates Asesinos & Www.tomatesasesinos.com.ar & \\
\hline Tortuga Dadá Vuelta & https://soundcloud.com/esty-exu & \\
\hline Trapecio & $\begin{array}{l}\text { https://www.facebook.com/trapecio.ar } \\
\text { http://trapecio.bandcamp.com/album/superconcien } \\
\text { cia } \\
\text { http://trapecio.bandcamp.com/album/neuroesp-ritu }\end{array}$ & \\
\hline TriØN & $\begin{array}{l}\text { https://www.facebook.com/pages/Tri\%C3\%98N/6 } \\
\text { 94310447332148?fref=ts } \\
\text { https://soundcloud.com/tri-on }\end{array}$ & $\begin{array}{l}\text { Ulises Labaronnie, Ernesto } \\
\text { Romeo, Sami Abadi }\end{array}$ \\
\hline
\end{tabular}




\begin{tabular}{|c|c|c|}
\hline Uirflu & $\begin{array}{l}\text { https://soundcloud.com/uirflu } \\
\text { https://uirflu.bandcamp.com// }\end{array}$ & \\
\hline Ulises Labaronnie & https://uliseslabaronnie.bandcamp.com/ & \\
\hline Vivi Pedraglio & $\begin{array}{l}\text { http://soundcloud.com/vivipedraglio } \\
\mathrm{http} / / / \text { youtube.com/vivipedraglio }\end{array}$ & \\
\hline Windom Earle & $\begin{array}{l}\text { windomearle9.bandcamp.com } \\
\text { soundcloud.com/windomearle9 }\end{array}$ & \\
\hline Estupendo & $\begin{array}{l}\text { https://soundcloud.com/estupendo-musica } \\
\text { https://www.facebook.com/estupendomusica }\end{array}$ & $\begin{array}{l}\text { sebastian mondragon, fernando } \\
\text { lamas }\end{array}$ \\
\hline Krater 47 & https://krater47.bandcamp.com/ & \\
\hline CNTV & http://circuitonortedetelevision.bandcamp.com/ & \\
\hline *Iviko azf! & http://ivikoazf.bandcamp.com & \\
\hline Chelo Ramone & https://soundcloud.com/sirius-wave & \\
\hline Her Czarniecki & https://soundcloud.com/hczarniecki & \\
\hline
\end{tabular}

\section{Géneros "mayores" y los demás}

Luego del relevamiento inicial nos dispusimos a comparar solo el nivel jerárquico superior de las fuentes disponibles que, subjetivamente, consideramos merecían mención por su pertinencia y seriedad. En términos más precisos, comparamos el nivel de las denominaciones que se presentan en cada caso como géneros "mayores", o sea: independientemente de las distinciones contenidas en cada una (i.e.: subgéneros), comparamos qué denominaciones concretas de nivel superior (i.e.: géneros) figuran en cada fuente. Como preveíamos, este primer paso del análisis arrojó como resultado la detección de numerosas divergencias y algunas continuidades. Presentaremos a continuación la lista de fuentes seleccionadas, pero antes debemos realizar algunas aclaraciones.

De entre las detectadas, seleccionamos aquéllas fuentes a) cuya confección es el resultado de (o contiene) intentos de sistematizar los géneros y subgéneros de la música electrónica de baile, b) donde resulta evidente la presencia de un trabajo exploratorio subyacente y c) donde es evidente que su confección no se basó en otra de las fuentes por nosotros seleccionadas. Tomamos estos recaudos procurando evitar o al menos minimizar las distorsiones en el trabajo analítico que nos proponemos hacer. Las fuentes y géneros "mayores" son:

\section{The evolution of Western Dance music ${ }^{412}$}

Breakbeat/Hardcore, Electro, (¿Hip Hop?), House, Jungle, SynthPop, Techno, Trance.

\section{The proliferation of EDM 413}

Breakbeat, Downtempo, Dub, Drum'n'Bass, Hardcore, House, Jungle, Techno, Trance, UK Garage.

412 The evolution on western dance music. Mapa interactivo en línea. $<\mathrm{s} / \mathrm{f}>$. Accesible en http://www.thomson.co.uk/blog/wp-content/uploads/infographic/interactive-music-map/index.html [25112014]

${ }_{413}$ Martin, B. (2013). "The proliferation of EDM" en: The McGill Tribune. Accesible en http://www.mcgilltribune.com/features/the-proliferation-of-edm/ [27042016] 


\title{
Electronic Music Guide 414
}

Breaks, Disco, Downtempo, Garage, Hardcore, Hip Hop, House, Industrial, Techno, Trance.

$$
\text { Árbol genealógico de la música moderna }{ }^{415}
$$

Electro, House, Jungle, Música electroacústica, Techno, Trance.

Como diferenciar los distintos géneros de música electrónica ${ }^{416}$

Ambient, Breakbeat, Dance, Disco, Downtempo, Electro, Electronic art music, Hardcore, House, Industrial, Jungle/Drum'n'Bass, Mediterranean progressive, Minimalismo, Psychedelic, Techno, Trance.

Géneros de la música electrónica ${ }^{417}$

Ambient, Breakbeat, Dance, Electro, House, Minimal, Techno, Trance.

Ishkur's Guide to Electronic Music/ New House of Techno ${ }^{418}$

Breakbeat, Downtempo, House, Hardcore, Jungle, Techno, Trance.

$$
\text { Música electrónica. (géneros, subgéneros y estilos) }{ }^{419}
$$

Ambient, Breakbeats, Chiptune, Disco, Downtempo, Drum'n'Bass/Jungle, Electrónica, Electro, Electrónica con influencia rock, Hardcore, Noisecore, House, Hi-NRG, Techno, Trance, Postdisco, UK Garage.

\author{
Beat Explorers Dance Music Guide ${ }^{420}$
}

Bass, Hard Dance, House, Techno, Trance

Unlocking the groove ${ }^{421}$

\footnotetext{
414 Electronic Music Guide (Music infographics). (2013). Infografía [en línea]. Accesible en http://www.designinfographics.com/music-infographics/electronic-music-guide\# [27042016]

415 Árbol genealógico de la música moderna. (2011). Gráfico. [en línea]. Accesible en https://soundworkscolombia.wordpress.com/2011/03/10/arbol-genealogico-de-la-musica-moderna/ [25042016]

${ }^{416}$ Como diferenciar los distintos géneros de música electrónica. (2015). [en línea]. Accesible en http://smallmoments1.blogspot.com.ar/2015/04/como-diferenciar-los-distintos-generos.html [25112014]

417 "Géneros de la música electrónica". (2008). [en línea]. Accesible en http://www.djs.es/generos-de-lamusica-electronica/ [18042016]

${ }_{418}$ Ishkur's Guide to Electronic Music. <s.f.> Mapa interactivo. [en línea] Accesible en http://techno.org/electronic-music-guide/ [18042016]

419 "Música electrónica. (géneros, subgéneros y estilos)". (2013). Artículo en el sitio Taringa! [en línea]. Usuario "ShadowBrony". Accesible en http://www.taringa.net/post/info/15968399/Musica-electronicageneros-subgeneros-y-estilos.html [18042016]

420 The Dance Music Guide. [en línea]. Sitio (aparentemente) aún en desarrollo. Accesible en http://thedancemusicguide.com/ [25042016]
} 
Ambient, Big Beat, Breakbeats, Downtempo, Drum'n'Bass/Jungle, Hardcore, House, UK Garage (?), Techno, Trance

\author{
The Dance Music Manual ${ }^{422}$
}

Ambient/Chill Out, Drum'n'Bass, Dubstep, Hip-Hop (rap), House, Techno, Trance, Trip Hop, UK Garage.

$$
\text { Wikipedia en ingles }{ }^{423}
$$

Ambient, Breakbeat, Disco, Downtempo, Drum'n'Bass, Dub, Electro music, Electroacoustic music, Trap, Electronic rock, Electronica, Hardcore/Gabber, Hardstyle, Hi-NRG, House music, Industrial music, IDM, Jungle, Post-disco, Techno, Trance music, UK Garage, Video game music.

\title{
Wikipedia en español ${ }^{424}$
}

Ambient, Breakbeat, Chiptune, Disco, Drum'n'Bass/Jungle, Electrónica, Electro, Electrónica con influencia rock, Techno Hardcore, Hardstyle, House, Hi-NRG, Música industrial, Nu rave, Post-disco, Techno, Trance, UK Garage.

Por la influencia que tiene sobre la comunidad relacionada a estas músicas sugerimos también visitar el sitio en línea nightclubber. Espacio "obligado" para la difusión de eventos de música electrónica de baile en Argentina, en su foro de debates se incluye la Guía de estilos de la música electrónica. ${ }^{425}$ En una extensa entrada, el usuario DJ RamaX describe brevemente y sin categorizar una enorme cantidad de géneros, subgéneros y estilos. Si bien hemos preferido incluir dicha información con el ordenamiento dado por el usuario Small Moments (responsable del blogspot incluido en una de las listas previas), en esta publicación (al igual que en la nota "Géneros y subgéneros de la música electrónica" del usuario Sobre música electrónica de la red

\footnotetext{
${ }^{421}$ Butler, M. (2003). Op.cit. pp. 86. Por la sintaxis, persiste cierta ambigüedad en cuáles son los géneros considerados "mayores". El autor asume en primer término esta clasificación basada en la práctica de los fans (i.e.: "fan-based classification").

${ }_{422}$ Snoman, R. (2004/09/13). Op. cit. Se incluyen la totalidad de los géneros analizados en las tres ediciones.

${ }_{423}$ Wikipedia en ingles. [en línea]. Entrada "List of electronic music genres". Accesible en https://en.wikipedia.org/wiki/List of electronic_music_genres [16042016]

${ }_{424}$ Wikipedia en español. [en línea]. Entrada "Géneros de música electrónica". Accesible en https://es.wikipedia.org/wiki/Anexo:G\%C3\%A9neros de_m\%C3\%BAsica_electr\%C $3 \%$ B3nica [16042016]

425 "Guía de Estilos de la Música electrónica". Artículo en el sitio Nightclubber. [en línea]. 2007. Accesible en https://www.nightclubber.com.ar/foro/11/discusiones-generales-musica/49049/guia-estilosmusica-electronica.html [18042016]
} 
social facebook $^{426}$ ) el contenido publicado por DJ RamaX se reproduce solo parcialmente. Recorrer la versión original y completa resulta nuevamente ilustrativo de la forma asistemática y subjetiva con que usualmente se trata el tema.

Antes de dar paso al análisis de similitudes y discrepancias entre las fuentes creemos necesario explicitar que detrás de cada una de ellas subyacen perspectivas diferentes: el punto de vista de los deejays y sus objetivos difiere necesariamente del de los musicólogos, del de quienes participan de este universo en calidad de bailarines y del de los aficionados que desean interiorizarse más acerca de la especie. Ninguno de estos actores busca la misma información que los demás y esto necesariamente se reflejará en las diferentes publicaciones, según los intereses y objetivos (en muy pocos casos explicitados) de cada sitio y autor. El momento en que cada lista fuera confeccionada es otro factor a considerar: la rápida transformación de la especie y el veloz surgimiento de nuevos géneros, las predilecciones del público y las fuerzas del mercado de bienes culturales provoca que el juicio acerca de cuáles son los géneros "mayores" varíe de un año a otro o de una región del planeta a otra. Advertido esto, pasemos al análisis.

Observamos que los géneros House, Techno y Trance se mencionan en todos los listados. A vista de la comunidad electrónica no cabe duda que estas tres denominaciones forman parte de los géneros "mayores". Lo mismo podemos decir de las entrevistas que realizáramos: fueron mencionados en todos los casos.

Drum'n'Bass/Jungle y Breakbeat se mencionan en diez de los trece y -si consideramos los argumentos de Butler acerca de que ambos pertenecen a los géneros basados en "samples de breakbeats" ${ }^{427}$ - podemos incluso entender que dicho género o expresión estética solo se encuentra ausente en una de las fuentes. Por otra parte, la categoría "Bass" de Beat explorers contiene aquéllos subgéneros que suelen asociarse con la cualidad descripta, lo que permitiría considerar que aquí también encuentran su lugar dichas músicas.

Algo similar sucede con los géneros Ambient/Chill out y Downtempo: ausentes ambos en cuatro fuentes, considerando que estos términos pueden entenderse como formas diferentes de referir a un conjunto de músicas "tranquilas" y/o "relajadas", de tempos lentos (de allí su denominación) esta ausencia se reduce a solo tres.

También en nueve de las trece fuentes se menciona al Hardcore, aunque es necesaria la salvedad de que en un caso se presenta asociado al Breakbeats y en otro bajo el rótulo híbrido

\footnotetext{
426 "Géneros y subgéneros de la música electrónica". Nota en la red social facebook. [en línea]. 2013. Usuario "Sobre Musica electronica". Accesible en https://www.facebook.com/notes/so bre-musicaelectronica/generos-y-subgeneros-de-la-musica-electronica/271576009646127/ [18042016]

${ }_{427}$ Samples de los compases de "corte" donde solo suena la batería (los mentados "breakbeats"), tradicionales en numerosos temas de la música funk y disco de los años 60's y 70's. Como veremos más adelante, varios géneros de música electrónica de baile basan su estructura sobre breakbeats provenientes de temas de los géneros mencionados.
} 
Techno Hardcore. ${ }^{428}$ Como antes, la categoría "Hard Dance" de Beat Explorers contiene en su interior al Hardcore y Hardstyle por lo que esta podría comprenderse como la sección dedicada a los géneros de carácter más "agresivo" o "enérgico". ${ }^{429}$ Si bien en número entendemos que no, esta denominación se aleja de las anteriores en la claridad con que se la menciona en las fuentes.

Electro y UK garage le siguen al ser ambos mencionados en siete oportunidades. Si bien el segundo aparece en la infografía de Electronic Music Guide como simple "Garage", al interior de la categoría figuran aproximadamente los mismos subgéneros del UK Garage que se incluyen en las demás fuentes citadas. Encontrarnos entre otros con 2 step, Grime, Dubstep, Future Garage y, sobre todo, UK Garage debería despejar toda duda que pudiera persistir respecto de su inclusión como caso de mención. ${ }^{430}$

Alcanzado para las últimas dos denominaciones un número de menciones que apenas supera el 50\% daremos por terminada la incorporación de géneros. No afirmamos que sean los únicos, tampoco los que más piezas musicales tienen ni los más influyentes, sino apenas aquéllos que se mencionan más en fuentes de diversa procedencia y objetivos, y que contienen información acerca del tema. Sin embargo, creemos tener un argumento suficientemente fuerte para cerrar nuestra lista de candidatos.

Las siguientes denominaciones en la lista serían Disco y Música electroacústica. ${ }^{431}$ Alcanzando cada una cinco (5) menciones, se corresponden con géneros históricos que dieron origen a la música electrónica de baile. El Disco "vive" sublimado en numerosos samples de gran cantidad de piezas de varios de sus géneros mientras que la Música electroacústica comparte la afinidad con la tecnología y se desarrolla junto a su igual danzable retroalimentándose de los logros y monstruos de cada una. No es de extrañar entonces que las denominaciones que refieren a sus principales influencias históricas sean las que le siguen a los principales géneros "reales" de la especie.

\footnotetext{
${ }^{428}$ Como ser verá debajo, así se lo incluye en la lista de géneros de Wikipedia en su versión en español. Utilizamos la expresión "rótulo híbrido" ya que los subgéneros incluidos en esta categoría abarcan y exceden los que figuran bajo "Hardcore/Gabber" en la versión en inglés de la enciclopedia. Esta misma razón nos condujo a sumar este caso como una de las menciones del Hardcore en las fuentes.

${ }_{429}$ Al momento de la redacción de este capítulo (comienzos de 2016) el sitio Beat Explorers Dance Music Guide podría encontrarse aún en desarrollo. La intervención de uno de sus autores en un foro de debate en línea -donde varios usuarios dialogaban acerca de que el paso del tiempo y la falta de actualización originaba la pérdida parcial de validez de Ishkur's Guide to Electronic Music- nos permitió inferir también que quizá este proyecto se haya propuesto encontrar nuevos criterios de organización de los géneros y subgéneros; criterios que contemplen no solo los desarrollos (ya) históricos sino las direcciones impresas actualmente a aquéllos. Si bien esta intervención es de 2013 carecemos de datos para afirmar o negar que el sitio se encuentre al día de hoy terminado. Si el caso fuera de que aún hoy se encuentra en desarrollo, podría explicar el mayor grado de divergencia en las denominaciones utilizadas en este sitio. Aquí el debate: https://www.reddit.com/r/trance/comments/247ctv/ishkurs guide to electronic music/ [27042016]

${ }_{430}$ De no ser este el caso, hubiera podido suponerse que con el término "Garage" los autores de la publicación se referían al género newyorkino que dio origen a su versión británica (que motivó la preposición de la sigla "UK").

${ }^{431}$ Independientemente de cómo se la denomine, en las fuentes hemos identificado aproximadamente los mismos subgéneros bajo las etiquetas "Música electroacústica", "Electronic art music", "Electrónica" (esp.), "Electronica" (ing.) y "Electroacoustic music".
} 
Debatiremos más extensamente luego acerca del UK Garage y del Electro; baste decir ahora que realizar una búsqueda de las entradas "Electro" o "Electro music" en YouTube (procedimiento que nos ha servido como forma de evaluar la pertinencia y validez de las denominaciones de la música electrónica de baile) arroja primordialmente como resultado videos y listas de reproducción donde lo que se menciona es el "Electro House". Esta denominación ha surgido en los últimos años e indica a músicas pertenecientes al género House donde suenan sonidos "electro" o "eléctricos": timbres donde se evidencia la hibridación descripta en su denominación. Veamos entonces que resultados podemos extraer de los datos relevados.

En resumen, siguiendo la lógica de Butler de "los más nombrados", ${ }^{432}$ los géneros “mayores” resultan ser, en número decreciente de menciones:

\section{House - Techno -Trance}

Drum'n'Bass/Jungle - Breakbeat

Ambient/Chill out - Downtempo

\section{Hardcore}

Electro - UK Garage

Como sucede con los listados previos, también en esta selección encontramos cuestiones para las que aún no tenemos respuesta. Suponiendo que nuestra selección sintetiza lo que sucede en la especie en términos de similitudes y diferencias técnico-estéticas musicales, ¿deberíamos presentar al Breakbeat solo o asociado con el Drum'n'Bass/Jungle? ¿No resulta más apropiado asociarlo al Hardcore como sucede en alguna fuente?

Similares preguntas nos hacemos acerca de las denominaciones Ambient/Chill out y Downtempo. Si bien el Downtempo aparece quizá algo más asociado a la cualidad "experimental" y al mismo tiempo puede presentar algo más de actividad o activación ${ }^{433}$ que el Ambient/Chill Out, todas son formas que cuando remiten a la danza lo hacen de algún modo elípticamente. Algunas fuentes incluso dudan de que estas sean formas de música de baile. A pesar de que su relación no es lineal ni sencilla, esta asociación parece más razonable al menos desde el punto de vista de la mencionada activación.

Estas y otras preguntas surgen del hecho de que algunas fuentes presentan a estos géneros asociados, otras por separado, terceras subordinando a uno en tanto subgénero del otro

\footnotetext{
${ }^{432}$ Véase nota al pie 121.

${ }^{433}$ Nos referimos mediante esta expresión no a la ya mencionada activación corporal sino a la cualidad musical análoga (asociada al ritmo en sentido amplio, abarcando todos los "ritmos" de la música) que puede ser descripta como la densidad de eventos percibida en un período de tiempo determinado y que resulta en una sensación subjetiva de mayor o menor "actividad" o "movimiento". Dependiente al menos en parte del tempo percibido (i.e.: tempo independiente del indicado si existiera partitura), suele asociarse -contiene y excede- a la densidad cronométrica.
} 
y cuartas sosteniendo la esquizofrenia de utilizar al mismo tiempo la misma denominación para nombrar a) a un género "mayor", b) a un subgénero del mismo y c) a un subgénero contenido en un género diferente. A pesar de la aparente irracionalidad, veremos luego que las últimas perspectivas quizá no están del todo erradas y poseen alguna razón de ser.

Antes de dar paso al análisis que dé cuenta de estas cuestiones creemos necesario hacer justicia con la "Guía de Ishkur" por ser la que más se aproxima a nuestros resultados. Si bien podría pensarse que la coincidencia no es tal debido a que en aquélla se encuentran ausentes el Electro y el UK Garage, cabe destacar que en nuestro relevamiento -de entre los que más- estos son los dos géneros menos mencionados, y su status como tales aún debe validarse.

Independientemente de otros análisis posibles y a pesar de las limitaciones de aplicabilidad de los resultados, también hallamos grandes similitudes en las respuestas brindadas por 12 usuarios de tres grupos de facebook a una encuesta en línea que organizáramos ad hoc. ${ }^{434}$ Sintetizamos aquí nuestro análisis.

\section{Géneros mayores de la música electrónica. Síntesis de los resultados.}

Encuesta "Géneros mayores de la música electrónica"

Mediante la plataforma en línea e-encuesta.com se presentó esta encuesta a los integrantes de las comunidades de facebook "Argensynth", "Argenlive" y "Armado de módulos de sintetizador analógicos" (vinculadas estrechamente a la música realizada con medios electrónicos). Limitando las opciones a un mínimo de 6 y un máximo de 9 respuestas abiertas, 12 usuarios respondieron a la pregunta:

"¿Cuáles considera que son los géneros "mayores" de la música electrónica (en todas sus expresiones)?"

Respuestas discriminadas usuario a usuario.

- Tech House, Techno, Deep House, Progressive House, Minimal, Trance, Electronic

- House, Techno, Psy, Drum'n'Bass, Ambient, Noise/glitch/lo-fi

- Electro, Synth Pop, Minimal, Trip hop, EDM, Trance, Drum'n'Bass, Ambient, Breakbeats

- House, Progressive, Techno, Trance, Psytrance, Techhouse

- Techno, Deep House, Tech House, House, Progressive House, Minimal, Trance, Psytrance, Electro House

- House, Techno, Pop, Ambient, Downtempo, Minimal

- Techno, EDM, House, Pop indie, IDM, Drum'n'Bass, Chill out, Ambient, Modular synth only

- House, Disco, Drum'n'Bass, Chill out, Minimal, Techno, Tech House, Deep House, Progressive

- House, Downtempo, Disco, Techno, Hiphop, Breakbeat, Trance, Ambient, Experimental

- Ambient, Downtempo, Techno, House, Trip Hop, Big Beat, Breakbeats, Progressive, Hardcore

- House, Techno, Trance, Disco, Garage, Industrial, Downtempo, Hip Hop, Breaks

- House, Techno, Electro, Drum'n'Bass, Ambient, Hip Hop, Dubstep, Breakbeats

Ordenadas según la cantidad de votos que recibió cada denominación

(entre paréntesis, las que fueran mencionadas y son plausibles de ser incluidas como categorías equiparables o subcategorías de otras denominaciones)

Techno 11 (+4 Tech House)

House $\quad 10(+4$ Tech House +3 Deep House +2 Progressive House +1 Electro House $)$

Ambient $\quad 7$ ( +4 Downtempo +2 Chill out $)$

Trance $\quad 6$ (+2 Psytrance)

Breakbeats $\quad 5$ (+5 Drum'n'Bass) $[(¿)+3$ Hip Hop, +2 Trip Hop, +1 IDM +1 Big Beat (?)]

Drum'n'Bass $\quad 5$ (¿ídem anterior?)

Minimal

Downtempo

Techhouse

5

4

4

${ }^{434}$ Lamentablemente la convocatoria no alcanzó el grado de adhesión esperado. Entre otras razones, por tratarse de un relevamiento de muy pocos casos preferimos no incluir los resultados en nuestras estadísticas. Otras características y detalles de la encuesta pueden apreciarse ingresando en: http://www.eencuesta.com/answer?testId=nkX4bdq4ndY\%3D [01072016] 
3 votos: Deep House, Progressive, Disco y Hip hop.

2 votos: Progressive House, Electro, Trip hop, EDM, Psytrance y Chill out.

1 voto: Electronic, Psy, Noise/glitch/Lo-fi, Synth pop, Electro house, Pop, Pop indie, IDM, Modular synth only, Experimental, Big Beat, Hardcore, Garage, Industrial y Dubstep.

Resulta especialmente digno de mención el vínculo que puede establecerse entre la selección emergente y los argumentos que esgrime Mark Butler en relación a ciertos "tipos rítmicos" presentes en la música electrónica de baile. En su tesis, el autor tomará posición y dirá que la música electrónica de baile tiene en el ritmo y la métrica sus elementos esenciales. Así dirá que:

\begin{abstract}
A pequeña y gran escala, la organización de la música electrónica de baile tiende hacia los patrones binarios, pero dentro de estos condicionamientos crea diversidad métrica a través de ritmos asimétricos, patrones desplazados y agrupamientos rítmicos contrapuestos/ conflictivos. Ritmo y metro interactúan íntimamente con la textura: los procesos texturales casi siempre tienen ramificaciones métricas y estratos texturales independientes frecuentemente conducen a disonancias métricas. ${ }^{435}$
\end{abstract}

A partir de esta premisa el autor propone esencialmente tres tipologías que atravesarían todos los géneros de la especie. Estas son:

a) Ritmos basados en lo que llamamos "bombo en negras" (i.e.: "four-to-the-floor" o "four-on-the-floor" en inglés), se caracterizan por presentar una rítmica regular, donde el sonido que oficia de bombo suele sonar casi sin pausa en cada tiempo de un compas que casi sin excepción es de 4/4. A este respecto el autor dirá que:

Los patrones rítmicos característicos que ocurren en la música electrónica de baile tienden a aparecen en conjunción con ciertos instrumentos. Algunas asociaciones entre instrumentos y ritmos se extienden a través de géneros, mientras otros juegan un rol de distinguir diferentes estilos. En los géneros [basados en] bombo-en-negras como techno, house y trance, por ejemplo, el patrón de bombo 1/5/9/13 (según notación TUBS) es casi universal. ${ }^{436}$

El resto de la sección de percusión (electrónica) suele presentar conformaciones también regulares y que suelen "concretar en sonido" las demás unidades de la métrica musical (acento métrico, división y subdivisión). Veremos más en detalle esta cuestión cuando analicemos las cualidades técnico-estéticas de la especie.

\footnotetext{
${ }^{435}$ Butler, M. (2003). Op.cit. pp. vi

436 "The characteristic rhythm patterns that occur in electronic dance music tend to appear in conjunction with certain instruments. Some associations between instruments and rhythms stretch across genres, while others play a role in distinguishing different styles. In four.on-the-floor genres such as techno, house, and trance, for example, the bass drum pattern 1/5/9/13 (shown below in TUBS notation) is almost universal." Butler, M. (2003). Op.cit. pp. 105
} 
A este grupo pertenecen los tres primeros géneros de nuestra selección y son las únicas tres denominaciones a las que Butler claramente indica como "estilos primarios" (i.e.: "primary styles") y luego "estilos más grandes" (i.e.: "larger styles"), dando a entender que las ve como categorías de nivel máximo que contienen dentro otras menores.

Coincidiendo con Butler, en cada una de las tres ediciones de The Dance Music Manual Rick Snoman dedica un capítulo especial a analizar cada uno de estos géneros.

b) Ritmos basados en samples de breakbeats. Como explicáramos antes, Drum'n'Bass/Jungle y Breakbeats son mencionados por Butler como exponentes de este tipo de rítmicas junto a Big Beat y Hardcore, pero aquí se presenta una ambigüedad debido a que el autor refiere a que:

Los géneros de música electrónica de baile 'motorizados' por breakbeats incluyen hardcore, jungle/drum'n'bass y big beat, así como la categoría conocida simplemente como "breakbeat" o "breaks". [...] breakbeats son patrones de batería muestreados [n.d.t.: "sampleados"] tomados de las secciones de percusión a solo, o "cortes" de viejas grabaciones de funk. ${ }^{437}$

Menos categórico que en el caso anterior, Butler elije no tomar partido por unos u otros géneros, dejando abierta la posibilidad de que los nombrados no sean los únicos géneros "mayores". A pesar de lo dicho y como puede observarse, nuestro relevamiento arroja más géneros de coincidencia que de divergencia con la lista confeccionada por este autor. De los mencionados por Butler, solo el Big Beat resultó excluido.

Por nuestra parte, creemos además que la denominación "breakbeat" puede considerarse una forma genérica de referirse a todas aquéllas músicas que hacen uso evidente y prolífico de dicho recurso técnico-estético. ${ }^{438}$ Preservando en mayor o menor medida pero siempre parcialmente- las cualidades musicales incluidas en los breakbeats "sampleados" (provenientes de los géneros de origen, funk, soul y disco principalmente), las piezas pertenecientes a este grupo presentan ritmos muy sincopados y "orgánicos", en algún sentido opuestos a los ritmos "a tierra" y "maquinales" del grupo anterior. ${ }^{439}$

Disentimos con la apreciación de Butler respecto del Hardcore. Recorrer tanto los ejemplos propuestos por diversos usuarios de YouTube como los incluidos en diversos

${ }^{437}$ "Breakbeat-driven genres of electronic dance music include hardcore, jungle/drum'n'bass and big beat, as well as a category known simply as "breakbeat" or "breaks". [...] breakbeats are sampled drum patterns taken from the percusion-only sectiones, or "breaks", of old funk records." Butler, M. (2003). Op.cit. pp. 87

${ }^{438}$ Basamos nuestra afirmación en las escuchas realizadas y en que en varias ocasiones diferentes músicos electrónicos y deejays consideraron al Breakbeat apenas como otra forma algo más "tranquila" y mas "lenta" de Jungle/Drum'n'Bass.

${ }^{439}$ Creemos necesaria una advertencia: las breves descripciones de cada género pueden distorsionar la imagen de cada grupo y de las relaciones recíprocas. Estas son esquematizaciones muy simplificadas con las que pretendemos apenas orientar mínimamente la comprensión hacia las cualidades básicas que Butler utiliza para diferenciar cada grupo y con las que -salvo donde se explicita- acordamos. 
blogs dedicados a la música electrónica de baile ha evidenciado que este género presenta a) diferencias en relación a los dichos de Butler y b) una diversidad rítmica que no puede sintetizarse en el carácter derivado de los breakbeats. De hecho, los ejemplos que presentan las cualidades sincopadas de los breakbeats son los menos. La base rítmica de la amplia mayoría se inscribe en el grupo anterior de bombo en negras mientras que algunos presentan la mixtura de ambas tipologías rítmicas y otros presentan rítmicas que dificultan su inclusión en uno u otro grupo. Numerosos son los ejemplos que además incluyen varias secciones con bases rítmicas diferenciadas que podríamos sintetizar en la oposición ritmos "a tierra"/ritmos "sincopados" o "cruzados". En definitiva, sostenemos que esta denominación refiere a un modo o carácter que se diferencia por la "agresividad", "dureza" o "fuerza" expresada en la misma ("hard-core" puede traducirse literalmente como "núcleo duro"). ${ }^{440}$ Estas cualidades se expresan en tempos veloces, timbres distorsionados, resultantes espectrales que suelen presentar componentes en todo el rango audible; cualidades que, en su conjunto, provocan una respuesta emotiva que podemos calificar como de "saturación" general. ${ }^{441}$ Ahora bien, este modo se presenta asociado a un rango de cualidades estéticas tan amplio (siempre "agresivo") que -en algunos casos- puede ser considerado un género independiente como -en otros- un estilo o modo "duro" de algún otro. En este marco nos resulta significativo que Snoman no analizara esta expresión en ninguna edición de su manual. Si bien no lo consideramos determinante, creemos digno de mención que al mismo tiempo sí incluyera al más recientemente surgido Dubstep.

c) Piezas cuyos ritmos se caracterizan primordialmente como "lentos" o de baja actividad o activación, que pueden o no presentar similitudes con los modelos anteriores y/o (como dirá Butler) que se inscriben bajo un paradigma de "experimentación individualista". Demers dedica el capítulo 5 de su trabajo a estudiar estos géneros en conjunto con paisajes sonoros, grabaciones de campo y arte sonoro; allí analiza "cómo el sonido puede comunicar espacio, lugar y locación". ${ }^{442}$ En otras palabras, las piezas Ambient/Chill out y/o Downtempo pueden presentar acompañamientos rítmicos "libres" o incluso carecer completamente de dicha sección en su orgánico (i.e.: no presentar

\footnotetext{
${ }^{440}$ No podemos afirmarlo pero creemos que la apreciación (errónea a nuestro entender) de Butler puede haberse originado en las formas más experimentales del Hardcore, que se caracterizan por su heterogeneidad rítmico-tímbrico-registral; heterogeneidad que suele estar asociada a los géneros más actuales estructurados en torno a los breakbeats (i.e.: 2 step, Dubstep y demás subgéneros agrupados en el UK Garage). Dichas formas del Hardcore logran esta cualidad a partir de rápidas sucesiones de samples breves, recurso técnico-estético mediante el cual también las expresiones últimas lo logran. A pesar de los puntos de contacto, las rítmicas resultantes en los ejemplos a los que hemos accedido no presentan las distribuciones típicas derivadas de los breakbeats. Si bien ambas son sincopadas, a diferencia de los últimos los ritmos del Hardcore experimental suelen debilitar la percepción del compás, cualidad que Butler asocia también a aquéllas rítmicas.

${ }^{441}$ Valga la aclaración para quienes no se encuentren familiarizados con la tecnología musical: diversos tipos de distorsión se obtienen al llevar al sistema más allá de sus límites (i.e.: "saturándolo").

${ }^{442}$ Demers, J. 2010. Op. cit. pp. 15
} 
sección rítmica). Concebidas en una segunda etapa (luego de la de los pioneros del Ambient como Brian Eno) para amenizar los salones secundarios de los locales de baile donde los asistentes van a relajarse o reposar momentáneamente de la agitación de la pista principal, presentan como cualidad principal un carácter "tranquilo" o "relajado". ${ }^{443}$ A partir de estas simples cualidades, el claro contraste con los demás hacen del Ambient/Chill out/Downtempo un género fácilmente identificable. De amplio rango estético sin embargo, abarca desde expresiones muy experimentales a otras "new age" hipersimplistas.

Hasta aquí hemos seguido -con algunas excepciones- las ideas de Butler, veamos ahora el Electro, caso para el cual nos apartaremos algo más de la perspectiva del autor. Como mencionáramos previamente, realizar búsquedas de este tópico en YouTube conduce a unos pocos resultados donde, en todos los casos, la denominación se presenta asociada con el término "House". Recorriendo las fuentes seleccionadas, detectamos que se describe a este como un género histórico, surgido durante los primeros años de la música electrónica de baile. La ausencia de piezas recientes del estilo podría sugerir que el género ha caído en desuso o quizá que los productores perdieron, al menos momentáneamente, interés por las cualidades asociadas. La situación actual no impide que en un futuro el interés resurja y el género renazca renovado; no sería la primera vez que esto suceda en el seno de la especie.

Desde otro punto de vista, el término "Electro" se observa también asociado a numerosos otros en el nivel de los subgéneros. Como sucede con "Acid", "Dream", "Psy" o los mismos "Techno" y "House", la denominación parece haberse convertido en un índice de que algunas cualidades (quizá previamente asociadas al género de origen) se hallan mixturadas con las de otros en piezas "híbridas". Así encontramos los subgéneros Electro-industrial, Electropop, Electro swing, Electro House, Electroclash, Electronicore o Electropunk. Sin ser los únicos casos, algo similar sucede con los mencionados Techno y House: así tenemos Ambient House, Tech House, Tech Trance o Aggrotech. La diferencia entre uno y otro caso radicaría en que el Electro parecería haberse diluido en las hibridaciones experimentadas; no así el Techno y el House.

Incluso aquéllas denominaciones que se incluyen en el género Electro del listado de Wikipedia en español (Crunk, Trap, Electro swing y otras) son muy diversas en sus cualidades estético-técnicas musicales: algunas pueden describirse como House, otras como rap (o algún otro género basado en breakbeats, siempre evidenciando influencias afro), otras como Tech House... todas sin agotar las asociaciones posibles, a veces múltiples dentro de una misma pieza. Al mismo tiempo, la mayoría de los ejemplos posee una cualidad similar que puede

\footnotetext{
${ }^{443}$ Procurando evitar confusiones preferimos explicitar que esta cualidad no es necesariamente sinónimo de música libre de "conflicto". Tampoco significa que las piezas del género carezcan de elementos orientados a la danza.
} 
describirse como debida al uso de algún tipo de distorsión (en algunos casos analógica, en otros digital) y/o bit crushing. ${ }^{444}$ Además, en muchas piezas se utilizan sonidos de sintetizador líder (i.e.: "leads" en la jerga) que incluyen estos mismos procesos, sobrecompresión ${ }^{445}$ y/o que contienen a su interior ruido de algún tipo que vuelve a las texturas iteradas y "sucias". ${ }^{446}$ Esto se ve acompañado por secciones rítmicas muy potentes y enérgicas, presentando gran activación. Es usual también encontrar rápidas sucesiones de breves y muy diversos samples, lo que genera un alto grado de heterogeneidad tímbrica, textural, registral y rítmica; todo en uno. Pero, nuevamente, otros ejemplos o secciones se aproximan mucho más a estéticas identificables con el House y que, como veremos, presentan características más estables. A pesar de lo dicho, estos ejemplos comparten con los previos su cualidad en algo "ruidosa" y "distorsionada" de electrones corriendo, de tensión eléctrica. Las expresiones últimas son quizá las más acertadas para describir la cualidad tímbrica de estas músicas: los timbres de cajas de ritmos (usualmente del estilo de los generados por la Roland TR808), los timbres de sintetizador descriptos supra, o incluso las voces procesadas (donde el vocoder es el dispositivo paradigmático) suenan en algún sentido a electricidad, a eléctrico.

Aquí creemos que debemos una vez más hacer una aclaración: cuando nos referimos, como en los párrafos inmediatos anteriores, a géneros o expresiones actuales resulta muy difícil realizar cualquier tipo de generalización; en los últimos años la especie ha ingresado en un proceso que provocó un alto grado de hibridación entre sus propios géneros, como también con músicas de origen no-electrónico usualmente también de baile. Esta es otra razón que nos impulsa a afirmar que el término Electro debe ser visto como un índice y no como un género en sí mismo. Sin perjuicio de que no lo consideramos un tema cerrado, en el marco del presente trabajo asumiremos esta posición.

Las similitudes en la descripción del Hardcore y el Electro son evidentes. Encontramos que la diferencia entre uno y otro radica en que el carácter de aquel resulta mejor descripto como "agresivo" o incluso "violento" mientras que el de este es solo "enérgico". Sin embargo, estamos convencidos que las coincidencias no son casuales y que en ellas empieza a

\footnotetext{
${ }^{444}$ Proceso que consiste en reducir digitalmente la profundidad de sampleo o bitdepth, lo que trae aparejado distorsiones agudas (para las cuales no encontramos otro adjetivo más que "ruido digital agudo") que quizá en algo se asemeja al crepitar agudo del aceite hirviendo.

${ }_{445}$ Aplicación "excesiva" del proceso de compresión dinámica o reducción del rango de intensidad. Nuevamente, utilización "monstruosa" que trae aparejadas distorsiones de diversos tipos que se reflejan en el sonido.

${ }^{446}$ Quizá por el alto contenido de componentes agudas, las melodías asignadas a estos timbres generan la sensación de que fueran "gritadas". Es probable que esta sensación resulte incentivada por la aplicación de reverberaciones con largos tiempos de decaimiento, las cuales construyen la ilusión de que dichos sintetizadores resuenan en espacios grandes. A modo de ejemplo posible escúchese el remix de piezas de los 1980s contenido en Late 80's Old Skool Electro Mix y compáreselo con el reciente remix contenido en Electro \& House 2016 Best of Party Dance, Remix, EDM, Mix. Subidos respectivamente por DerWall2005 y DJFlyBeatMusic y accesibles en https://youtu.be/rwIdQH2Zgp8 y https://youtu.be/J2zisMGK0z8. Nótese cómo a pesar de las diferencias (originadas, creemos, en los cambios tecnológicos acaecidos y en la mixtura con cualidades del House), persisten las cualidades tímbricas Electro descriptas. [04102016]
} 
evidenciarse otra posible forma de comprender la complejidad inherente a la música electrónica de baile.

A diferencia del Hardcore o el Electro, el UK Garage es quizá una expresión de límites estético-técnicos más claros y definidos. De surgimiento algo más reciente, la problemática en este caso se origina en el desarrollo histórico de esta forma musical: esta expresión es, a la vez, una deriva e hibridación de varios géneros históricos de la música electrónica de baile; lo que origina que se encuentren ejemplos que pueden generar confusión y límites difusos con las denominaciones previamente tratadas. Según las fuentes consultadas ${ }^{447}$ deben rastrearse sus orígenes hasta el "Garage", "US Garage" o "NY Garage", pasando luego por el llamado "Speed garage" hasta, finalmente, alcanzar su forma inglesa. Siguiendo dichas sugerencias realizamos escuchas que parecen confirmar esta afirmación.

Similar al caso del House, tomando su nombre del local de baile newyorquino Paradise Garage, esta forma musical tuvo durante los primeros 1980s un desarrollo paralelo a aquélla y al Techno. Brevemente descripta, pertenece al grupo de músicas basadas en cajas de ritmos y bombo en negras. Posee cualidades que pueden asociarse en la mayoría de los casos al House y, en menos, al Techno. Se le han asignado expresiones que la adjetivan como una forma de estilo más "refinado" o "sofisticado", con rítmicas más "orgánicas" y más próxima al funk, soul y disco que su contrapartida proveniente de Chicago. ${ }^{448}$ Las huellas de estos géneros históricos son hallables en las armonías, ritmos, samples de voces y en la sensación general de "groove" suscitada por los diferentes elementos y ritmos que los componen. ${ }^{449}$

${ }^{447}$ Véanse por ejemplo los artículos en línea https://en.wikipedia.org/wiki/Garage music_(US garage), "A history of speed garage" y "UK Garage History \& Family Tree: 20 Years of UKG!". Accesibles en http://www.toucanmusic.co.uk/articles/speedgarage.php y http://www.musicismysanctuary.com/thehistory-of-the-uk-garage-family-tree (las tres en inglés). [04102016]

${ }^{448}$ Quizá en estas adjetivaciones puedan hallarse huellas de la expresión norteamericana de la oposición "civilización/barbarie", asignándole a lo newyorkino el primer elemento. Ciudad cosmopolita, capital del imperio moderno y centro del comercio mundial una, la otra posee el mote de "segunda ciudad".

${ }_{449}$ "Groove" es descripto en Wikipedia como "la 'sensación', rítmicamente expansiva, o el sentido de 'swing' creado por la interacción de la música interpretada por la sección rítmica de una banda (batería, bajo eléctrico o contrabajo, guitarra y teclados). El groove es un factor importante en los distintos subgéneros del jazz, y de ahí a otros géneros como salsa, funk, rock y soul. El término suele utilizarse, también, para describir un tipo de música que incita al movimiento o al baile. Los musicólogos y otros académicos comenzaron a analizar el concepto de 'groove' en los años 1990. Se ha afirmado que el 'groove' es una 'comprensión del patrón rítmico', o un 'sentimiento', y 'una sensación intuitiva' de un 'ciclo en movimiento', que surge a partir de 'patrones rítmicos cuidadosamente dispuestos', que ponen en movimiento al oyente." Accesible en https://es.wikipedia.org/wiki/Groove_(m\%C3\%BAsica) [04102016]. En el entorno del tango existe un término que refiere a cuestiones similares: el "canyengue"; especialmente cuando refiere al movimiento (tanto musical como corporal). Wikipedia también dice al respecto de este término que "El 'caminar canyengue' es una manera de caminar del compadrito, de cadenciosos movimientos de cadera. También se lo llama 'caminar arrabalero' (siendo 'arrabal', los suburbios o barrios bajos de las antiguas ciudades de Buenos Aires y Montevideo)." Si bien los "movimientos" a los que remiten una y otra expresión son diferentes, ambas siguen siendo en algún sentido equivalentes al referir a cierto vaivén que parecieran sugerir las conformaciones musicales a partir de desvíos rítmicos (tomando como referencia a la grilla que establecen las herramientas métricas musicales de pulso, división, metro y demás). Por otra parte y en sentido anecdótico, ambas expresiones provienen de formas populares del lenguaje de barrios periféricos y marginales (i.e.: "slang" y "lunfardo"). A la entrada "canyengue" se accede en https://es. wikipedia.org/wiki/Canyengue [04102016]. 
En estos términos coincidimos con las afirmaciones realizadas por algunos autores de que el NY Garage es el "pariente" soul (i.e.: "alma" o "espiritu" en ingles) del House de Chicago: soul tanto por las referencias más claras al género musical afronorteamericano histórico, como a sus cualidades musicales (más emocional y humano, menos "maquinal" y con "espíritu"). Estas características las creemos asociadas a la presencia de armonías entendidas desde una perspectiva tradicional, en tanto evolución lineal o secuencias armónicas funcionales. Secuencias armónicas típicas del soul se manifiestan principalmente en a) los instrumentos acompañantes (sonidos sintetizados similares a instrumentos de teclado, samples de ensambles de vientos de metal y otros), b) numerosos samples de voces solistas y coros de carácter gospel, soul y disco, y c) sonidos de bajos que, a diferencia de muchos ejemplos típicos del House de la época, desarrollan conformaciones lineales (i.e.: líneas melódicas). En otras palabras, esta forma de música electrónica de baile presenta relaciones más cercanas que otras con estructuras musicales tradicionales, facilitando el vínculo emocional y su caracterización "soul".

Las similitudes no deberían asombrar ya que Frankie Knuckles y Larry Levan respectivamente, los deejays de "The Warehouse" en Chicago y "Paradise Garage" en Nueva York- se conocían y, hasta que el primero emigrara a Chicago para hacerse cargo de la "disco" que diera nombre al género House, habían compartido al menos parte de su historia de desarrollo profesional. Según Snoman:

\begin{abstract}
Levan comenzó una residencia en The Continental Baths mientras Knukles comenzó en Better Days, solo seis meses después volvió a reunirse con Levan en The Continental Bath. Ambos trabajaron juntos hasta 1977[. Entonces fue] cuando Levan dejó el club para comenzar uno propio y [al mismo tiempo] le ofrecieron ser DJ en un nuevo club llamado Warehouse en Chicago. Como Levan dirigía ahora su propio club, rechazó [el ofrecimiento] pero recomendó a Knuckles, quien aceptó la propuesta y rápidamente se mudó a Chicago. ${ }^{450}$
\end{abstract}

Las relaciones personales entre los actores principales de estos géneros se expresan, en boca de los mismos, en el documental "Pump up the volume". ${ }^{451}$ Sugerimos visitar también la entrada de YouTube "Larry Levan The Final Night Of Paradise Garage September 1987", donde puede apreciarse una de las presentaciones (i.e.: "deejay set" en la jerga) de quien es considerado el "padre" del NY Garage. ${ }^{452}$

\footnotetext{
450 "Levan began residency at The Continental Baths while Knuckles began at Better Days, to soon rejoin Levan at The Continental Baths six months down the line. The two worked together until 1977 when Levan left the club to start his own and was asked to DJ at a new club named the Warehouse in Chicago. Since Levan was now running his own club, he refused but recommended Knuckles who accepted the offer and promptly moved to Chicago." Snoman, R. 2014. Op. cit. pp. 344. Véase también Butler, M. 2003. Op. cit. pp. 15

${ }^{451}$ Pump Up The Volume: La Historia De La Musica House. Subido por DJ ZendobeatZ. Accesible en https://youtu.be/1OWxN32NH5Q [26052016]

${ }^{452}$ Larry Levan The Final Night Of Paradise Garage September 1987. Subido por BergamoStreetArmy. Accesible en https://youtu.be/epsFK_sg1EI [28042016]
} 
Sobre esta base se desarrollaría luego en el Reino Unido lo que se conoce hoy como Speed Garage. Con un tempo algo más rápido, incorpora la rítmica y gestualidad de los breakbeats (en samples de breakbeats a veces, y en nuevas formas de reelaboración en otras) y las combina con el bombo en negras (a veces simultáneamente, otras en alternancia o sucesión). Además, reemplaza las conformaciones de los sonido de bajo por profundas y graves gestualidades más próximas al reggae y $d u b$; a partir de estas variaciones el vínculo y groove propio del soul comenzaría a desdibujarse. Ejemplos ilustrativos de esta instancia del proceso de transformación estética son "Love bug" de Ramsey \& Fen y "Rip Groove" de Double-99. ${ }^{453}$ Mencionados en este sentido en diversas fuentes en línea, presentan diferentes formas de cualidades musicales intermedias, que operan como nexo entre el Garage y el UK Garage. ${ }^{454}$

Quizá la aceleración del tempo, típicamente alrededor de 135ppm (contra el rango comprendido aproximadamente entre 120-128 del Garage original), y la complejización aportada por las rítmicas breakbeat contribuyeran a la eliminación de los ataques del sonido de bombo de los tiempos 2 y 4 del compás de 4/4. Lo cierto es que el patrón típico del Garage sería reemplazado por estructuras más emparentadas con el funk. Transcribimos debajo algunos que suelen asignarse a sonidos semejantes a los del bombo y redoblante de la batería acústica.

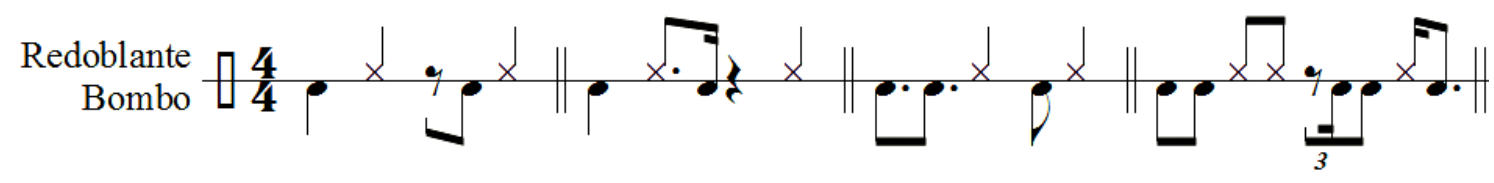

A partir de estas interacciones básicas se desarrollan, en dos vertientes complementarias, las reelaboraciones y transformaciones que mencionáramos antes:

a) Unas mantendrán más o menos invariante la parte del redoblante (atacando usualmente en los tiempos 2 y 4 del compás de 4/4) mientras el sonido de bombo realiza rítmicas diversas "alrededor" del mismo. Contratiempos, alternancias, ataques en las partes débiles de los tiempos y momentos de repetición de uno o varios patrones medianamente estabilizados por la misma repetición, combinados con momentos de conformaciones que contradicen en mayor medida la métrica subyacente, se alternan en rápida sucesión generando una sensación de inestabilidad y cambio constante.

b) Invirtiendo los roles, será el sonido de bombo el que sostendrá un patrón constante mientras el de redoblante "danza" y "juega" alrededor libremente. Dependiendo del año

\footnotetext{
453 Ramsey \& Fen - Love Bug (HQ).(1998). Subido por Hamza Aslam. Accesible en https://youtu.be/DezDtCezXm4 y Double 99 -- RIP Groove -- Original MIX. (2001). Subido por Estrass FaMiLi. Accesible en https://youtu.be/X7PqbkBUwGw. [04102016]

454 Una mención de "Rip Groove" en estos términos puede hallarse por ejemplo en http://www.toucanmusic.co.uk/articles/speedgarage.php. [28042016]
} 
de cada ejemplo, es más común encontrar que el sonido de bombo realiza alguno de los primeros dos patrones que se incluyen en la figura precedente.

En una y otra variante el sonido que permanece constante se establece como el elemento de referencia, mientras el otro aporta variación y diversidad. Estos constantes cambios, contratiempos y síncopas son el elemento dinamizador del discurso y principal responsable de la sensación de ansiedad, agitación y frenesí que presenta el género.

En no pocos ejemplos se presenta lo que quizá constituye una tercera variante, en la cual tanto el sonido de bombo como el de redoblante se encuentran duplicados y realizando ambas funciones (elemento constante y cambiante). En estos casos, suele suceder que bombo y redoblante constantes presenten cualidades tímbricas diferenciadas de sus homólogos cambiantes. Esta diferencia es la que permite el doble juego de cada elemento.

Otros elementos intervinientes, usualmente en sonidos similares al platillo hi-hat, suelen cumplir también una doble función de a) interacción libre con el sonido de redoblante en un comportamiento de complementariedad rítmica y b) generadores de estabilidad y referencia temporal, desarrollando patrones basados en pulsaciones simples o breves grupos que abarcan apenas un tiempo de negra. Una y otra función se asocian respectivamente con a) las partes de hi-hat extraídas (e incluidas) en samples de breakbeats y b) sonidos de hi-hat provenientes de cajas de ritmos y programados en dichos dispositivos. Como sucede con bombos y redoblantes, si bien suelen ser timbres similares, en general presentan cualidades que permiten su individualización. Sin perjuicio de lo anterior, al compartir el rango de frecuencias y composición espectral, interactúan generando además una resultante rítmica compleja (i.e.: "suma" de ambas partes). Transcribimos debajo algunos patrones básicos de la segunda función:

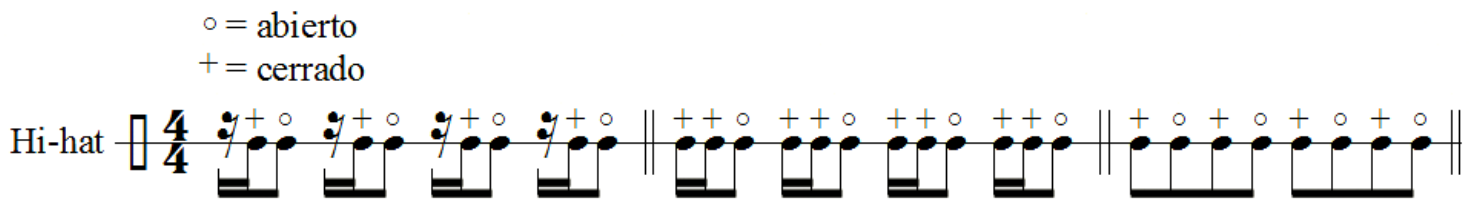

En numerosos casos y oportunidades las rítmicas se interpretan con swing. Si bien es un concepto bastante difundido preferimos explicarlo brevemente: el swing es una práctica común que consiste en que ciertos ritmos presentan desviaciones en sus puntos de ataque en relación a la grilla métrica. Dichas desviaciones generan rítmicas que, sin coincidir exactamente, se aproximan a las ternarias. ${ }^{455}$ Según sobre qué valores se aplique, serán la división o la

\footnotetext{
455 Significativamente, algo similar sucede en la saya, chaya, cueca y otros géneros del folklore sudamericano de origen nativo hallables en Bolivia, sur de Peru, norte de Chile y en el noroeste argentino. Si bien no podemos afirmar que exista algún vínculo de influencia mutua con la cultura africana, ambas presentan momentos de indefinición binaria-ternaria algo diferentes pero equiparables.
} 
subdivisión la que presente esta cualidad. Esta forma interpretativa, como varias otras tradiciones y prácticas musicales de origen afronorteamericano, ha penetrado en muchos aspectos de la música electrónica de baile y se encuentra presente en gran parte de sus géneros. Debajo, una aproximación al efecto del swing sobre la subdivisión.

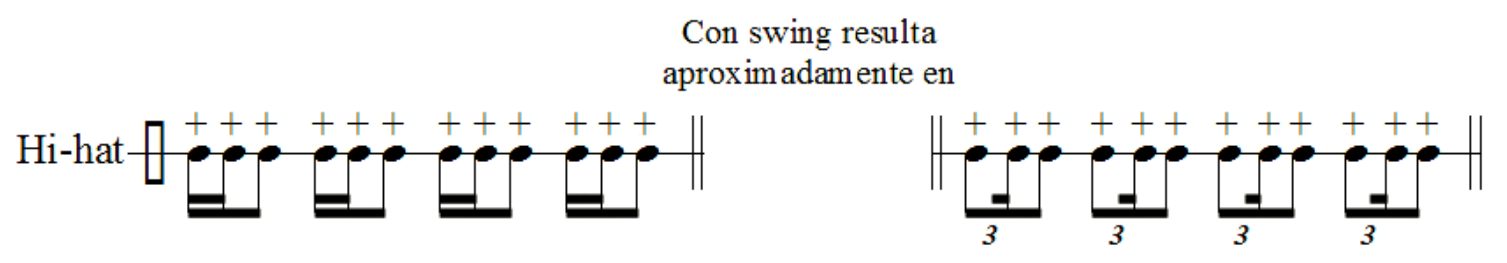

Toda esta riqueza rítmica forma parte de la batería de recursos del UK Garage. Pudiendo presentarse en toda su complejidad, o haciendo uso de sus recursos más sencillos y "directos", el las formas actuales del UK Garage configuran un género que en los últimos años se ha diferenciado de aquéllas músicas deudoras del soul afronorteamericano. Trasladando la oposición cambio/permanencia a todos los elementos de la textura (e incluso del timbre) se ha tornado un género del cual, si no conociéramos el camino recorrido, no podríamos reconocer sus orígenes. Tanto ha proliferado esta oposición a otros elementos constituyentes del total musical que en algunos casos, bombo y redoblante cumplen ambos el rol de referencia, manteniéndose siempre inalterados y realizando un patrón básico que ha dado nombre a estas nuevas formas: 2 step. ${ }^{456}$

Para no extendernos más en una sección que no es aún la del análisis musical propiamente dicha, baste con decir que este patrón se caracteriza por presentar sonidos de bombo en los tiempos 1 y 3 y de redoblante en 2 y 4 del compás de 4/4. Completan los elementos básicos, sonidos de bajo que suelen ser muy graves (alcanzando incluso el registro sub-sónico) y de ritmos extremadamente sencillos (en muchos casos apenas un ataque en el primer tiempo del compás). Por sobre esta configuración básica ocurren multiplicidad de timbres, ritmos, texturas y samples muy complejos, muy diversos y cambiantes; además de cortes, secciones con cualidades diferenciadas unas de otras y todo un arsenal de elementos muy diversos presentados "bestialmente". Un conjunto de cualidades inexistentes tanto en el mucho más estable y sutil House como en el "elegante" y "sofisticado" NY Garage.

Recapitulando entonces, nuestros análisis en busca de los "géneros" mayores arrojan el siguiente resultado:

House, Techno y Trance son sin lugar a dudas géneros "mayores". Los tres conforman un primer grupo de géneros estructurados sobre la firmeza y simplicidad del bombo en negras; siendo los dos primeros, géneros fundantes de la especie.

\footnotetext{
${ }^{456}$ Si bien da nombre a un subgénero, "2 step" puede comprenderse como la denominación genérica que designa el patrón rítmico básico utilizado. Los subgéneros comprendidos en el UK Garage (Dubstep, Grime, Breakstep y otros) suelen hacer uso actualmente de este patrón.
} 
Drum 'n'Bass/Jungle y Breakbeats constituyen el segundo grupo de géneros "mayores". Basados primordialmente en samples de breakbeats, son la expresión de los ritmos sincopados y en algún sentido inestables.

Ambient/Chill out y (en lo que respecta a nuestro estudio) Downtempo conforman el tercer grupo de géneros "mayores". Caracterizados estos por presentar una más baja activación y/o formas rítmicas libres. En las últimas se incluyen aquéllas que son resultado de una actitud esencialmente "experimental".

Hardcore: por momentos género y en otros casos estilo, se caracteriza por presentar siempre un carácter "agresivo" o "violento". Género "menor" entre los "mayores", aunque independiente, es en estos términos que lo incorporamos a la lista: sin alcanzar el status de los anteriores, creemos que posee en algunos casos existencia efectiva, en tanto conjunto de obras que presentan un carácter preciso y diferenciado (y que por lo tanto se escinden de otras). El problema para su definición en tanto género reside en la diversidad estético-técnica que presentan los ejemplos agrupados bajo esta denominación. En otras palabras, lo que las aúna en no pocos casos es ni más ni menos que el mencionado carácter. Si bien esto se refleja luego en cualidades técnico-estéticas, muchas de ellas pueden encontrarse en otros géneros de la música electrónica de baile. En definitiva, es esta ambigüedad lo que permite incluirlo al interior de la especie y lo que lo convierte en lo que podemos llamar un género "al límite de su existencia". Quizá al compararlo con el Electro se comprenda mejor lo que intentamos explicar.

UK Garage: género que originalmente hibridara cualidades asociadas a los dos primeros grupos, derivó en los últimos años final y efectivamente en un conjunto de cualidades que lo diferencian de aquéllos. Como en el caso previo y por su novedad, lo consideraremos en tanto forma en algún sentido "menor" debido a que aún no alcanza el corpus de obras que los anteriores han acumulado con el paso de los años.

Sin negar su rol e importancia histórica, dejamos así fuera de nuestra lista al Electro por considerar que el mismo ha diluido y sublimado su identidad en la forma de un difuso índice electro que otras expresiones presentan. La diferencia con el caso del Hardcore radica entonces en una cuestión de grado: mientras las piezas de aquel poseen un carácter Hardcore general que permea todos o gran parte de sus elementos constituyentes, el indice electro se presenta siempre como cualidades parciales de uno o varios elementos, siempre mixturados con cualidades y elementos en los cuales se reconocen otros géneros "mayores".

Finalizamos así nuestros análisis y selección de géneros "mayores". El resultado alcanzado es tan susceptible a las críticas como cualquiera de las listas incluidas en las fuentes consultadas, pero al menos creemos contar ahora con a) un conjunto de géneros que -por su cantidad- resulta manejable y b) una selección a la que le subyacen criterios y objetivos precisos y manifiestos. Esto nos brinda una base algo más firme a partir de la cual realizar los necesarios análisis estético-técnicos musicales que nuestro tema exige. Sin embargo, antes de dar por 
concluido el tema -y considerando la gran cantidad de denominaciones de diferente nivel que presentan algunas de las fuentes- creemos necesario realizar una comparación en procura de algún tipo de nexo que nos permita articular su relación con nuestra selección. Para ello deberemos por supuesto incluir un análisis de los subgéneros y de sus derivas de órdenes inferiores.

Debemos advertir, sin embargo, que indagar aquí con la profundidad con que lo hicimos para el nivel superior queda fuera del alcance del presente trabajo. Por ser una tarea muy extensa, nos desviaría demasiado de nuestro foco principal. Según arrojaron nuestras numerosas escuchas de ejemplos, tampoco resulta necesario tamaño esfuerzo: en nuestra selección de géneros "mayores" se encuentran representadas las diferentes vertientes estético-técnicas que constituyen la especie. Por otra parte, el trabajo necesario para definir nuestra selección de géneros "mayores" (i.e.: la multiplicidad de escuchas y análisis de ejemplos realizada) consistió justamente en determinar las denominaciones que debían ser "ordenadas" y cuales "subordinadas". En otras palabras, el trabajo sobre los géneros "mayores" ha sido simultáneamente también sobre los subgéneros. Recorreremos brevemente entonces los diversos niveles subordinados, con el objetivo de indagar lo que sucede con las denominaciones contenidas al interior de cada género "mayor". Confiamos en que al hacerlo pondremos en evidencia nuevos vínculos, problemáticas y soluciones. Tomaremos para ello, como casos de estudio y por tratarse de los más extensos, los listados organizados jerárquicamente de las versiones en inglés y español de Wikipedia.

\section{Subgéneros, sub-subgéneros y estilos}

Wikipedia, en sus diferentes versiones, difiere en la cantidad de géneros y subgéneros que se incluyen en la especie. Si bien el listado es de "géneros de la música electrónica" -dando a entender que algunos géneros no serían "de baile"- es el único que se aproxima a nuestro objeto con la suficiente claridad, especificidad, ordenamiento y desarrollo. Por otra parte, dos razones más nos impulsan a tomar esta fuente para su análisis:

a) Como ya dijimos, toda música es susceptible de ser danzada.

b) Exceptuando "Electroacoustic music" (en la versión inglesa) y algunos pocos subgéneros dentro de "Electrónica" (en la española), todos los géneros y subgéneros pertenecen a la música electrónica de baile, por lo que consideramos lícito pensar que las piezas que los integran fueron concebidas en función de la danza social.

Creyéndolo un caso representativo de lo que sucede en general con el tratamiento del tema, presentamos ambas listas según se exponen en los respectivos sitios. 
"List of electronic music genres." Wikipedia en inglés. ${ }^{457}$

\begin{tabular}{|c|c|c|}
\hline 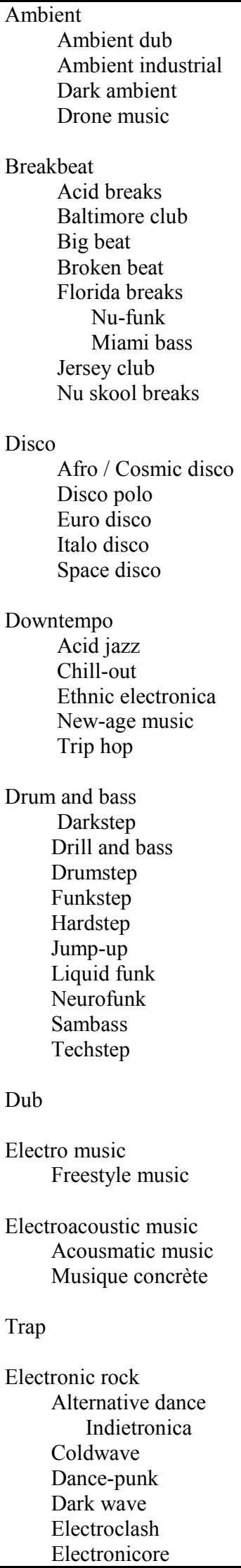 & 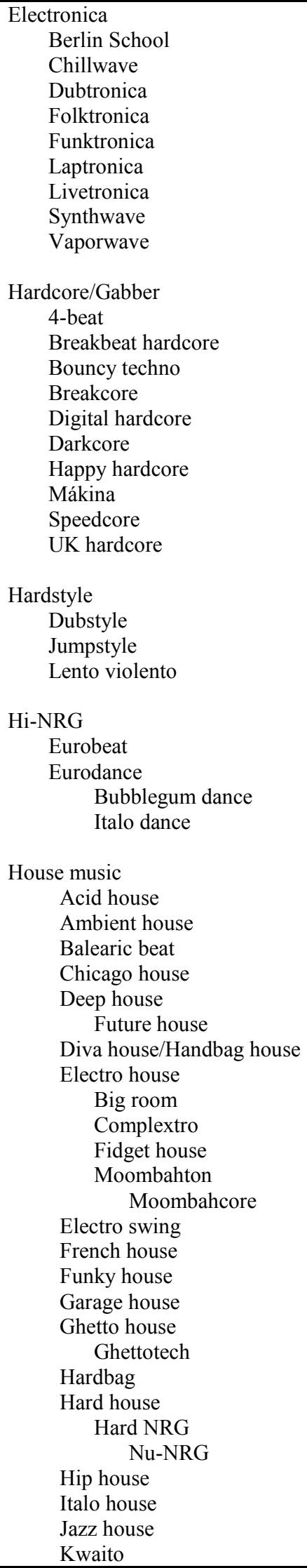 & 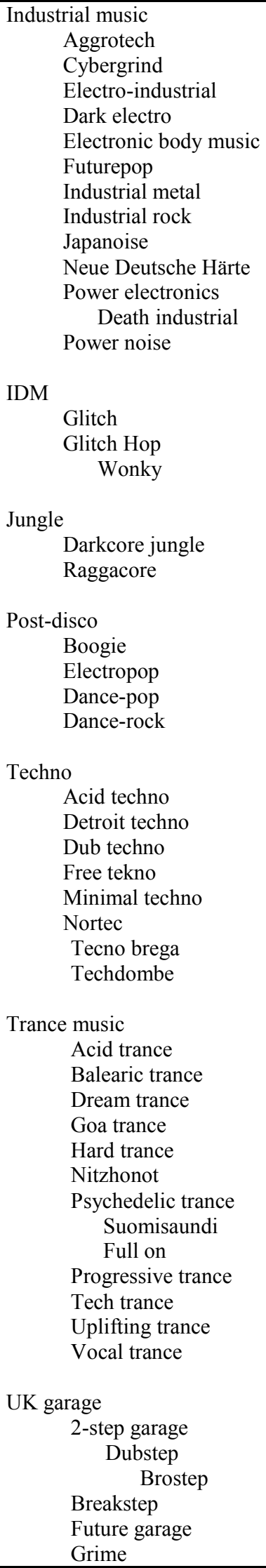 \\
\hline
\end{tabular}

457 Wikipedia en ingles. [en línea]. Entrada "List of electronic music genres". Disponible en https://en.wikipedia.org/wiki/List_of_electronic_music_genres [16042016] 


\begin{tabular}{|l|l|c|}
\hline Electropunk & Latin house & Grindie \\
Ethereal wave & Microhouse/Minimal house & Speed garage \\
Krautrock & New beat & Bassline/4x4 garage \\
Minimal wave & Nu-disco & UK funky \\
New rave & Outsider house & \\
Nu-gaze & Progressive house & Video game music \\
Space rock & Rara tech & Chiptune \\
Synthpop & Tech house & Bitpop \\
& Tribal house & Game Boy music \\
& Tropical house & Nintendocore \\
& Witch house/Drag & Skweee \\
& & \\
\hline
\end{tabular}

"Géneros de música electrónica". Wikipedia en español. ${ }^{458}$

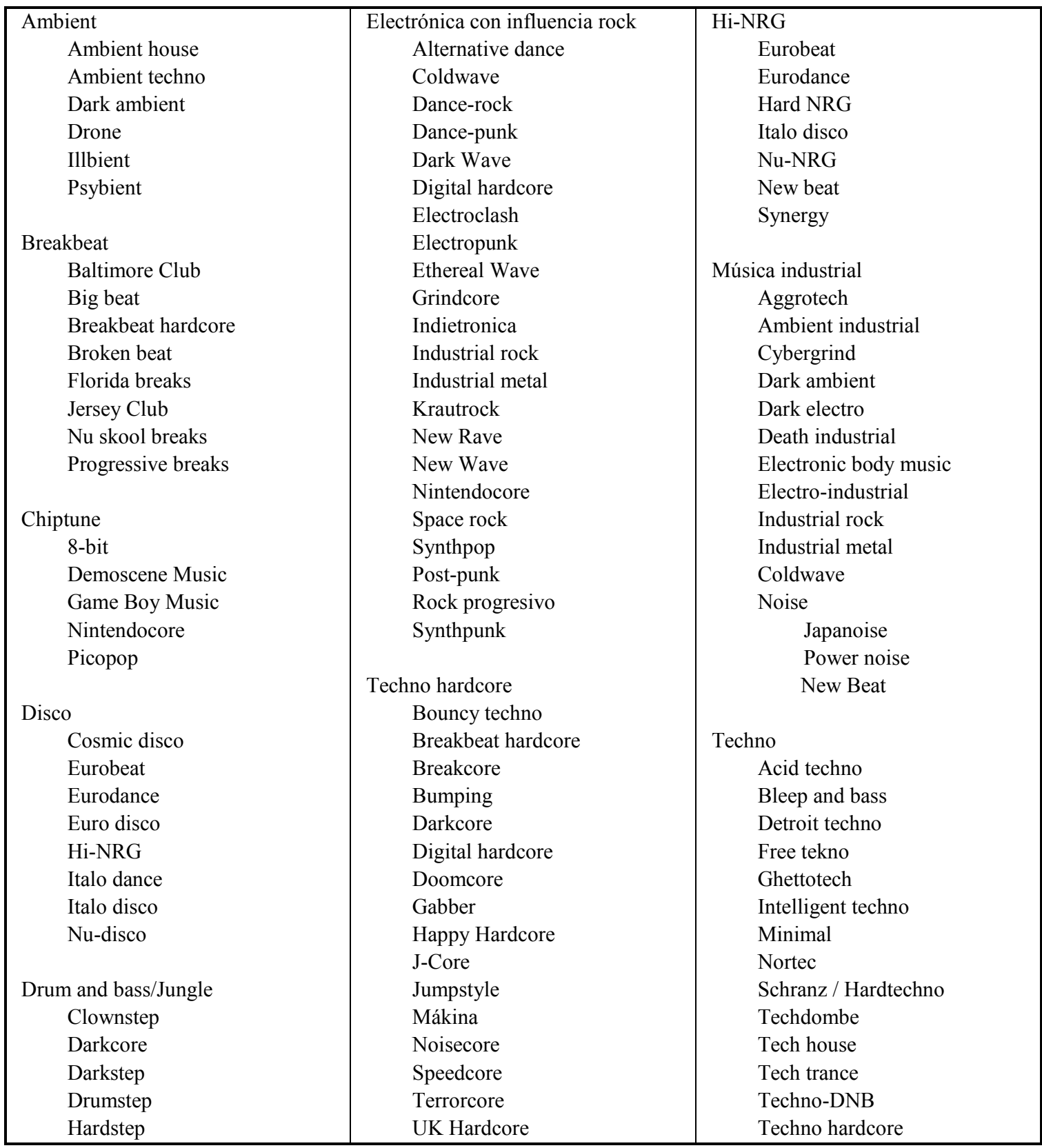

458 Wikipedia en español. [en línea]. Entrada "Géneros de música electrónica". Disponible en https://es.wikipedia.org/wiki/Anexo:G\%C3\%A9neros_de m\% $3 \%$ BAsica_electr\% $\%$ C3\%B3nica

[16042016] 


\begin{tabular}{|c|c|c|}
\hline 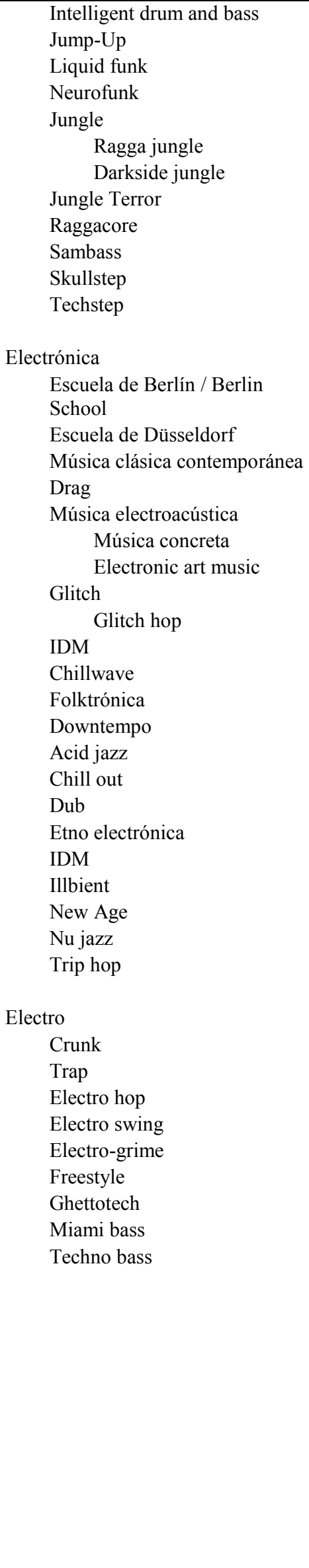 & 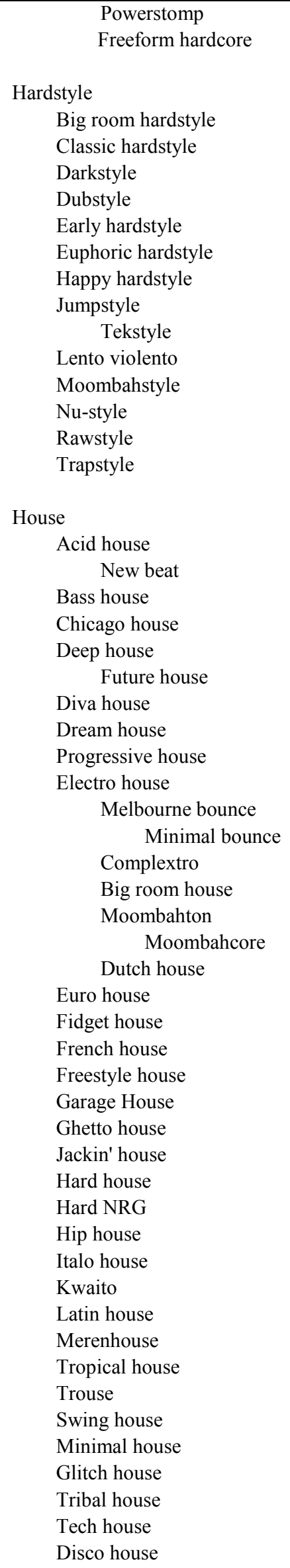 & 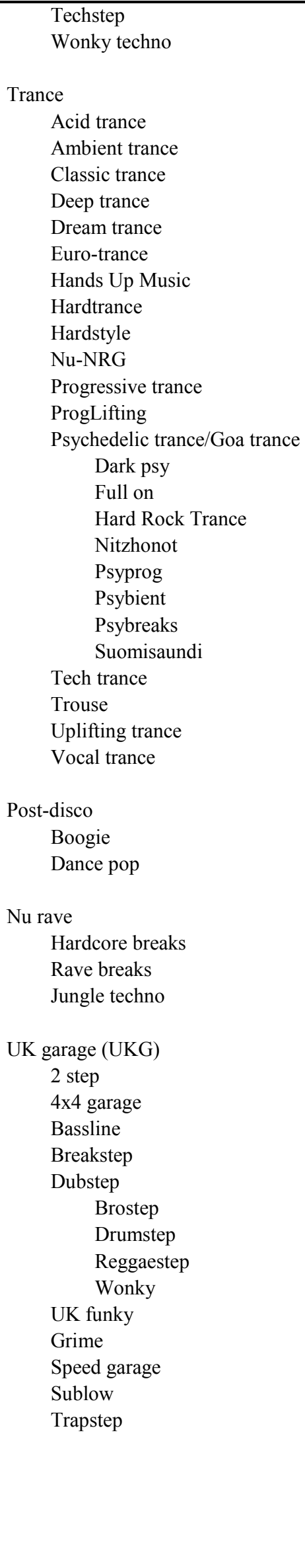 \\
\hline
\end{tabular}


Un rápido recorrido vuelve evidentes las diferencias en el contenido entre una y otra versión. Siendo una enciclopedia de creación colectiva, podría pensarse que estas responden a una falta de actualización de la versión inglesa. En otras palabras, la versión en español se encontraría reflejando géneros surgidos en el último período (desde la última actualización de la primera). Sin embargo este no es el caso: la última actualización de la versión anglosajona es realmente muy reciente: del 14 de abril de 2016 (i.e.: dos días antes de que transcribiéramos los cuadros). La edición en español por su parte, fue actualizada el 23 de marzo de 2016.

Analizados los encabezados nos preguntamos si las diferencias no radicarían en que una y otra focalizan en diferentes niveles del objeto ya que, mientras la versión en inglés habla solo de "géneros" (i.e.: "genres"), la española refiere a que la música electrónica "comprende multitud de géneros, subgéneros y estilos" ${ }^{459}$. Luego de las extensas búsquedas y escuchas mencionadas supra en el sitio Youtube ${ }^{460}$ nos convencimos de que tampoco esta afirmación debería ser sostenida. Fundamentamos esta aseveración en nuestros análisis y conclusiones al respecto del Hardcore y del electro: ambas versiones de Wikipedia son al menos parcialmente acríticas en lo que respecta a la inclusión de denominaciones y ponen en un pié de igualdad a dos que hemos caracterizado de forma diferente. Asimilable a lo que dijéramos para el electro y como otro ejemplo, también la denominación "Hardstyle" -la cual se presenta como géneropodría considerarse un "estilo", "carácter" o "modo" aplicado a diversos géneros o mixturas de géneros. De hecho, en la misma denominación encontramos dicho concepto (i.e.: "style" es el inglés de "estilo").

Nos preguntamos luego si las diferencias no tendría su razón de ser en inconsistencias o en superposiciones de diferentes criterios de clasificación: en la versión española las denominaciones "Techno hardcore", "Hi-NRG" y "Hardstyle" se utilizan respectivamente tanto para géneros independientes como para sub-géneros de "Techno", "Disco" y "Trance". Descartamos esta hipótesis al encontrar que la versión inglesa presenta problemas equiparables: el subgénero de "IDM" denominado "Glitch hop", llamativamente incorpora un único subsubgénero. Lo mismo sucede con el género "Electro music" y su subgénero "Freestyle music", con "Alternative dance" de "Electronic rock", con "Deep house" en "House" y algunos más. Por otra parte, el grado de coincidencia al menos a nivel de géneros, es suficientemente alto como para descartar esta hipótesis.

Estas y otras observaciones iniciales nos permitieron detectar los beneficios que podría tener un análisis comparativo entre una y otra lista. Procurando facilitarla, confeccionamos un nuevo cuadro que presenta ambas versiones en dos columnas enfrentadas.

\footnotetext{
459 Ibid.

460 Ingresamos como "entrada de búsqueda" las denominaciones de géneros, subgéneros y demás denominaciones incluídas en ambas listas de Wikipedia. Estas búsquedas consistieron en largas sesiones de escucha analítica de un gran número de ejemplos de cada género y subgénero, intentando alcanzar el mayor grado de exhaustividad posible (que siempre será parcial ya que ninguna lista contiene la totalidad) y atentos a similitudes y diferencias en las poéticas, estéticas y técnicas musicales.
} 
La primera consideración que debimos hacer para su confección fue la del reordenamiento de los géneros: ambas listas se ordenan alfabéticamente pero, aunque la mayoría de las denominaciones son en inglés, por diversas razones no todas coinciden generando aparentes diferencias que, como veremos, no son tales. Para resolver estos conflictos y por ser la más extensa en cantidad de subgéneros, decidimos tomar a la versión en español como referencia. Como consecuencia se reordenó parcialmente la versión inglesa. Este es, por ejemplo, el caso de las denominaciones "Video game music" y "Jungle". La versión española mantiene en todo su ordenamiento original.

Durante la confección del cuadro nos encontramos con que la mayoría de las denominaciones figuran en ambos listados. También encontramos otras que, aún figurando bajo diferente denominación, evidenciaban referir al mismo conjunto de obras. ${ }^{461}$ De los diferentes casos problemáticos detectados surgió la necesidad de encontrar ciertos criterios que permitieran determinar cuándo un género o subgénero debía considerarse efectivamente incluido en la columna opuesta; aún cuando allí no se encontrara textualmente la denominación presente en la primera. Para salvar cada caso particular debimos considerar diferentes factores y, debido a que creemos que existen diferencias en cuanto a la "calidad" de la inclusión que cada factor propicia, decidimos utilizar una codificación con diferentes colores que las pusiera de manifiesto. Así entonces mantuvimos el negro original para las denominaciones que poseen su igual textual y marcamos con rojo aquéllas para las que no encontramos par alguno. ${ }^{462}$ Para las categorías restantes, el color que le hemos asignado se explicita en su correspondiente descripción. Dicho esto, se considerarán incluidas en la columna opuesta aquéllas denominaciones que:

a) Aún sin tener su contrapartida textual, i) son la conjunción de denominaciones de mismo o diferente nivel (i.e.: géneros o subgéneros) que sí se incluyen en la columna opuesta a la de pertenencia, ii) son la conjunción de un género o subgénero ${ }^{463} \mathrm{de}$

\footnotetext{
${ }^{461}$ Un ejemplo muy claro de estas lo constituye el par "Chiptune"-"Video game music": en la versión inglesa no solo encontramos a la primera como subgénero de la segunda, sino que además comparten varios subgéneros. Quizá menos evidente para el no iniciado, ambos conjuntos refieren a músicas realizadas con tecnología ("chipsets") de principios de los años 1980s que en su momento fueran utilizadas en las consolas de videojuegos. Esta es la razón por la que estas músicas presentan múltiples cualidades particulares: sus tímbres suelen poseer poca profundidad de sampleo (de allí el "bit" de algunos subgéneros) y, al reproducir más de una nota simultánea, el chip responsable de la síntesis sonora suele producir una distorsión típica y reconocible. Esta cualidad implica entonces además una limitación textural ya que, cuantas más notas simultáneas se reproducen, mayor será la distorsión. Entre otros, este conjunto de características configura a esta modalidad de música electrónica y le otorga la cualidad sonora de "música de videojuegos de los años 1980s".

${ }^{462}$ Algunos géneros reciben más de un nombre (por ejemplo, Jungle/Drum'n'Bass), en esos casos mantuvimos el color negro independientemente de la denominación concreta utilizada en una y otra columna.

${ }^{463}$ Procurando no volver aún más engorrosa la redacción, utilizaremos aquí los términos "género" y "subgénero" como sinónimos de "denominaciones". Aclaramos sin embargo que este hecho no implica
} 
música electrónica de baile con otro que se reconoce entre aquéllos que la antecedieron y/o son fuente de cualidades o iii) evidentemente remiten a que su existencia depende del surgimiento posterior de distinciones dentro del género de nivel superior que la contiene (estas no deben considerarse un subgénero en sí mismas sino que refieren, de un modo redundante, al género en el cual se encuentran enmarcadas).

Ejemplos: i) "Ambient dub", "Ambient Techno", "Breakbeat hardcore", "Trouse" (i.e.: Trance+House) o "Techno-DNB", ii) "Disco House", "Electro-pop" o "Electro swing" iii) "Classic Hardstyle", "Early Hardstyle" o "Classic Trance".

Utilizamos para estos casos el color verde.

b) Presentan adjetivaciones que refieren a i) cualidades (en algún sentido) meta- o examusicales o aspectos del "carácter" con el que también se adjetiva a otros géneros o ii) una tecnología o instrumental determinados.

Ejemplo: i) "Psybient" (i.e.: Psychedelic+Ambient, utilizado también en Psychedelic Trance), "Progressive breaks" (utilizado en "Progressive Trance") o "Inteligent Drum'n'Bass" (utilizado también en IDM), ii) "Digital Hardcore", "Laptronica", "Livetronica" o "Bass House".

También incorporamos aquí casos como el de "Funkstep" ya que, en este contexto específico, ambas partículas ("funk" y "step") remiten implícitamente al carácter de géneros y a géneros sí incluidos. No así aquéllos casos en que la cualidad no resulta tan clara (i.e.: "Jungle Terror" o "Skullstep").

De modo similar incluimos aquéllos géneros que utilizan la partícula "Nu" o el término "New". En conjunción con partículas o términos que refieren a géneros de la música electrónica de baile (o a géneros-fuente de esta) estarían remitiendo a "nuevas formas" (electrónicas) de aquéllos. Ejemplos: "Nu-funk" o "Nu jazz". En algún sentido son la categoría complementaria de la descripta en el apartado a-iii) pero sin la claridad que aquéllas presentan.

Asignamos a estos el color azul.

c) Casos particulares que merecen aclaración:

- Música industrial/Noise: si bien el subgénero no se incluye en la edición inglesa, sí aparecen sus sub-subgéneros (Japanoise, Power Noise y New Beat). Lo mismo sucede con Industrial music/Power electronics. Quizá nos encontremos frente a dos modos de nombrar al mismo género, no podemos asegurarlo.

- Electro hop: conjunción del género "Electro" con Hip Hop (rap), género que se reconoce como fuente del Drum'n'bass/Jungle y sus derivados. En otras palabras,

que le otorguemos dicho estatus a estas entidades sino que solo tomamos este camino por cuestiones prácticas. 
pertenece a la primera categoría descripta en el apartado a). Su forma textual quizá no resulte clara para los no iniciados, preferimos evidenciarlo.

- Synthpunk: similar al Electro hop, el punk se inscribe en la misma tradición futurista que la electrónica. Así como algunas formas del rock, la electrónica es una especie "post-punk".

- Rave break: la denominación se refiere a piezas del género Breakbeat (supuestamente) destinadas a ser presentadas en raves. Subyace a la denominación "rave" la idea de "euforia", por lo que estas músicas presentan dicho carácter. Creemos acertado incluirlos como géneros de algún modo ya citados.

- Las denominaciones con la palabra "wave" refieren a diferentes formas del "New wave", el cual ha influido sobre todo sobre el Ambient/Chill out. Las diferentes expresiones conteniendo esta palabra pueden comprenderse como variaciones de carácter de dicho género. Ejemplo "Coldwave", "Synthwave" o "Vaporwave".

- "Escuela de Düseldorf": siendo una denominación que en el contexto histórico en que surgió se presentó como "opuesta" a la llamada "Escuela de Berlín", y encontrándose la última presente en ambas listas, tomamos la decisión de darla por implícita en la versión inglesa.

Por considerar que de algún modo pertenecen a las categorías previas también en estos casos utilizamos el color azul.

Comparación de géneros y subgéneros de la música electrónica de baile en Wikipedia

\begin{tabular}{|l|l|}
\hline \multicolumn{1}{|c|}{ Wikipedia en ingles } & \multicolumn{1}{c|}{ Wikipedia en español } \\
\hline Ambient & Ambient \\
Ambient dub & Ambient house (ver "House") \\
Ambient industrial (ver "Música industrial") & Ambient techno \\
Dark ambient (ver también "Música industrial") & Dark ambient \\
Drone music & Drone \\
& Illbient \\
& Psybient \\
& \\
\hline Breakbeat & Breakbeat \\
Acid breaks & Baltimore Club \\
Baltimore club & Big beat \\
Big beat & Breakbeat hardcore \\
Broken beat & Broken beat \\
Florida breaks & Florida breaks \\
Nu-funk & Jersey Club \\
Miami bass (ver "Electro") & Nu skool breaks \\
Jersey club & Progressive breaks \\
Nu skool breaks & \\
\hline Video game music & Chiptune \\
Chiptune & 8-bit \\
Bitpop & Demoscene Music \\
Game Boy music & Game Boy Music \\
Nintendocore (ver también "Electrónica con & Nintendocore \\
influencia rock") & Picopop \\
Skweee & \\
\hline
\end{tabular}




\begin{tabular}{|c|c|}
\hline $\begin{array}{l}\text { Disco } \\
\text { Afro / Cosmic disco } \\
\text { Disco polo } \\
\text { Euro disco } \\
\text { Italo disco } \\
\text { Space disco (género fuente:"Space rock", ver } \\
\text { también "Cosmic disco") }\end{array}$ & $\begin{array}{l}\text { Disco } \\
\text { Cosmic disco } \\
\text { Eurobeat (ver "Hi-NRG") } \\
\text { Eurodance (ver "Hi-NRG") } \\
\text { Euro disco } \\
\text { Hi-NRG (ver "Hi-NRG") (*) } \\
\text { Italo dance (ver "Hi-NRG") } \\
\text { Italo disco } \\
\text { Nu-disco (ver "House") }\end{array}$ \\
\hline $\begin{array}{l}\text { Drum and bass } \\
\text { Darkstep } \\
\text { Drill and bass } \\
\text { Drumstep (ver también "UK Garage") } \\
\text { Funkstep } \\
\text { Hardstep } \\
\text { Jump-up } \\
\text { Liquid funk } \\
\text { Neurofunk } \\
\text { Sambass } \\
\text { Techstep (ver también "Techno") } \\
\text { Jungle } \\
\text { Darkcore jungle } \\
\text { Raggacore }\end{array}$ & $\begin{array}{l}\text { Drum and bass/Jungle } \\
\text { Clownstep } \\
\text { Darkcore } \\
\text { Darkstep } \\
\text { Drumstep } \\
\text { Hardstep } \\
\text { Intelligent drum and bass } \\
\text { Jump-Up } \\
\text { Liquid funk } \\
\text { Neurofunk } \\
\text { Jungle } \\
\quad \text { Ragga jungle } \\
\quad \text { Darkside jungle (¿"Darkcore jungle"?) } \\
\text { Jungle Terror } \\
\text { Raggacore } \\
\text { Sambass } \\
\text { Skullstep } \\
\text { Techstep }\end{array}$ \\
\hline $\begin{array}{l}\text { Downtempo } \\
\text { Acid jazz } \\
\text { Chill-out } \\
\text { Ethnic electronica } \\
\text { New-age music } \\
\text { Trip hop } \\
\text { Dub } \\
\text { Electroacoustic music } \\
\text { Acousmatic music } \\
\text { Musique concrète } \\
\text { Electronica } \\
\text { Berlin School } \\
\text { Chillwave } \\
\text { Dubtronica } \\
\text { Folktronica } \\
\text { Funktronica } \\
\text { Laptronica } \\
\text { Livetronica } \\
\text { Synthwave } \\
\text { Vaporwave (ver debajo "Casos particulares") } \\
\text { IDM } \\
\text { Glitch } \\
\text { Glitch Hop } \\
\text { Wonky (ver "UK Garage") }\end{array}$ & $\begin{array}{l}\text { Electrónica } \\
\text { Escuela de Berlín ("Berlin School") } \\
\text { Escuela de Düsseldorf } \\
\text { Música clásica contemporánea (?) } \\
\text { Drag (ver "House") } \\
\text { Música electroacústica } \\
\quad \text { Música concreta } \\
\quad \text { Electronic art music } \\
\text { Glitch } \\
\quad \text { Glitch hop } \\
\text { IDM } \\
\text { Chillwave } \\
\text { Folktrónica } \\
\text { Downtempo } \\
\text { Acid jazz } \\
\text { Chill out } \\
\text { Dub } \\
\text { Etno electrónica } \\
\text { IDM (?) } \\
\text { Illbient } \\
\text { New Age } \\
\text { Nu jazz } \\
\text { Trip hop }\end{array}$ \\
\hline $\begin{array}{l}\text { Electro music } \\
\quad \text { Freestyle music } \\
\text { Trap }\end{array}$ & $\begin{array}{l}\text { Electro } \\
\text { Crunk } \\
\text { Trap } \\
\text { Electro hop (ver debajo "Casos particulares") } \\
\text { Electro swing (ver "House") } \\
\text { Electro-grime }\end{array}$ \\
\hline
\end{tabular}




\begin{tabular}{|c|c|}
\hline & $\begin{array}{l}\text { Freestyle } \\
\text { Ghettotech (ver "House) } \\
\text { Miami bass (ver "Breakbeat") } \\
\text { Techno bass }\end{array}$ \\
\hline $\begin{array}{l}\text { Electronic rock } \\
\text { Alternative dance } \\
\text { Indietronica } \\
\text { Coldwave } \\
\text { Dance-punk } \\
\text { Dark wave } \\
\text { Electroclash } \\
\text { Electronicore } \\
\text { Electropunk } \\
\text { Ethereal wave } \\
\text { Krautrock } \\
\text { Minimal wave } \\
\text { New rave } \\
\text { Nu-gaze } \\
\text { Space rock } \\
\text { Synthpop }\end{array}$ & $\begin{array}{l}\text { Electrónica con influencia rock } \\
\text { Alternative dance } \\
\text { Coldwave } \\
\text { Dance-rock (ver "Post-disco") } \\
\text { Dance-punk } \\
\text { Dark Wave } \\
\text { Digital hardcore (ver "Hardcore") } \\
\text { Electroclash } \\
\text { Electropunk } \\
\text { Ethereal Wave } \\
\text { Grindcore } \\
\text { Indietronica } \\
\text { Industrial rock (ver "Industrial Music") } \\
\text { Industrial metal (ver "Industrial Music") } \\
\text { Krautrock } \\
\text { New Rave } \\
\text { New Wave } \\
\text { Nintendocore (ver "Video game music") } \\
\text { Space rock } \\
\text { Synthpop } \\
\text { Post-punk } \\
\text { Rock progresivo } \\
\text { Synthpunk }\end{array}$ \\
\hline $\begin{array}{l}\text { Hardcore/Gabber } \\
\text { 4-beat } \\
\text { Breakbeat hardcore } \\
\text { Bouncy techno } \\
\text { Breakcore } \\
\text { Digital hardcore } \\
\text { Darkcore } \\
\text { Happy hardcore } \\
\text { Mákina } \\
\text { Speedcore } \\
\text { UK hardcore }\end{array}$ & $\begin{array}{l}\text { Techno hardcore } \\
\text { Bouncy techno } \\
\text { Breakbeat hardcore } \\
\text { Breakcore } \\
\text { Bumping } \\
\text { Darkcore } \\
\text { Digital hardcore } \\
\text { Doomcore } \\
\text { Gabber } \\
\text { Happy Hardcore } \\
\text { J-Core } \\
\text { Jumpstyle (ver "Hardstyle") } \\
\text { Mákina } \\
\text { Noisecore } \\
\text { Speedcore } \\
\text { Terrorcore } \\
\text { UK Hardcore } \\
\text { Powerstomp } \\
\text { Freeform hardcore }\end{array}$ \\
\hline $\begin{array}{l}\text { Hardstyle } \\
\text { Dubstyle } \\
\text { Jumpstyle (ver también "Techno hardcore") } \\
\text { Lento violento }\end{array}$ & $\begin{array}{l}\text { Hardstyle } \\
\text { Big room hardstyle (ver "Big Room" en "House") } \\
\text { Classic hardstyle } \\
\text { Darkstyle } \\
\text { Dubstyle } \\
\text { Early hardstyle } \\
\text { Euphoric hardstyle } \\
\text { Happy hardstyle } \\
\text { Jumpstyle } \\
\text { Tekstyle } \\
\text { Lento violento } \\
\text { Moombahstyle }\end{array}$ \\
\hline
\end{tabular}




\begin{tabular}{|c|c|}
\hline & $\begin{array}{l}\text { Nu-style } \\
\text { Rawstyle } \\
\text { Trapstyle (ver "Trap") }\end{array}$ \\
\hline $\begin{array}{l}\text { House music } \\
\text { Acid house } \\
\text { Ambient house (ver "Ambient") } \\
\text { Balearic beat } \\
\text { Chicago house } \\
\text { Deep house } \\
\quad \text { Future house } \\
\text { Diva house/Handbag house } \\
\text { Electro house } \\
\quad \text { Big room } \\
\quad \text { Complextro } \\
\quad \text { Fidget house } \\
\quad \text { Moombahton } \\
\quad \text { Moombahcore } \\
\text { Electro swing(ver "Electro") } \\
\text { French house } \\
\text { Funky house } \\
\text { Garage house } \\
\text { Ghetto house } \\
\quad \text { Ghettotech (ver "Electro") } \\
\text { Hardbag } \\
\text { Hard house } \\
\quad \text { Hard NRG (ver "Hi-NRG") } \\
\quad \text { Nu-NRG (ver "Hi-NRG" y "Trance") } \\
\text { Hip house } \\
\text { Italo house } \\
\text { Jazz house } \\
\text { Kwaito } \\
\text { Latin house } \\
\text { Microhouse/Minimal house } \\
\text { New beat (ver "Hi-NRG") } \\
\text { Nu-disco (ver "Disco") } \\
\text { Outsider house } \\
\text { Progressive house } \\
\text { Rara tech } \\
\text { Tech house (ver también "Techno") } \\
\text { Tribal house } \\
\text { Tropical house } \\
\text { Witch house/Drag (ver "Electrónica") } \\
\text { (n) }\end{array}$ & $\begin{array}{l}\text { House } \\
\text { Acid house } \\
\quad \text { New beat } \\
\text { Bass house } \\
\text { Chicago house } \\
\text { Deep house } \\
\text { Future house } \\
\text { Diva house } \\
\text { Dream house (ver "Dream trance") } \\
\text { Progressive house } \\
\text { Electro house } \\
\quad \text { Melbourne bounce } \\
\quad \text { Minimal bounce } \\
\quad \text { Complextro } \\
\quad \text { Big room house } \\
\quad \text { Moombahton } \\
\quad \text { Moombahcore } \\
\quad \text { Dutch house } \\
\text { Euro house } \\
\text { Fidget house } \\
\text { French house } \\
\text { Freestyle house } \\
\text { Garage House } \\
\text { Ghetto house } \\
\text { Jackin' house } \\
\text { Hard house } \\
\text { Hard NRG } \\
\text { Hip house } \\
\text { Italo house } \\
\text { Kwaito } \\
\text { Latin house } \\
\text { Merenhouse } \\
\text { Tropical house } \\
\text { Trouse } \\
\text { Swing house } \\
\text { Minimal house } \\
\text { Glitch house } \\
\text { Tribal house } \\
\text { Tech house } \\
\text { Disco house }\end{array}$ \\
\hline $\begin{array}{l}\text { Hi-NRG } \\
\text { Eurobeat (ver también "Disco") } \\
\text { Eurodance (ver también "Disco") } \\
\text { Bubblegum dance } \\
\text { Italo dance (ver "Disco") }\end{array}$ & $\begin{array}{l}\text { Hi-NRG } \\
\text { Eurobeat } \\
\text { Eurodance } \\
\text { Hard NRG (ver "House") } \\
\text { Italo disco } \\
\text { Nu-NRG (ver "House") } \\
\text { New beat (ver "House") } \\
\text { Synergy }\end{array}$ \\
\hline $\begin{array}{l}\text { Industrial music } \\
\text { Aggrotech } \\
\text { Cybergrind } \\
\text { Electro-industrial } \\
\text { Dark electro } \\
\text { Electronic body music } \\
\text { Futurepop } \\
\text { Industrial metal }\end{array}$ & $\begin{array}{l}\text { Música industrial } \\
\text { Aggrotech } \\
\text { Ambient industrial (ver "Ambient") } \\
\text { Cybergrind } \\
\text { Dark ambient (ver "Ambient") } \\
\text { Dark electro } \\
\text { Death industrial }\end{array}$ \\
\hline
\end{tabular}




\begin{tabular}{|c|c|}
\hline $\begin{array}{l}\text { Industrial rock } \\
\text { Japanoise } \\
\text { Neue Deutsche Härte } \\
\text { Power electronics } \\
\quad \text { Death industrial } \\
\text { Power noise }\end{array}$ & $\begin{array}{l}\text { Electronic body music } \\
\text { Electro-industrial } \\
\text { Industrial rock } \\
\text { Industrial metal } \\
\text { Coldwave } \\
\text { Noise (ver debajo "Casos particulares") } \\
\quad \text { Japanoise } \\
\quad \text { Power noise } \\
\quad \text { New Beat (ver también "House") }\end{array}$ \\
\hline & $\begin{array}{l}\text { Nu rave } \\
\text { Hardcore breaks } \\
\text { Rave breaks } \\
\text { Jungle techno }\end{array}$ \\
\hline $\begin{array}{l}\text { Post-disco } \\
\text { Boogie } \\
\text { Electropop } \\
\text { Dance-pop } \\
\text { Dance-rock (ver "Electrónica con influencias } \\
\text { rock") }\end{array}$ & $\begin{array}{l}\text { Post-disco } \\
\text { Boogie } \\
\text { Dance pop }\end{array}$ \\
\hline $\begin{array}{l}\text { Techno } \\
\text { Acid techno } \\
\text { Detroit techno } \\
\text { Dub techno } \\
\text { Free tekno } \\
\text { Minimal techno } \\
\text { Nortec } \\
\text { Tecno brega } \\
\text { Techdombe }\end{array}$ & $\begin{array}{l}\text { Techno } \\
\text { Acid techno } \\
\text { Bleep and bass } \\
\text { Detroit techno } \\
\text { Free tekno } \\
\text { Ghettotech (ver "House") } \\
\text { Intelligent techno } \\
\text { Minimal } \\
\text { Nortec } \\
\text { Schranz / Hardtechno } \\
\text { Techdombe } \\
\text { Tech house (ver "House") } \\
\text { Tech trance (ver "Trance") } \\
\text { Techno-DNB } \\
\text { Techno hardcore (*) } \\
\text { Techstep (ver también "Drum'n'bass") } \\
\text { Wonky techno }\end{array}$ \\
\hline $\begin{array}{l}\text { Trance music } \\
\text { Acid trance } \\
\text { Balearic trance } \\
\text { Dream trance } \\
\text { Goa trance } \\
\text { Hard trance } \\
\text { Nitzhonot } \\
\text { Psychedelic trance } \\
\quad \text { Suomisaundi } \\
\quad \text { Full on } \\
\text { Progressive trance } \\
\text { Tech trance } \\
\text { Uplifting trance } \\
\text { Vocal trance } \\
\\
\end{array}$ & $\begin{array}{l}\text { Trance } \\
\text { Acid trance } \\
\text { Ambient trance } \\
\text { Classic trance } \\
\text { Deep trance } \\
\text { Dream trance } \\
\text { Euro-trance } \\
\text { Hands Up Music } \\
\text { Hardtrance } \\
\text { Hardstyle }\left(^{*}\right) \\
\text { Nu-NRG } \\
\text { Progressive trance } \\
\text { ProgLifting } \\
\text { Psychedelic trance/Goa trance } \\
\text { Dark psy } \\
\text { Full on } \\
\text { Hard Rock Trance } \\
\text { Nitzhonot } \\
\text { Psyprog } \\
\text { Psybient } \\
\text { Psybreaks } \\
\text { Suomisaundi }\end{array}$ \\
\hline
\end{tabular}




\begin{tabular}{|c|l|}
\hline & Tech trance \\
& Trouse \\
& Uplifting trance \\
& Vocal trance \\
& \\
\hline UK garage & UK garage (UKG) \\
2-step garage & 2 step \\
Dubstep & $4 \times 4$ garage \\
Brostep & Bassline \\
Breakstep & Breakstep \\
Future garage & Dubstep \\
Grime & Brostep \\
Grindie & Drumstep (ver "Drum'n'bass") \\
Speed garage & Reggaestep \\
Bassline/4x4 garage & Wonky (ver "Glitch") \\
UK funky & UK funky \\
& Grime \\
& Speed garage \\
& Sublow \\
& Trapstep \\
& \\
\hline
\end{tabular}

Incorporar al cuadro la información derivada de los criterios expuestos previamente nos permite inicialmente apreciar con mayor claridad dos cuestiones centrales:

a) El nivel mayor presentan muchas similitudes. Tanto en la cantidad de categorías como en las denominaciones utilizadas. Cuando esto no sucede, la denominación se ha detectado en un conjunto de nivel inferior que presenta fuertes similitudes en sus elementos constituyentes. En otras palabras, ambas listas coinciden en cuales músicas concretas conforman la especie música electrónica. ${ }^{464}$

b) Los niveles inferiores presentan también menos diferencias de lo que en principio parecía. La disparidad cuantitativa y cualitativa de subgéneros y demás denominaciones de niveles inferiores puede considerarse efectivamente menor.

Cuando iniciáramos el trabajo contábamos respectivamente en las versiones inglesa y en español con 23 y 18 denominaciones de nivel superior y 173 y 250 de niveles inferiores. Luego de tomar en consideración los factores de inclusión encontramos que:

a) A nuestro criterio, son entre 14 y 27 las denominaciones de subgéneros y categorías inferiores (i.e.: ninguna de nivel superior) que no poseen denominación equivalente en la columna opuesta. Estas cantidades reducen substancialmente las diferencias iniciales:

\footnotetext{
${ }^{464}$ Incluso el caso de "Nu rave" -al que hemos marcado en rojo- podría considerarse contenido en algún otro grupo de la columna opuesta. Sin embargo Wikipedia lo indica como una fusión entre la electrónica y el indie rock. Coincidimos plenamente en que se trata de un caso debatible. Basamos nuestra posición en que la amplia mayoria de los ejemplos a los que accedimos presenta principalmente rasgos estéticotécnicos asociados al segundo "género". En otras palabras, podríamos decir que existen casos electrónicos del género $\mathrm{Nu}$ rave.
} 
de un total de 423 denominaciones, 41 constituyen poco menos de un $10 \%$. Considerando las 300 nuevas denominaciones que, según refiere, Butler documentó como surgidas en el término de apenas un año, este porcentaje se vuelve repentinamente menos relevante. ${ }^{465}$

b) A pesar de la reducción en su número, la persistencia de estas diferencias y el porcentaje que constituyen las vuelve a nuestros ojos merecedoras de algún análisis. Nuevas búsquedas en el sitio YouTube nos condujeron a afirmar que: al igual que entre los géneros "mayores", también en los niveles inferiores hay coincidencia en relación a qué músicas y estéticas componen la especie. En términos generales y en gran mayoría, para cada conjunto de cualidades musicales a las que refiere cada denominación en una de las columnas, hay un conjunto equivalente en la columna opuesta. ${ }^{466}$

c) Se evidencian múltiples cruces y vinculaciones que exceden los límites de las denominaciones de nivel mayor. Este dato, que resultara invisibilizado en la argumentación relativa a nuestra selección de géneros "mayores", solo se hace evidente al recorrer los niveles inferiores. ${ }^{467}$

A modo de paréntesis y para finalizar el análisis directo del cuadro comparativo, nos llama la atención la ausencia de Balearic beats/Balearic trance en la edición española. Este caso particular nos resulta relevante ya que diferentes fuentes consideran esencial su influencia sobre la música electrónica de baile. Género o estilo que se desarrollara en Ibiza (España) principalmente de la mano del deejay argentino Alfredo Fiorito, significaría una temprana

\footnotetext{
${ }^{465}$ En este contexto, que sobre 423 denominaciones solo el $10 \%$ no coincida refuerza sobre todo al $90 \%$ que sí lo hace. En otras palabras, podemos entender a esta relación 9/1 como una síntesis, como el emergente de las relaciones que se establecen entre las denominaciones incluidas en las listas y muchas más ausentes (por ejemplo: las presentes, mas las 300 de Butler y todas las que surgen cada año). Al igual que los géneros "mayores", cada categoría incluida en los niveles "inferiores" puede ser comprendida como síntesis de las denominaciones más nombradas a su interior, periódicamente actualizadas. A mayor cantidad de casos, mayores las probabilidades de que las relaciones se tornen más estables ya que los porcentuales se vuelven convergentes. Si este no fuera el caso (sabemos que el último es un argumento debatible y puede no convencer a algunos), de cualquier modo veremos en breve que las afirmaciones que motivaron esta argumentación se refuerzan al analizar los mismos datos desde una perspectiva diferente.

${ }_{466}$ Variadas razones provocan las diferencias cuantitativas y cualitativas entre una y otra lista. Expondremos luego una hipótesis que podría explicarlas y que simultáneamente explica el proceso que hoy atraviesa la especie; comunmente entendido en términos de "hibridaciones entre géneros".

${ }^{467}$ En este hecho vemos un indicio que apunta hacia un posible nuevo criterio para comprender la proliferación de denominaciones; criterio que, como consecuencia directa, podría redundar en una reducción de su número. En esta línea argumental y anticipándonos al tratamiento que daremos en breve a este punto en particular, no nos extraña que sean "Disco", "House" y "Hi-NRG" las que más cruces presentan. Como dijéramos, a) al menos parte del House utilizó y utiliza samples de temas Disco (i.e.: fue y es su sublimación electrónica) y b) multiples fuentes refieren al "Hi-NRG" como una forma o estilo "energético" del House.
} 
influencia sobre la escena europea. ${ }^{468}$ Pasemos ahora a recorrer algunas cuestiones que, si bien no pueden ser apreciadas directamente, el cuadro refleja.

\section{Subgéneros, sub-subgéneros y demás... en los géneros "mayores"}

Adentrarnos en el nivel de los subgéneros permite ver las relaciones entre géneros "mayores" con nuevos ojos: a diferencia de lo que sucede con los últimos, en los niveles inferiores se vuelve mucho más evidente el profundo entrecruzamiento de características que atraviesa transversalmente a la especie. Como puede apreciarse en numerosos ejemplos de las categorías del listado incluidos en el sitio YouTube, la hibridación de cualidades se hace manifiesta no solo a la escucha (en las cualidades estético-técnicas musicales detectadas y detectables) sino incluso en los términos utilizados en las denominaciones que algunos subgéneros reciben. ${ }^{469}$

Por otra parte, más allá de las cualidades rítmicas que analizáramos -y que reúne en nuestra selección a los "mayores" en apenas 3 grandes grupos y 2 casos particulares-, los géneros y subgéneros (incluidos en los listados de Wikipedia y otros, y con ejemplos hallables en YouTube) son muy diversos en sus cualidades estéticas y técnico-musicales. Esta diversidad les brinda a sus productores una inmensa riqueza de recursos y materiales que suelen ser aprovechados en cada nueva creación. Quizá resultado de que en la especie se conjugan tradiciones que tienen origen en muy diversas partes del planeta ${ }^{470}$ y épocas históricas, cada género por sí mismo ofrece a sus productores una amplia paleta de recursos. En el seno de una comunidad propensa a la proliferación y que idolatra al reusó y al remix, tanta riqueza solo puede conducir a la constante mixtura e hibridación detectadas.

Los hay rápidos y lentos, de texturas simples y complejas, unos motorizados por progresiones armónico-melódicas, segundos por la repetición-permanencia y terceros ordenados a partir de las libertades-límites planteados por ciertos dispositivos tecnológicos concretos; los hay tranquilos, agitados y eufóricos, instrumentales y vocales-instrumentales, que apelan a convenciones provenientes de músicas populares o se presentan como primordialmente experimentales, centrados en estereotipos o excéntricos, algunos más y otros menos permeados por tradiciones musicales históricas... y una larga lista de otras cualidades que -aunque poseen

\footnotetext{
${ }^{468}$ Encontrándose incluido el Disco, resulta extraño que esta denominación no aparezca. Quizá lo mismo podríamos decir del Hip hop. La subjetividad de criterios propone grandes retos a la cuestión de los límites.

${ }^{469}$ Preferimos explicitar la aparente contradicción incluida en nuestras aseveraciones: ¿cómo pueden poseer los géneros "mayores" límites más definidos, si los subgéneros que contienen se encuentran profundamente hibridados? La contradicción parece evidente, al menos cuando se analiza el problema desde la perspectiva de géneros (la más tradicional y difundida hoy). Sin embargo creemos que efectivamente existe algo más de claridad en el nivel mayor. Pronto presentaremos las razones de esta afirmación.

${ }^{470}$ Por no atrevernos a decir "de todas".
} 
la potencialidad de manifestarse musicalmente- residen fuera del universo de cuestiones estrictamente estético-técnico-musicales.

Citados todos en tanto "géneros", por el uso que la comunidad electrónica hace de ellos $\mathrm{y}$ por cómo sus integrantes se refieren a los mismos, estos y sus subgéneros pueden ser definidos como:

conjuntos difusos de cualidades, clichés, formas y usos diversos medianamente definidos que (supuestamente) permiten agrupar a las piezas musicales de cualidades compartidas y segregarlas de aquéllas donde dichas cualidades difieren.

Así se hablará, por ejemplo, de géneros con tales o cuales cualidades musicales (tímbricas, rítmicas, armónicas, formales, instrumentales, de instrumentación, texturales, según su tempo, etc.), para tal o cual evento (noche "Trance", fiesta "Aggrotech", pista "Chill out", etc.), para el comienzo, medio o final de la noche/evento/fiesta (lo que implica diferentes "intenciones" o "caracteres") ${ }^{471}$ y un largo etcétera. Recorramos brevemente y como ejemplo lo que sobre el House dicen algunas fuentes (notas de revistas, libros, sitios en línea, periodistas y deejays entrevistados): caso paradigmático por tratarse del que más subgéneros incluye, su descripción o caracterización presenta contactos y desencuentros según la perspectiva asumida.

Snoman, entre otros autores, sostendrá que, si bien es un género muy diverso, el House se caracteriza esencialmente por basar su poética en fragmentos musicales extraídos de grabaciones de música disco de los 70s y que por ello preserva cierto "aura" del disco, funk y soul afronorteamericano. ${ }^{472}$ Esto es parcialmente cierto, muchas piezas House se basan en samples de música disco (sobre todo aquéllas producidas alrededor del año 2000)... pero muchas otras no. También es cierto que algo del groove del funk y soul (atravesado por la música disco) persiste en algunos subgéneros del House... mas no en todos. Pero entonces... ¿Cuál es el "peso específico" de este último "todos"? ¿Cuál es su relevancia efectiva?

Para que se comprenda cabalmente a qué nos referimos veamos la lista completa de subgéneros que la categoría de Wikipedia "House music genres" reconoce: big room house, acid house, french house, kwaito, latin house, ambient house, Baltimore club, Brick City club, Chicago house, deep house, diva house, electro house, electro swing, future house, garage music (US garage), ghetto house, hip house, italo house, Jersey club, progressive house, microhouse, nu-disco (o disco house), outsider house, so get up, tech house, tribal house, tropical house, UK hard house, y witch house.

\footnotetext{
${ }^{471}$ Usualmente se corresponde con: inicio, introducción o "warm up", momento de climax o euforia de la noche o "uplifting", momento o zona de descanso y relax o "chill out", para la fiesta posterior a la fiesta o "after" o "after party".

${ }^{472}$ Snoman, R. (2014) "House" en: Op. cit. pp. 343 y sgtes.
} 
Por si esto fuera poco, dicha página contiene un vínculo al tópico (también de Wikipedia) "Styles of house music". En esta nueva página los estilos previos se incluyen y describen brevemente, pero además se agregan afro house, balearic beat (o balearic house), bassline house, christian house, complextro, italo disco (o euro disco, o euro dance), dream house, dutch house, fidget house, funky house (subgénero que en su descripción dice estar conformado por sub-subgéneros también citados: french, italian, disco y latin house), glitch house, hardbag, hard bounce, hard dance, hard NRG, jazz house, madchester, moombahton, moombahcore, new beat, nu-NRG y soulfull house (o soul house). Suman un total de 51 subgéneros, solo al interior de uno de los aproximadamente 20 géneros que dicha enciclopedia reconoce como pertenecientes al nivel superior. A título de anécdota: este listado no coincide y supera en número de elementos al expuesto en el cuadro de géneros de la misma enciclopedia que incluimos previamente.

Otros autores centrarán su argumentación alrededor de una perspectiva histórica y dirán que el género deriva de las prácticas de Francis Grasso, deejay legendario del New York de fines de los años 60 a quien Levan y Knukles indican como quien les enseñara las técnicas de "beat matching" y "pitch cueing". ${ }^{473}$ Buscando que los bailarines no abandonaran la pista, Grasso inauguraría la era del flujo musical continuo, del moderno deejaying y de la creación e improvisación musical en base a la multiplicidad de dispositivos con que hoy cuentan los profesionales de la actividad. Sin lugar a dudas estos sucesos han influido e influyen enormemente en el género House. Ahora bien, en sus presentaciones Grasso mixturaba todo tipo de géneros como rock, disco, psicodelia, música tradicional africana y todo lo que considerara "apropiado" para el Sanctuary (salón de baile donde desarrolló parte de su actividad y que funcionaba en una antigua iglesia protestante).

El mismo eclecticismo y diversidad en la selección musical -según los mismos autoresreproduciría durante los últimos 1970s Frankie Knukles en la discoteca The Warehouse de Chicago. ${ }^{474}$ En este local de baile Knukles extendería las técnicas aprendidas de Grasso, lo que popularizaría tanto a la discoteca como a los "modos" y actitudes de aceptación de la diferencia practicadas por quienes asistían a la misma (en su mayoría individuos provenientes de la comunidad afronorteamericana homosexual). Para entonces, el sentido del término "house" no refería a un género musical particular y definido (a piezas de cualidades técnicas comunes, como indica hoy para muchos) sino -por un lado- a la mencionada actitud o modo de vida relajado, despreocupado o "cool" que configuraba el "ambiente" de la discoteca y -por otro- al modo en que Knukles presentaba aquéllas músicas, como un flujo continuo. ${ }^{475}$

\footnotetext{
${ }^{473}$ En pocas palabras, técnicas que permiten igualar los tempos de diferentes piezas grabadas.

${ }^{474}$ Véase al respecto el ya citado documental Pump up the volume.

${ }^{475}$ Véase por ejemplo Butler, M. (2003). Op. cit. pp. 23 y sgtes. o Snoman, R. (2014). Op. cit. pp. 231 y sgtes. Creemos oportuno mencionar algunas otras de las técnicas "creadas" por Knukles ya que consideramos que su influencia se percibe aún hoy en las músicas electrónicas de baile. Nos referimos en primer término a la técnica de "prolongar" una determinada sección de una pieza mediante la utilización
} 
Este hecho pone nuevamente en tela de juicio las hipótesis anteriores acerca de que los límites del género son dependientes de ciertas cualidades musicales determinadas. Según esta versión, la única cualidad estético-técnica musical que podría asociarse al House (al menos en la etapa de la génesis del género) es la de consistir en un flujo continuo de músicas de baile en el cual se enlazan secuencialmente múltiples cualidades musicales de muy diversa índole.

En su Energy flash Simon Reynolds reconoce también la influencia disco y agrega las obras de Giorgio Moroder y de la Escuela de Dusseldorf, ${ }^{476}$ músicas que radios locales acercaran a los habitantes de Detroit y Chicago. Según el autor, de aquí deriva la omnipresencia de sintetizadores, cajas de ritmo y secuencias en el género; como así también el ritmo de bombo en negras que lo caracteriza.

Pero entonces, ¿en qué consiste en definitiva el House? ¿Es este género que sublima al disco y que en el momento de su decadencia le permitiera sobrevivir, mixturado con influencias europeas? ¿O consiste por el contrario en cualquier flujo continuo de música de baile de características estético-técnicas diversas pero de límites indefinidos? Ni una ni otra aproximación basta para describirlo. De hecho, la última acepción resulta válida para el modo en que se presentan todos los géneros de música electrónica de baile en el transcurso de un determinado evento. ${ }^{477}$ La pertenencia de una pieza musical concreta a una u otra categoría particular posee un alto grado de subjetividad y esto se debe, al menos en parte, a que los géneros y demás denominaciones son hoy entidades extremadamente difusas, diversas, hibridadas, permeables y en constante evolución. Esta cuestión se evidencia en The Dance Music Manual: al momento de describir un determinado género al autor le resulta imposible asignarle características estético-técnicas concretas sin verse obligado luego a contradecirse y referir a diferentes salvedades y "excepciones". ${ }^{478}$

de dos discos idénticos o de cinta magnética grabada. Esta técnica consiste en reproducir el segundo ejemplar del disco desde el comienzo de la sección que se desea extender, "lanzándola" a la reproducción justo cuando el primer ejemplar alcanza el final de dicha sección. Técnica que dará origen a lo que luego se conocerá como "remix", permitía a Knukles extender la duración de piezas que, a su parecer, resultaban demasiado breves para la pista de baile. Otro elemento que determinará la estética en los años siguientes será la utilización de máquinas de ritmo (concretamente las Roland TR808 y TR909) superpuestas y sincronizadas a los discos en reproducción para reforzar la sección de percusión. Las secuencias rítmicas así producidas se constituía en otra forma de generar transiciones entre un disco y otro y así mantener el flujo continuo.

${ }^{476}$ Tendencia dentro del rock a la que también se llamó Kraut rock. Proyectos musicales que se mencionan como exponentes de este movimiento son Kraftwerk y Tangerine Dream.

${ }^{477}$ Solo en su sentido histórico esta acepción podría definir al concepto "House". Esto es, como un sinónimo en todo equivalente del actual "música electrónica de baile".

${ }^{478}$ En este marco creemos oportuno mencionar que no hemos considerado aún la influencia que tienen los elementos de músicas históricas o no electrónicas (i.e.: tango, cumbia, reggae, folklore, etc.) sobre los que podríamos llamar "géneros tradicionales" de la música electrónica de baile. Cualidades provenientes de aquéllos, constantemente se incorporan al repertorio de posibles de la especie, amplían aún más su diversidad y generan mayor ambigüedad sobre la hibridación "endógena". Para más detalles al respecto véase en el cuerpo principal del trabajo el título Localismos e hibridaciones. Primeras conclusiones en torno a la rítmica. 
La problemática del House, con matices y diferencias, es paradigmática de lo que sucede en general en la música electrónica de baile. Por ello, anclarnos a esta perspectiva solo puede conducirnos al mismo callejón sin salida de contradicciones e inconsistencias que caracteriza hoy a los intentos de explicar a la especie y a sus (sub y sub-sub) géneros. Si inicialmente tomamos este camino fue porque era necesario ubicarnos en lo que la comunidad electrónica toda utiliza como lenguaje común, y que por lo tanto determina el presente de la especie. Este recorrido nos permitió comprender sus modos de entender y explicar a su objeto predilecto y, simultáneamente, favoreció la detección de equivalencias entre las terminologías utilizadas en las comunidades electrónica y académica. Los términos ahora compartidos facilitan el diálogo entre estos dos universos.

\title{
Géneros, subgéneros, sub-subgéneros y más
}

Creemos oportuno recorrer ahora algunas perspectivas académicas en relación al tema. Específicamente los trabajos ya citados de McLeod y Demers.

En su Genres, Subgenres, Sub-Subgenres and More: Musical and Social Differentiation

Within Electronic/Dance Music Communities, Kembrew McLeod desarrollará los que considera los cinco factores principales que promueven el surgimiento de los géneros y demás denominaciones en la música electrónica de baile. Para el autor:

\begin{abstract}
El proceso de nombrar nuevos subgéneros dentro de las comunidades [vinculadas a la] música electrónica/de baile -no solo- se relaciona directamente con la naturaleza de veloz cambio de la música en sí misma [sino que] también es una función de las estrategias de mercadotecnia de las compañías discográficas, [de la] cultura del consumo acelerado y [de] la apropiación de músicas de (mayoritariamente) personas noBlancas de clases bajas por Blancos de clases media y media alta en los Estados Unidos [de América] y Gran Bretaña. Además, el proceso de nombrado actúa como un mecanismo de "guardián de puerta" que genera la necesidad de [poseer] una gran cantidad de capital cultural para ingresar a las comunidades electrónicas/de baile. ${ }^{479}$
\end{abstract}

Brevemente y en otras palabras, para McLeod nuevas denominaciones surgen:

a) Como respuesta a una genuina evolución de los estilos. Único factor que evidenciaría la ocurrencia de cambios estético-técnicos musicales reales, concretos. Evolución que además caracteriza como "veloz".

\footnotetext{
479 "The process of naming new subgenres within electronic/dance music communities is not only directly related to the rapidly evolving nature of the music itself. It is also a function of the marketing strategies of record companies, accelerated consumer culture, and the appropriation of the musics of largely nonWhite, lowerclass people by middle- and upper-middle-class Whites in the United States and Great Britain. Further, the naming process acts as a gate-keeping mechanism that generates a high amount of cultural capital needed to enter electronic/dance communities." McLeod, K. 2001. Op. cit. pp.60 Nótese el sesgo geopolítico al referir solo a los Estados Unidos y Reino Unido, en tanto las (únicas) naciones donde este fenómeno sucede y tiene origen.
} 
b) Promovidas por las empresas discográficas como estrategia de mercadeo. A nuestro modo de ver, muchas veces denominaciones caprichosas que acompañan músicas donde no se aprecian cambios estético-técnicos sustanciales que justifiquen su existencia. Las compañías pretenden así adelantarse a las respuestas del mercado y crear profecías autocumplidas ofreciendo falsas "nuevas tendencias que harán escuela".

c) Como ejemplo de la cultura de consumo acelerado. La manifestación, en el campo de la música, de constantes demandas de "nuevos" bienes culturales por parte de los consumidores. Conceptualmente vinculado a la obsolescencia programada, tanto aquéllas como esta son estimuladas por las compañías discográficas a través de las estrategias de mercadeo.

d) Como apropiación cultural, por parte de grupos sociales dominantes, de bienes culturales surgidos en comunidades o "ghettos" estigmatizados. McLeod dirá que

El acto de cambiar el nombre a los géneros (por ejemplo, de house a techno) puede ser visto como un acto de resignificar la "otredad" del nombre original, para darle un sentido que está menos asociado a la negritud y se rearticula como una música universal, global. ${ }^{480}$

e) Como un dispositivo de pertenencia a la subcultura (o comunidad) electrónica o "guardián de entrada". La posesión de este conocimiento especializado se vuelve la forma en la que los miembros "iniciados "de la comunidad se distinguen de quienes aún no poseen tal capital.

Estas reflexiones en torno a los posibles orígenes arrojan algo de luz acerca de las diversas razones que podrían encontrarse detrás del surgimiento y proliferación de las denominaciones, como así también expanden el abanico de sentidos que rodean a cada denominación y (sub-)género. Algunos ejemplos pueden ilustrar los modos en que interactúan algunos de los factores descriptos por McLeod.

En su libro The Dance Music Manual, Rick Snoman dedica algunos capítulos a ciertos géneros de la especie iniciando los mismos con un recuento de una posible historia de cada uno. En el dedicado al género Ambient/Chill Out Snoman narra cómo Alex Patterson, basándose en ciertos trabajos de Brian Eno, decidió unir fuerzas con Jimmy Cauty y formar el grupo The Orb para producir música electrónica de baile en un "estilo" diferente a los ya existentes en el momento: género más tranquilo, de tempo más lento, relajado y destinado a ciertos espacios de los clubes donde los bailarines iban a descansar ("chill out") de la agitación de la pista. En otras palabras, estos espacios brindarían un nicho de mercado para el cual no existía hasta entonces

480 "The act of changing genre names (for instance, from house to techno) can be seen as an act of resignifying the "otherness" of the original name, to give it a meaning that is less associated with Blackness and is rearticulated as a universal, global music." McLeod, K. 2001. Op. cit. p.71 Recuérdese aquí el orígen doblemente marginal (afronorteamericano, homosexual) de la música electrónica de baile. 
una música específica. Luego relatará que, frente al relativo éxito comercial del mismo, la industria discográfica y otros músicos independientes se "subieron a la ola" buscando rédito económico. Este proceso paulatino daría origen al género hasta que finalmente, "alrededor de 1995, las mayores compañías discográficas saturaron el mercado con incontables compilaciones ambient." ${ }^{481}$ Con matices, similares relatos de "encuentros" de pioneros "reunidos" alrededor de nuevas formas musicales y/o nuevas formas de crear música, seguidos luego por un número mayor de músicos y la industria discográfica imitándolos, se utilizan para explicar el surgimiento de varios géneros en las dos últimas ediciones de su libro. ${ }^{482}$

El origen de algunos géneros a partir de un comportamiento imitativo por parte de los productores -comportamiento estimulado a su vez por las compañías discográficas- puede ser constatado comparando algunas piezas de género y período histórico acotados. Como explicáramos en títulos previos, la imitación del "estilo" de artistas reconocidos, el sampleo de fragmentos reconocibles, el remix de piezas que alcanzaron conocimiento masivo, la adquisición del mismo modelo de dispositivo que utiliza el grupo admirado son, entre otros procesos imitativos, prácticas comunes y aceptadas entre los cultores de la música electrónica de baile. En algún sentido, estas prácticas son incluso esperadas por los simpatizantes de la especie. Los elevados precios de reventa que aún hoy poseen equipos clásicos como las Roland TR808 y TR909, o el sintetizador de bajos TB303 (también de Roland) dan cuenta de esto.

Ejemplo también es la peculiar historia alrededor de lo que se conoce como el "Amen Break": sample de menos de 6 segundos de duración originado en un corte de batería del lado B del disco simple Amen Brother de 1969 de la banda The Winston's. A partir de los primeros años de la década de 1980 el fragmento sería utilizado en incontables nuevas piezas dando origen al rap, género que a su vez sentaría las bases de los modernos Drum'n'Bass, Jungle y demás expresiones basadas en breakbeats ${ }^{483}$ y les brindaría una de sus características más distintivas y reconocibles. ${ }^{484}$ En la segunda edición de su libro, Snoman ofrece una lista de algunos de los artistas y piezas que lo utilizan. Ilustrativa de nuestros argumentos, la reproducimos aquí:

\author{
Mantronics: King of the Beats \\ 2 Live Crew: Feel Alright Yall \\ 4 Hero: Escape That \\ Amon Tobin: Nightlife
}

\footnotetext{
481 "By 1995, the larger record companies took the sound on board and saturated the market with countless ambient compilations." Snoman, Rick. The Dance Music Manual. Third Edition. (2014). Edición digital. pp.314

482 A modo de ejemplo, véase los capítulos correspondientes de la tercera edición de The Dance Music Manual de "Trance" (pág. 287), "Dubstep" (pág. 301), "Drum'n'bass" (pág. 329), "House" (pág. 343) y "Techno" (pág. 363).

${ }^{483}$ Wikipedia. Enciclopedia en línea. Vínculo disponible en https://es.wikipedia.org/wiki/Amen break [22032016]

${ }^{484}$ Incluimos el vínculo ya citado al video en línea Video explains the world's most important 6-second drum loop: https://www.youtube.com/watch?v=5SaFTm2bcac\&feature=share. [30032015]
} 
Aphex Twin: Boy/Girl Song

Atari Teenage Riot: Burn Berlin Burn

Brand Nubian: The Godz Must Be Crazy

Deee-Lite: Come on In, the Dreams are Fine

Dillinja: The Angels Fell

Eric B \& Rakim: Casualties of War

Freestylers: Breaker beats

Funky Technicians: Airtight

Heavy D: MC Heavy D!

Heavy D: Let it Flow

Heavy D: Flexin'

Heavyweight: Oh Gosh

J. Majik: Arabian Nights

J. Majik: Your Sound

Lemon D: This is Los Angeles

Level Vibes: Beauty \& the Beast

Lifer's Group: Jack U. Back ( So You Wanna Be a Gangsta )

Ltj Bukem: Music

Maestro Fresh Wes: Bring it On (Remix )

Movement Ex: KK Punani

Nice \& Smooth: Dope Not Hype

Salt-N-Pepa: Desire

Scarface: Born Killer

Schoolly D: How a Black Man Feels

Goldie: Chico: Death of a Rock Star

Roni Size: Brown Paper Bag ( Nobukazu Takemura Remix )

Oasis : Do Y'Know What I Mean

Frankie Bones: Janets Revenge 485

\section{[Paréntesis retro-tecnológico]}

Como puede apreciarse del uso dado por los productores al "Amen Break", lejos se encuentra la música electrónica de baile de hacer culto de las últimas tecnologías. Creemos oportuna la inclusión de ciertos dichos de Butler, muy clarificadores respecto de este asunto:

En la prensa popular, la música electrónica de baile suele retratarse como música "hightec" hecha con la última tecnología. Sin embargo, [...] esta caracterización es más que simplista. Por una parte, es cierto que las innovaciones tecnológicas [...] han provocado grandes impactos en el desarrollo de la EDM, y que muchos músicos de la EDM han recibido las nuevas invenciones con los brazos abiertos. Por el otro, sintetizadores analógicos, cajas de ritmos pre-MIDI y discos de vinilo son también esenciales en la creación de música EDM. Claramente, la tecnología obsoleta es tanto una parte de la fetichización de la máquina en la EDM como el último aparatito, y la herramienta simple puede ser tan importante como el dispositivo más complejo. ${ }^{486}$

[Fin del paréntesis]

\footnotetext{
485 Snoman, Rick. The Dance Music Manual. Tools, Toys \& Techniques. Second edition. (2009). Edición digital. pp.14-15

486 "In the popular press, electronic dance music is often portrayed as "high-tech" music made with the latest technology. However, [...] this characterization is overly simplistic. On the one hand, it is true that technological innovations [...] have had major impacts on EDM's develpment, and that many EDM musicians have welcomed new inventions with open arms. On the other hand, analog synthesizers, preMIDI drum machines, and vinyl records are also essencial to music-making in EDM. Clearly, obsolete technology is just as much a part of EDM's fetichization of the machine as is the latest gizmo, and the simple tool can be just as important as the most complex of devices." Butler, M. 2003. Op. cit. p. 51
} 
Retomando las perspectivas teóricas, Demers explicitará sus objetivos al decir que en su trabajo "ofrece una teoría estética de la música electrónica reciente, una teoría que reconoce la interconectividad de la estética con la cultura y la sociedad." ${ }^{487}$ Como en títulos precedentes, aquí también se refiere al tema de los géneros en un nivel superior al que hemos desarrollado y principalmente desde la perspectiva de la experimentación. Por ello dividirá a la música electrónica en los tres "metagéneros" que -considera- conforman la especie: música electroacústica institucional (nuestra música electrónica o electroacústica), electrónica (nuestra música electronica de baile) y arte sonoro (el cual no tratamos y al que ubica en los límites del concepto de música). En este contexto y siguiendo parcialmente a McLeod y a otros autores sostendrá que:

Parte de la clave para comprender a la música electrónica involucra comprender el [concepto de] género [...] Ayuda, pensar al género como una suerte de contrato social entre músicos y oyentes, una configuración de convenciones que pueden relativamente guiar la experiencia de escucha. Con suficiente experiencia, un oyente llega a conocer qué esperar de un track techno y porqué el techno generalmente se comporta diferente de, digamos, el house, aún cuando ambos son fundamentalmente formas similares de EDM. Los momentos interesantes en cualquier género ocurren, por supuesto, cuando las expectativas se frustran de algún modo, cuando un trabajo hace algo que no se "supone" que haga de acuerdo a las reglas de su género. [...] El género es de extrema importancia en cualquier discusión de música electrónica, porque el género gobierna a la música electrónica, dividiendo a sus participantes en campos que ellos mismos suelen percibir como inconmensurables entre uno y otro. ${ }^{488}$

Varios capítulos al interior del desarrollo, retomará este mismo tema para decir que:

Mucha de la dificultad al hablar de la estética de música electrónica reside en identificar qué es la música electrónica y decidir si consiste o no en una entidad demasiado grande para ser discutida como unidad. La mayoría de los practicantes probablemente coincidirían en que la música electrónica como un todo es demasiado heterogénea para ser considerada como un género único. Pero si esto es así, ¿a qué nivel de especificidad aparecen las demarcaciones de género? ¿Es suficiente distinguir entre formas alta y popular de música electrónica, o esas entidades deberían constituir metagéneros en vez de géneros? De cualquier modo, ¿qué significan hoy "alta" y "popular"? Y si refinamos el nivel de especificación a lo que una tienda de música en línea considera estilo, ya sea ambient, electroacústica o techno, ¿contrapesa la especificidad que podemos ganar de esas etiquetas, la confusión que un número siempre proliferante de estilos crea por igual

\footnotetext{
487 "... offers an aesthetic theory of recent electronic music, a theory that acknowledges the interconnectedness of aesthetics with culture and society." Demers, J. 2010. Op.cit. pp.7

488 "Part of the key to getting things right in electronic music involves understanding genre [...] It's helpful to think of genre as a sort of social contract between musicians and listeners, a set of conventions that can more or less guide the listening experience. With enough experience, a listener comes to know what to expect in a techno track and why techno generally behaves diff erently from, say, house, even though both are fundamentally similar forms of EDM. The interesting moments in any genre occur, of course, when expectations are in some way thwarted, when a work does something it is not "supposed" to do according to the rules of its genre. [...] Genre is of the utmost importance to any discussion of electronic music, because genre rules electronic music, dividing participants into camps that oft en perceive themselves as incommensurate with one another." Ibidem. p.10 Nótese como Demers sostiene la perspectiva tradicional de "oyente" (i.e.: "listeners") incluso para los bailarines de su electrónica.
} 
para oyentes y practicantes? En síntesis, podemos realizar una sucinta pregunta: ¿Qué esperamos que el género haga por nuestra comprensión de la música electrónica? ${ }^{489}$

Inmediatamente después ensayará algunas respuestas a su pregunta. Siguiendo a John Frow dirá que el género es un método de comunicar conocimiento. Para Frow, género "es una conformación de límites convencionales y altamente organizados en la producción e interpretación de sentido." ${ }^{490}$ Demers comentará entonces que "Aún con una conciencia pasajera del género al que un trabajo pertenece, las audiencias pueden predecir qué hará y que no hará el trabajo." ${ }^{491}$ Coincidirá luego con McLeod en que el género no es una cualidad abstracta sino un cociente de relaciones sociales y decisiones de consumidor. Focalizará especialmente en las razones de McLeod que hemos expuesto previamente en el apartado e) y vinculará dichos argumentos con los de Frow.

\begin{abstract}
McLeod deja esto en claro en su discusión acerca de la multitud de géneros de electrónica orientada a la danza, [multitud de géneros] que usualmente asciende a series de provocativas etiquetas para tipos de música que [a oídos de] inexpertos pueden sonar indistinguibles entre sí. [...] Entonces, mientras el género puede, de acuerdo a Frow, iluminar algo acerca de un trabajo, también puede colocar grandes expectativas en el conocimiento de un oyente. Género es, en otras palabras, una vía de cultivar una actitud de ustedes-y-nosotros que divide al público entre aquéllos que saben algo acerca de una música dada y aquéllos que no. ${ }^{492}$
\end{abstract}

Por último, relacionará estas ideas con las conclusiones a las que Kronengold arriba a partir de sus estudios sobre los géneros Disco y New Wave de fines de los 1970s.

[Estos estudios] nos recuerdan que así como las canciones se enmarcan en géneros, las canciones también contienen géneros. Muchas canciones disco casualmente invocan las convenciones de otros géneros como el pop del "Top 40" sin abandonar su propio formato disco y de baile. Un buen productor disco habrá manipulado el género tan fácilmente y con tanta amplitud como la estructura o la instrumentación. Pero a diferencia de otros parámetros maleables como la estructura o la interpretación, el género comunica conocimiento acerca del contexto del trabajo musical. Sitúa al trabajo

\footnotetext{
489 "Much of the difficulty in talking about electronic-music aesthetics lies in identifying what electronic music is and deciding whether it is too big to discuss as one entity. Most practitioners would probably agree that electronic music as a whole is too heterogeneous to be considered as a single genre. But if so, at what level of specification do the genre demarcations appear? Is it enough to distinguish between high and popular forms of electronic music, or should those entities constitute metagenres instead of genres? What do high and popular now mean, anyway? And if we hone down the level of specification to what an online music store might consider style, whether ambient, electroacoustic, or techno, does the specificity we can gain from such labels outweigh the confusion that an ever-proliferating number of styles creates for listeners and practitioners alike? In short, we can ask one succinct question: What do we expect genre to do for our understanding of electronic music?" Ibidem. pp.135-6

${ }^{490}$ Frow, J. 2005. Genre. Citado en Demers, J. 2010. Op.cit. p.136

${ }^{491}$ Ibidem.

492 "McLeod makes this clear in his discussion of the multitude of dance-oriented electronica genres, which often amount to a series of provocative labels for types of music that a nonexpert might hear as indistinguishable from one another. [...] So while genre can, according to Frow, illuminate something about a work, it can also place great expectations on a listener's knowledge.Genre is, in other words, a way of cultivating an us-and-them attitude that divides the public into those who know something about a given music and those who do not." Ibidem.
} 
de una manera análoga a la que un sonido particular, en una grabación de campo o en un paisaje sonoro, lo sitúa en una geografía local o trasfondo cultural [determinado]. ${ }^{493}$

A pesar de las diferencias respecto del objeto tratado, los argumentos de Demers son directamente trasladables a las relaciones al interior de la música electrónica de baile. Reemplazando las "formas altas" y "populares" por, respectivamente, "géneros" y "subgéneros" es posible aplicar sus dichos a las relaciones entre -a modo de ejemplo- unas y otras categorías. Además, no solo es debatible la unicidad de la especie que constituye nuestro caso de estudio sino que también pareciera pertinente preguntarnos a qué nivel o niveles de especificidad deberíamos aplicar (siempre dentro de la música electrónica de baile) las demarcaciones de géneros y subgéneros. La diversidad y variabilidad que se detecta al interior de cada género y subgénero -y que suscitara en primer término el desarrollo del presente anexo- vuelve más que evidente la importancia central de estas cuestiones. Reducir las categorías en demasía nos deja con denominaciones que, si comunican algo, apenas dicen generalidades de las cualidades de las piezas contenidas; mientras que un exceso en el número de aquéllas nos conduce al extremo opuesto de denominaciones que, si algo dicen, apenas comunican especificidades de casos particulares o incluso únicos. ${ }^{494}$

A partir del debate de autores, resulta claro entonces que una multiplicidad de sentidos musicales y extramusicales son incluidos en y comunicados por las piezas musicales como "información de género". También queda claro que todos los autores entienden a cada género en tanto conjuntos de sentidos esencialmente divergentes en relación a los demás. Si bien pueden existir puntos de contacto, estos deben ser siempre marginales ya que justamente en dicha divergencia reside la razón para la existencia efectiva de cada género; en las diferencias esenciales entre uno y otro se justifica la razón de ser de cada uno. Por otra parte, de múltiples maneras, la información asociada a cada género y denominación (y plasmada en cualidades poético-estético-técnicas musicales) comunica sentidos asociables a múltiples y muy diversas esferas de la existencia humana. Las interacciones dinámicas entre estos múltiples y muy diversos sentidos y géneros brinda más fuerza a los argumentos de Kronengold en el contexto de la música electrónica de baile ya que, en las piezas de la especie, se "invocan las convenciones de otros géneros" de forma mucho más directa. Esto es así desde que numerosas

\footnotetext{
493 "[Kronengold's examination of late-1970s genres such as disco and New Wave] reminds us that just as songs fit into genres, songs also contain genres. Many disco songs casually invoke the conventions of other genres such as Top 40 pop without abandoning their own disco-dance format. A good disco producer would have thus manipulated genre as easily and with as much latitude as song structure or instrumentation. But unlike other malleable musical parameters like structure or interpretation, genre communicates knowledge about the context of a musical work. It situates works in a manner analogous to the way a particular sound in a field recording or a soundscape composition situates a work within a geographical locale or cultural background." Ibidem. pp. 136-7

${ }^{494}$ En casos extremos de denominaciones que remiten a un número muy reducido o incluso a una única pieza, la denominación se vería reducida a comunicar mucho menos que la obra misma, perdiendo toda razón de ser al no operar en los sentidos referidos por los autores estudiados.
} 
piezas y géneros de la especie se basan en samples musicales extraídos de músicas preexistentes y/o utilizan samples extraídos de tomas de campo o sonidos encontrados. En otras palabras:

\title{
Todo género basado en samples de una mediana extensión que haga uso de
}

los mismos en formas próximas al original (i.e.: que el procesamiento no alcance el punto de volverlos irreconocibles, que no cambie demasiado sus cualidades sono-musicales identitarias básicas, esenciales) preservará y comunicará información y características estético-técnicas -siempre parciales- de la situación de captura y/o del género musical de origen del sample.

Demers dirá que la "electrónica" (recuérdese, su forma de referir a nuestra música electrónica de baile) considera y trata a la música en tanto signo y que, como tal:

\begin{abstract}
A pesar de que puede ser inocente ofrecer una teoría única para explicar cada faceta de cada género de electrónica, quiero hablar acerca de cómo oyentes y practicantes escuchan los sonidos de la electrónica como metáforas. Estas metáforas pueden vincular a una pieza particular con una red de conceptos externos tales como la historia de otros trabajos musicales, el espacio exterior, el pasado o el material en el cual el sonido se codifica. Los sonidos de la electrónica, en otras palabras, son siempre escuchados en relación a algo más allá de las piezas que los contienen, pero estos vínculos al mundo exterior no tienden a ser miméticos como [sí sucede] en la música electroacústica PostSchaefferiana. En la electrónica, la relación entre significante y significado no se basa en simple semejanza sino en convenciones que a través del tiempo emparejaron a cada sonido con un concepto exterior. ${ }^{495}$
\end{abstract}

Según la autora, esto sucede debido principalmente a que:

Las grabaciones congelan momentos en el tiempo y los pone en disponibilidad para reiteradas contemplaciones. En simples términos, las grabaciones cambian el status ontológico del sonido desde lo fugaz e impermanente a lo eternamente presente. La música basada en samples entonces posibilita un modo de comunicación imposible en toda música previamente creada, ya que los samples pueden cargar no solo con su contenido sónico y musical subyacente sino también con los sonidos involucrados en la mediación de la grabación que denotan la antigüedad de la misma. Muchos samples sobresalen en la textura de un trabajo [i.e.: de una pieza musical] gracias a los artificios de grabación como pops, scratches, o la manipulación de la velocidad o dirección de reproducción de la cinta [magnética de grabación]. Tentadoramente, sin embargo, los samples en la más reciente electrónica no revelan necesariamente su antigüedad. Las tecnologías de edición de sonido han hecho posible ocultar toda huella de los artificios

\footnotetext{
495 "While it would be naive to offer a single theory to explain every facet of every electronica genre, I want to talk about how listeners and practitioners hear electronica's sounds as metaphors. These metaphors can link a particular work with a web of external concepts such as the history of other musical works, outer space, the past, or the material on which sound is encoded. Electronica's sounds, in other words, are always heard in relation to something beyond the works in which they are housed, but these linkages to the outside world tend not to be mimetic as do the sounds in post-Schaeff erian electroacoustic music. In electronica, the relationship between signifier and signified is not based on simple resemblance but rather on conventions that over time have paired a sound with an exterior concept." Demers, J. 2010. Op.cit. pp. 45
} 
de grabación, permitiendo a un sample sonar contemporáneo [i.e.: creado sincrónicamente] a materiales interpretados en el presente. Contrariamente, es posible lograr que samples suenen como si fueran más antiguos que su verdadera edad mediante el agregado de artificios de grabación artificiales (como el sample de Parsifal en Wireles Fantasy). Los samples, en otras palabras, pueden mentir su edad, identidad y orígenes. ${ }^{496}$

Así podemos comprender entonces la remisión de cierto House al Disco y su identificación parcial mutua. Así también podemos comprender al subgénero Industrial -el cual utiliza samples provenientes de dicho contexto (sonidos capturados en industrias y fábricas)- y a su sub-subgénero Aggrotech -que recurre a sonidos de maquinaria agropecuaria. Ya sean samples reales (de grabaciones antiguas y originales del Disco o de motores, herramientas y motores de fábricas) o reconstrucciones (las "mentiras" de Demers), lo cierto es que estos sentidos son incorporados efectivamente en las cualidades musicales de las nuevas piezas. Refiriéndose al dúo Matmos y a los artistas (todos electrónicos) Steven Takasugi y John Wall, Demers dirá que "Los tres artistas reconocen que los samples necesariamente traen a nuevos trabajos asociaciones con sus entornos originales." ${ }^{497}$

Del mismo modo podemos comprender a la partícula "tech" de Aggrotech. Contracción de Techno, remite a una cualidad asociada a lo tecnológico. Quizá podríamos asociarla también a los sentidos de "futuro", "máquina", "robot", "metal", "circuitos", "engranajes", "motor" y toda aquélla cualidad vinculada a dispositivos construidos por la mano del hombre pero al mismo tiempo "no-humanos" o "anti-natural". Por supuesto, esta cualidad ha ido cambiando con el desarrollo tecnológico y así cambió también la cualidad de estas músicas con el paso del género... y del Tiempo. Tanto es así, que muchos opinan que no son lo mismo el Techno de los años 1980s con el Tecno de los 2010s (apenas veintitantos años después y una "h" menos). Las razones para esto son evidentes: las ideas que de "futuro", "no-humano", "anti-natural" y demás sentidos tuvimos y tenemos cambiaron al ritmo vertiginoso del desarrollo tecnológico. Recurriremos una vez más a Demers para explicar estas cuestiones:

\footnotetext{
496 " Recordings freeze moments in time and make them available for repeated contemplation. Simply put, recordings change the ontological status of sound from fleeting and impermanent to eternally present. Sample-based music thus affords the possibility for a mode of communication impossible in all previously created music, for samples can convey not only their underlying sonic or musical content but also the surrounding sounds of recording mediation that signify age. Many samples stand out from the texture of a work thanks to recording-mediation sounds such as pops, scratches, or the manipulation of tape-playback speed or direction. Tantalizingly, however, samples in much recent electronica do not necessarily reveal their age. Sound-editing technologies have made it possible to hide all traces of recording mediation, allowing a sample to sound contemporaneous with materials performed in the present. Conversely, samples can be made to sound older than their true age through the addition of artificial recording mediation (such as the Parsifal sample in Wireless Fantasy). Samples, in other words, can lie about their age, identity, and origins." Demers, J. 2010. Op.cit. pp. 54-55 Si bien puede parecer redundante hablar de "artificios artificiales", en este caso creemos que es el modo más apropiado de traducir el sentido del texto original. La obra referida es una pieza de 1960 de Vladimir Ussachevsky realizada principalmente en base a señales de radiofrecuencias y la cita mencionada. Vladimir Ussachevsky's "Wireless Fantasy". Subida por MrDrSmithJr. Accesible en https://youtu.be/bEShy2QIj4U [06102016]

${ }^{497}$ Ibidem. pp. 61
} 
Incontables músicos, abogados y personal de la industria musical han argüido que el proceso de sampleo se parece al robo. Parte de la inquietud alrededor del sampleo naturalmente involucra cuestiones de propiedad intelectual. Pero los valores en conflicto de originalidad y autoría fallan en explicar el más básico sentimiento: que el sampleo es fundamentalmente un fenómeno antinatural. Y esa antinaturalidad proviene de la conciencia de los oyentes de que los "collages" sonoros hacen, lo que no puede ninguna pieza regular de música: encadenar juntos a improbables sonidos. ${ }^{498}$

El hecho de que exista información incluida al interior de piezas musicales, evidente para el caso de las músicas basadas en samples, resulta cierto para todo sonido y conformación utilizados en toda música. Lo que analizáramos para la denominación "Techno" resulta aplicable, con matices y particularidades, a toda otra denominación utilizada en la música electrónica de baile. En diferentes grados y en múltiples dimensiones, todo evento sonoro y musical remitirá a la experiencia previa del sujeto perceptor $\mathrm{y}$, referenciándose en esta, convocará asociaciones y respuestas emotivas diversas. Incluso en aquéllas músicas en que sus autores pretenden alejarse lo más posible de esta referencialidad, la negación o desvío de la misma permanece activa generando, al menos, extrañamiento. Demers, siguiendo a Adorno lo dirá del siguiente modo:

\begin{abstract}
Aunque la síntesis puede ser definida técnicamente como la creación de nuevos sonidos, los oyentes inevitablemente comparan lo que escuchan con sonidos preexistentes y los categorizan de acuerdo al tipo de equipamiento que puede haberlos producido. Esta conclusión puede en principio parecer meramente una confirmación de lo que sabemos instintivamente: damos sentido a las percepciones sobre la base de lo que ya hemos vivido. Sonidos construidos, no importa cuánto se los pretenda nuevos, son en última instancia experimentados como metáforas que asemejan lo desconocido a lo familiar. ${ }^{499}$
\end{abstract}

En este marco y a modo de ejemplo, los diferentes sonidos y conformaciones que componen al "Trance" de algún modo refieren (o mejor, pretenden referir y promover) al estado hipnótico asociado a ciertos rituales y substancias psicoactivas. Si bien luego derivaría y se diversificaría, en oportunidad de su surgimiento los géneros y subgéneros que incorporaron este término pretendían tener vínculos con dichas prácticas. En algún sentido, el género "inducía" al

498 "Countless musicians, lawyers, and music industry personnel have argued that sampling is akin to theft. Part of the disquiet in sampling naturally involves issues of intellectual property. Yet conflicting values of originality and authorship fail to explain the more basic sentiment that sampling is a fundamentally unnatural phenomenon. And that unnaturalness stems from listeners' awareness that sound collages do what no regular piece of music can do in stringing unlikely sounds together." Ibidem. pp. 62 La frase final "stringing unlikely sounds together" (que tradujéramos en "encadenando juntos a improbables sonidos") resulta quizá confusa. Creemos que la autora pretendió significar que los mencionados "collages" presentan -juntos, agrupados- sonidos que asociamos a universos tan diferentes que resulta extraño escucharlos contenidos en un mismo y único contexto.

499 "Although synthesis might technically be defined as the creation of new sounds, listeners inevitably compare what they hear with preexisting sounds and categorize new sounds according to the type of equipment that might have produced them. This conclusion might at first seem merely to confirm what we know instinctually: we make sense of sensory perceptions on the basis of what we have already lived. Constructed sounds, no matter how much they might be intended as new, are ultimately experienced as metaphors likening the unknown to the familiar." Demers, J. 2010. Op.cit. pp. 50 
trance; el ordenamiento concreto de las cualidades estético-técnicas musicales generaba una pretendida promoción de estados alterados de conciencia; como si en esas cualidades estuviera "embebido" el trance, como si la música "fuera" trance. A partir de las derivas mencionadas, estos sentidos se trasladarían del "trance" al actual "psychedelic" (i.e.: el inglés para psicodélico) y a su contracción "psy". Del mismo modo pero comunicando otros sentidos, debe comprenderse a todas las denominaciones de la especie como "Electro", "Drum'n'Bass" o "Chill out", como también a aquéllas denominaciones que pueden no resultar tan evidentes para los no iniciados como "Darkstep", "Italo dance" o "Illbient". Creemos que parafrasear a Demers brindará gran claridad respecto de esta cuestión:

¿Es suficiente distinguir entre géneros y subgéneros de música electrónica de baile, o esas entidades deberían constituir índices en vez de géneros? De cualquier modo, ¿qué significan hoy "género" y "subgénero"?

Los términos que se utilizan para denominar a los (sub y sub-sub) géneros de la música electrónica de baile, independientemente de cuál fuera su rol de origen, deben ser comprendidos hoy en tanto:

índices que nominan cualidades y sentidos parciales, plausibles de ser mixturados e hibridados con otros.

Incorporando siempre cada índice informaciones de diferentes dimensiones, algunos comunicarán información musical (por ejemplo: del instrumental o timbres utilizados, del mismo género o de géneros previos y otros) mientras que otros comunicarán sentidos o informaciones de otra índole. Recorremos en el Anexo III algunas características estéticotécnicas musicales incluidas en los géneros que reconociéramos como "mayores", veamos aquí algunos de esos "otros" sentidos que podrían encontrarse incluidos en los diferentes (sub y subsub) géneros.

\section{Géneros, subgéneros, sub-subgéneros y estilos como índices}

Como Demers, consideramos que esta información multidimensional se encuentra efectivamente incluida tanto en las músicas agrupadas bajo cada denominación como en las denominaciones mismas. Debido a que se basa en "convenciones que a través del tiempo emparejaron a cada sonido con un concepto exterior", dicha información puede no resultar obvia y demandar "grandes expectativas en el conocimiento" del oyente no iniciado. A pesar de ello suelen bastar pocas palabras (por parte de alguien sí iniciado) para que aquél logre hacerse 
una idea aproximada del sentido contenido y comunicado; bastan pocas palabras para que se haga evidente al no iniciado la relación entre la denominación y la información implícita en ella.

Intentaremos entonces breves descripciones de cada género "mayor" a partir de un conjunto abierto de cualidades que creemos efectivamente incluidas tanto en las denominaciones (i.e.: en las "etiquetas" utilizadas para nombrar cada género "mayor") como en las cualidades técnico-estéticas de las músicas denominadas. Si bien esta aproximación puede $a$ priori parecer poco ortodoxa o de un carácter demasiado subjetivo, confiamos en que cotejar las breves palabras acerca de cada denominación con la escucha de ejemplos de los mismos permitirá acordar (por supuesto con matices) con nuestros argumentos. ${ }^{500}$

En otro orden de cosas, estamos convencidos de que todo músico coincidirá con nosotros en que:

la única síntesis posible de la complejidad musical es necesariamente una descripción de "carácter".

Dicho de otro modo, el intento de describir con breves palabras la "totalidad" (siempre virtual, parcial) de las cualidades estético-técnicas de una pieza musical concreta, desembocará siempre en una adjetivación que remite a cierto carácter musical. Carácter que definimos como:

ciertos sentidos, siempre múltiples, que parecen de algún modo comunicados por/contenidos en/referidos por las conformaciones poético-estético-técnicas de una pieza.

La razón de que puedan considerarse comunicados, contenidos y referidos reside en el propio acuerdo (nuevamente, nunca total, siempre parcial) detectado acerca de los mismos en las fuentes documentales y en nuestra interacción con la comunidad electrónica. Este acuerdo tiene por base la misma que sustenta a las denominaciones y géneros, y sería simplemente otra forma de decir que un determinado género posee tal o cual cualidad rítmica, tímbrica o de

\footnotetext{
${ }^{500}$ Habiendo atravesado este camino, comprendemos ahora lo que al inicio recibíamos como respuesta de quienes eran en su momento nuestras fuentes de consulta. Así como entonces se nos advirtió, así nos toca ahora a nosotros advertir a quien pretende iniciarlo: como todo conocimiento de índole práctica y vinculado a la música, éste solo se aprehende luego de horas y horas de escuchas atentas, conscientes e, idealmente, guiadas. Esperamos que los argumentos vertidos en el presente estudio sirvan de guía (o, al menos, de ayuda) y mitiguen la ansiedad que (quizá como a nosotros) puede asaltar al ánimo frente al desconcierto que genera no encontrar maneras de abordar tanta información similar y diferente a la vez. A quienes deseen incorporar este conocimiento les sugerimos la lectura de los trabajos citados de Reynolds, Butler, Demmers y Snoman, como también las demás fuentes citadas en el presente título. Juntos facilitan la tarea de discriminación de las diferentes cualidades bajo análisis. Lamentablemente, solo la primera de estas fuentes se encuentra disponible en idioma español.
} 
cualquier otra índole. En otras palabras, utilizaremos en las descripciones términos que hemos visto surgir en los debates acerca del tema.

Hechas las aclaraciones necesarias, tomaremos como referencia para realizar las descripciones-ejemplos, la lista de géneros "mayores" propuesta en la versión en español de Wikipedia. ${ }^{501}$ En síntesis y a modo de ejemplo, la música electrónica de baile contiene, refiere y comunica el siguiente:

\section{Listado de algunos sentidos posibles}

a.- Denotan con cierta claridad, información poético-estético-técnica musical.

Usualmente refiere a géneros en algún sentido históricos (ya sean antiguos géneros de la música electrónica de baile como géneros más antiguos), pero también puede proveer información musical de otro tipo.

\section{i.- Géneros ${ }^{502}$}

Breakbeat (remite principalmente a funk y disco), Disco y Post-disco (disco), Jungle/Drum'n'Bass (ídem Breakbeat), Electro (remite al género temprano de la música electrónica de baile), Electrónica con influencia rock (rock), Hardcore/Gabber/Techno Hardcore y quizá Hardstyle (Hardcore punk, metal, trash y demás géneros "agresivos" del rock y post-rock), House (en algunos casos, remite a las bases musicales del funk y el disco, y no a sus compases de "breaks"), Industrial (remite también al rock industrial), Trance (puede remitir a diferentes géneros de la música electrónica de baile, sobre todo al house, techno, ambient y a previos como el pop y otros), UK Garage (NY Garage, House).

ii.- Recursos instrumentales y/o de instrumentación

Breakbeat (rítmica sincopada en batería), Chiptune ("pequeño", "agudo" como sinónimo caprichoso de "pequeño" y "breve", "entrecortado" por secuencias de "breves" sonidos y otros), Jungle/Drum'n'Bass ("batería y bajo" por presencia de los elementos y por ser la combinación más prominentes en este género), Hardcore/Gabber/Techno Hardcore y Hardstyle (homorrítmias entre instrumentos de diferentes registros típicas de los géneros "duros" del rock; la homorrítmia permite concentrar la energía en un mismo

\footnotetext{
${ }^{501}$ Si bien para los fines del ejemplo hubiéramos podido utilizar cualquier otra, creemos que esta resume mejor ciertos agrupamientos que, nuevamente a modo de ejemplo, en la version inglesa se presentan desmembrados. Ejemplo de esto es la categoría "Electrónica". Sugerimos cotejar nuestros dichos con la información contenida en nuestro "Cuadro comparativo de géneros y subgéneros de la música electrónica de baile en Wikipedia" (ver supra).

${ }^{502}$ Damos por sobreentendido que aquéllas denominaciones que remiten a géneros lo hacen también (al menos parcialmente) a los (siguientes) "Recursos instrumentales y/o de instrumentación", texturas, tempos y a gran parte de las cualidades asociadas a aquéllos; aún cuando, luego, dichas cualidades resulten modificadas por adición o sustracción de elementos o características. Como en los demás casos, las remisiones son posibles según el grado de modificación aplicada sobre el sample utilizado, o según el grado de "conservación" que presente la reproducción de la cualidad heredada del género al que cada pieza concreta remite. Este grado de remisión deberá ser evaluado críticamente en cada pieza y para cada cualidad, sin que sea posible generalización alguna.
} 
instante, permitiendo la cualidad "hard"), House ("bombo en cuatro", percusión "a tierra" o "regular"), Industrial y Techno ("máquina", "herramienta", "dispositivo", "regularidad" y "repetitividad"), Trance (repetición en diferentes aspectos y niveles, "persistencia de cualidades" como forma musical del "trance" al que remite: ritmos de percusión y bajo, nota repetida en el bajo entre otros, incrementos y decrecimientos de la densidad instrumental y cronométrica, de la complejidad espectral y otros), UK Garage (mixtura y alternancia de recursos de géneros basados en breakbeats y "bombo en negras", redoblante en tiempos 2 y 4 del compás de $4 / 4$, samples acelerados y de afinación elevada en relación al original, tempos algo más rápidos que el House y el NY Garage).

iii.- Timbres

Breakbeat (percusión), Chiptune (calidad tímbrica digital, agudo, débil en frecuencias graves y otros), Jungle/Drum'n'Bass (Batería y bajo, calidad tímbrica "crudo"), Electro/Electronica/Hi-NRG (sonido de electricidad, tensión eléctrica, también como negación de instrumentos acústicos; similar a Hardcore...), Electrónica con influencia rock (formación clásica del rock aunque principalmente a la guitarra eléctrica procesada con distorsión y otros), Hardcore/Gabber/Techno Hardcore y Hardstyle (timbres "sucios", iterados, "ruidosos" y distorsionados, envolventes de sonoridad pronunciadas, similar a Electro...), Industrial (sonidos que pueden escucharse en industrias y trabajos humanos, timbres de herramientas como taladros, etc.), Techno (cualidad "maquinal" de los timbres como sinónimo al menos parcial de "dureza" por "deshumanización", todo tipo de instrumentos electrónicos como cajas de ritmos y sintetizadores), Trance (timbres que, como herencia del ambient, usualmente por reverberación denotan espacios amplios, combinados con otros que en la mezcla se presentan en primer plano), UK Garage (samples fragmentarios de voces que usualmente evidencian haber sido modificados en su afinación y/o velocidad o tempo, bajos usualmente profundos aunque esto debe relativizarse, puede incluir timbres asociables al Techno, al Hardcore/Hardstyle como también a otros).

iv.- Tempo o cantidad de activación

Ambient/Chill out/Downtempo (tempo lento), Electro/Hi-NRG (en tanto "energía", "energético", "agitado" sin llegar a extremos, literalmente "alta energía"), Hardcore/Gabber/Techno Hardcore (tempo rápido, "extremo"), House (tempo intermedio, un "agradable activo"), Industrial y Techno (actividad "regular", sin cambios, debida al carácter "maquinal"), Trance (atraviesa todos los tempos desde la "introspección" a la "euforia", desde la "calma" a la "agitación feroz" o "feliz", todos los caracteres y tipos que pueden asociarse a estados de trance hipnótico), UK Garage 
(similar al House aunque algunas formas pueden presentar varias temporalidades simultáneas -algunos elementos muy veloces y otros, usualmente el bajo, "a la mitad"). v.- Textura (al menos parcial)

Breakbeat (batería), Jungle/Drum'n'Bass ("batería y bajo"), Electrónica con influencia rock (bajo, batería, instrumento "líder", ripieno o acompañamiento armónico, voz, solo instrumental), Hardcore/Gabber/Techno Hardcore y Hardstyle (ídem Recursos instrumentales y/o de instrumentación y también la repetición "maquinal" mencionada para el Techno), House (ídem Recursos instrumentales y/o de instrumentación), Trance (bajos usualmente profundos pero definidos y sobre una nota repetida, rítmica resultante o sonido único que denota la subdivisión generando una iteración casi constante, ripienos armónicos con sonidos de sintetizador de cualidad "etérea" o que incorpora sutiles cantidades de ruido, o se presentan filtrados, drones/texturas evolutivas y otros), UK Garage (usualmente similar al House, con elementos de los géneros basados en breakbeats; algunas formas presentan derivas que independizan al género de sus fuentes).

b) Brindan información de algo que podría describirse como el carácter musical general.

Ambient/Chill out/Downtempo (crear un "ambiente" propicio para la relajación), Breakbeat (agitado, como la actividad y "desequilibrio" o "conflicto" que promueven los solos de batería del funk), Chiptune ("pedacito", "pequeño" y otros), Disco (fiesta, local de baile, movimiento y activación), Downtempo (lento, relajado, poca activación), Jungle ("jungla", "salvaje", "primitivo", "animal", "bestial" y otros), Electro (según el uso vulgar como "enérgico", "energía", "tensión" y otros, no involucra necesariamente "agitación"), Electrónica con influencia rock ("rockero", ¿"rebelde"?), Hardcore/Gabber/Techno Hardcore y Hardstyle ("agresivo", "violento", "oscuro", "duro"), House ("moderado", "agradable activo"), Hi-NRG (literalmente "alta energía", a diferencia de Electro aquí si "agitación"), Industrial y Techno ("frialdad" o "falta de humanidad" de la máquina, "monotonía" o "ausencia de cambio"), Trance (diferentes tipos de "introspección" que puede asociarse con "tranquilidad" o "euforia", todos los tipos y estados que pueden asociarse a estados de trance hipnótico), UK Garage (similar al Breakbeats, "discontinuo", "desequilibrio" o "conflicto"; también cierta "agitación moderada", sensación provocada por la evidente aceleración de los samples rítmicos; aquí también puede apreciarse la "moderación" del House).

c) Sugiere información de otra índole (social, de valores y muchas otras).

i.- Tecnología 
Chiptune ("chip" como "microchip" o "microprocesador" y como "pedacito"), Dub (apócope de "dubbing"=doblaje, reemplazo), Electro y Electrónica (en estos casos, la información es literal), Hi-NRG ("energía", indirectamente, tecnología de control y aprovechamiento de la misma), Industrial ("máquina", "herramienta", "metal", "engranaje", "trabajo", en cierto sentido "ausencia de humanidad"), Techno ("ausencia de humanidad" similar a Industrial).

ii.- Tecnología musical (procedimientos o dispositivos de creación musical)

Breakbeat/Jungle/Drum'n'Bass (tecnología del sampleo), Dub ("doblaje", "reemplazo", "ausencia de elementos", "mezcla" de varios canales de sonido y otros), Electro/Electrónica ("electricidad", tanto en sus formas analógica como digital), Electrónica con influencia rock (principalmente "distorsión", "guitarra"), Techno (todo tipo de instrumentos electrónicos desde sintetizadores a cajas de ritmos), UK Garage (mixtura de Breakbeat, Techno y otros; tecnología del sampleo y procesamiento de los mismos).

iii.- Origen étnico (siempre afro)

Breakbeats, Disco, Jungle/Drum'n'Bass, House y Post-disco.

iv.- Estados de conciencia (mental y corporal)

Ambient/Chill out/Downtempo (tranquilidad o lentitud), Breakbeats y Jungle/Drum'n'Bass (inestabilidad, cambio, tensión, quiebre, fragmentación), Chiptune (infantil, adolescente, asociado a los videojuegos) Disco (fiesta, celebración, ánimo festivo), Dub (relajación tonificada), Electro/Hi-NRG (tensión, exaltación, euforia), Hardcore/Gabber/Techno Hardcore y Hardstyle (agitación, agresividad, violencia, fuera de sí), Industrial y Techno (automatismo, actitud deshumanizada, robot, marcial, opresión), House (físicamente activo, mentalmente enfocado, festivo generalmente sin alcanzar la euforia), Trance (rango amplio de introspección a euforia), UK Garage (leve ansiedad y, similar al Jungle/Drum'n'Bass inestabilidad, cambio, tensión, quiebre, fragmentación).

d) Presentan nombres de fantasía asociados a lugares, locales, nombres de localidades, etc.

House (mítico local de baile The Warehouse: resulta significativo que una denominación como esta -según los términos previos, con un alto grado de indefinición y ambigüedad- indique al género que mayor amplitud estética presenta y que ha sido descripto por varios autores como la categoría donde se incluyen todas aquéllas músicas que no pueden ser incluidas en algún otro), $\mathrm{Nu}$ rave (nueva forma de "música para raves" que en algún sentido podría remitir al carácter "eufórico" asociado a dichos eventos), UK Garage (el único género "mayor" que presenta asociación geográfica; similar al House remite al también mítico local de baile newyorkino Paradise Garage). 
Si bien esta lista no cubre la totalidad de la información aportada por cada índice en cada dimensión, ya que siempre habrá más para decir de cada uno en cada una, y siempre se podrán agregar dimensiones a cada índice; al menos brinda una primera aproximación de lo que creemos una perspectiva más apropiada (que la tradicional "de géneros") para describir lo que sucede en cada pieza concreta y en la especie como totalidad. Secundariamente y como argumento que refuerza su validez, también refleja mejor los sentidos que se ponen en juego en los debates de géneros que hemos presenciado como integrantes de la comunidad electrónica.

Categorías y descripciones que son apenas breves ejemplos de todas las posibles, la amplia mayoría de los índices utilizados para describir a piezas de la especie remiten a sentidos que se asocian explícitamente con cuestiones de carácter o informaciones que pueden ser (y efectivamente son) plasmadas en formas y conformaciones musicales concretas. Una pieza que resulta designada por un determinado índice, incluye y comunica, con diversos grados de claridad, todas o algunas de las informaciones asociadas a aquel. ${ }^{503}$ A mayor cantidad de sentidos asociados a un único índice incluidos en una pieza, mayor será la identificación de esta con el género "tradicional" de la música electrónica de baile que se corresponde con dicho índice. En otras palabras y como ejemplo, una pieza que solo incluye sentidos asociados al índice trance es equivalente a decir, desde la perspectiva tradicional, "una pieza que pertenece al género Trance". En esta misma lógica, de poseer solo algunas de estas cualidades, la pieza presentará un grado mayor de hibridación, por lo que otros índices emergerán de esos otros conjuntos de cualidades divergentes presentes en la misma. Recurriendo nuevamente a un ejemplo, una pieza que presente mixturadas características asociadas a los géneros tradicionales Techno y Trance, probablemente resulte nominada como perteneciente al subgénero (del Trance, del Techno o de ambos) "Techno Trance"... o similar. ${ }^{504}$

\footnotetext{
${ }^{503}$ Como los géneros, también nuestros índices requieren del mismo capital subcultural para que la comunicación de sentidos se concrete. Nuestra perpectiva no cambia este aspecto pero sí modifica lo que podemos llamar los "alcances" de las denominaciones-índices al volver más difusos los límites de los conjuntos de cualidades indicadas. Contra lo que pudiera parecer, es esta mayor porosidad de los límites lo que permite a nuestros índices reflejar mejor lo que sucede en la realidad musical de la especie. Y esto último se debe justamente a la porosidad actual de los "géneros" que la constituyen.

${ }^{504}$ Estamos convencidos que, de forma limitada e imperfecta, esto es lo que intentan reflejar aquéllas denominaciones compuestas donde los elementos constituyentes remiten a diferentes índices (géneros, desde la perspectiva tradicional). De hecho, el subgénero Techno Trance de nuestro ejemplo existe y figura en las listas que incluyéramos. Aún así, consideramos que numerosos ejemplos escuchados requieren de más de dos índices para ser descriptos con un grado aceptable de precisión. Esta es otra forma en la que nuestra perspectiva es abierta, ya que la cantidad de índices a ser utilizados dependerá de cada caso y pieza concreta a describir. A modo de ejemplo, véa-escuche Music de los productores V. Virtanen (alias "Darude") y J. Salovaara. Accesible en https://youtu.be/AwBC2epxgJ4 [17062016], fue registrada en el año 2003 y se la incluye en listas bajo la denominación "Techno Trance". Cotéje los sentidos asociados a uno y otro índice en el Listado de sentidos posibles recientemente expuesto. Confróntelo también con los análisis poético-estético-técnico musicales de uno y otro índice que exponemos en nuestro Anexo III. Características identitarias generales de la música electrónica de baile y de los índices asociados a sus géneros "mayores".
} 
Encontramos en esta flexibilidad una de las virtudes de nuestra perspectiva, razón que a nuestros ojos explica su mayor eficacia para describir la especie. Por una parte, algunos índices poseen cualidades y/o informaciones en común con otros: aquí se evidencian solapamientos entre los diferentes conjuntos que constituyen los más tradicionales "géneros"; solapamientos que en dicha perspectiva se pierden de vista. ${ }^{505}$ Por otra, algunas piezas mixturan cualidades de varios índices, tomando de cada uno solo algunos de sus sentidos y cualidades. En estas piezas se producen nuevos solapamientos, al aunar en una misma obra sentidos pertenecientes a géneros ("tradicionales") diferentes que, en principio, podrían no presentar ningun sentido en común. Los dichos de Butler al describir los breakdowns (recordamos, nuestras paradas) toman así un sentido más definido:

En el trance, por ejemplo, los breakdowns suelen ser bastante largos, y tienden a introducir un carácter "ambient" mediante el uso de líneas sostenidas de sintetizador o cuerdas y sin acompañamiento de percusión. ${ }^{506}$

Ambas formas de intersección entre índices reflejan lo que sucede en las piezas concretas y, al mismo tiempo, explican y eliminan las contradicciones que mencionáramos al comienzo del presente anexo. En tercer término, también presentan un argumento que podría responder, al menos parcialmente, a la segunda línea de preguntas que nos hiciéramos entonces: la presencia de estos solapamientos apoyaría la hipótesis de que la música electrónica de baile es una especie estéticamente muy diversa pero única. Volveremos luego a este punto.

Creemos que otra virtud de nuestra perspectiva consiste en que:

a) la selección de categorías utilizada para describir cada índice es abierta y

b) las categorías utilizadas para describir un índice concreto pueden no coincidir con las utilizadas para la descripción de otros.

En otras palabras:

a) no todas las categorías se utilizan para describir a todos los índices y

b) no todos los índices comunican información o sentidos en todas las categorías.

\footnotetext{
${ }^{505}$ Recuérdese que los géneros son, en definitiva, "conjuntos de cualidades esencialmente divergentes" por lo que la perspectiva requiere que -de existir- dichos solapamientos entre conjuntos se mantengan en un mínimo. Esto último es algo que, como puede apreciarse en la infografía Electronic Music Guide, no sucede en la especie.

506 "In trance, for example, breakdowns are often quite long, and they tend to introduce an "ambient" feel through the use of sustained synt lines or strings without accompanying drumbeats." Butler, M. (2003). Op.cit. pp. 108
} 
En términos prácticos, nuevas categorías podrán agregarse para reflejar sentidos, cualidades y/o informaciones que no hayamos contemplado en nuestra lista-ejemplo. Dicha necesidad podría originarse en el surgimiento de un nuevo índice que trae aparejadas nuevas cualidades, o para segregar dos hipotéticos índices que a partir de las categorías que expusiéramos como ejemplos no denotaran diferencias. ${ }^{507}$

El mismo ejercicio que realizáramos para los géneros de Wikipedia puede extenderse a todas las denominaciones de niveles inferiores y, en general, a cualquier denominación utilizada para rotular géneros y subgéneros de música electrónica de baile. Damos como ejemplo el término "acid" (i.e.: de Acid jazz o Acid Trance), el cual puede ser asociado esencialmente con el uso del sintetizador Roland Tb303 Bassline. Secundariamente, el índice puede referir también (siempre a modo de ejemplo imperfecto) al uso de secuencias melódico-rítmicas reiteradas (usualmente sin exceder una extensión de compas), timbres resonantes y cambiantes (por la utilización y manipulación del énfasis o resonancia en los filtros), texturas conformadas esencialmente por solo dos elementos (sección rítmica y bajo sintetizado), rítmicas sincopadas y percusivas, nivel medio de agitación con cierto grado (también medio) de estabilidadinestabilidad y un estado de conciencia general (un carácter musical) signado por los efectos típicos del consumo de ácido lisérgico o LSD. Como puede apreciarse, este índice particular remite primordialmente a cualidades relativas a cuestiones musicales, a las que se agrega un sentido que tanto puede incluirse al interior del que llamáramos "Estado de conciencia (mental y corporal)" como puede volverse una nueva categoría relacionada a la influencia de sustancias psicoactivas.

\section{Formalización de la perspectiva a modo de conclusión al problema de los géneros}

Así comprendidas, las denominaciones utilizadas para etiquetar los géneros de la música electrónica de baile dejan de referir a estas entidades esencialmente divergentes para volverse índices multidimensionales que apuntan a conjuntos abiertos de cualidades diversas; conjuntos plausibles de ser mixturados con otros y que pueden presentar solapamientos parciales entre sí. A partir de aquí ya no diremos que tal o cual pieza musical pertenece a tal o cual "género" sino que aquélla posee tal cualidad proveniente del índice techno, tal otra del índice industrial y tal o cual otra del índice hardcore.

Resolvemos así numerosos problemas que expusiéramos durante el desarrollo del presente anexo. Visto de esta manera, la presencia de una misma denominación (por ej.: un subgénero) en más de una categoría de nivel superior (i.e.: contenida en dos o más géneros) deja de ser una inconsistencia para volverse expresión de los solapamientos. En otras palabras y retomando temporalmente la perspectiva de géneros para comprender la relación entre uno y

\footnotetext{
${ }^{507}$ Regresamos aquí a lo dicho acerca del Electro y el Hardcore para recordar que lo que diferencia a uno y otro índice es el carácter "agresivo" del segundo; o a la distinción que se hace entre House y Hi-NRG, donde el segundo es esencialmente igual al primero pero "más enérgico".
} 
otro punto de vista: una pieza concreta identificada como perteneciente a un género "A" (por poseer la mayoría de sus cualidades provenientes de este género) podrá poseer también algunas cualidades del género "B", otras de "C" y algunas de "D"; mientras que otra pieza también asociada al mismo género "A" poseerá al mismo tiempo cualidades de "F", "J" y "H".

Así expuesto vemos evidenciarse el origen tanto de las similitudes como de las diferencias entre piezas de un mismo género. Aquí reside también el origen de las confusiones y aparentes contradicciones que mencionáramos al inicio del capítulo: la forma tradicional de utilizar las denominaciones (como en la perspectiva de géneros) no alcanza para explicar lo que sucede con el material musical al interior de las piezas musicales concretas. En otras palabras, dos piezas del género House pueden resultar muy diferentes entre sí porque el término "género" es utilizado en la comunidad electrónica ya no como lo que es, sino como índice.

En nuestro ejemplo hipotético, lo que una y otra pieza posee del género House es diferente: la primera podrá presentar sus "Recursos instrumentales" y su "Textura", mientras la segunda tendrá de aquel la remisión al "Género" Disco ${ }^{508}$ y su "Carácter" general. Como contrapartida, lo que las diferencia será que aquélla referirá al "Género" Trance y presentará un "Carácter" Psychedelic mientras ésta incorpora "Recursos instrumentales" del Acid y en su "Textura" se reconocen cualidades Chiptune.

Del mismo modo, encontraremos piezas donde no preponderan cualidades de ningún género concreto sino que el origen de las mismas se reparte de forma equilibrada entre varios. Este último caso podría describir al Speed Garage, paso intermedio y origen del UK Garage, a algunos casos del Hardcore y a la actualidad del Electro.

Independientemente del contenido concreto, las fuentes Electronic Music Guide (Music infographics) y, en menor medida, la instalación multimedia interactiva Sync/Lost son quizá las que mejor representan este modo de comprender a la especie. Especialmente la primera, presenta un número reducido de géneros "mayores" que -por el lugar que ocupan y el modo en que se los representa- denotan cierto grado mayor de definición. Al interior de estos, subordinados, encontramos un extensivo conjunto de subgéneros donde, mediante líneas conectivas se representan numerosos "cruces", hibridaciones, influencias y cualidades compartidas. Es en este nivel (el de los subgéneros) y mediante las mencionadas líneas conectivas donde se evidencian los solapamientos mencionados, la porosidad de los géneros "mayores" que la perspectiva de índices pusiera de manifiesto.

Hablamos en síntesis de una aproximación a partir de modelos abiertos, donde la cantidad y cualidad de las categorías utilizadas dependerán del objeto que se persigue describir y no ya de alguna forma única y preestablecida superimpuesta a aquel. Así podremos formalizar esta descripción y decir (como en el cuadro que incluimos debajo) que en un determinado

\footnotetext{
${ }^{508}$ Para ser exactos, el uso de las comillas en la palabra "género" refiere precisamente a que el histórico género Disco se ha vuelto en este contexto el índice disco.
} 
subgénero, el género $\mathbf{A}$ comparte $x$-con-B e $y$-con-C pero no $x$-con-C. Mientras tanto $\mathbf{B}$ comparte $z$-con-C pero no con A. En esta lógica, $x l$ se podría corresponder con la categoría de análisis "timbre del sonido de bajo", $x 2$ "conformación melódica del bajo", $y l=1$ podría ser el "patrón rítmico característico A", $y l=2$ "patrón rítmico característico $\mathrm{B}$ " y uno de los valores de zl podría corresponderse con la cualidad definida "información de otra índole/tecnología: chip, microchip o pedacito", etc.

\section{Subgénero A}

Género A: $x 1(x 2, x 3, x 4 \ldots)=1 ; y 1(y 2, y 3, y 4 \ldots)=1 ; z 1(z 2, z 3, z 4 \ldots)=2 ; \ldots$

Género B: $x l=2 ; y l=2 ; z l=2 ; \ldots$

Género $\mathrm{C}: x l=2 ; y l=1 ; z l=2 ; \ldots$

A partir de este análisis y según los valores asignados a cada variable es posible identificar un número reducido de índices como síntesis de aquéllas. En otras palabras, si una pieza concreta es rotulada con la denominación de un determinado subgénero y esta refleja efectivamente el contenido en cualidades musicales, el o los términos incluidos en la denominación deberían indicar a aquéllos géneros que aportaron la mayor cantidad de cualidades a la pieza. De cualquier manera, hacer coincidir los índices con las denominaciones de los géneros y subgéneros "tradicionales" no es nuestro objetivo, sino que lo que pretendimos encontrar fue un método que permitiera describir con mayor precisión y pertinencia los sentidos y cualidades concretos detectados en los ejemplos visitados.

Resumiendo, hemos literalmente invertido las jerarquías, elevando las cualidades mínimas por sobre las categorías que las engloban. Así, los subgéneros derivarán de estas cualidades concretas y su denominación será una síntesis de aquéllas. Los géneros por su parte, cumplen un rol dual. Por un lado, al igual que los actuales subgéneros y en igualdad de jerarquía con estos, operan como síntesis de cualidades y sentidos; cualidades que en estos casos remiten a las que se encuentran o encontraban supuestamente presentes en sus formas (¿más restringidas?) históricas. ${ }^{509}$ Por el otro, nuestros géneros "mayores" actúan como conjuntos porosos que engloban a aquéllos subgéneros cuyas piezas musicales concretas contienen algunas de las cualidades históricas con las que se los asocia; a este nivel, dichas cualidades se presentan siempre mixturadas con otras provenientes de otros géneros "mayores" o incluso de géneros "exógenos".

Como vemos, las aparentes excentricidades que mencionáramos al inicio del anexo no eran tales y solo ponían de manifiesto el conflicto entre la realidad estético-técnica musical y la perspectiva utilizada para describir la especie. Las inconsistencias entre las fuentes respecto del

\footnotetext{
${ }^{509}$ Independientemente de que fuera efectivamente así, lo verdaderamente relevante aquí son los sentidos y cualidades asignados miticamente a los géneros históricos por la comunidad electrónica.
} 
lugar jerárquico asignado a algunos (sub y sub-sub) géneros, o respecto de la presentación asociada o disociada de otros, se neutralizan o poseen menor relevancia en esta categorización basada en índices. Si alguna vez hubo efectivamente en la especie géneros de cualidades claramente delimitadas este ya no es el escenario actual, por lo que persistir en esta forma de describirla carece de sentido. La perspectiva multidimensional de modelos abiertos puede resultar clarificadora incluso en los casos en los que no hay acuerdo respecto de las cualidades definitorias. En estos casos, este punto de vista permite al menos identificar y segregar las variables conflictivas, de aquéllas sobre las que existe acuerdo.

Mediante esta perspectiva hemos puesto en evidencia la complejidad y diversidad que subyace a la especie música electrónica de baile. Como viéramos, diversos factores incidieron sobre su desarrollo, impulsándola hacia su forma actual y obligándonos a la adopción de una perspectiva multidimensional para su descripción. Arribamos así -no a un relato único sino- a una multiplicidad de criterios que nos permitirán determinar, de manera difusa, lo que sucede al interior de cada pieza concreta en relación a los (sub y sub-sub) géneros "tradicionales" que constituye(ro)n la especie. Dando por resuelto lo que llamáramos el problema de los géneros, analizaremos a continuación aquéllos puntos que, por la complejidad del tema, dejáramos relegados para su tratamiento posterior.

\section{Un paso más allá: la cualidad experimental como índice transversal}

Mas allá de los argumentos expuestos, la cualidad experimental plantea un caso especial en relación a los demás índices. Como viéramos, esta característica es intrínseca a la música electrónica: la creación musical con dispositivos que a lo sumo existen desde hace unos 50 años (en algunos casos mucho menos, no llegan siquiera a una década) y que constantemente se renuevan, transforman y proponen nuevas formas de generación y/o interacción con la materia sonora, necesariamente implica asumir riesgos. Si así comprendemos a la experimentación, no caben demasiadas dudas al respecto de que al menos una parte en todas las músicas electrónicas es necesariamente experimental. Por supuesto, no todo en la música electrónica de baile puede ser entendido así, por lo que algunas consideraciones son necesarias.

Mas allá de los riesgos estético-técnicos que el artista voluntariamente asuma por sí (i.e.: más allá de los que asuma independientemente de otros factores, por propia voluntad de innovación) en el marco de la música electrónica de baile, ciertos lineamientos permiten evaluar las dimensiones en que se ha asumido algún riesgo. Veamos ahora estos factores, no sin antes explicitar que sobre estos se monta a la vez esta voluntad innovadora del creador, aportando grados mayores o menores de experimentación a cada pieza. La primera de las relaciones puede describirse del siguiente modo: 
A mayor innovación en el diseño del dispositivo tecnológico musical utilizado, mayor será el riesgo que el creador deberá asumir.

Las características, capacidades y limitaciones del dispositivo determinarán los modos en que este generará y/o modificará sonido, pudiendo incluso determinar la utilización de una materia sono-musical que, por los modos de generación, presente además en sí misma cualidades sui generis en relación a las pre-existentes. La novedad de los timbres y métodos de generación sonora, los métodos y libertades de control y transformación del sonido, como también las respectivas limitaciones que cada dispositivo ofrece y presenta, determinan "lo posible" de ser realizado (con dicho dispositivo) y lo segregan de "lo imposible". Simultáneamente, sugieren y separan lo compositiva o musicalmente trascendente (i.e.: aquello sobre lo que vale la pena trabajar en cada dispositivo) de lo mundano, intrascendente o redundante (i.e.: aquello que, de ser trabajado, no agrega nada a lo ya escuchado intertextualmente).

Este es el fundamento de la principal crítica que suele hacerse a la obra de Wendy Carlos "Switched-on Bach": en cierto sentido, esta versión en sintetizadores de la obra de Johann Sebastian Bach no solo sub-utiliza los recursos de un dispositivo que presenta inconmensurables otras posibilidades sino que, principalmente, las mayores capacidades del dispositivo pueden ser aprovechadas en contextos estéticos de características diferentes a las que presenta la obra del mencionado compositor y período histórico. En otras palabras, si deseamos interpretar la obra de Bach en sintetizadores, nos vemos obligados a neutralizar la amplia mayoría de las capacidades de control y transformación sonora que ofrecen dichos dispositivos. Si bien en la época quizá tuviera algún sentido realizarla (sobre todo social o comercial, en relación a la popularización de un dispositivo y recurso recientemente disponible), hoy es más evidente que entonces que el aporte concreto de dicha obra a la historia de la música es próximo a nulo y quizá solo anecdótico. ${ }^{510}$

La segunda de nuestras relaciones puede enunciarse del siguiente modo:

\footnotetext{
${ }^{510}$ Procurando evitar malas interpretaciones preferimos explicitar que no negamos la posibilidad de innovar a partir de dispositivos que presenten grados menores o nulos de innovación en su diseño. El hábito mismo de la comunidad electrónica de utilizar los dispositivos de modos "incorrectos" o "monstruosos" -mas allá de los modos para los que fueran originalmente pensados y diseñados- es un claro ejemplo de esto. Este es el caso también de las técnicas extendidas en el instrumental acústico. A pesar de esto y reforzando nuestros argumentos iniciales, un dispositivo que presenta una interfase o modos de generación sonora innovadores, implica una concepción musical diferente, demandando del creador la asunción de otro tipo de riesgos. Por otra parte, no debe perderse de vista aquí que, hasta el surgimiento de los dispositivos musicales electrónicos, los métodos de generación sonora se reducían esquemáticamente- a: tres modos de poner a vibrar un tubo, tres para hacer vibrar una cuerda y un número similar de formas de entregar energía a parches, placas y demás cuerpos vibrantes (los últimos en instrumentos de percusión). La totalidad de estos métodos pueden incluso resumirse aún más, como diferentes formas de realizar las acciones de rozar, golpear y pulsar. Para el momento del surgimiento de la tecnología electrónica estos métodos ya llevaban siglos siendo utilizados, por lo que la invención de la síntesis y grabación sonoras implicó un inmenso salto tecnológico y un cambio cualitativo para el intérprete musical en su relación instrumental.
} 
A mayor innovación en los materiales, procesos y/o procedimientos elegidos y utilizados, menor anclaje en estéticas musicales tradicionales o conocidas y, consecuentemente, mayor riesgo asumido.

Ya sea por elección del artista, o por las cualidades novedosas intrínsecas a los dispositivos mencionadas en el factor previo, la música electrónica en general (como también la de baile) implica aún hoy enormes novedades en sus materiales, procesos y procedimientos. A pesar de que esta música cuenta en la actualidad con una tradición de varias décadas, en nada puede comparársele a los milenios de relación con tubos, cuerdas, parches y placas del instrumental acústico. Quien decide realizar su práctica musical basándola en instrumental tecnológico posee (consciente o inconscientemente) una actitud que aún hoy en algún grado propende a la innovación y al riesgo. ${ }^{511}$

Por otra parte, la influencia de las vanguardias electrónicas de los años 1940s y 50s se encuentra plenamente presente y vigente en la conciencia de la mayoría de los productores de música electrónica de baile actuales. Del mismo modo, la tradición del futurismo italiano y las innovaciones de Edgar Varese se traducen, en no pocos casos, en una actitud rupturista e innovadora consciente; incluso -nos consta- en productores que no presentan formación musical sistemática ni han atravesado institución de enseñanza musical alguna.

Por último, como el factor anterior, tampoco éste obtura el posible uso "monstruoso" de materiales, procesos y/o procedimientos tradicionales. Nos referimos con esta expresión a usos que neutralizan o destruyen la lógica musical intrínseca a los materiales y/o modifican los efectos de los procesos y procedimientos tradicionales por su manipulación a partir de criterios ajenos a aquélla lógica. Así un fragmento de un tema Disco de los años 1970s puede ser utilizado tal cual el original o modificado hasta hacerse completamente irreconocible. En el medio, un gran abanico de diferentes gradaciones se encuentra a disposición de los productores.

Quizá una forma de explicar brevemente la situación sea decir que: materiales, procesos y procedimientos provenientes de la música electroacústica de vanguardia se mixturan con materiales, procesos y procedimientos provenientes de las músicas de baile "tradicionales". Y esta mixtura no debe ser comprendida como mero compartir espacio de obra, sino que, sobre las tres variables se dan entrecruzamientos e hibridaciones de características provenientes de una y otra fuente de influencias. Todas las posibles combinaciones e hibridaciones tienen lugar en la música electrónica de baile. Tanto se da que materiales provenientes de las músicas de baile reciben tratamientos propios de la música electroacústica, como que procesos y procedimientos provenientes de la primera se aplican a materiales usualmente asociados con la segunda. Esto da

${ }^{511}$ Por supuesto, esta actitud no es privativa de quienes eligen instrumental de base electrónica. Esta afirmación es solo válida en el sentido enunciado; en otras palabras, es falso decir que "quien decide innovar y tomar riesgos musicales solo pueden hacerlo utilizando instrumental tecnológico". 
origen a conformaciones -y en algunos casos, incluso piezas musicales completas- híbridas y exóticas que no permiten una inclusión, libre de conflictos, al interior de los índices que tratáramos previamente. En otras palabras:

las cualidades experimentales organizan a un índice independiente y en igualdad de jerarquía con los demás.

Tendremos entonces en la música electrónica de baile piezas puramente experimentales y otras donde un número variable de estas cualidades se conjugan con las asociadas a cada índice/género tratado con anterioridad. Pertenecen a esta categoría piezas denominadas mediante alguno de los índices previamente tratados (i.e.: house, trance, etc.) y adjetivadas además con el término "experimental", como también otras a las que se agrupa solamente al interior de este nuevo índice.

Incluimos así al interior de la especie a un universo de estéticas que hasta ahora resultaba excluido. Quizá por lo difuso que resulta el límite planteado por este nuevo índice es que la música electrónica de baile puede contener a su interior a piezas que -estamos seguros- la comunidad académica acordaría en llamar "música electroacústica de vanguardia", "música electrónica contemporánea" o alguna otra denominación que la emparente con las prácticas de la música "seria".

Estamos convencidos, también influyen las perspectivas provenientes del universo de las artes del movimiento. Quizá aquí puede hallarse otra razón que explique la contradicción que el encabezado del listado de Wikipedia presenta con el contenido de la lista (i.e.: "Géneros de música electrónica" como encabezado de una lista que, en más del 95\% es música electrónica de baile).

Secundariamente cabe destacar que este nuevo índice se establece como otro argumento que refuerza nuestra perspectiva por sobre la de géneros. La cualidad experimental es utilizada por la comunidad electrónica como una categoría transversal. Sin percatarse de que también así utilizan a las denominaciones asociadas a géneros, le asignan al término "experimental" un valor diferente. Mediante este término suelen explicar cualidades que divergen de lo esperable según los cánones del género al que una determinada pieza pertenece. Similar a la actitud que en el folklore argentino conduce a la denominación "aire de...", dirán entonces que una determinada pieza -a modo de ejemplo, esencialmente Trance- difiere de otras porque (la pieza o el productor) posee cierto carácter o estilo "experimental". Desde nuestra perspectiva y como dijéramos, el experimental es solamente otro índice en igualdad de jerarquías con los demás. 


\section{Otras formas experimentales}

Los factores hasta aquí tratados pueden ser los más evidentes, pero no fueron ni son los únicos. La música electrónica de baile ha sido y es experimental en otras formas mucho menos reconocibles. Analizaremos el sonido que cumple la función que en las demás músicas populares se asigna al bombo de batería como ejemplo de lo que ocurre con innumerables otros factores.

El bombo de batería es un cuerpo de percusión de la categoría membranófonos, donde un parche principal (instalado en un tubo cilíndrico de diámetros entre 20 y 18 pulgadas, semicerrado por un parche secundario o resonador en el extremo opuesto) es excitado por una maza de materiales duros diversos (a veces recubierta de fieltro) accionada por un pedal que se comanda con uno de los pies del intérprete e impacta cerca del centro. Este sistema genera un sonido breve, impulsivo, sin sostenimiento, de decaimiento rápido y con un espectro caracterizado por una banda de ruido centrada en la región grave del espectro de frecuencias. Posee numerosos transitorios de ataque determinados por la masa y el lugar donde se percute. $\mathrm{Su}$ decaimiento puede ser reducido aplicándole diferentes materiales al interior del resonador (entre otros suelen utilizarse lienzos pesados y ladrillos) y su afinación puede cambiarse modificando la tensión de uno y otro parche. Casi siempre amplificado en la música popular, el sonido puede ser drásticamente modificado por el tipo de micrófono utilizado, la localización del mismo y los diferentes procesos que comúnmente se le aplican (compresión, ecualización, aplicación de efectos, etc.). En músicas no electrónicas es usual que el timbre de este cuerpo de batería permanezca inalterado de principio a fin de cada pieza. Esta práctica seguramente se deba a que resulta difícil hacer modificaciones en tiempo real en un contexto de show en vivo. Esta cualidad condujo a que en general el timbre del bombo no sea un aspecto que se trabaje de forma dinámica en músicas no electrónicas.

El timbre del sonido de bombo electrónico puede ser de origen sintético o a partir de un sample. Cualquiera sea su origen, en las músicas electrónicas de baile suele ser un elemento dinámico que en algunos casos se transforma de maneras dramáticas. Esto se debe a que modificar la afinación, prolongar o acortar su duración, incrementar o reducir los transitorios de ataque -entre otros procesos- resulta tan sencillo como girar un potenciómetro o mover un deslizador. Aquí, un factor potencial de innovación que cabe destacar; sin embargo, restan varios aún.

Los ataques del sonido de bombo electrónico pueden producirse a partir de una interpretación en tiempo real (golpe a golpe, mediada por una interface que lo permita) ${ }^{512}$ o a partir de ser programados en un secuenciador. Sin importar el caso, estos dispositivos facilitan la realización de rítmicas humanamente imposibles. Solo como meros ejemplos: es posible tanto

\footnotetext{
${ }^{512}$ Usualmente almohadillas (i.e.: pads en ingles) de materiales semiblandos, sensibles a la intensidad con que se impacta sobre ellos con los dedos, baquetas o palillos. Para más detalles al respecto de estas y otras características de los secuenciadores ver el Anexo V y el Glosario.
} 
repetir "maquinalmente" sin modificación alguna rítmicas simples o muy complejas, como producir rítmicas imposiblemente veloces. Cualquiera de las dos posibilidades queda por fuera de los recursos del más virtuoso percusionista acústico. En estas rítmicas reside una nueva dimensión posible para la innovación y el riesgo.

El uso de samples implica potencialmente además la posibilidad de que la muestra sonora utilizada posea algún tipo de referencia a una fuente sonora diferente al instrumento acústico bombo de batería. En otras palabras, podemos utilizar en el rol de bombo un sonido reconocible cuya fuente es otra que el mencionado bombo de batería. Si bien no en esta función sino en la de redoblante, un reconocible ladrido de perro puede escucharse en la versión de estudio del tema "La, La, La, He, He, Hee" de Prince. ${ }^{513}$ Una dimensión más para posibles innovaciones.

La utilización de sintetizadores para la generación del sonido de bombo -y de otros sonidos que cumplen funciones equivalentes a fuentes acústicas- es quizá la forma de innovación más interesante y menos evidente en la música electrónica de baile. Esta es también la razón que nos condujo a describir con tanto detalle el modo de funcionamiento y generación de sonido del bombo de batería acústica. Debido seguramente al rol protagónico que este sonido cumple en la música electrónica de baile, Snoman explica con gran detalle los modos en que se sintetizan estos sonidos para cada uno de los géneros que analiza. Y es que la innovación aquí reside en que, a pesar de cumplir la misma función, existe una inmensa diferencia entre los modos acústico y sintético de generar el mencionado sonido (o "categoría sonora"):

Para obtener transitorios de ataque similares a los que caracterizan al bombo de batería acústica se recurre a un glissando descendente extremadamente veloz.

El procedimiento básico consiste en modular mediante una envolvente programable la frecuencia de una onda (usualmente una forma de onda sinusoidal o triangular) para que, en pocos milisegundos recorra un amplio rango de frecuencias, desde el registro agudo al grave. Los transitorios dependerán, entre otros factores, de cuál sea la frecuencia inicial y del tiempo que le tome al glissando recorrer desde ésta hasta la de arribo. La frecuencia de arribo, junto con el tiempo de decaimiento (i.e.: "decay" en la jerga) determinará la afinación (más aguda o grave) del sonido de bombo sintético.

Este procedimiento de síntesis permite arribar tanto a timbres muy próximos al de los bombos de batería acústicos como también producir sonidos que, aún poseyendo una identidad diferente claramente reconocible, pueden cumplir la misma función. La innovación consiste entonces en que:

\footnotetext{
${ }^{513}$ Una versión puede escucharse ingresando en https://www.mixcloud.com/ginovannelli94/la-la-la-hehe-hee-highly-explosive-prince/ [17062016]
} 
mediante principios acústicos esencialmente diferentes se sintetiza una conformación sonora esencialmente igual ${ }^{514}$ y que puede cumplir el mismo rol en el entramado musical.

Continuando la tradición heredada de la música electrónica desde el tiempo de sus pioneros, la función de bombo de batería -en tanto ejemplo elegido para ilustrar lo que sucede con diferentes elementos del entramado musical- sigue siendo hoy terreno de exploración e innovación donde continuamente surgen nuevos timbres y conformaciones sonoras novedosas. Luego de The Moody Blues y de algunos ejemplos previos de música electrónica "popular", ${ }^{515}$ la banda alemana Kraftwerk fue quizá el proyecto que optimizara y difundiera el recurso. Si bien en numerosas entrevistas sus integrantes definieron al proyecto como perteneciente a este tipo de música, los "lados B" de sus álbumes ${ }^{516}$ presentan piezas que en numerosas ocasiones pueden ser catalogadas como verdaderas obras experimentales y pertenecientes al repertorio de la música electroacústica o contemporánea. Con esto queremos significar que, a pesar de buscar posicionarse en el campo de la música "pop", Kraftwerk presentaba (y presenta aún hoy) un grado elevado de innovación y experimentación en muchas áreas de su producción artística. Uno de estos grados de innovación consiste precisamente en la aplicación del recurso que acabamos de enunciar. Los principios acústicos utilizados en las conformaciones sonoras de percusión sintética que pueden escucharse en la obra de Kraftwerk han sido incorporados en dispositivos modernos, continúan hoy siendo replicados, reutilizados y variados en innumerables nuevas piezas y son enseñados en libros de texto como los de Snoman. ${ }^{517}$

\footnotetext{
${ }^{514}$ Para ser exactos y como dijeramos antes, al menos potencialmente igual.

${ }^{515}$ Por ejemplo los trabajos de fines de los años 1950s de Tom Dissevelt realizados a partir de encargos que le hiciera la empresa Sony o de Delia Derbyshire, cuyo trabajo más conocido quiza sea el tema de la serie televisiva Dr. Who. Véase por ejemplo Acid house from 1958 ... Tom dissevelt \& Kid Baltan (Dick Raaijmakers ) syncopation en https://youtu.be/HW-n6GWFAvI o Delia Derbyshire - Ziwzih Ziwzih OO$O O-O O$ en https://youtu.be/jetzY-W78gg. [17062016]

${ }^{516}$ De esta forma se suele describir a aquéllas piezas relegadas al reverso de los discos de vinilo larga duración. Con esta expresión se pretende referir a que no todos los oyentes de estos discos escuchan estas piezas. Consecuentemente, dicho "lado B" se suele destinar (o al menos así era en el pasado) a las piezas que se consideraban menos "comerciales" o más "experimentales".

${ }^{517}$ En el video en línea Kraftwerk mit "Tanzmusik" 1973 im ZDF-aspekte-Studio puede apreciarse el modo en que este recurso era utilizado en sus presentaciones en vivo. Accesible en https://youtu.be/UIbSkw4yvec [17062016].
} 

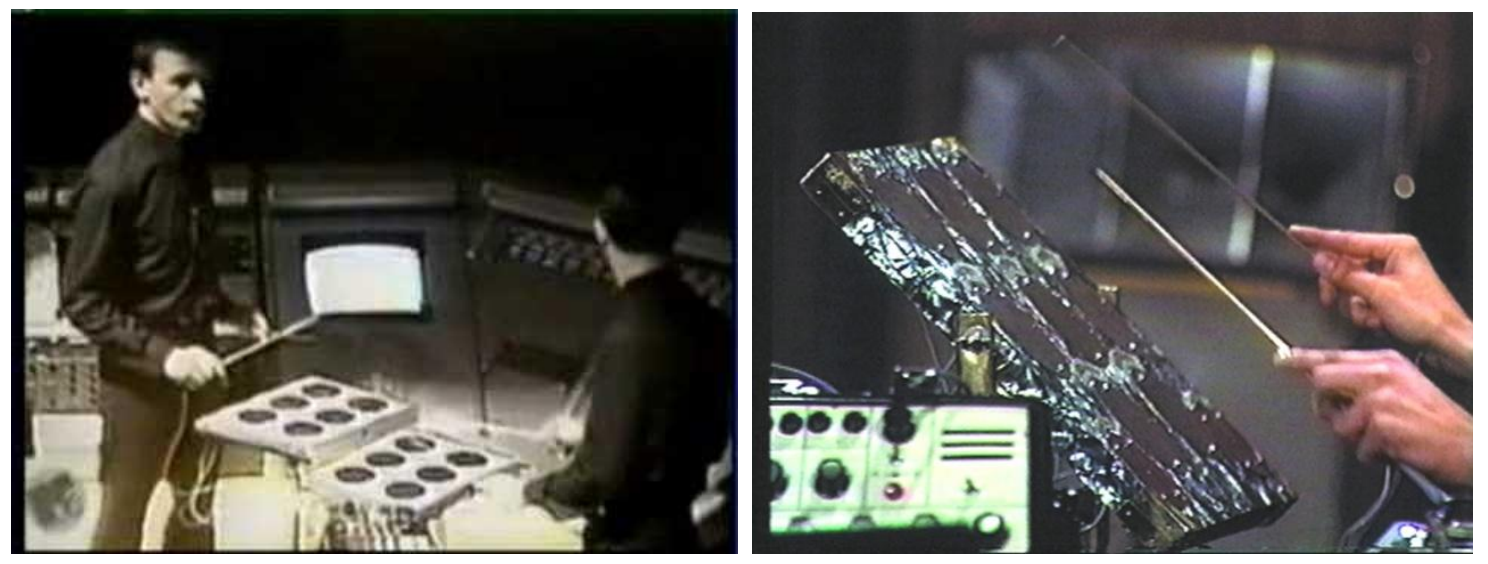

Dispositivo de control de la percusión sintética utilizada por Kraftwerk en sus presentaciones.

Es innegable la persistencia de múltiples tradiciones musicales en la música electrónica de baile. Sin embargo, esta persistencia (que podríamos describir brevemente en tanto herencia de las músicas de baile históricas) puede llegar a ocultar la innovación que hay detrás de su apariencia tradicional. Nacida contemporánea y (post-) moderna, en la música electrónica de baile conviven, interactúan y se integran sin conflicto tradición e innovación. Y es esta integración la que puede hacer que la innovación pase desapercibida, desfigurada detrás de formas aparentemente tradicionales. La música electrónica de baile propone no solo formas musicales novedosas sino que, como bien dice Demers, requiere tanto de nuevas formas de percepción y conceptualización como nuevas actitudes de escucha. 


\section{ANEXO III \\ Características identitarias generales de la música electrónica de baile y de los índices asociados a sus géneros mayores \\ Consideraciones preliminares}

Hemos visto que la expresión "música electrónica de baile" se encuentra fuertemente sesgada y centrada en las cualidades que emergen de los ejemplos surgidos en Estados Unidos de América y los países centrales de Europa. A pesar de este sesgo creemos que será útil describir algunas cualidades, en algún sentido básicas, esenciales, asociadas a los índices a los que denominamos "mayores" en las conclusiones de las pesquisas descriptas en nuestro Anexo

II. El problema de los géneros. Estas descripciones nos permitirán comprender el recorte que con dicha perspectiva se hace y apreciar las hibridaciones que -incorporando cualidades exógenas provenientes de géneros históricos locales de múltiples regiones del planeta- han dado origen, desde hace al menos una década, a la enorme cantidad y diversidad de estéticas y piezas que conforman hoy las músicas electrónicas utilizadas para el baile social.

El desarrollo que sigue tiene como objetivo último explicitar características poéticoestético-técnicas generales aún no descriptas de la especie-marco en que acontece y se genera sensación táctil y audiotáctil. Procurando brindar un anclaje más familiar, describiremos entonces estas cualidades a partir de perspectivas musicológicas más próximas a las tradicionales. Contar con análisis complementarios que recurren a categorías conocidas favorecerá una comprensión más profunda de las descripciones audiotáctiles que realizáramos en el cuerpo principal del texto y de sus implicancias últimas.

A pesar de los breves años transcurridos desde el surgimiento de la música electrónica de baile, su desarrollo veloz permite retrospectivamente apreciar cierto grado de cristalización de cualidades que ya podemos denominar históricas. Las piezas de cada índice que por última vez denominaremos "mayor" (por corresponderse con los géneros "mayores" de la selección que realizamos en el Anexo II. El problema de los géneros) ${ }^{518}$ presentan un conjunto difuso de cualidades poético-estético-técnicas musicales comunes y plausibles de ser asociadas y descriptas como propias del conjunto que resulta indicado por la denominación correspondiente.

Llegados a este punto, conscientes de la aparente contradicción que presenta el párrafo inmediatamente precedente en relación a la extensa argumentación desarrollada en el Anexo II.

\footnotetext{
${ }^{518}$ Para resolver cualquier ambigüedad que pudiera persistir y se nos comprenda cabalmente: llamamos de este modo a los índices que se corresponden con nuestra selección de "índices mayores" pero no implicamos con ello que dichos índices sean en algo superiores a, por ejemplo, los utilizados en subgéneros. Consideramos a todos los índices como jerárquicamente iguales. Los asociados a los históricos "géneros mayores" son solo el emergente del uso más o menos prolífico (en detrimento de otros) de cualidades provenientes de un determinado índice en una época, región geográfica, grupo o tribu social, u otros factores determinantes de la circulación de estos bienes culturales. En otras palabras, los "mayores" pueden comprenderse como aquellos que aportan más cantidad de cualidades a un determinado subconjunto de piezas actuales, siempre hibridadas, y siempre: piezas que conforman el grupo mayoritario en uno de los contextos sociales acotados descriptos en la sentencia previa.
} 
El problema de los géneros, nos sentimos obligados a realizar un paréntesis aclaratorio que responda a la siguiente pregunta:

¿Qué metodología podemos utilizar para determinar cuáles son las cualidades identitarias de cada índice si justamente lo que caracteriza a los últimos es su porosidad?

La aparente contradicción se resuelve fácilmente ya que en el "contradictorio" párrafo referimos a los géneros "mayores" en tanto índices y (he aquí lo relevante para esta cuestión) con un recorrido y desarrollo que podemos denominar como históricos. Si bien el período de tiempo considerado es breve en términos culturales, la música electrónica de baile presenta una velocidad de desarrollo que también la caracteriza en otros aspectos: los procesos en la especie son tan veloces, que en muy pocos años se produjeron gran cantidad de piezas musicales. Un mercado de bienes culturales musicales saturado -y por lo tanto competitivo- como el descripto, presionando sobre una comunidad donde sus productores tienden a la proliferación, impulsó e impulsa una búsqueda acelerada de diferenciación (por parte de los mismos productores) propiciando a su vez una diversificación acelerada en cada índice/género. Diversificación acelerada que, si tomamos los argumentos de McLeod como válidos, ${ }^{519}$ resulta funcional tanto a los intereses de la industria discográfica como para satisfacer el consumo cultural acelerado que caracteriza a los aficionados a la especie.

Contamos por estas razones con numerosas piezas donde se dan multitud de heterogeneidades y similitudes que permiten apreciar las transformaciones paulatinas que ocurrieron y ocurren al interior del subconjunto de piezas que remiten a cada índice. Estas similitudes y diferencias nos permiten a la vez rastrear aquellas cualidades que se detectan tanto en los ejemplos tempranos de cada índice ("puro", género "restringido") como en piezas más recientes. ${ }^{520}$ Las piezas de cualidades hibridadas, contrariamente a lo que podría en principio parecer, facilitan la tarea. Una pieza híbrida, comparada con otras (ya sean piezas old school o hibridadas), presentará cualidades compartidas; y son estas cualidades compartidas las que nos brindan, por comparación y contraposición con los elementos provenientes de los demás índices en una y otras piezas, aquello que constituye las cualidades propias del índice analizado y los elementos que constituyen sus límites (en algún grado) más definidos y restringidos. Tomaremos este principio como válido, aún cuando existe la posibilidad de que esta mayor definición se sustente, en algunos casos, ya no sobre cualidades efectivamente presentes en

\footnotetext{
${ }^{519}$ Para más detalles véase el título Géneros, subgéneros, sub-subgéneros y más de nuestro Anexo II. El problema de los géneros.

${ }^{520}$ A modo de ejemplo ofrecemos la transformación que experimentara el índice hardcore: ubicado en la actualidad entre los que hacen uso del patrón de bombo en negras, las piezas old school de los 1990s en cambio se inscriben en el grupo de índices basados en samples de breakbeats.
} 
ejemplos tempranos del género sino en cualidades míticamente asignadas al género-origen. Como ejemplificamos en nuestro Anexo II. El problema de los géneros, esto resulta posible debido a la utilización acrítica de dichas cualidades por parte de muchos productores actuales de música electrónica de baile. ${ }^{521}$

\section{Fuentes de consulta y metodología}

Aún cuando puede presentar ciertas inconsistencias y alguna falta de rigor, para el desarrollo de este punto hemos aprovechado la excelente información vertida por Rick Snoman en su libro The Dance Music Manual: Tools, Toys and Techniques. ${ }^{522}$ DJ de extensa experiencia, colaborador de artistas de gran reconocimiento masivo (como por ejemplo Madonna), expone en su obra los múltiples y variados aspectos y procesos técnico-estéticos que desde su rol como deejay y productor considera involucrados en la producción y presentación al público de música electrónica de baile. Su invalorable aporte se sustenta tanto en la gran cantidad y diversidad de información específica contenida en su libro como en el apoyo que sus argumentos tienen en una serie de ejemplos musicales descargables del sitio www.dancemusicproduction.com, propiedad del mismo autor.

Donde resultaron aplicables, cruzamos sus análisis con los realizados sobre el índice techno por Mark Butler en su ya citado Unlocking the groove. Rhythm, Meter, and Musical Design in Electronic Dance Music, tesis académica donde la rigurosidad y originalidad alcanzan a sus perspectivas teóricas, su metodología, objetivos y estudios de campo. Para lo que sigue adoptaremos, con algunas reservas, sus perspectivas generales en relación a los elementos rítmico-métricos. Desarrollaremos nuestro análisis a partir de aquellos de entre sus postulados que consideramos acertados y extenderemos su punto de vista donde lo consideremos necesario.

En síntesis, realizaremos primero un análisis de algunas propiedades generales de la especie que, creemos, ayudarán a comprender su amplitud estética. Concluida esta tarea incluiremos un resumen breve de las cualidades propias y particulares de cada índice. Recurriremos para ello a los argumentos expuestos durante cada sección de la presente tesis doctoral. Cubiertos cada uno de los índices por los autores citados, solo el hardcore nos resta como el único para el cual no halláramos análisis alguno. Cubriremos nosotros esta vacancia, aplicando los mismos criterios y perspectivas utilizados para los demás índices. Considerando lo que sobre éste dijéramos, dedicamos al mismo un desarrollo acorde.

Así también cubriremos con desarrollos propios las falencias múltiples hallables, en general, en los estudios sobre la especie. Debatiremos nuestros argumentos con los mencionados autores, aprovechando el anclaje que sus trabajos proveen.

\footnotetext{
${ }^{521}$ Nos referimos especialmente a aquellos que (siguiendo a Butler) denominamos "djs de dormitorio".

${ }^{522}$ Según refiere su autor, esta obra ha sido incorporada en la bibliografía de instituciones educativas que incorporan cursos específicos acerca de la especie. Sin razones para dudar de esta aseveración, tampoco hemos sido capaces de confirmarla.
} 
Antes de iniciar el análisis concreto nos resta realizar una necesaria pero breve revisión del trabajo de Snoman. Entre otras razones, merecen algunas reflexiones las múltiples diferencias existentes entre las sucesivas ediciones de su trabajo.

\section{Audición de deejay}

Snoman describe con gran profundidad los procesos de síntesis necesarios para lograr, por ejemplo, un sonido que cumpla la función de bombo, como también el funcionamiento de sintetizadores y samplers o la programación y operatividad de otros dispositivos electrónicos utilizados por músicos electrónicos, deejays y productores. Explica con lujo de detalles las configuraciones necesarias en compresores, ecualizadores y efectos diversos para lograr una mezcla y masterizado "apropiados" para cada tipo de sonido y "género" (i.e.: que replique el tipo de "sonido" o tímbrica usualmente utilizado en cada género). ${ }^{523}$ Expone también algunos rudimentos de teoría musical y se adentra incluso en las formas de difusión y promoción de la producción propia y en la problemática legal involucrada en la utilización de fragmentos musicales provenientes de grabaciones preexistentes (i.e.: samples).

En términos generales el autor demuestra un profundo conocimiento de cada tópico involucrado en la producción de música electrónica de baile siendo quizá la única excepción la sección de teoría musical: capítulo especialmente breve comparado con los demás, incorpora algunas ambigüedades y desaciertos. Como fuera mencionado, el libro cuenta con tres ediciones; este problema será subsanado, no por completo pero en gran medida, en la tercera.

Luego de una primera sección general, el autor se adentra en la descripción de cualidades y procesos de producción específicos de la mayoría de los índices que resultaran incluidos en nuestra selección de géneros "mayores". Algo reiterativo e insistente al realizar salvedad tras salvedad respecto de la validez de cada aspecto estético-técnico descripto, aún así provee una inmensa cantidad de información útil y que incitan a su experimentación práctica. ${ }^{524}$

Publicado originalmente en 2004, posee dos ediciones posteriores que datan de 2009 y 2014, presentando cada nueva edición gran cantidad de modificaciones y actualizaciones. En las introducciones respectivas Snoman explica que aquellas responden a los cambios en los procesos de producción musical, y que estos son consecuencia de las innovaciones tecnológicas. Si bien no lo menciona, consideramos que dichas modificaciones también dependen de los cambios en las tendencias estéticas dentro de la especie y del crecimiento profesional y de formación del autor. A partir de estas diferencias creemos relevante poner de manifiesto tres consideraciones que hacen a una mejor comprensión de la perspectiva adoptada por Snoman, en tanto desarrollo desde su rol de deejay y productor.

\footnotetext{
${ }^{523}$ Utilizaremos aquí el término "género" para evitar confusiones y debido a que Snoman se refiere de este modo a nuestros índices.

${ }^{524}$ Creemos que estas salvedades derivan, nuevamente y en gran medida, de los múltiples problemas que genera la perspectiva de géneros.
} 
a) Falencias en teoría musical.

Como mencionáramos, la sección dedicada a este tema evidencia debilidades en su formación musical tradicional. En la tercera edición se renueva el capítulo por completo mitigando en gran medida los problemas detectados en las ediciones previas. De cualquier modo, persiste una perspectiva que evidencia un conocimiento en alguna medida superficial o a-critico. No nos resulta extraño: los deejays y productores se relacionan con la música a través de una perspectiva que, ni mejor ni peor, presenta cierta distancia con la teoría musical occidental y se encuentra más próxima a una actitud "futurista", "experimentalista", "a-histórica", "punk" o (siguiendo a Augusto Boal) de "espect-actor". ${ }^{525}$

b) Relativización sistemática de las aseveraciones realizadas para cada género.

Cada capítulo dedicado a los géneros musicales se inicia y finaliza, sin excepción, con una formula donde el autor explicita que todas las aseveraciones acerca de las formas musicales, timbres descriptos, procesos utilizados y configuraciones de efectos deben comprenderse como meras generalizaciones o aproximaciones, y que ello no quita que existan innumerables piezas musicales donde las premisas presentadas se incumplan. Representativo de los términos hallables en otros capítulos, en su tercera edición contradictoriamente dirá que:

El trance puede ser un genero ambiguo a partir de que se manifiesta en un gran número de formas y pocos acuerdan en exactamente qué hace que la música genere "trance". Sin embargo, puede ser generalizado como la única forma de música dance que está construida alrededor de melodías exóticas que son vigorosas, tranquilas o presentan cualquier carácter intermedio. ${ }^{526}$

Este fragmento apunta en la misma dirección que los resultados obtenidos durante el análisis de los numerosos géneros que conforman la especie y que se incluyen en el Anexo II: si alguna vez la perspectiva de géneros tuvo alguna utilidad para describir a la música electrónica de baile, hoy la ha perdido por completo.

\footnotetext{
${ }^{525}$ Referimos a la obra Juegos para actores y no actores. Publicada originalmente en 1999, allí dirá Boal que "El Teatro del Oprimido es teatro en la acepción más arcaica de la palabra: todos los seres humanos son actores, porque actúan, y espectadores, porque observan. Somos todos espect-actores." Análogamente, los deejays serán músicos por crear música, aún cuando en algunos casos no posean una formación musical sistemática. Como viéramos, también los bailarines cumplirán -en relación con el deejay- un rol activo de espect-actor. Boal, A. Juegos para actores y no actores. (1999). pp. 21

526 "trance can be an ambiguous genre since it manifests itself in a large number of forms and few will agree on exactly what makes the music 'trance'. However, it can be generalized as the only form of dance music that's constructed around exotic melodies that are vigorous, laid-back or pretty much anywhere in between." The Dance Music Manual. Third Edition. (2014). Snoman, Rick. pp.287.
} 
c) Diferencias en la selección y orden de los géneros descriptos.

Como puede verse debajo, las tres ediciones presentan variaciones en relación a los géneros seleccionados para ser descriptos.

$1^{\circ}$ edición: trance, Hip-hop (rap), Ambient/Chill Out, house, techno y Trip-hop.

$2^{\circ}$ edición: house, trance, UK Garage, techno, Hip-Hop (rap), Trip-Hop, Ambient/Chill Out y Drum'n'Bass

$3^{\circ}$ edición: trance, Dubstep, Ambient/Chill Out, Drum'n'Bass, house y techno.

Más allá de los insuficientes dichos incluidos en las introducciones, en ninguna parte de ninguna de las ediciones se explicitan las razones que motivaron el análisis de estos géneros por sobre otros. Tampoco se explica porqué se modificó su orden de aparición ni porqué se optó, edición tras edición, por quitar algunos, mantener otros e incorporar los que antes no se incluían. A partir de los trabajos realizados en relación al problema de los géneros nos convencimos de que la respuesta podría ser la siguiente: en oportunidad de cada edición y re-edición, el autor incluyó aquéllos géneros que consideró los más representativos de la escena electrónica británica (tanto de ese momento como en perspectiva histórica). Nos basamos para esta aseveración en la desaparición en la $3^{\circ}$ edición de Hip-hop, Trip-Hop y UK Garage, en la aparición del Drum'n'Bass a partir de la $2^{\circ}$, y en la incorporación del Dubstep en la $3^{\circ}$. Estos cambios resultan coincidentes con las tendencias que aproximadamente por aquellos años motorizaban los cambios estéticos en la especie. Además, la persistencia a través de los años del house, trance, techno y Ambient/Chill Out se corresponde con lo que sucedía y sucede en la escena electrónica: como viéramos, estos géneros son los que más años de existencia poseen al interior de la especie.

Apelaremos a la información vertida por Snoman cuando tratemos cada índice particular. Profundizaremos antes la perspectiva de Butler que esbozáramos en el Anexo II. EI problema de los géneros.

\section{Necesarias y múltiples perspectivas de análisis}

Antes de iniciar el estudio de algunas de las cualidades que describen a la música electrónica de baile creemos oportuno advertir que el mismo debe ser comprendido como ejemplo de referencia respecto de las perspectivas de análisis que la especie exige. Nos 
referimos con esta frase de apariencia altisonante a que, como veremos en el desarrollo siguiente:

múltiples perspectivas teóricas y aproximaciones diferenciadas son necesarias para comprender los fenómenos que acontecen en cada dimensión de análisis al interior de la música electrónica de baile. ${ }^{527}$

Esto se debe a que la diversidad poético-estético-técnica de la especie es tal que ninguna aproximación puede abarcar todas sus cualidades ni ser aplicada en todos los casos. Además, la ocurrencia simultánea y en una misma pieza de elementos que presentan cualidades divergentes (característica muy difundida en la especie) implica la complejidad extra de que, en dichos casos, múltiples perspectivas deben ser combinadas para el análisis de una única y misma dimensión musical (dimensión donde ocurre la mencionada divergencia de cualidades). ${ }^{528}$ Para el estudio de las cualidades poético-estético-técnicas de la música electrónica de baile ${ }^{529}$ deberemos adoptar una aproximación abierta y flexible que considere en cada caso la adopción de una o varias perspectivas teóricas y el entrecruzamiento de los datos suministrados por cada una.

A modo de ejemplo, podrán adoptarse puntos de vista tonales para analizar algunos procedimientos, comportamientos y conformaciones detectables en ejemplos trance y house. Esta lógica sin embargo, resulta inútil para muchas piezas techno o incluso en otros ejemplos de los mismos índices antes mencionados. En algunos casos podrán ser útiles las categorías textural de melodía o la formal de canción, mientras que en otros deberá utilizarse el concepto de "pista", "cantante", "vocal" u otra.

Una de las formas de apreciar la gran amplitud estética de la especie quizá se expresa en la oposición entre Unfinished Sympathy de Massive Attack y Jerical de Jeff Mills. ${ }^{530}$ La audición de una y otra pieza ilustra dos de las múltiples y muy diversas formas que puede asumir la música electrónica de baile. Una, expresión de la sutileza de una canción jazz con detalles soul y funk, con acompañamiento de orquesta de cuerdas (sintetizadas o sampleadas), interpretada por una voz femenina y, en su versión de estudio al menos, con características del índice breakbeats. La otra, la crudeza descarnada de la repetición interminable de patrones en

\footnotetext{
${ }^{527}$ Como puede verse la frase puede ser todo menos orgullosa. La razón que nos llevó a incluirla es más una razón para vergüenza.

528 Tampoco descartamos la aplicabilidad que pudieran tener perspectivas no contempladas en el desarrollo posterior. Sospechamos por ejemplo que la aproximación "acentual" utilizada por Pierre Boulez en su famoso análisis de "La Consagración de la Primavera" de Igor Strawinsky podría ser útil para el análisis de ciertas piezas techno. En honor a la brevedad lo incluimos solo a pié de página.

${ }_{529}$ Valga la aclaración, también de las músicas electrónicas utilizadas para el baile social.

530 Massive Attack - Unfinished Sympathy y JEFF MILLS - Jerical. Subidos respectivamente por emimusic y 62MISSION77. Accesibles en https://youtu.be/ZWmrfgj0MZI y https://youtu.be/6sNJegD22u0 [17092016]
} 
máquinas de ritmos (con su timbre completamente "desnudo", sin un solo efecto aplicado) y de algún que otro sintetizador que por momentos "escupe" breves patrones de timbres saturados, rugosos, iterados... techno. Patrones múltiples que -casi meras pulsaciones, sin antecedente ni consecuente- se suman o restan de la textura en base a una lógica duracional que mucho tiene de sinrazón, de experimental y de una expresividad que podemos denominar anti-romántica, nohumana o maquinal. ${ }^{531}$

Por supuesto, el eje que esta oposición posible establece se encuentra inmerso en el vasto campo estético multidimensional que bocetáramos en Géneros, subgéneros, subsubgéneros y estilos como índices y que, preferimos reiterarlo, permite numerosas otras formas y ejes de oposición. En otras palabras, como bien lo ilustra la infografía de Electronic Music Guide ${ }^{532}$ ninguna oposición puede ilustrar la inabarcable vastedad estética que caracteriza a la música electrónica de baile. ${ }^{533}$

Sentimos además la obligación moral de explicitar que: a nuestro modo de entender y a pesar de que es considerada parte del repertorio de la música electrónica de baile, la primera de las piezas de nuestro ejemplo presenta pocas dimensiones que permiten su identificación con estéticas electrónicas. De hecho, en los términos de Teruel o Izarra que incluyéramos en Música electrónica $^{534}$ poco -si algo- en Unfinished Sympathy puede caracterizarse de este modo. Una pieza alternativa, que presenta mayor cantidad de aspectos electrónicos y que con pocas modificaciones en su descripción puede ocupar el lugar de la de Massive Attack es Lady (Hear Me Tonight) de Modjo. ${ }^{535} \mathrm{Si}$ bien las diferencias en relación a Unfinished Sympathy no pueden ser subestimadas, en ambas:

a) subyace la concepción del formato de música popular canción (entre otras: textura de melodía con acompañamiento, voz humana que incluye contenido literario cumpliendo rol de figura, estructura de estrofas),

b) opera en mayor o menor grado una lógica tonal de organización de las alturas y

c) subsiste una expresividad musical vinculada a la transmisión de emotividad; cualidad heredada, como mencionáramos, del período clásico (en sentido amplio) de la historia de la música y especialmente asociada al período romántico.

\footnotetext{
${ }^{531}$ Para más detalles al respecto de los términos utilizados para las descripciones véase nuestro Anexo II. El problema de los géneros.

532 Electronic Music Guide (Music infographics). Accesible http://www.designinfographics.com/music-infographics/electronic-music-guide\# [27042016]

$\overline{533}$ Este es exactamente el principio que enunciáramos previamente al referirnos a las exigencias que la especie presenta.

${ }_{534}^{534}$ Véanse las cita correspondientes a las notas al pie 155 y 156.

${ }^{535}$ Modjo - Lady (Hear Me Tonight). (2000). Subido por Modjo. El videoclip oficial del tema es accesible en https://youtu.be/mMfxI3r_LyA. [02072016]
} 
Con la inclusión de esta segunda opción posiblemente evitaremos algunas críticas. Si elegimos en primera instancia la pieza de Massive Attack fue por el formato banda que este proyecto presenta y que aquí nos resultó útil para contrarrestar un sesgo que detectáramos en el trabajo de Mark Butler. Dicho autor comprende a la música electrónica de baile como el formato que ubica al productor en la soledad de su estudio y donde el deejay, munido de las "grabaciones" realizadas por aquel, ${ }^{536}$ es el artista que con exclusividad presenta estas producciones al público. A nuestro modo de ver, este recorte ha generado distorsiones en su punto de vista; distorsiones que lo condujeron a adoptar posiciones y perspectivas poco abarcativas y que tienen poca o nula aplicabilidad en el análisis de las técnicas y acciones realizadas -y resultados obtenidos- en los actos en vivo (i.e.: "live acts") de músicos electrónicos.

Estas técnicas, acciones y resultados son parte efectiva de la experiencia y universo vinculados a las músicas electrónicas utilizadas para el baile social y, como puede apreciarse en el Anexo IV. Actores involucrados en la escena electrónica, pueden presentar características propias y diferenciadas de las involucradas en el hacer de los deejays. Dicho en términos simples y directos, técnicas y acciones que nada tienen que ver con el manejo de bandejas tocadiscos ${ }^{537}$ Conformando una porción para nada despreciable de las actividades vinculadas a una especie que pretendemos comprender en su totalidad y en tanto marco donde se genera sensación táctil, no podemos más que apartarnos del mencionado autor y procurar una perspectiva que sirva a nuestros fines. De todas maneras, como puede comprobarse en el título próximo, su trabajo continuará siendo fuente para el debate en varias oportunidades y cuestiones por venir. Hechas las aclaraciones necesarias pasemos al análisis de la especie.

\section{Características generales de la música electrónica de baile. Análisis complementarios a los realizados desde la perspectiva audiotáctil.}

\section{Rítmica}

En apretada síntesis, Mark Butler superpone dos perspectivas para analizar el fenómeno rítmico-métrico en la música electrónica de baile. Heredera cada una de tradiciones culturales de diferentes orígenes y -simultáneamente- desarrollos teóricos realizados a partir de músicas de cualidades divergentes, serán las herramientas utilizadas para analizar lo que él llama el "motor" de la especie. ${ }^{538}$ A partir de esta mirada en algún sentido dual, el autor propone tres tipos rítmicos a los que denominará ritmos "regulares", "diatónicos" y "sincopados". En estos términos e incluyendo antecedentes teóricos, fuentes y ejemplos desarrollará su perspectiva.

\footnotetext{
${ }^{536}$ Ya sea utilizando discos de vinilo, CDs o en reproductores de archivos virtuales, siempre operando sobre la música ya mezclada.

${ }^{537}$ Nobleza obliga. Como también fuera mencionado en múltiples oportunidades previas: las expresiones "poner música" o "reproducir discos" no alcanzan para describir el hacer artístico de muchos deejays.

${ }^{538}$ Representativo de la diversidad contenida en la especie, veremos que incluso estas dos perspectivas serán insuficientes para su descripción.
} 
Acordamos en términos generales con su punto de vista y con las divisiones que esta visión genera en la especie, por lo que en primer término expondremos las características centrales de cada tipo rítmico. Así también, nos apartaremos de esta perspectiva cada vez que lo consideremos necesario. Iniciamos de este modo una descripción en general de lo que cada uno de los grupos de índices poseen en común.

\section{Ritmos regulares}

Butler refiere con esta denominación a lo que la musicología eurocéntrica más tradicional comprende con estos términos; en otras palabras, compases de 2, 3 y 4 tiempos de división binaria o ternaria. A esto agrega la casi total omnipresencia del compás de 4 tiempos binarios. Más allá de las cuestiones métricas y respecto del ritmo propiamente dicho, dirá también que esta rítmica presenta un alto grado de regularidad en la distribución de los eventos en el tiempo. En otras palabras, los patrones que se asocian con este tipo rítmico consisten esencialmente en:

a) pulsaciones de diferente duración (coincidentes con las diferentes unidades métricas e hipermétricas: compás, acento métrico, pulso, división, hipermetro, etc.) y

b) breves grupos rítmicos simples repetidos (grupos de período usualmente coincidente con alguna de las unidades métricas).

Estos grupos se repiten y combinan generando patrones de repetición de formas simples $\mathrm{y}$ breves. En términos métricos y en conjunto, estas formas suelen presentar períodos comprendidos entre 1 o 2 tiempos y 4 compases. Mediante mínimas variaciones periódicas además, se establecen articulaciones formales que son casi sin excepción múltiplos geométricos de estas duraciones (i.e.: pequeños cambios generan articulaciones cada 2, 4, 8, 16, 32, 64... compases).

Acordamos en todo con esta descripción. Creemos interesante además remarcar que estos ritmos presentan lo que podemos llamar un fuerte carácter tético o "a tierra". ${ }^{539}$ Revisar la traducción del término inglés "even" utilizado por Butler puede clarificar lo que pretendemos decir.

El concepto inglés "even" posee múltiples acepciones, entre las que se encuentran aquellas que se traducen en "regular", "simétrico", "par", "parejo" y "estable". Como puede verse, en su conjunto remiten a una distribución igual. Simplificando, esta distribución se concreta en la casi sin pausa presencia del sonido de bombo en los cuatro tiempos de negra del compás de 4/4, del sonido de redoblante y/o sonido de palmas en los tiempos 2 y 4 y en

\footnotetext{
${ }^{539}$ Aquí entendido como opuestos a "sincopado", "cruzado".
} 
conformaciones rítmicas simples (usualmente de duración no mayor a un tiempo) de los sonidos de hi-hat abierto y cerrado.

Así distribuida la energía, lo que se obtiene es una resultante rítmica que, si bien puede presentar acentuaciones a contratiempo, genera una clara referencia perceptual regular y periódica sobre la parte fuerte de cada tiempo, sobre los tiempos fuertes de cada compás y (a veces) el primer tiempo (fuerte) del compás. A partir de esto es que resulta posible describir a estos ritmos como "téticos" y "a tierra".

La simplificación previa no debe ser tomada completamente al pié de la letra. Si bien son poco comunes las piezas que presentan una métrica diferente a $4 / 4$, muchas presentan ambigüedades en uno o varios niveles métricos, como también complejas polirrítmicas. Butler dirá que:

La experiencia rítmica y métrica en la música electrónica de baile usualmente involucra ambigüedad: el comienzo de un patrón puede ser poco claro, y la ausencia de estratos de movimiento pueden socavar la claridad perceptiva métrica. La organización formal es modular y de final abierto. Tres tipos de entidades repetitivas - los "loops" (breves patrones rítmicos), secuencias (combinaciones instrumentales de varios compases) y grabaciones- funcionan como los "ladrillos" que pueden ser combinados y yuxtapuestos con gran flexibilidad. ${ }^{540}$

No son para nada extrañas a la especie principalmente dos ambigüedades:

a) Ambigüedad respecto de cada cuantos ataques agrupar a la pulsación usualmente asignada al sonido de bombo o, desde la perspectiva métrica tradicional, ambigüedad del metro.

Esto sucede debido a que, si bien es siempre posible generar eventos acentuados o que generen diferente sonoridad en las cajas de ritmos, muchos productores prefieren la regularidad maquinal de una sonoridad invariante. Esto trae aparejado que la periodicidad del sonido de bombo, aislada del resto de los elementos, resulte igual a un único evento. En otras palabras, si representamos al ritmo de este elemento en negras, al ser todos iguales en todo, su periodicidad será igual a una negra. Como bien explica Butler, la consecuencia implícita que podemos extraer de aquí es que la estructura métrica en la música electrónica de baile -en los casos en que es posible extraer una única- resulta ser muchas veces un emergente de la interacción entre varios de los elementos que conforman la textura de una pieza determinada.

b) Ambigüedad respecto de donde se inicia el gesto musical, el patrón emergente de todos los elementos de la textura o, en términos métricos tradicionales, cual es el tiempo fuerte o primer tiempo del compás.

${ }^{540}$ Butler, M. (2003). Op.cit. pp. vi 
Múltiples son los ejemplos que, si bien son claros y coincidentes en la periodicidad del o de los patrónes incluidos, presentan gestualidades que se contradicen mutuamente en términos acentuales. ${ }^{541}$ Algo similar a lo que sucede en las músicas populares que se inscriben en la tradición del rock ocurre en la música electrónica de baile: el redoblante genera acentos atacando sobre los tiempos 2 y 4 del compás de $4 / 4$. Lo diferente es que en este último caso las ambigüedades poseen un rango mayor, abarcando desde:

i) una competencia acentual tiempo a tiempo entre, a modo de ejemplo, el sonido de bombo "a tierra" en cada tiempo del compás y -usualmente- el sonido de hi-hat a contratiempo, en la segunda corchea de cada tiempo binario: ambos o ninguno resultan en definitiva acentuados. Lo que en cambio sucede es que, a partir de su contraste registral grave-agudo provocan una cadencia que suele reflejarse en la danza con movimientos de vaivén usualmente coincidentes con el período establecido por esta contraposición...

...hasta:

ii) discordancias de índole fraseológica que pueden presentarse, entre otros casos, entre diferentes diseños rítmicos y/o melódicos simultáneos que presentan acentuaciones (agógicas, dinámicas, etc.) en momentos diferentes, y que cuestionan donde se encuentra el inicio efectivo del gesto emergente. Como se comprenderá, esta última ambigüedad se produce en una escala temporal algo mayor al caso previo.

Resulta más que evidente que estos efectos perceptivos son, en muchos casos, buscados por los productores: da cuenta de ello una técnica muy extendida para la generación de variaciones que consiste en el desplazamiento temporal de un elemento de la textura en relación a los demás. Desplazamientos de valores iguales a la (sub-)división, el pulso o múltiplos de estos, modificarán las relaciones acentuales entre el elementos fijo y el desplazado, provocando nuevas conformaciones acentuales y rítmicas. ${ }^{542}$

${ }^{541}$ Siguiendo a Lerdahl y Jackendoff, Butler describe a los acentos en tanto "eventos que crean saliencias en la superficie musical" ("events creating salience at the musical surface"). Butler, M. (2003). Op. cit. pp. 118

${ }_{542}$ En algún sentido, el efecto logrado puede emparentarse con el que caracteriza a las polimetrías, donde uno y otro material musical de período diferente (presentados simultáneamente y reiterados) se ven renovados por las nuevas relaciones acentuales y rítmicas provocadas por su desplazamiento mutuo relativo. En el caso último, la renovación se da de forma automática mientras que en aquél debe hacerse manualmente. 
Sin embargo, aún en las piezas que presentan estas ambigüedades, la cualidad tética o "a tierra" persiste porque el ritmo del sonido de bombo genera un fuerte anclaje perceptual sobre su regularidad y periodicidad. Del mismo modo, y como resalta Butler, la práctica común de eliminar temporariamente de la textura dicho elemento amplifica las posibles ambigüedades que pudieran encontrarse presentes. Ya sea que esto lo realice el productor en la soledad de su estudio o el deejay/músico electrónico en tiempo real frente a los bailarines, los fragmentos sin sonido de bombo provocarán la dinámica (entre deejay/músico y bailarines) típica de las paradas.

Coincidimos con Butler en que tanto este tipo rítmico como el que describiremos a continuación son los que primordialmente caracterizan a los índices basados en el patrón de bombo en negras house, techno y trance. Las mismas cualidades aparecen también en algunos ejemplos ambient/chill out/downtempo y suelen ser las rítmicas más prominentes en numerosos ejemplos hardcore actuales. ${ }^{543}$ Veamos ahora el segundo.

\section{Ritmos diatónicos}

En esta categoría Butler incluye algunos casos de los ritmos que desde la perspectiva tradicional suelen describirse como "aditivos". Siguiendo a Richard Cohn dirá que estos son "duraciones combinadas" o "distribuciones combinadas" ("mixed spans") por mixturar valores que son múltiplos de dos o más números enteros primos. ${ }^{544}$ Como para otras músicas populares, para la música electrónica de baile esas duraciones son 2 y 3 , siendo los casos más difundidos $3+3+2$ y $3+3+3+3+4$. Siguiendo luego a Jay Rahn Butler denominará a estos ritmos con el término "diatónico" para remitir, por analogía, a ciertas propiedades de la escala tonal que cree encontrar también aquí y que son las responsables de restringir los casos a solo algunas de las combinaciones de valores posibles con estos materiales. Para explicar estas propiedades Butler recurre al método de representación rítmica que el etnomusicólogo Phillip Harland creara para ilustrar en ensambles de percusión la ubicación de cada punto de ataque en una grilla de unidades abstractas iguales (i.e.: isócronas). Tomando como base la semicorchea (aunque cualquier otra figura es posible de ser equiparada al valor unitario), el patrón de bombo en negras se representa del siguiente modo:

\footnotetext{
${ }^{543}$ Los ritmos concretos utilizados en este último índice son sin embargo menos consistentes en relación a lo que sucede en los demás índices. Una mayor variabilidad se refleja en el hecho de que, mientras su actualidad se asocia a los índices basados en el patrón de bombo en negras, sus piezas old school presentan cualidades rítmicas claramente derivables de samples de breakbeats. Es precisamente en estas diferencias rítmicas tan acusadas (finalmente creemos encontrarnos en condiciones de afirmarlo) que basamos nuestra posición de que el hardcore consiste -no en un "género mayor" sino- más en un estilo caracterizado por su agresividad.

${ }^{544}$ También siguiendo a Cohn, Butler describe al tipo rítmico previo "regular" como "duraciones puras" o "distribuciones puras" ("pures spans" en ingles). Si no lo explicitamos antes fue en búsqueda de brevedad.
} 


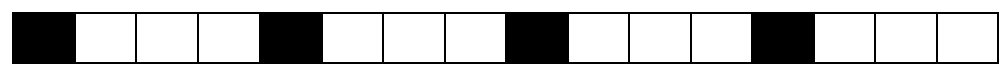

El contratiempo en corcheas usualmente asignado a hi-hats se grafica:

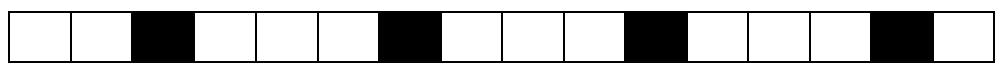

$3+3+3+3+4$ se visualiza:

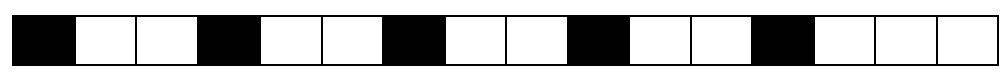

y $3+3+2($ corchea $=1)$ :

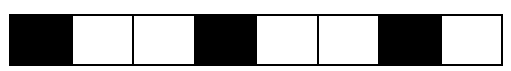

El "Sistema de Cajas de Unidades de Tiempo" (o "TUBS" por su sigla en inglés "Time Unit Box System") simplifica la grafía al eliminar la necesidad de ligaduras o silencios, facilita la detección de regularidades y similitudes al interior de patrones rítmicos y -a excepción de la recurrencia del valor unitario subyacente- no implica ningún tipo particular de jerarquía métrica.

Aprovechando estas virtudes, Butler explica que ciertas distribuciones de estos valores generan la "máxima regularidad" ("maximal evenness") posible. En otras palabras, sus ataques se distribuyen tan regularmente cómo es posible utilizando solo los valores regulares que ofrece un determinado compás. Lo explica diciendo que $3+3+2$ es una distribución que para 3 ataques en un compás de $4 / 4$ presenta mayor máxima regularidad que $2+4+2 .{ }^{545}$ Veamos las representaciones $T U B S$ respectivas, donde además puede apreciarse la aplicabilidad y virtudes de este modo representacional.

\section{$3+3+2($ corchea $=1)$}

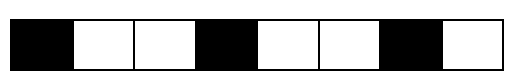

$2+4+2$

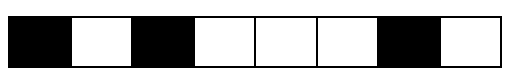

Para el autor (como para nosotros), estas rítmicas son en cierto sentido una extensión del tipo rítmico regular previamente descripto. Butler dirá que:

Por supuesto, muchos de los ritmos "regulares" que describo previamente, como el patrón de "bombo-en-negras", son también máximamente regulares; lo que es significativo de los patrones asimétricos es que son máximamente regulares sin ser absolutamente regulares. En términos musicales, esto significa que pueden crear interés

545 Lamentamos la redacción. Privilegiamos la claridad en la explicación por sobre la corrección gramatical. 
al dividir al compás irregularmente, y aún así son casi tan regulares como los patrones métricos. ${ }^{546}$

Los patrones máximamente regulares utilizados en la música electrónica de baile ${ }^{547}$ presentan además máxima individualización: cada ataque dentro del patrón presenta un juego único de relaciones con los demás. Por ejemplo, el cuarto ataque en $2+1+2+1+2$ (variante de $3+3+2$ ) se encuentra 5 unidades después del primero, 3 del segundo, 2 del tercero y 1 del último. Ningún otro ataque en este patrón presenta el mismo conjunto de relaciones. Como consecuencia secundaria de esta máxima individualización, la jerarquía métrica de cada ataque se debilita: los ataques coincidentes con las unidades métricas se perciben más inscriptos en la lógica de la máxima regularidad y menos como ataques fuertes y débiles. ${ }^{548}$

Para Butler, estas rítmicas son formas de "acomodar" máximamente regularizados y sin utilizar valores irregulares a un número impar de ataques en un compás con un número par de valores unitarios (ej.: $2+1+2+1+2+1+2+1+4$ ordena máximamente regularizados 9 ataques en las 16 semicorcheas del compás de 4/4). Luego en su desarrollo dirá:

Hice notar que la prevalencia de ritmos binarios en la EDM podría explicar el uso frecuente de divisiones asimétricas del compás, desde que los ritmos binarios están limitados en formas que fuerzan a los compositores a buscar nuevas estrategias para crear interés musical en el reino del ritmo y el metro. ${ }^{549}$

Como puede observarse, aún sin negar que se trata de ritmos sincopados, la perspectiva de Butler se encuentra claramente dirigida por la convicción de que esta es una forma extendida del tipo rítmico regular. Tanto es así que a continuación y para finalizar su tratamiento, cuestiona la caracterización de "asimétrica" utilizada incluso (aunque provisionalmente) por él mismo. Un poco más adelante en el desarrollo lo explicitará diciendo que:

A un nivel fundamental, proponemos dos amplias categorías de ritmos más que tres: ritmos regulares -una categoría que incluye tanto a los patrones puros binarios

\footnotetext{
546 "Of course, many of the "even" rhythms I describe above, such as the four-on-the-floor pattern, are also maximally even; what is significant about asymmetrical patterns is that they are maximally even without being absolutely even. In musical terms, this means that they can create interest by dividing the measure irregularly, and yet they are still allmost as regular as metrical patterns." Butler, M. (2003). Op.cit. pp. 95

${ }^{547}$ Como también en la música del África sub-sahariana, lo que denota la influencia afronorteamericana en la especie.

${ }^{548}$ En otras palabras, este tipo rítmico volvería al grupo rítmico más pregnante para la percepción, provocando un consecuente detrimento de la influencia que sobre dichos grupos podría presentar la grilla métrica regular (tradicional, occidental). Dicho aún de otro modo, la linealidad de la sucesión rítmica -o la forma los grupos rítmicos- se hace más pregnante y se impone a la estructuración métrica.

549 "I further noted that the prevalence of pure duple spans in EDM may explain the frequent use of asymmetrical divisions of the measure, since pure duple rhythms are constrained in ways that force composers to seek new strategies for creating musical interest in the realm of rhythm and meter." Butler, M. (2003). Op.cit. pp. 116
} 
absolutamente regulares y a los ritmos diatónicos de máxima regularidad- y a los ritmos sincopados, que se escuchan en relación a una norma binaria pura. ${ }^{550}$

Coincidimos plenamente con esta convicción aunque cuestionamos el ejemplo que brinda para justificar su afirmación. Adjetiva al ordenamiento $3+3+4+3+3$ como "palíndromo" rítmico, sin considerar las diferencias existentes entre puntos de ataque y duración. Sin embargo esta objeción, el tipo rítmico diatónico presenta similitudes perceptuales con el previamente tratado.

Los patrones rítmicos diatónicos, de modo similar a ciertas piezas de Bela Bartok, de Astor Piazzolla o de la tradición musical de raíz africana, establecen una regularidad -siempre parcial- que permite describirlos como cuasi-pulsos. Incluso cuando se presentan superpuestos a ritmos del tipo regular no se subordinan a aquellas métricas sino que "crean su propia regularidad a través de sus propiedades estructurales distintivas". ${ }^{551}$ Este fenómeno se hace evidente por ejemplo en la conformación $3+3+3+3+4$, donde solo el valor final contradice al - de otro modo- pulso de división ternaria. Cuando estos patrones se combinan con una ejecución con swing, la distinción binario-ternario puede volverse especialmente conflictiva como perspectiva de análisis, y virtualmente imposible de ser aplicada. Como fuera dicho y si bien existen diferencias importantes, los puntos de contacto entre la ambigüedad rítmica tratada y ciertos ritmos de nuestro folklore del altiplano merecen mayor exploración.

Como también dirá Butler y hemos experimentado en nuestra práctica profesional, estos patrones son utilizados de modo similar al pulso de la métrica occidental tradicional, como elementos de referencia para la sincronización entre múltiples intérpretes. Lo que se conoce como "clave" en las músicas afrosudamericanas o "marcha camión" en nuestro candombe son ejemplos concretos de esto.

\section{Ritmos sincopados}

Asociándolos principalmente con los ritmos originados en samples de breakbeats, Butler establecerá dos tipos de ataques sincopados:

a) aquellos a los que denominará de "tipo general" y que consisten simplemente en lo que la teoría tradicional refiere como "síncopas"; en otras palabras, un acento sobre un tiempo de compás débil o en una parte débil de cualquier tiempo, y

b) los que se perciben como anticipaciones o retardos en relación a un punto temporal donde cierta expectativa determina que dicho ataque debería producirse.

\footnotetext{
550 "At a fundamental level, then, we are actually positing two categories of rhythm rather than three: even rhythms -a category that includes both the absolute evenness of pure duple patterns and the maximal evenness of diatonic rhythms- and syncopated rhythms, which are heard in relation to a pure duple norm." Butler, M. (2003). Op. cit. pp. 103

551 "Rather than being measured against an even, pure duple norm, they create their own kind of evenness through their distinctive structural properties." Ibidem. pp. 102
} 
Poco puede agregarse en relación al primero de los tipos de síncopas. Para el segundo en cambio Butler utilizará ciertas variaciones y extensiones de los desarrollos que David Temperley aplica al análisis de melodías del repertorio rock. A diferencia de su fuente, limitará el alcance de la perspectiva "a situaciones donde la música explícitamente establece patrones jerárquicos de acentuación". ${ }^{552}$ Dicho de otro modo, Butler considera que este fenómeno es posible sólo cuando la rítmica evidencia claramente a la estructura métrica subyacente. ${ }^{553}$ Comprenderá a estos patrones en tanto generadores de expectativas respecto de la posición temporal donde deberían ocurrir las acentuaciones. En este marco, las síncopas serán entonces aquellos ataques y acentos que acontecen desplazados respecto de la posición esperada. Sobre el efecto y modo en que estos desplazamientos se perciben dirá que:

[...] la tensión entre nuestra percepción de la posición de la nota y nuestro sentido de donde debería estar crea algo similar a un tirón gravitacional hacia el ataque, una especie de énfasis negativo en la posición desde la cual la nota es desplazada. ${ }^{554}$

Debido a que en la música electrónica de baile la sección rítmica es el elemento más prominente, esta se establece tanto en el factor que genera las expectativas como también en aquel en el que se producen los desplazamientos mencionados. ${ }^{555}$

Creemos que el fenómeno referido es análogo al que sucede en el contrapunto, donde los campos interválicos (i.e.: los acordes) y las melodías estructuran tanto expectativas respecto de los puntos temporales donde se producirán los cambios armónicos como los desvíos o desplazamientos que constituyen las anticipaciones y retardos. Como en el contrapunto, estos desplazamientos provocan tensiones que pueden o no resolverse con posterioridad. Podríamos aventurarnos a decir entonces que, en cierto sentido, Butler propone un modelo de contrapunto rítmico.

Aunque Butler no lo mencione, no deben perderse de vista las expectativas que podría generar per se la regularidad que establece la división isócrona del tiempo, subyacente a todos los ritmos medidos. A este tipo rítmico pertenecen tanto las músicas de baile históricas como este y los demás modelos rítmicos descriptos y utilizados en la amplia mayoría (casi totalidad) de los elementos texturales de la música electrónica de baile. La detección consciente o

\footnotetext{
552 "I only apply this approach in situations where the music explicitly establishes hierarchical patterns of accentuation". Butler, M. (2003). Op.cit. pp. 99

${ }_{553}$ Aunque consideramos que otros casos son posibles, Butler la identifica concretamente con el compas de $4 / 4$.

554 "[...] the tension between our perception of a note's position and our sense of where it should be creates a kind of gravitational pull toward the beat, a sort of negative emphasis on the position from which the note is displaced." Ibidem. En nuestra traducción, como en el original, el término "nota" ("note") debe ser comprendido como "ataque" o como "evento sonoro". Realizamos una traducción literal debido a que la gramática de la cita podría de otro modo provocar ambigüedades de sentido.

${ }^{555}$ En el rock en cambio -explicará Butler-, la sección rítmica opera como elemento de referencia métrica y es en las melodías vocales o instrumentales donde Temperley encuentra los desplazamientos.
} 
inconsciente de esta regularidad opera como un indicio para nuestra percepción y estimula la búsqueda de regularidades a otros niveles organizacionales. De hecho, nuestra mención aquí de esta perspectiva se encuentra en línea con lo que luego argumentará Butler en relación al concepto de "proyección"; modo perceptivo que toma del libro de 1997 Meter and Rhythm, de Christopher Hasty. Según lo comprende Butler, para Hasty el metro ocurre cuando el oyente "proyecta" (i.e.: prevé) la repetición de la duración de un evento. El principio perceptivo puede ser enunciado del siguiente modo:

Dado un evento (A) sucedido inmediatamente por otro (B): la indefinición inicial de la duración de aquel se concreta y define con y en el comienzo de este. En el mismo instante, la indefinición duracional del segundo evento (B) se abre a la posibilidad de que dure exactamente lo mismo que el primero.

De concretarse reiteradas veces esta expectativa se establece una regularidad que, dependiendo de la escala temporal y de la cantidad de eventos contenidos, dará lugar al pulso (o tactus), división, metro e hipermetro. A diferencia de las estructuras presupuestas, subyacentes e ideales de la Teoría generativa de la música tonal de Lerdahl y Jackendoff (1983), los diferentes niveles de la métrica occidental son para Hasty eventos concretos que describe en términos de inicio, continuación, anacruza y -para el caso de los compases de tiempos imparespostergación. Nos interesa de esta perspectiva la dependencia e identificación mutua (parcial) que se establece entre los ritmos y la métrica. En la música electrónica de baile esta identificación facilitará el análisis y conceptualización de las conformaciones rítmicas y duracionales.

Como tercer factor generador de expectativas no podemos dejar de mencionar que las piezas electrónicas que utilizan rítmicas sincopadas conviven al interior de la especie con piezas cuyos ritmos se encuentran fuertemente identificados con los diferentes elementos de la métrica tradicional occidental. Las síncopas de uno y otro tipo entonces -como, por supuesto, las rítmicas diatónicas- operan también en una relación intertextual con las rítmicas regulares que tratáramos previamente. A partir de la perspectiva de Hasty podemos afirmar que los ritmos del último tipo concretan y explicitan -de un modo "brutal" en la música electrónica de baile- los diferentes niveles de organización métrica, las diferentes unidades de medición temporal.

Butler aprovechará uno de los dos samples de breakbeats más utilizados de la historia de la especie para demostrar el funcionamiento de su perspectiva acerca de los ritmos sincopados. Haremos aquí una síntesis de su exposición basada en el famoso sample del tema Funky Drummer de 1970 de James Brown. Mucho de lo que expondremos a continuación es 
también válido y puede ser aplicado con muy pocas modificaciones al sample de Amen Brother. ${ }^{556}$

Funky Drummer de James Brown

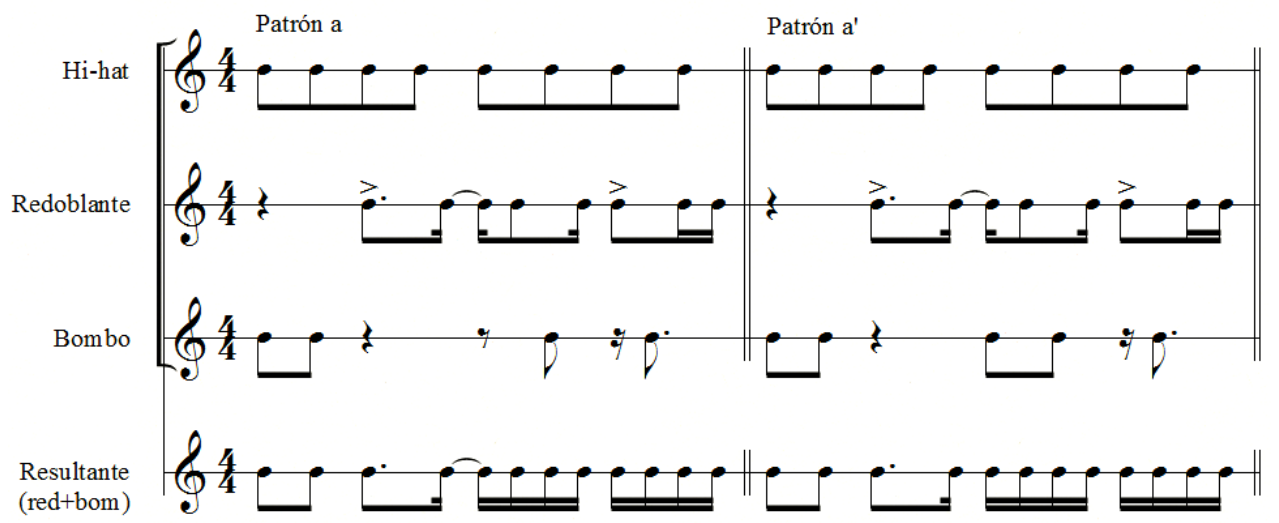

Los compases reproducidos aquí han sido utilizados generalmente independizados uno del otro. La transcripción expone los cuerpos de batería acústica que suenan en ambos patrones. A pesar de su fuerte carácter sincopado, el modo en que se presenta cada sample en las piezas que los incluyen -reiterados una y otra vez casi sin descanso- permite con gran claridad el establecimiento y detección perceptual del compás de 4/4 descripto por su rítmica. El primer ataque de bombo además, se identifica perceptualmente sin ambigüedades como el primer tiempo del compás. Práctica común en el funk, también aquí el hi-hat opera como elemento de referencia métrica al exponer claramente la división del pulso. Sintéticamente expuesto, Butler:

a) Asocia al tercer ataque del bombo en el patrón a con la primera de las formas de síncopas descriptas.

b) Descarta, en tanto síncopas, los ataques acentuados de redoblante en los tiempos 2 y 4 del compás de 4/4. Se basa para ello en la coincidencia de estos con los ataques de este cuerpo de batería en estas mismas posiciones de compás, omnipresentes en las músicas populares con influencia africana. ${ }^{557}$

\footnotetext{
${ }^{556}$ En los siguientes vínculos podrá acceder respectivamente al sample de Funky drummer varias veces reiterado, a la pieza original de James Brown donde se lo incluye (aprox. a los 8' 57"), a una Lista de reproducción con piezas que hacen uso del mismo y a un ejemplo de su manipulación en tiempo real. En el último puede apreciarse también la consola de deejay y sampler KAM GM50. Los videos: Funky Drummer Loop. Subido por JamTracksChannel. Accesible en https://youtu.be/b85lmY613Yk, James Brown - Funky Drummer (Full Version, 1970) - HQ. Subido por Funk Forum. Accesible en https://youtu.be/AoQ4AtsFWVM, Samples of Funky Drummer. Compilado por alexandre pereira. Accesible en https://youtu.be/q0b0jIaCEHU?list=PLwgKsDSf-8374jqkxBCELPAa1no-ILLbA y Funky Drummer Sample. Subido por Wayland Twiston Davies. Accesible en https://youtu.be/ T8a4HFvS9I. [27062016]

${ }_{557}$ Aquí podemos ver una expresión de los sentidos contenidos/incluidos/comunicados que describimos durante nuestra discusión respecto de los géneros. Ciertas convenciones provenientes del funk se
} 
c) Caracteriza al $2^{\circ}$ y $3^{\circ}$ ataque de redoblante en ambos patrones como "desplazamientos" que evitan la articulación del $3^{\circ}$ tiempo del compás. Respectivamente y en nuestros términos, se corresponden con una anticipación y un retardo. Como alternativa, propone al $3^{\circ}$ ataque como síncopa del primer tipo (no "desplazada") y agrega que junto al posterior ataque de bombo y al siguiente de redoblante conforman un levare hacia el $4^{\circ}$ tiempo.

d) Describe al último ataque de bombo en ambos patrones como un "desplazamiento" (retardo) del $4^{\circ}$ tiempo.

e) Finalmente, en función de lo descripto en el apartado $c$, describe al $3^{\circ}$ ataque de bombo del patrón a' como una forma de resolución de la tensión creada por los ataques evitados en el redoblante. ${ }^{558}$

Estos desplazamientos, de modo similar al efecto que provocan los levares, refuerzan a los tiempos evitados al convocar nuestra atención mediante las tensiones gravitatorias que (siempre en los términos utilizados por Butler) "tiran" y "empujan" de ellos.

Este tipo rítmico es el que primordialmente caracteriza a los índices jungle/drum'n'bass, breakbeats y hardcore en sus versiones históricas; encontrándose quizá una diferencia entre ellos en los agrupamientos rítmicos concretos que se utilizan en uno y otro. ${ }^{559}$ Es posible intuir que además, el índice breakbeats presenta una variabilidad mayor en los agrupamientos y conformaciones rítmicas concretas: siempre manteniendo las cualidades generales descriptas, las piezas breakbeats parecen hacer uso de una variedad mayor de samples, provenientes de un mayor número de piezas. Luego de un primer período donde los patrones surgieran casi exclusivamente de samples de breakbeats de piezas del funk y del disco las fuentes se diversificarían, siendo hoy mucho más común encontrar ejemplos donde estos patrones se elaboran a partir de samples de ataques discretos o sonidos sintetizados.

Encontrando algunas divergencias con otras ideas de Butler abandonaremos temporalmente el seguimiento de su trabajo. Quedan sin embargo en relación al ritmo de la música electrónica de baile algunas cuestiones pendientes de tratamiento y aclaración.

\section{Rítmicas regulares-sincopadas combinadas}

El índice que por excelencia presenta este tipo rítmico es el $u k$ garage. Incluyendo elementos texturales que describen ritmos regulares y otros que desarrollan valores altamente sincopados y cambiantes, este índice sintetiza ambas rítmicas en una única expresión. Sin

\footnotetext{
"embeben" y determinan los modos perceptivos con que se "lee" el sentido de las piezas que incorporan estos samples. Para más detalles ver el Anexo II. El problema de los géneros.

${ }^{558}$ Aquí vemos un factor de similitud más que refuerza nuestra propuesta de asignar a esta perspectiva el nombre de "contrapunto rítmico".

${ }^{559}$ Derivados del sample concreto que se utilice, en algunos casos quizá influyen también diferencias de tempo.
} 
embargo, la resultante más evidente, la cualidad rítmica más pregnante y que termina imponiéndose y dominando la sensación rítmica general es la derivada del segundo tipo. Los elementos rítmicos que permanecen y que tienden a establecerse como los eventos de referencia temporal y rítmica suelen resultar disminuidos y debilitados frente a la pregnancia de una complejidad tímbrica, registral, de densidad y rítmica siempre cambiante y usualmente colocada "al frente" (en la mezcla) por un énfasis basado en una mayor sonoridad general. ${ }^{560}$

En este sentido resulta más acertado asociar este índice a los ritmos sincopados. En definitiva, al momento de establecer los límites mutuos y recíprocos entre los índices jungle/drum'n'bass y breakbeats consideramos que es más apropiado remitir a las diferencias en los ritmos concretos asociados a -los sonidos equivalentes a- cada cuerpo de la batería que describimos durante el tratamiento de su evolución histórica. ${ }^{561}$

\section{Polimetrías}

El tratamiento de las cuestiones rítmicas a partir del desarrollo planteado por Mark Butler puede haber generado la falsa impresión de que toda rítmica en la música electrónica de baile se estructura dentro de los límites del compás de cuatro tiempos binarios. Si bien la amplia mayoría de ejemplos se organiza alrededor de estas cualidades y mucha de la rítmica responde a los casos descriptos, también es cierto que existe un cuerpo de obras muy numeroso que presenta ejemplos de verdaderas y propiamente dichas polimetrías.

Algunas veces más evidentes y otras menos, algunas veces simples oposiciones 4 contra 6 y otras complejas 11 contra 7, a veces enmascaradas bajo un velo de 4/4 y otras evidenciando la influencia del índice experimental, la polimetría es un recurso que forma parte de la batería de posibles de la música electrónica de baile. Como en cuestiones tratadas previamente, vemos aquí también la influencia de tradiciones originarias del África negra y de la música electroacústica de vanguardia.

Es usual que cada período de duración (cada frase polimétrica describiendo un período concreto) se presente identificado con un estrato textural donde las cualidades métricas inciden sobre todos los parámetros musicales. Sin embargo, en piezas donde la influencia del índice experimental es mayor pueden detectarse polimetrías simultáneas influyendo independientemente sobre uno u otro parámetro de un único estrato textural. ${ }^{562}$

\footnotetext{
${ }^{560}$ Nótese que en el detalle de la complejidad mencionada incluimos casi todas las cualidades del sonido.

${ }^{561}$ En otras palabras, creemos que las diferencias mutuas son equiparables a las que separan a nuestra chacarera de la cueca o de la chaya. Para detalles acerca del surgimiento y evolución histórica del índice ver Anexo II. El problema de los géneros.

${ }^{562}$ Valga como ilustración de esta cuestión el hecho de que cajas de ritmos que incluyen secuenciador por pasos -por ejemplo, la MFB Tanzbar o la (de reciente salida al mercado) Arturia Drum Brute- permiten establecer períodos de repetición independientes para cada uno de los sonidos que son capaces de generar. Véase en el vínculo siguiente la revisión en video del último dispositivo que el canal de YouTube Sonic Lab publicara el 7 de octubre de 2016. Arturia Drum Brute In Depth Preview-Sonic LAB. Subido por
} 
Este elemento es otro factor más que se suma a los tratados previamente y que realiza su aporte a las demás ambigüedades rítmicas usuales en la música electrónica de baile. Siendo un fenómeno demasiado amplio y heterogéneo y no constituyendo el foco del presente estudio, limitaremos su tratamiento a los casos particulares que pudieran surgir durante el análisis de piezas.

\section{Ritmo no medido}

En la música electrónica de baile tienen lugar todos los tipos de rítmicas que la teoría musical ha conceptualizado. Ritmos que usualmente se describen como aquellos que priorizan la dimensión duracional del Tiempo (i.e.: duraciones que denotan la ausencia de cualquier división isócrona subyacente) tienen lugar y evidencian su presencia primordialmente en piezas de los índices experimental, ambient/chill out y downtempo. Así también podemos encontrar estratos texturales que presentan estas cualidades rítmicas en ejemplos trance, techno, jungle/drum'n'bass y en algunas paradas de diferentes índices. En resumen, es posible encontrar elementos texturales que presentan estas cualidades rítmicas en todo tipo de piezas y contextos, impidiendo su asociación con algún índice o situación particular: tanto se evidencian en la forma de interminables drones o texturas evolutivas como en texturas de puntos; ya sean a partir de fuentes sintetizadas de rítmica azarosa como originados en samples con rítmicas (no medidas) propias de sonidos encontrados; ${ }^{563}$ algunas veces presentados en soledad, otras en la forma de estratos texturales acompañados de otros que presentan rítmica medida.

Los ritmos no medidos se establecen como otra forma de generar diversidad rítmica y duracional y de cuestionar la rigurosidad e imperio del compás de 4/4. Conformaciones que desde el punto de vista textural pueden describirse como heterofonías, ${ }^{564}$ los elementos que presentan ritmos no medidos suelen fluir con cierta independencia de los demás estratos texturales, generando extrañamiento y permitiendo una descripción que (similar a los postulados de Demers al cuestionar su pertenencia a la categoría de música) los ubica "sobre" o "por detrás" de estos.

A su vez, estos estratos pueden recibir tratamientos y procesamientos que modifican su estructura rítmica caótica. Compuertas ("gates") y otras funciones de modulación permiten que a ciertos continuos sonoros se les sobreimpongan rítmicas medidas. Si estas transformación se realizan de forma paulatina, la división entre uno y otro tipo de rítmica se vuelve más difuso: un elemento textural caracterizado por presentar ritmo no medido se reconvierte gradualmente

sonicstate. Accesible en https://youtu.be/GBcI6kvRjPA. [14102016] Como en otras oportunidades, lamentablemente en idioma inglés.

563 Como explicáramos en ocasiones previas, grabaciones de eventos sonoros provenientes de la cotidianeidad, la naturaleza o de actividades humanas que no tienen como finalidad específica la generación de sonido.

${ }_{564}$ Como ya fuera dicho, una textura caracterizada por presentar la convivencia simultánea de elementos inconexos, sin vinculación ni nexo mas allá de coexistir en un mismo contexto. 
hasta describir un ritmo medido. Además, cuando aquellos estratos se encuentran acompañados de otros que presentan ritmo medido, los ritmos sobreimpuestos pueden presentarse sincronizados. De modo similar al efecto provocado por la aplicación paulatina de swing sobre ritmos binarios, este tratamiento flexible se vuelve otra forma de cuestionar la rigidez de la rítmica medida, cubriendo con un velo de un nuevo tipo de ambigüedad a todos los tipos rítmicos existentes.

Encontramos aquí otra forma donde la música electrónica de baile cuestiona los límites entre las segmentaciones tradicionales de "música popular" y "música contemporánea-seria"; de esta manera cuestiona también los límites que usualmente se establecen entre conservación e innovación. Como evidenciáramos en el Anexo II. El problema de los géneros, en la música electrónica de baile es necesario rastrear a la experimentación ya que esta se encuentra en lugares inesperados.

\section{Ritmos de valor agregado}

Siendo quizá el tipo rítmico menos extendido en la especie, algunas formas pueden hallarse en las texturas de puntos descriptas en el tratamiento de ritmo no medido. Formas duracionales que denotan lógicas similares a las basadas en un valor unidad de pulsación veloz como los utilizados por Olivier Messiaen en su Modes de valeurs et d'intensités, pueden escucharse en ejemplos experimentales, ambient/chill out y downtempo y en estratos texturales secundarios en piezas de índices primordialmente jungle/drum'n'bass, trance o psy trance. Nuevamente, no siendo esta una cualidad principal de la música electrónica de baile ni el foco específico de nuestro estudio, limitaremos su tratamiento a estas breves menciones.

\section{El swing en los ritmos medidos}

La herencia africana ha dejado aún otra huella en las rítmicas utilizadas en la música electrónica de baile. Consistente en ciertas desviaciones mínimas y no tan mínimas en relación a la precisión de la segmentación isócrona de la grilla métrica occidental, suelen aplicarse sobre ataques que ocurren coincidentes con los tiempos, la división o la subdivisión.

Agregando algunos otros datos a los ya expuestos en ocasiones previas, dichas desviaciones abarcan un rango que va desde los pocos milisegundos de anticipación o retardo a una desviación que transforma valores de división binarios hasta aproximarse y percibirse casi coincidentes con la grilla de división ternaria. Presente en el jazz y en otras músicas de origen afronorteamericano, como tantas otras cualidades pasó a formar parte de los recursos de la música electrónica de baile.

Como veremos en el siguiente título, la coexistencia en algunas piezas de ambas divisiones y/o la ambigüedad o indefinición de la propiedad binaria/ternaria en otras, será una propiedad de la especie que facilitará su hibridación con ciertos géneros locales sudamericanos. 


\section{Localismos e hibridaciones. Algunas conclusiones en torno a la rítmica}

Como pudo apreciarse en el desarrollo previo, las rítmicas utilizadas en la música electrónica de baile presentan una diversidad mucho mayor a la que en general se considera propia de la especie. Esta diversidad es incluso mayor a la considerada y descripta por los autores que constituyen nuestras fuentes. Sin embargo, la actualidad de la especie hace necesario dar aún un paso más: a las cualidades rítmicas que describiéramos en tanto tipos, deben agregarse también las conformaciones y agrupamientos particulares derivados de géneros que llamaremos "locales", incorporados más recientemente a la especie.

La presencia del ritmo diatónico $3+3+2$, tanto en la música electrónica de baile como en algunas tendencias del tango y la milonga, abrieron la puerta a que estos géneros ingresaran a formar parte de las expresiones electrónicas de baile, incorporando al interior de ambas especies el resto de sus cualidades y gestualidades rítmicas. Los nexos que las respectivas tradiciones de origen africano establecen entre ambas músicas facilitaron su hibridación, visibilizando en el contexto local la posibilidad de apropiación cultural de estas músicas. ${ }^{565}$

Por otra parte, grandes similitudes con algunos grupos rítmicos presentes en los índices basados en samples de breakbeats facilitaron la inclusión de cualidades presentes en el género del altiplano sudamericano wayno o huaino, dando origen al índice reggaetón. Surgido inicialmente en la zona norte de América del Sur, la migración al interior de la región facilitaría luego la aparición en nuestro país del índice hoy conocido como electrónica tropical o cumbia electrónica.

El impulso dado por la música rioplatense y tropical, los puntos de contacto hallables en la polimetría y en cierta indeterminación de la división binaria/ternaria, y un período histórico caracterizado por una revalorización de lo nacional, propiciaron que gestualidades propias de géneros folklóricos ampliaran su influencia al interior de la especie. En el contexto local al menos, estas hibridaciones han repercutido en un evidente aumento en la cantidad de piezas que hoy presentan compases de 3 tiempos y/o división ternaria/medianamente indeterminada. ${ }^{566} \mathrm{La}$ complementariedad 3/4 - 6/8 propia del folklore argentino y latinoamericano, con la distribución registral propia de los toques de bombo legüero y su identificación grave=parche y agudo=aro, resulta menos extraña y se hace presente hoy en contextos antes dominados casi con exclusividad por cualidades musicales de origen euro-norteamericanocéntricos. ${ }^{567}$

\footnotetext{
${ }^{565} \mathrm{La}$ influencia afro no solo se deja ver aquí. Aquellas piezas que evidencian sin lugar a dudas samples de percusiones u otras cualidades fonéticas de dicho origen conforman en la música electrónica de baile el índice tribal.

${ }^{566}$ Véase al respecto la nota publicada en la edición digital del diario La Nazion del 22 de julio de 2011. Titulándola "Tecnofolk: música de raíz y nuevas tecnologías" Gabriel Plaza realiza una descripción y recorrido por las cualidades del índice. Accesible en línea en http://www.lanacion.com.ar/1391345tecnofolk. [02092016].

${ }^{567}$ Referimos aquí no tanto a la realidad de los materiales musicales sino al intento universalizador e invisibilizador del relato que la industria discográfica intentó e intenta imponer alrededor de la música
} 
Estas y otras múltiples hibridaciones aún en desarrollo en diferentes partes del planeta han gestado para la especie una actualidad caracterizada esencialmente por la mixtura. Ya sea entre cualidades propias de índices pertenecientes históricamente a la especie o con cualidades provenientes de múltiples géneros locales de diversas regiones del planeta, este mestizaje trajo aparejado una aún mayor difuminación de los límites poético-estético-técnicos tanto propios como de los géneros con los que la música electrónica de baile se ha hibridado. Dicho de otro modo, las hibridaciones han sido y son en ambos sentidos y el intercambio de cualidades, mutuo.

\section{Textura}

\section{"Música de percusión"}

Para iniciar el tratamiento de la textura en la música electrónica de baile (y para caso, también de las músicas electrónicas utilizadas para el baile social) tomaremos nuevamente algunas ideas de Butler. Si bien disentimos con muchos de sus puntos de vista por considerarlos generalizaciones demasiado simplistas o recortes en algún sentido caprichosos, debatir con su línea argumental nos permitirá describir algunos aspectos generales de las texturas hallables en la música electrónica de baile. Confiamos en que estas descripciones brindarán un marco poético-estético-técnico más claro acerca del contexto musical en que ocurre sensación táctil.

Butler comprende a la música electrónica de baile como música de percusión. Partiendo de esta idea dirá que en su textura no puede hallarse una única "voz" predominante sino que, por el contrario, esta es heterogénea y conformada por partes relativamente iguales entre sí en términos jerárquicos. Refiriendo sin nombrarla a cualidades asociadas tradicionalmente con el concepto de "contrapunto", diferenciará a la textura de la música electrónica de baile oponiéndola a aquélla que (para el autor) define a las demás músicas populares y "clásicas": la melodía con acompañamiento.

Aunque creemos estar diciendo una obviedad preferimos explicitarlo: en cada una de las músicas mencionadas es posible hallar texturas diferentes a las asignadas por Butler y son muy numerosos los ejemplos que contradicen su perspectiva. Si bien es cierto que la melodía con acompañamiento es la más extendida en las músicas populares, esto no puede ser sostenido para la totalidad de ellas y, mucho menos aún, para las músicas académicas o clásicas. ${ }^{568}$ En este marco no comprendemos qué razones podrían haberlo conducido a realizar una afirmación semejante, imposible de sostener frente a un enorme cuerpo de obras que rebate sus

electrónica de baile. Múltiples autores (Reynolds, Demers, Butler, Snoman, etc.) explican el surgimiento en Europa de la denominación "Drum'n'Bass" como un intento de borrar las huellas culturales afronorteamericanas presentes -para la industria discográfica- en la denominación "Jungle" utilizada originalmente para este índice en los Estados Unidos de Norteamérica. Con un trasfondo claramente discriminatorio, mediante este cambio pretendieron brindar al público neófito una imagen universalizada de un género cargado de cualidades de origen afro.

${ }^{568}$ Sobre todo teniendo en cuenta que el autor utiliza este término en su acepción amplia, conteniendo en su interior al menos a toda la música europea del período tonal. 
argumentos. ${ }^{569}$ Sin embargo, a partir de lecturas entre líneas de sus posiciones, encontramos una posible respuesta parcial a esta última cuestión.

Creemos no equivocarnos al suponer que el capital cultural en teoría musical de Butler tiene su principal basamento en músicas populares. Además de los argumentos que explicitáramos y los que paulatinamente podrán apreciarse en nuestro desarrollo, creemos correcta esta afirmación a partir tanto de ciertos dichos y terminologías utilizadas al exponer algunos temas ${ }^{570}$ como de su mención explícita de haber participado activamente como creador y bailarín de música electrónica de baile. Este hecho podría haberlo llevado a establecer como elemento de referencia el uso que tradicionalmente se ha dado a la batería en dichas músicas. ${ }^{571}$ Si bien nuestras suposiciones no son más que hipótesis de bases mucho menos que firmes, las tomaremos como ciertas por considerarlas útiles para continuar nuestro desarrollo.

Brevemente, la batería en la música popular -y en no pocos casos la percusión en otros repertorios- es entendida como un instrumento único constituido por múltiples "cuerpos" (i.e.: siendo "cuerpos" el redoblante, cada platillo, el bombo, etc.). Estos cuerpos ofrecen timbres y registros disimiles, por lo que la cualidad del mencionado instrumento único es esencialmente heterogénea. Además ( $\mathrm{y}$ aunque pueda parecer una obviedad), los sonidos producidos son impulsivos y relativamente cortos (i.e.: nuestros sonidos percusivos) ${ }^{572}$ Por último pero no por ello menos importante, el principio que más usualmente se utiliza para organizar la interacción entre los diferentes cuerpos, timbres y registros de la batería es el de la complementariedad. ${ }^{573}$ Como veremos en breve, quizá en estas cualidades reside el origen de la expresión "música de percusión" que Butler utiliza para caracterizar a la música electrónica de baile. Llegados apenas a este punto y por más que parezca una digresión, antes de continuar con la línea argumental principal y para que la misma se comprenda, nos vemos obligados a hacer otra observación.

Las piezas seleccionadas y analizadas por Butler presentan, en algunos sentidos, un grado elevado de experimentación. A modo de ejemplo, las escasas melodías y armonías

\footnotetext{
${ }^{569} \mathrm{Ni}$ en su tesis doctoral ni en sitios en línea que tratan su formación y áreas de interés encontramos datos que pudieran explicar el porqué de esta posición. Su postura nos extraña sobre todo teniendo en cuenta que en los demás aspectos demuestra un conocimiento profundo de la materia musical. Tampoco hemos sido capaces de encontrar las razones precisas que lo llevaron a establecer una relación lineal entre las "músicas de percusión" (sean estas las que sean, ya que no las define mas allá de lo que mencionáramos) y la ausencia de voz predominante/igualdad jerárquica entre partes. Nuevamente, numerosos ejemplos -sobre todo provenientes del repertorio contemporáneo o académico- rebaten el establecimiento de una relación tal.

${ }^{570}$ En varias ocasiones sus explicaciones surgen a partir de la jerga utilizada por la comunidad electrónica, dejando implícito su sentido de pertenencia a la misma.

${ }^{571}$ El mismo desarrollo y los modos de exposición del tema en su trabajo parecen sugerir que esto es efectivamente así. Algo de estos modos se refleja en nuestro próximo título Heterogeneidad y complementariedad. El "motor" regular.

${ }^{572} \mathrm{Si}$ bien es posible realizar sonidos sostenidos y largos (por ejemplo) rozando los platillos, este es un tipo de excitación que podemos describir como "lateral" y muy poco usual en las música populares.

${ }^{573}$ Es posible suponer que las cualidades previamente descriptas promovieran este tipo de organización; siendo un instrumentos heterogéneo y posibilitando esencialmente sonidos percusivos, la organización en base a criterios de complementariedad pareciera la forma más directa y sencilla de conseguir un discurso musical continuo, con variedad y sostenido en el tiempo.
} 
hallables en las piezas techno analizadas (cuando alguna ocurre) son defectivas: queremos significar con esto que no presentan desarrollos ulteriores ni correlatos formales asimilables al aporte que las mismas realizan, o que podrían imaginarse derivables de dicho aporte (al menos) en contextos de músicas populares, de baile, menor o ligera. ${ }^{574}$ En el contexto en que se presentan y por el tratamiento dado a las mismas, estas melodías y armonías pueden ser en muchos casos reducidas y casi en todo equiparadas a los demás eventos presentes en la textura; eventos que en su amplia mayoría se asignan a timbres de altura tonal no definida y donde lo esencial es su conformación rítmica, eventos que esencialmente aportan a la sección rítmica. A modo de ejemplo, la sintaxis melódica (i.e.: las propiedades esenciales de conformaciones que basan su identidad en una lógica estrictamente formal) es desestimada en y para ulteriores desarrollos formales.

En algún sentido, es aquí aplicable el concepto de objeto sonoro de Pierre Schaeffer: eventos conteniendo información armónica tonal (i.e.: acordes plaqué aislados o una secuencia armónica en acordes plaqué, por ejemplo) o información melódica (i.e.: el sample de una melodía interpretada con un timbre de cuerdas frotadas por ejemplo) se presentan en modos que neutralizan, al menos parcialmente, sus propiedades formales. Expuestos una y otra vez sin modificación alguna o, todo lo contrario, con altos índices de variación en otros aspectos, las cualidades concebidas tradicionalmente como centrales o esenciales para estas conformaciones pierden el peso históricamente asignado. En nuestros ejemplos, la gravitación armónica tonal pierde al menos parte de su capacidad resolutiva y la sintaxis melódica cede al menos algo de su protagonismo al aspecto fonético (i.e.: tímbrico). Estas neutralizaciones múltiples tienen como consecuencia última que lo que persiste de los elementos descriptos (además de lo detallado en cada ejemplo) es solamente su "ocurrencia" y el momento en que esta sucede; en síntesis, su aporte rítmico y duracional. Dicho en los términos que utilizáramos durante el análisis audiotáctil de la altura: una perspectiva absoluta prima sobre otra relacional.

Como ejemplo de armonía parcialmente desfuncionalizada sugerimos la escucha del sample de piano incluido en (y repetido durante todo) el tema Clint Eastwood de la banda Gorillaz. ${ }^{575}$ En esta pieza son esencialmente los movimientos del bajo los que plantean cambios funcionales (i.e.: tonales). Ejemplos posibles y muy disimiles de neutralización parcial de las cualidades formales de una melodía son el sample de (la melodía de) cuerdas del tema Bitter Sweet Symphony de The Verve $e^{576}$ o la melodía inicial y el tratamiento aplicado a la misma en el

\footnotetext{
574 En otras palabras, se les asigna un rol pasivo precisamente a aquellas conformaciones cuya reelaboración es, en la tradición musical occidental, lo que mantiene el interés en la obra y motoriza su devenir.

575 Gorillaz - Clint Eastwood (Official Video). (2001). Subido por el usuario Gorillaz. Accesible en https://youtu.be/1V xRb0x9aw. [11072016]

576 The Verve - Bitter Sweet Symphony. (1997). Subido por el usuario emimusic. Accesible en https://youtu.be/1lyu1KKwC74. [11072016]
} 
ya citado Nevermind del duo Infected Mushrooms. ${ }^{577}$ Siguiendo el vínculo que ilustra esta última pieza, a partir de los 8'51", en la pieza Nothing to say puede escucharse también otro ejemplo que ilustra la transformación de las propiedades de un elemento que esencialmente contiene información armónica hasta el punto de quitarle completamente dicha información en favor del... ¿ritmo? ¿timbre? ¿textura? De un modo mucho menos abarcativo Butler dirá que:

Como lo hicieran notar autores como Temperley y Covach, la percusión permanece en el fondo en la mayoría de la música rock, donde su función es la de proveer un ritmo firme y establecer el metro; el cantante (y, en pasajes como los solos de guitarra, el sustituto instrumental del cantante) es el verdadero foco de atención. Pero en la música electrónica de baile (y especialmente en el techno), la percusión es la música, al grado que los pocos elementos melódicos presentes (e.g.: los riffs) frecuentemente asumen también un rol percusivo. ${ }^{578}$

Inadvertida quizá para el autor, la heterogeneidad implícita, en su descripción y en la percusión referida, resulta invisibilizada y disminuida en favor del ritmo.

Que no se nos malinterprete, la subordinación de otras variables musicales al ritmo debida a la prosecución de (valga la redundancia) fines rítmicos es, a nuestro modo de ver, el argumento más fuerte de Butler. Si bien, como dijéramos ya varias veces, acordamos con el autor en esta cuestión, lo creemos sin embargo un argumento insuficiente para establecer una relación directa entre la "música de percusión" e -incluso- los ejemplos por él seleccionados. Al ampliar el área de observación a todo el techno o a toda la música electrónica de baile lo creemos directamente desacertado e inaplicable. Dicho de otro modo, esta perspectiva se encuentra lejos de agotar las conformaciones texturales hallables en la música electrónica de baile.

Escúchese por ejemplo la pieza Get Lucky del duo francés Daft Punk. ${ }^{579}$ Esta pieza es apenas uno de muchos ejemplos donde la melodía ejecutada por la voz del cantante, de una melodía con acompañamiento presenta muchos más prominentes desarrollos rítmicos que en registro o alturas. Sin embargo estos desarrollos, su conformación tímbrica se caracteriza por la homogeneidad: el estrato textural melodía principal con contenido literario se encuentra siempre a cargo de la voz identificable de Pharrel Williams. Independientemente de la intención compositiva que pudiéramos suponer, resulta más que evidente que el mencionado estrato textural contribuye en mucho al carácter rítmico de la pieza. Sin embargo, esta cualidad nada suma ni resta a una textura que, sin lugar a dudas, consiste en una clara melodía con

\footnotetext{
${ }^{577}$ Infected Mushrooms. (2012). Op.cit. Accesible en https://youtu.be/uloBD9xxwZ0. [11072016]

578 "As authors such as Temperley and Covach have noted, drums remain in the background in most rock music, where their function is to provide a steady beat and establish the meter; the singer (and, in passages such as guitar solos, the singer's instrumental surrogates) is the real focus of attention. But in electronic dance music (and especially in techno), drums are the music, to the extent that the few melodic elements that are present (e.g., the riffs) frequently assume a percussive role as well." Butler, M. (2003). Op.cit. pp. 109-10

${ }^{779}$ Daft Punk - Get Lucky (Official Audio) ft. Pharrel Williams, Nile Rodgers. (2013). Subido por el usuario DaftPunkVEVO. Accesible en https://youtu.be/5NV6Rdv1a3I [10072016]
} 
acompañamiento. A nuestro humilde modo de oír, aún cuando en Get Lucky es posible una descripción desde la perspectiva rítmica de Butler, dicho análisis no agota la descripción de aquellas cualidades que creemos definitorias y esenciales del ejemplo.

En síntesis, coincidimos en que en la mayoría de los casos (por no decir en todos) los diferentes elementos de la textura en la especie se configuran en función de fines rítmicos. Disentimos sin embargo en que este hecho condicione a las texturas en el grado que el autor afirma: si bien la especie presenta cualidades que pueden ser asimilables a la "música de percusión", esta descripción no se encuentra siquiera cerca de agotar todas las posibilidades detectadas y en numerosos casos resulta inaplicable. Elegimos no caracterizar a la música electrónica de baile de este modo sino que preferimos describirla en los términos que antes utilizáramos: numerosas piezas en la música electrónica de baile:

a) presentan cualidades heterogéneas, entre otros aspectos, en timbre y registro;

b) en numerosas oportunidades, dicha heterogeneidad tiende a ser identificada por sus creadores como "proveniente de una única fuente"; ${ }^{580}$

consecuentemente, dichos creadores:

c) tienden a organizar y transformar materiales heterogéneos a partir de criterios de complementariedad.

Como pudo apreciarse y veremos en lo que sigue, a pesar de las falencias en la perspectiva de Butler es posible extraer algunas ideas que nos serán útiles para comprender lo que ocurre en la especie en materia textural. Expuestas en términos y con modos algo diferentes, estas mismas ideas solo parcialmente ciertas pueden arrojar aún alguna luz acerca de las perspectivas a aplicar en el estudio de numerosos casos hallables en la música electrónica de baile. Debatiremos con esta hipótesis, estableciendo en cada caso nuestros acuerdos y disensos.

Tómese entonces lo que expondrá en los dos títulos siguientes respecto de sonidos constituyentes de la sección rítmica como una descripción posible de la textura completa de numerosas piezas de la especie. Descripción que también resulta aplicable a las relaciones que se establecen entre sonidos de bajo, sintetizador, samples, melodías, rellenos armónicos, arpegios y muchos otros.

\footnotetext{
${ }^{580}$ Piénsese por ejemplo en la heterogeneidad incluida en un sample que contiene varios compases de la interpretación de un baterista (como en el caso de los samples de breakbeats).
} 


\section{Heterogeneidad y complementariedad. El motor regular}

Como describiéramos brevemente, en la amplia mayoría de las músicas populares recientes la batería es considerada un único instrumento de múltiples cuerpos. Dicha concepción redunda en que, con algunas excepciones y en términos generales, a cada cuerpo se le asigna una función y ritmo complementarios a los demás. Si bien suele ser posible aislar perceptualmente las rítmicas descriptas por cada uno, es también cierto que, quizá por tratarse en general de sonidos de altura tonal no definida o inarmónicos, una mejor y más completa aproximación al sentido musical se alcanza al contrastar -al menos- los datos derivados del análisis rítmico y tímbrico-registral del conjunto.

Analizaremos entonces las interacciones que se establecen entre dichos cuerpos en uno de los patrones rítmicos más comunes y extendidos en la música electrónica de baile. El estudio del patrón de bombo en negras nos permitirá evidenciar la vinculación estrecha que se establece entre ritmo y textura al interior de la especie; secundariamente, nos servirá para ejemplificar y comprender las relaciones que en algunas piezas exceden incluso los límites de la sección rítmica. En tercer término y aún cuando presentan algunas diferencias entre sí, habremos descripto las características básicas comunes de la sección rítmica de los índices house, trance y techno.

En los patrones de tipo regular de bombo en negras, el sonido de bombo ataca en cada tiempo del compás de $4 / 4$ y suele hallarse acompañado de un sonido de hi-hat abierto, acentuado y a contratiempo (en la segunda corchea de cada tiempo). Este último sonido suele sostenerse justo hasta el ataque del siguiente sonido de bombo, estableciendo una articulación legato y generando una sensación de levare hacia el tiempo siguiente. La constante alternancia rápidamente configura una breve cadencia repetida: inmediatamente después de que el bombo ataca "a tierra" (relativamente corto, grave y fuerte) el hi-hat "se eleva" y "encamina" (largo, agudo y fuerte) hacia el siguiente bombo.

Así se conforma un simple y breve gesto musical contrastado, donde cada uno de sus elementos opera de forma dual: ambos entregan energía y, al mismo tiempo, renuevan la energía entregada por su complementario. Esta renovación inmediata posterior facilita a su vez una nueva entrega de energía de cualidades opuestas a la última, permitiendo el establecimiento de un tren de impulsos constante y continuo que constituye el gesto musical que caracteriza para muchos a la música electrónica de baile. "Motor" que en la especie impulsa tanto a la música como al movimiento y baile asociado a esta, las cualidades opuestas de uno y otro componente se conjugan en lo que Hans Zeiner-Henriksen ha dado en llamar "The PoumTchak Pattern": patrón básico a partir del cual dicho autor analizará la relación entre música y movimiento y 
donde nosotros encontramos un ejemplo de lo que denomináramos oscilación/alternancia de intensidad. $^{581}$

Simultáneamente y llevando al ejemplo un paso más allá, es extremadamente común que el sonido de redoblante y/o de palmas ${ }^{582}$ ataque en los tiempos 2 y 4 conformando una nueva alternancia de características similares a las descriptas previamente pero de período igual a dos ciclos del patrón "Poumtchak". ${ }^{583}$ Si bien redoblante y/o palmas ataca simultáneamente al bombo, la alternancia bombo - bombo+redoblante resulta equiparable de múltiples formas a la relación que el primero establece con el hi-hat.

A continuación puede apreciarse el patrón descripto y tres de sus variantes más comunes representados tanto en notación tradicional como en sistema TUBS. Para facilitar la comparación y por tratarse de variaciones que solo involucran a la parte de hi-hat, en el sistemas de notación tradicional exponemos cada patrón abarcando solo una duración total de blanca. Advertimos sin embargo que, en la mayoría de los casos, un único patrón suele presentarse reiterado sin variaciones durante secciones enteras o de principio a fin de la pieza; en un menor número de piezas en cambio (usualmente, en ejemplos que ofrecen en la sección rítmica conformaciones más "humanas" y menos "maquinales") puede hallarse una combinación de estos o incluso variaciones constantes entre estos y otros patrones similares. Salvo contadas excepciones, siempre en compás de $4 / 4$.

En el sistema TUBS exponemos cada patrón en compás completo. Incorporamos a este sistema una modificación: para denotar diferentes niveles en la sonoridad al negro utilizado originalmente agregaremos la opción de un tono de gris. El negro original será entonces fuerte o acentuado y el gris sonoridad normal. Posibilitamos así la representación en el sistema TUBS de una prestación usualmente disponible en las máquinas de ritmo que integran secuenciador: la posibilidad de incluir en la secuencia ataques acentuados. ${ }^{584}$

${ }^{581}$ Zeiner-Henriksen, H. (2010). Op.cit. Tanto Butler como Snoman, en sus respectivos trabajos, refieren también en términos similares a este patrón. Estos, entre otros autores, coinciden en que el rol cumplido por esta conformación rítmico-textural es esencial tanto para la música como para la danza. Las paradas y la dinámica que en dichas situaciones se establecen entre el deejay y los bailarines son ejemplos directos de este vínculo. Por supuesto, no implicamos aquí que este patrón sea privativo de la especie: como ya mencionáramos, el patrón de bombo en negras caracteriza a varias músicas de baile entre las que se encuentran el disco y el funk, dos de las principales fuentes de influencia de la música electrónica de baile. Sin embargo, los sonidos de bombos utilizados en esta última especie presentan cualidades propias que, a nuestro modo de ver, facilitan más que sus equivalentes acústicos la generación de sensación táctil y la incitación al movimiento.

${ }_{582}$ Dependiendo del índice del que se trate, será más común el uso de uno, otro o ambos sonidosinstrumentos simultáneos.

${ }^{583}$ En síntesis: bombo (grave) - bombo+redoblante/palmas (grave+medio agudo). Los timbres más usuales son los mencionados; sin embargo, en algunos ejemplos pueden encontrarse enriquecidos o directamente reemplazados por otros que, aún presentando diferencias (por ejemplo, samples donde se reconoce la fuente) poseen las cualidades suficientes para cumplir el rol asignado.

${ }^{584}$ Como puede verse, hemos utilizado el negro para todos los ataques de bombo. Esquemáticamente podemos decir que en la especie es poco común hallar diferencias de sonoridad en este sonidoinstrumento. Por otra parte, siendo por lo general el sonido-instrumento más prominente de todos en la textura, creemos pertinente igualarlo en su representación con los ataques fuertes. Si hiciéramos honor a 


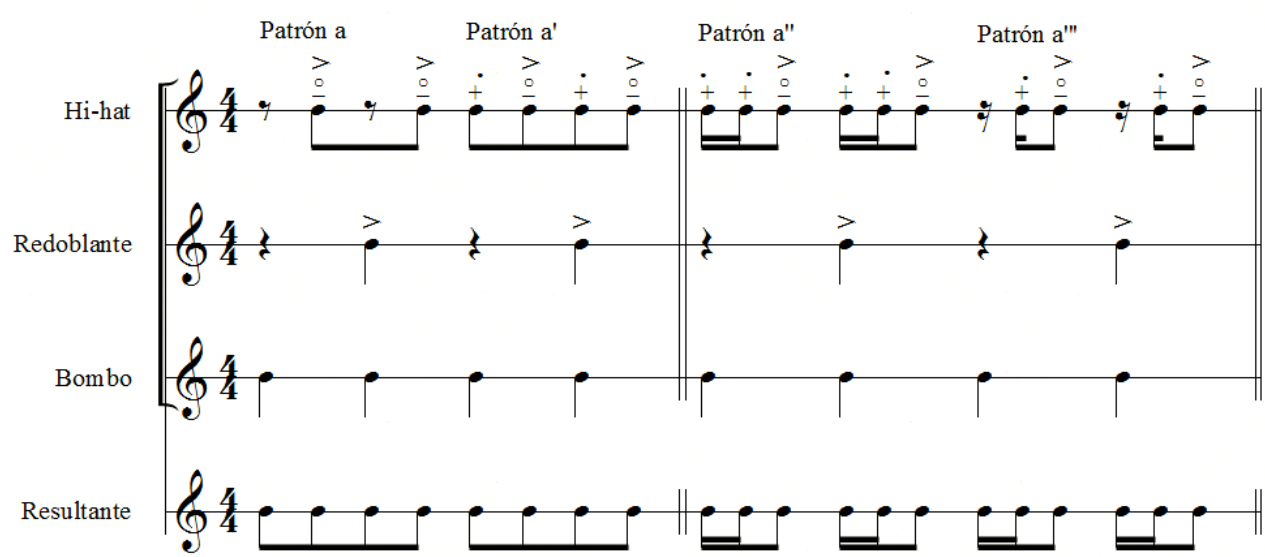

Patrones básicos del ritmo de tipo regular usualmente denominados como de bombo en negras expresados en el sistema de representación musical tradicional.

Los mismos patrones de la figura previa expresados en notación TUBS (compás completo).

Patrón a

\begin{tabular}{|l|l|l|l|l|l|l|l|l|l|l|l|l|l|l|l|l|}
\hline Hi-Hat & & & & & & & & & & & & & & & & \\
\hline Redoblante & & & & & & & & & & & & & & & & \\
\hline Bombo & & & & & & & & & & & & & & & \\
\hline
\end{tabular}

Patrón a'

\begin{tabular}{|l|l|l|l|l|l|l|l|l|l|l|l|l|l|l|l|l|}
\hline Hi-Hat & & & & & & & & & & & & & & & & \\
\end{tabular}

Patrón a"

\begin{tabular}{|l|l|l|l|l|l|l|l|l|l|l|l|l|l|l|l|}
\hline Hi-Hat & & & & & & & & & & & & & & & \\
\hline Redoblante & & & & & & & & & & & & & \\
\hline Bombo & & & & & & & & & & & & & & & \\
\hline
\end{tabular}

Patrón a"'

\begin{tabular}{|l|l|l|l|l|l|l|l|l|l|l|l|l|l|l|l|l|}
\hline Hi-Hat & & & & & & & & & & & & & & & & \\
\hline Redoblante & & & & & & & & & & & & & & & & \\
\hline Bombo & & & & & & & & & & & & & & & \\
\hline
\end{tabular}

\section{Relaciones transversales en el patrón de bombo en negras}

Como dijéramos previamente, en los patrones recientemente expuestos el ritmo descripto por cada cuerpo suele conducir a que cada sonido-instrumento resulte claramente discernible de los demás; sin embargo, su sentido musical solo puede comprenderse en la

lo que en concreto suele suceder en las piezas, deberíamos incluso utilizar un tercer tono que denote la usual diferencia de sonoridad detectable entre este cuerpo y todos los demás. 
complementariedad rítmico-tímbrico-registral del conjunto. En otras palabras, el sentido rítmico no puede alcanzarse sin considerar cuestiones texturales. Butler explicita estos vínculos (e implica al principio de complementariedad) al decir que:

Cuando se los considera individualmente, los patrones rítmicos en los loops de la EDM son simples. La complejidad viene de las formas en las cuales se los combina. Con el fin de abordar esta relación especial entre ritmo y textura será útil considerar brevemente la textura -una de las características más interesantes de la música electrónica de baile- más generalmente. ${ }^{585}$

Recorrer un ejemplo a partir de los ritmos descriptos nos permitirá comprender estos vínculos. Veremos también emerger otras variables sono-musicales que, lógicamente, resultan involucradas por tratarse -ritmo y textura- de aspectos musicales complejos.

Supóngase que una pieza se inicia únicamente con el primero de los patrones rítmicos de hi-hat sonando en soledad. Por sus cualidades regulares, es altamente probable que esta pulsación construya una sensación de a tierra; frente a la ausencia de toda otra referencia (i.e.: frente al silencio) cada ataque se conforma como un momento acentuado. Al menos en el marco referencial que establece la cultura occidental, este hecho provocará la sensación de que el ataque ocurre en la parte fuerte de cada tiempo.

Hasta aquí expuesto, nuestro ejemplo nos permite elaborar ya una conclusión: el sentido de contratiempo (o "arriba") se establece perceptualmente sólo en interacción con el patrón de bombo. Solo con el ingreso de dicho elemento textural ${ }^{586}$ el sentido musical a contratiempo se construye, resignificando retrospectivamente lo acaecido hasta entonces.

En la generación de este efecto de corrimiento influyen cuestiones culturales: como dijéramos previamente, es tal la omnipresencia del bombo articulando ataques mayormente en las partes fuertes de los tiempos en muchas músicas populares que, al menos entre quienes poseen dicho capital cultural, su ocurrencia convoca casi por sí mismo la sensación de a tierra. Sin embargo, como veremos a continuación, este no es el único factor que propicia dicha sensación.

Volvamos por un momento a la situación inicial del sonido de hi-hat sonando aislado. Creemos no equivocarnos al afirmar que, dada dicha situación, ni siquiera la presentación del patrón de redoblante y/o palmas contrarrestará la gravitación a tierra de la pulsación en el hihat. Podemos ensayar varias respuestas para explicar las diferencias con el caso del bombo.

\footnotetext{
585 "When considered individually, the rhythm patterns in EDM loops are simple. Complexity comes from the ways in which they are combined. In order to address this special relationship between rhythm and texture, it will be useful to briefly consider texture -one of the most interesting feature of electronic dance music- more generally." Butler, M. (2003). Op.cit. pp. 109 Debemos aclarar que aquí Butler refiere con el término "patrón" al descripto por cada sonido-instrumento individual.

${ }^{586}$ Nótese que no nos referimos al patrón rítmico descripto por el bombo como un estrato textural. Reservaremos esta expresión para aquellos componentes que, por presentar una independencia de sentido mayor, permiten una segregación más evidente de los demás elementos presentes simultáneamente en la textura.
} 
En primer término, el mismo argumento respecto del uso convencional de cada cuerpo en las músicas populares influye aquí en el sentido opuesto. Si bien el redoblante y/o palmas suele atacar en la parte fuerte de los tiempos, dichos tiempos suelen corresponderse con los débiles del compás. Entre quienes poseen el capital cultural antes mencionado, este sonidoinstrumento posee una jerarquía menor a la del bombo.

En íntima relación con el argumento previo, la ocurrencia de los ataques en un período de tiempo mayor al del hi-hat (y el bombo) debilita aún más la influencia del primero. Por cada dos hi-hata ocurre un único redoblante y/o palmas. También aquí el último se encuentra en desventaja.

En tercer término, el contraste que provoca la presencia de frecuencias graves en el bombo, y la ausencia de dicho registro en el espectro de los demás sonidos-instrumentos, pareciera tener una relevancia central en esta cuestión. ${ }^{587}$ Nos vemos obligados aquí a una digresión.

[Digresión: sonidos de bombo y la sensación de a tierra]

Como hemos dicho ya, en las músicas electrónicas utilizadas para el baile social las versiones sintetizadas de este sonido-instrumento -compuesto primordialmente de frecuencias graves- suelen construirse a partir de una onda sinusoidal. ${ }^{588}$ Dependiendo sobre todo del índice de la pieza para el que se lo sintetiza, se afinará en diferentes frecuencias (usualmente en relación armónica simple con los demás componentes de la textura). Para Snoman, al momento de sintetizar un sonido-instrumento de esta categoría:

[...] la primera consideración debería hacerse sobre la frecuencia de la onda sinusoidal ya que esta determinará fundamentalmente el cuerpo o profundidad del bombo. Un bombo de EDM se posiciona comúnmente entre 40 y $80 \mathrm{~Hz}$ (mil y mi2 en un teclado típico) dependiendo del género, del estilo de bombo y de la tonalidad requerida. Para esta última, afinar el bombo en la $5^{\circ}$ nota de la escala trabajada usualmente produce un resultado armónico más consonante y placentero que afinándolo en la tónica. ${ }^{589}$

Nótese en la cita la asociación de los términos "cuerpo" y "profundidad" con el parámetro frecuencia y el registro grave; asociación muy difundida en la comunidad musical

\footnotetext{
${ }^{587}$ Nótese también, cualidad relevante para la generación de sensación táctil.

${ }^{588}$ También llamada "tono puro", esta forma de onda es descripta idealmente como poseyendo una única frecuencia y ha sido utilizada históricamente en la investigación científica para explorar la interacción entre la frecuencia del estímulo y la resonancia que esta produce en múltiples objetos y cuerpos, entre los que se cuenta el cuerpo humano. En estos contextos ha sido vista usualmente como el estímulo más apropiado debido a la posibilidad que brinda de focalizar las respuestas y resonancias originadas en una única frecuencia. Para más detalles al respecto de investigaciones que la utilizan como estímulo para la detección de sensación táctil véase Kogan Musso, P. (2004) Op.cit.pp. 105-7

589 "[...] the first consideration should be on the frequency of the sine wave since this will determine the ultimate body or depth of the kick. An EDM kick is commonly positioned between 40 and $80 \mathrm{~Hz}$ (E1 to E2 on a typical keyboard) depending on the genre, style of kick and the key required. For the latter, tuning the kick to the fifth note of your working scale often produces a more consonant and pleasing harmonic result than tuning it to the root note." Snoman, R. (2014). Op.cit. pp. 210-11.
} 
toda (no solo en la electrónica) para referirse a las componentes graves de los sonidos. En estos conceptos encontramos indicios que apuntan, por una parte, a la incitación al movimiento corporal y, por otra, a la generación de sensación de a tierra. Respecto del primero -que influirá sobre el segundo-, a partir de ciertos datos recabados en nuestras experiencias de campo, hemos visto que:

a) las frecuencias graves son las responsables de la generación de sensación táctil más evidente y

b) las músicas electrónicas utilizadas para el baile social concentran la mayor cantidad de energía acústica en el registro grave/sub-grave (recordamos, frecuencias inaudibles que generan sensación táctil). ${ }^{590}$

Nuestra práctica profesional de años y las envolventes de sonoridad registradas en las experiencias de campo nos permiten afirmar además que las mencionadas vibraciones subsónicas pueden originarse a partir de:

a) El sonido de bombo por sí solo. Independientemente de la frecuencia en que se lo afine, los métodos utilizados para su síntesis promueven la inclusión de diferentes bandas de frecuencias, sobre todo como transitorios durante la fase de ataque. Por otra parte, en la creación de sonidos de bombos es usual superponer múltiples capas. De muy diversos orígenes posibles, cada capa suele aportar componentes en diferentes regiones del espectro de frecuencias: en ciertas ocasiones suelen incluirse algunas que suministran al bombo componentes sub-graves o sub-sónicas.

b) La interacción del bombo con otros componentes de la textura musical. Como describe Snoman, es usual la afinación del bombo sobre el $5^{\circ}$ grado de la escala utilizada. Independientemente de que la pieza en concreto presente cualidades tonales u otras, existe entre los productores cierta tendencia hacia la generación de tonicidad: como viéramos, son numerosos los ejemplos donde el sonido de bajo (o similar) presenta un grado elevado de recurrencia sobre una determinada altura-frecuencia, ${ }^{591}$ en no pocas ocasiones este consiste incluso exclusivamente en la reiteración de una misma y única altura-frecuencia. ${ }^{592}$ Es altamente probable que la interferencia mutua entre la

\footnotetext{
${ }^{590}$ Para más detalles véase Kogan Musso, P. (2004) Op.cit. pp.105-7

${ }^{591}$ Utilizamos la expresión "altura-frecuencia" ya que, dependiendo del contexto, la nota presentada por el sonido de bajo cumplirá roles diferenciados. En ciertos casos oficiará de bajo armónico, en algunos otros en cambio, incluso hablar de función de bajo resulta inapropiado. Nos referimos a aquellos contextos descriptos en nuestro análisis de la altura donde la ocurrencia de sonidos graves diferentes al bombo deben entenderse como mera ocupación o presencia de componentes en el registro grave.

${ }^{592}$ Los pedales sobre una altura-frecuencia repetida son más usuales en el trance, menos en el techno y menos aún en el house. Aunque es común encontrar pedales sobre una única altura-frecuencia en casi todos los índices, lo que quizá distingue al trance es que en este índice son más persistentes y el sonido de
} 
frecuencia del bombo y la altura-frecuencia sobre la que el sonido de bajo recurre, provoque el acontecimiento de sonidos diferenciales. Dado el intervalo de $5^{\circ}$ justa, esta vibración tendrá una frecuencia igual a la mitad de la del sonido de bajo. En otras palabras, cada ataque del bombo coincidente con el bajo conformará un complejo armónico constituido por el equivalente a una nota fundamental (la vibración diferencial, reconstituida) y sus dos primeros armónicos $\left(2^{\circ}\right.$ armónico de $8^{\circ}$ en el bajo y $3^{\circ}$ armónico de $8^{\circ}+5^{\circ}$ en el bombo).

c) Resonancias y/o cancelaciones derivadas de las características arquitectónicas del local de baile, a partir de la excitación originada en las vibraciones musicales. Considerando la gran longitud de onda de las frecuencias graves (del orden de 18-25 metros) no resulta extraño que ciertos espacios o sub-sistemas arquitectónicos (i.e.: elementos que formen parte de la arquitectura del local) resuenen en ciertas frecuencias dependiendo de sus dimensiones, materiales y formas. ${ }^{593}$ Esta resonancia es capaz de amplificar y/o cancelar frecuencias presentes en la música, incrementando la sonoridad de frecuencias en relación armónica (i.e.: múltiplos de las frecuencias presentes). De esta forma, aunque pueden no encontrarse en la música reproducida, por las condiciones acústicas de la reproducción misma, la ocurrencia de vibraciones subsónicas es posible.

Complementariamente, como en la mayoría de las músicas, las electrónicas utilizadas para el baile social presentan además elementos y estratos texturales en registros más agudos. De hecho, siendo el ideal de la especie sonar fuerte y a espectro completo, la mayor parte del tiempo presentan componentes en todo el rango de frecuencias.

Es un principio acústico ampliamente probado y utilizado que, cuando se desea alcanzar altas sonoridades, distribuir (i.e.: instrumentar u orquestar) los instrumentos por todo el registro de frecuencias siguiendo la disposición de la serie de armónicos redunda en una sonoridad mayor que si se concentra toda la energía acústica en una única altura-frecuencia. ${ }^{594}$ Como en muchas otras músicas populares recientes o actuales, en la especie que nos ocupa es usual que los componentes en registros más agudos se distribuyan siguiendo relativamente la distribución que plantea la serie de armónicos. ${ }^{595}$ Como viéramos, la presencia de energía acústica en frecuencias agudas coincidentes con los armónicos de las frecuencias presentes en el registro

bajo suele atacar reiteradas veces en valores cortos, mientras que en los demás índices (sobre todo en los que utilizan samples de breakbeats y presentan rítmicas "sincopadas") los ataques suelen ser más espaciados y de duraciones más largas.

${ }^{593}$ Recordamos nuestra mención en títulos previos del testimonio del deejay respecto del resonar de las columnas de la cabina de deejay.

${ }^{594}$ De hecho este es precisamente el principio aplicado en las afinaciones de bombo y bajo que acabamos de analizar.

${ }^{595}$ De grave a agudo, los intervalos entre componentes que plantea la serie se inician como sigue: $8^{\circ}, 5^{\circ}$ justa, $4^{\circ}$ justa, $3^{\circ}$ mayor, $3^{\circ}$ menor, $3^{\circ}$ menor baja, $2^{\circ}$ mayor, $2^{\circ}$ mayor, ... En términos musicales y a modo de ejemplo, las notas que componen esta serie para la nota do son: do, do $\left(8^{\circ}\right.$ más aguda), sol $\left(8^{\circ}+5^{\circ}\right)$, do $\left(8^{\circ}+8^{\circ}\right)$, mi $\left(8^{\circ}+8^{\circ}+3^{\circ}\right)$, etcétera. 
grave repercute en el sistema derivando energía desde aquéllas hacia éstas, lo que refuerza la sonoridad de los componentes graves.

El literal impacto que esta onda expansiva genera sobre el cuerpo de los bailarines, provoca una sensación corporal de golpe. La importancia central que Snoman atribuye a la generación de esta sensación puede apreciarse en el siguiente pasaje donde, describiendo los sonidos de bombo que las máquinas de ritmo Jomox Mbase01 y Mbase11 producen, dirá que "sus capacidades para producir instantáneamente bombos golpeapecho ha resultado en que estas se conviertan en el pilar de muchos estudios de EDM." ${ }^{596}$ De presentar el bajo una duración extendida y como viéramos durante el análisis de la altura, la sensación táctil de golpe se prolongará y transformará en una sensación de vibración o resonancia. En otras palabras, el cuerpo del sujeto perceptor, aún si se encuentra en reposo, será literalmente puesto en movimiento al ser impactado, penetrado, recorrido y atravesado por ondas de vibración audibleinaudible que habitarán su cuerpo y carne durante el tiempo que dure la vibración audiotáctil. ${ }^{597}$ Por si esto fuera poco, para conformar la sensación de a tierra que asociamos con el sonido de bombo debemos aún agregar la influencia del segundo de nuestros indicios.

Como conclusión de nuestra digresión recapitulamos y sintetizamos lo dicho respecto de la importancia del contraste en el establecimiento de la sensación de a tierra. Creemos que secundariamente- nuestro aporte es incluso una explicación posible para comprender a) el uso que se le ha dado al bombo en las músicas populares, b) la importancia que adquiere en las músicas electrónicas utilizadas para el baile social y c) los sentidos con los que se ha asociado y asocia tradicionalmente a los sonidos graves -en general- en las artes que hacen uso de sonido y música.

Las razones que en las músicas electrónicas utilizadas para el baile social pueden explicar que el sonido de bombo a) genere casi por sí mismo la sensación de atacar a tierra,b) sea el más prominente en sonoridad y c) sea considerado el elemento más importante para la incitación al baile son:

a) El uso tradicional que se le ha dado y da en muchas músicas populares (atacando usualmente en las partes fuertes de los tiempos),

b) Su cualidad de sonido grave (incluyendo frecuencias sónicas y sub-sónicas) en contraste con las componentes primordialmente agudas de los demás sonidosinstrumentos intervinientes en el patrón bajo análisis,

\footnotetext{
596 " $[\ldots]$ their capabilities for producing instant chest-thumping kicks have resulted in them becoming the mainstay of many EDM studios." Snoman, R. Op. cit. (2014). pp. 210 Como resulta implícito a sus dichos, no solo Snoman considera importante a esta cualidad sino que muchos artistas procuran generar la misma sensación táctil.

${ }^{597}$ Este tipo de conformación entre bombo y bajo sucede, a modo de ejemplo, en piezas de los índices basados en samples de breakbeats.
} 
c) El tipo de interacción particular que establece con los demás elementos de la textura (especialmente con el bajo y por la capacidad de generación de sonidos diferenciales), d) La capacidad de producir mayor energía acústica derivada de su localización en el registro grave/sub-grave y de las interacciones descriptas en el ítem previo,

e) Su capacidad acústica de capitalizar parte de la energía de los elementos texturales que pudieran incluirse en registros más agudos,

f) Su capacidad de generar sensación táctil y literalmente poner en movimiento al cuerpo de los sujetos perceptores,

[Fin de la digresión]

Finalizaremos el tratamiento del ejemplo que iniciáramos antes de la digresión agregando algunos datos tímbricos que, creemos, también influyen en los modos en que se percibe el patrón básico del house, techno y trance.

Independientemente del sonido-instrumento concreto utilizado (i.e.: redoblante, palmas o ambos), también las cualidades espectrales respectivas interactúan en las relaciones que se establecen al interior de este patrón. Hi-hat, redoblante y palmas no solo poseen la mayoría de sus componentes espectrales en el mismo registro, sino que además presentan una mayor similitud tímbrica entre ellos que con el bombo.

Como claramente expone Snoman en su capítulo "Kicks and Percussion", ${ }^{598}$ la versión sintetizada de estos tres sonidos-instrumentos usualmente involucra la utilización de un generador de ruido blanco; como viéramos, el bombo no. En redoblante y hi-hat se utilizan además ondas triangulares mientras que para sintetizar palmas se suele utilizar una onda dientes de sierra. A pesar de esta diferencia, ambas formas de onda y sus timbres consecuentes se asemejan más entre sí que con la onda sinusoidal del bombo. ${ }^{599}$

Como dijéramos antes de la digresión, la renovación constante de la energía entregada depende del contraste entre bombo y hi-hat. En otras palabras, la capacidad de renovar la energía entregada depende de la complementariedad de cualidades entre uno y otro sonidoinstrumento. ${ }^{600} \mathrm{~A}$ mayor contraste de cualidades, mayor será la renovación de la energía entregada. En este marco, los matices detectados entre hi-hat y redoblante y/o palmas resultan mínimos frente a las enormes diferencias que presentan ambos con las cualidades del bombo. Este último puede ser descripto (metafóricamente por supuesto) como el sonido "opuesto" al hihat. Siendo el hi-hat más agudo que el redoblante y/o palmas, no queda mucho más para decir:

\footnotetext{
${ }^{598}$ Snoman, R. Op. cit. (2014). pp. 205 y sgtes.

599 Brevemente descriptas, las ondas triangular y dientes de sierra presentan múltiples componentes armónicos mientras que -recordamos- la sinusoidal o senoidal resulta idealmente en una única frecuencia aislada.

${ }^{600}$ Nótese la similitud con las condiciones que describiéramos como necesarias para el establecimiento de oscilaciones/alternancias de intensidad.
} 
hi-hat y bombo son los sonidos-instrumentos donde el contraste y la complementariedad se pone de manifiesto con mayor claridad. ${ }^{601}$

En resumidas cuentas, en la construcción del sentido musical de los patrones bajo análisis interactúan los datos perceptivos rítmicos, tímbricos y registrales. Como se deriva de nuestro desarrollo, en el cruce de estas informaciones diversas se construye no solo el sentido en relación a la rítmica sino también respecto de la textura. En otras palabras, ampliando lo que dijéramos al inicio de nuestro análisis y en varias oportunidades previas, la complementariedad se manifiesta no solo como la interacción entre los elementos del ritmo sino que se establece como el vínculo íntimo mutuo entre ambas dimensiones.

Por supuesto, también debemos incluir aquí a los datos audiotáctiles. Respecto del rol del cuerpo en el proceso de construcción del sentido musical Mark Leman sostiene que:

El cuerpo humano puede ser visto como un mediador biológicamente diseñado que transfiere energía física elevándola a un nivel de sentidos orientados a la acción, a un nivel mental en el que experiencias, valores e intenciones forman los componentes básicos de la significación musical. El proceso inverso es también posible: que el cuerpo humano transfiera una idea, o una representación mental, a materia o forma energética. Esta proceso de mediación bidireccional está en gran medida restringido por los movimientos corporales, de los cuales se asume que juegan un rol central en todas las actividades musicales. La aproximación de la cognición musical corporeizada asume que la mente-entendimiento-comprensión (musical) resulta de esta interacción corporeizada con la música. ${ }^{602}$

Acordamos con la totalidad de estos argumentos. Tratándose nuestra especie de música orientada al baile, los dichos de Leman resultan aplicables en su totalidad. A partir de ellos, la asociación de sonidos graves con objetos grandes y pesados que tratáramos como segundo indicio adquiere una nueva significación. Encontramos en este vínculo un argumento que explica la usual coincidencia entre el patrón PoumTchak y ciertos movimientos corporales verticales analizados por Zeiner-Henriksen: el autor describe el acontecimiento sincrónico entre a) el sonido de bombo y movimientos corporales de dirección descendente y b) el sonido de hihat y movimientos corporales de dirección ascendente. Al referirse a la relación de este patrón con ciertos movimientos Zeiner-Henriksen dirá que:

${ }^{601}$ Recuérdense además las cuestiones rítmicas descriptas y lo dicho durante el análisis de la altura respecto de la relación cuasi-tonal que en muchas piezas se establece entre los registros grave y agudo.

602 "The human body can be seen as a biologically designed mediator that transfers physical energy up to a level of action-oriented meanings, to a mental level in which experiences, values, and intentions form the basic components of music signification. The reverse process is also possible: that the human body transfers an idea, or mental representation, into a material or energetic form. This two-way mediation process is largely constrained by body movements, which are assumed to play a central role in all musical activities. The embodied music cognition approach assumes that the (musical) mind results from this embodied interaction with music." Citado en Zeiner-Henriksen, H. (2010). pp.19 El término "mind" presenta múltiples sentidos en el idioma inglés, obligándonos a traducirlo como múltiples términos para facilitar la comprensión de la cita. 
Este patrón rítmico parecía especialmente efectivo para evocar específicos patrones de movimiento como respuesta. En su contexto cultural apropiado y con el tempo correcto aparentaba representar un punto de partida o estructura básica para bailar como también para [realizar] una variedad de patrones de movimiento verticales, tales como cabeceos, golpes con el pie o rebotes del torso, que también aparecían fuera de la pista de baile. Se presentaba como un nexo para las relaciones entre música, movimiento general o inconsciente y baile. Parecía también haber una correspondencia adicional entre los sonidos de bombo y un movimiento corporal de dirección descendente (en los tiempos fuertes/"a tierra"), y entre los sonidos de hi-hat y un movimiento ascendente (en los contratiempos), juntos conformando un continuo y ondulante patrón de movimiento vertical ejecutado con diferentes partes del cuerpo. ${ }^{603}$

En honor a la brevedad agregaremos aquí apenas una de sus conclusiones. Hacia el final de su trabajo el autor se refiere a la teoría de la metáfora de Lakoff y Johnson; en dicho marco, ciertas "metáforas primarias" (i.e.: "aquellas metáforas que están incorporadas a nuestro entendimiento $\tan$ a fondo que no las vemos como metáforas" ${ }^{\text {604 }}$ ) se encuentran "inseparablemente vinculadas a movimientos físicos". ${ }^{605}$ Apoyándose en este conocimiento teórico Zeiner-Henriksen afirmará que:

[...] la alternancia entre el "bajo" sonido de bombo y el "alto" sonido de hi-hat en el patrón poumtchak apoya una correspondencia con las alternancias entre una posición baja y una alta en un patrón de movimiento vertical. ${ }^{606}$

Agregamos entonces aquí un argumento más (aún otro vinculado a lo corporal) a la larga lista de razones que expusiéramos como justificaciones posibles para la asignación del sentido a tierra al sonido de bombo. Retomemos ahora y para finalizar, el tratamiento de los patrones básicos del house, techno y trance.

Muchos ejemplos en la música electrónica de baile presentan alguno de los patrones tal cual los incluyéramos. Otros agregan elementos, configurando una sección rítmica más compleja cuya densidad vertical suele rondar los $6 \mathrm{u} 8$ sonidos-instrumentos. ${ }^{607}$ En ambos

\footnotetext{
603 "This rhythmic pattern seemed especially effective at evoking specific movement patterns in response to it. In its proper cultural context and with the right tempo it appeared to represent a starting point or basic structure for dancing as well as a variety of vertical movement patterns, such as head nodding, foot tapping, or upper-body bouncing, that also appeared off the dancefloor. It presented itself as a nexus for the relations among music, general or unconscious movement, and dancing. There also seemed to be a further correspondence between the bass drum sound and a body movement downward (on the downbeats), and the hi-hat sound and a movement upward (on the upbeats), together comprising a continuous and undulating vertical movement pattern performed with different parts of the body." ZeinerHenriksen, H. (2010). Op.cit. pp.3

${ }^{604}[\ldots]$ ".."primary metaphors" refers to those metaphors that are incorporated into our understanding so thoroughly that we do not see them as metaphors." Ibidem. pp. 251

$605[\ldots]$ "inseparably linked to a physical movement" Ibidem.

${ }^{606}[\ldots]$ "the alternation between the "low" bass drum sound and the "high" hi-hat sound in the poumtchak pattern supports a correspondence with the alternations between a low and a high position in a vertical movement pattern." Ibidem.

${ }^{607}$ A modo orientativo, véanse los sonidos-instrumentos más comúnmente incluidos en las máquinas de ritmos descriptos en nuestro Anexo V. Dispositivos tecnológicos asociados a las músicas electrónicas utilizadas para el baile social. Los timbres y patrones descriptos por estos elementos extra presentan mayor variabilidad que los usualmente asignados a bombo, redoblante y hi-hat, impidiendo generalizaciones como las aplicadas para estos últimos. A modo de ejemplo, son hallables desde timbres
} 
casos, la mejor aproximación para describir a las conformaciones texturales resultantes suele ser la que parte del concepto de complementariedad que hemos descripto en párrafos precedentes.

En este marco y contrariamente a los dichos de Butler acerca de que cada sonidoinstrumento se establece como un estrato textural independiente, creemos que lo que en muchas piezas se percibe es en realidad esta red de patrones rítmico-tímbrico-registrales que interactúan de forma complementaria. Como en el contrapunto melódico, también en este contrapunto rítmico es posible que uno de los elementos que lo constituyen se presente en soledad, sin que ello elimine la influencia que el contexto "contrapuntístico" tiene sobre la interpretación de dicho elemento. Como expusiéramos previamente, el elemento en solitario será percibido retrospectivamente como parte de un todo complementario; será reinterpretado retrospectivamente a medida que el resto de los elementos se incorporan a la textura contrapuntística. Dependiendo de cuál sea el elemento en concreto que se presente aislado (y cual el patrón rítmico descripto por dicho elemento) veremos emerger algunos de los casos de ambigüedad que mencionáramos durante el tratamiento del ritmo y que, como ahora vemos, involucraban ya consideraciones texturales y tímbricas.

Evidencia de su carácter central en la música electrónica de baile, pudimos apreciar en los últimos párrafos los modos en que la rítmica permea a otras variables musicales. Como dijéramos previamente, acordamos con Butler al respecto de este punto. Menos énfasis que dicho autor haremos nosotros sin embargo en relación a la textura: si bien consideramos que entre los productores de la especie existe un fuerte interés por estas cuestiones, también creemos que existe una inmensa e intensa innovación tímbrica, procedimental, material y formal que, como expusiéramos en el cuerpo principal, excede al territorio de aquel concepto.

A partir de la reformulación que hiciéramos de las ideas de Butler podemos ahora explorar las diferentes perspectivas que creemos apropiadas para abordar la textura en la música electrónica de baile.

\section{Perspectivas para el análisis de la textura}

Luego del tratamiento de las cuestiones rítmicas generales expusimos algunos argumentos que fundamentan la necesidad de utilizar múltiples perspectivas de análisis para el estudio tanto de la música electrónica de baile como de su sublimación actual. Derivada de las cualidades abierta y totalizadora y considerando que la que nos ocupa es una especie que puede contener en su seno -al menos parcialmente- a todas las músicas existentes y pasadas, poco más es necesario decir. Así como hiciéramos para el ritmo, también a la textura deberemos abordarla desde múltiples ángulos y perspectivas. Además, en el tratamiento de este tema concreto deberemos considerar ciertas particularidades que solo ocurren al interior de la especie.

y ritmos asociables a géneros de baile centroamericanos hasta ritmos, timbres y texturas abstractos y que no presentan caracteres asociables sin ambigüedades a ningún origen cultural. 
A diferencia de otras músicas, en las electrónicas utilizadas para el baile social las piezas creadas por sus productores pueden presentarse al público tal cual fueran concebidas o fuertemente modificadas. Pueden presentarse por sus propios productores interpretando sintetizadores, samples $\mathrm{y} / \mathrm{u}$ otros dispositivos en lo que denominamos actos en vivo; o por deejays utilizando una grabación cerrada pero que se "mezclará" en tiempo real con otras pistas, pudiendo además sumarle o restarle elementos a partir de la interpretación en vivo de instrumentos, de intervenciones o de procesamientos diversos.

A estas dos opciones además, se le ha sumado muy recientemente una tercera: esta deriva de la creación -por parte de la empresa alemana Native Instruments- del formato de audio stems, el cual codifica, en un formato compatible con el histórico estereo, cuatro canales independizables. Dirigido a unos y otros actores de la comunidad electrónica, es aún demasiado pronto como para saber el impacto real que tendrá esta invención; sin embargo vale su mención ya que la misma se propone como un punto intermedio entre los actos en vivo y las que llamaremos presentaciones de deejay.

Queremos significar con lo expuesto que la textura de una pieza grabada, tal cual surge del estudio del productor, quizá nunca llegue a oídos de los bailarines; en otras palabras, en las músicas electrónicas utilizadas para el baile social la textura es, de varias maneras y entre otras, una forma o dimensión abierta. Dividiremos entonces en dos partes el tratamiento del tema. Trataremos en primer término la situación de estudio/actos en vivo y luego la presentación de deejay. De esta manera seguiremos el mismo camino que recorre la textura en el proceso de producción musical. Al momento de analizar las presentaciones de deejay, conocer las cualidades establecidas en la etapa de producción previa nos permitirá comprender las transformaciones que experimentan las categorías y cualidades texturales que se establecen durante la primera etapa.

Preferimos aclarar nuestra posición en este punto: ya sea a manos de los productores en los actos en vivo o en las del deejay en la presentación de deejay:

el proceso de producción musical finaliza, en la casi totalidad de los casos, frente a los bailarines y en interacción casi continua con estos. ${ }^{608}$

Aún nos resta por exponer otra particularidad de la textura en las músicas electrónicas utilizadas para el baile social. Como dijéramos, en la especie conviven múltiples músicas

\footnotetext{
${ }^{608}$ Incluso aquí el uso del verbo "finalizar" resulta inapropiado. Por una parte, ciertas particularidades que presentan las músicas electrónicas utilizadas para el baile social provocan que los actos en vivo involucren en numerosas ocasiones algún grado de improvisación; esto tiene como consecuencia que la obra musical se "abra" en cada interpretación. Por otro, la reproducción intervenida -en algún grado intrínseca al hacer de los deejays- provoca el mismo efecto de "apertura" sobre la obra. En otras palabras, sin importar el modo utilizado para su presentación pública, las piezas musicales suelen terminar transformadas, cuestionando la apreciación muy difundida de que los deejays simplemente "pasan música".
} 
provenientes de diferentes culturas, regiones geográficas y períodos históricos. Además, materiales, formas de organización y procedimientos identificados tradicionalmente como "musicales" (por un público no iniciado en estéticas experimentales) conviven e interactúan con materiales, formas de organización y procedimientos derivados de estéticas más recientes y/o de índole extramusical. En otras palabras, expresividades musicalmente tradicionales, originadas en múltiples culturas diversas, conviven con expresividades originadas en lógicas:

a) provenientes de la música contemporánea o derivadas de una actitud experimental,

b) derivadas de otras actividades humanas $\mathrm{y} / \mathrm{o}$

c) derivadas de fenómenos naturales.

Incluidas algunas de estas en samples de orígenes diversos y conteniendo informaciones virtualmente infinitas en su diversidad, esta particularidad provoca que en la especie acontezcan texturas y estratos texturales que pueden ser comprendidos a partir de los tipos texturales históricos, como también texturas y estratos texturales que desafían o lisa y llanamente niegan dichos modelos y que requieren de otro tipo de aproximación. Incluso el primero de los casos no se encuentra libre de problemas: la utilización de samples musicales extraídos de piezas del pasado involucra la complejidad de que en algunos casos debamos considerar a una textura completa (la de la pieza contenida en el sample) en tanto estrato textural subsumido al interior de una textura de jerarquía superior. ${ }^{609}$ Por otra parte y como ya fuera expuesto, debemos agregar la complejidad de que ritmos y texturas completos suelen ser expuestos a procesos extremos que reconvierten las cualidades de una dimensión en las de otras.

Por la ocurrencia de casos tan diversos creemos apropiado para el análisis de la especie aplicar los principios de la perspectiva de tipos texturales y, dependiendo la situación concreta en cada oportunidad, los de la que denomináramos como espectral. En honor a la brevedad y habiendo transitado la segunda durante los análisis audiotáctiles de sonoridad y altura, nos limitaremos entonces a describir a la especie a partir de las premisas derivadas de la primera y, sólo cuando sea estrictamente necesario, recurriremos a la segunda.

\footnotetext{
${ }^{609}$ Por si esto fuera poco, lo dicho resulta solo parcialmente cierto. En aquellos casos en que "artificios" o procesamientos evidencian que dicho material musical se incluye al interior de un sample, la misma categoría de estrato textural resulta cuestionada. A modo de ejemplo, considere un sample de una melodía con acompañamiento (i.e.: un fragmento de tema de una sinfonía clásica incluyendo todos sus elementos texturales: melodía, relleno armónico, bajo, etc.) interactuando con máquinas de ritmo y diversos sonidos sintetizados (i.e.: en diferentes registros y cumpliendo múltiples roles texturales: otro relleno armónico, bajo, melodía, etc.). ¿Cómo debemos evaluar a los elementos contenidos en el sample? ¿Es un estrato textural único, son varios o es un elemento único-múltiple? Sin espacio para responder a estas preguntas preferimos plantearlas como ejemplo del inmenso campo que estas cuestiones involucran.
} 


\section{Texturas en estudio y en actos en vivo. Estratos texturales}

Resulta medianamente sencillo referirnos aquí, desde una perspectiva occidental tradicional, a los elementos que en las músicas electrónicas utilizadas para el baile social pueden ser asociados a la conformación de estratos texturales. En la especie se incluyen melodías, contramelodías, bajos y rellenos armónicos, arpegios, pedales y secciones rítmicas; todas cumpliendo las funciones texturales históricamente asignadas a cada categoría. Así también, durante el análisis audiotáctil de la altura describimos algunos casos donde estas mismas formas operan de maneras novedosas o donde estratos texturales presentan solo algunas de las cualidades de las categorías mencionadas (recuérdese para lo último el extenso desarrollo realizado respecto de pseudo-(o proto-)melodias y armonías pseudo-tonales o a-tonales). Considerando a los primeros como estratos texturales "tradicionales", drones, riffs y conformaciones complejas sintéticas o incluidas en samples (como por ejemplo bucles o sonidos encontrados) pueden ser descriptos como estratos texturales "extendidos".

Por supuesto, todo lo dicho en títulos previos respecto de la posibilidad de transformar las cualidades de todo elemento presente en una determinada pieza mantiene su validez aquí. Como viéramos para la función textural de bajo durante el tratamiento de la altura, o para la sección rítmica durante el análisis de la pieza Nevermind: todas y cada una de las características de la textura de una pieza (desde las de un elemento o estrato único a las de la totalidad, independizadas o "totalizadas") pueden ver transformadas sus cualidades identitarias volviéndose uno o varios elementos de características completamente diferentes. En las músicas electrónicas utilizadas para el baile social la identidad de las conformaciones texturales resulta, al menos en potencia, tan lábil como cualquier otra identidad. ${ }^{610}$

En contextos no-tonales o tonales defectivos, las funciones -por ejemplo- de bajo y relleno armónico pueden volverse pseudo-armónicas. Como viéramos, la eliminación de la necesidad de definiciones tonales y la ausencia de estas lógicas conduciendo y condicionando el discurso permite que ambas funciones se desdibujen. En este contexto, las diferentes propiedades sono-musicales se liberan de los constreñimientos que dicho sistema les impone, facilitando la ocurrencia de complejidades como por ejemplo: rítmicas polimétricas, timbres con diferentes grados de (in)definición de su altura tonal y otros.

Un caso textural particular lo constituyen los samples: el hecho de que puedan contener cualquier tipo de información sonora o musical, proveniente de fuentes igual de diversas, los convierte en un tema donde resulta virtualmente imposible contemplar todos los casos.

\footnotetext{
${ }^{610}$ Escúchese a modo de ejemplo la voz "lider" de la pieza Harder, Better, Faster, Stronger de Daft Punk. Nótese como, con el transcurrir de la pieza, la voz humana-sintetizador (procesada, "robotizada" mediante el uso de vocoder) se transforma paulatinamente en un solo de lo que, por sus propiedades idiomáticas, podemos llamar "guitarrasintetizadorvoz". El ejemplo en video que incluimos, realizado por una aficionada al artista, resulta muy ilustrativo de la estructura de oquetus realizada a partir de los samples de voz. Daft Hands - Harder, Better, Faster, Stronger. Subido por Fr. Eckle Studios. Accesible en https://youtu.be/K2cYWfq--Nw. [20102016]
} 
Postergaremos su tratamiento en general para referirnos ahora a aquellos donde el contenido es estrictamente musical. Campo ya de por sí vasto, procurando brevedad nos limitaremos a tratar cuestiones generales.

\section{Samples conteniendo información musical como estratos texturales}

Los samples pueden contener un rango de información musical que abarca desde algo tan mínimo como un sonido aislado de un único instrumento o sonido-instrumento (del cual incluso puede preservarse apenas un fragmento) hasta incorporar una pieza musical completa. Si bien el último difícilmente podamos considerarlo en esta categoría, ${ }^{611}$ el primero es un caso muy común en la especie: a modo de ejemplo, un conjunto de muestras (el equivalente castellano de sample) puede funcionar a veces como un sustituto económico de un dispositivo "vintage" (i.e.: clásico y antiguo), oneroso o muy difícil de conseguir. Presentando grandes diferencias entre sí, no todos cumplen con las condiciones necesarias como para configurar estratos texturales por sí mismos. A partir de este abanico de posibilidades, estableceremos una serie de categorías en base a la cantidad y calidad de información musical contenida, como también a partir de ciertos usos que se les asignan en la especie. Así serán:

a) samples de sonido-instrumento: aquellos constituidos por un único ataque de un único instrumento o sonido-instrumento. Son los mencionados en los ejemplos que anteceden a esta clasificación y que tratáramos en títulos previos. Ej: sonido de bombo proveniente de la máquina de ritmos Roland TR909; grupo de samples que, en conjunto, conforman una réplica de un instrumento acústico o electrónico como un piano eléctrico Rhodes. Estos son utilizados en reemplazo de los dispositivos tradicionales. Usualmente se procura que su cualidad de samples no se evidencie, aunque existen numerosas excepciones y áreas grises para esta regla.

b) samples de ataque: aquellos que, constituidos por un único ataque, presentan cualidades que impiden su inclusión en la categoría previa. Usualmente, samples donde la fuente es reconocible. Ej: exclamación única, uno o pocos ataques ( 2 a 5 aprox.) interpretados por una o varias voces humanas, uno o pocos ataques de un conjunto instrumental, uno o pocos acordes en un instrumento único, etc. Por el uso que se les suele dar en la especie, estos se constituyen como un caso aparte y diferenciado del anterior; es usual que en esta categoría se evidencie su cualidad de samples.

c) samples de frases: de diversas extensiones, serán los primeros en presentar (al menos mínimas) estructuras musicales sucesivas y/o simultáneas evidentes. Esta categoría incluye aquellos ejemplos que, dependiendo de las cualidades musicales incluidas,

${ }^{611}$ Los integrantes de la comunidad electrónica probablemente llamarían a esto una pista, limitando la categoría de sample como máximo a aquellos conteniendo un fragmento de una pieza. 
presentan las características necesarias para configurarse como un estrato textural por sí mismo. Durando usualmente algunos pocos segundos o compases, en esta categoría se inscriben los samples de breakbeats, la melodía en cuerdas de Bitter Sweet Symphony, la secuencia rítmico-armónica en guitarra de Lady (Hear me tonight) y la amplia mayoría de los samples que motorizan las piezas del duo francés Daft Punk. ${ }^{612}$

Como anticipáramos, en los samples conteniendo información musical se incluyen contenidos culturales cuyo origen puede encontrarse en cualquier parte del planeta. Así también se puede acceder a músicas del pasado reciente ${ }^{613} \mathrm{y} / \mathrm{o}$ a piezas del pasado lejano (siempre y cuando exista alguna reconstrucción registrada). Por otra parte, los procesos posibles de ser aplicados sobre aquéllos permiten su transformación al punto de eliminar múltiples elementos (de entre los contenidos en la fuente original), dejando solo cualidades parciales. Por estas razón, los samples son capaces de incluir todos los estratos texturales mencionados como también todos los tipos texturales históricos.

Como habrá podido inferirse, incluso las texturas menos pensadas y actuales pueden samplearse mientras se las presenta por primera vez. El mundo de las muestras de sonido se inscribe en las lógicas de los infinitos incontables; solo por esta razón, a pesar de encontrarse en constante expansión, no crece instante a instante. Al incorporar al análisis los samples de sonidos encontrados, al infinito incontable previo se le suma otro de iguales proporciones. Todo puede sonar en e incorporarse a las músicas electrónicas de baile... y efectivamente se incorpora.

\section{Texturas en estudio y en actos en vivo. Tipos texturales}

También en este nivel jerárquicamente superior resulta relativamente sencilla la descripción de esta cualidad. Como para los estratos y, nuevamente, desde la perspectiva occidental tradicional, ${ }^{614}$ la especie presenta tanto casos de todos y cada uno de los tipos texturales históricamente utilizados como también de otros extendidos. Las únicas salvedades

\footnotetext{
${ }^{612}$ Véase como otro ejemplo el tema Weak generation del duo francés independiente Revolte. Una escucha atenta permitirá apreciar que la amplia mayoría de los sonidos utilizados son basados en samples. revolte - weak generation (clip). $<\mathrm{s} / \mathrm{f}>$. Subido por rosebud17. Accesible en https://youtu.be/xEoXRhOqQAI Las diferencias entre categorías pueden apreciarse con mucha claridad en las interpretaciones de varios virtuosos incluidas en el siguiente "mix" generado por la propia plataforma de YouTube. Mix: Jeremy Ellis performs on MASCHINE MIKRO. Accesible en https://youtu.be/0K2aynMMBpo?list=RD0K2aynMMBpo; video-demostraciones del funcionamiento de diversos dispositivos tecnológicos musicales, se basan por completo en samples. [15072016].

${ }^{613}$ Debemos hacer aquí una aclaración muy importante: el pasado mencionado puede ser tan reciente como el acontecido inmediatamente antes de la reproducción del sample (i.e: un artista puede samplear lo que acaba de configura y se encuentra sonando en ese preciso momento). Como dijéramos en nuestra introducción, la capacidad de registro sonoro aportó a la humanidad el eterno presente.

${ }^{614}$ Por última vez, recordamos que a lo incluido a continuación deben agregarse las conformaciones texturales y procesos peculiares que describiéramos durante el tratamiento audiotáctil de la altura.
} 
que deben hacerse derivan de cuestiones ya tratadas, por lo que nos limitaremos aquí a mencionarlas para evidenciar la vinculación.

\title{
Tipos texturales tradicionales
}

Las texturas, desde perspectivas tradicionales de origen occidental se organizan a partir de criterios dispares, situación que condujo al establecimiento de una serie de categorías o "tipos" texturales inconsistentes en lo que a basamento teórico refiere. Dichos tipos se estructuran sobre la base de reconocer que una serie de eventos discretos sucesivos (i.e.: ataques, las notas de una melodía, los acordes de un relleno armónico) resultan organizados y agrupados por nuestra percepción en "estelas" o "corrientes auditivas". A partir de que ciertas características (registrales, tímbricas, formales etc.) persisten con nulo o muy leve cambio e involucrando diversos factores, nuestra percepción es capaz de agrupar algunos elementos y segregar otros (a los cuales también agrupa), organizando los datos percibidos en varias "corrientes auditivas" simultáneas. Estas corrientes constituirán lo que hemos denominado "estratos texturales" y, dependiendo de su número, de sus cualidades internas y de las relaciones que pueden establecerse con los potenciales otros estratos presentes, se determinará el tipo de textura que una pieza o sección presenta.

En muy pocas palabras, a modo de ejemplo y respecto de su conformación interna, considérese a un estrato que presenta notas en sucesión y de una a la vez (i.e.: nunca simultáneas): según se configuren algunas otras variables, se dirá que nos encontramos frente a una melodía. Por oposición, si en una misma estela detectamos múltiples notas ocurriendo simultáneamente (y nuevamente, dependiente de múltiples otras cualidades) se dirá que dicho estrato consiste en un acompañamiento, relleno armónico o alguna otra denominación similar.

Respecto de las relaciones, baste con decir que estas suelen evaluarse en términos de status jerárquico en relación a la pregnancia perceptiva que cada estrato presenta; pregnancia derivada nuevamente de la conformación interna de cada uno. Dicho esto, en la especie encontramos casos de:

\begin{abstract}
Monodía
Textura constituida por una única línea melódica. ${ }^{615}$ En las músicas electrónicas utilizadas para el baile social momentos monódicos suelen asociarse a melodías "orquestadas" con timbres en múltiples registros. Similar a un unísono orquestal a tutti y ocupando un gran rango de frecuencias, melodías de carácter épico en muchas
\end{abstract}

\footnotetext{
${ }^{615}$ Procurando eliminar cualquier duda, la cantidad de estratos resulta completamente independiente tanto de la cantidad de sonidos-instrumentos intervinientes como de los registros simultáneos donde se la interprete.
} 
ocasiones en timbres de sintetizador conocidos como supersaw $^{616}$ son típicas de las paradas de los índices bajo la, ilustrativa, denominación uplifting trance. ${ }^{617}$

\section{Homofonía}

Múltiples líneas melódicas diferentes en las alturas pero coincidentes en el ritmo. En la especie es usual hallar esta textura en ocasiones similares a las descriptas para la monodía como también conformando uno de varios estratos texturales. Suele utilizarse para reforzar o enriquecer el carácter "enérgico", reconociéndose en esos casos una melodía principal jerarquizada por diversos medios y otras secundarias.

\section{Polifonía}

Múltiples líneas melódicas diferentes -aunque interdependientes- en las alturas y el ritmo. Involucra un elevado nivel de complementariedad melódica. Si bien existen matices suele entendérsela como sinónimo de contrapunto. Menos común en una especie donde la sencillez (como viéramos, aparente) resulta una búsqueda evidente, ejemplos de la acepción tradicional son algo escasos. Requiriendo para su acontecimiento de un tratamiento lineal del Tiempo, esta textura resulta disminuida en cantidad de ocurrencias.

\section{Melodía con acompañamiento}

Una melodía (el elemento principal, más pregnante) ocurre simultáneamente a otros elementos que, por presentar cualidades de mayor permanencia o estatismo, se establecen como "contexto" o acompañamiento de aquella. Como en otras músicas populares, quizá la textura más extendida en la especie.

Sin embargo, vale aquí la advertencia de que en gran cantidad de pistas, texturas "de acompañamiento" no presentan melodía alguna o solo en breves fragmentos del total de la pieza. Oficiando casi como excusa, en estas piezas la mayor parte del tiempo se detecta en solitario lo que, por este hecho, resulta difícil llamar "acompañamiento". ${ }^{618}$

\footnotetext{
${ }^{616}$ Sonidos sintetizados a partir de dos osciladores con ondas dientes de sierra (sawtooth en inglés) con algunos pocos cents de diferencia en su afinación mutua. La mínima diferencia genera un timbre con gran cantidad de componentes, que se suman a los timbres ya de por sí ricos en agudos de cada oscilador.

${ }^{617}$ Una monodía con timbre de sintetizador supersaw como el descripto se incluye al 1'46" de Dark By Design \& Phil York - 1998 (Steve Hill vs Technikal mix). Subido por infernorism ${ }^{T M}$ territory. Accesible en https://youtu.be/4 y86HZ1KfQ. Varios ejemplos de este tipo de configuraciones pueden escucharse en la Lista de reproducción que incluye a la pieza anterior: Oldschool/Uplifting trance. Compilado por aboutinvain. Accesible en https://youtu.be/4 y86HZ1KfQ?list=PLWmvzI0oySG7oC5XhgrlpYeEz-2--aa$\mathrm{M}[20102016]$

${ }^{618}$ Vemos en esta cualidad una manifestación de la textura como obra abierta: el productor evitará incluir en la pieza material melódico para facilitarle al deejay la intervención de la misma. De cualquier manera (y sobre todo en las piezas que se realizan teniendo en mente su presentación en locales de baile), los productores de la especie no se caracterizan por focalizar su trabajo en el desarrollo melódico y prestan
} 
Quizá una expresión acertada para denominar a estas conformaciones últimas sea la de textura de contexto: en otras palabras, una textura que establece (lo que tradicionalmente fuera utilizado como) contexto para algo más. Si bien nada resulta contextualizado, el propio establecimiento del contexto permite denominarlas así. Adoptaremos esta categoría en descripciones por venir.

\section{Heterofonía}

Dos o más estratos texturales divergentes en múltiples dimensiones (sintáctica, fonética, idiomáticamente y otras). Referimos aquí a la textura que anticipáramos en el cuerpo principal como heterofonía por carencia de relación causal: diferentes estratos se comportan como compartimentos estancos y describen conformaciones notablemente diferentes entre sí que, además, suelen no intercambiar cualidades (i.e.: no interactúan ni se interfieren). A modo de ejemplo, en las melodías con acompañamiento ocurren equivalencias simultáneas entre las notas presentes en el estrato melódico y las del acompañamiento o relleno armónico; equivalencias que permiten describir al transcurrir melódico-armónico como presentando un destino común. En la heterofonía en cambio, la organización de la altura en cada estrato es divergente, pudiendo coexistir -como ejemplo- configuraciones tonales con sonidos de altura tonal no definida y gran ancho de banda.

En la especie, la heterofonía es quizá la textura tradicional que rivaliza en cantidad de ejemplos con la melodía con acompañamiento; independientemente de los índices concretos, son muy numerosas las piezas que presentan algún grado de carencia de relación causal entre los elementos y/o estratos que las conforman. Como viéramos, la objetivación origina relaciones heterofónicas: los términos utilizados para caracterizar a esta textura son apenas otra forma de describir el rol articulador que asignáramos a la objetivación. ${ }^{619}$ Considerando estos argumentos no resulta extraño que en la especie prolifere este tipo textural. Circunscribiéndonos a la acepción tradicional y brevemente descriptas, suceden heterofonías originadas en:

Divergencias en las conformaciones sintácticas e idiomáticas

Respondiendo a la acepción tradicional sin matices, la amplitud estética que la especie presenta repercute sin embargo en que a su interior pueden hallarse conformaciones heterofónicas extremas (i.e.: donde las divergencias resultan muy acusadas y evidentes). Incluimos en esta sub-categoría a piezas que

mayor atención a la conformación de texturas-timbres totales (de hecho, como viéramos, no focalizan su trabajo en casi ningún desarrollo).

${ }^{619}$ Véase en el Capítulo II nuestro Paréntesis breve: la objetivación como articulador de estéticas divergentes. 
incorporan y se originan en polimetrías complejas (i.e.: que describen extensos períodos temporales antes de repetirse), pantonalismos, coexistencia de estratos proto-(o pseudo-)tonales con estratos atonales y otros. Presentes principalmente en piezas con alguna influencia del índice experimental, es más común encontrar este tipo de relaciones en pistas que en piezas que evidencian concepciones formales más próximas a las tradicionales. ${ }^{620}$

Divergencias en la activación o por la coexistencia de múltiples tempos Asimilables hasta cierto punto con la categoría previa, estratos de desenvolvimiento lento, coexistiendo con otros describiendo transformaciones veloces, agitadas y vertiginosas se encuentran principalmente en los índices jungle/drum'n'bass/breakbeats y uk garage. Aunque con menores grados de contraste, es también relativamente común encontrar este tipo de conformaciones en algunos (sub-) índices del trance y del techno. En su capítulo dedicado al drum'n'bass, luego de describir la sección rítmica Snoman dirá que "El segundo elemento vital del drum'n'bass es el bajo. En términos generales, el bajo consiste en notas interpretadas a un cuarto o mitad del tempo del ritmo de los tambores." ${ }^{621}$ En los géneros mencionados -como viéramos, caracterizados por una elevada activación especialmente en la sección rítmicaes también usual la ocurrencia simultánea de drones y texturas evolutivas de evolución muy lenta.

Divergencias por el origen o calidad de los estratos texturales

Cualidades heterofónicas emergen a partir de samples conteniendo fragmentos musicales que incorporan texturas completas o próximas a completas y que evidencian su cualidad de muestreadas (por medios descriptos en oportunidades previas). La objetivación derivada del sampleo origina una percepción diferenciada de los elementos contenidos en el sample: aún cuando estos puedan encontrarse en consonancia armónica con el resto de los estratos, el extrañamiento que suele generar su condición (de muestreados) establece una separación entre ambos; separación que en algunas ocasiones impide el establecimiento de relaciones (de otro modo) tradicionales entre el estrato en cuestión y los demás. Quizá una heterofonía que se encuentra en los límites del

\footnotetext{
${ }^{620}$ Para detalles respecto de esta distinción véase nuestro Glosario, como así también el siguiente Anexo IV. Actores involucrados en la escena electrónica. La distinción entre pistas y temas se trata especialmente en esta última sección.

621 "The second, vital element of Drum ' $n$ ' Bass is the bass. Generally speaking, the bass consists of notes that play at either one quarter or half the tempo of the drum rhythm." Snoman, R. 2014. pp. 336
} 
concepto tradicional, así también podría incluírsela entre los casos de heterofonía extendida que trataremos a continuación. Si la ubicamos aquí es porque algunos casos incluyen samples cuya cualidad muestreada puede pasar desapercibida para oídos no avezados.

Finalizamos así una breve enumeración de los tipos texturales tradicionales hallados en piezas de la especie. Sin pretender configurar una perspectiva unificada ni sistemática, veamos ahora algunos casos de tipos extendidos.

\section{Tipos texturales extendidos}

Incluimos aquí a diversas formas de interacción entre los elementos y/o estratos texturales que, por diversos motivos, no se condicen con los tipos texturales tradicionales. En algunos casos por la conformación interna de aquellos, en otros por las relaciones que se establecen -o no se establecen- entre elementos y/o estratos, y en otros por las transformaciones a las que son expuestos unos, otros y/o la totalidad de la textura de una pieza determinada. Situaciones derivadas en muchos casos de la técnica del sampleo o muestreo, todas las descriptas redundan en la emergencia de texturas de cualidades divergentes, en diferentes grados, respecto de los modelos históricos.

\section{Polifonía rítmica o de timbres}

Resultan bastante frecuentes en la especie polifónicas breves (de períodos que suele estar comprendido entre 2 tiempos y 2 compases) donde, como viéramos, intervienen todos o la amplia mayoría de los elementos que componen la textura. Describimos de esta forma a aquellas texturas contrapuntísticas, basadas en comportamientos complementarios, a las que Butler denominara "músicas de percusión". Una particularidad de este tipo textural, a la que aún no nos hemos referido, consiste en que el comportamiento complementario de los diferentes elementos texturales resulta compatible con múltiples tipos texturales tradicionales; en otras palabras y solo a modo de ejemplo, encontramos en la especie piezas donde la textura puede ser descripta como una melodía con acompañamiento (en algún grado defectiva) y, simultáneamente, polifonía rítmica o de timbres. En otras palabras, la igualdad jerárquica propia de las texturas polifónicas se manifiesta sólo en la rítmica de los elementos incluidos; en otras dimensiones de análisis pueden entonces detectarse estratos texturales jerarquizados. Entre otras, esta textura también puede identificarse (en relación 1:1) con la textura de puntos (que veremos en breve) y con aquella que describiéramos como textura de contexto. 
Parafonía

Textura (o estrato textural, como también sucede con la melodia-monodía) que presenta una fundamentación compleja y que quizá genere controversias, la proponemos hasta cierto punto como "opuesto" de la homofonía. Creemos encontrarla especialmente en aquellos acordes o conformaciones complejas sampleados (i.e.: un único acorde o conformación compleja contenido en un único sample) y repetidamente transpuestos en el transcurso de una pieza. Acordes y conformaciones objetivados por su cualidad muestreada, configuran un tratamiento mixto de la altura. A modo de ejemplo: describiendo a veces melodías y otras rellenos armónicos, de presentar al interior del sample relaciones tonales pueden mantener parte de su funcionalidad. Debido al uso asignado y a la disposición fija de las notas (al interior del sample) que lo componen, el acorde se configura simultáneamente como un timbre determinado y como una parafonía o "melodía engrosada". ${ }^{62}$

Otra forma que asume esta categoría se basa también en la técnica del sample y de su transposición, pero esta vez lo que resulta muestreado y transpuesto es una textura completa (pudiendo incluir sección rítmica y todo otro elemento presente). Por incorporar sonidos de altura tonal no definida, el cambio provocado por las transposiciones se vuelve difuso en su cualidad y resulta en transformaciones tanto en (lo que, coherentes con nuestras nomenclaturas, denominaremos) la "altura total" como en el timbre total. Se dificulta describir a este movimiento como parafónico; sin embargo, basándonos en la técnica utilizada y en lo que sucede con las alturas tonales contenidas elegimos incluir a este caso aquí.

\section{Heterofonías extendidas}

Más allá de las heterofonías de diversos orígenes y formas que tratáramos en los tipos tradicionales, ciertas cualidades no contempladas en su definición permiten considerar a algunos casos como extensiones de la mencionada categoría. Como para las situaciones previas, aquí también imperan criterios no unificados.

\section{Derivadas de objetivaciones por repetición}

Como expusiéramos durante el tratamiento audiotáctil de la cualidad altura, un elevado número de repeticiones invariantes tiende a objetivar al material

\footnotetext{
${ }^{622}$ Con esta expresión se refiere algunas veces a ciertas parafonías hallables en obras de Igor Strawinsky o (por ejemplo) en Szenario de Mauricio Kagel. mauricio kagel - szenario [un chien andalou] (1982, perf. 1994). Subido por Alexis Kazazis. Accesible en https://youtu.be/U2gaPMxRrEQ. Un ejemplo de su uso en la especie que nos convoca puede verse en Transposing Chords With The AKAI MPC RENAISSANCE, donde el usuario del dispositivo referido en el título explica los pasos a seguir para distribuir en 16 almohadillas la misma cantidad de transposiciones de un único acorde sampleado. Véase especialmente a partir de los 2'10". Subido por djtechdirect. Accesible en https://youtu.be/fXq214z8-7g. [20102016].
} 
musical. Dicho efecto de la reiteración afecta incluso a materiales que presentan cualidades tonales; el material repetido, dependiendo siempre de sus propiedades concretas, verá al menos parcialmente neutralizadas sus funciones. Un único material tonal reiterado numerosas veces, coexistiendo con otros materiales variantes y que describen direcciones de transformación divergentes en relación al primero, configuran un tipo de heterofonía nuevamente al límite de la acepción tradicional. Situación muy común frente a la presencia de secuencias, lo novedoso es quizá el origen de las divergencias.

Por la coexistencia de estratos musicales y no musicales

Referimos con esta denominación a numerosas piezas en las que conviven elementos y estratos texturales que preservan cualidades musicales tradicionales (i.e.: que se reconocen como musicales, aún cuando dichas músicas se inscriban en tradiciones altamente experimentales) con sonidos encontrados (i.e.: paisajes sonoros naturales, sonidos originados en herramientas de creación humana, discursos de personajes históricos, fragmentos extraídos de medios de comunicación, etcétera).

A partir de estos elementos es posible detectar heterofonías que parecen inscriptas en un nuevo nivel: pretendemos significar con esta expresión que en estos casos la cualidad heterofónica involucra incluso cuestionamientos al respecto de qué materiales, procesos y transformaciones son percibidos como musicales y cuáles no. Demasiado extenso para tratar aquí, nos limitaremos a plantear la siguiente pregunta: ¿podemos considerar musical la presentación de una grabación de campo a la que no se le realiza intervención alguna? Más allá de que su coexistencia con otros materiales implica intervenirla, existen grandes diferencias entre este caso y las prácticas tradicionalmente consideradas y aceptadas como vinculadas al hacer musical (incluso cuando dicha tradición incluye a su interior a la música concreta) ${ }^{623}$

Textura de puntos

Surgidas en el seno de las músicas electrónicas de vanguardia, ejemplos de esta textura se configuran como "nubes" constituidas por numerosos eventos breves. Aún cuando en la especie estos eventos suelen distribuirse temporalmente a partir del establecimiento de una "determinista" pulsación regular, es usual que la organización de sus ataques se perciba como respondiendo a lógicas probabilísticas. En la especie suelen hallarse

${ }^{623}$ Cuestiones de este tipo derivaron en el establecimiento del campo artístico del arte sonoro; campo segregado, al menos en algún grado, del que se asigna a la música. 
secuencias con períodos de ataque muy breve (i.e.: equivalente o próximo a la subdivisión o aún más breves) y donde una o varias cualidades sonoras describen comportamientos azarosos o "probabilísticos" (i.e.: azar en las alturas, timbre, localización en el campo estereo, etc.) que configuran, sin lugar a dudas, casos de este tipo textural.

Textura de masas o masa de sonido

Parafraseando a Michele Edwards diremos que esta textura minimiza la importancia de los eventos sonoros individuales para preferir la textura, el timbre y la dinámica como principales formadores del gesto y el impacto. ${ }^{624}$ Mediante la proliferación de eventos, por la presentación simultánea (i.e.: en un tiempo breve) de un elevado número de eventos musicales, se busca la saturación de la capacidad de segregación perceptual. Con estos recursos se procura el establecimiento de una configuración musical masiva, indiferenciada y fusionada, donde los cambios en cada elemento constituyente sean percibidos como una transformación parcial de las características del elemento totalizador de nivel superior. Si bien es para la especie quizá una de las texturas menos comunes, algunos drones pueden incluirse en esta categoría. Ciertos estilos de ambient/chill out/downtempo hacen uso prolífico de conformaciones como la descripta.

Para finalizar el tratamiento de la textura en estudio y en actos en vivo creemos necesario llamar la atención sobre algunas cuestiones.

Primero, invitamos a revisar los casos descriptos bajo el prisma de comportamientos complementarios; ya no como polifonía rítmica sino en sentido amplio. Dicha revisión pone en evidencia que la amplia mayoría puede pensarse en estos términos. ${ }^{625}$

En segundo lugar, creemos posible afirmar que, por influencia de las objetivaciones de diversos orígenes hallables en la especie, la mayoría de las piezas presentan algún grado de cualidades heterofónicas o ausencia de relación causal entre sus estratos. Hemos mencionado previamente esta cuestión; habiéndolo hecho en otros términos preferimos reiterarnos aquí.

En tercer lugar, vale aquí remarcar que, como evidenciáramos para la melodía-monodía y la parafonía, todas y cada una de las texturas descriptas pueden resultar incluidas en una textura de jerarquía mayor, volviéndose consecuentemente un estrato al interior de aquella y configurando una resultante total más compleja.

\footnotetext{
${ }^{624} \mathrm{La}$ frase original siendo "minimiza la importancia de las alturas musicales individuales para preferir la textura, el timbre y la dinámica como principales formadores del gesto y el impacto". Edwards, M. 2001. Citado en Wikipedia en español, entrada "Masa de sonido". Accesible en https://es.wikipedia.org/wiki/Masa_de sonido [21102016].

${ }^{625}$ Considérese por ejemplo la superposición de tempos diferenciados que expusiéramos como usual en el jungle/drum'n'bass o los demás casos de heterofonía.
} 
Por último, no consideramos un exceso recordar nuevamente que todo elemento, estrato o textura parcial o total puede reconvertirse y volverse un estrato, timbre o ritmo de un nuevo estrato o textura. A modo de nuevo ejemplo sencillo y diferente de los previamente brindados explicitamos que los dispositivos tecnológicos hace posible que un productor realice la siguiente transformación: supongase un arpegio de alturas tonales definidas donde, paulatinamente, las duraciones de cada evento-ataque se reducen al mínimo (volviéndose apenas un breve chasquido de altura tonal no definida), al volver a incrementarlas, el estrato que constituyera el arpegio presenta el mismo ritmo y estructura acentual pero está compuesto de sonidos de percusión (i.e.: sonidos de bombo, redoblante, hi-hat, etcétera). Su función textural se ve consecuentemente transformada desde relleno armónico a sección rítmica.

Las músicas electrónicas utilizadas para el baile social toman las innovaciones de la música experimental (i.e.: contemporánea) y las realizan en un marco de referencia mucho más claro para la amplia mayoría del público. Al hacerlo, le agregan a la transformación formal de estas, la puesta en evidencia de la innovación de sentido que dichas transformaciones implican. En otras palabras, cuando todo es innovación... nada lo es. En su calidad de neo-clasicismo experimental reside quizá uno de los principales aportes de la especie. Desde este punto de vista, las músicas electrónicas utilizadas para el baile social resultan un oxímoron.

\section{Presentaciones de deejay}

Los deejays tienen -literalmente- un oído puesto en la música que los aficionados bailan y otro en la que sonará luego. Además, tienen -metafóricamente- un ojo puesto en los discos de vinilo, CDs y/o archivos en reproducción, otro en los que reproducirá en breve y un tercero ${ }^{626}$ en las reacciones de "la pista" (i.e.: de los bailarines). Queremos significar con esto que el hacer de estos artistas suele consistir en el desarrollo de múltiples tareas simultáneas (y no solo en poner a reproducir piezas finalizadas).

Descontando los trabajos preparatorios, el accionar mínimo de un deejay durante un evento de músicas electrónicas utilizadas para el baile social consistirá en:

a) Seleccionar el $1^{\circ}$ material a reproducir (pista o tema) e iniciar su reproducción.

b) Mientras se reproduce aquel, seleccionar y pre-escuchar el $2^{\circ}$ material.

c) Igualados los tempos, ${ }^{627}$ explorar en ambas piezas el punto donde más fluida funciona la mixtura o mezcla mutua.

d) Iniciar la reproducción del $2^{\circ}$ material. ${ }^{628}$

\footnotetext{
${ }^{626}$ ¿Provendrán de este "tercer ojo" las relaciones trascendentales que describiéramos en el cuerpo principal? Chascarrillo.

${ }^{627}$ Dependiendo del equipamiento utilizado, el beat matching será una función automática o deberá hacerse manualmente.
} 
e) Paulatina o repentinamente (según lo desee del deejay) hacer sonar en el sistema de amplificación el $2^{\circ}$ material (subiendo el control de volumen, mezclándolo con el $1^{\circ}$ ).

f) Pasado un determinado tiempo, reducir el nivel del $1^{\circ}$ (lo que permite escuchar el $2^{\circ}$ material en soledad).

g) Finalmente y durante horas, repetir numerosas veces los pasos descriptos desde el apartado $b$.

Una opción diferente (combinable en el transcurso de un evento con las acciones descriptas) consiste en que el deejay no permita que un único material se escuche en soledad sino que se encuentre siempre mezclado con algún otro. Configuración que requiere mayor preparación, se conoce a esta técnica con el nombre de mash up ${ }^{629}$ Sea un caso $\mathrm{u}$ otro, algunos autores y deejays refieren a los momentos de mezcla de materiales como el " $3^{\circ}$ disco" (siendo el $1^{\circ}$ y $2^{\circ}$ los materiales que dan origen a la mezcla).

Vemos con lo dicho hasta aquí que, como describiéramos en ocasiones previas, las piezas no llegan a los aficionados tal cual salen del estudio de los productores. Al menos su inicio y final resultan mixturados con otras piezas, "abriendo" su macroforma al fluir musical continuo que caracteriza a la especie. Pero son muy pocos los deejays de las músicas electrónicas utilizadas para el baile social que se limitan a las acciones descriptas. La amplia mayoría alternará aquéllas con una gran diversidad de otras acciones, que tienen como resultado una intervención más profunda de las piezas reproducidas. Dependiendo de la predilección y formación de cada deejay particular, sin que el orden en que los presentamos indique nada respecto de mayores o menores ocurrencias, estos suelen:

a) Interpretar instrumentos (usualmente también electrónicos) en vivo.

Tocando o programando sintetizadores y samplers y/o haciendo sonar secuencias en máquinas de ritmo agregarán elementos a estratos texturales incluidos en los materiales reproducidos o sumarán estratos completamente nuevos. Este tipo de intervención musical o de interpretación en vivo puede incluir también cantantes y otros músicos. En algunas raras ocasiones, el aspecto visual de la cabina del deejay se asemeja mucho en cantidad de personas interviniendo sobre la música a lo que puede verse en la presentación de un grupo de músicos electrónicos o incluso de una banda musical típica de otros géneros populares.

b) Seleccionar fragmentos del material reproducido y prolongarlos mediante reiteradas repeticiones.

\footnotetext{
${ }^{628}$ Usualmente, hasta aquí (e incluyendo este apartado) el sistema de amplificación solo reproduce el $1^{\circ}$ material; todo el resto se realiza en la "intimidad" de la cabina (o los auriculares) del deejay, quien sí tiene la posibilidad de escuchar ambos materiales.

${ }^{629}$ Véase la nota al pie 312 para un ejemplo de esta técnica.
} 
Repetición de la repetición, aquí también la forma de la pieza original se "abre" a la intervención. De hecho, es poco usual que una pieza se reproduzca de inicio a fin (aún cuando es mezclada con otra).

c) Aplicar efectos y procesamientos agregando elementos $\mathrm{y} / \mathrm{o}$ estratos texturales completos.

Múltiples y muy variados efectos y procesos se incluyen en los modernos dispositivos utilizados por los deejays. A modo de ejemplo, mediante la manipulación de los parámetros de un efecto de eco (delay) y un filtro, el deejay podrá agregar pulsaciones cambiantes, incorporando a la textura del material reproducido un elementos o estrato nuevo. Cuando sus equipos principales no incluyen este tipo de funciones, muchos deejays agregan otros para tal fin: desde dispositivos ideados y fabricados especialmente para la tarea, hasta juguetes o herramientas concebidas para otros propósitos se aprovechan para generar variedad. Una actitud lúdica reside en la base de estos comportamientos; actitud que la multitud de bailarines suele recibir con agrado.

d) Aplicar efectos y procesamientos jerarquizando o eliminando elementos y/o estratos texturales de entre los incluidos en el material reproducido.

Las mismas herramientas que sirven para los fines descriptos en el apartado previo suelen servir también para estos. Los filtros de frecuencias son sin lugar a dudas los más evidentes: filtros pasa-altos se utilizan para "recortar" o eliminar las frecuencias graves/sub-graves y generar así una parada aún cuando en el material reproducido no la hay; filtros pasa-bajos eliminan las frecuencias agudas y provocan un efecto similar que podría describirse como de "ahogar" a los parlantes y a la música. ${ }^{630}$

Todos y cada uno de los tipos de intervenciones descriptos se constituyen -en conjunto y por sí mismos- en los diferentes límites difusos entre las presentaciones de deejay y los actos en vivo de músicos electrónicos. Así como en aquéllos la intervención puede tener un protagonismo central, en estos puede haber fuerte presencia de material pre-producido y reproducido, por lo que los límites se vuelven más difusos aún.

En no pocas oportunidades hemos presenciado que el material interpretado en vivo o programado in situ en uno o varios dispositivos, excede en relevancia a aquél o aquellos que están siendo reproducidos y, en el momento, no pareció algo que incomodara ni a unos ni a

\footnotetext{
${ }^{630}$ Aunque su uso es mucho menos frecuente, suele generar una respuesta de movimiento similar a la que provocan los filtros pasa-altos (i.e.: movimientos menos definidos y dubitativos). Sin embargo, este recurso no genera el estallido de energía y baile eufórico que sí puede producir el retorno de frecuencias graves/sub-graves luego de una parada generada a partir de esta herramienta. Vemos aquí otra incidencia de cuestiones audiotáctiles.
} 
otros participantes. ${ }^{631}$ De hecho, exploraciones de este estilo suelen ser muy bien vistas por los asistentes a estos eventos.

En definitiva, los límites entre las que denomináramos presentaciones de deejays y actos en vivo no resultan tan claras y pueden reducirse -en cierta medida- a cuestiones de grado: dependiendo a) de la incidencia concreta de los materiales producidos en tiempo real sobre el o los materiales reproducidos y b) de cuál sea el porcentaje de tiempo (sobre la duración total del evento) en que predomine uno u otro material, podremos aproximarnos a una definición y decir que nos encontramos en una presentación de deejay o en un acto en vivo.

Finalizamos así el tratamiento de la textura. Sin embargo, antes de pasar a otros asuntos preferimos dejar planteada una cuestión que aquí consideramos oportuna. Cuando las intervenciones frente al público sobre piezas pre-producidas son tan numerosas y profundas con las descriptas, resulta pertinente preguntarse si realmente nos encontramos frente a una reproducción o si, por el contrario, no es más apropiado hablar de re-producción (i.e.: piezas vueltas a hacer, hechas "otras", transformadas en "otras" formas).

\section{Timbre}

Así como dijéramos para el caso de la textura, durante los análisis audiotáctiles hemos realizado un análisis general de las cualidades tímbricas que pueden hallarse en la especie y que resultan relevantes para la generación de sensación táctil. Si bien esta característica puede gravitar en la diferenciación mutua entre algunos índices, creemos que las descripciones de tipos rítmicos y texturales resultan suficientes para dicha tarea. Conscientes de la extensión actual del presente trabajo, de la que involucraría el tratamiento de este tema y pretendiendo no extendernos más de lo estrictamente necesario, daremos por realizado el análisis tímbrico y postergaremos para ocasiones futuras la realización de una distinción pormenorizada y desde perspectivas tradicionales de esta cualidad musical. Por otra parte, si bien no puede considerarse un estudio sistemático, hemos dado cuenta (en la descripciones de propiedades y mediante la inclusión de ejemplos) de múltiples y muy diversas cuestiones vinculadas a esta cualidad. Si bien el cuadro no resulta para nada completo, hemos brindado gran cantidad de datos respecto de las peculiaridades que en esta cuestión presentan las músicas electrónicas utilizadas para el baile social. Dicho esto, realizaremos ahora descripciones de las particularidades de los índices que resultaran jerarquizados en nuestro Anexo II.

\section{Cualidades de los índices más nombrados de la música electrónica de baile}

Incluimos a continuación una breve descripción comparativa de ciertas cualidades generales de los índices que resultaran jerarquizados en el Anexo II. Apenas una aproximación

\footnotetext{
${ }^{631}$ No es que encontremos razones para que alguna incomodidad pudiera sentir el deejay o los músicos electrónicos, solo describimos lo presenciado.
} 
incompleta, pretende ser una guía para la identificación de similitudes y diferencias en las cualidades que las expresiones de la música electrónica de baile (descriptas por los relatos más difundidos como) históricas aportaran a las músicas electrónicas utilizadas para el baile social. A las cualidades descriptas aquí respecto de cada índice agréguese la información incluida en el Listado de algunos sentidos posibles del Anexo II, como también aquellas que mencionáramos en cada sección del desarrollo.

\section{HOUSE $^{632}$}

\section{Tipo rítmico}

Ritmos regulares con superposición de diatónicos. Patrón de bombo en negras con aplicación de diversos grados de swing. Rango aproximado de tempos usualmente utilizados: 120-135. Métrica: 4 tiempos binarios.

\section{Tipo armónico}

Predominantemente proto o pseudo-tonal con subgrupos de piezas más claramente tonales. Armonía tonal defectiva por la predominancia de pedales armónicos sobre una única conformación y/o de secuencias armónicas de un número muy reducido de acordes reiteradas casi con exclusividad durante toda la pieza.

Resulta usual en aquellas piezas o remixes destinados a "clubes" (i.e.: locales de baile, piezas que constituyen un sub-índice) que presenten de principio a fin una única armonía o armonías parcialmente indefinidas por los timbres utilizados. En estos casos, siempre resulta más usual encontrar al menos una altura tonal definida oficiando de pedal, en general en el registro grave/sub-grave.

\section{Tipo textural}

Mayoritariamente melodía con acompañamiento plena en formato canción o defectiva en formato pista por incidencia de proto o pseudo-melodías y/o armonías breves. La mayoría de los estratos texturales incluidos presentan usualmente cualidades (rítmicas, de altura, tímbricas, por su conformación interna, etc.) asociables con funciones y/o estratos tradicionales (i.e.: sección rítmica, función de bajo, relleno armónico, etc.). En piezas con formato pista resulta usual hallar texturas de contexto por la ocurrencia de proto o pseudo-melodías y/o armonías de aproximadamente 1 compás de extensión; son también comunes uno o varios estratos texturales extendidos (drones, riffs u otros).

\footnotetext{
${ }^{632}$ En los videos incluidos a continuación es posible apreciar múltiples ejemplos de piezas house creadas respectivamente- en los años 1980s y 1990-2000s. Oldschool Chicago Deep house mix 1984-1990 HOUSE NATION y 90's Old School house Mix - house Musica. Subidos respectivamente por JFK MUSIC [house Nation] y OLDSCHOOLHARDHOUSE. Accesibles en https://youtu.be/BRQsLysczbA y https://youtu.be/Zcd7MI1szEM. [21102016]
} 
En muchos casos se configuran polifonías rítmicas o de timbres.

\section{Tipo formal}

Macro-forma: amplio espectro, abarcando desde la tradicional canción de estilo pop (incluyendo melodías y contenido textual a cargo de voces líderes) hasta un más experimental formato pista. En ambos formatos la amplia mayoría de piezas es monotemática y diversas variaciones suelen presentarse en la textura de principio a fin. En términos generales suceden articulaciones formales cada 8/16/32/64/128 compases, donde la proporcionalidad suele responder a una lógica que puede ser descripta como fractal: en los arcos más prolongados -en cantidad de compasesocurren articulaciones con mayor incidencia sobre la macro-forma. ${ }^{633}$ En el formato canción es muy común la inclusión de estribillos y de los llamados "material c". ${ }^{634}$

Micro-forma: las pistas suelen presentar patrones de períodos no mayores a 1 o 2 compases que, luego de una serie de repeticiones y siguiendo las proporciones mencionadas previamente, experimentan alguna modificación.

\section{Instrumentación ${ }^{635}$}

En términos generales, el índice hace referencia a instrumentos acústicos. Dicha referencialidad se concreta a través de la tímbrica (i.e.: timbres asociables a instrumentos acústicos tanto por el uso de samples como por mímesis sintética; primordialmente sonidos de altura tonal definida) y en las configuraciones que dichos timbres describen (en varias dimensiones, las configuraciones presentan referencias a estructuras formales asociables con cualidades tradicionalmente referidas como "musicales"). En otras palabras, es un índice que suele presentar referencialidad formal (intertextual y a "música") antes que a otro tipo de sentidos. ${ }^{636}$ En piezas en formato pista la referencialidad formal es más débil tanto tímbrica como (valga la redundancia) formalmente.

Entre los instrumentos remitidos se incluyen: sección rítmica, batería y percusión (acústica sampleada o sintetizada), bajo eléctrico o sintetizado, guitarra eléctrica, sintetizadores y/o piano eléctrico, orquesta de cuerdas, metales, maderas, vocalista, coros.

\footnotetext{
${ }^{633}$ Esta estructuración de los materiales resulta posible de ser aplicada en general a todos los índices de la especie. La excepción la constituyen muchos ejemplos ambient/chill out - downtempo.

${ }^{634}$ De este modo se denomina, en ciertas comunidades de músicas populares, al material usualmente diferente de estrofa y estribillo que se incluye al promediar la duración total de la forma canción. El mismo suele ser interpuesto (en general luego de la tercer estrofa) con el objetivo de renovar, por contraste, los materiales de estrofas y estribillos.

${ }^{635} \mathrm{De}$ forma limitada y tomando como referencia al concepto de sonido-instrumento que hemos adoptado para situaciones previas, incluimos en esta categoría a ciertas cuestiones tímbricas no tratadas. Mucho más puede decirse respecto del timbre y/o de los dispositivos concretos (en muchos casos incluyendo marca y modelo) más utilizados en algunos índices. Respecto de esta cuestión, recordamos por ejemplo nuestros dichos respecto del índice acid y su vinculación directa con el sintetizador de bajos Roland Tb303 y con las capacidades de control que este dispositivo brinda.

${ }^{636}$ Vemos surgir aquí una aplicación posible para una dimensión de análisis que estableciéramos años atrás con otros fines. Véase nuestro Anzil, I. 2011. Op.cit. pp.4
} 
Conformaciones rítmico-melódicas usuales

El patrón de bombo en negras suele complementarse con otras percusiones que brindan mayor variabilidad a la sección.

Bajo: patrones melódicos breves y reiterados (algunas veces con variaciones), usualmente cargado de síncopas.

Guitarra: rítmica. Usualmente realizando agrupamientos y gestualidades rítmicomelódicas identificables con el género funk.

Sintetizadores: muy diversas conformaciones y timbres.

Pianos: apoyo y ripieno armónico, usualmente elementos secundarios y relegados en la textura por menor sonoridad y/o menor elaboración y pregnancia tímbrica. Rol similar al de "relleno" rítmico-armónico propio del jazz.

Orquestas: ripieno armónico, relleno espectral en el registro agudo, esporádicas contramelodías y/o rol textural de figura melódica durante intermedios instrumentales. Vocalista: figura principal de la textura en formato canción. Usualmente ausente en pistas.

\section{Incidencia del índice experimental ${ }^{637}$}

Usualmente de bajo a medio. Algunos casos pueden caracterizarse incluso como presentando incidencia nula de este índice.

\section{Otras cualidades generales}

Gestualidad con rasgos de origen afronorteamericanos en numerosos elementos incluidos en samples o en interpretaciones ad hoc (conformaciones en el bajo, pianos, voces cantadas, guitarras eléctricas, etc.). Elementos reconocibles del funk, disco y jazz. A pesar de lo dicho, al comparar piezas old school (1980's) con piezas más recientes (1990's, 2000's y 2010's) esta cualidad particular parece diluirse y desdibujarse paulatinamente.

Al hacer mayor hincapié sobre la repetición algunas piezas en formato pista se apartan -al menos parcialmente- de la expresividad musical tradicional y de la temporalidad lineal. Incluyen conformaciones más próximas a objetos sonoros y presentan una temporalidad en cierto grado suspendida o cíclica.

Si bien cualquier generalización resulta falaz, las piezas que responden al formato canción suelen organizarse alrededor de un único material melódico-armónico: melodía a cargo del o de la vocalista, de fraseos usualmente libres, con cierto grado de improvisación y sobre una

\footnotetext{
${ }^{637}$ Como fuera dicho, índice transversal, se convierte en una dimensión de análisis que permite clarificar la segregación que entre algunos índices se realiza.
} 
secuencia armónico-rítmica reiterada y sostenida ${ }^{638}$ Este material domina la mayor parte de la pieza y se alterna con interrupciones ("breaks"), fórmulas acentuales breves ("fills") y otros materiales diversos que lo renuevan al aportar contrastes.

\section{TECHNO $^{639}$}

\section{Tipo rítmico}

Ritmos predominantemente regulares. Sobre un patrón de bombo en negras son hallables todos los tipos de ritmos: elementos texturales regulares no contemplados en el patrón de bombo en negras (i.e.: ritmos aditivos no-diatónicos), valores irregulares, pulsaciones de diversas escalas (en tempos divergentes con el descripto por la sección rítmica principal), ritmos diatónicos, ritmos no medidos, polimetrías simples y complejas, etcétera. Rango aproximado de tempos usualmente utilizados: 128-145. Métrica: 4 tiempos binarios.

\section{Tipo armónico}

Predominantemente atonal. Menor cantidad de piezas presenta una proto o pseudo-tonalidad o tonicidad originada en la persistencia de una única conformación armónica usualmente reiterada durante toda la pieza. En piezas del último grupo la incidencia de la objetivación por repetición debilita el posible establecimiento de una sensación de reposo o distensión que la persistencia sobre una única altura o conformación espectral pudiera producir.

\section{Tipo textural}

Mayoritariamente polifonía rítmica o de timbres y/o texturas de contexto. Generalizada ausencia de estratos melódicos; más comunes resultan proto o pseudo-melodías y armonías inconclusas, con timbres de tonicidad débil y de períodos que rondan los 2 tiempos de compás.

Salvo la sección rítmica (incluso ésta en algunas ocasiones), resulta difícil asociar a los estratos texturales incluidos con funciones y/o estratos tradicionales. Aunque no puede tomarse como regla general, cuando dichas funciones se incluyen suelen presentar solo cualidades parciales o defectivas. Resulta aplicable aquí extender el tipo de denominación que utilizáramos para los elementos melódico-armónicos; algunos ejemplos son: (proto-)o pseudo-función de bajo y (proto-) o pseudo-relleno armónico.

Estratos texturales extendidos como drones, riffs o texturas evolutiva son más comunes que en el house.

\footnotetext{
${ }^{638}$ Quizá la excepción la constituyan aquellas piezas que presentan estribillo, donde este suele presentar un carácter y diseño melódico-armónico diferenciado de las estrofas.

${ }^{639}$ En las Listas de reproducción incluidas a continuación pueden apreciarse la cualidades de piezas techno old school. Pure Old School techno.2 y PURE OLD SHOOL TECHNO. Subidas por Zab Jim y kamaskg. Accesibles respectivamente en https://youtu.be/c-vf3TwbOgY?list=PLw8nrWrT A2f9aWbhCRYHI5163N4rSNg y https://youtu.be/WEHbMju7gDk?list=PL0F8724AA50D4A353. [21102016]
} 


\section{Tipo formal}

Macro-forma: formato pista casi con exclusividad. La amplia mayoría de piezas presentan un único material y diversas variaciones de principio a fin.

Micro-forma: predominancia de patrones de períodos no mayores a 1 o 2 compases repetidos sin variación alguna durante largos períodos de tiempo originan su carácter "maquinal" o "automático" típico. Siguiendo las proporciones mencionadas supra algunos patrones experimentan modificaciones que se constituye en las referidas articulaciones formales.

\section{Instrumentación}

Predominancia de sonidos sintéticos "crudos" (i.e.: iterados, con componentes de ruido, saturaciones y distorsiones varias) y de timbres con poca o nula tonicidad. La remisión de timbres y conformaciones a cualidades y estructuras musicales tradicionales resulta débil, imponiéndose (por las numerosas repeticiones) un carácter "des-humanizado". En otras palabras, sobre una débil referencialidad formal (intertextual y a "música") se impone y prepondera una referencialidad externa concordante con el sentido incluido en la denominación del índice.

Sección rítmica (batería y diversas percusiones, todas usualmente sintéticas) y diversos sonidos sintetizados y/o sampleados cuyos timbres suelen no remitir a instrumentos acústicos. Cuando se incluyen, voces sampleadas suelen presentar también fragmentaciones y procesamientos que las des-humaniza y le agregan cualidades "tecnológicas" al evidenciar dichos procesamientos.

\section{Conformaciones rítmico-melódicas usuales}

Otras percusiones complejizan la sección al describir rítmicas muy heterogéneas.

Sintetizadores cumpliendo (proto-) función de bajo. Proliferan las rítmicas sobre una única nota repetida o breves secuencias de pocas alturas.

Otras funciones instrumentales y texturales incluyen secuencias o arpegios de períodos entre 1 tiempo y 2 compases. Cuando se presentan categorías de este tipo sus cualidades y el tratamiento aplicado las inscribe entre las (proto-) o pseudo-melodías y (proto-) o seudo-armonías.

\section{Incidencia del índice experimental}

Usualmente de medio a alto. El anclaje principal a estéticas musicales tradicionales se presenta principalmente en la rítmica, a partir de la configuración de un compás estable e invariante. A pesar de lo dicho, otras cualidades rítmicas aportan diversos grados de ambigüedad y experimentación también a este aspecto. 


\section{Otras cualidades generales}

Gestualidad caracterizada principalmente por la des-humanización. Alto grado de repetición e invariancia provoca la objetivación de materiales y el establecimiento de una temporalidad claramente suspendida o cíclica.

El material principal y usualmente único se alterna con interrupciones ("breaks"), fórmulas acentuales breves ("fills") y materiales diversos que lo renuevan mediante la generación de contraste.

\section{TRANCE ${ }^{640}$}

\section{Tipo rítmico}

Ritmos regulares con superposición de diatónicos. Patrón de bombo en negras. Ciertas cualidades asociables a la polifonía rítmica parecen organizadas con el objetivo de conformar una pulsación equivalente a la subdivisión. Dicha oscilación/alternancia de intensidad, en algunas piezas puede competir con el "bombeo" ("pumping") originado en una (sobre)compresión por cadena lateral conducida por el bombo y aplicada sobre todos o la mayoría de los componentes texturales. El incremento de intensidad en el contratiempo (derivado de la compresión) opera como un levare de corchea al tiempo siguiente. Dicho levare es usualmente reforzado por los transitorios de ataques de hi-hats abiertos atacando también a contratiempo. Rango aproximado de tempos usualmente utilizados: 130-150. Métrica: 4 tiempos binarios.

\section{Tipo armónico}

El trance es el índice más próximo a la tonalidad y a estéticas musicales tradicionales. Numerosas piezas responden sin objeciones a los principios de dicho sistema.

A partir principalmente de la influencia del índice psychedelic, psy o Goa (tres denominaciones que remiten a las mismas cualidades) se detectan piezas que se apartan de la lógica tonal y se organizan de principio a fin a partir de pedales de una única armonía usualmente consonante y triádica por intervalos de terceras. En este subgrupo, la evolución se traslada de la armonía al timbre y las piezas adquieren características propias del formato pista.

\section{Tipo textural}

Melodía con acompañamiento vocal-instrumental o instrumental. Las melodías juegan un rol destacado. Diseños simples con acentos a contratiempo alternan entre ritmos diatónicos y regulares. Los timbres sintéticos usualmente utilizados -al complejizar su timbre y por la aplicación de reverberación- suelen "llenarse" paulatinamente. Esta ampliación del espectro de frecuencias genera una sensación de espacialidad "grande"; sublimación del unísono o tutti

${ }^{640}$ Ejemplos old school del índice pueden apreciarse en el compilado Back to The 90's - Remember Oldschool trance Mix. Subido por KlangExtase. Accesible en https://youtu.be/V3KQACqpwbQ [28102016] 
orquestal, en contrapunto homorrítmico con otros estratos y con el bajo, configura un timbre que puede ocupar gran parte del espectro audible.

En piezas con incidencia psy la textura es mejor descripta como de contexto; en ambos formatos (canción y pista) suelen incluir estratos texturales que reemplazan a la melodía como figura principal: conformaciones espectrales complejas y evolutivas convocan la atención por su pregnancia relativa.

Otros estratos característicos lo constituyen arpegios y rellenos armónicos de cualidades similares. Sintetizando cualidades de los bajos alberti y de secuencias por pasos, son muy diversos en su rítmica, acentuación y timbre.

Las conformaciones de bajos pueden describirse esencialmente como pedales sobre una misma nota atacando a contratiempo o generan un juego rítmico que interactúa con los bombos en negras. De este modo diversifica y dinamiza la rítmica de la región grave/sub-grave del espectro. Sus configuraciones suele ser también complementarias a las melodías y el ritmo descripto dependerá en general de aquellas.

\section{Tipo formal}

Prima el formato canción. Una excepción la constituye quizá el subgrupo con incidencia del índice psychedelic, donde son mayoría las piezas en formato pista.

Quizá el índice con cualidades formales más marcadas, presenta características diferenciadas de sección en sección que se reflejan y pueden ejemplificarse con el ritmo armónico: iniciándose sobre un pedal de tónica hasta la primera parada, en la misma se introduce una secuencia armónica que suele continuarse desde entonces y hasta el final de la pieza. Breves y básicas progresiones armónicas tonales, usualmente repetidas sin modificaciones, se organizan alrededor de las relaciones tonica-subdominante-dominante. Nuevamente, el índice psy opera neutralizando las propiedades tonales.

En el trance las paradas pueden rivalizar en duración con las secciones más activas rítmicamente; algunas piezas incluyen, además, más de una. Éstas constituyen largos períodos transicionales que usualmente presentan densificaciones verticales progresivas y direccionales (por el agregado de nuevos elementos y/o estratos), cronométricas (por inclusión de ritmos cada vez más agitados) y espectrales (por el incremento en las bandas de frecuencias ocupadas).

Fórmulas anticipatorias de los cambios son características del índice. Tanto en paradas como en secciones "regulares", redobles en redoblante, bombo u otros sonidos-instrumentos (no necesariamente de percusión) suelen describir densificaciones cronométricas que van más allá de lo cuantificable y de lo posible para la motricidad humana. Su extensión temporal puede generar incluso que se establezcan en sí mismas como una parte de la macro-forma. Concebidas evidentemente como acumulaciones graduales de tensión, esta misma extensión temporal en 
algunas piezas cuestiona o neutraliza tanto a la tensión como a dicha función. ${ }^{641}$ La ausencia de alternancia por prolongación de la tensión debilita o neutraliza a las posibles funciones tonales presentes. $^{642}$

\section{Instrumentación}

Timbres sintéticos y gran preponderancia de referencialidad formal. Piezas con influencia psychedelic presentan mayor gravitación de referencialidad externa, la cual se expresa en una remisión a un estado alterado de conciencia o transe hipnótico (i.e.: "introspección activa" y "euforia").

Melodías a cargo de timbres complejos ocupan amplias zonas registrales.

Sonidos de bajo de ataque impulsivo a contratiempo y usualmente sobre una única nota refuerzan el efecto originado en la compresión por cadena lateral. En otras secciones describe movimientos armónicos acordes a las funciones tonales incluidas (ver Tipo armónico).

Los timbres de la sección rítmica resultan una cualidad definitoria: caracterizados en general por envolventes de intensidad de transiciones muy rápidas, presentan por esta razón gran cantidad de transitorios de ataque y componentes agudos.

\section{Incidencia del índice experimental}

Usualmente bajo, medio en piezas con influencia del índice psychedelic.

\section{Otras cualidades generales}

Coincidiendo con ciertos dichos de Demers, el índice puede describirse como "grande" y compuesto para "grandes espacios": una única idea melódica o melódico-armónica (i.e.: homofónica) suena fuerte, ocupando todo el espectro de frecuencias y describiendo ritmos que permiten escuchar "colas" de reverberación. Dicha reverberación, además, presenta cualidades que sugieren un espacio de grandes dimensiones. La interacción entre los ritmos y la reverberación generan la sensación de que poseen tal forma porque se buscó alcanzar oídos que se encuentran lejos (i.e.: al fondo de un estadio o espacio amplio y abierto).

Piezas con influencia psychedelic presentan un carácter marcial que se expresa en el ritmo. Un amplio rango dinámico en sonidos percusivos y marcados -donde el compresor (entre ataque y ataque) lleva a la sonoridad hasta el silencio- provoca un carácter que puede describirse como

\footnotetext{
${ }^{641}$ Ténganse presentes los argumentos expuestos en el título Función cuasi-tonal de los registros graveagudo y en el Paréntesis a modo de descanso: paradas o bajones.

${ }^{642}$ Ésta característica se encuentra extendida hoy a gran parte de la especie, por lo que ha dejado de ser definitoria del índice y se ha convertido en una manifestación más de la hibridación descripta en otras secciones. Durante nuestra exploración de los diferentes géneros, los redobles serían indicados por diferentes interlocutores como una cualidad propia del Trance; sin embargo, esto sería luego cuestionado por numerosos ejemplos escuchados, generándonos confusión. Valga esta mención anecdótica como ejemplo de las complejidades atravesadas para aprehender a la especie y como advertencia para quienes deseen recorrer el mismo camino.
} 
tético, donde todos los elementos atacan o parecen atacar sincrónicos al bombo. En la emergencia de esta sensación también incide el levare por compresión mencionado supra.

A estas cualidades se le suelen contraponer secciones con muchos más elementos a contratiempo, siendo quizá ésta oposición una característica del índice.

\section{JUNGLE/DRUM'N'BASS/BREAKBEATS ${ }^{643}$}

\section{Tipo rítmico}

Ritmos sincopados con circunstanciales alternancias con regulares. Secciones rítmicas basadas en samples de breakbeats o reconstrucciones de dicho tipo rítmico. Fuerte incidencia del swing. En estratos diferentes a la sección rítmica pueden ocurrir cualquiera de los tipos rítmicos analizados. Rango aproximado de pares de tempos usualmente utilizados (dos temporalidades superpuestas): 63/126-93/186. Métrica: 4 tiempos binarios.

\section{Tipo armónico}

Atonal o (proto-) pseudo-tonal por recurrencia sobre una única altura o por de breves secuencias armónicas (son usuales dos armonías diferenciadas que alternan en relación 1:1). El desarrollo histórico describe un recorrido que se aleja cada vez más de cualidades propias del sistema tonal. En ejemplos tempranos se evidencian influencias de armonizaciones típicas del jazz.

\section{Tipo textural}

Heterofonía por carencia de relación causal por superposición de diferentes temporalidades. Cierta complementariedad entre estratos o un grado parcial de polifonía rítmica o de timbres promueve la heterogeneidad y divergencia rítmica. Textura caracterizada por la imprevisibilidad e inestabilidad propias de los ritmos sincopados. En ciertos pasajes, ritmos a mitad de tiempo generan otro de los contrastes y discontinuidades que caracterizan al índice.

La textura consiste esencialmente en una sección rítmica agitada y sonidos graves/sub-graves $a$ mitad de tiempo. El resto de los componentes texturales presentan mayor variedad, presentándose desde estratos miméticos de instrumentos y funciones musicales tradicionales (pianos, arpa, orquestas de cuerdas y otros realizando melodías, rellenos armónicos, etc.) hasta sonidos de cualidades nóveles. En ambos casos son usuales artificios y cualidades tímbricas que denotan el origen muestreado que caracteriza al índice.

\footnotetext{
${ }^{643}$ Próximos a la finalización de la redacción de la presente tesis dialogamos con algunos deejays y músicos electrónicos especializados en estos índices. La opinión de los consultados coincidió en que el término "breakbeats" refiere al mismo conjunto de piezas y puede ser entendido como sinónimo de "jungle" y "drum'n'bass". Una salvedad fue hecha (aunque relativizada luego): quizá éste haga uso de un tempo algo más lento y presente un carácter más "tranquilo", menos "agitado" o "frenético". Siendo esta la experiencia recogida durante nuestras sesiones de escucha asumimos esta perspectiva unificada para su descripción. Ejemplos old school se incluyen en la Lista de reproducción old skool jungle classics. Compilados por verona patterson. Accesible en https://youtu.be/H48FpOylZg4?list=PLHK99FDXXodbLilaD0K4AyAz3ZZKU8fX_ [28102016]
} 


\section{Tipo formal}

Por lo general formato pista, con minoría de formato canción rap: base rítmica o rítmicoarmónica sobre la que el maestro de ceremonias ("MC" en la jerga) improvisa versos rimados y ritmados.

Usualmente monotemático, en ciertas secciones se contrasta por medio de decrecimientos en la densidad de elementos y/o estratos texturales.

Micro-forma: usualmente patrones reiterados de períodos no mayores a 2 compases.

\section{Instrumentación}

Predominancia generalizada de tímbricas y conformaciones que permiten reconocer su origen muestreado. Consecuente preponderancia de referencialidad formal en timbres y conformaciones que incluyen instrumentos y grupos instrumentales acústicos y electrónicos y materiales musicales en general (i.e.: menor ocurrencia de sonidos encontrados).

\section{Conformaciones rítmico-melódicas usuales}

Sección rítmica y rellenos armónico-rítmicos funcionalmente ambiguos o espectrales (i.e.: samples incluyendo materiales con altura tonal definida, de tonicidad debil o sonidos de altura tonal no definida) generan una sensación generalizada de inestabilidad e imprevisibilidad. Complementariamente, el sonido de bajo -usualmente acentuando el primer tiempo del compás- contrarresta en alguna medida dichas sensaciones.

Bajos usualmente sintéticos y voces sampleadas o interpretadas en vivo incluyen conformaciones tímbrico-melódico-rítmicas propias del reggae y del dub.

En piezas de formato canción rap, los versos improvisados del $M C$ describen gran variedad rítmica y acentual y se constituyen en el estrato más pregnante (i.e.: figura) de la textura.

Otros estratos presentan mayor variabilidad: desde drones hasta secciones de metales (usualmente sampleados) realizando rítmicas típicas de tradiciones musicales diversas. La sección rítmica puede verse enriquecida con numerosos elementos de orígenes diversos.

\section{Incidencia del índice experimental}

Bajo a medio. Principalmente detectable en redobles imposibles de realizar por medios acústicos, en algunos drones y textutas evolutivas y en samples fragmentarios de voces y sonidos de orígenes diversos. 


\section{Otras cualidades generales}

Carácter primordialmente agitado e inestable. La oposición de temporalidades diferenciadas refuerza y realimenta la inestabilidad descripta por los ritmos agitados de la sección rítmica. Algunos ejemplos referencian a estéticas y géneros musicales como reggae, dub, jazz, funk, soul y rap; pudiendo referir a varios en una misma pieza.

\section{AMBIENT/CHILL OUT - DOWNTEMPO ${ }^{644}$}

La gran amplitud estética de este índice abarca desde piezas que podrían incluirse en el repertorio de músicas contemporáneas académicas y experimentales hasta piezas del soul, easy listening y new age. Para facilitar el análisis se modificó el orden de las variables utilizadas en las descripciones.

\section{Incidencia del índice experimental}

El ambient/chill out - downtempo presenta todo el arco de posibilidades, desde piezas con incidencia virtualmente nula de este índice a extremos esencialmente experimentales. Ciertos casos dificultan incluso su caracterización como electrónicos por presentar casi con exclusividad cualidades musicales asociables con estéticas tradicionales. Siendo su propiedad principal un tempo más lento, mientras la activación musical permanezca en niveles relativamente bajos y permita movimientos relajados, ligados o suaves, cualquier pieza puede ser considerada parte del conjunto. Cumplida la condición enunciada, el índice acepta a todas y cada una de las cualidades de todos los demás índices de las músicas electrónica utilizadas para el baile social y -más importante aún- de toda otra música. La cualidad abierta y totalizadora de la especie tiene su forma más abarcativa en este índice que, a diferencia de sus pares complementarios, no debe cumplir siquiera el requisito de ser claramente danzable. En consecuencia y como sucediera con otros géneros nacidos marginales, ${ }^{645}$ algunos de sus productores evidencian una mayor predisposición hacia la experimentación, aportándole la amplitud estética antes descripta.

Enlazado a lo anterior, su ubicación en la intersección entre músicas populares y electrónicas la vuelven un campo especialmente abierto a toda estética, permitiendo la inclusión -sin distinción ni prejuicio- de cualidades provenientes tanto de las primeras como de tradiciones contemporáneas o académicas. Un subconjunto de piezas del índice pueden incluso caracterizarse como al límite de la distinción entre música y arte sonoro; cualidad que diera origen al apelativo "ambient": más que música, un "ambiente" sonoro o sono-musical.

\footnotetext{
${ }^{644}$ Brindamos algún tipo de referencia respecto del índice a partir de los siguientes compilados incluidos en el sitio YouTube. En ambos pueden hallarse ejemplos con diversos grados de influencia del índice experimental. Soundcloud Artists Special (mix) - Ambient/Chill Out/Experimental/Downtempo. Subido por Steve Thomas. Accesible en https://youtu.be/OxLxgmokzOE. Nebulus |Psy-dub + Downtempo Mix. Subido por flrstper0n. Accesible en https://youtu.be/V9aLRO2hAKI. [28102016].

${ }^{645}$ El ambient/chill out se originó como un complemento de la música presentada en la pista principal; una expresión pensada para una pista más "tranquila" y secundaria.
} 
Si bien nuestros dichos parecen sugerir que cualquier descripción carece de sentido, recorrer las propiedades que utilizáramos para describir a los demás índices permitirá comprender algunos de los límites que de hecho pueden hallarse en las piezas que componen a este conjunto.

\section{Tipo rítmico}

Todos los tipos rítmicos descriptos son hallables en este índice. Polirritmias de números primos, tempos simultáneos divergentes y otras formas de interacción compleja son más comunes que en los demás índices. También se detectan piezas con rítmicas provenientes de otros géneros y especies del mundo. Todo ritmo puede ser incluido mientras la activación permanezca en niveles bajos. Rango aproximado de tempos usualmente utilizados: <muy lento>-120. Métrica: 4 tiempos binarios aunque con mayor índice de variabilidad. Se incluyen, además, piezas con ritmo no medido.

\section{Tipo armónico}

Desde tonales new age, presentando unas pocas armonías triádicas extremadamente simples, hasta piezas "ruidistas" incluyendo solo sonidos de altura tonal no definida. Pueden incluir extensos samples de verdaderos paisajes sonoros como configurarse esencialmente a partir de dicho tipo de sonidos.

Las piezas que incluyen armonías (cuando no establecen pedales de inicio a fin) presentan casi sin excepción acordes triádicos en estado fundamental, con muy bajo grado de disonancia y describiendo ritmos armónicos lentos.

\section{Tipo textural}

Todo tipo textural ocurre en este grupo. Aquéllas que en otros índices resultan marginales tienen en piezas del conjunto un lugar destacado: drones, texturas evolutivas, de masas, de puntos y todo otro tratamiento plástico del sonido derivado de lógicas espectrales son más frecuentes en el ambient/chill out - downtempo. En cierto subgrupo de piezas éstas asumen incluso roles preponderantes y principales.

\section{Tipo formal}

La monotematicidad es usual en piezas más próximas a estéticas tradicionales. En aquéllas con mayor incidencia del índice experimental el tratamiento del timbre desde perspectivas espectrales redunda en general en piezas unimembres: sonidos continuos de evolución lenta donde las posibilidades de transformaciones "extremas" mencionadas en otras secciones suele aplicarse en toda la amplitud que el recurso brinda. En piezas con ritmo no medido estas herramientas suelen utilizarse para generar todo tipo de pulsaciones y rítmicas periódicas o cuasi-periódicas. 


\section{Instrumentación}

Predominancia de sonidos sintéticos con envolventes de sonoridad de desarrollo lento en todas sus etapas ("pads" en la jerga) y componentes de ruido medianamente agudo (i.e.: sonidos de cualidades "etéreas"). Drones y texturas evolutivas resultan comunes, como también conformaciones de otros tipos pero describiendo arcos de evolución extendidos temporalmente. En piezas más ligadas a estéticas musicales tradicionales, las envolventes de intensidad utilizadas pueden ser descriptas como "suaves" y se recurre a timbres reducidos en componentes agudos.

Predomina la referencia externa a una idea (sonora) de "tranquilidad", "relajación", "placer", etc. Comparados con las cualidades de los demás índices, los elementos en todas las piezas se encuentra en función de generar estos estados anímicos.

Es usual la aplicación de reverberaciones de decaimiento lento como también efectos de eco. Frente a una mayoría de sonidos largos y sostenidos, ${ }^{646}$ los efectos aplicados pueden cumplir la función de generar una leve activación.

Conformaciones rítmico-melódicas usuales

No es posible establecer patrones típicos del índice, salvo que sus cualidades denotan una intención de mantener la activación y el conflicto musicales en grados bajos.

\section{Otras cualidades generales}

Carácter "tranquilo", "relajado", "meditativo" e "introspectivo". Temporalidad lenta lineal o cíclica. En algunas piezas la temporalidad se percibe más suspendida que en cualquier otro índice.

En aquellas con mayor vínculo con estéticas musicales tradicionales pueden hallarse gestualidades y características del género soul y de músicas asociadas al movimiento new age.

Resulta ilustrativo mencionar que piezas del índice suelen utilizarse para acompañar sesiones de meditación.

\section{HARDCORE $^{647}$}

Tipo rítmico

Utilización casi exclusiva de ritmos regulares. Patrón de bombo en negras (en algunos casos solo parcial). Cualidad tética en extremo con gran cantidad de elementos y estratos texturales

\footnotetext{
${ }^{646}$ Llamamos la atención sobre esta característica, en relación con nuestros dichos acerca de la mayor ocurrencia de sonidos cortos en músicas de baile.

${ }^{647}$ Lista de reproducción de YouTube con ejemplos old school del índice: oldshool hardcore 1994-2003. Subido por anna guerini. Accesible en https://youtu.be/c7u 2nB2q 8?list=PL029A378AC980CDDC [28102016]
} 
homorrítmicos con el bombo. Rango aproximado de tempos usualmente utilizados: 155-240. Métrica: 4 tiempos binarios.

\section{Tipo armónico}

Predominantemente proto o pseudo-tonal con subgrupos de piezas más claramente tonales. Timbres "saturados" y con gran cantidad de componentes de ruido aportan a la indefinición armónica descripta. Armonía tonal defectiva por la predominancia de pedales armónicos sobre una única conformación y/o de secuencias armónicas de un número muy reducido de acordes reiteradas casi con exclusividad durante toda la pieza.

\section{Tipo textural}

Mayoritariamente homofonía defectiva de proto o pseudo-melodías y armonías solo parcialmente definidas por incidencia del tipo de timbres utilizados. Conformaciones extremadamente simples donde la mayoría de los estratos son homorrítmicos con el bombo y describen apenas una pulsación igual a la usualmente asignada en la especie a dicho sonidoinstrumento. Elementos secundarios suelen marcar el contratiempo. La presencia de riffs en timbres con diversos grados de definición en su altura tonal es más común que en otros índices y puede ser visto como una herencia de estilos asociados del rock.

Suelen incluirse samples fragmentarios y reiterados de voces humanas (en general habladas, no cantadas); provenientes de diversas fuentes, evidencian con artificios y procesamientos su carácter de muestreados.

\section{Tipo formal}

Macro-forma: formato pista monotemática que presenta un único material y diversas variaciones de principio a fin.

Micro-forma: suelen presentar patrones reiterados de períodos no mayores a 1 o 2 compases; con diversas modificaciones, se presentarán de principio a fin de la pieza.

\section{Instrumentación}

Sonidos en su mayoría sintetizados y otros sampleados presentan timbres "saturados", "crudos", iterados, estridentes y con gran carga de componentes de ruido.

\footnotetext{
Conformaciones rítmico-melódicas usuales

Bombo, redoblante y/o palmas, hi-hat y la amplia mayoría de la sección rítmica marcan un patrón básico y reiterado limitado a describir una pulsación coincidente con el pulso. Bajo y la amplia mayoría de sonidos que componen la textura describen exactamente el mismo ritmo que la sección rítmica.
} 
Samples de voces habladas y elementos aislados se apartan del ritmo dominante a modo de proto (o pseudo) melodías breves y fragmentarias. Estos elementos ofician de figura defectiva.

\section{Incidencia del índice experimental}

La extrema simplicidad de los materiales involucrados dificultan evaluar la incidencia de este índice. En términos tímbricos quizá similar al techno, sus configuraciones texturales y rítmicas extremadamente básicas lo vuelven un índice cuya existencia se justifica por las diferencias que presenta con otros precisamente en las dimensiones mencionadas.

\section{Otras cualidades generales}

Carácter "duro" y "agresivo" que en algunos ejemplos parece sugerir cierto cinismo. Algunas cualidades sugieren posicionamientos político-artísticos heredados del movimiento punk. Es lícito aventurar que de estas actitudes surge el "desprecio" por formas más "musicales". Una excepción la constituya quizá la pieza DJ Jappo \& DJ Lancinhouse - Fukem Outro - MOK 83 incluida en la posición 14 de la Lista de reproducción ofrecida como ejemplo: si bien se mantiene dentro de los cánones estéticos del índice, presenta sin embargo una diversidad y variabilidad mucho mayor.

\section{UK GARAGE $\left(2\right.$ STEP/DUBSTEP) ${ }^{648}$}

\section{Tipo rítmico}

Ritmos sincopados generalizados en todos los estratos texturales. El sonido de bombo suele describir continuas variaciones sincopadas alrededor de un redoblante y/o palmas en tiempos 2 y 4 del compás. Sin embargo, las rítmicas utilizadas presentas mayor variabilidad que en (a modo de ejemplo) el índice jungle/drum'n'bass/breakbeats. Fuerte incidencia del swing. En algunos ejemplos se detecta la coexistencia con ritmos diatónicos. Rango aproximado de tempo usualmente utilizado: 128-145. Métrica: 4 tiempos binarios.

\footnotetext{
${ }^{648}$ Describimos aquí al índice en su forma clásica u old school. En los aspectos que así lo requieran realizaremos descripciones de ciertas cualidades más recientes que han dado origen a las "nuevas formas" mencionadas en nuestro Anexo II. Ejemplos posibles del primer grupo pueden hallarse en UKG - Sunship - Try Me Out (Let Me Lick It) - A (This Side). Subido por funbags82. Accesible en https://youtu.be/qnE9Sn-k4Xc?list=PLWy9yjUMNKfZ3-a7EUy8yedAaLQKCLV5Y. Para piezas más próximas en el tiempo sugerimos escuchar Mr Distance UK Garage Mix 2000 2005. Subido por Mr Distance. Accesible en https://youtu.be/-HbBgI-2uDk. Para las formas más reciente del 2 step y dubstep véase 2step у OldSchool Dubstep (Playlist, 2007 - early 2010's). Subido por Александр Шумилов у MangooQc. Accesible en https://youtu.be/pkj9m2eQaWc?list=PL6KyG7bbcmjFozkFulked_gwEt0fRzIM y en https://youtu.be/a-Ur6GvbjYk?list=PL9 MUxg5UidlI6GVyn_ORPdTSQnEgOii. Para más detalles al respecto del dubstep -en tanto deriva del $u k$ garage que presenta cualidades divergentes- véase la entrada de Wikipedia en español "Dubstep". A diferencia de lo que ocurre con otras entradas donde los datos aportados suelen ser vagos y escuetos, para este caso se ofrece información técnico-musical precisa y en gran cantidad. Se incluyen también desarrollos históricos. Accesible en https://es.wikipedia.org/wiki/Dubstep. [28102016].
} 
2 STEP/DUBSTEP: algunos elementos y/o estratos texturales describen ritmos a la mitad, lo que resulta en un rango de tempos doble 64/128-73/146.

\section{Tipo armónico}

Predominantemente proto o pseudo-tonal con subgrupos de piezas más claramente tonales. Armonía tonal defectiva por predominancia de pedales armónicos sobre una única conformación y/o de secuencias armónicas de un número muy reducido de acordes reiteradas casi con exclusividad durante toda la pieza.

\section{Tipo textural}

Melodías con acompañamiento defectivas y texturas de contexto por incidencia de proto o pseudo-melodías y/o armonías breves. En menor número, piezas en formato canción incluyendo melodías con acompañamiento plenas con voces interpretando melodías que incluyen texto.

La mayoría de los estratos texturales incluidos presentan usualmente cualidades asociables con funciones y/o estratos tradicionales. En piezas más recientes se incluyen en mayor medida elementos y estratos texturales extendidos.

2 STEP/DUBSTEP: son más usuales las heterofonías por carencia de relación causal, como también la configuración de polifonías rítmicas o de timbres (lo último es también válido en piezas recientes que no pertenecen a estos nuevos índices).

\section{Tipo formal}

Formato pista generalizado con minoría de formato canción. Usualmente monotemático. Suelen producirse contrastes a partir de decrecimientos en la densidad de elementos y/o estratos texturales.

Micro-forma: usualmente patrones de período no mayor a 2 compases.

\section{Instrumentación}

En términos generales, el índice refiere a funciones texturales asociadas a instrumentos acústicos; referencia que se concreta más en las configuraciones que dicho instrumental describe (se presentan configuraciones asociables con músicas de origen afronorteamericanas, especialmente del funk) y menos a través de la tímbrica (aunque en general se incluyen sonidos de altura tonal definida, los timbres utilizados presentan cualidades primordialmente sintéticas o evidenciando ser muestreadas). Entre otros, se incluyen conformaciones que remiten a los instrumentos y grupos instrumentales siguientes: sección rítmica, batería, percusión (acústica o sintetizada), bajo eléctrico o sintetizado, sintetizadores, órganos y/o piano eléctrico, orquesta de cuerdas, metales, maderas, vocalista, coros. 
La referencialidad formal (intertextual y a música de origen afronorteamericano) prepondera sobre la referencialidad externa.

Conformaciones rítmico-melódicas usuales

Conformaciones de todo tipo evidencian la influencia del género funk.

Patrones de ritmos sincopados brindan una gran variabilidad a la sección rítmica.

Bajo: patrones melódicos breves y reiterados (algunas veces con variaciones), usualmente cargado de síncopas.

Sintetizadores: muy diversas conformaciones y timbres.

Pianos y órganos clásicos: apoyos acentuales (acordes plaqué) y relleno armónico similares al rol de relleno rítmico-armónico del jazz y el funk.

Orquestas: intervenciones circunstanciales, relleno armónico, relleno espectral en el registro agudo, esporádicas contramelodías y/o rol textural de figura melódica durante intermedios instrumentales. Instrumentos de viento -principalmente metales- realizan ataques o grupos de pocos ataques breves propios del funk.

Vocalista: figura principal de la textura y/o fragmentos de voces sampleadas formando parte del entramado de la polifonía rítmica o de timbres.

2 STEP/DUBSTEP: en términos generales las diferencias en relación al uk garage pueden describirse como un debilitamiento del índice funk, el cual se reemplaza por cualidades reggae y $d u b$. Esto sucede en el bajo (que en estas expresiones presenta sonidos muy graves atacando esencialmente en el primer tiempo del compás) y en pianos y órganos clásicos. Esta misma razón determina la desaparición de instrumentos de viento de la familia de los metales.

\section{Incidencia del índice experimental}

Usualmente de bajo a medio. Se expresa principalmente en el entramado rítmico-textural y en algunos elementos intervinientes en la polifonía rítmica o de timbres.

2 STEP/DUBSTEP: mayor influencia del índice experimental.

\section{Otras cualidades generales}

Rasgos provenientes de músicas de origen afronorteamericanos se detectan en conformaciones del bajo, pianos, voces cantadas, sintetizadores y órganos. Elementos reconocibles principalmente del funk como también del disco y del jazz. Como en el house, comparar piezas old school (1990s) con piezas más recientes (2000s y 2010s) demuestra que esta cualidad particular se diluye y desdibuja. 
A diferencia del house, las conformaciones características le otorgan al uk garage una temporalidad claramente cíclica.

Las piezas que responden al formato canción suelen organizarse alrededor de un único material melódico-armónico: melodía a cargo del o de la vocalista, de fraseos usualmente libres, con cierto grado de improvisación y sobre una secuencia armónico-rítmica reiterada y sostenida. ${ }^{649}$ Este material domina la mayor parte de la pieza y se alterna con interrupciones ("breaks"), fórmulas acentuales breves ("fills") y otros materiales diversos que lo renuevan al aportar contrastes.

2 STEP/DUBSTEP: como fuera dicho, las características provenientes del funk y demás géneros afronorteamericanos se reemplazan por cualidades del reggae y el dub.

${ }^{649}$ Como en el house, quizá la excepción la constituyan aquellas piezas que presentan estribillo, donde este suele presentar un carácter y diseño melódico-armónico diferenciado de las estrofas. 
ANEXO IV

Actores involucrados en la escena electrónica

Entre los integrantes que conforman la comunidad electrónica hay algunos que desempeñan roles destacados y tienen mayor influencia sobre el devenir estético de las músicas electrónicas utilizadas para el baile social. Este subgrupo lo integran productores, músicos electrónicos, deejays y, en algo secundariamente, bailarines. Pudiendo un mismo sujeto desempeñar varios de los roles mencionados, cada uno presenta peculiaridades que merecen destacarse y que permitirán comprender con mayor detalle el tipo de dinámicas relacionales que se establecen al interior de la comunidad electrónica.

Habiendo tratado cuestiones relativas a este tema en diversas secciones de la presente tesis, nos limitaremos aquí a explicitar aquellas que aún no fueran mencionadas y que resultan relevantes para una mejor comprensión de nuestro objeto de estudio. Intentando no repetirnos recorreremos cada rol procurando agregar algunos datos puntuales. Por esta razón y por nuestra búsqueda de brevedad el contenido que sigue resulta en alguna medida episódico y disgregado.

\section{Conocimiento musical "vulgar"}

Como mencionáramos en diversas secciones del cuerpo principal, multiplicidad de participantes de la comunidad poseen algún nivel de conocimiento musical y se vinculan, al menos en la intimidad y de forma lúdica, con la creación musical. Esta no es solo la experiencia de un sub-grupo de aficionados a la especie sino que suele ser la forma de muchos de iniciarse en su hacer como productores, deejays y músicos electrónicos, por lo que repercute determinando (hasta cierto punto) el tipo de conocimiento musical que cierto grupo de artistas, posee al menos, al inicio de sus carreras. Este hecho será explicado por Mark Butler en términos de democratización del acceso a la creación musical, cuestión que expresará del siguiente modo:

Un grado tan alto de participación en la creación musical es posible por una variedad de razones. Primero, uno puede ser productor o DJ por propia cuenta; no hay necesidad de formar una banda, organizar ensayos, o ganar acceso a estudios de grabación de la industria musical. Segundo, la tecnología requerida es generalmente barata: aunque los profesionales pueden tener más piezas de equipamiento, algunos de los cuales serán lo suficientemente costosos como para quedar fuera del alcance de la mayoría de los amateurs, formas baratas de estudios y de tecnologías de DJ se encuentran ampliamente disponibles. Tercero, como con la música clásica, la abstracción de la EDM puede hacer a la actividad de DJ y de producción [de música electrónica] particularmente atractiva como forma "en acto" de aproximación al aprendizaje de la música; trabajando con un instrumento (ya sea acústico o electrónico) en interpretación o composición es un camino para incorporar la música al cuerpo. ${ }^{650}$

\footnotetext{
650 "Such a high degree in participation in music-making is possible for a variety of reasons. Fist, one can be a producer or a DJ on one's own; there is no need to form a band, organize rehersals, or gain access to music industry recording studios. Second, the technology required is generally inexpensive, though professionals might have more pieces of equipement, some of wich would be costly enough to be beyond the reach of most amateurs, cheap forms of studio and DJ technology are widely available. Third, as with classical music, the abstraction of EDM may make DJing and production particularly appealing as handson ways of getting to know the music better; working with an instrument (whether acoustic or electronic)
} 
A los argumentos de Butler creemos necesario agregar que las cualidades propias de las músicas electrónicas utilizadas para el baile social la vuelven una especie aparentemente sencilla de abordar sin conocimiento musical tradicional sistemático. ${ }^{651}$ Este podría ser aún otro factor que impulse un mayor grado de participación en la creación musical al interior de la especie. $^{652}$

El descripto suele ser el tipo de conocimiento y nivel de formación musicales que poseen aquellos aficionados y bailarines que describiéramos (siguiendo también a Butler) como "deejays de dormitorio"; conocimiento parcial y asistemático que suele circular entre los participantes de la comunidad electrónica que no pretenden un ejercicio musical profesional. Como podrá suponerse, este hecho genera una comunidad donde la información técnica musical difiere de aquella que usualmente circula en las vinculadas a otras especies de música popular, y resulta un factor determinante del "recorrido" de muchos artistas, hoy reconocidos, de las músicas electrónicas utilizadas para el baile social. ${ }^{653}$

\section{Productores}

El productor será aquel artista que, en la intimidad de su estudio (usualmente propio o compartido con otros productores también de músicas electrónicas) creará piezas de la especie. En algunos casos especializados en uno o varios índices, es usual que cumplan simultáneamente los roles de compositor, intérprete, arreglador, diseñador (de los timbres de sintetizador a utilizar), programador (de secuencias), técnico de grabación (de los samples a utilizar y de sus creaciones en general) y otros. Aunque menos usual, es posible que también se ocupe de la operación completa de su estudio, lo que conduce a que realice las mezcla y masterizado de las piezas producidas. ${ }^{654}$

La concentración de todas estas funciones en una misma persona constituye una diferencia esencial en relación a otros períodos históricos y a lo que suele suceder en el proceso de producción de grabaciones de otras especies musicales. Resulta así debido en parte al estrecho vínculo entre el productor y la tecnología que la especie exige. Butler comparará las diferentes acepciones del término y dirá que, en la música electrónica de baile:

in performance or composition is one way of grounding music in the body." Butler, M. Op. cit. (2003). pp. 26

${ }^{651}$ Entre otras que mencionáramos: su amplitud estética, el grado elevado (en relación a otras músicas) de heterofonías por carencia de relación causal y su atonalismo (parcial o total).

${ }^{652}$ Vemos evidenciarse esta mayor participación en el elevado número de "deejays de dormitorio" en comparación con (a modo de ejemplo, los que podríamos llamar) "guitarristas de dormitorio" en el rock.

${ }^{653}$ Aunque lo consideramos excesivo preferimos aclarar que este no ha sido ni es el único camino y que un número de artistas igual de significativo poseen formación y conocimientos musicales sistemáticos en estéticas tanto tradicionales como electrónicas y experimentales.

${ }^{654}$ Mezcla y masterizado resultan los procesos o etapas básicos para la finalización de una grabación y para que esta pueda ser publicada y puesta a disposición del público. 
[...] el que más se aproxima a la noción convencional de "creador" musical es el del productor. En la mayoría de las músicas populares contemporáneas, el término "productor" refiere a alguien que supervisa el proceso de grabación en un estudio. Mientras que este tipo de productor puede tener un impacto significativo en el sonido de una grabación, el(la) no es considerado/a como un cancionista [o escritor de canciones]. En la mayoría de la música electrónica de baile sin embargo, la tecnología está integrada directamente en el acto de composición, y la persona que crea música usualmente es quien también la graba. Por lo tanto las distinciones entre productor, cancionista y técnico/artista de grabación comienza a resquebrajarse; el productor de EDM personifica todos los tres roles. ${ }^{655}$

A modo de ejemplo, si bien siempre resulta posible que un individuo concreto utilice solo sonidos creados por otro diseñador en la producción de sus creaciones (i.e.: no diseñe sus propios sonidos), esta situación resulta virtualmente inexistente entre productores profesionales.

En estas razones se basa también que cada productor prefiera, en general, realizar su actividad creativa en su estudio personal: a diferencia de lo que sucede en otras especies musicales, en las músicas de base tecnológica la diferenciación entre estudio e instrumento musical se diluye y funde en una única herramienta. Su estudio (el conjunto de sus dispositivos de efectos, procesadores, software, micrófonos, etcétera; como sus sintetizadores, samplers y demás), es para el productor de la electrónica sinónimo de "instrumento".

Este vínculo estrecho con la tecnología lleva incluso a que numerosos artistas -no solo productores- procuren adquirir conocimientos de electrónica para a) clonar dispositivos existentes $^{656}$ o históricos por alguna razón inaccesibles, b) realizarle modificaciones a instrumentos propios y/o c) fabricarse sus propios dispositivos. Inscriptos en una tradición que en la comunidad se considera en algún sentido iniciada en los intonarrumori de los hermanos Russolo, los artistas electrónicos son capaces de gestar toda clase de dispositivos y "engendros" generadores de sonidos y "ruidos" en busca de "el" sonido (cuyas cualidades no encuentran en ningún otro objeto existente). ${ }^{657}$

\section{Músicos electrónicos}

Hemos incluido esta categoría debido a cierto sesgo detectado en el trabajo de Mark Butler y que pretendimos neutralizar en nuestro trabajo. Como mencionáramos en

\footnotetext{
655 "Of the three roles I have outlined, the one that conforms most closely to conventional notions of a musical "creator" is that of the producer. In the majority of contemporary popular music, the term "producer" refers to someone who oversees the process of recording in a studio. While this type of producer can have a significant impact on the sound of a recording, (s)he is not generally thought of as a songwriter. In most electronic dance music, however, technology is integrated directly into the act of composition, and the person who creates music usually records it as well. Hence the distinctions between producer, songwriter, and recording artist begin to break down; the EDM producer embodies all of these roles." Butler, M. Op. cit. (2003). pp. 26

${ }^{656}$ Copiar sus circuitos uno por uno, creando un dispositivo que sin ser el original, funciona -e, idealmente, suena- exactamente como aquél.

${ }^{657}$ Ilustrativo de esta faceta resulta la existencia del sitio en línea Music from outer space (conocido también como "MFOS"), dedicado a brindar apoyo e información para la construcción de dispositivos musicales de base tecnológica "DIY" (i.e.: "Do It Yourself" o "Hágalo Usted Mismo"). Accesible en http://www.musicfromouterspace.com/ [03102016]
} 
oportunidades previas, dicho autor implica en sus argumentos que el único modo en que las músicas electrónicas utilizadas para el baile social alcanzan a su público es a través de lo que llamáramos "presentaciones de deejay"; sin embargo, al menos en el contexto local eventos de este tipo son tan comunes como los que indicáramos como "actos en vivo". Si bien la distinción entre aquellas y estos resulta (como fuera dicho) una cuestión de grado, también es cierto que en los extremos del eje difuso en que ambos formatos se inscriben pueden hallarse ejemplos "puros" de uno y otro. ${ }^{658}$

"Músico electrónico" es entonces el rol desempeñado por aquellos artistas que realizan música electrónica en actos en vivo, utilizando para ello esencialmente dispositivos musicales de base tecnológica diferentes a las bandejas tocadisco ${ }^{659}$ y haciendo uso mínimo o nulo de pistas. A diferencia de las presentaciones de deejay, los actos en vivo se caracterizarán por un mayor grado de creación en tiempo real de material musical; los músicos electrónicos suelen recurrir a mayor cantidad y diversidad de dispositivos que los deejays, por lo que los diferentes elementos y/o estratos texturales presentan un mayor grado de independencia y más posibilidades de intervención, modificación y eliminación.

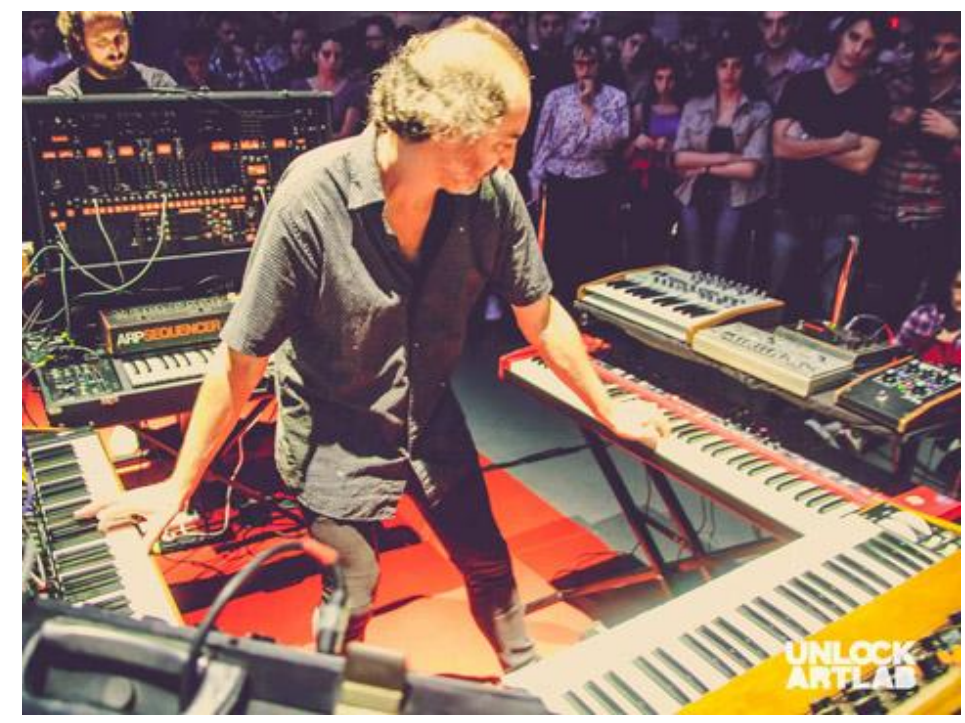

Ernesto Romeo durante la presentación de su proyecto Klauss. Festival Sonar Buenos Aires, 3 de diciembre de $2015^{660}$

A modo de ejemplo, es altamente probable que en un acto en vivo se incluya, entre múltiples otros dispositivos, a una caja de ritmos. Su inclusión posibilita la edición y

\footnotetext{
${ }^{658}$ Apoyándonos en el hecho de que las presentaciones de deejay "puras" son un formato más difundido, ofrecemos en cambio un video que ilustra un tipo posible de acto en vivo. NYNOISE.TV | SIMIAN MOBILE DISCO- Its The Beat (LIVE -KEXP). Subido por NewYorkNoise. Accesible en https://youtu.be/0hTky0X3eT4. [31102016]

${ }^{659}$ En otras palabras, sintetizadores, samplers, secuenciadores, máquinas de ritmo, además de aquellos dispositivos utilizados en presentaciones en vivo de otras especies musicales.

${ }_{660}$ Fuente: http://static-cms.sonar.es/sonarBuenosAires/uploads/images/e/r/n/ernesto-romeo-klauss-1.jpg. [05112016]
} 
modificación completa, momento a momento, de los ritmos que podría describir la sección rítmica. Este grado de libertad se replica y multiplica -en una relación directa- con cada dispositivo independiente que los músicos electrónicos incluyan en su orgánico (en la jerga, otras de las acepciones de "set"). Sus acciones pueden describirse como centrada alrededor de la creación en tiempo real de material musical nuevo y original.

En contraste, ya sea que se encuentre grabada en un disco de vinilo o contenida en un archivo digital de sonido, una pista presenta a todos y cada uno de los elementos y estratos texturales "mezclados" en una única entidad. Este hecho dificulta y limita las posibles intervenciones y acciones modificatorias que pudiera pretender el deejay. En otras palabras y especialmente a partir de la incorporación de ciertas herramientas surgidas en los últimos años, el trabajo de los deejays puede describirse como centrada alrededor de la intervención de una pista $y / o$ de fragmentos de una o varias pistas.

Por supuesto, tal y como hiciéramos para las presentaciones de deejay, también para este caso es necesario considerar las condiciones enunciadas con cierto grado de flexibilidad. En otras palabras, ciertas presentaciones podrán ser consideradas actos en vivo aún cuando hagan uso de pistas. Aunque pueda parecer una contradicción y como antes dijéramos, las herramientas tecnológicas permiten procesos tan extremos que, dependiendo del tratamiento que se les brinde, las pistas podrán perder su función de tales; también aquí el límite es difuso.

\section{Deejays}

Mark Butler realiza una excelente síntesis -que al mismo tiempo resulta en un ejemplode las cuestiones involucradas en el hacer de los deejays. Explicará el papel activo que este actor desarrolla diciendo que:

El DJ de EDM es mucho más que una persona que pone discos; el/ella funciona como un/a intermediario/a entre el productor y la audiencia, es la persona que hace a música tecnológicamente mediada, inmediata. La música electrónica de baile está fuertemente asociada con el entorno de la pista de baile, y es el DJ quien da forma a la música que allí se escucha. Los DJs escuchan los discos que los productores han hecho, eligen algunos de ellos, y los arreglan en un orden particular para crear una única ejecución continua (un "set") de una hora o más de duración. Un set es una unidad: no solo los DJs crean un flujo continuo de sonido, ellos también minimizan las distinciones entre las pistas individuales, para que entonces el énfasis esté en el todo mayor más que en sus componentes. Además, los arreglos de DJs dentro del set son intencionalmente nuevos; uno de los principales logros del accionar de los DJs es crear algo nuevo a partir de diversas fuentes. Con este fin, los DJs combinan pistas en formas inesperadas; superponen partes de pistas sobre partes de otras pistas (por ejemplo, la línea de bajo de una grabación con un único compás de la línea vocal de otra) y crean pastiches estilo collages (sic.) alternando entre grabaciones. También manipulan pistas individuales en grado considerable. Por lo tanto, el acto de DJ es compositivo, aún cuando DJs no crean música "de la nada" [desde cero]. ${ }^{61}$

661 "The EDM DJ is much more than a person who plays records; (s)he functions as an intermediary between the producer and the audience, the person who makes technologically mediated music inmediate. Electronic dance music is strongly associated with its dance floor environment, and it is the DJ who 
Aquí se comprende por qué las pistas creadas por los productores presentan las características que hemos descripto. Su cualidad "abierta" o "inconclusa" se encuentra en función de brindarle a los deejays la oportunidad y el "espacio" para desarrollar las intervenciones que estos crean apropiadas y oportunas en cada ocasión en que las presenten. Las pistas se producen teniendo en cuenta la posibilidad de que, llegado el caso, un deejay podría utilizar (del total de elementos que las conforman) apenas un fragmento de la textura de un único compás, o incluso menos. Dicho fragmento, por si fuera poco, puede que aparezca siempre combinado con fragmentos de otras pistas del mismo u otro productor.

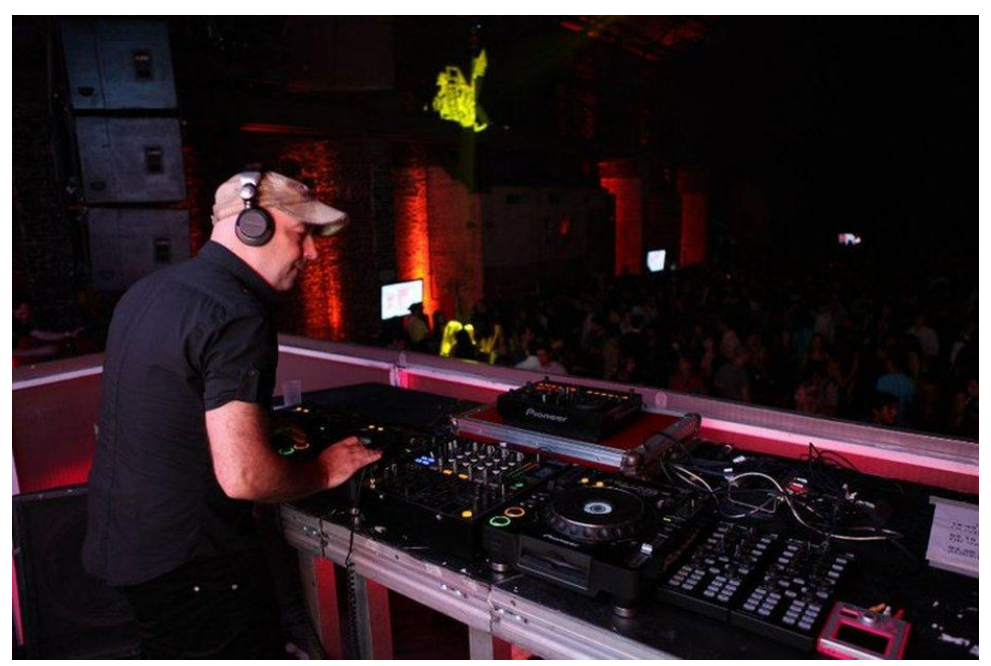

DJ Zuker, residente del local de baile Crobar, tal y como aparece en una nota realizada a partir de una de sus presentaciones. ${ }^{662}$

Vemos aquí otras formas concretas en que difieren los compositores de otras especies musicales de los productores de la electrónica. Diferencias que apenas mencionáramos durante la Introducción del Capítulo I, se basan, a su vez y en definitiva, en las diferencias entre los respectivos campos estéticos de referencia en que se inscriben las piezas de las músicas

shapes the music heard there. DJs listen to the records producers have made, choose certain ones of them, and arrange them in a particular order to create a single continuous performance (a "set") lasting an hour or more in length. A set is a unity: not only do DJs create an unbroken flow of sound, they also minimize the distinctions between individual tracks, so that the emphasis is on the larger whole rather than its components. Furthermore, the DJ's arrangements within the set are intentionally novel; one of the primary goals of DJing is to create something new from diverse sources. To this end, DJs combine tracks in unexpected ways; they layer parts of tracks on top of parts of other tracks (for instance, the bass line of one record with a single measure of another record's vocal line); and they create collage-like pastiches by cutting back and forth between records. They also manipulate individual tracks, often considerably. Hence, DJing is a compositional act, even though DJs do not create music "from scrath." Butler, M. Op. cit. (2003) pp. 27

${ }^{662}$ Nótense las diferencias en el equipamiento en relación a la foto precedente de Ernesto Romeo. 2 bandejas tocadiscos con una mezcladora al medio (dispositivo con el cual realizar las transiciones entre un disco y otro) constituyen el centro. A la derecha de la $2^{\circ}$ bandeja (Zuker se encuentra delante de la $1^{\circ}$ ) y sobre la caja roja pueden apreciarse algunos dispositivos extras dispuestos de un modo que evidencia su rol secundario (su ubicación no permite un acceso rápido y cómodo). Fuente (de la imagen): http://www.eltribuno.info/este-sabado-dj-zuker-una-nueva-fiesta-cooltura-n446690. [05112016] 
electrónicas utilizadas para el baile social y otras especies. En otras palabras, mientras a las piezas de otras especies les subyace la idea de obra "cerrada" de un único individuo (i.e.: poseen autor), las de las electrónicas utilizadas para el baile social pueden comprenderse como fragmentos a veces anónimos de una producción colectiva y holística donde el o los autores (si hay alguno) son la totalidad de la comunidad de creadores de la especie. ${ }^{663}$ Como veremos en breve, en la comunidad electrónica y hasta cierto punto, incluso los bailarines son considerados parte del grupo creador.

Respecto de la evolución histórica del rol, Butler destacará que:

En general, los relatos de las formas tempranas de música electrónica de baile enfatizan la programación [la selección de pistas] por sobre la composición. Escritores intentando captura el éxtasis de la pista de baile disco (ej: Holleran 1978) durante los 1970s usualmente describen el placer de escuchar una pista particular en un momento particular; la programación era claramente donde se ponía el énfasis en los clubes gay de New York en los 1980s también, como el relato de Fikentscher's (2000) revela. Desde los 1990s, el lado compositivo de la actividad de DJ se ha vuelto más prominente, y se ha vuelto mucho menos común escuchar pistas identificables, discretas en un set de DJ. Sin embargo, la programación se enfatiza en un grado considerable al interior de ciertos géneros. ${ }^{664}$

Esta distinción entre el hacer de unos y otros deejays persiste aún hoy: mientras algunos prefieren limitarse a "respetar" las pistas en las formas elegidas por sus respectivos productores, otros toman el camino opuesto realizando producciones (en estudio) propias y ofreciendo presentaciones donde los pocos elementos reconocibles se detectan al interior de reconfiguraciones novedosas, asumiendo el deejay un rol muy próximo (sino asimilable) al de nuestro músico electrónico.

\section{Bailarines}

En diversas oportunidades nos referimos al rol activo de los bailarines y de los modos en que sus acciones inciden sobre las formas finales que asumen las músicas electrónicas utilizadas para el baile social, creemos oportuno aquí agregar algunas consideraciones al respecto. Para estos fines nos basaremos nuevamente en razones esgrimidas por Mark Butler con las cuales hallamos múltiples coincidencias de perspectiva. Sugerimos entonces entrecruzar

\footnotetext{
${ }^{663}$ Esta afirmación no puede hacerse para todos los casos y existen numerosos artistas "de renombre" mundial.

664 "In general, accounts of earlier types of (electronic) dance music emphasize programming (la selección de tracks) over composition. Writers atempting to capture the ecstasy of the disco dance floor (e.g. Holleran 1978) during the 1970s often describe the joy of hearing a particular rack at a particular moment; programming was clearly a major emphasis in New York gay clubs in the 1980s as well, as Fikentscher's (2000) account reveals. Since the 1990s, the compositional side of DJing has become more prominent, and it has become much less common to hear identifiable, discrete tracks within a DJ's set. However, programming is still emphasized to a considerable degree within certain genres." Butler, M. Op. cit. (2003) pp. 27
} 
lo que sigue con nuestra exposición al respecto de la aparente "sencillez" de las músicas utilizadas para el baile social (véase para ello el título homónimo Sencillez).

Como en ocasiones previas, Butler se referirá a esta cuestión en términos propios y apelando a otros autores:

El tercer rol creativo asociado con la música electrónica de baile es aquel del bailarín. Retratar al bailarín en esta capacidad puede parecer ir demasiado lejos, especialmente desde que la academia musical ha largamente mantenido una división fundamental entre el creador de la música y su audiencia. La división entre creación y recepción es fundamental en la musicología, por ejemplo, mientras una dicotomía similar entre producción y consumo ha sido largamente una parte de los estudios en música popular. Sin embargo, bailar es esencial para experimentar la EDM; es tan importante como (y tan conectada con) el acto de escuchar. Los productores crean música con la expectativa de que esta será bailada, y un significativo número de aficionados a la EDM experimentan la música solo mientras bailan, desde que no compran la música para escucharla en sus hogares. Aquellos que escuchan estas músicas en entornos nodanzantes casi invariablemente tienen un léxico de memorias físicas [corporales] asociadas con aquella.

Además, bailar no es una actividad menos musical que la actividad del DJ o que la de producción [musical]. Porque bailar EDM no involucra pasos predeterminados, cada bailarín debe conformar su respuesta a la música mientras esta se desarrolla, y los ritmos de los movimientos del bailarín agregan un contrapunto a los patrones de la propia música. Por lo tanto la descripción de Fikentscher's de la danza de la EDM como "musicando en movimiento" parece particularmente apropiada; como el nota, "musicando en sonido y musicando en movimiento ocurren simultaneamente y en relación con la otra" (2000:58). Las dos formas de "musicar" [éstas comillas son nuestras] se desarrollan a través de una dinámica de interacción entre el DJ y la audiencia. ${ }^{665}$

A partir de estos dichos quizá se comprendan mejor nuestros argumentos al respecto de que la mentada "sencillez" de la especie resulta solo una apariencia: en el momento de la creación e interpretación ("musicales") tanto productor como músico electrónico y/o deejay consideran no solo las propiedades "puramente musicales" que presentan las conformaciones por ellos determinadas sino que también intentan anticipar las cualidades más probables que

665 "The third creative role associated with electronic dance music is that of the dancer. Portraying the dancer in this capacity migth seem to go too far, especially since scholarship on music has long maintained a fundamental division between music's creator and its audience. The division between creation and reception is fundamental to musicology, for instance, while a similar dichotomy between production and consumption has long been a part of popular music studies. However, dancing is essential to experiencing EDM; it is as important as (and closely connected to) the act of listening. Producers create music with the expectation that ti will be danced to, and a sifnificant number of EDM fans experience the music only while dancing, as they do not purchase the music for home listening. Those who do listen to the music in nondance environments almost invariably have a lexicon of physical memories associated with it.

Furthermore, dancing is no less musical an activity than DJing or producing. Because dancing to EDM does not involve predetermined steps, each dancer must shape his or her response to the music as it unfolds, and the rhythms of the dancer's motions add a counterpoint to the patterns of the music itself. Hence Fikentscher's description of EDM dance as "musicking in movement" seems particularly appropriate; as he notes, "musicking in sound and musicking in movement happen simultaneously and in relation to each other" (2000:58). The two forms of musicking unfold via an interactive dynamic between DJ and audience." Butler. Op.cit. (2003). pp. 28 Fikentscher deriva el concepto de "musicar" de Christopher Small. Music of the Common Tongue: Survival and Celebration in Afro-American Music. New York: Riverrun. (1987) y refiere a una forma de conceptualizar la música como una actividad. 
asumirán las interpretaciones o apreciaciones musicales en movimiento. En otras palabras, los creadores no solo escuchan las músicas por ellos creadas sino que realizan lo que podemos llamar un "análisis corporal a futuro": evalúan e intentan predecir las posibles asociaciones que las conformaciones musicales pueden sugerir al momento de crear el "contrapunto" de movimiento al que refiere Butler. Al menos una de las complejidades de las músicas concebidas para ser bailadas reside en esta consideración (que podemos llamar "doble") respecto de las configuraciones que se incorporan a una pieza: para la subjetividad del creador, dichas configuraciones no solo deben ser bellas en términos de escucha sino también en términos corporales y de movimiento y danza. Aquí hallamos entonces otro vínculo entre las músicas de baile históricas y las electrónicas actuales; a la creación de ambas les subyace esta lógica de la "doble belleza".

En otro orden de cosas, en una sucesión de posiciones solidarias ocurre también el siguiente paralelismo: así como el productor "cede espacios" para permitir las posibles expresiones de aquellos deejays que programen sus pistas al interior de sus sets, los deejays y músicos electrónicos "ceden espacios" en sus sets y actos en vivo para que los bailarines puedan desarrollar sus expresiones en movimiento. Aunque presentando diferentes grados de variabilidad según el artista y la situación concreta, en el evento electrónico deejay/músico electrónico y bailarines interactuarán momento a momento, determinando ambos los modos y las direcciones en que un determinado set o acto en vivo evolucionará. En otras palabras y parafraseando a dichos ya citados de Mark Butler: las acciones de cada actor en la EDM son simples, la complejidad emerge de las formas en que se combinan. ${ }^{666}$

Precisamente respecto de la interacción entre deejay y bailarines, a la que nuevamente agregaremos a los músicos electrónicos, este mismo autor dirá que:

\begin{abstract}
Además de sus respuestas creativas individuales, la audiencia como todo puede tener una poderosa influencia en la forma de la música de una velada. Los DJs exitosos están muy en sintonía con el comportamiento de la multitud: como regla general no tocan sets predeterminados, prefiriendo por el contrario conformar su interpretación mientras la velada se desarrolla, para conseguir la máxima respuesta de la gente en la pista [de baile]. ${ }^{667}$
\end{abstract}

Vemos aquí que la "cesión de espacios" del deejay y del músico electrónico se realiza no solo al interior de "su" set o acto en vivo sino que la conformación misma del set o acto en vivo resulta determinada en alguna medida por las reacciones de los bailarines. Como antes, encontramos aquí a un sujeto colectivo antes que al individuo iluminado de otras especies; no

\footnotetext{
666 "When considered individually, the rhythm patterns in EDM loops are simple. Complexity comes from the ways in which they are combined. " Butler, M. (2003). Op.cit. pp. 109

667 "In addition to their individual creative responses, the audience as a whole can have a powerful influence on the shape of an evening's music. Successful DJs are highly attuned to the crowd's behavior: the do not, as a general rule, play predetermined sets, instead preferring to shape their performance as the evening unfolds in order to get a maximal response from the people on the floor." Butler, M. Op. cit. (2003) pp. 28-29
} 
resulta extraño entonces que, en relación a otras especies, en las músicas electrónicas utilizadas para el baile social un mayor número de artistas elijan presentar su producción desde el anonimato y no busque el reconocimiento de su propia persona.

Estas mismas razones impulsan a que al interior de sus sets y actos en vivo los deejays y músicos electrónicos incluyan ciertos grados de improvisación. Apoyados en la flexibilidad que brinda una música organizada alrededor de la carencia de relación causal, de la temporalidad cíclica o suspendida y de numerosas piezas donde la tonalidad cumple un rol defectivo o ninguno en absoluto, los artistas de la electrónica elegirán momento a momento prolongar o reducir la duración de una determinada sección de una pieza en función de las respuestas de "la pista".

Del mismo modo y por las mismas razones, la "audiencia" del (por ejemplo) rock no es tal en la comunidad electrónica: el bailarín no asiste a apreciar la "genialidad" del artista (sea deejay o músico electrónico) sino que se acerca en cambio a disfrutar un momento compartido, donde todos y cada uno juegan un rol activo, consciente y acordado. Si bien lo que sigue debe relativizarse de múltiples formas, en cierta medida es posible describir a la escena electrónica como un espacio más "democrático" y "horizontal" que otras escenas musicales (al menos, esta resulta una pretensión de algunos de sus actores).

Un ejemplo que ilustra con claridad la íntima relación que se establece entre los artistas y los bailarines lo constituye la dinámica que entre estos actores se establece en las paradas. Hemos descripto algunos aspectos de las mismas, confiamos en que ofrecer algunos datos extras respecto de cuestiones técnico-musicales concretas brindará mayor claridad a ciertos otros dichos incluidos en el cuerpo principal de nuestra tesis.

Fragmentos sin sonido de bombo y/o sonidos graves/sub-graves provocan una serie de acciones e interacciones (algunas sincrónicas, otras sucesivas) similares a las que se describen a continuación:

i) Los bailarines asumen una actitud expectante, su baile se torna menos enérgico, sus movimientos menos definidos y más "dubitativos"; su mirada puede incluso dirigirse hacia el deejay. En otras palabras, la ausencia del sonido de bombo o sonidos graves/sub-graves se establece como una clara articulación formal en el fluir musical continuo y se interpreta casi como una detención del discurso musical. ${ }^{668}$

ii) El deejay puede brindar a los bailarines alguna señal visual de que es consciente de la expectativa generada y, sea que la parada esté pre-producida o no, es usual que

\footnotetext{
${ }^{668} \mathrm{Si}$ bien el flujo musical continuo estrictamente no se detiene, estas pausas pueden en algún sentido equipararse a las que en épocas pasadas se sucedían entre pieza y pieza en los locales de baile. En estos momentos es común también ver un incremento en el diálogo entre bailarines. Es cierto también que, en un entorno acústico que no propicia el diálogo, resulta más sencillo este tipo de intercambio en los momentos en que no suena el elemento que mayor energía acústica genera.
} 
desarrolle acciones que construyen auditivamente un incremento o crecimiento paulatino de las densidades vertical y/o cronométrica. En otras palabras, realizará acciones que agreguen elementos a la música.

iii) Este incremento es interpretado por los bailarines como la preparación o anticipo del retorno del sonido de bombo y del flujo musical continuo. Mediante exclamaciones y vítores los bailarines pueden expresar su aprobación por los modos "correctos" en que el deejay realiza tal acción. En términos interpretativos, el incremento suele manifestarse como aumento de la tensión o conflicto musical; cuestiones cuya resolución (al mejor modo tonal) se representan en el retorno del sonido de bombo y demás elementos graves/sub-graves de la textura.

iv) Este retorno es respondido con la euforia de los bailarines; euforia que se manifiesta con un baile más enérgico, exclamaciones, gritos de aprobación, saltos, brazos y manos elevadas ("manos en el aire" en la jerga).

v) Final y paulatinamente, esta euforia se va aplacando para dar paso a un movimiento de baile en nivel energético promedio, la "velocidad crucero" de movimiento que cada evento propone.
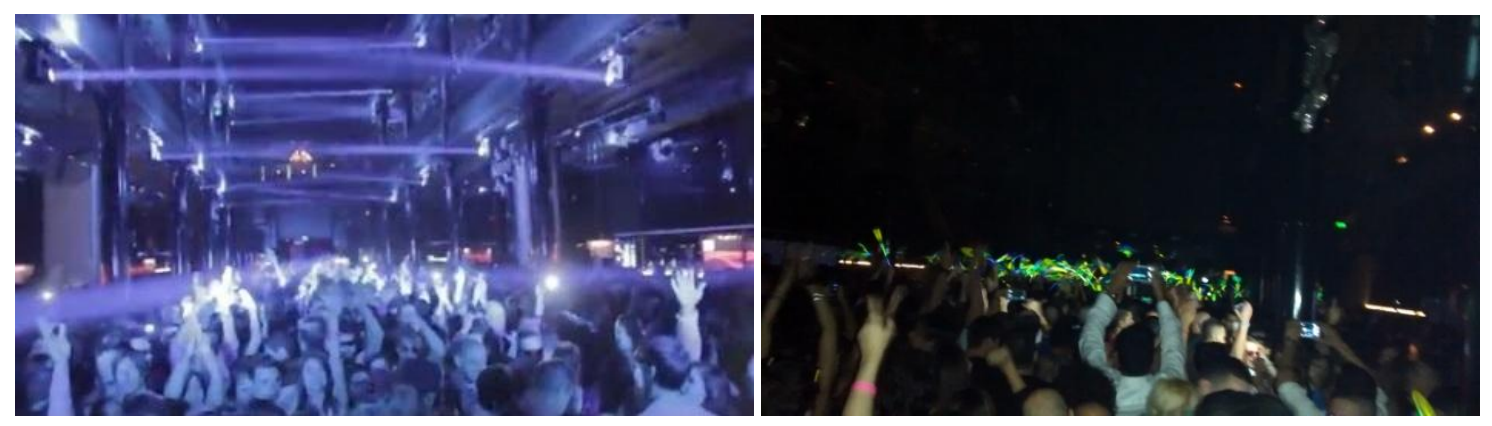

Las "manos en el aire" celebrando al deejay. Imágenes tomadas en la misma oportunidad en que se realizaran las experiencias de campo.

Habiendo finalizado la exposición de los que consideramos datos complementarios necesarios para una mejor comprensión de las cuestiones tratadas en el cuerpo principal, damos por finalizado el presente anexo. 


\section{ANEXO V}

Dispositivos tecnológicos asociados a las músicas electrónicas utilizadas para el baile social

Exceptuando quizá a las bandejas tocadiscos, ${ }^{669}$ los mismos dispositivos musicales de base tecnológica se utilizan hoy tanto en las músicas electrónicas utilizadas para el baile social como en otras especies que hacen uso de tecnología. Si bien en los últimos años algunos dispositivos presentan un -quizá incipiente- mayor grado de especificidad para con la especie, no existen diferencias sustanciales entre los que pueden hallarse en la música (a modo de ejemplo) rock y la electrónica (en sentido amplio). ${ }^{670}$

Por otra parte, en las músicas electrónicas utilizadas para el baile social los mismos dispositivos resultan involucrados tanto en la producción en estudio como en las presentaciones ante el público. Con algunas salvedades, cumpliendo quizá roles algo diferentes, variando el o los dispositivos que resultan el "corazón" de la actividad en una y otra situación y presentando matices según el tipo de artista de que se trate, todo dispositivo utilizado en estudio encuentra su utilidad en las presentaciones de deejay y en los actos en vivo.

Entre los dispositivos comunes a la electrónica y otras especies se encuentran todos aquellos destinados al registro y almacenamiento de "sonido": ${ }^{671}$ micrófonos, todo tipo de cables y conectores, preamplificadores, consolas, placas de sonido, computadoras, sistemas de grabación y almacenamiento, monitores y sistemas de amplificación, procesadores (compresores, compuertas de ruido, ecualizadores, filtros y otros) y efectos (flanger, chorus, delay, unidades de reverberación y otros).

Aquellos que resultan en algún sentido más específicos de la especie electrónica son: bandejas tocadiscos, sintetizadores, samplers, cajas de ritmos, secuenciadores y múltiples dispositivos de control. Además, completan esta lista una multiplicidad de fuentes de sonido no convencionales entre las cuales podemos incluir: a) aquellas donde el objetivo principal subyacente a su creación no fuera el de crear sonidos "musicales" y b) las invenciones de los mismos artistas -devenidos en diseñadores de fuentes sonoras- que mencionáramos en el Anexo IV. Respecto de este último punto creemos necesario agregar un dato anecdótico que, sin embargo, ilustra la amplitud estética de la especie: en algunas ramas dentro de las músicas electrónicas, estas fuentes no convencionales pueden ser las únicas utilizadas durante la totalidad de una presentación.

Siendo un campo demasiado vasto y en constante actualización veremos aquí solo a los dispositivos convencionales del último grupo. Estos suelen constituirse en el centro o "corazón" de la mayoría de los sistemas de producción de piezas de la especie y, consecuentemente, son

\footnotetext{
${ }^{669}$ Excepción que además presenta múltiples casos que la contradicen.

${ }^{670}$ Como explicáramos en el Anexo IV, la mayor diferencia reside en las formas de uso.

${ }^{671}$ Las comillas en "sonido" se deben a que lo que resulta almacenado no será específicamente sonido sino a) cambios análogos a la energía acústica, pero en otra energía (i.e.: energía magnética por ejemplo, en los sistemas analógicos de grabación en cinta) o b) la información necesaria para reconstruir dichos cambios en la energía acústica (i.e.: información en formato digital en los dispositivos cuya base es tal).
} 
los que mayor incidencia tienen sobre la cualidad sonora final. Por su uso prolífico en la especie veremos también algunos casos particulares de los dispositivos incluidos en el primer grupo. Por sus cualidades y usos asignados diferenciados, analizaremos a las bandejas tocadiscos por separado. Para comprender concretamente en qué consiste cada uno de estos dispositivos intentaremos primero una categorización que permita apreciar el marco mayor en el que se inscriben.

\section{Categorización de los dispositivos tecnológicos musicales}

Numerosas empresas producen y han producido, en diferentes escalas y volúmenes, numerosos y muy diversos instrumentos electrónicos. Impulsando con sus innovaciones el desarrollo tecnológico tanto histórico como actual y estableciendo un mercado donde compiten múltiples marcas y modelos, han creado un universo de dispositivos con una gran diversidad de ofertas. ${ }^{672}$ En términos generales sin embargo, a partir de considerar las características y prestaciones comúnmente ofrecidas por los mismos, esta diversidad se reduce a unas pocas categorías.

A grandes rasgos, cada tipo o clase de dispositivo se configura alrededor de un conjunto de funciones diferenciadas que, hasta cierto punto, permiten caracterizarlo y distinguirlo de aquellos otros que incorporan un conjunto de funciones diferentes. Dicho de otro modo, qué funciones concretas ofrece un determinado dispositivo determinará la clase o tipo a la que este pertenece, a la que se lo puede asociar.

Por otra parte, múltiples funciones resultan compartidas entre diferentes tipos de dispositivos, por lo que la diferenciación entre unos y otros resultará en muchos casos parcial y derivada de aquellas (funciones) que entre unos y otros resultar divergentes. En otras palabras, no debe confundir a las funciones con los instrumentos en sí; si bien en algunos casos pueden identificarse mutuamente, unas y otros no son lo mismo. ${ }^{673}$

\footnotetext{
${ }^{672}$ Valga decir también que no solo la innovación ha impulsado el surgimiento de nuevos dispositivos, y que incluso resulta a veces dificultoso caracterizar a algunos con el término "nuevos". Jugando un rol para nada despreciable, los intereses económicos y el mercado de consumo acelerado han propiciado muchas veces el desarrollo de dispositivos para los que poca justificación puede hallarse salvo la de conseguir ganancias monetarias para los accionistas de la empresa que los fabrican. Una excelente fuente de información respecto de dispositivos modernos y "clásicos" resulta el sitio Vintage Synth Explorer: base de datos en línea de toda clase de dispositivos musicales de base tecnológica, describe prestaciones e incluye fotos, videos y audios de cada uno (como en otras ocasiones, lamentablemente también en ingles). Accesible en http://www.vintagesynth.com/ [03112016]

${ }^{673}$ Un ejemplo claro resulta el siguiente. Múltiples dispositivos "secuenciadores" cumplen con una única función que consiste en el control de otros dispositivos. Al mismo tiempo, son también numerosos los sintetizadores y samplers que incorporan (i.e.: como una prestación, como otra posibilidad de control de sus propios parámetros) la función de secuenciador. En el primer caso la función única se asocia con el dispositivo mismo al cual brinda su nombre; en el segundo, se incluye al "interior" de dispositivos que para agregar claridad- presentan como función principal la de generar sonido (i.e.: muchos sintetizadores no incluyen prestaciones de secuenciación por lo que esta podría considerarse una característica en algún sentido secundaria). En el video en línea TT 303 Programming puede verse la programación de un secuenciador por pasos incluido como función (del clon de la compañía cyclone del sintetizador Roland $T B$-303) mientras que en KORG SQ1 Y VOLCA BASS puede apreciarse cómo el secuenciador Korg SQ1
} 
Considerándola la perspectiva más apropiada, intentaremos entonces una categorización de los dispositivos a partir de las múltiples funciones que incorporan. El tipo de tecnología utilizada y (lo que llamamos) el "tipo de soporte" serán otras dos dimensiones de análisis que agregarán algunos datos respecto de las cualidades y posibilidades que los diferentes dispositivos presentan y ofrecen.

A partir de nuestro conocimiento en la materia creemos oportuna una advertencia: en lo que sigue, sugerimos avanzar en la lectura aún si no se comprende cabalmente en qué consiste cada categoría; estas resultarán sencillas cuando las apliquemos para caracterizar a dispositivos concretos.

Función desempeñada

Diversos dispositivos incorporan funciones de generación, reproducción, modificación/procesamiento y de control de sonido. A estas funciones debe sumarse también la de control de otros dispositivos. Siendo quizá la dimensión más compleja y diversa, en algunos dispositivos resulta difuso el límite entre una función y otra.

Tecnología utilizada

Podemos segmentar a los dispositivos entre aquellos que basan su funcionamiento en tecnología analógica o digital. Cabe mencionar que en algunos casos se combinan ambas en dispositivos híbridos.

Tipo de soporte

Distinción surgida a partir de las tecnologías de la información, en esta categorización hallamos dos valores: dispositivos físicos y virtuales. Como en el caso previo resulta necesaria una salvedad: numerosos dispositivos recientes integran ambos soportes y complementan las prestaciones ofrecidas en uno con las incorporadas en el otro en instrumentos mixtos.

Expuestos los criterios, pasemos a la descripción de los dispositivos concretos.

\section{Sintetizadores}

Estos dispositivos son en primer término generadores de sonido. Consistentes todos en una serie de módulos con finalidades específicas y diferenciadas (vendidos por separado o integrados en un único cuerpo indivisible), presentan en sus paneles frontales múltiples formas de control y (en algunos casos) modificación de las propiedades que el sonido sintetizado 
asumirá. En su origen dispositivos analógicos físicos, hoy el mercado ofrece un gran número de unidades tanto analógicas, digitales e híbridas como físicas, virtuales y mixtas.

Aquellos que utilizan tecnología analógica generan sonido a partir de la aplicación de una determinada carga eléctrica a uno o varios componentes electrónicos denominados "osciladores", los cuales, a su vez, inducirán una oscilación en una corriente eléctrica. Esta oscilación será la forma de onda eléctrica que, en último término (al final de la "cadena de audio") será transducida (i.e.: convertida) en energía acústica por el movimiento de los parlantes. Los sintetizadores digitales por su parte, generan esta oscilación a partir de cálculos originados en algoritmos matemáticos y/o a partir de una o varias formas de onda digitalizadas (i.e.: samples) ${ }^{674}$ Los fabricantes han hallado numerosas y diversas formas de combinar ambas tecnologías; entre otras posibilidades encontramos sintetizadores donde:

a) el control es digital y la generación de sonido completamente analógica,

b) algunos osciladores son analógicos y otros digitales, y/o

c) los osciladores son analógicos y ciertos modificadores o efectos resultan de la aplicación de tecnología digital.

Los sintetizadores analógicos, por las características de dicha tecnología, son necesariamente físicos (i.e.: dispositivos corpóreos o "hardware"). Consecuentemente y por implicar esta misma tecnología, también serán físicos los sintetizadores analógico-digitales (o al menos aquellos módulos, de entre los que compongan un determinado sintetizador, que se basen en tecnología analógica). Los sintetizadores digitales por su parte, pueden encontrarse tanto en formato físico como virtual (i.e.: en el segundo formato pueden consistir en programas independientes o que funcionan al interior de otros programas anfitriones). ${ }^{675}$

Por otra parte, el advenimiento en 1984 del protocolo estandarizado de comunicación MIDI (sigla de la expresión inglesa "Musical Instrument Digital Interface" o "Interfase Digital para Instrumentos Musicales") permitiría la comunicación entre múltiples dispositivos tecnológicos musicales; entre otras capacidades, dicho protocolo permitiría el surgimiento de

\footnotetext{
${ }^{674}$ Como podrá comprenderse, los últimos sintetizadores difuminan las fronteras existentes entre estos dispositivos y los samplers. Sin embargo, es usual que los primeros ofrezcan ciertas formas de onda preconfiguradas (i.e.: "de fábrica") y no permitan grabar nuevos sonidos. Siendo la característica principal de los samplers ofrecer la capacidad de grabar y reproducir sonidos, esta limitación permite diferenciar a unos y otros dispositivos.

${ }^{675}$ Hasta hace algunos pocos años -y gracias al impulso dado por el incremento en la potencia de procesamiento que experimentaron las computadoras- el número de sintetizadores virtuales creció exponencialmente, lo que generó una gran influencia sobre las formas de producción y sobre el sonido general de las músicas electrónicas utilizadas para el baile social. Actualmente y gracias a ciertos avances tecnológicos, la industria se encuentra atravesando un "renacimiento" de los dispositivos analógicos y físicos. Creemos posible afirmar que los avances tecnológicos mencionados han sido un factor central en el establecimiento (en las músicas electrónicas) de etapas o períodos diferenciados donde, al contraponerse, ciertas características estéticas presentan cualidades divergentes.
} 
múltiples dispositivos entre los que se cuentan numerosos sintetizadores físicos-virtuales actuales. Algunas configuraciones híbridas posibles (y hallables) son las siguientes:

a) sintetizadores físicos que incluyen y se comunican con programas de computadora que replican sus paneles frontales. Mediante esta integración:

i) facilitan la edición de nuevos sonidos,

ii) permiten el almacenamiento de sus programas en la memoria de la computadora (i.e.: el conjunto de configuraciones que determinan como sonará un determinado sonido) y/o

iii) permiten la integración del dispositivo en programas de creación musical y la automatización de los movimientos de sus controles en dicho software. ${ }^{676}$

b) sintetizadores virtuales (programas basados en computadoras) que se ofrecen con dispositivos controladores físicos dedicados (i.e.: especialmente construidos y diseñados para controlar al dispositivo virtual con el cual se complementan).

c) dispositivos físicos que operan como anfitriones de sintetizadores virtuales. Quizá los dispositivos más recientes y sin lugar a dudas los menos numerosos, se los denomina "plug-outs" por invertir lo que en contextos informáticos se conoce como "plug-ins": dispositivos virtuales (los últimos) diseñados para operar al interior de programas anfitriones basados en computadoras, pueden utilizarse de forma similar en estos dispositivos físicos (i.e.: sin la necesidad de una computadora). ${ }^{677}$

Los sintetizadores ofrecen para el control de sus parámetros numerosas perillas, deslizadores, ruedas, cintas sensitivas, teclado de tipo piano, secuenciadores, superficies táctiles $\mathrm{y} / \mathrm{u}$ otras interfases que permiten al intérprete-operador modificar momento a momento las cualidades que asume el sonido sintetizado. Como regla general, es posible afirmar que cuantos

\footnotetext{
${ }^{676}$ Se utiliza el término "automatizar" para referir a la capacidad que la tecnología digital ofrece de registrar los movimientos de las perillas y demás controles de los dispositivos. Una vez registrados dichos movimientos en un programa de grabación y edición musical que lo permita, no será necesario repetirlos ya que cada vez que se reproduzca la pieza donde se los registró el mismo programa de grabación se ocupará de replicar los efectos (sobre el sonido) que dichos movimientos generaron en primer término. En otras palabras y para evitar confusiones, no se almacenan los cambios en el sonido sino que se registra la información del movimiento de los controles.

${ }^{677}$ Los dos últimos casos no se limitan a sintetizadores, solo los presentamos aquí por tratarse de la primera ocurrencia de los formatos. Por una parte y a modo de ejemplo, existen samplers híbridos asimilables a los sistemas descriptos en el apartado $b$; por otra, en los sistemas físicos del apartado $c$ suele ser posible "cargar" todo tipo de dispositivos musicales virtuales que se ofrezcan en formato plugin. Valga decir que estos dispositivos físicos anfitriones no son llamados "computadoras" solo por presentar una forma orientada a un uso específico; en otras palabras, a pesar de su aspecto diferenciado, al interior contiene componentes electrónicos que presenta mucho en común y pueden equipararse (al menos parcialmente) con una computadora. De aquí deriva que puedan almacenar y ejecutar programas creados para computadoras.
} 
más controles presente un sintetizador en sus paneles frontales, mayor será la paleta de sonidos posibles que dicho dispositivo será capaz de generar.

Un caso especial lo constituyen los sintetizadores "modulares": este formato (el primero que asumieran los sintetizadores en la historia) incrementa enormemente los grados de libertad al ofrecer, además, la posibilidad de determinar concretamente cuales módulos atravesará la señal de audio, como así también en qué orden los recorrerá. Por diversos métodos, el operador selecciona los módulos que desea utilizar y los interconecta en el orden que prefiera; en cierto sentido "recreando" al sintetizador con cada conexión.

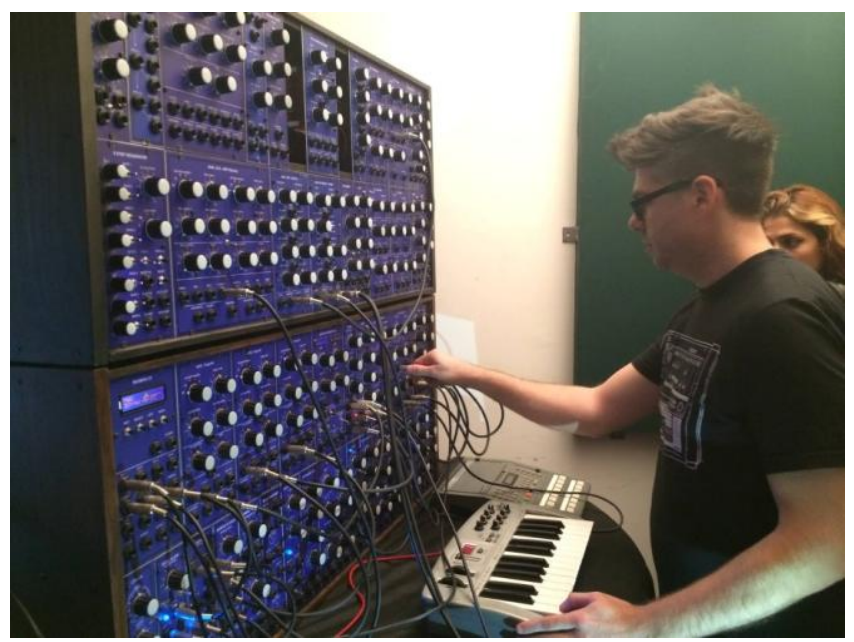

Sebastián Cordoves frente al sintetizador modular de su creación Su sonido puede apreciarse en su proyecto "Cosaquitos en globo". ${ }^{678}$

\section{Samplers}

Los samplers constituyen la otra forma principal de generación sonora. A diferencia de los sintetizadores, los sonidos de estos dispositivos no se producen a partir de osciladores o fórmulas matemáticas sino que consisten en sonidos originalmente emitidos por otras fuentes, registrados por algún medio y reproducidos. Consistiendo en una extensión de los dispositivos de grabación y reproducción sonora (i.e.: similares a los conocidos grabadores de cinta, de disco y demás), mediante diferentes métodos de edición -parcialmente compartidos con los utilizados en sintetizadores- los samplers son capaces de crear múltiples variaciones y desarrollos a partir de una o varias "muestras" o "capturas" de sonido. A excepción de uno o dos antecesores primitivos, estos dispositivos son todos digitales, hallándose modelos tanto físicos como virtuales y mixtos.

De entre las múltiples aplicaciones que en las músicas electrónicas utilizadas para el baile social se realizan de estos dispositivos, quizá la que más se destaca sea la de las llamadas "vocales": samples de voces humanas cantadas o habladas que, por incluir contenido literario, resaltan en las texturas. Como sucede con la voz del cantante en otras especies y en el formato

\footnotetext{
${ }^{678}$ Fuente: http://4tocircuito.blogspot.com.ar/ [03112016]
} 
canción, en las músicas electrónicas utilizadas para el baile social suele suceder que elementos y/o estratos texturales de este tipo devienen en la "figura" destacada o más pregnante. La particularidad en la especie consiste en que, en numerosas oportunidades (quizá en la mayoría), los samples incluidos resultan fragmentarios y reiterados, lo que deriva en que la configuración resultante puede ser descripta como una proto-o (pseudo-)melodía. Aún así, las propiedades del estrato logran imponerse sobre los demás y, en diversos contextos, atraen la atención. En su cualidad fragmentaria y "artificiosa" se vuelve quizá más evidente el carácter electrónico de los samples.

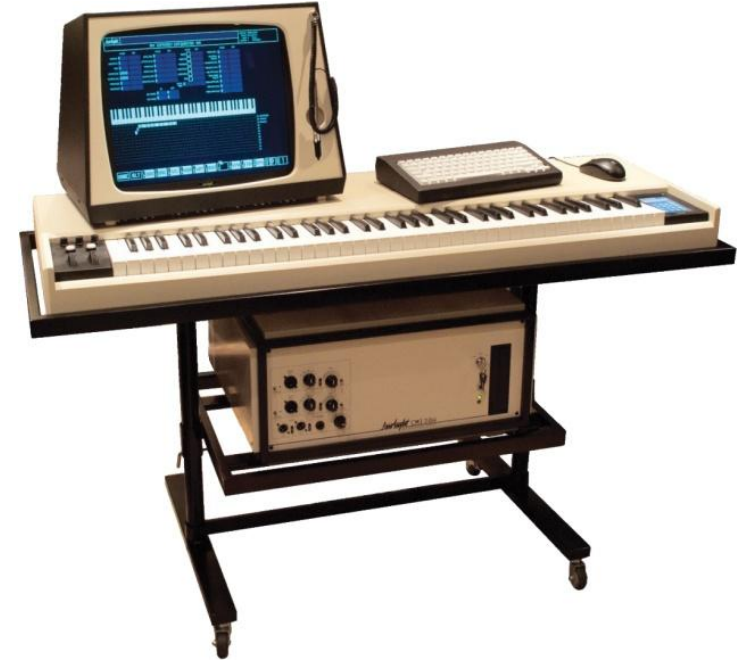

Fairlight CMI. (1979) considerado el primer sampler de la historia. ${ }^{679}$

Un formato de samplers especialmente relevante para la especie (y consecuentemente, también de samples) lo constituyen los llamados "samplers de ritmos": uno de los tipos de máquinas de ritmos, lo veremos en breve cuando describamos dichos dispositivos.

\section{Secuenciadores}

Por su rol histórico y actual, los secuenciadores han adquirido un status de dispositivo independiente que excede en múltiples situaciones a la mera función de control de otros dispositivos en que se inscriben. Dispositivos originalmente analógicos físicos, limitarnos a decir que en la actualidad se ofrecen unidades digitales y virtuales resulta injusto para con estos dispositivos ya que -al menos hasta cierto punto- su función se configura como el corazón mismo de los modernos programas de producción musical basados en computadoras. Si bien estos exceden en mucho las capacidades de aquellos, tanto el origen como el principio de organización de las modernas estaciones de sonido digital (o "DAW"s: "Digital Audio Workstation") como Ableton Live, Cubase, Pro Tools y varios otros, reside en los modestos pero poderosos secuenciadores por pasos.

${ }^{679}$ Fuente: http://www.musictech.net/2014/05/studio-icons-fairlight-cmi/ [03112016] 
Los secuenciadores no generan sonido alguno sino que se utilizan para generar y almacenar la información necesaria que permita controlar a aquellos dispositivos (como sintetizadores o samplers) que sí lo hacen. Fabricados a partir de circuitos analógicos relativamente simples, los originales secuenciadores por pasos permitían y permiten el control de múltiples parámetros simultáneamente, siendo lo más usual encontrarlos controlando ritmos, alturas y sonoridad (como ataques acentuados y con sonoridad "normal").

En su capacidad de control (uno de los tipos de automatización posible) los artistas electrónicos encuentran la virtud de que libera sus manos, disponibles así para manipular otros de entre los numerosos controles que sintetizadores y samplers ofrecen. Su funcionamiento se basa en la programación de una serie limitada (en cantidad de eventos) de puntos de ataque, que pueden ocurrir en uno de los tantos "casilleros" sucesivos de duración isócrona ofrecidos. Usualmente múltiplos de 8 pasos, el rango osciló/oscila entre 8 y 64, con una amplia mayoría no excediendo los 16.

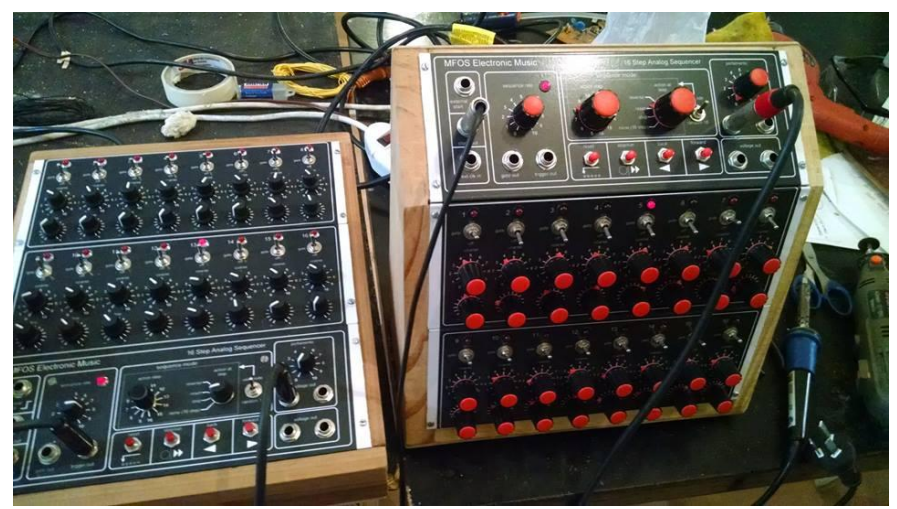

Dos secuenciadores de 16 pasos basados en un diseño de MOFS. Obra de Manuel Osorio, responsable de Tercer Brazo Estudio - Taller. ${ }^{680}$

Esta limitación sería definitoria para la forma estética que adquirirían las modernas músicas electrónicas utilizadas para el baile social y, como viéramos durante nuestro análisis audiotáctil de la sonoridad, sería un factor de gran influencia para el establecimiento de las oscilaciones/alternancias de intensidad tanto a nivel de la (sub-)división/pulso como a nivel de (semi-)frase. La disponibilidad limitada de puntos de ataque reforzaría un marco de referencia ya presente en las sociedades con influencia de la cultura occidental-europea, favoreciendo simultáneamente la repetición en dos niveles y de dos formas diferentes.

Tendencia ya presente en los músicos con la formación mencionada, la repetición sería estimulada a partir de que estos dispositivos establecen -en primer término- una pulsación isócrona (i.e.: repetición de la duración, repetición del período) como base de los ritmos

\footnotetext{
${ }^{680}$ Nótese, en uno y otro secuenciador la diferente distribución de los mismos módulos. Diferencias que probablemente se basen en la comodidad que una y otra presenta para el usuario concreto que solicitara el dispositivo, este factor no modifica en nada sus características de funcionamiento interno. Fuente: https://www.facebook.com/pg/TercerBrazoEstudioTaller/photos/?ref=page_internal. [03112016]
} 
posibles. En segundo término, un segundo nivel de repetición derivaría de otra de las lógicas de funcionamiento de estos dispositivos: finalizada por completo la ejecución de la llamada "secuencia de pasos" (configurada por el operador, e independientemente de la cantidad de "pasos" que la componga) la misma se reiterará, estableciendo una periodicidad igual a un múltiplo de la unidad determinada por y en cada "paso".

En otro orden de cosas, es muy sencillo asociar los $8 / 16$ puntos de ataque disponibles con los 8/16 valores de (sub-)división de un compás de 4/4. Dada esta igualdad, en el marco cultural mencionado sería casi inevitable que emergieran ritmos presentando relaciones estrechas con las demás unidades métricas (i.e.: pulso y acentos métricos).

Estas y otras características de fabricación -creemos- resultaron en factores que interactuaron e influyeron en que las longitudes iguales a dichas unidades métricas resulten las que más veces pueden hallarse en las secuencias y bucles ("loops") de las músicas electrónicas utilizadas para el baile social. Ya sean estas realizadas por sintetizadores, sonidos de bajos o secciones rítmicas, su período más usual suele encontrarse dentro de estos límites. ${ }^{681}$
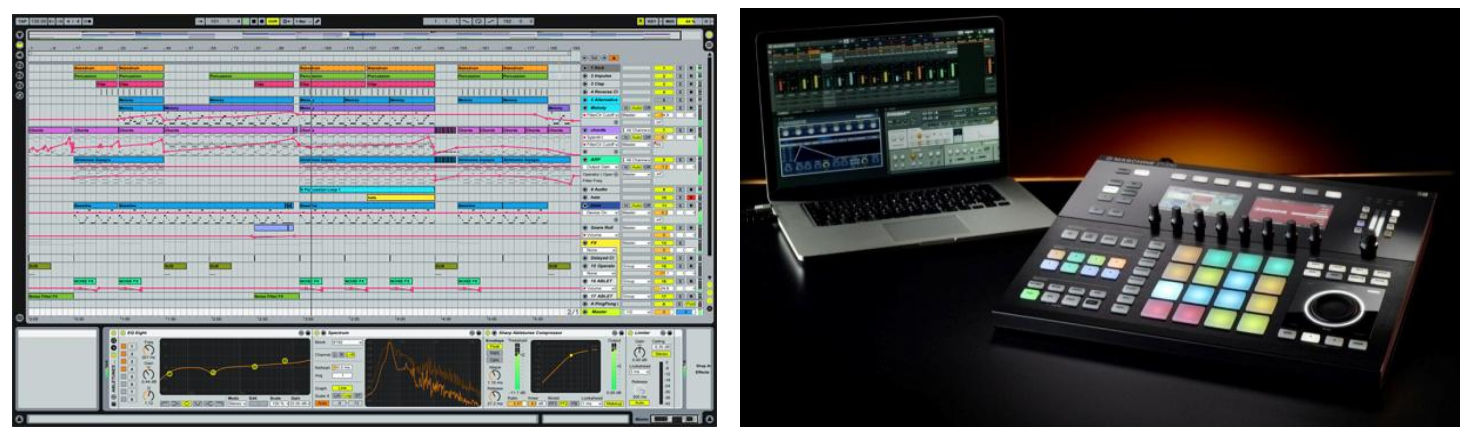

Una de las pantallas principales de Ableton Live (izq.) y el sistema Maschine de Native Instruments (der.). Complejos sistemas que en su raíz mantienen las lógicas de funcionamiento de los primitivos secuenciadores por pasos, el segundo también resulta un sampler de ritmos físico-virtual. ${ }^{682}$

\section{Cajas de ritmos}

También conocidas como "máquinas de ritmos", no son más que sintetizadores o samplers especializados en la generación de sonidos de cualidades asociables a instrumentos de percusión. Para describirlos con más precisión, para que un sintetizador o sampler de percusión pueda ser considerado una caja o máquina de ritmos debe incluir algún tipo de función que permita programar secuencias con los sonidos que el dispositivo es capaz de generar.

Como para los sintetizadores, aquellas cajas de ritmos basadas en síntesis sonora pueden ser analógicas, digitales o híbridas (las últimas ofreciendo algunos sonidos-instrumentos analógicos y otros digitales, usualmente samples), mientras que máquinas de ritmos basadas en samples son posibles, como antes, solo en formato digital. Unas y otras, en sus versiones

\footnotetext{
${ }^{681}$ Nótese también el vínculo que puede establecerse con las "articulaciones formales" descriptas en el título Cualidades de los índices "mayores" de la música electrónica de baile de nuestro Anexo IV.

682 Fuentes : http://abletunes.com/product/progressive-house/sirius/ y http://www.zzounds.com/item-NATMASHSTU. [07112016]
} 
digitales o híbridas, pueden hallarse en formato físico, virtual o mixto. Sin embargo, la razón de ser y practicidad de estos dispositivos se encuentra hasta cierto punto asociada a las funcionalidades de interacción que solo las versiones físicas pueden ofrecer; por esta razón, las versiones virtuales (que las hay) resultan menos comunes que para otros dispositivos y que aquellas que se comercializan asociadas con algún tipo de controlador físico. ${ }^{683}$

Además de diversas capacidades de secuenciación, algunas unidades físicas o mixtas incluyen matrices de almohadillas (i.e.: "pads") sobre las que resulta posible percutir con los dedos o baquetas. Sensibles a la intensidad del impacto, cada una suele "disparar" (i.e.: enviar al sintetizador o sampler la instrucción de hacer sonar) un sonido-instrumento determinado, permitiendo una interpretación similar a la que se realizaría sobre una serie de instrumentos de percusión acústicos.

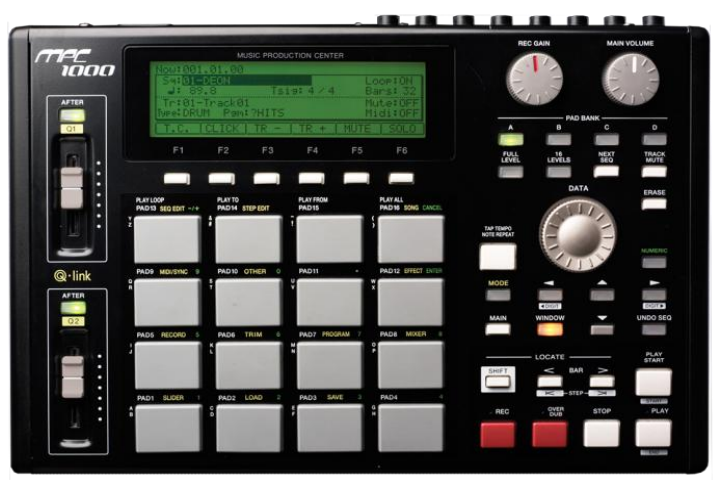

AKAI MPC 1000. Sampler de percusión con secuenciador. Uno de los tantos modelos de la serie $M P C$, fueron definitorios para la estética de los índices basados en samples de breakbeats. En color gris, la matriz de 16 pads sensitivos. ${ }^{684}$

Por el origen mismo de los sonidos y por sus capacidades de edición, las cajas de ritmos basadas en samples son capaces de transformar casi cualquier tipo de sonido en uno factible de ser utilizado para producir ritmo e integrar una sección rítmica. Esta capacidad ha sido aprovechada al extremo en el rap (primero) y en el jungle/drum'n'bass/breakbeats (luego). Aquellas que basan su funcionamiento en la síntesis en cambio, ven limitada su variedad a la que sus componentes, circuitos y/o algoritmos les permiten. Aún así, han sido y son muy buscadas (especialmente las analógicas) por una cierta "calidez" y cualidad "orgánica" con que se identifica a sus sonidos.

Un factor que gravita fuertemente sobre esta preferencia es el hecho de que dispositivos de esta clase se utilizaron en el período fundacional de la música electrónica de baile y, por lo tanto, sus propiedades tímbricas y de funcionamiento tiñen en gran medida a un gran número de

\footnotetext{
${ }^{683}$ Afirmación solo parcialmente cierta: múltiples emulaciones virtuales de máquinas de ritmos "clásicas" proliferaron y proliferan debido a los altos costos y al difícil acceso a los dispositivos originales. La cotización de estos clones es muy buena en el mercado de dispositivos software.

${ }^{684}$ Fuente: sitio oficial de la empresa AKAI. Accesible en http://www.akaipro.com/product/mpc1000. [05112016]
} 
ejemplos de la "vieja escuela" (i.e.: "old school"). Aún cuando no dispusimos del espacio suficiente como para tratar esta cuestión, las cualidades mencionadas resultan para algunos índices un relevante factor de distinción mutua. Sin lugar a dudas, las cajas de ritmos Roland TR-909 y TR-808 (y quizá también la E-Mu Systems Emulator) son las que más han influido e influyen sobre la calidad tímbrica de las secciones rítmicas de, al menos, los índices basados en el patrón de bombo en negras. ${ }^{685}$
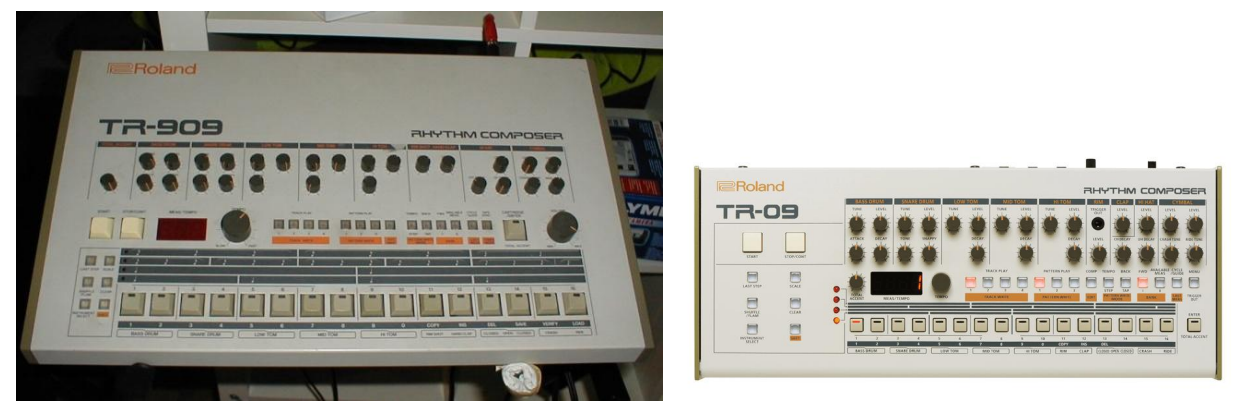

La clásica Roland TR-909 (1984) y su reciente reedición digital física (2016) TR-09. ${ }^{686}$

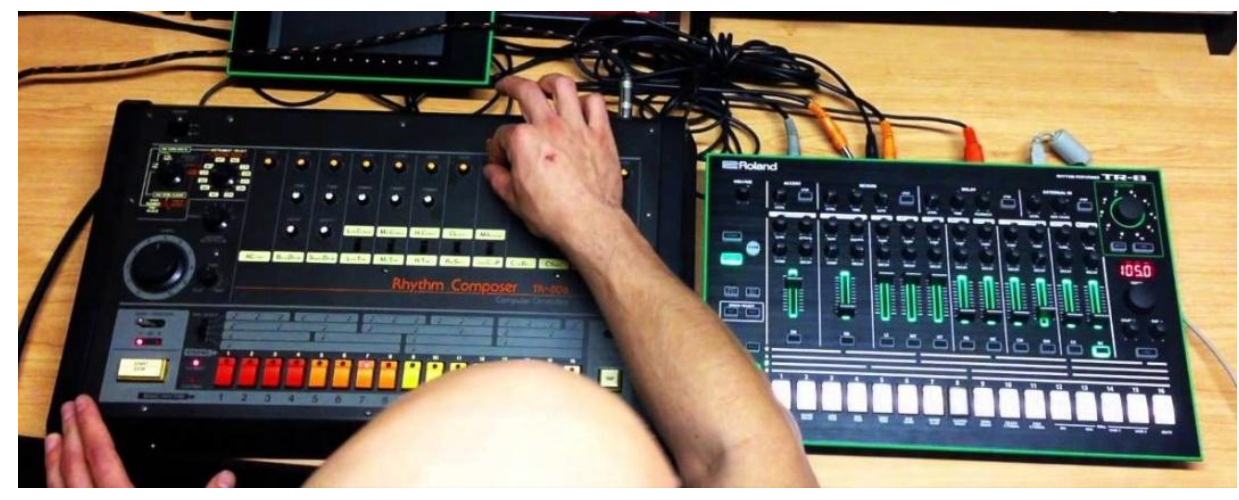

La legendaria Roland TR-808 (1980) y la moderna (basada en samples) $T R-8 .{ }^{67}$

Los sonidos-instrumentos que suelen incluirse en las cajas de ritmos basadas en síntesis suelen seguir en mayor o menor medida el modelo establecido por estos dos dispositivos. Estos son, sonidos de bombo ("bass drum"), redoblante ("snare drum"), toms/congas (idem; usualmente dos o tres afinaciones en un mismo dispositivo, cuando presentan ambos permiten alternar entre uno y otro timbre), rim shot (idem; sonido que imita un golpe en el aro del

${ }^{685}$ La calidad sonora general de uno y otro modelo puede apreciarse en el video en línea "Sorry, I don't have an AIRA" - Early '90s Techno with SH-101, TR-909, TB-303, TR-808. Subido por SynthMania. Accesible en https://youtu.be/FirM3sy5YvY. [05112016] Como reza el título, allí pueden apreciarse sonidos de los también clásicos sintetizadores Roland $S H-101$ y TB-303 (dispositivos, ambos, que ejercieran una gran influencia sobre el sonido de la música electrónica de baile).

686 Fuentes (de las imágenes): https://upload.wikimedia.org/wikipedia/commons/9/99/Tr-909.jpg y http://i1.wp.com/www.synthtopia.com/wp-content/uploads/2016/09/roland-tr-09-drummachine.png?fit $=895 \% 2 \mathrm{C} 404$. [05112016]

${ }_{687}$ Incluyendo samples de la $T R-808, T R-909$ y con espacio para ampliaciones, la $T R-8$ (2014) se promocionó como posible sustituto de ambos dispositivos. Sin embargo, precisamente por basarse en samples no tuvo una acogida demasiado benévola por parte de los productores y resultó en menos ventas de las esperadas. Fuente (de la imagen): https://i.ytimg.com/vi/pkWWKvIrBhM/maxresdefault.jpg. [05112016] 
redoblante), palmas/maracas ("hand clap/maracas", algunos modelos permiten alternar entre uno y otro sonido), hi-hat (también conocido como platillo "charleston", usualmente ofrecen dos decaimientos diferenciados para permitir el efecto de hi-hat abierto y cerrado), platillo suspendido ("cymbal"; una o dos opciones, conformaciones espectrales similares a los platillos "crash" y "ride"), cencerro ("cow bell") y shaker (ruido de banda estrecha similar a las maracas, en el entorno local se utiliza el mismo término inglés).

Debemos aquí hacer una advertencia: como puede apreciarse en los ejemplos en video ofrecidos, a pesar de que:

a) los nombres remiten a instrumentos o cuerpos de percusión acústicos,

b) cada sonido-instrumento es capaz de cumplir la función de dichos instrumentos y cuerpos acústicos y

c) la conformación espectral de cada sonido-instrumento remiten, en cierta medida, al instrumento o cuerpo referido por su denominación...

...los timbres de cada sonido-instrumento no se asemejan a los instrumentos y cuerpos respectivos y presentan sin lugar a dudas una cualidad sintética.

Sugerimos la lectura de la nota recientemente publicada de Scott Wilson en la revista en línea FactMag: titulada "The 14 drum machines that shaped modern music" ("Las 14 máquinas de ritmos que dieron forma a la música moderna") constituye un excelente resumen de la evolución histórica de las máquinas de ritmos. ${ }^{68}$

\section{Dispositivos de control}

Los dispositivos de control se desarrollaron principalmente con el advenimiento de la informática. A medida que las computadoras personales adquirieron la suficiente potencia de procesamiento como para hacer posible a) la administración de información MIDI originada y dirigida a los dispositivos físicos y b) la grabación, procesamiento y reproducción de audio digital, se volvió evidente la practicidad de contar con dispositivos físicos que permitieran controlar tanto a las versiones virtuales de consolas de mezcla, sintetizadores, samplers, cajas de ritmos, efectos y demás dispositivos contenidos al interior de programas anfitriones, ${ }^{689}$ como a las propias funciones de los programas anfitriones. Los operadores de estudios "tradicionales"

\footnotetext{
${ }^{688}$ Wilson, S. (2016) "The 14 drum machines that shaped modern music" en FactMag. Accesible en http://www.factmag.com/2016/09/22/the-14-drum-machines-that-shaped-modern-music/. [07112016]

689 A dichos dispositivos virtuales (programas) se los denomina "plug-ins" por estar "enchufados" virtualmente al programa anfitrión. Así como un sintetizador físico se enchufa a una consola física para mezclar su sonido con otras fuentes y enviarlo a los parlantes, así un sintetizador virtual (o "plug-in") se enchufa virtualmente a una consola virtual para realizar finalmente la misma función (a través de las capacidades multimediales de la computadora). Las estaciones de sonido digital Ableton Live, Pro Tools, Nuendo o Samplitude, entre muchos otros, son programas que operan como anfitriones de múltiples otros programas plug-ins.
} 
(en otras palabras, físicos), acostumbrados a mover simultáneamente múltiples perillas, deslizadores, presionar botones y demás controles, se encontraron repentinamente limitados a mover con el (torpe y único) mouse un único control por vez; esto abriría el camino para un mercado de dispositivos cuya función consiste en ser el equivalente físico de controles virtuales contenidos en los diversos programas mencionados (y "sólo" visibles en las pantallas de las computadoras).
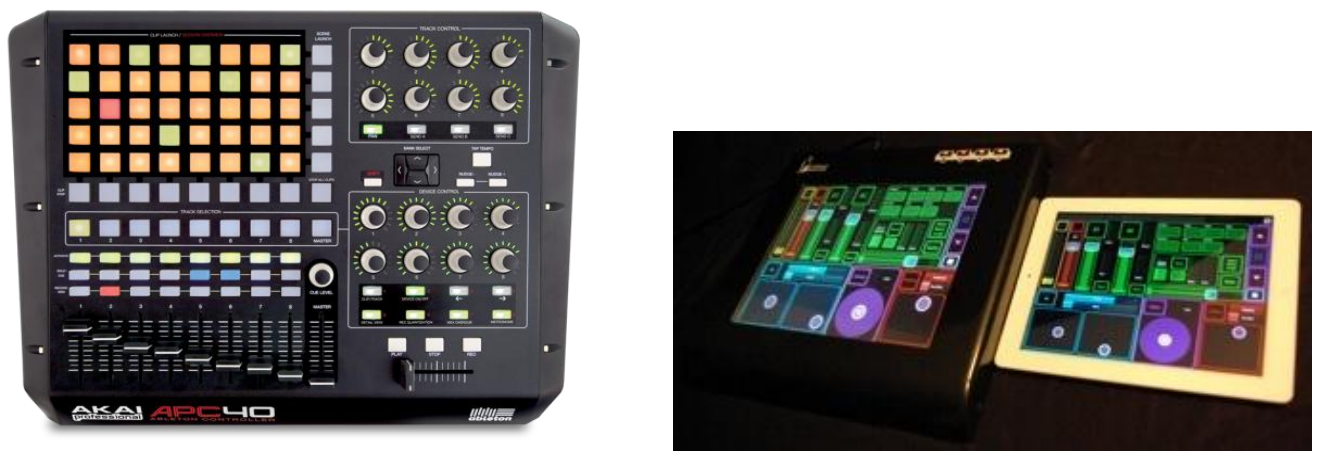

AKAI APC40 (izq.). Dispositivo físico especialmente diseñado para controlar al programa Ableton Live. JazzMutant Lemur y su versión software para Ipad (der.). Dispositivo de pantalla táctil genérico, con capacidad de control sobre diversos programas de computadora. ${ }^{690}$

Dispositivos digitales, constituyen hoy un mercado en constante y vertiginoso desarrollo que continuamente propone nuevas formas de interacción con los parámetros del sonido. Por esta razón aún no se han generado estandares ni se han establecido formatos "clásicos". Entre muchos otros dispositivos diversos hay algunos que, por el tipo de controles que ofrecen, resultan semejantes a consolas de mezcla; hay también pantallas táctiles, sensores infrarrojos de proximidad, guantes sensitivos a las posiciones de las articulaciones y sistemas que, basados en las cámaras Microsoft kinect, determinan el resultado sonoro a partir de capturar el movimiento de un cuerpo en un espacio determinado.
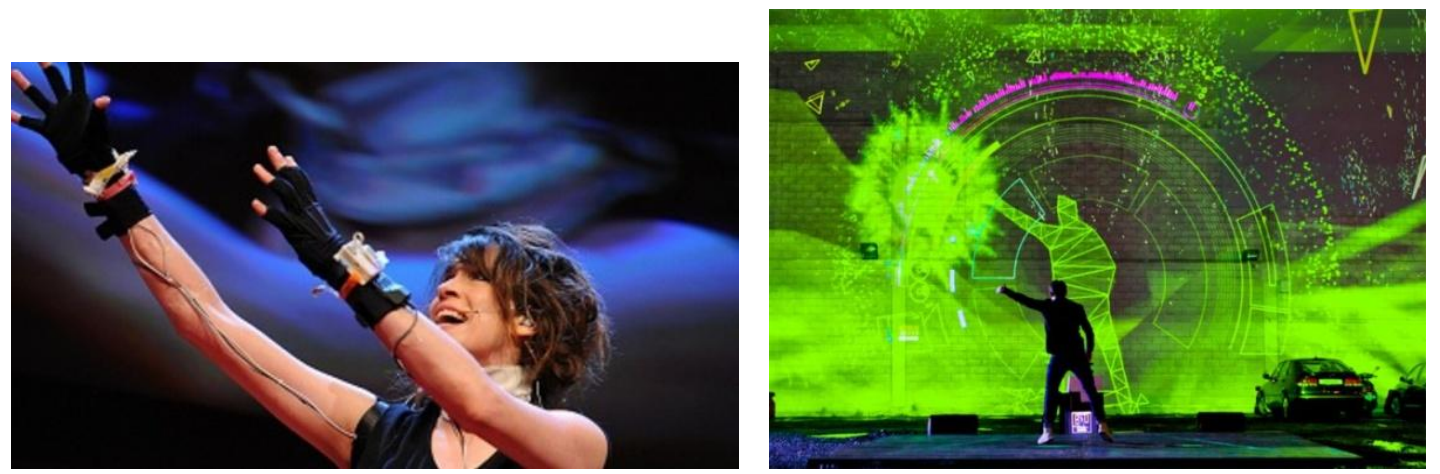

La música y emprendedora tecnológica inglesa Imogen Heap y sus "guantes musicales" (izq.) y un instante de la presentación de V Motion Project (der.), proyecto de control de parámetros musicales a partir de la captura de movimiento con cámara kinect. ${ }^{691}$

\footnotetext{
690 Fuentes (de las imágenes): http://www.akaipro.com/product/apc40 y https://www.mindtreatstudios.com/tag/kinect/ [05112016]
} 


\section{Bandejas tocadiscos}

Las bandejas tocadiscos son el dispositivo principal de los deejays y la función más difundida en la especie consiste en la reproducción de pistas en las presentaciones a público. La configuración básica consiste en dos bandejas tocadiscos conectadas a una consola de mezclas.

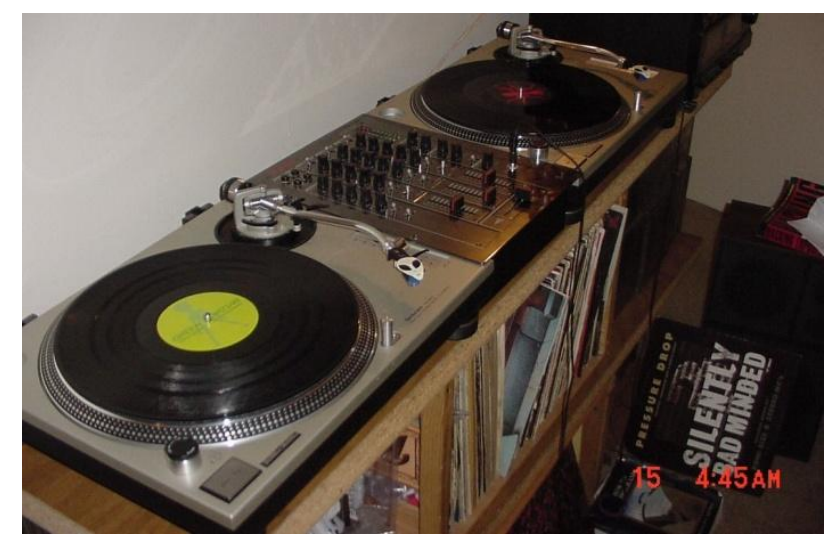

Configuración básica para discos de vinilo (sistema analógico). En la ilustración, dos legendarias bandejas Technics SL-1200. ${ }^{692}$

La consola permite configurar si se escuchará una, otra o ambas bandejas mediante un control deslizable que se conoce como "crossfade" (i.e.: "fundido cruzado") y que permite subir el nivel de una al mismo tiempo que desciende la otra. Estas consolas suelen tener además múltiples otras capacidades (de ecualización, filtrado, etc.) y, según su complejidad, incluir algunos modificadores/procesos y efectos aplicables al sonido proveniente de las bandejas. Es mediante las prestaciones que brindan las consolas de mezcla que los deejays pueden, a modo de ejemplo, filtrar los graves para producir una parada, samplear un fragmento de la pieza que se reproduce y/o agregar un elemento y/o estrato textural mediante la aplicación de un efecto de eco. Por la función que desempeña suele ubicársela entre ambas bandejas y así tener acceso a sus controles sin importar cuál de aquellas se encuentra activa.

Como en otros casos, todos dispositivos originalmente físicos y analógicos, hoy pueden hallarse también digitales físicos y virtuales y sistemas mixtos (software de computadoras con controladores físicos dedicados); siendo los últimos quizá hoy los más numerosos.

Paralelamente al desarrollo de las músicas electrónicas utilizadas para el baile social y como sucediera con los actos en vivo, los deejays han agregado a sus presentaciones paulatinamente diversas fuentes de sonido, procesadores y efectos integrados en dispositivos únicos y especializados o a partir de una multiplicidad de otros. Reflejando hoy lo que sucediera con el transcurrir de los años y el desarrollo tecnológico, los primeros fueron incorporando más

691 Fuentes (de las imágenes): http://guardianlv.com/2014/04/imogen-heap-puts-the-magical-musicalgloves-on/ y https://www.mindtreatstudios.com/tag/kinect/. [05112016]

${ }^{692}$ Fuente: https://es.pinterest.com/pin/1477812348599433/. [07112016] 
y más funciones, automatizando procesos y, en una relación dialéctica con sus usuarios, transformando el rol del deejay.

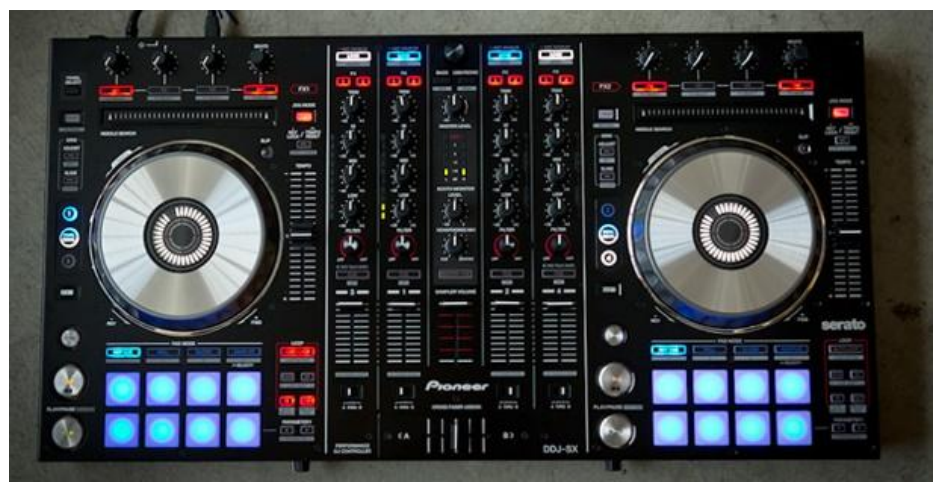

Pioneer DDJ-SX. Controlador que, junto al software Serato DJ, conforman uno de los sistemas mixtos más renombrados del momento. ${ }^{693}$

Algunos deejays, en sus presentaciones utilizan las bandejas como verdaderos instrumentos. Ya sea a partir de vinilos industriales o grabados especialmente (encargados por el mismo deejay), reproducen secuencialmente muy breves fragmentos, logrando una continuidad heterogénea a partir de segmentos diferenciados. Un ejemplo de este último puede apreciarse en el video en línea DJ ANGELO - Funky Turntablism: verdadera sesión virtuosística, al mismo tiempo demuestra el funcionamiento de la configuración básica de dos bandejas y consola. ${ }^{694}$

Por último, especialmente aquellos artistas que producen piezas de índices basados en samples de breakbeats utilizan en sus estudios las bandejas tocadiscos analógicas (reproductoras de discos de vinilo) para reproducir pistas y temas y obtener a partir de allí los samples a utilizar. Aquí el dispositivo se limita a la función para la que fuera originalmente concebido: reproducir sonido grabado.

\section{Otros dispositivos destinados a deejays}

Ciertos dispositivos introducidos recientemente al mercado ofrecen prestaciones que pueden pensarse dedicadas a satisfacer roles particulares que ocurren solo -o al menos especialmente- en las músicas electrónicas utilizadas para el baile social. En los últimos años resulta evidente el crecimiento que experimenta el mercado de dispositivos orientados a supuestamente- "satisfacer las necesidades de los modernos deejays y productores"; ${ }^{695}$ estos dispositivos incorporan en una misma unidad (i.e.: en un cuerpo único) funciones que usualmente se hallaban en dispositivos distintos y destinados a diferentes mercados. "Híbrido" o

\footnotetext{
${ }^{693}$ Fuente: http://djtechtools.com/2012/11/28/review-pioneer-ddj-sx-controller-for-serato-dj/. [07112016] ${ }^{694}$ DJ ANGELO - Funky Turntablism. Subido por DJ ANGELO. Accesible en https://www.youtube.com/watch?v=tr3ftsCVXhc. [09052016]

${ }^{695}$ La mercadotecnia se ocupa de crear nuevas necesidades por lo que toda necesidad convertida en un producto comercial posee componentes creados para impulsar el éxito de ventas de dicho producto. De allí que consideremos a esta necesidad como supuesta.
} 
"cruce" entre lo que puede llamarse la versión digital de una bandeja tocadiscos, ${ }^{696}$ un sampler de percusión, un secuenciador por pasos y diversos procesadores ( y además incorporando tecnología digital y analógica), el recientemente surgido Toraiz SP-16 de la marca Pionner resulta un claro ejemplo de la amplitud de la región media y del límite difuso entre las presentaciones de deejay y los actos en vivo. ${ }^{697}$

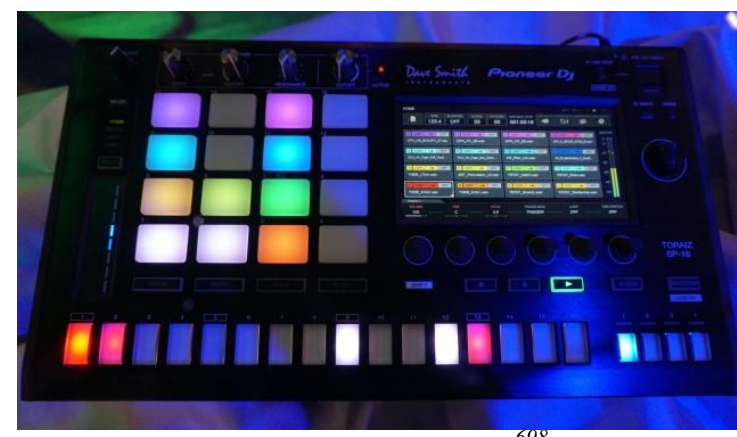

Pioneer Toraiz SP-16. ${ }^{698}$

Del mismo modo, el ya mencionado formato de audio digital Stems propone un límite difuso entre ambos tipos de eventos al permitir que una pista o tema completamente mezclado sea dividido en cuatro (4) señales de audio independientes, "abriendo" la pista o tema a un procesamiento y/o aplicación de efectos segmentado. Ya sea en el campo de los dispositivos físicos o de las herramientas virtuales, el avance tecnológico continúa cambiando las formas de hacer música.

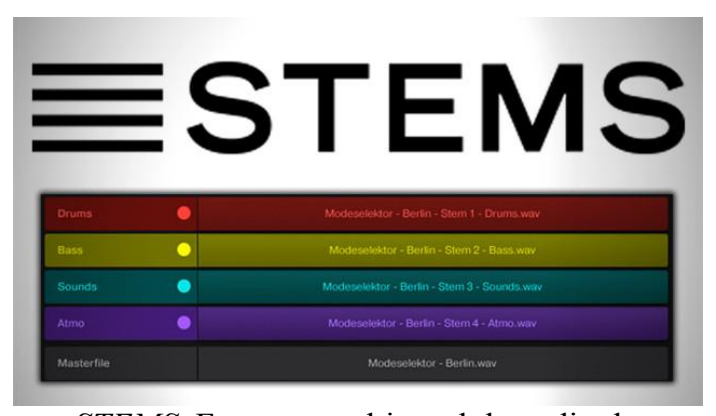

STEMS. Formato multicanal de audio de la empresa Native Instruments. ${ }^{699}$

\section{Otros dispositivos de uso extensivo}

Más allá de los expuestos hay un conjunto de dispositivos que, si bien pueden inscribirse entre aquéllos que hemos excluido inicialmente de nuestras descripciones, por el uso

\footnotetext{
${ }^{696}$ Similares al sistema integrado por el controlador Pioneer DDJ-SX y el programa SERATO DJ, estos dispositivos no reproducen ni vinilos, ni CDs, ni discos de ninguna clase sino que son reproductores de archivos digitales. Sin embargo se inscriben en la tradición (i.e.: ofrecen las funciones asociadas) de las mencionadas bandejas tocadiscos.

${ }^{697}$ Para más detalles respecto de las prestaciones ofrecidas por el dispositivo y de los modos en que se lo promueve comercialmente véase la promoción en línea que la propia empresa Pionner realiza. Accesible en https://www.pioneerdj.com/es-es/product/production/toraiz-sp-16/black/overview/ [03112016]

${ }^{698}$ Fuente: http://www.mpc-forums.com/viewtopic.php? $\mathrm{f}=36 \& \mathrm{t}=180088$. [07112016]

${ }^{699}$ Fuente: http://djtechtools.com/2015/06/22/native-instruments-launches-stems-music-com-first-look-atstems-creator-tool/. [07112016]
} 
extendido que les han dado productores, músicos electrónicos y deejays, merecen al menos ser mencionados. Sin pretender exhaustividad y excluyendo otros que podrían resultar incluso más importantes, los que describiremos ilustran -a nuestro modo de ver- cuestiones que exceden el campo tecnológico para adentrarse en el campo de las ideologías y de lo "actitudinal".

\section{Vocoders}

Los vocoders son modificadores/procesadores que transforman el timbre y afinación de un sonido a partir de combinarlo con el de una onda sintetizada, permitiendo incluso realizar armonías a partir de un sonido de altura tonal no definida. Mayormente utilizados para procesar voces, mediante estos dispositivos (por ejemplo) Kraftwerk y Daft Punk lograron las voces "robóticas" en sus respectivas "The robots" y "Human after all". ${ }^{700}$ Derivados del voder (1939), ${ }^{701}$ el vocoder se volvería icónico en la especie debido quizá a que las voces generadas permiten una asociación sin obstáculos con el concepto de "máquina". Mediante su uso, unos y otros artistas harían "hablar" a la máquina; quizá como una alegoría del futuro le brindarían voz a la "tecnología" y a lo "des-humanizado". Originalmente analógicos físicos, hoy los hay basados en todas las tecnologías y tipos de soportes.

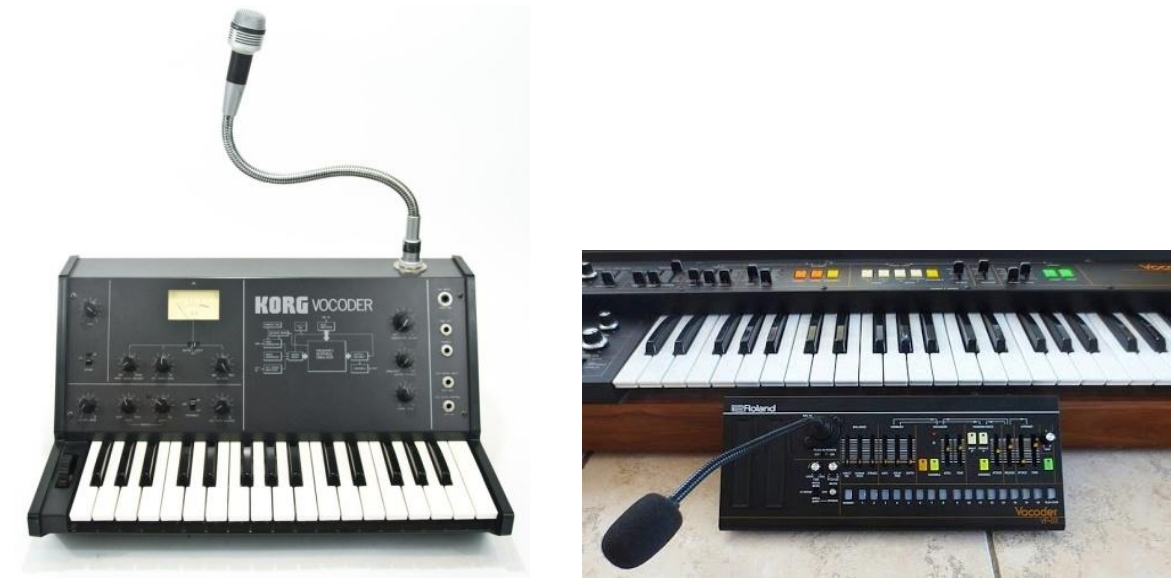

Vocoders Korg VC-10 (izq. 1978) y Roland VP-03 (der. 2016). Detrás del segundo, el modelo análogo VP-330 Vocoder Plus (1979) del cual es reedición digital física. ${ }^{702}$

\footnotetext{
${ }^{700}$ Kraftwerk - The Man-Machine (Full Album + Bonus Tracks) [1978] y DAFT PUNK - HUMAN AFTER ALL (OFFICIAL AUDIOS). Subidos por Megaherz Kraftwerkiano y Daft Punk. Accesibles en https://youtu.be/NL3NqfFTec8 y en https://youtu.be/PXYeARRyDWk. [09112016]. Especialmente en Human after all el uso de vocoder es extensivo. Escúchese en la pieza de Kraftwerk cómo el interés por el establecimiento de pulsaciones se encuentra presente ya en ese entonces, y como este hecho provoca la ocurrencia de varias oscilaciones/alternancias de intensidad diferentes según el pasaje de que se trate (llamamos también la atención acerca del uso del registro grave/sub-grave).

${ }^{701} \mathrm{Al}$ respecto del voder véase The Voder - Homer Dudley (Bell Labs) 1939. Subido por MonoThyratron. Accesible en https://youtu.be/5hyI dM5cGo. [09112016]

${ }^{702}$ Fuentes: https://es.pinterest.com/kyledixon/synthesizers/ y https://youtu.be/Y KRQlFCwkk. El Roland SVC 350 Vocoder utilizado por Daft Punk es la versión en formato "rack" (sin teclado) del VP 330 incluido en la imagen. Para más detalles al respecto sugerimos visitar http://www.daftpunkanthology.com/dpa/instruments-softs y https://es.wikipedia.org/wiki/Vocoder. Otra fuente interesante resulta el video en línea The Secret History of the Vocoder. Subido por The New Yorker. Accesible en https://youtu.be/OvR4qK0B--w. [09112016]
} 


\section{Cortocircuito creativo o "circuit bending"}

En esta actitud de "dar voz a la máquina"703 surge otro ejemplo que, a modo de anécdota, permite apreciar el tipo de relaciones que se establece entre la tecnología y los creadores de las músicas electrónicas utilizadas para el baile social. Dicho ejemplo consiste en el juguete sintetizador de voz Speak \& Spell de Texas Instruments; dispositivo que (quizá en parte por el uso que se le diera y da en la especie) ha sido incluso homenajeado con versiones virtuales. ${ }^{704}$ Usualmente modificado para agregarle funciones y variables (actividad a la que se denomina "circuit bending"), sonidos posibles pueden apreciarse en el video-demostración realizado por Ramiro de la Cruz Larrain Circuit Bend Speak \& Spell + Analog Deelay (Microesfera/Vlisa Live Play). ${ }^{705}$

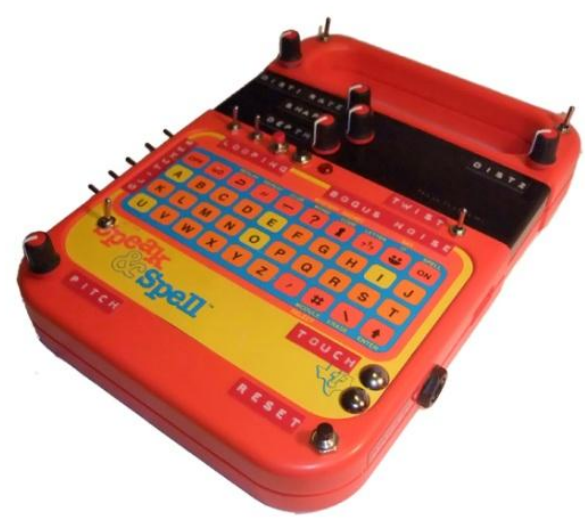

Texas Instruments Speak \& Spell modificado. Nótense las perillas y botones evidentemente agregadas. ${ }^{706}$

\section{Modificadores/procesadores y efectos (Korg Kaoss Pad)}

El dispositivo Korg Kaoss Pad integra en una misma unidad múltiples y diversas funciones que se inscriben como modificadores/procesadores (algunas) y como efectos (otras). Estas funciones se encuentran disponibles en múltiples dispositivos de todo tipo y soporte y son parte esencial (más allá de la especie musical) de cualquier estudio de producción musical. En el Kaoss Pad de la compañía Korg las funciones se combinan simultáneamente, permitiendo imprimir grandes cambios en el sonido que atraviesa sus circuitos; siendo esta una práctica habitual en la producción musical y habiendo el Kaoss Pad ejercido un gran impacto sobre la

${ }^{703}$ Como fuera mencionado en el debate con el testimonio de Ernesto Romeo, no negamos ni el argumento de que detrás de toda máquina hay un ser humano que la creara ni los interrogantes que plantean hoy a este respecto y a futuro los avances actuales en inteligencia artificial.

704 Juguete educativo (en habla inglesa) de 1978, en español su nombre significa "Habla y deletrea". Frente a la baja accesibilidad que presenta y al igual que lo que relatáramos para las máquinas de ritmo, las emulaciones virtuales lo ponen a disposición de los interesados en utilizar sus sonidos en sus creaciones. Una versión en línea puede experimentarse en el sitio http://www.speaknspell.co.uk/speaknspell.html. [08112016]

${ }^{705}$ Circuit Bend Speak \& Spell + Analog Deelay (Microesfera/Vlisa Live Play). Subido por Microesfera. Accesible en https://youtu.be/Bq1hqfoFOYI. Respecto del circuit bending sugerimos el video (en inglés) Reed Ghazala, the Father of Circuit Bending: Sound Builders. Subido por Motherboard. Accesible en https://youtu.be/KHDL9iGxDPM. [09112016]

706 Fuente: http://www.bogus-noise.co.uk/bends/speak-and-spell/, sitio dedicado al circuit bending. [08112016] 
especie, lo consideramos apropiado como forma de ofrecer una breve demostración de cuan radicales pueden resultar las transformaciones derivadas de la aplicación de modificadores/procesadores y efectos sobre cualquier tipo de sonido. Aunque aquí no resulte nuestro foco de interés, este instrumento ofrece también algunas limitadas posibilidades de sampleo, otras de síntesis y algunas (muy básicas) secuencias de percusión. Todas estas prestaciones lo vuelven un dispositivo aún más poderoso al permitir (sobre todo por la primera de las tres funciones "extras") la replicación y transformación en tiempo real de aquello mismo que se encuentra sonando en un momento determinado. Nos valdremos entonces de su descripción como ejemplo de los numerosos dispositivos existentes en el mercado que (por un lado, algunos) modifican/procesan sonido de diferentes formas y/o (por otro, otros o los mismos) desafían cualquier categorización.

Dispositivo digital físico, su éxito de ventas suele atribuirse, por una parte, a la cantidad $\mathrm{y}$ variedad de prestaciones que ofrece en una única unidad y, por otra, al tipo de control que ofrece para sus parámetros: un panel sensitivo de dos ejes, usualmente denominado panel "XY". Al deslizar un dedo sobre la superficie del panel (i.e.: al modificar su localización en los ejes cartesianos XY) el nivel de uno o varios procesos y/o efectos se modifica. Esta simplicidad para su control lo vuelve un dispositivo muy deseable por una comunidad de individuos que fácilmente pueden encontrarse "rodeados", "sitiados" por las numerosas perillas, botones, deslizadores y demás controles de sus dispositivos que "piden" ser modificados. ${ }^{707}$

Su tercera versión de 2006, conocida como "KP3", se promociona en el sitio de la empresa como un "procesador de efectos/sampler en tiempo real con control instantáneo sobre efectos de última generación". ${ }^{708}$ Ofrece 150 efectos, entre los cuales la promoción destaca: una emulación del efecto que sobre el sonido grabado produce detener un disco de vinilo, compresión por cadena lateral, posibilidades de manipular los bucles (i.e.: los samples almacenados en el dispositivo por el usuario) y "efectos que usted puede usar para las 'paradas' en su interpretación como DJ." ${ }^{709}$ En el mismo sitio puede apreciarse un video demostrativo de su funcionamiento. Así también sugerimos ver el video en línea Daft Punk - Get Lucky - Live Remix w/ KaossilatorPro $+\&$ KP3+, el cual contiene un remix realizado por Igor Willcox del tema Get lucky de Daft Punk: allí pueden apreciarse las prestaciones y tipo de operación que ofrece tanto el KP3+ como su complementario, el sintetizador digital Kaossilator Pro.$+{ }^{710}$

\footnotetext{
${ }^{707}$ Nos referimos con esta expresión a que, de no modificarse dichos parámetros, en muchos casos se corre el riesgo de que las configuraciones musicales se vuelvan reiterativas y no presenten interés. De aquí la importancia que asume la posibilidad de automatización que diversos dispositivos ofrecen.

708 "A real-time effects processor/sampler with instant control over cutting-edge effects". Fuente: http://www.korg.com/us/products/dj/kaoss_pad_kp3 plus/. [09112016]

709 "Effects you can use for breaks in your DJ play.". ibidem.

${ }^{710}$ Daft Punk - Get Lucky - Live Remix w/ KaossilatorPro + \& KP3+. Subido por Igor Willcox. Accesible en https://youtu.be/4mC_U67ehug. [09112016]
} 


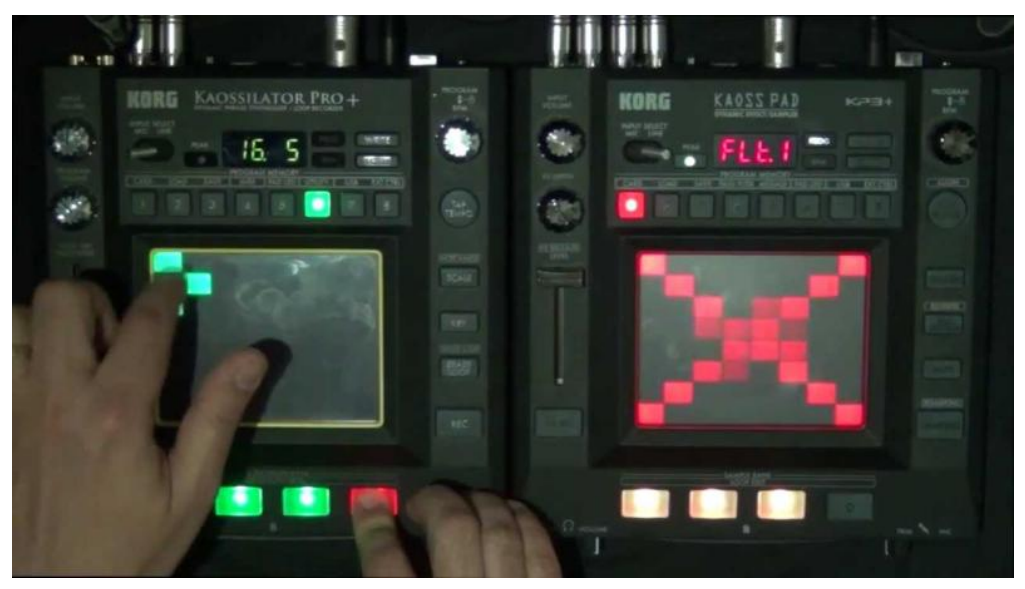

Korg Kaossilator Pro+ (izq.) y Kaoss Pad 3+(der. $)^{711}$

Dada la brevedad requerida, consideramos que los ejemplos en video ofrecidos resultan suficientes en tanto síntesis de las transformaciones posibles a partir de modificadores/ procesadores y efectos. Damos entonces por finalizado este anexo, esperando que el mismo resultara de ayuda como guía básica de los dispositivos utilizados en la especie. Gran cantidad de estos (con sus respectivos accesorios, especificaciones técnicas y estéticas) han quedado fuera de este brevísimo y en algo -necesariamente- desorganizado resumen. Así también, infinidad de información se encuentra disponible y diseminada en los sitios en línea de los fabricantes, en sitios y revistas especializados y en la forma de revisiones en video (i.e.: "reviews") de usuarios en el sitio YouTube. Invitamos a quienes deseen ampliar su conocimiento en la materia a recorrer las fuentes mencionadas, método que resulta el mismo que utilizamos aquellos que desarrollamos nuestra actividad en el contexto tecnológico que fuera el foco de este anexo.

\footnotetext{
${ }^{711}$ Fuente: ibidem.
} 


\section{GLOSARIO}

Activación (musical): sensación de activación, actividad o movimiento percibido en la música. Asociación entre la densidad cronométrica y una cierta sensación de movimiento corporal. Al respecto dirá Zeiner-Henriksen:

La conección entre música y movimiento corporal parece inmediatamente obvia a la luz de cómo se consiguen los sonidos musicales. Los movimientos corporales producen sonidos en los instrumentos, y muy pocos músicos son capaces de tocar apropiadamente sin un repertorio de movimientos auxiliares: el/la pianista de jazz puede percutir con su pie para mantener el tiempo, mientras que clarinetistas clásicos pueden corporizar sus frases melódicas mediante inclinaciones de cabeza y hombros. Semejantes conexiones son igualmente evidentes en la recepción de música, y especialmente los movimientos corporales de la música de baile responden a características específicas [presentes] en la música de ballet clásico coreografiado, danza folklórica estilizada y danza de club improvisada. $^{712}$

Activación (de movimiento): cantidad, velocidad y amplitud del movimiento o agitación corporal y de baile.

Almohadillas ("pads"): comando de control consistentes usualmente en pequeños tacos de goma $\mathrm{u}$ otro material flexible sobre los que resulta posible percutir con los dedos o con baquetas. Sensibles a la fuerza con que se los impacta, envían una orden de hacer sonar alguna fuente sonora electrónica.

Altura: ver Frecuencia.

Altura tonal definida: timbre conformado principalmente por oscilaciones periódicas y en relación armónica simple. Sus relaciones generan un sonido percibido como afinado sobre una única nota.

Altura tonal no definida: timbre conformado por bandas de frecuencias. Es percibido como no afinado. También llamado sonido de "altura relativa".

Intensidad: cantidad de movimiento del cuerpo vibrante que originará sensación sonora. Se corresponde con la sensación psicológica de sonoridad, la cual suele describirse con los términos fuerte o débil. En escala logarítmica, se mide en décimas de Bell o decibell (dB) y se

\footnotetext{
712 "The connection between music and body movement seems immediately obvious already in light of how musical sound is made. Body movements produce sounds on instruments, and very few musicians are able to play properly without a repertoire of auxiliary movements as well:36 the jazz pianist might tap his or her foot to keep time, while the classical clarinettist might embody his or her melodic phrases through dips of head and shoulders.37 Such connections are equally apparent in the reception of music, and especially dance music - body movements respond to specific features in the music of choreographed classical ballet, stylized folk dance, and improvised club dance." Zeiner-Henriksen, H. 2010. Op.cit. pp. 12
} 
estima que el rango de la audición humana abarca unos $120 \mathrm{~dB}$ entre el sonido apenas perceptible y aquel que genera dolor (con riesgo de daño al sistema auditivo). Ver también Rangos extendidos de frecuencias e intensidades.

Ancho de banda: la región o zona de frecuencias continuas que componen un sonido (usualmente de altura tonal no definida). Fenómeno complejo, suele describírselo refiriendo al área comprendida entre la frecuencia inferior y superior que delimitan la región ocupada. A modo de ejemplo, el sonido conocido como ruido blanco (conteniendo todas las frecuencias a la misma intensidad) presenta un ancho de banda teóricamente infinito. También se utiliza la expresión para referirse al rango de frecuencias que un dispositivo puede (re)producir.

Batimento: el resultado de la interferencia de dos ondas con frecuencias ligeramente diferentes. Dependiendo de dicha diferencia puede resultar en una fluctuación en la intensidad del sonido o en la emergencia de un nuevo sonido, de frecuencia igual a la diferencia mencionada (i.e.: diferencial).

Bucle: el español de "loop", refiere a un fragmento musical o sonoro que se reitera (en la especie, usualmente numerosas veces). El término deriva del período analógico; en ese entonces, para repetir un sonido grabado se recurría mediante diversas técnicas a generar un bucle (de cinta magnética) o un surco cerrado (en discos de vinilo). Según Mark Butler:

El término "loop" generalmente refiere a un patrón instrumental único (o a un único sample que se repite, como en los breakbeats loopeados), aunque múltiples loops pueden ser combinados en secuencias repetitivas. ${ }^{713}$

y también:

Aficionados y músicos describen a los patrones repetitivos que ocurren en la EDM como "loops" ["bucle"]. El loop es la unidad fundamental de la estructura musical en la música electrónica de baile: la mayoría de los tracks ["pista"] se componen primariamente (sino enteramente) de loops, y cualquiera de los tres tipos rítmicos básicos (regulares, diatónicos o sincopados) pueden ser usados en un loop. El indicador primario de una estructura basada en loops es la repetición cíclica: si el ritmo de una cierta parte de la textura varía libremente, sin patrón de repetición discernible, probablemente no sea un loop. Patrones no loopeados ocurren en la EDM, particularmente en pistas que incorporan [partes] vocales en vivo, pero estructuras basadas en loops son mucho más comunes. ${ }^{714}$

\footnotetext{
713 "The term "loop" generally refers to a single instrumental pattern (or to a single repeating sample, as with looped breakbeats), though multiple loops can be combined into repeating sequences." Butler, M. (2003). Op.cit. pp. 104

714 "Fans and musicians describe the repeating patterns that occur in EDM as "loops." The loop is the fundamental unit of musical structure in electronic dance music: most tracks are composed primarily (if not entirely) of loops, and any of the three basic rhythmic types (even, diatonic, or syncopated) may be used within a loop. The primary indicator of loop-based structure is cyclical repetition: if the rhytm of a
} 
Canción: tipo de composición musical donde una voz humana interpretando una melodía con contenido textual se configura como un estrato textural jerarquizado, y donde los demás elementos y/o estratos conforman (en conjunto) un contexto o acompañamiento considerado secundario. Si bien en otras especies esta denominación conlleva también una organización formal determinada, utilizamos esta expresión con cierta flexibilidad, implicando solo lo previamente explicitado.

Complejos conceptuales-vivenciales: resumimos en esta expresión las complejidades implícitas a ciertos conceptos que involucran, además, vivencias. Asociadas en nuestro trabajo a sonido y música, referimos con esta expresión tanto a sus conceptos como a las percepciones, prácticas y reflexiones derivadas de experimentar aconteceres sonoros y musicales.

Complementariedad (musical): principio organizativo que se caracteriza por asignar a entidades diferentes funciones disimiles y donde el sentido musical último emerge de/reside en la interacción de la totalidad de dichas entidades.

Comunidad electrónica: el conjunto de productores, músicos electrónicos, deejays (profesionales, amateurs y "de dormitorio"), bailarines, aficionados y demás individuos que participan de algún modo de eventos con presencia de músicas electrónicas utilizadas para el baile social y tienen -como consecuencia de dicha participación- algún tipo de conocimiento de la especie.

Conformación espectral o espectro (de un sonido): las múltiples oscilaciones simultáneas presentes en todo fenómeno vibratorio. Fenómenos siempre complejos, se los considera en su evolución temporal. Ver también Timbre.

Deslizador ("fader"): comando de control deslizable, usualmente hallable en consolas y otros dispositivos tecnológicos.

Diferencial (frecuencia o sonido): sonido que se origina por la interferencia de dos sonidos de frecuencias similares. Siendo uno de los casos contenidos en las oscilaciones de segundo orden, su frecuencia será igual a la diferencia entre la frecuencia mayor y la menor (de aquí lo "diferencial").

certain part of a texture varies freely, with no discernible pattern of repetitionk, it is probably not a loop. Non-looping patterns do occur in EDM, particularly in tracks incorporating live vocals, but loop-based structure is much more common." Butler, M. (2003). Op.cit. pp. 103-4 
Distorsión armónica: componentes de ruido que se agregan al sonido en un determinado dispositivo. Consiste en una deformación de la onda eléctrica. Cuando su origen es un nivel demasiado elevado de la tensión eléctrica se referirá a esto como "saturación" (de la señal de audio).

Drone o textura evolutiva: sonidos sostenidos de duración prolongada y conformación espectral indeterminada plausibles de ser manipulados de diferentes modos. Usualmente conformaciones espectrales complejas y verdaderas texturas en sí mismas, pueden en otros casos consistir en timbre de pocos componentes. Las posibilidades de modulación que los sintetizadores presentan habilitan la automatización de transformaciones en períodos largos de tiempo, permitiendo la ocurrencia de complejas y diversas conformaciones sin la intervención de operador alguno. Similares evoluciones prolongadas pueden suceder en ciertos sonidos provenientes del mundo no musical, pudiendo ser incluidos en las piezas en forma de samples. Esta última cualidad es la que seguramente gravitara para que estos elementos recibieran la denominación con la que se los conoce actualmente: "drone" entidad autónoma que opera y evoluciona sin la necesidad de intervención humana.

Elemento textural: evento sonoro, sonido-instrumento, ataque u otros que, integrado a otros elementos similares o diferentes configuran un estrato textural. Ejemplo: el patrón rítmico descripto por el sonido de bombo al interior del estrato de la sección rítmica.

Envolvente de intensidad: la evolución temporal de la intensidad de un sonido. Los dispositivos tecnológicos suelen ofrecer controles para configurar el modo en que la intensidad evoluciona. Típicamente conocida como envolvente "ADSR" (Attack, Decay, Sustain, Release) permite configurar las fases sucesivas de ataque, decaimiento, sostenimiento y liberación (o extinción).

Espectro (de un sonido): ver Conformación espectral.

Estrato textural: parte la textura musical que se reconoce perceptualmente como independiente de otras que ocurren simultáneamente. Conjunto de elementos que en sucesión se perciben agrupados y conformando "estelas" o "corrientes" auditivas independientes de otras. Presenta un grado de completitud tal que permite asignarle algún tipo de sentido. Ejemplo: melodía, acompañamiento armónico, pedal, etc.

Fonón: sonón o partícula acústica. Fenómeno vibratorio de gran ancho de banda, con componentes graves/sub-sónicos y de gran presión acústica. Sonido percusivo (de ataque y extinción virtualmente instantáneos) en el que las cualidades descriptas se concentra en un muy 
breve espacio-tiempo. Fenómeno que en principio presenta las características ideales para la generación de sensación táctil, alcanza al cuerpo del sujeto perceptor impactándolo en la forma de "pared de presión acústica" que literalmente lo atraviesa deformando efímeramente su materia corporal.

Frecuencia (de la oscilación): cantidad de oscilaciones (ciclos) por segundo que cumple una fuente de sonido. Medida en Hertz (Hz), a mayor cantidad de oscilaciones más agudo será el sonido. Se corresponde con la sensación subjetiva de altura, que se describe como aguda o grave. Se estima que la audición humana detecta como sonido oscilaciones comprendidas entre los 20 y los 20.000 ciclos por segundo. Las frecuencias menores se consideran sub-sónicas y las superiores super-sónicas. Se supone que ni unas ni otras generan sensación auditiva, cuestión que condujo a que no se las considere en los estudios musicológicos. En un dispositivo electrónico se referirá entonces como rango de frecuencias a las frecuencias comprendidas entre la más aguda y grave que dicha herramienta puede (re)producir. Ver también Rangos extendidos de frecuencia e intensidad.

Groove: (fuente Wikipedia en español) la "sensación", rítmicamente expansiva, o el sentido de "swing" creado por la interacción de la música interpretada por la sección rítmica de una banda (batería, bajo eléctrico o contrabajo, guitarra y teclados). El groove es un factor importante en los distintos subgéneros del jazz, y de ahí a otros géneros como salsa, funk, rock y soul. El término suele utilizarse, también, para describir un tipo de música que incita al movimiento o al baile. Los musicólogos y otros académicos comenzaron a analizar el concepto de "groove" en los años 1990. Se ha afirmado que el "groove" es una "comprensión del patrón rítmico", o un "sentimiento", y "una sensación intuitiva" de un "ciclo en movimiento", que surge a partir de "patrones rítmicos cuidadosamente dispuestos", que ponen en movimiento al oyente.

Herramientas métricas (o de medición): en músicas que basan su organización temporal sobre la división del tiempo en partes iguales (isócronas), los ritmos y duraciones suelen establecer ciertas regularidades. Estas se configuran como unidades de medición que permiten (a modo de ejemplo) la organización del discurso y la sincronización entre intérpretes. Pulso, compás, división (y en algunas perspectivas) meta-compás son diferentes unidades que se ordenan jerárquicamente donde unas suelen ser múltiplos y/o fracciones de otras.

Hertz: ver Frecuencia.

Heterogeneidad: cualidad que evidencia y describe la presencia de diferencias. 
Iteración: oscilaciones o alternancias (en una o varias cualidades de un sonido) que provocan la sensación de que dicha cualidad posee un "relieve" o "rugosidad".

Legato: el italiano de "ligado". Tipo de articulación musical donde los eventos discretos sucesivos generan sonido continuo ( $\sin$ silencios intermedios). $\mathrm{Su}$ posible opuesto complementario resulta el staccato, tipo de articulación que podemos asociar con nuestros sonidos percusivos.

Levare: gesto musical en la parte débil de un tiempo o compás que provoca la sensación de impulso hacia el siguiente momento acentuado.

Lógica difusa: la utilizamos aquí por oposición a la lógica binaria aristotélica donde las proposiciones solo tienen valor binario verdadero o falso. En la lógica difusa o borrosa, las proposiciones tienen un valor porcentual de verdad. Se inscribe en los estudios de la complejidad y de los sistemas que incorporan numerosos elementos y (algunas veces) múltiples dimensiones. Utilizada cotidianamente, permite (a modo de ejemplo) describir a un canario como "amarillo" aún cuando sus patas y pico son de color rosado, sus ojos, negros y sus plumas pueden presentar veteados de diferentes otros colores.

Loop: ver Bucle.

Longitud de onda: en una onda periódica, la distancia (en centímetros, metros) entre un pico máximo y el siguiente.

Mash up: en la comunidad electrónica, una pieza creada a partir de combinar materiales (usualmente reconocibles) provenientes de dos o más piezas preexistentes.

Mezcla (música "mezclada"): expresión que en diferentes contextos asume sentidos diferenciados. 1. En la comunidad electrónica, la mezcla (o "mix") puede ser una pieza musical finalizada, donde todos sus elementos constituyentes se encuentran unificados e inseparables en una única grabación analógica o digital. Por oposición, en una composición no mezclada los elementos que la componen (i.e.: la sección rítmica, melodías, acompañamientos, drones, etc.) se encuentran independizados, lo que permite modificar las propiedades de cualquiera sin incidir en nada sobre los demás. 2. En la comunidad electrónica también refiere a las acciones llevadas adelante por el deejay, consistentes en reproducir simultáneamente dos piezas o fragmentos de piezas musicales diferentes. Ver también Remix. 
MIDI (sistema): sigla del inglés "Musical Instrument Digital Interfase"; protocolo de estandarización digital que permite la comunicación entre dispositivos tecnológicos musicales. De gran influencia histórica, originado en un acuerdo entre compañías fabricantes, agregaría numerosas capacidades a los instrumentos. Entre muchas otras se cuenta la posibilidad de sincronización entre diferentes dispositivos o el control de uno por otro.

Modulación (de intensidad): técnica de modificación del sonido que consiste en que una onda ("moduladora") de ciertas características, modifica las cualidades de otra ("onda portadora"). En el caso de la modulación de intensidad, la onda moduladora genera decrecimientos e incrementos alternados en la intensidad de la onda portadora.

Objetivación: aquellos procesos que conducen a que ciertas configuraciones sonoras presenten propiedades estables y fácilmente reconocibles. En las músicas electrónicas utilizadas para el baile social posiblemente se incluyeran e incluyen como una forma de articular materiales muy diversos en sus principios constructivos. Repetición y sampleo son los principales procesos que inciden de este modo sobre los materiales musicales. Ver también Objeto sonoro.

Objeto sonoro: conformación sonora de propiedades estables y fácilmente reconocibles. Sus propiedades provocan que la forma sonora "objetivada" u "objetuada" (i.e.: vuelta, por analogía, objeto) hasta cierto punto se cierre y desvincule de su contexto, adquiriendo sentido por sí misma. Sus cualidades se aproximan a un tratamiento "absoluto" y se alejan de uno "relativo". Ciertas características de los samples pueden provocar una percepción diferenciada de los sonidos contenidos a su interior: aún cuando estos contengan material musical que puede encontrarse en consonancia armónica con otros estratos texturales simultáneos, el extrañamiento que puede generar su condición (de "muestreados") establece una separación entre unos y otros; separación que en algunas ocasiones impide el establecimiento de relaciones musicales tradicionales. Como ejemplo, las notas de una melodía tonal contenida en un sample presentado varias veces pueden ver debilitadas sus relaciones mutuas (valga la redundancia, tonales) por el hecho de presentar una completa invariancia hasta en sus aspectos sonoros más mínimos.

Oscilaciones de primer orden: las vibraciones principales y secundarias que constituyen al acontecer sonoro en sí mismo. En sonidos de altura tonal definida, cada uno de los armónicos; en timbres inarmónicos, los parciales; en aquellos de altura tonal no definida, las diversas bandas que lo componen.

Oscilaciones de segundo orden: vibraciones que de diferentes modos y presentando diversos orígenes modifican la evolución temporal de las oscilaciones de primer orden. Usualmente 
utilizadas en los instrumentos musicales de base tecnológica para agregar componentes espectrales y/o dinamizar el timbre al generar cambios en su devenir temporal. Ejemplos posibles son: moduladores (de intensidad, de fase, etc.), efectos (chorus, flanger, etc.) y batimentos originados en mínimas diferencias en la afinación de osciladores. En otros casos, su origen puede encontrarse en la repetición periódica de un mismo sonido. Para más detalles véase en el cuerpo principal el título Iteratividad.

Perfil de sonoridad: ver Envolvente de intensidad.

Pista: en múltiples sentidos identificables con el concepto de "obra abierta" de Humberto Eco, utilizamos este término para referirnos a ciertas piezas de músicas electrónicas utilizadas para el baile social que, por sus cualidades y/o por el uso que de las mismas realizan los deejays y músicos electrónicos frente a público, presentan diferencias en relación a los formatos "canción" o "tema". A diferencia de estas, las pistas suelen crearse dejando espacios para las intervenciones que se realizarán durante las presentaciones referidas supra. Para más detalles véase el Anexo IV. Actores involucrados en la escena electrónica.

Potenciómetro: comando de control rotatorio, es uno de los controles más usuales. Debido a que ocupa poco espacio y a su fiabilidad, suele ser el más numeroso en la amplia mayoría de los dispositivos.

Pregnancia perceptiva: índice que denota cuan relevante resulta un determinado estímulo a nuestra percepción. De un estímulo que requiere de nuestra parte más atención (que otro), se dirá que es más "pregnante". De esta manera se refiere a que, en una textura de melodía con acompañamiento, la primera será más pregnante que el segundo.

Presión acústica: perturbaciones de la presión del aire originadas en la presencia de vibraciones. Tomando como referencia la presión atmosférica, son precisamente estas perturbaciones las que originarán la sensación auditiva que interpretamos como sonido y las sensaciones táctiles que constituyen nuestro objeto de estudio.

Presión sonora: ver Presión acústica.

Principio de indeterminación acústico: derivado del más general principio de incertidumbre propuesto por el físico Werner Heisenberg, establece que la definición de la altura tonal de un sonido es directamente dependiente de su duración. En otras palabras, un sonido breve presentará menos definición tonal (se percibirá menos "afinado") que un sonido largo. Otra 
forma de enunciarlo (con gran aplicabilidad en nuestro estudio) consisten en decir que: cuanto más veloces son los cambios en la intensidad de una oscilación, mayor será el ancho de banda del sonido en cuestión.

Programar (instrumentos musicales de base tecnológica): la acción de configurar ciertas variables para que, con posterioridad, un dispositivo tecnológico suene en consecuencia. Ejemplo: en un secuenciador se "programan" los puntos de ataque donde dicho dispositivo enviará a otro la instrucción de sonar (i.e.: se "programa" el ritmo como también, usualmente, la altura e intensidad de cada sonido).

Rangos de frecuencias e intensidades: ver respectivamente Frecuencia e Intensidad.

Rangos extendidos de frecuencias e intensidades: frecuencias e intensidades que exceden -de diversos modos- los originados en instrumentos acústicos. Especialmente aplicable para el rango de frecuencias, consiste principalmente en la capacidad de algunos dispositivos de base tecnológica de producir frecuencias sub-sónicas.

Remix o "remezcla": presenta dos acepciones: a) reversión de una pieza preexistente, la cual puede o no pertenecer a las músicas electrónicas utilizadas para el baile social y b) la acción llevada a cabo por deejays y/o músicos electrónicos- de modificar e intervenir una pieza en tiempo real y frente al público. Las compañías discográficas suelen encargar "remixes" a artistas diferentes a los autores originales como modo de promocionar a la pieza y al artista. En ocasiones, el mismo lanzamiento de una pieza se acompaña con varios "remixes". El objetivo de estas campañas es que la pieza se conozca al ser (nuevamente) "remezclada" en locales de baile. Ver también Mezcla.

Riff: breves fragmentos melódicos o proto-melódicos usualmente reconocibles. Suelen constituirse en el elemento más pregnante de la pieza. A veces samples reconocibles o de piezas conocidas, aportan su identidad (en estos casos "ajena") a la pieza en que se los incluye.

Ruidos parásitos: ruidos propios del funcionamiento de un dispositivo, utilizados algunas veces en la especie para evidenciar el "artificio" de la reproducción. Ejemplo: los "cracks" y "pops" de los discos de vinilo o el "hiss" de las cintas magnéticas.

Sample: el inglés de "muestra". Fragmento de audio grabado. De muy diversas longitudes y conteniendo virtualmente infinitas informaciones diferentes, las músicas electrónicas de baile hacen un uso prolífico de los mismos. 
Saturación: ver Distorsión armónica.

Sensación de activación: ver Activación.

Señal de audio: corriente eléctrica alterna que transporta información plausible de ser transformada en sonido mediante un sistema de parlantes. La forma de la onda puede originarse en un dispositivo de síntesis o consistir en una transducción (i.e.: una copia en otra energía) de la presión acústica creada por una fuente sonora acústica (i.e.: un sample).

Serie de armónicos: oscilaciones cuyas frecuencias se encuentran en relación matemática simple. Sonidos en relación matemática simple son percibidos como integrando un único sonido, el cual presenta a la percepción lo que se conoce como altura tonal definida (vulgarmente, una nota o sonido afinado). De grave a agudo, los intervalos entre componentes que plantea la serie (teóricamente infinita) se inician como sigue: $8^{\circ}, 5^{\circ}$ justa, $4^{\circ}$ justa, $3^{\circ}$ mayor, $3^{\circ}$ menor, $3^{\circ}$ menor ("baja", desafinada), $2^{\circ}$ mayor, $2^{\circ}$ mayor, ... En términos musicales y a modo de ejemplo, las notas que componen esta serie ideal para la nota do son: do, do $\left(8^{\circ}\right.$ más aguda), sol $\left(8^{\circ}+5^{\circ}\right)$, do $\left(8^{\circ}+8^{\circ}\right)$, mi $\left(8^{\circ}+8^{\circ}+3^{\circ}\right)$, etcétera.

Sonido-instrumento: utilizamos esta expresión para referir a elementos presentes en la textura de una pieza que permiten su segregación e identificación perceptual a partir de a) analogía con ciertos roles asignados a instrumentos acústicos, b) por remitir a un determinado instrumento a partir de cierta similitud tímbrica con este o, c) por una combinación de los dos factores previos. Hablamos así del sonido-instrumento redoblante para referir, a modo de ejemplo, a un timbre sintetizado o sampleado que cumple el rol asignado en otras músicas a dicho cuerpo del instrumento de percusión batería. Véase también Sonido de...

Sonido de...: expresión destinada a diferenciar el rol asignado a un determinado sonido sintetizado o sampleado, del timbre o fuente concreto que se utiliza en dicho rol. Ejemplo: sonido de redoblante refiere a que el rol textural usualmente asignado a dicho cuerpo de batería lo cumple un sonido de origen sintético o sampleado (y no un redoblante acústico). Dependiendo de la claridad que permita el contexto utilizamos esta u otras expresiones tanto como la denominación que refiere solamente al instrumento. El último caso no deja de implicar la distinción referida aquí. Véase también Sonido-instrumento. 
Sonido encontrado: expresión concebida por los pioneros de la música concreta, refiere a la utilización de grabaciones de sonidos (tradicionalmente concebidos como) no musicales o "de la vida cotidiana" en piezas musicales.

Sonoridad: ver Intensidad.

Textura (musical): el resultado perceptual de la interacción de componentes simultáneos que, por múltiples factores, se segregan mutuamente. En su segregación mutua, eventos sucesivos se perciben configurando múltiples devenires únicos que constituyen "estelas" o "corrientes auditivas" independientes y simultáneas. Dichas "estelas" configuran estratos de diferentes cualidades que interactúan, configurando finalmente la textura de una pieza.

Textura evolutiva. ver Drone.

Tiempo real (interpretación en...): expresión usualmente utilizada para referir al conjunto de acciones que modifican de algún modo el sonido y son realizadas frente a público. En la comunidad electrónica se la opone a la "simple" acción de presionar el botón que inicia la reproducción de una pieza mezclada. Esquemáticamente, suele asociársela más con los actos en vivo y menos con las presentaciones de deejay; sin embargo, esto debe ser relativizado (nos referimos a este respecto en diferentes secciones del cuerpo principal). En algún sentido sinónimo de "interpretación musical", difiere de esta en que las acciones concretas realizadas pueden ser divergentes respecto de las que tradicionalmente se asocian a dicha expresión. A modo de ejemplo, el agregado de efectos, el procesamiento, la adición o sustracción por filtrado y muchas otras acciones realizables sobre piezas mezcladas son consideradas acciones en tiempo real.

Timbre: cualidad del sonido que totaliza a las demás (altura, sonoridad y duración). Describe la síntesis que la percepción humana realiza a partir del espectro de una oscilación. Permite -como ejemplos y entre muchos otros- reconocer la fuente que origina un determinado sonido, los materiales que componen a dicha fuente, los modos en los que se le entrega energía, etc. Ver también Conformación espectral.

Track: ver Pista.

Transitorios de ataque: componentes de ruido o bandas de frecuencias presentes al inicio de un sonido. Estos suceden y se hacen más pronunciados (presentan mayor intensidad) principalmente en sonidos de ataque impulsivo. 
Tren de impulsos: repetición veloz de sonidos breves que, por la velocidad en que se presentan se configuran como un único evento múltiple. Véase también Iteración.

Vocal: en la comunidad electrónica, elemento y/o estrato textural conformado por voces humanas. Se designa con este término tanto a las melodías cantadas en las piezas en formato canción como a exclamaciones, voces habladas, breves fragmentos de melodías de voz, (muchas veces) altamente procesados y conformados por samples conteniendo voces humanas. 


\section{BIBLIOGRAFÍA}

- 1. Diccionario inglés en línea. http://diccionario.reverso.net/ingles-definiciones/kinesthetic [20072010]

- 2. Fiestas "Avant Club". Alsina 921. Capital Federal. Cartel publicado en la puerta de ingreso del local.

- 3. Enciclopedia en línea. http://www.nationmaster.com/encyclopedia/\%0FAcoustic-phonon [20072010]

- Aguila Soto, Antonio. Procedimiento de Evaluación de Riesgos Ergonómicos y Psicosociales. Universidad de Almería. En línea. Accesible en http://www.ual.es/GruposInv/Prevencion/evaluacion/procedimiento/B$\% 20$ Condiciones $\% 20 f \%$ EDsico-ambientales/6-Vibraciones.pdf _[20112016]

- Akbarian, Schahram y otros. (1994). Corticofugal connections between the cerebral cortex and brainstream vestibular nuclei in the macaque monkey. J. Comp. Neurol. 339, 421-437

- Anache, Damian. (2013). El rol del intérprete en la música electrónica: estado de la cuestión. Jornada de la Música y la Musicología. Jornadas Interdisciplinarias de Investigación: Investigación, creación, re-creación y performance, X, 4-6 septiembre 2013. Universidad Católica Argentina. Facultad de Artes y Ciencias Musicales; Instituto de Investigación Musicológica "Carlos Vega", Buenos Aires. Accesible en http://bibliotecadigital.uca.edu.ar/repositorio/ponencias/rol-interprete-musica-electronicaanache.pdf. [18112014]

- Anton, Susana. (2001). La música electrónica. Revista HUELLAS... Búsquedas en Artes y Diseño, $\quad \mathrm{n}^{\circ} 1, \quad$ año $2001, \quad$ p.86- $89 . \quad$ Accesible en http://bdigital.uncu.edu.ar/objetos_digitales/1378/antonhuellas1.pdf. [18112014]

- Anzil, Iván. (2012). Des-limitados. En actas del V Seminario Internacional Políticas de la Memoria. Arte y Memoria. Miradas sobre el pasado reciente. C. C. de la Memoria Haroldo Conti, Archivo nacional de la memoria y Secretaría de Derechos Humanos, Ministerio de Justicia y Derechos Humanos, Presidencia de la Nación. C. C. de la Memoria Haroldo Conti. Buenos Aires, Argentina. Accesible en https://unlp.academia.edu/IvanAnzil [20112016]

- Anzil, Iván. (2013). Ideo-materialismo musical. Crítica a los conceptos tradicionales de "sonido" y "música". Bajo el foco de la sensación táctil. INÉDITO. Accesible en línea en https://unlp.academia.edu/IvanAnzil [20112016]

- Anzil, Iván. (2010a). Iván Anzil - Propuesta de tema y plan de tesis. Publicado durante el 8vo Encuentro de Cooperación e Intercambio - @UTN Arte+Nuevas Tecnologías. Vínculo a la descarga accesible en http://ceiarteuntref.edu.ar/node/155. [17112016]

- Anzil, Iván. (2011). "Nuestra carne en el espacio. Sensación táctil en la música." en Revista Arte e Investigación. №8. Secretaría de Publicaciones y Posgrado. Facultad de Bellas Artes UNLP. La Plata.

- Anzil, Iván. (2010b). Sensación táctil y/o audio-táctil de vibraciones de baja frecuencia en música reforzada electroacústicamente. Propuesta de tema y plan para la tesis doctoral. Accesible en http://www.ceiarteuntref.edu.ar/taxonomy/term/17. [17112016]

- Baquedano, Miguel. (2011). Apunte de cátedra de la asignatura Apreciación Musical II. Universidad Nacional del Arte, Departamento de Artes del Movimiento "Maria Ruanova".

- Basso, Gustavo. (2001). Análisis espectral. La Transformada de Fourier en la Música. Editorial de la UNLP-REUN, La Plata.

- Basso, Gustavo. (1999). El principio de indeterminación en acústica musical. En actas de la XIII Conferencia anual de la Asociación Argentina de Musicología, Buenos Aires.

- Basso, Gustavo. (2000). "Nuevas tendencias en acústica musical" en: Revista Arte e Investigación. Año 4, nº 4.Facultad de Bellas Artes, UNLP. ISSN: 1850-2334

- Basso, Gustavo. (2006) Percepción auditiva. Editorial de la Universidad Nacional de Quilmes. ISBN: 9875580821

- Bertram, Martin y otros. (2005). Phonon Tracing for Auralization and Visualization of Sound. $16^{\text {th }}$ IEEE Visualization (Vis 2005) p.20

- Boal, Augusto. (1999). Juegos para actores y no actores. Alba editorial. 2002. Colección: Artes Escénicas. ISBN: 97884-84281344. Accesible en http://abacoenred.mayfirst.org/wpcontent/uploads/2015/10/boal_augusto_-juegos_para_actores_y_no_actores.pdf. [19092016] 
- Briggs, John y Peat, David. (1989). Espejo y reflejo: del Caos al Orden. Guía ilustrada de la teoría del caos y la ciencia de la totalidad. Traducción de Carlos Gardini. Editorial Gedisa S.A., Barcelona. ISBN: 84-7432-388-6. Accesible en http://www.salud-sindolor.com/plataforma/Cursos/Cursos483/Clases185/Libro\%20El\%20Espejo\%20y\%20el\%20Ref lejo\%20de\%20briggs-peat.pdf. [16092016]

-Martin, Brontë. (2013). "The proliferation of EDM" en: The McGill Tribune, nov 2013. En línea. Accesible en http://www.mcgilltribune.com/features/the-proliferation-of-edm/. [27042016]

- Butler, Mark. (2003). Unlocking the groove: Rhythm, meter and musical design in electronic dance music. Indiana University. UMI Number: 3094278

- Calne, D. y Pallis, C. (1966). Vibratory Sense: A Critical Review. Brain. 89(4):723-46.

- Clark Synthesis. What is Tactile Sound? En línea. Accesible en http://www.clarksynthesis.com/knowlegebase/WhitePages/WhatistactileSound.pdf [20072010]

- Cambridge Dictionaries online. Diccionario y traductor inglés-español en línea dependiente de la Universidad de Cambridge. Accesible en http://dictionary.cambridge.org/dictionary/ [30032016]

- Collins, D. y otros. (2005). Cutaneous Receptors Contribute to Kinesthesia at the Index Finger, Elbow, and Knee. J Neurophysiol 94: 1699-1706

- De Andrade, Iracema. (2013). "La música electroacústica mixta: el intérprete y los desafios de la praxis musical contemporánea." en: Revista Vórtex, Curitiba, n.2 2013, p.49-64. Accesible en http://www.revistavortex.com/andrade2.pdf. [18112014]

- Deines, Eduard y otros. Sound visualization using phonon tracin and FEM. Institute for data analysis and visualization. Institute of Data Analysis and Visualization. En línea. http://www.idav.ucdavis.edu/research/projects/sound_vis [20072010]

Deleuze, Giles. (1969). Lógica del sentido. En línea. Libros Tauro. Accesible en

http://www.philosophia.cl/biblioteca/Deleuze/L\%F3gica\%20del\%20sentido.pdf Trad. de

Miguel Morey. [21042013]

Deleuze, Giles y Guattari, Félix. (1991). ¿Qué es la filosofia? Editorial Anagrama, Barcelona. 2001. Trad. Thomas Kauf.

- Demers, Joanna. (2010). Listening through the noise. The aesthetics of experimental electronic music. Oxford University Press. ISBN: 978-0-19-538765-0; 978-0-19-538766-7

- Després, O. y otros. (2005). Auditory compensation in myopic humans: Involvement of binaural, monaural, or echo cues? Brain Reserarch 1041. 56-65

- Diccionario Espasa Calpe. (2000) Director: Juan Ignacio Alonso Campo. Archivos gráficos del Istituto Geográfico DeAgostini y ESPASA CALPE. España, ISBN: 84-239-2944-9

- Diez Rasines, Sara. (2015). Techno, repetición y trabajo. AusArt Journal for Research in Art. 3 (2015), 2, pp. 117-129 www.ehu.es/ojs/index.php/ausart DOI: 10.1387/ausart.15944. ISSN 2340-8510 ISSNe 2340-9134. Accesible en http://www.ehu.eus/ojs/index.php/ausart/article/viewFile/15944/14172. [19102014]

- Eimer, M. (2004). Multisensory Integration: How Visual Experience Shapes Spacial Perception. Current Biology, Vol. 14, R115-R117

- Eiriz, Claudio. (2012). "El oido tiene razones que la física no conoce. (De la falla técnica a la ruptura ontológica)" en: Cuadernos del Centro de Estudios en Diseño y Comunicación. №41, pp. 59-80. Buenos Aires. ISSN: 1668-5229. http://www.scielo.org.ar/pdf/ccedce/n41/n41a04. [25112014]

- Eiriz, Claudio. (2013). "Los cuatro conceptos fundamentales del "Tratado de los objetos musicales" de Pierre Schaeffer." en Reflexión académica en Diseño y Comunicación NoXXI. pp.128-134. Buenos Aires. ISSN: 1668-1673. Accesible en http://fido.palermo.edu/servicios_dyc/publicacionesdc/archivos/430_libro.pdf. [18112014]

- Enciclopedia Espasa Calpe. (2000). Dir. editorial: Juan Ignacio Alonso Campos. Espasa Calpe S.A. España. ISBN: 84-239-2977-9

- Fessel, P. (1996). "Hacia una caracterización formal del concepto de textura." en Revista del Instituto Superior de Música. №5. pp. 75-93. En línea. Accesible en http://bibliotecavirtual.unl.edu.ar/ojs/index.php/ISM/article/view/514/612 [21112016]

- festival internacional La música en el Di Tella. Resonancias de la modernidad. Homenaje al Centro Latinoamericano de Altos Estudios Musicales (CLAEM) en su $50^{\circ}$ aniversario. (2011). 
Director: José Luis Castiñeira de Dios. Secretaría de Cultura de la Presidencia de la Nación. Buenos Aires. ISBN: 978-987-9161-82-1

- Gómez Gutierrez, Emilia. (2009). Síntesis por modulación. Departament de Sonologia. Escola Superior de Musica de Catalunya. Curso 2009-2010. Accesible en http://www.dtic.upf.edu/ egomez/teaching/sintesi/SPS1/Tema6-Modulacion.pdf. [18112014]

- Guerreiro, Leila. (1998). "Raves. Las fiestas interminables." en Revista La Nazión, 20 sept 1998, ed. impresa. Accesible en http://www.lanacion.com.ar/212024-raves-br-las-fiestasinterminables. [18112014]

- Guest, S. y otros. (2002). Audiotactile interactions in roughness perception. Exp. Brain Res. 146:161-171

- Guldin, W.O. y Grusser, O.J. (1998). Is there a vestibular cortex? Trends Neurosci. 21, 254259

- Hirschberg, A. y otros. (1996) Shock Waves in trombones. Journal of Acoustics. Soc. Am. 99 (3), March 1996

- Holmes, Thom. (1985).Electronic and Experimental Music. Technology, Music and Culture. Tercera edición. 2008. Routledge, New York. ISBN 0-203-92959-4 Master e-book ISBN

- Intersecciones. La música en la cultura electro-digital. (2004). Juan Ruesga Bono (editor). arte/facto. Colectivo Cultura Contemporánea. Sevilla. Accesible en http://www.ccapitalia.net/reso/articulos/intersecciones/intersecciones.pdf. [18112014]

- Jagadeesh, G., (2008). Fascinating world of shock waves. Resonance. Indian Academy of Science. August 2008. Pp.752-767

- Jousmäki, V. y Hari, R. (1998). Parchment-skin illusion: sound-biased touch. Current Biology 8(6):R190

- Kayser, C. y otros. (2005). Integration of Touch and Sound in Auditory Cortex. Neuron, Vol.48, 373-384.

- Kogan Musso, Pablo. (2004). Análisis de la Eficiencia de la Ponderación "A” para Evaluar Efectos del Ruido en el Ser Humano. Accesible en http://www.fceia.unr.edu.ar/acustica/biblio/kogan.pdf. [29072015]

- Kyrou, Ariel. (2002). Techno rebelde. Un siglo de músicas electrónicas. Edición Traficante de sueños (2006), Madrid, España. Traductor: Manuel Martínez Forega. ISBN-13: 978-84-9645310-3

- LaMotte, R. y Mountcastle, V. (1975) Capacities of humans and monkeys to discriminate vibratory stimuli of different frequency and amplitude: a correlation between neural events and psychological measurements. Journal of Neurophysiology, Vol 38, Issue 3 539-559

- Lanza, Andrea. $<\mathrm{S} / \mathrm{f}>$. Historia de la música, 12. Material de la cátedra Historia de la música I y II, Capítulo III - Punto 24.1-4, pp.115-130. Facultad de Bellas Artes, UNLP. Accesible en http://www.fba.unlp.edu.ar/hmusica1y2/Historia2/bloque\%20v\%20txt8.pdf. [18112014]

- Lenarduzzi, Victor. (2012a). No puedo tomar notas mientras bailo. Accesible en https://www.academia.edu/7379851/VICTOR LENARDUZZI-

NO_PUEDO TOMAR NOTAS MIENTRAS_BAILO. [29072015]

- Lenarduzzi, Victor. (2012b). Placeres en movimiento. Cuerpo, música y baile en la "escena electrónica". AIDOS Editores. Buenos Aires. ISBN: 978-987-33-2581-6

- Levänen, S. y Hamdorf, D. (2001). Feeling vibrations: enhanced tactile sensitivity in congenitally deaf humans. Neuroscience Letters 301 75-77

- Ljunggren, F., Wang, J. y Ågren, A. (2007). Human vibration perception from single- and dual-frequency components. Journal of Sound and Vibration 300 13-24

- Long, C. (2003-04). Shock wave theory. Riffle Internal Ballistics, Longitudinal shock waves, and Shot Dispersion. En línea. www.the-long-family.com/OBT_paper.htm [20072010] Versión .pdf disponible en la misma dirección.

- Lyver, D. (2000). Principios básicos del sonido para video. Editorial Gedisa. Barcelona.

- Maher, R. (2006). Summary of Gun Shot Acoustics. En línea. www.coe.montana.edu/ee/rmaher/publications/maher_aac_0406.pdf [19072010]

- Mastropietro, Carlos y otros. (2014). Música y timbre: el estudio de la instrumentación desde los fenómenos tímbricos. Ed. Al margen, La Plata. ISBN: 978-987-618-207-2

- McLeod, Kembrew. (2001) "Genres, Subgenres, Sub-Subgenres and More: Musical and Social differentiation with Electronic/Dance Music Communities." en Journal of Popular Music 
Studies 13, no. 1:59-76. Accesible en http://ir.uiowa.edu/cgi/viewcontent.cgi?article=1001\&context=commstud_pubs. [14042016] - Merzenich, M. y Harrington, T. (1969). The Sense of Flutter-Vibration Evoked by Stimulation of the Hairy Skin of Primates: Comparison of Human Sensory Capacity with the Responses of Mechanoreceptive Afferents Innervating the Hairy Skin of Monkeys. Exp. Brain Res. 9, 236-260 - Morgan, M. (1999). Sensory perception: Supernormal hearing in the blind? Current Biology 9:R53-R54

- Morioka, M. y Griffin, M. (2006). Magnitude-dependence of equivalent comfort contours for fore-and-aft, lateral and vertical hand-transmitted vibration. Journal of Sound and Vibration 295 633-648

- Mowbray, G. y Gebhard, J. (1957). Sensitivity of the Skin to Changes in Rate of Intermitent Mechanical Stimuli. Science 28, Vol. 125. no. 3261, pp. 1297 - 1298

- Murfee, W. y otros. (2005). High-frequency, low-magnitude vibrations suppress the number of blood vessels per muscle fiber in mouse soleus muscle. J Appl Physiol 98:2376-2380

- "Music and the heart" en revista Circulation. Journal of the American Heart Association. (2007). Circulation. 2007;116:F139-F144. doi: 10.1161/CIRCULATIONAHA.107.187676 Circulation is published by the American Heart Association, 7272 Greenville Avenue, Dallas, TX 75231 Copyright (C) 2007 American Heart Association, Inc. All rights reserved. Print ISSN: 0009-7322. Online ISSN: 1524-4539. Accesible en http://circ.ahajournals.org/content/circulationaha/116/24/F139.full.pdf. [27092016]

- Música electrónica y electroacústica. $<\mathrm{S} / \mathrm{f} / \mathrm{a}>$. Material de cátedra del Instituto Nacional de Tecnologías Educativas y de Formación del Profesorado. España. Accesible en http://recursos.cnice.mec.es/musica/temas/documentos/imp_com_muselec.pdf. [18112014]

- NASA. (2001) Good Vibrations. A new treatment under study by NASA-funded doctors could reverse bone loss experienced by astronauts in space. En línea. http://science.nasa.gov/headlines/y2001/ast02nov 1.htm [18072010]

- Noya, Miguel. (2008). Cinta en reverso. Revista en línea venezolana Música en clave, vol. 21, Enero-Abril 2008. http://www.musicaenclave.com/articlespdf/cintaenreverso.pdf. [18112014] - Penrose, R. (2004). The Road to Reality. Traducción de Sanz, J. (2006). El Camino a la realidad. Debate, Barcelona.

- Plaza, G. (2011). "Tecnofolk: música de raíz y nuevas tecnologías" en: diario La Nazion, 22 jul 2011, ed. digital. Accesible en http://www.lanacion.com.ar/1391345-tecnofolk. [02092016]

- Puig, S. (1997). Audio digital y MIDI, Guías Monográficas. Anaya Multimedia, Madrid

- Ramos, O. y Arias, C. (1997). Human Echolocation: The ECOTEST System. Applied Acoustics. Vol. 51, No. 4, pp. 439-445

- Reynolds, Simon. (2014). Energy Flash. Traducción de Begoña Martínez, Gabriel Cereceda y Silvia Guiu. Contra Ediciones. Barcelona ISBN: 978-84-942167-3-2

- Robertson, Roland. (1995). "2. Glocalization: time-space and homogeneity-heterogeneity" en: Global Modernities. Sage Publications, Londres. pp. 25-44. Accesible en http://www.worldhistory.pitt.edu/DissWorkshop2011/documents/rolandrobertsonglocalization.p df [30112016]

- Rodriguez Caeiro, Martín. (2009). La plasticidad del fonón: Matrices polifónicas y poliédricas. Revista El artista. ISSN (versión electrónica): 1794-8614. Accesible en http://www.redalyc.org/pdf/874/87412239009.pdf. [18112014]

- Rossell, Oriol. Oigo un mundo nuevo: los pioneros de la música electrónica (1910-1968). Mat. de la cátedra Historia de la música I y II, Facultad de Bellas Artes, UNLP. Accesible en http://www.fba.unlp.edu.ar/hmusica1y2/Historia2/B\%20VI\%20TXT\%209\%20.pdf. [18112014] - Russell, D. (ca. 2001). En línea. http://www.kettering.edu/ drussell/demos.html [20072010]

- Russo, Frank A., Patel, Anniruddh D. y Ammirante, Paolo. (2016a). "Synchronizing to auditory and tactile metronomes: a test of the auditory-motor enhancement hypothesis" en: Psychonomic Bulletin \& Review. DOI: 10.3758/s13423-016-1067-9

- Russo, Frank A. (2016b). Understanding music perception from the perspective of oscillation and resonance. En actas del $22^{\circ}$ Congreso Internacional de Acústica, Buenos Aires.

- Russo, Frank A., Ammirante, Paolo y Fels, Deborah, I. (2012). "Vibrotactile Discrimination of Musical Timbre" en Journal of Experimental Psychology: Human Perception and Performance. American Psychological Association. DOI: 10.1037/a0029046 
- Schaeffer, Pierre. (1966). Tratado de los objetos musicales. Versión española de Araceli Cabezón de Diego. (1998). Alianza Editorial, Madrid. ISBN: 84-206-8540-2. Accesible en http://monoskop.org/images/1/1e/Schaeffer_Pierre_Tratado_de los_objetos_musicales.pdf.

[25112014]

- Settles, G. y otros. (2008). Schlieren imaging of loud sounds and weak shock waves in air near the limit of visibility. ISFV13 - 13th International Symposium on Flow Visualization FLUVISU12 - 12th French Congress on Visualization in Fluid Mechanics July 1-4, 2008, Nice, France. DOI: 10.1007/s00193-009-0226-6

- Schürmann, M. y otros. (2004). Hands help hearing: Facilitatory audiotactile interaction at low sound-intensity levels. The Journal of the Acoustical Society of America, Vol.115, Issue 2, 830-832

- Schürmann, M. y otros. (2006). Touch activates human auditory cortex. NeuroImage, Vol. 30, Issue 4, 1325-1331

- Snoman, Rick. (2009). The Dance Music Manual. Tools, Toys \& Techniques. Second Edition. Focal Press, Oxon, Reino Unido. ISBN: 978-0-2405-2107-7

- Snoman, Rick. (2014). The Dance Music Manual. Third Edition. Focal Press, Oxon, Reino Unido. Edición digital. ISBN: 978-0-203-38364-3

- Štěpánek, J. (2006). Musical Sound Timbre: Verbal Description and Dimensions. Proc. Of the $9^{\text {th }}$ Int. Conference on Digital Audio Effects (DAFx-06), Montreal, Canada, pp.121-126

- Tema 14: Música del siglo XX desde la Segunda Guerra Mundial. $<\mathrm{s} / \mathrm{f} / \mathrm{a}>$. Departamento de música, IES Santa María de Arcos, Ciudad Real, España. Accesible en http://depmusica.wikispaces.com/file/view/LA+MUSICA+DEL+SIGLO+XX+DESDE+LA+II +GUERRA+MUNDIAL.pdf. [18112014]

- Toledo, Marcelo. (2006). Mapa del ruido en la música del siglo XX. Revista Horizonte, vol. 1, num. pp. 40-53. Accesibleen http://www.marcelotoledomusic.com/Mapadel_Ruido.pdf. [18112014]

- Toma, S. y Nakajima, Y. (1995). Response characteristics of cutaneous mechanoreceptors to vibratory stimuli in human glabrous skin. Neuroscience Letters 195 61-63

- Urias, C. (2007). Vibración. Seguranca e Trabalho Online. En línea. http://www.segurancaetrabalho.com.br/download/vibracion-carlos urias.ppt [20072010]

- Vazquez, Hernan G. (2015). Conversaciones en torno al CLAEM. Entrevistas a compositores becarios del Centro Latinoamericano de Altos Estudios Musicales. Instituto Nacional de Musicología "Carlos Vega". Buenos Aires. ISBN: 978-950-9726-13-0

- Von Gierke, H. y Nixon, C. (1959). M11. Experiments on the Bone-Conduction Threshold in a Free Sound Field. The Journal of the Acoustical Society of America. Volume 31, No. 1, 128

- Watabe, Y. y otros. A study of bone conduction and its applications for audio signal transmission. Journal of the Acoustical Society of America. Volume120, No.5, Pt. 2, 3330

- Wernert, E. y Arns, L. (2004). Lecture 3.1 - Human Perception (II): Olfactory, Haptics, Motor Capabilities, \& Sensory Interaction en Introduction to Virtual Environments. En línea. Universidad de Indiana. I590_VR - Lecture 3.1 - Human Perception II

- - Wilson, S. (2016) "The $1 \overline{4}$ drum machines that shaped modern music" en: Revista en línea FactMag. Accesible en http://www.factmag.com/2016/09/22/the-14-drum-machines-thatshaped-modern-music/. [07112016]

- Zeiner-Henriksen, Hans T. (2010). The PoumTchak Pattern. Correspondences between Rhythm, Sound and Movement in Electronic Dance Music. Department of Musicology. Faculty of Humanities. University of Oslo. Accesible en http://folk.uio.no/hanst/ThePoumtchakPattern.pdf. [10072016]

\section{Fuentes en línea}

- 120 Years of Electronic Music. Wordpress de Simon Crab, Londres. Inició su actividad en 1995. Múltiples entradas. http://120years.net/ [25112014]

- II Encuentro de Armado de Sintetizadores y otras demencias. Vínculo al evento de la red social facebook relativo al encuentro realizado el 28 de julio de 2016 en Espacio Cultural Mi Casa. Accesible en https://www.facebook.com/events/1408399509461547/. [31072016] 
- "A history of speed garage" en: toucanmusic.com, sello discográfico especializado en música electrónica de baile. (1998). Artículo autoría de "John M.". Accesible en http://www.toucanmusic.co.uk/articles/speedgarage.php [04102016]

- Audials. Sitio dedicado al desarrollo de tecnología digital de audio. Accesible en http://audials.com/en/genres/dance_music.html [27042016]

- Arpsynth. Sitio dependiente de la compañía Korg dedicado a los desarrollos modernos derivados del histórico sintetizador ARP Odyssey de 1972. Accesible en http://www.arpsynth.com/en/about/. [28072016]

- Arte sonoro. Sitio dependiente de la Universidad de Castilla-La Mancha. Múltiples entradas. http://www.uclm.es/artesonoro/elarteruido.html [18112014]

El arte de los ruidos. (1916) Luigi Russolo. Del original "L'arte dei Rumori" (1913).

Versión en línea de la edición publicada por Taller de ediciones, Centro de creación experimental. Universidad de Castilla-La Mancha, España.

- Blizzhackers. Red social donde se incluye comentario del usuario Full-Torqe respecto de los tempos en la música electrónica de baile. $<s . f .>3^{\circ}$ página de la cadena de debate a la que se accede en http://www.blizzhackers.cc/viewtopic.php? $\mathrm{f}=162 \& \mathrm{t}=372572 \&$ start $=30$ [27042016]

- daftpunk-anthology.com. Sitio dedicado al dúo francés Daft Punk. Accesible en http://www.daftpunk-anthology.com/dpa/instruments-softs [09112016]

- El RUIDO y la música. Blog de Luis Antonio Pacheco Montoya. Múltiples entradas. http://elruidoylamusica.blogspot.com.ar/ [18112014]

Futurismo y música I: Pratella. http://elruidoylamusica.blogspot.de/2013/03/futurismoy-musica.html (y ssgts.)

Pierre Schaeffer y la "musique concrète".

http://elruidoylamusica.blogspot.com.ar/2013/03/pierre-schaeffer-y-la-musique-

concrete.html

"Música futurista" Francesco Balilla Pratella.

http://elruidoylamusica.blogspot.de/2013/02/musica-futurista-francesco-balilla.html.

Texto del manifiesto de 1910.

- Evolution of electronic music. Sitio dedicado a la historia de la música electrónica. Cita como fuente a Darter, Tom and Greg Armbruster. (1984). The Art of Electronic Music. New York, NY: GPI Books, https://emhistory.wikispaces.com/[25112014]

- Faunanrg. Blog especializado en música electrónica de baile y que contiene información respecto de las fiestas que organizara la radio FM NRG 101.1. https://faunanrg.wordpress.com/category/fiestas-y-raves-nrg-baires/ [20112016]

- Futur-ism.it. Sitio acerca del "Futurismo". http://www.futur-ism.it/ [18112014]

- "Géneros de la música electrónica" en: djs, sitio especializado en música electrónica de baile. (2008). Accesible en http://www.djs.es/generos-de-la-musica-electronica/ [18042016]

- "Géneros mayores de la música electrónica de baile". (2016). Vínculo a los resultados de la encuesta realizada entre los usuarios del grupo de la red social Argensynth. Accesible en http://www.e-encuesta.com/answer?testId=nkX4bdq4ndY\%3D [01072016]

- "Géneros y subgéneros de la música electrónica" en: red social facebook. (2013). Usuario Sobre Musica electronica. Accesible en https://www.facebook.com/notes/so bre-musicaelectronica/generos-y-subgeneros-de-la-musica-electronica/271576009646127/ [18042016]

- "Guía de Estilos de la Música Electrónica" en: Nightclubber, red social dedicada a la música electrónica de baile. (2007). Accesible en https://www.nightclubber.com.ar/foro/11/discusionesgenerales-musica/49049/guia-estilos-musica-electronica.html [18042016]

- korg.com. Sitio oficial donde la compañía promueve su producto Korg Kaoss Pad. Accesible en http://www.korg.com/us/products/dj/kaoss pad kp3 plus/. [09112016]

- La enciclopedia de la música electrónica. Entrada "Luigi Russolo". Publicado por Tadeo cyclical tracks. http://enciclopediaelectronica.blogspot.com.ar/2012/02/luigi-russolo.html [18112014]

- Listado de artistas electrónicos argentinos. Documento del grupo ("cerrado") de la red social facebook. Accesible (requiere ser miembro del grupo para visualizarse) en https://www.facebook.com/notes/201577609965209/Base $\% 20 \mathrm{de} \% 20$ datos $\% 20 \mathrm{~m} \% \mathrm{C} 3 \%$ BAsico s\%20Argensynth/623575601098739/ [25062016] 
- Music from outer space (o "MFOS"). Sitio dedicado a dispositivos musicales de base tecnológica "DIY" (i.e.: "Do It Yourself" o "Hágalo Usted Mismo"). Accesible en http://www.musicfromouterspace.com/ [03102016]

- "Música electrónica. (géneros, subgéneros y estilos)"en: Taringa!, red social argentina. (2013). Nota. Usuario "ShadowBrony". Accesible en http://www.taringa.net/post/info/15968399/Musica-electronica-generos-subgeneros-yestilos.html [18042016]

- Pionner. Sitio de la empresa Pionner donde promociona su dispositivo Toraiz SP-16. Accesible en https://www.pioneerdj.com/es-es/product/production/toraiz-sp-16/black/overview/ [03112016]

- Synthopia. Sitio dedicado a la música electrónica. http://www.synthtopia.com/ [25112014]

- Theremins. Sitio acerca de Bob Moog que refiere a este instrumento. https://www.moogmusic.com/products/Etherwave-Theremins [18112014]

- Usa diversos tempos para crear beats de diferentes géneros. Nota de reciente publicación en el sitio de la revista (impresa) Future Music. Accesible en http://www.futuremusic-es.com/usadiversos-tempos-para-crear-beats-de-diferentes-generos/ [19092016]

- Vintage Synth Explorer. Sitio y base de datos de toda clase de dispositivos musicales de base tecnológica. Accesible en http://www.vintagesynth.com/ [03112016]

- Wikipedia. Enciclopedia colaborativa. Múltiples entradas en sus versiones española e inglesa. Fecha de última entrada: [18112016]

"african dances", "Amen break", "arte sonoro", "audión", "canyengue", "dance", "dance music", "dubstep", "electronic dance music", "electronic musical instrument", "Emile Berliner", "fonógrafo", "Géneros de música electrónica", "Garage music (US garage)", "Géneros y formas musicales de danza", "gramófono", "groove (música)", "Iannis Xenakis", "Léon Theremin", "List of electronic music genres", "Luigi Russolo", "Manifiesto futurista", "Masa de sonido", "Música electrónica", "música electrónica de baile", "musique concrète", "Ondes martenot", "Telharmonium", "theremin", "Thomas A. Edison", "vocoder" y otros.

\section{Contenidos multimediales (en múltiples idiomas)}

- Arbol genealógico de la música moderna. (2011). Gráfico ilustrativo de las influencias mutuas entre músicas del mundo. Accesible https://soundworkscolombia.wordpress.com/2011/03/10/arbol-genealogico-de-la-musicamoderna/ [25042016]

- Como diferenciar los distintos géneros de música electrónica. (2015). Entrada en la red social blogspot. Usuario SmallMoments. Accesible http://smallmoments1.blogspot.com.ar/2015/04/como-diferenciar-los-distintos-generos.html [25042016]

- Electronic Music Guide (Music infographics). (2013). Infografía. Accesible en http://www.designinfographics.com/music-infographics/electronic-music-guide\# [27042016]

- Ishur's Guide to electronic music. $<\mathrm{s} / \mathrm{f} / \mathrm{a}>$. Mapa interactivo la evolución de géneros de música electronica de baile. Accesible en http://techno.org/electronic-music-guide/ [25112014]

- La, La, La, He, He, Hee. Pieza del artista Prince. Ejemplo de rol textural de redoblante cumplido con un sample de otro sonido (ladrido de perro en esta pieza). Accesible en https://www.mixcloud.com/ginovannelli94/la-la-la-he-he-hee-highly-explosive-prince/ [17062016]

- Ominous | Incaranted sound sculpture (Xth sense). (2014). Pieza musical que utiliza el sistema de composición interactiva y bioacústica "Xth sense". Subido por Marco Donnarumma. Accesible en https://vimeo.com/86766860 [25112014]

- Risveglio di una citta. Compuesta por Luigi Russolo (1913-14). Accesible en http://ubumexico.centro.org.mx/sound/russolo luigi/die kunst/Russolo-

Luigi_01_Risveglio.mp3 [18112014] 
- Speaknspell. Versión en línea e interactiva del juguete infantil de finales de los años 1970s. Accesible en http://www.speaknspell.co.uk/speaknspell.html. [08112016]

- The Dance Music Guide. <s.f.> Sitio especializado en música electrónica de baile aparentemente aún en desarrollo. Accesible en http://thedancemusicguide.com/ [25042016]

- The evolution on western dance music. $<\mathrm{s} / \mathrm{f} / \mathrm{a}>$. Mapa interactivo de la evolución de géneros la música electrónica occidental de baile. Accesible en http://www.thomson.co.uk/blog/wpcontent/uploads/infographic/interactive-music-map/index.html [25112014]

- "UK Garage History \& Family Tree: 20 Years of UKG!" en: Music is my sanctuary <s.f.>. Sitio y radio especializados en música. Accesible en http://www.musicismysanctuary.com/thehistory-of-the-uk-garage-family-tree [04102016]

\section{Videos en la plataforma YouTube (en múltiples idiomas)}

- 1930s Russian Drawn Sound: Arseny Avraamov's 'Ornamental Sound Animation'. Video demostración de la técnica de creación Sonora del compositor y teórico musical ruso Avraamov (1930). https://youtu.be/8EGFPZdiVqI [25112014]

- 2step. Ejemplos del moderno índice 2 step. Subido por Александр Шумилов. Accesible en https://youtu.be/pkj9m2eQaWc?list=PL6Ky-G7bbcmjFozkFulked_gwEt0fRzIM. [28102016]

- 90's Old School House Mix - House Musica. Ejemplos del índice house. Subido por OLDSCHOOLHARDHOUSE. Accesible en https://youtu.be/Zcd7MI1szEM. [21102016]

- Acid house from 1958 ... Tom dissevelt \& Kid Baltan (Dick Raaijmakers) syncopation (2009). Una de las primeras piezas de música popular realizada con medios electrónicos. Subido por radio4forum. https://youtu.be/HW-n6GWFAvI [15062016]

- ARP 2600 demo by Audio Visual Algebra. (2013). Ejemplo de iteración en una forma de onda sintética. Subido por avalgebra's channel. Accesible en línea en https://youtu.be/iGA86VkFL4Y. [31072016]

- Arturia Drum Brute In Depth Preview- Sonic LAB. Ejemplo de máquina de ritmos con capacidades polirrítmicas. Subido por sonicstate. Accesible en https://youtu.be/GBcI6kvRjPA. [14102016]

- Back to The 90's - Remember Oldschool Trance Mix. Ejemplos del índice trance. Subido por KlangExtase. Accesible en https://youtu.be/V3KQACqpwbQ [28102016]

- Best Dub Compilation. (2013). Ejemplo del índice dub y del uso del efecto de "eco" o "delay". Subido por Reggae Box, incluye múltiples clásicos del índice. Accesible en https://youtu.be/7iCxjXZOYsU [28072016]

- Bs As Energy Parade 2000 Parte 1/3. (2012). Video de las famosas "raves" de Parque Centenario. Subido por Robert Quinteros. Accesible en https://youtu.be/VGm3vWk67qc [18072016]

- BUENOS AIRES NRG PARADE 2000. (2012). Video promocional del evento. Subido por djsebaparatodos. Accesible en https://youtu.be/TcYQy0lM6kg. [18072016]

- Circuit Bend Speak \& Spell + Analog Deelay (Microesfera/Vlisa Live Play). Ejemplo de cortocircuitado creativo o circuit bending. Subido por Microesfera. Accesible en https://youtu.be/Bq1hqfoFOYI. [09112016]

- Daft Punk - Robot Rock - Oh yeah (Official audio). (2007). Ejemplo de mash up entre dos piezas; secundariamente, ejemplo de voces procesadas con vocoder. Subido por Daft Punk. Accesible en línea en https://youtu.be/lVKbF8khsrI. Véase también http://dai.ly/xr5ass [28072016]

- Dances of Southern Africa. Documental sobre música africana de danza. Subido por Penn Museum. Accesible en https://youtu.be/FvzHCMlgkvA [19092016]

- Darude -Music (2009). Pieza del año 2003, considerada del género híbrido Techno Trance. Subido por Darude. https://youtu.be/AwBC2epxgJ4[18062016]

- David Morales Presents The Face Needin' U (Original Mistake).mp4. Subido por revistauay. Accesible en https://youtu.be/ZpWbT6jEVWg. [04102016]

- deadmau5 - Raise Your Weapon. (2010). Ejemplo conteniendo sonidos con componentes graves por incidencia de iteración. Subido por Ultra Music. Accesible en línea en https://youtu.be/YnwfTHpnGLY. [26072016] 
- Delia Derbyshire - Ziwzih Ziwzih OO-OO-OO (2010). Temprana pieza de música popular electrónica. Subido por ziggybollus. Accesible en https://youtu.be/jetzY-W78gg [15062016]

- Dengue Dengue Dengue! - Simiolo. Ejemplo de Global Bass. Subido por Dengue DengueDengue. Accesible en https://youtu.be/Zi49IeO011k [05072016]

- Digital Tribalism [Tribal Psybient Compilation Vol. 1]. Ejemplo de música electrónica que le asigna a la cultura africana el valor de "primitiva". Subido por Psybrations. Accesible en https://youtu.be/DOMeAReXICg. [20102016]

- Discovering electronic music (1983) Documental acerca del desarrollo de la música electrónica. Subido por Baghira Drums. https://youtu.be/Ig6vIRmfoNI [28042016]

- DJ ANGELO - Funky Turntablism. Ejemplo de uso de bandejas tocadiscos a modo de instrumento musical. Subido por DJ ANGELO. Accesible en https://www.youtube.com/watch?v=tr3ftsCVXhc. [09052016]

- DJ Tonio - Queen (ANNA Remix) [Suara]. (2015). Pieza sobre la que se realizara un análisis de las oscilaciones/alternancias de intensidad multiniveladas a partir de la repetición de una única altura en sonidos de bajo. Secundariamente, ejemplo de secuencia con múltiples alturas. Subido por Suara Music. Accesible en https://youtu.be/qTvpcD9giDk. [26082016]

- Double 99 -- RIP Groove -- Original MIX. (2001). Ejemplo del índice speed garage. Subido por Estrass FaMiLi. Accesible en https://youtu.be/X7PqbkBUwGw. [04102016]

- Daft Hands - Harder, Better, Faster, Stronger. Ejemplo de transformación de las propiedades de un estrato textural. Subido por Fr. Eckle Studios. Accesible en https://youtu.be/K2cYWfq-Nw. [20102016]

- Daft Punk - Get Lucky (Official Audio) ft. Pharrel Williams, Nile Rodgers. (2013). Ejemplo de textura de melodía con acompañamiento. Subido por el usuario DaftPunkVEVO. Accesible en https://youtu.be/5NV6Rdv1a3I [10072016]

- Daft Punk - Get Lucky - Live Remix w/ KaossilatorPro+ \& KP3+. Ejemplo de múltiples efectos y del modo de funcionamiento del dispositivo Korg Kaoss Pad 3+. Subido por Igor Willcox. Accesible en https://youtu.be/4mC U67ehug. [09112016]

- Dark By Design \& Phil York - 1998 (Steve Hill vs Technikal mix). Ejemplo de monodía en timbre de sintetizador supersaw. Subido por infernorism ${ }^{\mathrm{TM}}$ territory. Accesible en https://youtu.be/4_y86HZ1KfQ. [20102016]

- Electro \& House 2016 Best of Party Dance, Remix, EDM, Mix y - Late 80's Old Skool Electro Mix. Ejemplos comparativos del índice electro actual y "old school". Subidos respectivamente por DJFlyBeatMusic y DerWall2005. Accesibles en https://youtu.be/J2zisMGK0z8 y https://youtu.be/rwIdQH2Zgp8. [04102016]

- ELECTRONDE (Theremin) of Martin Taubman. (2010). Pieza interpretada en este instrumento por su inventor. Subido por Peter Pringle. https://youtu.be/6HSH7OTgt4U [25112014]

- Elisha Gray. (2012). Pieza musical electrónica. Del disco non-automated process de Syrtis Major. Subido por Syrtis Major.https://youtu.be/jxRTV1eR7rI [25112014]

- File manager - Mutek 05 pt. 1 (y ssgts). (2008). Dir: Paulino Estela. Documental sobre el Festival Mutek de música electrónica y nuevas tecnologías. Montreal, Canada. Subido por Paulino Estela. https://youtu.be/2zt36JhmW0c [19112014]

- Filippo Tommaso Marinetti - Cinque sintesi radiofoniche. Música de su autoría (1933). Subido por AltriSuoniTube. https://youtu.be/WwjBbYrHMkw [18112014]

- Frankie Knuckles - Your Love. Ejemplo de objetivación por repetición. Subido por Backintday. Accesible en https://youtu.be/LOLE1YE oFQ. [07092016]

- Funky Drummer Loop. Ejemplo del sample del tema homónimo de James Brown que caracteriza a los índices basados en breakbeats. Subido por JamTracksChannel. Accesible en https://youtu.be/b85lmY613Yk. [27062016]

- Funky Drummer Sample. Ejemplo de manipulación en tiempo real del sample del tema Funky Drummer de James Brown. Subido por Wayland Twiston Davies. Accesible en https://youtu.be/ T8a4HFvS9I. [27062016]

- Gorillaz - Clint Eastwood (Official Video). (2001). Ejemplo de armonía parcialmente desfuncionalizada. Subido por el usuario Gorillaz. Accesible en https://youtu.be/1V xRb0x9aw. [11072016] 
- Halim El-Dabh - “Wire Recorder Piece” (1944). Primera pieza musical compuesta para ser reproducida por y realizada para grabador de alambre. Subido por Razor Edge. https://youtu.be/j_kbNSdRvgo [25112014]

- Hammond Organ Tone Generator. Video donde puede apreciarse el sistema de generación de sonido que poseen los órganos Hammond. Subido por bobmann107. https://youtu.be/7Qqmr6IiFLE [25112014]

- Henry Cowell - The Tides Of Manaunaun. Heterofonía por carencia de relación causal. Subida por Tal Grünberg. Accesible en https://youtu.be/bgNTWJwsG E [12082016]

- Infected Mushrooms - Army Of Mushrooms Full Album. (2012). Ejemplo de la identificación mútua entre ritmo, textura y timbre. Entre los 4'28" y los 4'50" incluye un fragmento analizado. Secundariamente, ejemplo de neutralización parcial de las cualidades melódicas formales. En el mismo vínculo, pieza Nothing to say (8'51"): ejemplo de transformaciones que exceden las categorías tradicionales de análisis musical. Subido por el usuario Frank Aguilar. Accesible en línea en https://youtu.be/uloBD9xxwZ0. [11072016]

- James Brown - Funky Drummer (Full Version, 1970) - HQ. La pieza de James Brown conteniendo uno de los samples más utilizados en la especie. Subido por Funk Forum. Accesible en https://youtu.be/AoQ4AtsFWVM. [27062016]

- JEFF MILLS - Jerical y Massive Attack - Unfinished Sympathy. Ejemplos comparativos de la amplitud estética de la música electrónica de baile. Subidos respectivamente por 62MISSION77 y emimusic. Accesibles en https://youtu.be/6sNJegD22u0 y https://youtu.be/ZWmrfgj0MZI [17092016]

- Kilometro 11. Tránsito Cocomarola. Subtitulada. Ejemplo de percusividad melódica. Subida por Pancho Vertigen. Accesible en https://youtu.be/VUYdnu0B9hM [26092016]

- KORG SQ1 Y VOLCA BASS. Ejemplo de un secuenciador por pasos controlando a un sintetizador. Subido por Guillermo Moran. Accesible en https://youtu.be/1sz1315h-LY. [03112016]

- KORG volca kick - ANALOGUE KICK GENERATOR. Ejemplo de ambigüedad en los sonidos-instrumentos y roles texturales; en este caso entre bombo y bajo. Subido por Korg. Accesible en https://youtu.be/rgs7p17ElOY [02092016]

- Kraftwerk - The Man-Machine (Full Album + Bonus Tracks) [1978] y DAFT PUNK HUMAN AFTER ALL (OFFICIAL AUDIOS). Ejemplos de uso de vocoder. Subidos por Megaherz Kraftwerkiano y Daft Punk. Accesibles en https://youtu.be/NL3NqfFTec8 y en https://youtu.be/PXYeARRyDWk. [09112016]

- Kraftwerk mit "Tanzmusik" 1973 im ZDF-aspekte-Studio (2015). Presentación de la banda en un show televisivo. Subido por True Mania. Accesible en https://youtu.be/UIbSkw4yvec [15062016]

- Larry Levan The Final Night Of Paradise Garage September 1987. Set del legendario deejay. Subido por BergamoStreetArmy. Accesible en https://youtu.be/epsFK sg1EI [28042016]

- Late 80's Old Skool Electro Mix y Electro \& House 2016 Best of Party Dance, Remix, EDM, Mix. Ejemplos comparativos del índice electro "old school" y actual. Subidos respectivamente por DerWall2005 y DJFlyBeatMusic. Accesibles en https://youtu.be/rwIdQH2Zgp8 y https://youtu.be/J2zisMGK0z8. [04102016]

- LFO - We Are Back (Warp) 1991. (1991). Ejemplo de tonalidad aparente. Subido por el usuario partyfreaks.net. Accesible en https://youtu.be/YYX1bHl8WMo [20112016]

- Luiggi Russolo - Macchina Tipografica. Música de su autoría. Subido por UnexpectedExpressive. https://youtu.be/VcHJySm7ZO0 [18112014]

- Luigi Russolo - Risveglio di una Città. Subido por Jack OneEyed. Accesible en https://youtu.be/IC3KMbSkYNI [04102016]

- Magnétophone a fil ERFIL - Wire Recorder ERFIL - Erfil Baby. Demostración del funcionamiento de un magnetófono de alambre. Subido por specialbinson. https://youtu.be/hzn ndtGvkI [18112014]

- MARKASATA / FLOR DE CACTUS, CARAMBA CHIQUITA, UN CORAZON COMO EL $M I O$. Sikuriada con incremento en el tempo. Subido por Bolivian MTV. Accesible en https://youtu.be/8xfck2huoZc. [26092016]

- Massive Attack - Unfinished Sympathy y JEFF MILLS - Jerical. Ejemplos comparativos de la amplitud estética de la música electrónica de baile. Subidos respectivamente por emimusic y 
62MISSION77. Accesibles en https://youtu.be/ZWmrfgj0MZI y https://youtu.be/6sNJegD22u0 [17092016]

- Matador - The Enemy ft Felix Da Housecat (Original Mix) - The Enemy EP. (2016). Pieza sobre la que se realizara un análisis de las oscilaciones/alternancias de intensidad multiniveladas a partir de la repetición de una única altura en sonidos de bajo. Subido por matador. Accesible en línea en https://youtu.be/ma51mUT8NBM. [26082016]

- mauricio kagel - szenario [un chien andalou] (1982, perf. 1994). Ejemplo de parafonía o "melodía engrosada". Subido por Alexis Kazazis. Accesible en https://youtu.be/U2gaPMxRrEQ. [20102016]

- Mix: Jeremy Ellis performs on MASCHINE MIKRO. Ejemplos de las diferentes categorías de samples propuestas. Accesible en https://youtu.be/0K2aynMMBpo?list=RD0K2aynMMBpo [15072016]

- Moby's Drum Machine \& Synth Collection. $<\mathrm{s} / \mathrm{f}>$. Entrevista al músico electrónico conocido como "Moby" y su colección de "máquinas de ritmo". Subido por geroin31337. https://youtu.be/r9q48UlfD1w [17042015]

- Modjo - Lady (Hear Me Tonight). (2000). Ejemplo de pieza con pocas cualidades electrónicas. Subido por Modjo. Accesible en https://youtu.be/mMfxI3r_LyA. [02072016]

- Mr Distance UK Garage Mix 2000 2005. Ejemplos recientes del índice uk garage. Subido por Mr Distance. Accesible en https://youtu.be/-HbBgI-2uDk. [28102016]

- Music for 16 Futurist noise intoners. Documental acerca de Luigi Russolo que incluye registros de interpretaciones de piezas para y en dispositivos recreados a partir de los de su invención. Subido por Performa. https://youtu.be/Lqej96ZVoo8 [18112014]

- Nebulus | Psy-dub + Downtempo Mix. Ejemplos posibles del índice ambient/chill out/ downtempo. Subido por f1rstper0n. Accesible en https://youtu.be/V9aLRO2hAKI. [28102016]

- NYNOISE.TV | SIMIAN MOBILE DISCO-Its The Beat (LIVE -KEXP). Ejemplo de acto en vivo. Subido por NewYorkNoise. Accesible en https://youtu.be/0hTky0X3eT4. [31102016]

- old skool jungle classics. Ejemplos del índice jungle/drum'n'bass/breakbeats. Compilados por verona patterson. Accesible en

https://youtu.be/H48FpOylZg4?list=PLHK99FDXXodbLilaD0K4AyAz3ZZKU8fX_ [28102016]

- Oldschool Chicago Deep House mix 1984-1990 HOUSE NATION. Ejemplos del índice house. Subido por JFK MUSIC [House Nation]. Accesible en https://youtu.be/BRQsLysczbA. [21102016]

- OldSchool Dubstep (Playlist, 2007 - early 2010's). Ejemplos del moderno índice Dubstep. Subido por MangooQc. Accesible en https://youtu.be/a-Ur6GvbjYk?list=PL9 MUxg5UidlI6GVyn ORPdTSQnEgOii. [28102016]

- oldshool hardcore 1994-2003. Ejemplos del índice hardcore. Subido por anna guerini. Accesible en https://youtu.be/c7u 2nB2q 8? list=PL029A378AC980CDDC [28102016]

- Oldschool/Uplifting Trance. Ejemplos de piezas conteniendo textura monódica y timbres de sintetizador supersaw. Compilado por aboutinvain. Accesible en https://youtu.be/4 y86HZ1KfQ?list=PLWmvzI0oySG7oC5XhgrlpYeEz-2--aa-M [20102016]

- Pavel Petrov - Ayahuasca (Original Mix). (2016) Ejemplo de repetición de una única altura con timbre de altura tonal no definida. Subido por Mia Mendi. Accesible en https://youtu.be/2bnZliAjPUk [02092016]

- Pierre Schaeffer -- Études de bruits (1948). Música de su autoría (1948). Subido por dS. https://youtu.be/CTfOyE15zzI [18112014]

- Pump Up The Volume: La Historia De La Musica House. Documental sobre el surgimiento del House. Subido por DJ ZendobeatZ. Accesible en https://youtu.be/1OWxN32NH5Q [26052016] - PURE OLD SHOOL TECHNO. Ejemplos del índice techno. Subida por kamaskg. Accesible en https://youtu.be/WEHbMju7gDk?list=PL0F8724AA50D4A353. [21102016]

- Pure Old School Techno.2 Ejemplos del índice techno. Subida por Zab Jim. Accesible en https://youtu.be/c-vf3TwbOgY?list=PLw8nrWrT_A2f9-aWbhCRYHI5163N4rSNg. [21102016] - Ramsey \& Fen - Love Bug (HQ).(1998). Ejemplo del índice speed garage. Subido por Hamza Aslam. Accesible en https://youtu.be/DezDtCezXm4 [04102016] 
- Reed Ghazala, the Father of Circuit Bending: Sound Builders. Documental sobre el iniciador del movimiento de cortocircuitado creativo o circuit bending. Subido por Motherboard. Accesible en https://youtu.be/KHDL9iGxDPM. [09112016]

- revolte - weak generation (clip). $<\mathrm{s} / \mathrm{f}>$. Ejemplo de uso prolífico de samples en una misma pieza. Subido por rosebud17. Accesible en https://youtu.be/xEoXRhOqQAI [15072016]

- Rhythmicon demonstration. Video demostrativo del funcionamiento del instrumento encargado por Henry Cowell a Leon Termen. Subido por Andrey Smirnov. https://youtu.be/HkodVcuPVAo [25112014]

- Royksopp - What Else Is There (Trentemoller Remix) (HD). (2005). Ejemplo de oscilaciones/alternancias de intensidad multiniveladas y cambiantes. Subido por weihnachtsmann07. Accesible en línea en https://youtu.be/HT5o8s4VKXg. [26072016]

- Samples of Funky Drummer. Lista de piezas que hacen uso del sample del tema Funky Drummer de James Brown. Compilado por alexandre pereira. Accesible en https://youtu.be/q0b0jIaCEHU?list=PLwgKsDSf-8374jqkxBCELPAa1no-ILLbA. [27062016]

- Simian Mobile Disco - 10000 horses can't be wrong. (2009). Ejemplo de percusividad. Subido por SMDTV. Accesible en línea en https://youtu.be/Ko5ryBx65ZM [23072016]

- Sinfonía para un hombre solo. Fragmentos de la pieza de Pierre Schaeffer y Pierre Henry (1949-50) en Lista de reproducción. https://youtu.be/qwCmr6ERXfU?list=PL06C0A33CCC93F48E [18112014]

- "Sorry, I don't have an AIRA" - Early '90s Techno with SH-101, TR-909, TB-303, TR-808. Ejemplo de la calidad tímbrica de las máquinas de ritmos clásicas de la compañía Roland. Subido por SynthMania. Accesible en https://youtu.be/FirM3sy5YvY. [05112016]

- Soundcloud Artists Special (mix) - Ambient/Chill Out/Experimental/Downtempo. Ejemplos posibles del índice ambient/chill out/downtempo. Subido por Steve Thomas. Accesible en https://youtu.be/OxLxgmokzOE. [28102016]

- SYNTH BRITANNIA documental BBC - 2006 (en español). Documental sobre la electrónica en Reino Unido. Subido por Forge Music. https://youtu.be/TK1P93r9xes [18112014]

- TB-303 Documentary - Bassline Baseline (2005). (2005). Breve documental sobre el dispositivo de empresa Roland cuyo timbre se volvió ícono de la especie. Subido por geroin31337. https://youtu.be/TLQwwtjtiY4 [17042015]

- techno/experimental/idm. (2015). Lista de reproducción con piezas donde prepondera (en diferentes grados) un tratamiento absoluto de la altura. Subida por Filip Makara. Accesible en https://youtu.be/YYX1bHl8WMo?list=PLZ1xQmYItdzRi2POf-KkztDo-rOlKqplr [12082016]

- The Chemical Brothers - Out Of Control. (1999). Ejemplo de reiteratividad. Subido por Astralwerk. Accesible en línea en https://youtu.be/6sOpbRL8R4g [23072016]

- The Chemical Brothers - Setting Sun. (1996). Por oposición a Out of Control, ejemplo de oscilación/alternancia de intensidad. Subido por Astralwerk. Accesible en https://youtu.be/p5NX1FC-7-w [25072016]

- The Secret History of the Vocoder. Documental acerca de los orígenes del vocoder. Subido por The New Yorker. Accesible en https://youtu.be/OvR4qK0B--w. [09112016]

- The Story of the RCA Synthesizer. Documental sobre el sintetizador musical RCA Mark II Sound Synthesizer. Subido por alanoneuser. Accesible en https://youtu.be/rgN VzEIZ1I [18112014]

-The track. Lista de reproducción que ilustra el tiempo y trabajo que los productores dedican a la sección rítmica y (en particular) al sonido de bombo. Compilado por Future Music Magazine. Accesible

en https://youtu.be/RKhUs2wxuE4?list=PLzRVf2noPwEFGdrgQOrurKcZ7sOmctYDC. [28082016]

- The Verve - Bitter Sweet Symphony. (1997). Ejemplo de neutralización parcial de las cualidades melódicas formales. Subido por el usuario emimusic. Accesible en https://youtu.be/1lyu1KKwC74. [11072016]

- The Voder - Homer Dudley (Bell Labs) 1939. Video acerca del dispositivo que diera origen a los modernos vocoders. Subido por MonoThyratron. Accesible en https://youtu.be/5hyI dM5cGo. [09112016] 
- Todo por amor - Buenos Aires dance. (2003-04). Dir: Paulino Estela. Documental sobre la "movida electrónica" del momento. Subido por Diego Coehlo. https://youtu.be/Eeaf0oj7ZKQ [19112014]

- Transposing Chords With The AKAI MPC RENAISSANCE. Ejemplo de parafonía originada en la transposición del sample de un único acorde. Subido por djtechdirect. Accesible en https://youtu.be/fXq214z8-7g. [20102016]

- TT 303 Programming. Ejemplo de programación de un secuenciador por pasos. Subido por Alpharisc. Accesible en https://youtu.be/44SRK0sUcTE. [03112016]

- UKG - Sunship - Try Me Out (Let Me Lick It) - A (This Side). Ejemplos del índice uk garage. Subido por funbags82. Accesible en https://youtu.be/qnE9Sn-k4Xc?list=PLWy9yjUMNKfZ3a7EUy8yedAaLQKCLV5Y [28102016]

- Ultimate EDM Playlist. Ejemplos de tratamientos de la altura como cualidad relativa. Compilados por Spinnin' Records, ofrecen diferentes grados de tonicidad (en sentido amplio). Accesible en https://youtu.be/gCYcHz2k5x0?list=PLw6eTMMKY24QLYfmrU2rB8x$\underline{\text { 1P5Fas2dY [09102016] }}$

- Video explains the world's most important 6-sec drum loop. (2006). Breve documental sobre la historia del sample de batería del tema de 1969 "Amen brother" de The Winstons; sample que es base de varios géneros de música electrónica (jungle, hip hop, Drum\&Bass. Subido por Landon Proctor. https://youtu.be/5SaFTm2bcac [30032015]

- Vladimir Ussachevsky's "Wireless Fantasy". Ejemplos de artificios de grabación agregados (incluidos en la pieza de Ussachevsky). Subida por MrDrSmithJr. Accesible en https://youtu.be/bEShy2QIj4U [06102016]

- What the Future Sounded Like (2006). (1976). Breve documental acerca del surgimiento de la música electrónica en el Reino Unido de Gran Bretaña. Subido por AntiProtonBoy. https://youtu.be/8KkW8U17Q1I [17042015]

- Yangge Dancing in Shenyang. Danza china. Subido por Danwei TV. Accesible en https://youtu.be/EXLUTxldQ_g [19092016]

- ZZK Mixtape 17 El Remolon Selva. Ejemplo de cumbia electrónica o electrónica tropical. Subido por zzkrecords. Accesible en https://youtu.be/76c0LIXn_P0. [05072016] 